\title{
CHARLES DICKENS AND HIS
}

\section{ORIGINAL ILLUSTRATORS}

\section{Jane R. Cohen}

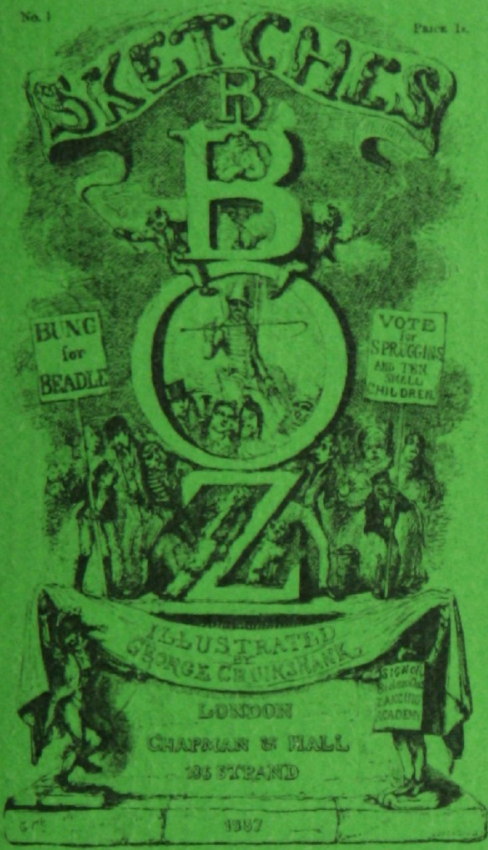

(e)

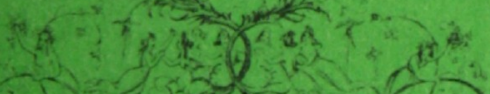

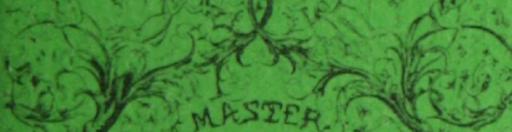

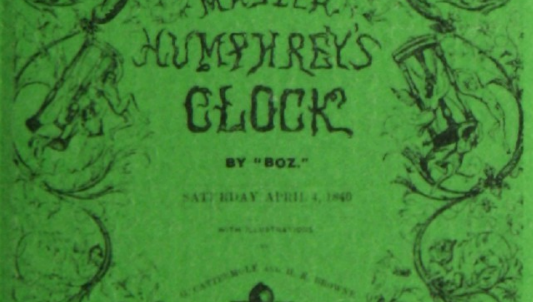

(3) $\frac{a}{4}$ a

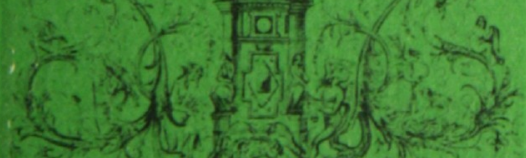
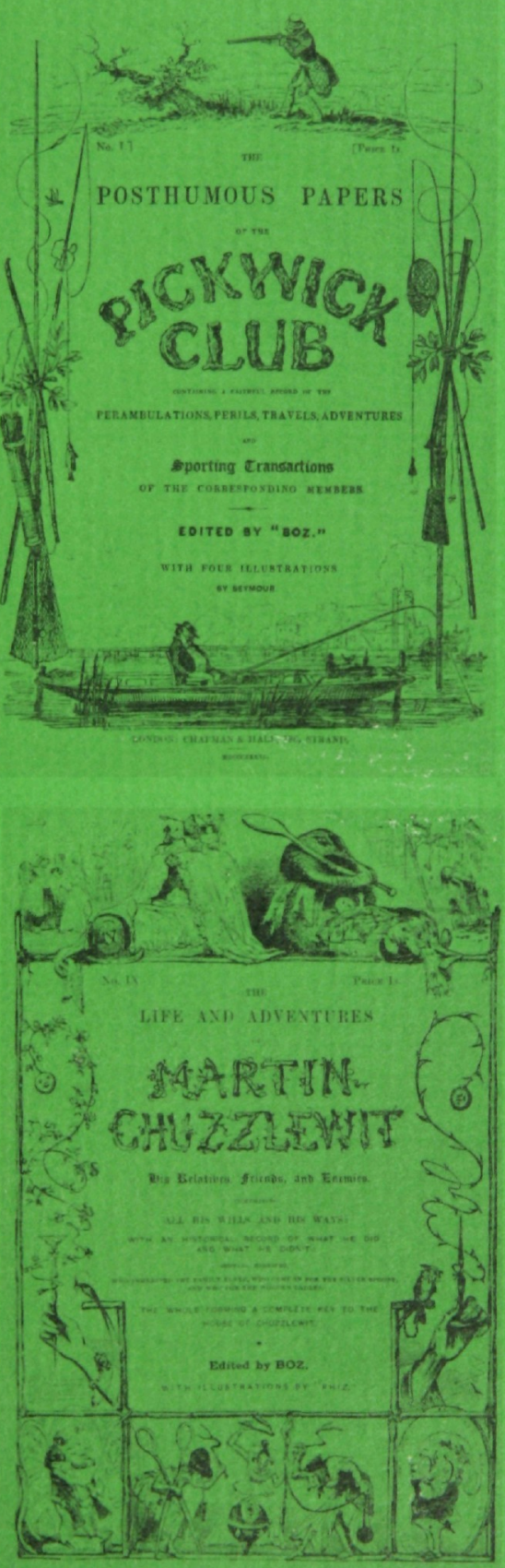
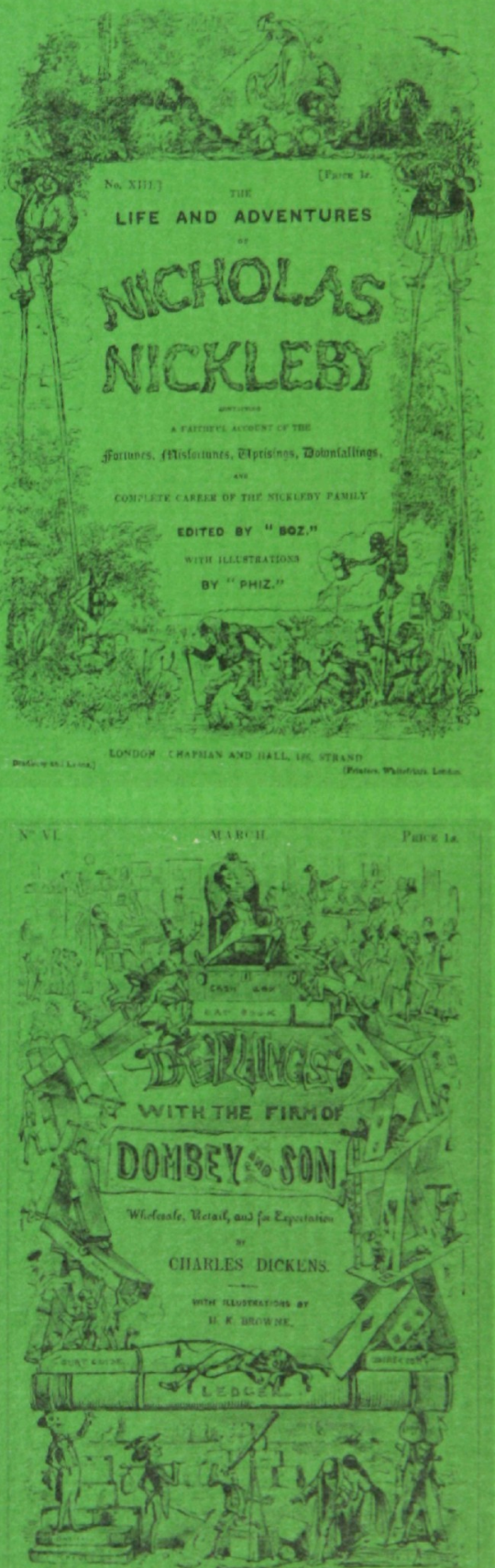


\section{CHARLES DICKENS and $\mathrm{His}$ \\ Original Illustrators \\ By Jane R. Cohen}

Even casual readers of Charles Dickens have always recognized Mr. Pickwick, Fagin, and Scrooge when they see them in pictures, though they may not know the names of the artists who first portrayed them. For better or worse, consciously or unconsciously, our conception Dickens's work seems ineluctably tied to the representations of his characters and scenes by the eighteen draftsmen with whom he variously and closely worked.

In unidertaking to treat systematically comprehensively for the first time in this century Dickens's personal and professional relations with the first illustrators of his books, Dr. Cohen proceeds on the basis of her conviction that knowledge of these artists and their special contributions is essential to a rounded understanding of the novelists's life and works, and argues that the indivisible blend of historical, psychological, aesthetic, and technical facts that shaped representative illustrations serves best to elucidate them.

As Dr. Cohen demonstrates, Dickens himself left abundant testimony to his intense involvement in most of the nearly nine hundred original illustrations to his books; and the drawings were a part of the initial publication of nearly all of his major works from Sketches by $\mathrm{Boz}$ of 1836 to The Mystery of Edwin Drood of 1870 . He had close personal as well as professional relationships with many of the eighteen artists who worked with him. He was highly susceptible to being disappointed in the illustrations to his books; but even when his reputation had become secure, his sales steady, and his audience sufficiently literate to permit him to publish his texts unadorned (as some critics urged that he do), he usually retained the pictorial format - clearly convinced, despite the difficulties of coordinating pictures and text, of its advantages to himself, to his publishers, to a less extent to his illustrators, and above all to his readers. Dickens had, in facl, revolutionized the publication of new fiction between 1836 and 1870 when he issued The Pickwick Papers in illustrated serial form - an enormously successful commercial venture that caused other authors and publishers to rush to emulate it. 


CHARLES DICKENS AND HIS ORIGINAL ILLUSTRATORS 

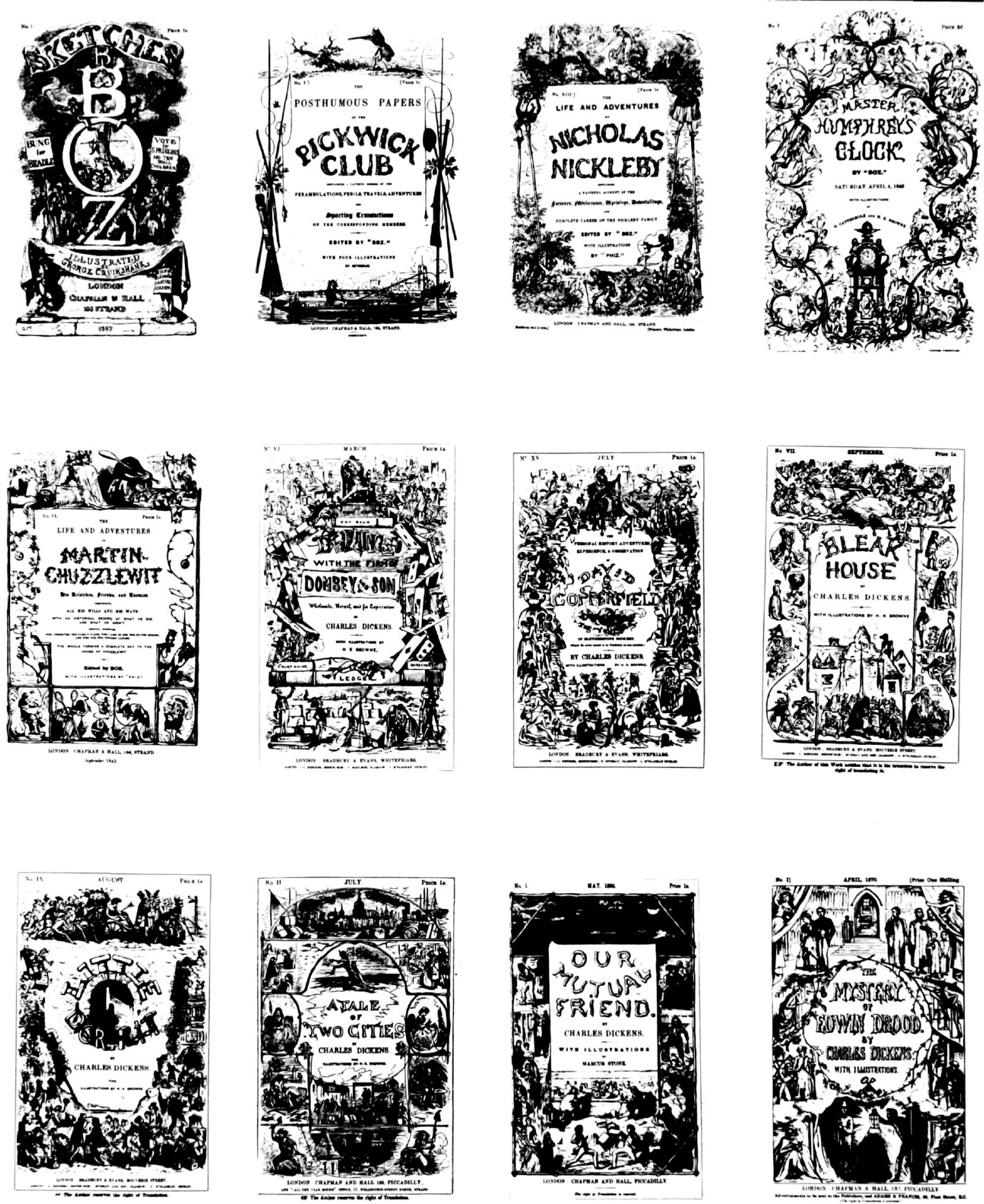

Wrappers for the Novels of Charles Dickens First Published in Illustrated Monthly Parts. The Nonesuch Dickens. Woodcuts. $8^{3 / 4} 4^{\prime \prime} \times 5^{3 / 4}{ }^{\prime \prime}(22.2 \times 14.6 \mathrm{~cm})$. From the author's library. 


\title{
CHARLES DICKENS \\ and His Original Illustrators
}

\author{
JANE R. COHEN
}


Copyright $\mathcal{O} 1980$ by the Ohio State University Press All Rights Reserved.

Library of Congress Cataloging in Publication Data

Cohen, Jane R. 1938-

Charles Dickens and his original illustrators.

Bibliography: p.

Includes index.

1. Dickens, Charles, 1812-1870-Friends and associates. 2. Dickens, Charles, 1812-1870-Illustrations. 3. Illustrators-Great Britain-Biography. 4. Novelists, English-19th century-Biography. 1. Title. $\begin{array}{lrr}\text { PR4586.C6 } 623^{\prime} .8 & \mathbf{7 9 - 2 1 5 7 0}\end{array}$ ISBN 0-8142-0284-6 
For Steven, Adam and Rosie 



\section{CONTENTS}

List of Illustrations viii

Preface xi

Acknowledgments $\mathrm{xv}$

List of Abbreviations xix

Chronology xxi

Introduction: Dickens and the Rise of the English Illustrated Novel after $1836 \quad 3$

\section{Part One: Dickens and His Early Illustrators}

1. George Cruikshank 15

2. Robert Seymour 39

3. Robert Buss 51

Part Two: Dickens and His Principal Illustrator

4. Hablot Browne 61

\section{Part Three: Dickens and His Other Illustrators}

The Other Illustrators of Master Humphrey's Clock

5. George Cattermole 125

6. Samuel Williams 135

The Illustrators of the Christmas Books

7. John Leech 141
8. Richard Doyle 152

9. John Tenniel 155

10. Daniel Maclise 159

11. Edwin Landseer 174

12. Clarkson Stanfield 179

13. Frank Stone 186

The Illustrators of Pictures from Italy and A Child's History of England

14. Samuel Palmer 193

15. Francis Topham 197

The Illustrators of Our Mutual Friend and The Mystery of Edwin Drood

16. Marcus Stone 203

17. Charles Collins 210

18. Luke Fildes 221

Conclusion: Dickens and the Decline of the English Illustrated Novel after 1870229

Appendix: Dickens and His Would-Be Illustrator: William Thackeray 235

Notes 237

Selected Bibliography 277

Index 289 


\section{LIST OF ILLUSTRATIONS}

Frontispiece. Wrappers for the novels of Charles Dickens first published in illustrated monthly parts

1. Richard Doyle, Sketch of the distribution of Master Humphrey's Clock, Number 3, April 16, 1840

2. Daniel Maclise, Portrait of George Cruikshank, 1833

3. George Cruikshank, 'Public Dinners'

4. After William Hogarth, A Jewish Peddler. Detail from 'The Election Series,' plate 2, Canvassing for Votes

5. George Cruikshank, Fagin. Detail from 'Oliver's reception by Fagin and the boys'

6. George Cruikshank, Self-portrait. Detail from 'George Cruikshank frightening Society'

7. George Cruikshank, Fagin. Detail from 'Fagin in the condemned Cell'

8. George Cruikshank, Sketch portrait of Dickens, 1837

9. George Cruikshank, Lord Bateman

10. William Thackeray, Lord Bateman

11. Richard Doyle, Lord Bateman. Detail from title page for "The Loving Ballad of Lord Bateman"

12. George Cruikshank, Sketch of the artist with Mrs. Gamp, 1847

13. George Cruikshank, Sketch for tailpiece to "A Letter from Hop-o'-My-Thumb to Charles Dickens"

14. Robert Seymour, Unpublished self-portrait miniature

15. Robert Seymour, Unpublished portrait miniature of Mrs. Jane Holmes Seymour

16. Robert Seymour, Thin prototype of Mr. Pickwick, 1833

17. Robert Seymour, Fat prototype of Mr. Pickwick, 1833

18. Robert Seymour, Mr. Pickwick, March, 1836. Detail from 'Mr. Pickwick addresses the Club'

19. Robert Buss, Unused study for Mr. Pickwick, May, 1836

20. Robert Buss, Unused study for Mr. Pickwick, May, 1836

21. Hablot Browne, Mr. Pickwick, June, 1836. Detail from 'First appearance of Mr. Samuel Weller'

22. Robert Seymour, Unsatisfactory sketch for 'The dying Clown'

23. Robert Seymour, Altered sketch for 'The dying Clown'

24. Robert Seymour, 'The dying Clown'

25. Hablot Browne, 'The dying Clown'

26. Robert Buss, Self-portrait, ca. 1837

27. Robert Buss, 'May-day in the Evening'

28. George Cruikshank, 'The First of May'

29. Robert Buss, Unpublished studies of the Pickwickians
30. Robert Buss, Unpublished sketch for "The fat boy awake on this accasion only

31. Robert Buss, Unpublished final sketch for 'The fat boy awake on this occasion only'

32. Robert Buss, 'The fat boy awake on this occasion only'

33. Hablot Browne, 'The fat boy awake on this occasion only'

34. James Abbott McNeill Whistler, Unpublished sketch of Mrs. Wardle and the fat boy, ca. 1854

35. Robert Buss, 'Dickens's Dream'

36. Artist Unknown, Portrait of Hablot Knight Browne

37. Hablot Browne, "The middle-aged lady in the doublebedded room,' 1836

38. Hablot Browne, "The middle-aged lady in the doublebedded room,' 1838

39. Artist Unknown, Portrait of Dickens, 1837

40. Attributed to Hablot Browne, 'King Pickwick'

41. Hablot Browne, Portrait of Mary Hogarth, 1837

42. Hablot Browne, Ralph Nickleby. Detail from 'Mr. Ralph Nickleby's first visit to his poor relation'

43. Hablot Browne, Squeers. Detail from "The Yorkshire Schoolmaster at the "Saracen's Head"'

44. Hablot Browne, Master Wackford Squeers. Detail from 'The breaking-up at Dotheboy's Hall'

45. Hablot Browne, Arthur Gride. Detail from "The Consultation'

46. Hablot Browne, Mr. Bray. Detail from Nicholas makes his first visit to the lodgings of Mr. Bray'

47. Hablot Browne, Sir Mulberry Hawk, Lord Frederick Verisopht, Pluck, and Pyke. Detail from 'Miss Nickleby introduced to her Uncle's friends'

48. Hablot Browne, 'The children at their cousin's grave'

49. George Cattermole, 'Nell and the Old Man looking back at London'

50. John Martin, 'The Celestial City'

51. Hablot Browne, 'Quilp and Nell'

52. Hablot Browne, 'Quilp at the tavern window'

53. George Cattermole, 'Quilp in the Old Curiosity Shop' 76

54. George Cattermole, 'The best apartment' 79

55. Hablot Browne, 'Mr. Chester lounging' 79

56. Hablot Browne, 'Mr. Chester dressing' 79

57. Hablot Browne, 'Mr. Chester's chair' 79

58. Hablot Browne, 'Mr. Chester with Mrs. Varden' 79

59. George Cattermole, 'Miss Haredale walking'

9

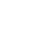


60. Hablot Browne, 'Mr. Chester leaving the Maypole'

61. Hablot Browne, 'Mr. Chester and Edward'

62. George Cattermole, 'In Westminster Hall'

63. Hablot Browne, 'Mr. Haredale draws'

64. Hablot Browne, 'Sir John Chester's bedchamber'

65. George Cattermole, 'Death of Sir John'

66. Hablot Browne, Sketch of the artist and Charles Lever

67. Hablot Browne, 'Meekness of Mr. Pecksniff, and his charming daughters'

68. Hablot Browne, 'Martin meets an acquaintance at the house of a mutual relation'

69. George Cruikshank, 'The Pawnbroker's Shop'

70. George Cruikshank, 'Mrs. Toddles'

71. Honoré Daumier, 'La Garde-Malade'

72. Hablot Browne, Mrs. Gamp. Detail from 'Mrs. Gamp propoges a toast'

73. Hablot Browne, 'The thriving City of Eden as it appeared on paper

74. Hablot Browne, "The thriving City of Eden as it appeared in fact'

75. Hablot Browne, Studies for Mr. Dombey

76. Hablot Browne, Sketch for 'The Dombey Family'

77. Hablot Browne, Sketch for 'The Dombey Family'

78. Hablot Browne, 'The Dombey Family'

79. Hablot Browne, 'Paul and Mrs. Pipchin'

80. Hablot Browne, 'Major Bagstock is delighted to have that opportunity

81. Hablot Browne, 'Mr. Dombey introduces his daughter Florence'

82. Hablot Browne, 'Coming home from Church'

83. Hablot Browne, 'Mrs. Dombey at Home'

84. Hablot Browne, 'Mr. Dombey and his "confidential agent",

85. Hablot Browne, 'Florence and Edith on the Staircase'

86. Hablot Browne, 'Mr. Carker in his hour of triumph'

87. Hablot Browne, 'Another wedding'

88. Hablot Browne, Sketch for 'I make myself known to my Aunt'

89. Hablot Browne, Sketeh for 'I make myself known to my Aunt'

90. Hablot Browne, Sketches for 'I make myself known to my Aunt'

91. Hablot Browne, 'I make myself known to my Aunt'

92. Hablot Browne, 'The friendly Waiter and I'

93. Hablot Browne, 'Changes at Home'

94. Hablot Browne, 'The momentous interview'

95. Hablot Browne, "Traddles and I, in conference with the Misses Spenlow'

96. Hablot Browne, 'Our Housekeeping'

97. Hablot Browne, 'My child-wife's old companion'

98. Hablot Browne, 'A Stranger calls to see me'

99. Hablot Browne, 'I make the acquaintance of Miss Mowcher'

100. Hablot Browne, 'Martha'

101. Hablot Browne, 'Mr. Peggotty's dream comes true'

102. Hablot Browne, 'Attorney and Client, fortitude and impatience'

103. Hablot Browne, 'Coavinses'

104. Hablot Browne, 'Tom all alone's'

105. John Brown, 'Mint-street, looking towards High-street,
Southwark'

106. Hablot Browne, 'Sunset in the long Drawing-room at Chesney Wold'

107. Hablot Browne, 'Shadow'

108. Hablot Browne, 'The Night'

109. Hablot Browne, 'The Morning'

110. Hablot Browne, Unpublished sketch for 'The Mausoleum at Chesney Wold'

111. Hablot Browne, 'The Birds in the Cage'

112. Hablot Browne, 'The Travellers'

113. Hablot Browne, 'The Room with the Portrait'

114. Hablot Browne, Frontispiece, Little Dorrit

115. Hablot Browne, Title Page, Little Dorrit

116. Hablot Browne, 'The Sea Rises'

117. Hablot Browne, 'The rioters at Moorfields'

118. Hablot Browne, 'Mr. Varden and the Mob'

119. Hablot Browne, 'L'Allegro,' 1837 and 'Il Penseroso,' 1879

120. Artist Unknown, Portrait of George Cattermole

121. George Cattermole, 'The ruin in snow'

122. George Cattermole, 'Nell dead'

123. George Cattermole, Tailpiece to The Old Curiosity Shop

124. Hablot Browne, 'Quilp at the Gateway'

125. Richard Lane, Portrait of Dickens, ca. 1842

126. George Cattermole, 'The Maypole Inn'

127. George Cattermole, 'The Turret'

128. Samuel Williams, 'Nell in bed'

129. John Leech, Drawing of Tom Smart and the Chair

130. John Leech, First sketch for 'Richard and Margaret'

131. John Leech, Canceled print of 'Richard and Margaret'

132. John Leech, Altered sketch for 'Richard and Margaret'

133. John Leech, 'Richard and Margaret'

134. John Leech, 'The Night of the Return'

135. John Millais, Portrait of John Leech, 1854

136. John Leech, Sketch portrait of Dickens, ea. 1856

137. John and Charles Watkins, Portrait of Richard Doyle

138. Richard Doyle, 'The Dinner on the Steps'

139. Richard Doyle, Caricatures of Dickens and Forster

140. G. I. R., Sketch portrait of John Tenniel, 1844

141. John Leech, 'Scrooge's third Visitor'

142. John Tenniel, 'The Spirit of Christmas Present'

143. E. M. Ward, Portrait of Daniel Maclise, 1846

144. Attributed to Daniel Maclise, Unpublished portrait of Dickens as a parliamentary reporter, ca. 1837

145. Daniel Maclise, Portrait of Dickens, 1839

146. Daniel Maclise, Sketch of the apotheosis of Dickens's raven

147. Hablot Browne, 'Barnaby and the Raven'

148. Daniel Maclise, Portrait of the Dickens children, 1842

149. Daniel Maclise, Sketch of Devonshire Terrace

150. Daniel Maclise, 'Waterfall at St. Nighton's Keive, near Tintagel,' 1842

151. Daniel Maclise, Portrait of Mrs. Charles Dickens, ca. 1846

152. Daniel Maclise, Portrait of Mrs. Charles Dickens

153. Daniel Maclise, Sketeh portrait of Georgina Hogarth, Catherine Dickens, and Charles Dickens, 1843

154. Daniel Maclise, 'Nell and the Sexton'

155. Daniel Maclise, Frontispiece to The Chimes
110

111

111

112

112

113

115

116

116

117

117

119

119

119

122

126

129

129

130

130

131

132

132

136

142

144

144

145

145

148

150

151

152

153

154

156

157

157

159

160

161

161

161

162

162

164

165

165

166

166

167 
156. Daniel Maclise, Sketch of The Chimes reading, December, 1844

157. Daniel Maclise, Frontispiece to The Cricket on the Hearth

158. Daniel Maclise, Frontispiece to The Battle of Life

159. Daniel Maclise, Sketch of Forster as Kitely and Dickens as Bobadil, 1845

160. Carl Vogel von Vogelstein, Unpublished portrait of Landseer, July 5, 1834

161. Richard Doyle, 'Chirp the First'

162. Edwin Landseer, 'Boxer'

163. John Leech, Boxer. Detail from 'The Dance' 177

164. Clarkson Stanfield, 'The Carrier's Cart'

165. John and Charles Watkins, Portrait of Clarkson Stanfield

166. Clarkson Stanfield, "The Old Church"

167. Clarkson Stanfield, 'The Nutmeg-Grater'

168. Clarkson Stanfield, 'The Lighthouse'

169. Clarkson Stanfield, 'The Logan Rock, Cornwall,' 1842

170. Clarkson Stanfield, 'S.S. Britannia'

171. Artist Unknown, Portrait of Frank Stone

172. Frank Stone, Sketch for 'Milly and the Old Man'

173. Frank Stone, 'Milly and the Old Man'

174. John Linnell, Portrait of Samuel Palmer

175. Samuel Palmer, Sketch for 'The Villa d'Este at Tivoli, from the Cypress Avenue'

176. Samuel Palmer, 'The Villa d'Este at Tivoli, from the Cypress Avenue'

177. Samuel Palmer, Unpublished drawing of 'View in the Campagna'

178. Artist Unknown, Francis W. Topham. Detail of Mr. Topham as 'T. Homespun in 'Artists' Amateur Performance of "The Heir-at-Law," St. James's Theatre -The Epilogue'
179. Francis W. Topham, Frontispiece for A Child's History of England, vol. 2

180. Artist Unknown, Photograph of Marcus Stone, 1856

181. Marcus Stone, Sketch for the wrapper of Our Mutual Friend

182. Marcus Stone, "The Person of the House and the Bad Child'

183. Marcus Stone, 'Pa's Lodger and Pa's Daughter'

184. Marcus Stone, 'Mr. Boffin Does the Honours of the Nursery Door'

185. Marcus Stone, Unpublished sketch for 'Eugene's Bedside'

186. Marcus Stone, 'Eugene's Bedside'

187. Marcus Stone, Portrait of Kate Dickens Collins, 1865

188. John Millais, Portrait of Charles Collins, 1850

189. Charles Collins, Sketch for the wrapper of The Mystery of Edu'in Drood

190. Charles Collins, Wrapper for The Mystery of Edwin Drood

191. Charles Collins, Sketch for the opium den scene

192. Charles Collins, Sketch for the opium den scene

193. Charles Collins, Unpublished sketch for the opium den scene

194. Luke Fildes, 'In the Court'

195. Artist Unknown, Photograph of Luke Fildes, 1866

196. Luke Fildes, 'Houseless and Hungry'

197. Luke Fildes, 'Jasper's Sacrifices'

198. Luke Fildes, Unused sketch of 'In Rochester Cathedral'

199. Luke Fildes, 'The Empty Chair'

200. Vincent van Gogh, 'Gauguin's Chair,' 1888

201. Daniel Maclise, Sketch portrait of William Makepeace Thackeray, 1835

202. William Makepeace Thackeray, Sketch for the wrapper of Sketches by Boz 


\section{PREFACE}

In her survey of Dickens for Lionel Stevenson's guide to research in Victorian Fiction (1964), Ada Nisbet remarked that the history of the novelist's relationships with his original illustrators had never received proper scholarly attention. She was, of course, judging by current professional standards. The subject had, in fact, received considerable attention in the nineteenth century, but largely from gentleman scholars who wrote before studies of native or any modern literature and art became academic disciplines. The best of these writers, whatever their pedantic deficiencies, brought to their work remarkable compensating advantages: many were contemporaries or friends of Dickens or some of his first artists; they were often artists or collectors themselves; they had readier access to their materials, whether in public or private hands; and they conveyed the results of their researches or recollections with a selfless enthusiasm. Their work forms a more substantial foundation than has been acknowled ad $_{\mathrm{f}}$ in present studies, many of which are specialized elaborations of what was taken for granted or casually known to our Victorian predecessors. A brief review of their contributions should make their value clear.

In Dickens's lifetime, some of the most perceptive remarks about his artists and illustrations were made in published reviews and essays, as well as privately in autobiographical materials-letters, diaries, memoirs-some of which are just now coming to light. Even before Dickens's death in 1870, family members and other informed observers showed considerable interest in his first artists; as often for their own sake as for their association with the author. The son and namesake of Robert Seymour, for example, probably provided the brief overview of his father's life (1867) that also affects our interpretation of Robert Buss's account and Joseph Grego's public history of Dickens and the three original Pickwick illustrators (1899). Buss's own record of his career was written for his family, who made its contents known to J. W. T. Ley, among others, which inspired many Dickensian articles as well as its publication in Ley and Walter Dexter's The Origin of Pickwick (1936), and which must affect all future accounts of this particular artist. George Cruikshank inspired numerous appreciations in his lifetime, the most notable being the one by Thackeray (1840). He was also the subject of Blanchard Jerrold's full-scale biography (1883) as well as monographs and articles by William Bates, John Bursill, Walter Hamilton (all in 1878), Frederick Stephens (1891), G. S. Layard $(1889,1893,1907)$, and W. H. Chesson (1903), in addition to massive bibliographies by George Reid (1871), Frederick Marchmont (1897), Richard Douglas (1903) and, above all, Albert Cohn (1914, 1915, 1924). Hablot K. Browne (Phiz) engendered less industry but was treated in a brief pamphlet by Frederick G. Kitton (1882), in books by D. C. Thomson (1884) and by his son Edgar (1913), and necessarily figured in almost every account of Dickensian illustration. Daniel Maclise found a biographer in W. Justin O'Driscoll (1883), and John Leech inspired a brief account by Kitton (1883), two large volumes by William Frith (1891), and a small one by Gordon Tidy (1931). Clarkson Stanfield was considered by Clark Cumberland because of his friendship with Dickens (1918), and Edwin Landseer was taken up for his own sake by Moses Sweetser (1879) and James Manson (1902) among others. Within their lifetimes, Marcus Stone was treated by A. L. Baldry (1896), Luke Fildes by D. C. Thomson (1895), and John Tenniel by Punch staffers (1901). Though George Cattermole, Samuel Williams, Richard Doyle, Frank Stone, Francis Topham, and Charles Collins never inspired long studies, each is mentioned in the records of the era as well as in many accounts of Dickens, and all are guaranteed continued immortality by their inelusion in the Dictionary of National Biography (1885-1901 and supplements). The culmination of all these nineteenth-century studies was Frederick G. Kitton's Dickens and His Illustra- 
tors (1899), the ancestor of this present book. In his rich volume, Kitton, a former Graphic apprentice, etcher, and writer, who devoted himself to Dickens-particularly to the art inspired by his life and works-utilized all available materials, as well as interviews with those of the original illustrators still living or their descendants, in his fairminded consideration of his subjects

With the publication of Kitton's work, interest in Dickensian illustration crested and then ebbed. Efforts of the Dickens Fellowship, however, which Kitton helped to found in 1902, kept aspects of the subject alive in the early decades of the twentieth century, culminating in Ley's The Dickens Circle (1927), which included accounts of the author's personal relationships with his first artists. The next burst of concerted activity occurred in the 1930's, preparing the ground for years to come. Retrospectus and Prospectus: The Nonesuch Dickens (1937) (also known as Nonesuch Dickensiana) announced the publication of a limited edition of Dickens's collected works and letters, featuring the illustrations from the original plates and blocks to be distributed to the 877 subscribers; the slim volume also included Arthur Waugh's lively, if unscholarly, survey of "Charles Dickens and His Illustrators," as well as Thomas Hatton's useful and generally reliable list of all the original illustrations done under the author's supervision. This edition, together with the widely accessible film adaptations of the author's most popular novels in the 1930's and 1940's, heralded a Dickens revival in general and renewed interest in the graphic aspects of his work in particular, though that was longer in coming. During the Second World War, while readers assimilated the seminal sociological and psychological essays of George Orwell (1940) and Edmund Wilson (1941) that were to shape the mainstream of subsequent studies of the author, T. W. Hill helped to carry on The Dickensian with brief but detailed analyses of each of Browne's illustrations for Dombey and Son, David Copperfield, and Bleak House (1942-44), which anticipated the more sophisticated iconographical analyses of our day.

After the peace in 1945, the Dickens revival recommenced. Those interested in his first artists were now aided by an alliance of publishers and scholars. The New Oxford Illustrated Dickens (1947-58) made the original illustrations far more widely available than had the Nonesuch edition. Long-range plans were made in the 1950's for the scholarly Pilgrim edition of Dickens's letters, as well as for the Clarendon edition of his novels, and the less costly but well-edited Penguin paperbacks, both of which included commentary on, as well as reproductions of, the first illustrations. The first volumes of all these editions began to appear soon after Nisbet's remarks in 1964 . Thus challenged and assisted, scholarly interest in Dickensian illustration began to manifest itself in exhibits and articles, followed by books.

Cruikshank once again received the lion's share of attention. Professors William F. Axton and Richard Vogler organized and catalogued an exhibition of "The Illustrious George" at the University of Louisville in 1968; William Feaver and his associates at the Victoria and Albert Museum performed the same services on a larger scale for the British in 1974. Between these two occasions appeared a spate of essays: mine on the artist's complex relations with Dickens (1969); Professor J. Hillis Miller's seminal analysis of the pair's brand of realism in Sketches by Boz and Oliver Twist, together with David Borowitz's account of the artist's private life (1970, pub. 1971); and a "Revaluation" of Cruikshank from many perspectives in the Princeton University Library Chronicle (1973-74), edited by Professor Robert L. Patten, who is now engaged in writing a scholarly book on the artist, as are some of his contributors. Two generalist books, one by Hilary and Mary Evans about Cruikshank's life and career, the other by John Wardroper about his caricatures, have recently appeared (1978). Robert Seymour was featured in articles by Fred Cutler and by me in 1971. Individual and sequential illustrations by Hablot Browne have been the object of perceptive commentary in various articles by Patten, as well as more extensive, if not always convincing, psychoanalytic and inconographical analyses by Professor Michael Steig. Steig's comprehensive book on Dickens's principal illustrator has just appeared (1978), too late to be consulted for this study, as has John Buchanan-Brown's volume of representative works by "Phiz" with a valuable introduction to his life and career (1978). Browne also necessarily commanded a good deal of attention in three other studies of varying length and consequence: Nicolas Bentley's rapid survey of "Dickens and His Illustrators" in E. W. F. Tomlin's centennial volume (1970); Queenie Leavis's provocative, though sometimes arbitrary, chapter on "The Dickens Illustrations: Their Function," which concluded her and F. R. Leavis's Dickens the Novelist (1970); and, by far the most important, John Harvey's Victorian Novelists and Their Illustrators, which dealt with Cruikshank and Browne, and their work for authors other than Dickens, as weil as Thackeray's selfillustrated novels (1971). Meanwhile, further work on Browne may emerge from the dissertations of Drs. Geoffrey Hemstedt (1971), Nancy Hill (1972), and Robert Kaufman (1974).

At the same time, many of Dickens's other original artists have been revaluated, more on their own account than for their association with Dickens. Cattermole's relations with 
Dickens were reviewed in my article (1970). Richard Ormond's perceptive discussion of Maclise (1968) heralded his and John Turpin's comprehensive exhibit and catalogue of his work (1972). Dr. Michael Slater took brief but perceptive notice of all the illustrators of the Christmas books in his Penguin edition (1971); Michael Patrick Hearn focused on Leech in his annotated edition of The Christmas Carol (1977); Campbell Lennie has written a new popular biography of Landseer (1976); and Philip Skottowe is working on Stanfield. Raymond Lister has reinforced the current popularity of Palmer with books on his period (1966), his etchings (1969), and his life (1974); as well as a scholarly edition of his letters (1974); and Professor David Paroissien discussed his work for Dickens in his elegant edition of Pictures from Italy (1973). Dr. Ira Simmons devoted part of his dissertation (1972) to Marcus Stone, and the remainder to Luke Fildes, who has also been the subject of a biography by his son (1968) and, together with Collins, of articles (1974-75, 1977) by Margaret Cardwell, editor of the Clarendon Edwin Drood (1972). Meanwhile, the achievement of Dickens and his first artists can be viewed in better historical perspective because of the splendid catalogue issued by Graham Reynolds and his staff at the Victoria and Albert Museum for the Dickens Centenary exhibit (1970); the monumental works by Mary Dorothy George (1967) and Professor Ronald Paulson (1970, 1971) on Hogarth and his influence on English artists and writers; and the surveys of Victorian book illustration from different perspectives (1971) by Percy Muir, Geoffrey Wakeman (1973), and Professor Gordon N. Ray (1976). The many obligations of the present book to all the works noted here, as well as others cited elsewhere, are, I trust, adequately acknowledged throughout.

This book aspires to achieve in our century what Kitton's did in his: to treat comprehensively Dickens's personal and professional relations with his first artists. Its initial missionary purpose- to convince present and future readers that knowledge of the author's original illustrators and their contributions is essential to a rounded understanding of his life and works-is still necessary as far as the general reader is concerned, if not the specialist. Its argument is necessarily more cyclical than linear, but its development, in all its rich variety, should add valuable dimensions and correctives to our present perceptions. Though some of my "new" evidence and conclusions have been anticipated by colleagues working in greater depth on single artists or illustrated works, there still exists an obvious need for a systematic reconsideration of the subject in the light of accumulated materials and developments in modern scholarship. Such a study, of course, can claim to be only the latest rather than the last word; a definitive treatment must await the publication of all twelve volumes of the monumental Pilgrim edition of Dickens's letters, only four of which have appeared to date. In the meantime, this book hopes to advance knowledge while providing its readers with a resource and reference work that incorporates past and present thought on the subject, utilizes updated information and current analytic modes, and anticipates directions that might well be pursued in future studies.

The particular organizational and philosophical prineiples that have shaped this book should be known to its readers. In general, I have modeled the form on that of Kitton, as the similarity in our titles intentionally suggests. Like Kitton, I treat each of Dickens's first artists in separate, but interlocking, chapters, though he chose to mention Williams only briefly in his Cattermole discussion and made Collins share space with Fildes. I share Kitton's implicit belief that a biographical framework, whether thin as in the Browne or ample as in the Maclise chapters, for example, best contains the indivisible blend of historical, psychological, aesthetic, and technical factors that shaped representative illustrations and thus best elucidates them. The varying chapter lengths indicate the relative importance of the artist to the subject as a whole. But within each chapter, the balance between an artist's personal and professional dealings with Dickens has necessarily been determined by the available evidence. These two spheres are more or less balanced in the chapters on Cruikshank and Marcus Stone, for example, whereas the professional element dominates in the chapters devoted to Browne or Tenniel, just as the personal looms larger in the discussion of Maclise and Leech; the author's extraordinary effect on Seymour and Buss, though he worked with each briefly and saw nothing of them socially, puts them in a separate category altogether.

In assembling and selecting from the massive, often rare, and usually widely scattered materials, here brought to bear on the subject for the first time, I have thought, like Kitton, that the pertinent anecdote or popular legend need not take second place to the rare or unpublished document, if it alters, reinforces, or rounds out our view. My reliance on quotation from contemporary comments, aside from their intrinsic value, helps demonstrate repeatedly, yet variously, that the illustrations played an integral part in the response of the first and, to a lesser extent, successive readers of Dickens's works. The chapters follow one another in roughly the chronological order in which the artists worked with the author. Efforts have been made to minimize the inevitable redundancy that must occur, for example, in discussing the three Pickwick illustrators, the seven who embellished the five Christmas books, and the 
two involved in Edwin Drood. Finally, like Kitton, I have included in the study only the work these artists did for Dickens, except where their other work is relevant to their relationship with the author. Unlike my predecessor, I have not discussed the illustrations for Dickens's novels by other artists during or after his lifetime, a subject that deserves separate study in its own right.

The several other ways in which this book departs from Kitton's practice stem from the increased volume of material on the subject since 1899 and the heterogeneity of the audience. The accumulated evidence and greater perspective of the eight decades since Kitton wrote make it possible not only to deal more profoundly with each artist and his relations with Dickens, but to attempt to relate their achievement to the history of the illustrated novel in England from the eighteenth century to the present. Though this territory, especially the period before Pickwick, has been frequently surveyed in our time, it has not yet been studied from this particular and undoubtedly useful viewpoint, general, retrospective, and speculative as it must be.

With regard to the graphic reproductions, I have generally used portraits of the artists, when available, that were made during or near to the years of their closest association with Dickens. Some of the other reproduced visual materials relevant to Dickens's life or works are, to my knowledge, previously unpublished or almost unknown; but many of the others, though widely familiar and available elsewhere, have been found worthy of inclusion because they were especially meaningful to our Victorian principals. The present locations of these works, together with the original ones in Dickens's part-issues or volumes, have been provided whenever possible, as has data about their media and size, usually by their current individual or institutional owners. To further assist interested readers and scholars, so often more remote from one another and from central repositories of material than they were in Kitton's day, I have assembled the first comprehensive, though not exhaustive, bibliography on this field of inquiry. For the same reason, I have supplied abundant footnotes, which suggest still other materials, supply documentation even for facts or theories with which Dickensians will be thoroughly acquainted, and register, less disruptively than in the text, most of my disagreements with other writers, as well as corrections of their occasional errors. Whatever the scholarly advances of this book over the work of Kitton and other "old-fashioned" writers, it cannot improve on the tolerant objectivity of their studies of the subject. I hope it may at least emulate their selfless and enthusiastic appreciation of a collective achievement that remains unique in our common cultural heritage.

Cambridge, Massachusetts

J.R.C. 


\section{ACKNOWLEDGMENTS}

My debts are as numerous as Dickens's illustrations and as difficult to acknowledge adequately. My outstanding obligation is to Professor Edgar Rosenberg, whose professional brilliance and personal kindness inspired me long after my experience of his teaching literature at Harvard. Professor Harry Levin encouraged my study of book illustration during and after his stimulating seminar on the Victorian humourists. He and Professor Monroe Engel, whose course on problems in the novel had been provocative, supervised my dissertation on Dickens and his first artists, which combined these interests. At this time, the late Professor Noel Peyrouton, Pilgrim editors Graham Storey and the late Madeline House provided indispensable help, as has Professor Laurence Senelick from the beginning, and Professor Robert L. Patten and Dr. Michael Slater at later stages. The published results of these early explorations-a seminar paper on The Mystery of Edwin Drood in Dickens Studies (1970), dissertation chapters on Cruikshank and Seymour in the Harvard Library Bulletin (1969 and 1971) and on Cattermole in the first Dickens Studies Annual (1970)-are recycled here by permission of Emerson College, Harvard University, and the Southern Illinois University Press, respectively. These earlier versions, however, are superseded in all respects by their counterparts in this book. The discussion of Sir John Chester in the present Browne chapter first appeared in The Dickensian (1976) and is here reprinted with slight alteration by permission of the Honourable Editor.

I am deeply grateful to the Radcliffe Institute, which granted me a fellowship in 1972-74 to write this book and provided invaluable supports before as well as after that period. Former and present staff members-Alice K. Smith, Susan S. Lyman, and Patricia Graham, Hilda Kahne, Doris Lorentzen, Jean Hammacher, and Nancy Downey-went far beyond merely implementing the institute's Woolfian ideals. I was also able to benefit fully from their support because of the added help of Wanda Beard, Meg Campbell,
Sondra Workman Hanley, Eliot and Ann Quill, Rebecca Ruggles, Lois Slayman, Olga Smulders, and, above all, Wendy Young Miyaji.

My book depends heavily on rare materials, generously made available to me by many individuals as well as institutions. I wish to thank first those Dickens family members who so graciously provided materials and information in their possession, as well as living links to the subject matter: Cedric Dickens; Mrs. Stuart Dickens McHugh; the late Mrs. Elaine Dickens Waley; Archdeacon Michael Whinney; and, most especially, Captain Peter Dickens. I am also grateful to those collectors who have done so much to preserve the work and advance the reputations of Dickens and contemporary illustrators, and who willingly shared their knowledge and treasures with me and future readers: David J. Borowitz; Frank Bradburn; the late William J. Carlton; Professor Robert D. Fellman; Lady Dione Gibson; the late Colonel Richard E. Gimbel; Professor Gordon N. Ray; Chester M. Sawtelle; and William Self.

My debts to libraries and museums, especially those connected with Harvard University, are incalculable. I particularly wish to thank Eleanor Nicholes, former curator of the Harry Elkins Widener Collection and her staff, and her successor, Marthe Eliza Shaw, who also presides so graciously over the Houghton Library reading room, ably assisted by Deborah Kelley, Jessica Owaroff, Martha Ramsey, and Hinda Sklar. At the Houghton Library, I am also indebted to its director, Professor William Bond, as well as to Rodney Dennis and Scott Ward. At the Harvard College Library, my work was facilitated beyond any reasonable expectation by Joanna Robinson, Barbara Allsep, and Jay Willworth of the Photography Department; Barbara Dames and Ruth Hoppe of the Interlibrary Loan office; and Dr. Gerald C. Schwertfeger, the indefatigable head of the Tracing Department. At the Fogg Museum, I am especially indebted to Marjorie B. Cohn of the Conservation Department for so generously and enthusiastically sharing 
her expertise in graphics; and in the Photography Department, James Ufford, Michael Nedzweski, Barry Donahue, and Susannah Stuart, who executed my countless orders with unfailing skill and good humor.

I have also received indispensable services from staff members representing institutions both in this country and abroad, to whom I would like to express my gratitude: at the Ashmolean Museum, Ian Lowe; at the Beinecke Rare Book and Manuscript Library at Yale University, Marjorie Wynne, Christina Hansen, and Gay Gibson McDonald; at the Boston Athenaeum, Jack Jackson; at the Boston Museum of Fine Arts, Roy Perkins and Sarah Phelps; at the Boston Public Library, Sinclair Hitchings and Catherine Nicholson; at the British Library, Alison Gould; at the British Museum, Reginald Williams and Peter Moore; at the William Andrews Clark Memorial Library, William Conway; at Dickens House, Marjorie E. Pillars, the dedicated former curator, Dr. David Parker, her successor, and their accommodating staff; at the Free Library of Philadelphia, Howell J. Heaney, who can never be adequately thanked; at the Garrick Club, Betty Beesley; the Historical Society of Pennsylvania; at the Henry E. Huntington Library, Mary Isabel Fry, Virginia J. Renner, Dr. Robert Wark, and, in particular, Jean Preston; at the Library of Congress, Sam Daniel; at the City of Manchester Art Galleries, Julian Treuherz; at the New England Deposit Library, the obliging Edward W. Sweney; at the Pierpont Morgan Library, Charles A. Ryskamp, Evelyn W. Semler, Felice Stampfle, Cara Denison, Mary Laura Gibbons, and Helen Mules; at the National Portrait Gallery, London, thanks to the infinite kindness of Richard Ormond, Sally Prescott, Kathleen Lockley, and Sarah Wimbash; at the New York Public Library, Lola L. Szladits, David Parkow, Joseph Rankin, and Faye Simkin; at the Castle Museum, Nottingham, David Phillips; at the City of Portsmouth Museums and Art Gallery, Mrs. Susan Stock; at the Princeton University Library, Robert S. Fraser and Charles Greene; at the Rosenbach Foundation, Ann Bolin; at the Royal Academy of Arts Library, Christine Harding and Constance Parker; at the Royal Library, Windsor Castle, the Honourable Mrs. Jane Roberts; at the Staatliche Kunstsammlungen, Dresden, Werner Schmidt; at the Stedelijk Museum, Amsterdam, H. W. Hamel; the Toledo-Lucas Public Library; at the University Research Library, University of California at Los Angeles, Brooke Whiting; at the University of Louisville, Kentucky, Madge Hoon; at the University of North Carolina Library, Laurence F. London; at the Humanities Research Center at the University of Texas at Austin, June Moll and David J. Farmer; and at the Victoria and Albert Museum, Graham Reynolds, C. N. Kauffman,
John Murdock, and Stephen Calloway, and, above all, Anthony Burton.

I would also like to express my appreciation to the following individuals, in addition to those mentioned elsewhere, who answered inquiries, gave advice, provided materials, or in other ways facilitated this study: Janet Abramowicz; Professor Arthur A. Adrian; Rodney Merrington and June Collins for Thomas Agnew \& Sons, Ltd.; Professor Morton Bloomfield; Professor Joseph Blotner; Professor Lillian Bulwa; David Chase; Lavinia Davies and Shaunaugh Fitzgerald for P. \& D. Colnaghi \& Company, Ltd.; David Coombs for Connoisseur: Peter Davison; Aida Donald; Julian Edison; Daphne Abeel, Professor Donald Fanger; Professor Frances Fergusson; Colin Franklin; Alice Kinzler Fuld; Tracy Gilday; David R. Godine; the late John Greaves; Sheila K. Hart; Draper Hill, Margaret Hurd; Philip Hofer, Mrs. G. Rees for H. T. Jantzen, Ltd.; Professor Emeritus Edgar Johnson; Dr. Frances S. Jowell; Professor Robert and Jana Kiely; Carolyn Refsnes Kniazzeh; Tony Lee; Raymond Lister; Victor Schmalzer for Liveright Publishers; W. Lent for Maggs Brothers, Ltd.; Mary Lutyens; Melissa Marsh; Ann Louise McLaughlin; Monsignor Edward Murray; M. H. Mushlin; Bernice Shattuck for the National Geographic; Dr. Leoné Ormond; Ann Orlov; Dan Davin and Herbert F. Mann for the Oxford University Press; Marian Parry; Dudley Massey for Pickering \& Chatto, Ltd.; Professor David A. Robertson, Jr.; Irwin Rosen for Mandrake Books; Dr. Roger and Virginia Rosenblatt; the late Michael Papantonio for the Seven Gables Book Shop; Dr. Scott Schaeffer; Professor Lilian L. Shiman; Dr. Evelyn Simha; Anne Blake Smith; Nellie Clark for Walter T. Spencer, Ltd.; Professor Michael Steig; Ian Hamilton for the Times Literary Supplement; Professor Emeritus H. T. Van Vleck; Professor Martha Vicinus; Maud Wilcox; Gisela Wyzanski; Liz Zagaroff; and Dr. Ana Laura Zambrano.

Many old and new friends provided heartwarming hospitality and other kinds of assistance during my numerous research trips: in New Haven, Professors Howard Felperin, Marilyn Powell, Phyllis Rose, and Mark Rose; in Princeton, Professor Stephen and Judy Adler; in Philadelphia, Mrs. R. Parry, thanks to Perdita Buchan Connolly, and Richard and Susan Davidson Ravenscroft; in San Francisco, Joan Seegal Lenzner; in Pasadena, Professors Robert and Joan Coward, thanks to Professor Lenore O'Boyle; in Los Angeles, Professors S. Barbara Canner, Ada Nisbet, and Richard Vogler, thanks to Dr. Priscilla Shames-Oak, and Dr. Larry and Susan Diamond Johnson who know how further indebted I am to them. It is difficult to convey to Brian Rendell, Norman and Rachael Evans, and especially Victor 
Stone, what their hospitality has meant to me in England. And there is probably no way I can thank Estelle, Philip, and Amy Zimet for their lifelong, loving services in New York City.

I am deeply obligated to the following people who, in addition to their other indispensable contributions, noted throughout, read parts of this manuscript at various post-dissertation stages: Anthony Burton; Professor Jerome Buckley; Dr. Margaret Cardwell; Eleanor M. Garvey; Professor Helen Heineman; Professor Harry Levin; Raymond Lister; Richard Ormond; Professor David Paroissien; Professor Robert L. Patten; Professor Gordon N. Ray; Professor Edgar Rosenberg; Professor Laurence Senelick, Philip F. Skottowe; and, most especially, Dr. Michael Slater. I have invariably incorporated their valuable suggestions throughout the book as well as those of style also tactfully made by the late Joan Samson Carberg, Dr.
Katharine Tait, and Lynne Wakefield. Dr. Marc Saperstein meticulously transcribed English materials in my behalf in this book's earliest stage; in its later ones, Elaine F. Young indefatigably checked references and sources in London. I do not know how I could have managed throughout without the talents of Mrs. Martha Robinson, who has always done far more than impeccably type my labyrinthine manuscripts. Despite the Herculean efforts of all these individuals to prevent errors, no doubt some remain for which I take full responsibility.

I am blessed with parents who have long supported their daughter's esoteric pursuits and with parents-in-law who also have been tolerant of them. The only way I can begin to repay my husband and children for what they have contributed as this book evolved is to dedicate it to them with gratitude, with apologies, and with love. 



\section{LIST OF ABBREVIATIONS}

All page references to the work of Charles Dickens and his original illustrators, which are cited parenthetically in the text of this book, refer to their locations in The Nonesuch Dickens, edited by Arthur Waugh, Hugh Walpole, Walter Dexter, and Thomas Hatton, published in Bloomsbury by the Nonesuch Press in 1938. The Nonesuch Dickens is still the most nearly complete of all the editions of Dickens, containing three volumes of his letters in addition to his fiction, speeches, and reprinted articles, and will remain unique because of its illustrations, which, with few exceptions, were printed from the original plates or wood blocks, subsequently distributed among the original subscribers to the edition. As The Nonesuch Dickens is not easily available to readers, each chapter (and division letter or book or part number, when relevant) has been cited together with the page reference to facilitate their being located in any edition of Dickens with illustrations, such as the Oxford New Illustrated Dickens or the volumes issued to date in the Clarendon Press or Penguin series. When necessary, the original or subsequent date and place of publication of a Dickens work or illustration is supplied in a separate footnote, as are all the sources of Dickens's correspondence. The following abbreviations of Dickens's name and titles are used throughout the book:

AN American Notes (which also contains $P F I$ and CHE)

BH Bleak House

BR Barmaby Rudge

$C B$ Christmas Books (which contain A Christmas Carol (CC), The Chimes (TC), The Cricket on the Hearth (CH), The Battle of Life (BL), and The Haunted Man (HM)

CD Charles Dickens

CHE A Child's History of England (in AN volume)

$C P, 1$ Collected Papers, 1 (which includes miscellaneous pieces, articles for the Examiner and from Household Words, "Mrs. Gamp with the Strollers," etc.)
$C P, 2$ Collected Papers, 2 (which includes articles from All the Year Round, "Lord Bateman," Poems, and Speeches)

DC David Copperfield

D\&S Dombey and Son

ED The Mystery of Edwin Drood

$F$ Frontispiece to this book (which furnishes reproductions of the wrappers of CD's initially illustrated fiction in reduced size)

GE Great Expectations (which also contains $H T$ )

$H T$ Hard Times (in $G E$ volume)

LD Little Dorrit

MC Martin Chuzzlewit

NL, 1, 2, 3 The Letters of Charles Dickens, ed. Walter Dexter (Bloomsbury: The Nonesuch Press, 1938)

NN Nicholas Nickleby

OCS The Old Curiosity Shop

OMF Our Mutual Friend

OT Oliver Twist

Pilgrim, 1 The Letters of Charles Dickens: Volume One, 1820-1839, ed. Madeline House and Graham Storey. The Pilgrim Edition (Oxford: Clarendon Press, 1965)

Pilgrim, 2 The Letters of Charles Dickens: Volume Two, 1840-1841, ed. Madeline House and Graham Storey. The Pilgrim Edition (Oxford: Clarendon Press, 1969)

Pilgrim, 3 The Letters of Charles Dickens: Volume Three, 1842-1849, ed. Madeline House, Graham Storey, and Kathleen Tillotson. The Pilgrim Edition (Oxford: Clarendon Press, 1974)

Pilgrim, 4 The Letters of Charles Dickens: Volume Four, 1844-1846, ed. Kathleen Tillotson. The Pilgrim Edition (Oxford: Clarendon Press, 1977)

$P F I$ Pictures from Italy (in $A N$ volume)

PP The Pickwick Papers

RP Reprinted Pieces (which includes miscellaneous stories and The Uncommercial Traveller)

$S B B$ Sketches by $B o z$ (which is divided into four sections: OP, Our Parish; S, Scenes; C, Characters; and T, Tales. This volume also contains Sunday under Three Heads, parts of Bentley's Miscellany other than OT, Sketches of Young Gentlemen, Sketches of Young 


\author{
Couples, and Master Humphrey's Clock except \\ for $O C S$ and $B R$ ) \\ TTC A Tale of Two Cities
}

The following abbreviations for public and private collections, libraries, and museums have been used throughout the footnotes:

Arents Collection. George Arents Collection, New York Public Library

Beinecke Library. Beinecke Rare Book and Manuscript Library, Yale University

Berg Collection. Henry W. and Albert A. Berg Collection, New York Public Library

Borowitz Collection. Private Collection of David Borowitz, Chicago

Bradburn Collection. Private Collection of Frank S. Bradburn, Liverpool

Carlton Bequest. W. J. Carlton Bequest, Dickens House, London

Clark Library. William Andrews Clark, Jr. Memorial Library, University of California, Los Angeles

Cruikshank Collection. Victoria and Albert Museum, South Kensington

Dickens House. Dickens House (also referred to as Dickens House Museum)

Elkins Collection. William H. Elkins Collection, The Free Library of Philadelphia

Forster Collection. John Forster Collection, Victoria and Albert Museum, South Kensington

Gimbel Collection. Collection of Colonel Richard Gimbel, USAF, Beinecke Rare Book and Manuscript Library, Yale University

Houghton Library. Houghton Library, Harvard University

Huntington Library. Henry E. Huntington Library, San Marino, California

Morgan Library. Pierpont Morgan Library, New York
Meirs Collection. Richard Wahl Meirs Collection of Cruikshank, Department of Rare Books and Special Collections, Princeton University Library

NPG. National Portrait Gallery, London

NYPL. New York Public Library

Rosenbach Museum. Philip H. and A. S. W. Rosenbach Museum, Philadelphia

Suzannet Collection. Gifts from the Collection of the late Comte Alain de Suzannet, Dickens House, London

UCLA. Department of Special Collections, University Research Library, University of California at Los Angeles

Widener Collection. Harry Elkins Widener Collection, Harvard University Library

The following abbreviations for secondary sources have been used throughout the footnotes:

Browne Edgar Browne, Phiz and Dickens

Dick. The Dickensian

DNB The Dictionary of National Biography, ed. Leslie Stephen, Sidney Lee, et al.

DS Dickens Studies

DSA Dickens Studies Annual

DSN Dickens Studies Newsletter

Forster John Forster, The Life of Charles Dickens, ed. J. W. T. Ley

Harvey John Harvey, Victorian Novelists and Their Illustrators

Kitton, DI Frederic G. Kitton, Dickens and His Illustrators

Kitton, $P+P$ Frederic G. Kitton, Charles Dickens by Pen and Pencil

Leavis Q. D. Leavis, "The Dickens Illustrations: Their Function." In Dickens the Novelist, by F. R. Leavis and Q. D. Leavis, pp. 332-71.

PULC George Cruikshank: A Revaluation, ed. Robert L. Patten, Princeton University Library Chronicle 35 (Autumn and Winter, 1973-74) 


\section{CHRONOLOGY}

1764

October 26

William Hogarth dies at age 67.

1812

February 7

Charles Dickens born.

1815

June

June 1

1824

February-?June

March-May

1827

April 22

1830

May?

1833

May

December 1

1834

August

August-December

Dickens becomes reporter on

Morning Chronicle. Dickens's first story published in the Monthly Magazine.

Dickens employed at Warren's

Blacking warehouse.

Dickens's father in the Marshalsea prison for debt.

Death of Thomas Rowlandson.

Dickens meets Maria Beadnell.

à Beckett attacks Robert Seymour in Figaro.

December

Dickens takes chambers at 13

Furnival's Inn.

1835

?May

Dickens becomes engaged to Catherine Hogarth.

November 17
1836

February 8

February 10

February 17

March 31October, 1837

March 31 and May 31

April 2

April 20

Late April?

Late Aprilearly May?

May?

June

June 30

Mid-August?

November 4

December 17
Sketches by Boz, First Series, published with illustrations by George Cruikshank.

William Hall invites Dickens to write The Pickwick Papers.

Dickens moves to larger quarters at 15 Furnival's Inn.

The Pickwick Papers is published in twenty monthly parts, the first two with illustrations by Seymour.

Two Boz sketches published in The Library of Fiction illustrated by Robert Seymour and Robert Buss. Dickens marries Catherine Hogarth. Robert Seymour commits suicide. Robert Buss is hired to illustrate Pickwick.

William Thackeray applies to illustrate Pickwick.

Hablot Browne is hired to illustrate Pickuick. Buss is fired.

Sunday under Three Heads is published with illustrations by Browne.

Pickwick No. 4 is published with first illustrations by Browne, which include Sam Weller's first appearance.

John Leech applies to illustrate Pickwick.

Dickens becomes editor of Bentley's Miscellany.

Sketches by Boz, Second Series, published with illustrations by Cruikshank. 
December 25?

1837

January

January 6

January 31-

April, 1839

Early April

May 7

June 20

Late October-

November, 1839

1838

January 30

February 6

February 10

February 26

March 6

March 31-

October 1, 1839

August 20

October 29-

November 8

1839

January 31

June

June

October 29

Early December
Dickens meets John Forster.

The Strange Gentleman published with frontispiece by Browne.

Charles Culliford Boz Dickens born. Oliver Twist published in Bentley's Miscellany in twenty-four monthly installments with illustrations by Cruikshank.

Dickens moves to 48 Doughty

Street.

Death of Dickens's sister-in-law, Mary Hogarth.

Victoria becomes Queen of England. Samuel Palmer begins two-year stay in Italy.

Dickens visits Yorkshire with Browne.

Sketches of Young Gentlemen published with illustrations by Browne.

Memoirs of Joseph Grimaldi published with illustrations by Cruikshank.

Mary ("Mamie") Dickens born.

Nicholas Nickleby published in twenty monthly parts with illustrations by Browne.

George Cattermole marries Clarissa Elderton.

Dickens tours Wales with Browne and Midlands where Forster joins them.

Dickens resigns editorship of Bentley's Miscellany.

The Loving Ballad of Lord

Bateman is published with introduction and notes by Dickens (unsigned) and illustrations by Cruikshank.

Daniel Maclise finishes portrait of Dickens.

Kate Macready Dickens born.

Dickens moves to No. 1 Devonshire Terrace.
1840

February 10

Sketches of Young Couples published with illustrations by Browne.

February 10 Queen Victoria marries Prince Albert.

April $4 \quad$ Master Humphrey's Clock, No. 1 is published with illustrations by Cattermole and Browne.

April 25- $\quad$ The Old Curiosity Shop is published February 6, 1841 in forty weekly installments with illustrations by Browne, Cattermole, Samuel Williams (1), and Maclise (1).

1841

February 13- Barnaby Rudge is published in

November 27, 1841

June 19-July 18

August 8

October?

1842

January 4

June 7

October 18

November

December

1843

January-

June, 1844

December

1844

July 1June 1845 forty-two weekly numbers with illustrations by Browne and Cattermole.

Dickens and his wife visit Scotland. The Pic Nic Papers is published, edited by Dickens, with illustrations by Cruikshank, Browne and others. Maclise makes watercolor of Dickens's four elder children and a sketch of Devonshire Terrace.

Dickens and his wife sail on S.S. Britannia for Boston.

The Dickenses return from New York.

American Notes is published. Dickens visits Cornwall with Forster, Maclise, and Clarkson Stanfield.

Maclise uses Dickens's sister-in-law, Georgina Hogarth, as model in his painting of a Cornish waterfall.

Martin Chuzzlewit is published in twenty monthly parts with illustrations by Browne.

A Christmas Carol is published with illustrations by John Leech.

Dickens and his family leave for Italy. 
November 30-

December 6

December

1845

September 20

December

1846

January 21

February 9

May

June?

October

April, 1848

December

1847

February

Oetober?

1848

?

December

1849

January 15

May-

November, 1850
Dickens visits London and reads

The Chimes to his friends.

The Chimes is published with illustrations by Leech, Maclise, Stanfield, and Richard Doyle.

Debut of Dickens's amateur theatrical company.

The Cricket on the Hearth is published with illustrations by Leech, Maclise, Stanfield, Doyle, and Edwin Landseer.

First issue of the Daily News, edited by Dickens.

Dickens resigns editorship of the Daily News.

Pictures from Italy is published with illustrations by Samuel Palmer.

Dickens and his family leave

London for Switzerland.

Dickens writes The Life of Our

Lord.

Dombey and Son is published in twenty monthly parts with illustrations by Browne.

The Battle of Life is published with illustrations by Leech, Maclise, Stanfield, and Doyle.

Dickens returns to London due to oldest son's illness.

Cruikshank is interviewed by

R. Shelton Mackenzie.

Dickens begins writing his autobiographical fragment.

The Haunted Man is published with illustrations by Leech, Stanfield, John Tenniel, and Frank Stone.

Birth of Henry Fielding Dickens, eighth child, fourth son.

David Copperfield is published in

twenty monthly parts with

illustrations by Browne.
July-October

The families of Dickens and Leech take neighboring houses at Bonchurch, Isle of Wight.

1850

March 30-

May 28, 1859

November 27

1851

April 14

November child.

Dickens moves to Tavistock House.

1852

March-

Bleak House is published in twenty

September, 1853 monthly parts with illustrations by Browne.

1852-1854

A Child's History of England is published in three volumes with frontispieces by Francis W. Topham.

1854

April 1-

August 12

$?$

1855

June 15

December-

June, 1857

1856

March 14

\section{7}

July 9
Dickens buys Gad's Hill in Kent.

Hard Times is published weekly in Household Words with no illustrations.

Mrs. Robert Seymour publishes her Account.

Dickens produces, directs, acts in "The Lighthouse" by Wilkie Collins with sets by Stanfield at Tavistock House.

Little Dorrit is published in twenty monthly parts with dedication to Stanfield and illustrations by Browne.

Dickens gives special performance of Collins's "The Frozen Deep" before Queen Victoria. 
August Dickens hires Ellen Ternan for performances of "The Frozen Deep" on August 21 and 22.

1858

April 29

April-May

June 12

1859

April 30-

November 26

May 28

November 18

1860

July 17

October

December 1August 5, 1861

1861

December 14

Death of Prince Albert.

1864

MayOur Mutual Friend is published in

November, 1865 twenty monthly parts with

October 29 illustrations by Marcus Stone.

1865

June 9

Death of John Leech.

Dickens is in Staplehurst railway accident.

November $11 \quad R$. Shelton Mackenzie publishes 1847 claims by Cruikshank to Oliver Twist.

1866

March 24-April 7 The controversy over Pickwick's origins is revived by Seymour's son and Dickens.

1872

March 2

April 28

June 9

1871

December

December 30

1873

April 9

1878

February 1

1882

July 8

1892

December

1893

1899

Death of Stanfield.
Dickens returns to England. Death of George Cattermole.

Charles Collins designs wrapper and makes trial sketches for The Mystery of Edwin Drood but is too ill to continue.

Luke Fildes is hired to illustrate Drood.

Dickens gives final public reading.

The Mystery of Edwin Drood is published in six of the twelve planned monthly parts with illustrations by Fildes.

Death of Daniel Maclise.

Death of Dickens at Gad's Hill.

Publication of the first of three volumes of John Forster's The Life of Charles Dickens.

George Cruikshank advances his claims to Oliver Twist in letter to the Times.

Buss writes "My Connexion with The Pickwick Papers" for his children.

Death of Charles Collins.

Death of George Cruikshank.

Death of Hablot Browne.

Publication of Thackeray's "The Loving Ballad of Lord Bateman."

John Tenniel awarded a knighthood.

Dickens sails to America for reading tour.
Publication of Frederic G. Kitton, Dickens and His Illustrators. 
1901

January 22

1921

March 24

1927

February 27

1936

1938
Death of Queen Victoria.

Death of Mareus Stone.

1965

Death of Luke Fildes.

Centennial of The Pickwick Papers.

1970

Publication of The Nonesuch
Dickens with illustrations printed from the original plates, which were then distributed by lot to the 877 subscribers.

Publication of the first of twelve planned volumes of The Pilgrim Edition of The Letters of Charles Dickens.

Centennial of Dickens's death. 

CHARLES DICKENS AND HIS ORIGINAL ILLUSTRATORS 



\section{Introduction DICKENS AND THE RISE OF THE ENGLISH ILLUSTRATED NOVEL AFTER 1836}

"You know how I build up temples in my mind that are not made with hands (or expressed with pen and ink, I am afraid)," Dickens once complained to John Forster. ${ }^{1}$ Dickens was highly susceptible to disappointment about the illustrations for his books; it is impossible, however, to credit those who suggest that Dickens wished his books had never been illustrated. ${ }^{2}$ He left abundant testimony to his intense involvement in most of the nearly nine hundred original illustrations of his writing, and the pictures were a part of the initial complete publication of nearly all his major works: the collected Sketches by Boz; all the novels except Hard Times and Great Expectations, which first appeared in Dickens's own unillustrated periodicals; all five Christmas books; and the finished versions of Pictures from Italy and $A$ Child's History of England. ${ }^{3}$ He had a close personal as well as professional relationship with many of the eighteen artists who worked with him. ${ }^{4}$ Even when his reputation was secure, his sales steady, and his audience literate enough to permit him to publish his texts unadorned, as some critics urged, he usually retained the illustrated format clearly convinced, despite the difficulties of coordinating text and pictures, of its advantages to himself, his publishers, his illustrators to a lesser extent, and, above all, to his readers.

Illustrations may have been so important to Dickens partly because the world into which he was born on February 7, 1812 was deprived of visual material compared to our own. Lacking television, movies, photographs, a regular illustrated press, and even a public art museum, the semiliterate audience keenly anticipated, relished, and remembered what it was able to see. ${ }^{5}$ There were, of course, random pictures in broadsides, advertisements, signs, and, later, annuals or "keepsakes" with their glossy views of fashionable women so admired by Mrs. Nickleby ( $N N$,
XXVII, 343-44). Yet Dickens acknowledged mainly two sources of graphic stimulation: prints-the realistic satires of William Hogarth and, to a lesser extent, the grotesque caricatures of Thomas Rowlandson and James Gillray-and the illustrations for nursery tales and adult fiction. Both sources profoundly affected his imagination and his art.

From the Sketches by Boz in 1836 to The Mystery of Edwin Drood in 1870, Dickens's books reveal his exposure and his debt to prints, particularly those by Hogarth, with whom he has consistently been compared. ${ }^{6}$ Before his father's bankruptcy, he may have spent many evenings thumbing through a rented or owned print portfolio, a property common to the libraries of many families aspiring to gentility. ${ }^{7}$ Even as an impoverished drudge at Warren's Blacking warehouse, young Dickens could have seen without cost the latest prints in the printsellers' windows, which served the public as an art gallery (fig. 1). ${ }^{8}$ Old favorites,

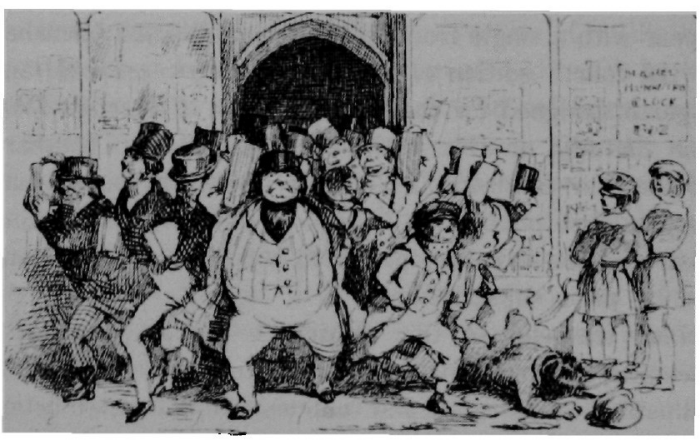

Fig. 1. Richard Doyle, Sketch of the Distribution of Master Humplerey's Clock, Number 3, April 16, 1840. MS, Dick Doyle's Joumal, 1840 , p. 47 . Pen and ink. 27/16" $\times 4^{\prime \prime}(6.2$ $\times 10.2 \mathrm{~cm}$ ). By permission of the Trustees of the British Museum. 
such as Hogarth's prints, graced the walls of the humblest shops and hovels as well as prosperous homes like those of Mrs. Thrale, Lord Byron, and, much later, Dickens's own at Gad's Hill. These prints not only helped to form Dickens's vision of his world-and that of his older illustrators-but, as has been suggested, taught him ways of conveying it to others. ${ }^{9}$ They suggested the importance of making every detail of character and setting contribute to a point, usually a moral one. They may have inspired him to seek verbal equivalents for the graphic narrative or "progress," the emblematic detail, the physical and mental idiosyncrasy, and the revealing gesture. As the best of the prints by Hogarth and his heirs-Rowlandson, Gillray, and Cruikshank-were often meant to be "read," so Dickens's prose was meant to be visualized. If the so-called Hogarthian tradition became attenuated in Victorian graphic art, its vital qualities survived in the graphic prose (as well as in many of the best illustrations) of a Dickens novel.

Dickens was also influenced by the book illustrations of his youth, which were less taken for granted than they are now. If, in his maturity, he occasionally doubted the desirability of illustrations in his books, he must have recalled that his literary predecessors were frustrated by having no choice in the matter. The eighteenth-century doctrine of ut pictura poesis, whose abuse prompted Pope's complaint about books in which "the pictures for the page atone" (Dunciad, I, 1, 139), did not apply to fiction of that time, which almost always appeared in three volumes, occasionally graced by a portrait or a map, but more usually unadorned. Swift vainly wished that Hogarth would "draw the beasts as I describe them"10 and Fielding was forced to refer the first readers of Tom Jones to Hogarth's paintings for the appearance of some of his characters (I, xi; II, iii). Only when a novel was an established commercial success might it be counted on to appear with a single frontispiece, such as Fuseli furnished for the fourth edition of Smollett's Peregrine Pickle and Hogarth designed for the second edition of Sterne's Tristram Shandy, or even with several designs, as Stothard provided for Goldsmith's Vicar of Wakefield thirty years after its first publication in $1766 .{ }^{11}$ But very often these illustrated classics were produced in a limited edition and sold by prior subscription.

Near the end of the eighteenth century, however, mechnical advances enabled pictures to be printed cheaply in illustrated part-issues and volumes, and illustrated fiction classics became easily available. These illustrations remained ineffaceable in the memories of Dickens and other readers of his century. Charles Lamb, poring over Thomas Stothard's portrayals of "Clarissa mournful, and prim Grandison/ All Fielding's, Smollett's heroines" believed they really existed; John Ruskin was more moved by the "rude" vignettes of Robinson Crusoe crashing into the rocks and escaping the wreck than by most of the "High Art" of his maturity; and even at age eighty-four, Thomas Hardy recalled his fright at the picture of Apollyon fighting Christian in his copy of Pilgrim's Progress. ${ }^{12}$ Much eighteenth-century fiction specialized in moral assessment rather than visual description, yet despite or because of the quality, Dickens remembered the plates in many books more vividly than the texts. ${ }^{13} \mathrm{As}$ an author, he made his own prose increasingly graphic, at the same time as he tried to maintain the highest standards for the illustrations that accompanied it.

Throughout Dickens's youth, graphic materials, however sparse, probably reached a far wider audience than any literature. Even when pictures were accompanied by a text, as in Pierce Egan's popular Life in London (1821) and modish travel and sporting books, the pictures were the important asset. When Boz began his sketches in the mid-1830's, authors still wrote "up" to the artist whose plates were counted on for a work's success. Only by a series of accidents at the start of The Pickwick Papers-the publishers' selection of Dickens as serial writer, the suicide of the first illustrator, Robert Seymour, and its unprecedented success-did Dickens manage to reverse the supremacy of artist over author in his lifetime. ${ }^{14}$

Dickens's introduction of Pickwick in an illustrated serial format, with parts published separately, revolutionized the publication of new fiction between 1836 and $1870 .{ }^{15}$ Illustrations had always bolstered sales of already established fiction: Sir Walter Scott had observed in 1831, after issuing a new edition of his works, that "without plates 5000 less of the Waverley novels would have been sold at a difference on the whole work of $£ 13,000 . " 16$ But the success of Pickwick, a new story, was such that publishers and authors rushed to emulate it in every respect. Illustrations, once a luxury, now became commonplace. New fiction, if issued serially with illustrations, was clearly more profitable and less risky than the traditional unembellished three-volume sets had ever been. The presence of plates in the cheap monthly (or, less often, weekly) issues attracted the widest possible audience; the increased number of readers attracted more advertisers; and the additional profits absorbed the extra graphic costs. By contrast to a bound volume, part-issues elicited several notices from reviewers instead of just one; and the illustrations made perfect advertisements for booksellers' windows at regular intervals. Furthermore, if a work of new fiction was failing -and even Pickwick's fate had been doubtful for a while-publication could easily slow down or cease alto- 
gether. It was more likely, however, that this format guaranteed higher sales and steadier incomes over longer periods not only for the publisher, but for the author and artist as well.

The importance of illustrations to the commercial success of post-Pickwick fiction was lost neither on Dickens nor on contemporary novelists and their publishers. Profitability made the once despised form respectable ( $P P, \mathrm{XIX}$ ). William Ainsworth, Charles Lever, William Thackeray, and Anthony Trollope introduced most of their major works in illustrated monthly parts; later novelists preferred to issue their writing in illustrated magazines: Thomas Hardy often used this format; George Meredith and Charles Reade tried it twice; George Eliot once. ${ }^{17}$ Although Dickens never admitted his dependence on illustrations as openly as some of his peers, during his anxious years in the 1840 's, as the Times snidely observed, he did not send his Christmas books "to market" without the aid of many wellknown artists. ${ }^{18}$

Yet Dickens's concern with illustrations was not motivated purely by economic considerations, for it continued long after illustrations were needed to help boost sales. Apparently illustrations provided a necessary outlet for the overflow of his remarkably visual imagination. "There is no writer, in my opinion, who is so much a painter and black-and-white artist as Dickens," declared Vincent van Gogh, driven like so many commentators to commonplace rhetoric to describe the distinctive quality of the author's prose. ${ }^{19}$ Dickens explained his creative process to Forster by saying, "I don't invent it-really do not-, but see it, and write it down." ${ }^{20}$ His instructions to his artists indicate that he visualized the scenes he wanted illustrated thoroughly indeed. He usually specified the number of the characters as well as their position, gestures, expressions, dress, and settings; in one instance, he even supplied details of color, though the illustration, as usual, was to be black and white. ${ }^{21}$ Similarly, Dickens endowed his protagonists with his own ability to visualize experiences and perceptions with memorable painterly details.

Dickens concerned himself not only with illustrations but with every aspect of the appearance of his books. He refused, for example, to accept even for presentation purposes the first copies of $A$ Christmas Carol, whose colors had not turned out well in printing. The friends who finally received presentation copies never knew that the author had gone to great trouble and expense to change the endpapers from green to yellow and the title page print from red and green to red and blue. ${ }^{22}$ When the weekly installments of Master Humphrey's Clock provided the opportunity to "drop" wood engravings into the text-the steel engravings in the monthly issues preceded the text-Dickens, not his illustrators, determined where to put them to obtain the best dramatic and aesthetic effect. ${ }^{28}$ Dickens even took pains with the arrangement of his paragraphs, breaking them up or running them together for visual effect: in David Copperfield, he insisted on a white line left before each of the three paragraphs disconnected in time-concerning the progress of Dora's illness (LIII, 758-60); and in Great Expectations, he instructed the printer to leave two white lines between the description of Orlick's assault and Pip's recovery to reinforce visually the hero's "blank" of unconsciousness (LIII). ${ }^{24}$ Even Dickens's detailed criticisms of the early sketches of illustrations appear to stem less from disapproval than from frustration at the difficulty of conveying to his illustrators what his mind's eye so fully conceived.

Dickens exerted unprecedented authority over everything but the actual execution of the illustrations to his works. With few exceptions, he selected and entitled (often ironically) the subjects, provided the proofs or précis, and suggested conceptions, models, and details. He usually inspected not only the final drawings, but the preliminary sketches as well, which he rarely returned without ideas for improvement. He was not "mechanically acquainted" with drawing or painting $(C P, 1: 67$ and $P F I$, XVIII, 244); he could enliven his letters only with occasional crude sketches. ${ }^{25}$ Otherwise, like Thackeray and George du Maurier, Dickens might well have illustrated his own novels. If he shared his success with his illustrators, however, at least he did so on his own terms. He never worried, as did later authors like Henry James, that his prose might suffer from rivalry with another medium. ${ }^{26}$

Indeed, the force of Dickens's personality and of his pictorial imagination determined the success of his illustrations as much as the talent of his artists. Although he was flattered at first by the opportunity to collaborate with George Cruikshank and Robert Seymour, the two most famous illustrators of the 1830 's, Dickens soon found the traditional subordination of author to artist intolerable and managed to reverse the roles on his own works. It was no accident that Hablot Browne (Phiz), who was young, obscure, and diffident, succeeded to the post held by these two more assertive veterans and retained it so long. Nor was it mere coincidence that most of Dickens's other illustrators were either intimates, giving their services out of friendship for a short time only, or unknowns and dependents. A William Blake, Thomas Bewick, or Joseph Turner-as Cruikshank, perhaps the most independent of Dickens's artists, discovered-would not have long toler- 
ated such authorial dominance. ${ }^{27}$ Though Dickens is ultimately important for what he wrote, not what others illustrated of his works, modern readers owe it to him to give his artists the same extensive consideration of their efforts that he did.

Despite the impetus given to English book illustration after 1836 by Dickens and by continuing technological advances, illustrating remained a hard, ill-paid occupation. ${ }^{28}$ Many artists cut their teeth on illustrated fiction; indeed, there was such a flood of scenes in the 1840's from The Vicar of Wakefield alone that Thackeray publicly protested. ${ }^{29}$ But few artists possessed Hablot Browne's talent and, at the same time, the temperament to pursue book illustration full time. Most, like Marcus Stone and Luke Fildes, used it as a stepping-stone to careers in painting; others, like George Cattermole and Daniel Maclise, supplemented what income they could earn from more "serious" art by accepting occasional commissions to do illustrations. Yet even at the height of book illustration in the Victorian era, book illustrators remained to painters what novelists are to poets: the less prestigious, though usually the more popular, practitioners of their craft.

On the whole, Dickens's original illustrators fared better than most of their colleagues: Robert Buss was the only one whose career was impaired by his association with the author. If George Cruikshank and Robert Seymour hastened Dickens's rise to fame, they, in turn, were assured immortality by their work for him. Hablot Browne's stature rested almost exclusively on his illustrations for Dickens. John Leech's name on the title pages of Dickens's Christmas books consolidated his reputation as a talented graphic satirist, and John Tenniel's helped lead perhaps to his work for Punch and for Lewis Carroll. Some illustrators were already respected painters when they worked for Dickens: Daniel Maclise, Clarkson Stanfield, Edwin Landseer, and Frank Stone were prominent members of the Royal Academy; and George Cattermole, Samuel Palmer, Frank Topham, and Charles Collins were celebrated in more esoteric circles. With few exceptions, until the recent revival of interest in Victoriana, most of them were better remembered for their casual illustrations of or for Dickens than for their labored canvases. Marcus Stone and Luke Fildes parlayed the attention attracted by their work for Dickens into successful careers as Royal Academy painters. Certainly many of Dickens's illustrators, like Landseer and Palmer, have earned a place in Victorian art history irrespective of their work for him, and there may have been better artists who never attained deserved fame because they never had the luck to associate with him. All of
Dickens's original illustrators are gaining stature still as scholars begin to realize that the major graphic achievement of the Victorian era may be that of book illustration. ${ }^{30}$

At the time of their work with Dickens, however, the artists were compensated mainly by the value of their friendship with Dickens. The artists who illustrated his books were personally as well as professionally important to Dickens. Indeed, he counted more artists than writers among his intimates since his friendships, as George Bernard Shaw perceived, were determined by "social" rather than "cultural" factors. ${ }^{31}$ They supplied companionship during the collaborations and after them when the stern taskmaster unwound over meals and on excursions. When Dickens involved them in his numerous charitable theatricals and committees, it was as much for the continued pleasure of their company as for the immediate usefulness of their names and talents.

Indeed, Dickens had a notable affinity for all kinds of artists, many of whom never illustrated his books. His appreciation was clearly reciprocated: he was one of the few outsiders ever invited to the weekly $P$ unch round tables or to address as well as attend the annual Royal Academy dinners $(C P, 2: 441,466-67,532-34){ }^{32}$ In his frequent capacity as sitter, he came to know still other artists than his illustrators. By the end of his life, Dickens had better reason than Mr. Snevellicci to boast that "most men have seen my portrait" (NN, XXX, 393). And, although he could not know all the Victorian artists whom his books inspired, he was gratified to see so many of his characters depicted in canvases as well as in cartoons. ${ }^{33}$ The paintings and drawings hanging in Dickens's homes were predominantly portraits of himself and his family or subjects from his books, executed and given to him by his illustrators and other artist friends. ${ }^{34}$

The author was as discreet as he was entertaining. Though Dickens increasingly utilized his knowledge of paintings, portraits, and objets d'art in his novels to suggest-long before Henry James-the moral as well as literal wealth or poverty of their owners, he never exploited his knowledge of his artist friends. Though he often recognizably incorporated the traits of his acquaintances in his fiction, Leigh Hunt/Harold Skimpole in Bleak House being the most notorious example, he proved unusually reticent about his illustrators. In Dickens's novels, neither the two professional artists-Miss La Creevy and Henry Gowan-nor the amateur artists-Jack Redburn, John Westlock, Mr. Carker, Edith Granger, and Edwin Drood - bore any resemblance to his artists. ${ }^{35}$ Dickens exercised other kinds of discretion on behalf of his illustrators. He may have removed from the 1867 edition of The Pickwick Papers 
an allusion to an earlier scandal involving a portrait by Maclise not only because it was too topical and dated but lest it still pain his friend. ${ }^{36}$ After their deaths, he gave prospective biographers of Maclise, Leech, and Stanfield polite but short shrift, telling them their lives were best illustrated by their works. ${ }^{37}$ Dickens remained a loyal friend to the families of many of his artists even after their deaths.

If Dickens was discreet about his illustrators in his fiction, he was their willing publicist in articles and speeches. When Pictures from Italy came out in 1846, he was attacked by commentators for his philistine art criticisms and his unwillingness to separate moral from aesthetic judgments. Thereafter, for the most part, he confined his public remarks on art to praise of his illustrators for work unrelated to his own. Accordingly, his illustrators escaped his general censure of the fine arts, whose rules, cant, models, and bores, he repeatedly claimed, perpetrated false views of history and humanity and hence various social and moral evils. His comments on them reveal that his aesthetic judgments stemmed from some positive standards, and not just from some generalized cantankerousness. Thus Dickens praised many of the works, though not the distorted philosophy, of George Cruikshank's temperance period. He appreciated that the artist's revelations of the grotesque were capable both of shocking viewers into recognizing the social wretchedness around them-if not its causes-as in 'The Drunkard's Children,' and of stretching their imaginations, as in his Fairy Tales (CP, 1: 157-60, 464). The caricatures of Leech earned Dickens's admiration for their beauty, which he and his contemporaries came to feel conveyed satirical points more pleasantly and hence more effectively than the repellent ugliness employed by Rowlandson and Gillray (CP, 1: 190-93). The author's adulation of Maclise's 'Spirit of Chivalry' for the rebuilt Houses of Parliament clearly indicated his profound belief that art, by the grandeur and fine execution of its subjects, ennobled man and his endeavors $(C P, 1: 34-39)$. His tribute to "The Late Mr. Stanfield," like that to "The Friend of the Lions," Edwin Landseer (CP, 1: 634-38), testified to his high estimation of forcefulness and truth in $\operatorname{art}(C P, 2: 45-47)$, the kind of truth that elevated a subject and its associations, not degraded them as he felt the early Pre-Raphaelites had done (CP, 1: 291-96). If Dickens's motives were sometimes biased, his remarks were always sincere and often judicious. Such comments had the advantage to the artists of a wider audience than the more sophisticated opinions of erudite art critics.

Dickens was not aesthetically blinded, however, by his affection for his artist friends. If he expressed only approbation of their works publicly, in private certain reservations emerged. At the 1855 Paris Art Exposition, for example, he perceived that the innovative canvases of Corot, Manet, Courbet, and Degas excelled the conventional ones by his Royal Academy friends like Maclise and Stanfield. As he wrote Forster, "It is of no use disguising the fact that what we know to be wanting in the men is wanting in their works-character, fire, purpose, and the power of using the vehicle and the model as a mere means to an end. There is a horrid respectability about most of the best of them-a little, finite, systematic routine in them, strangely expressive to me of the state of England itself." Considerations of friendship, of course, prevailed over those of criticism, and publicly Dickens held his tongue. (But it seems no coincidence that his very next novel, Little Dorrit, portrayed England as a victim of its routine-encrusted institutions, and contained his only sustained, full-length, and completely contemptuous portrait of a painter, Henry Gowan.) The author had no pretensions about his ability as an art critic. Yet it must be recalled that he not only reflected the tastes of his time, but often helped to mould them. Today, many still share Dickens's assessment of the work of his own illustrators and other artist friends.

The published illustrations, so important to the author and his first audiences, hardly revealed the extraordinary effort that went into producing each one. As Miss La Creevy remarked to Kate Nickleby, "the difficulties of art, my dear, are great" $(N N, \mathrm{X}, 115)$. The inherent difficulties of book illustration-those stemming from the necessity of resolving the clash between two talents and two media-were compounded by Dickens's mode of publication and by his personality. Because Dickens's work was published in monthly serial issues, his illustrators had to work more closely with him over a longer period of time than they usually did with other authors. Furthermore, Dickens ruled over the visual as well as the verbal spheres of his books like a benevolent tyrant. As Forster observed, "even beyond what is ordinary between author and illustrator, his requirements were exacting." ${ }^{39}$ Accordingly, Dickens doubtless was found high-handed by Cruikshank, subversive by Seymour, arbitrary by Browne, and indifferent by Maclise, though younger artists, such as Marcus Stone and Fildes, called him paternalistic. Even so, Dickens maintained a better than average professional relationship with his illustrators for authors were, as a group, notoriously and variously difficult to satisfy (as Tenniel learned working for Lewis Carroll, and Marcus Stone for Anthony Trollope). ${ }^{40}$

If Dickens's brand of supervision was dictatorial, at least it relieved his illustrators of some decisions; plenty remained, of an aesthetic and technical nature, to complicate 
their task. It was never easy for illustrators, even when dealing with a known text by a dead author, to enhance the appearance, interest, and meaning of the text for the reader. When confronted with a text executed at monthly intervals by a demanding author, the problems were formidable. Although Dickens's narrative was usually created before the illustrations, it was visual material that the reader saw first each month-the wrapper design and the two plates that were bound in together before the text. Thus, the original illustrator of each of Dickens's long, serial stories had to produce a wrapper design that would be eye-catching not just once, but month after month, usually for over a year. At a point when only a few chapters were actually written, the artist had to create a wrapper design that encompassed the general drift and even specific events of the entire narrative, and to do so without confining the author or misleading the reader. The illustrator executed the two plates that accompanied each installment after Dickens had written or, at least, conceived the relevant text, but because the plates were placed first, he had to illustrate the story without giving it away.

Dickens's first illustrators had to sustain a delicate balance between pictures and text throughout the narrative. George Eliot, after working with Frederic Leighton on Romola, her only work initially published with illustrations, admitted "the inevitable difficulty, nay, impossibility of producing perfect correspondence between my intention and the illustrations." ${ }^{\text {11 }}$ Dickens never conceded this impossibility, and his attitude was infectious. He expected his illustrators to attract readers but never compete with him for attention, and trusted them to follow his text and instructions with care, yet not slavishly. When Dickens's description of a scene or character was minute, they had to incorporate myriad details without blurring their overall design; when he supplied fewer details, they had a freer hand, but ran a greater risk of not realizing the scene to the author's satisfaction. Whether portraying major or minor characters, representing decisive or fleeting actions, reinforcing themes, conveying atmosphere, or suggesting psychological significance, the illustrators had to make their visual compositions natural outgrowths of Dickens's verbal one. Dickens's original illustrators were not always able to realize his intention, but they succeeded in more plates in more books over a longer period of time than have the illustrators of most other authors.

Dickens's first artists also faced more tangible problems. As the narratives were often set in the recent, if not remote, past, they had to worry about the authenticity of costumes and interiors. Given contemporary stories, Dickens's early illustrators depended on memory or imagination for details, but his last illustrators used models and did research in books and locations. Deadlines were an even greater problem. Ideally, an illustrator should have time to ponder a completed text. Often, all his illustrators received from Dickens were marked-up proofs, hastily written précis, or brief verbal instructions-and those at the last minute. Then, too, the artists had to adjust their schedules to those of publishers, printers, and engravers, even at the expense of other commissions.

The illustrators also had technical problems. They had to worry about the limits imposed by the predetermined size and shape of the page and the conditions and requirements of the metal or wooden surfaces of the plates and blocks. ${ }^{42}$ The skills of the etcher or engraver who transferred his drawings to the printed page were especially crucial to the artist, for it was the latter's reputation at stake. Dickens's illustrators dealt with this problem in various ways. ${ }^{43}$ His first artist, Cruikshank-one of the few to have mastered the etching process, which was démodé in the 1830 's - was able to execute his own drawings on copper plates, which were later coated with steel; Dickens's second illustrator, Seymour, also executed his own etchings, but the inferior quality of the new polished steel surface of his plates added to his other misfortunes on Pickwick; Robert Buss learned to etch in a fortnight but, not surprisingly, his plates failed to do justice to his drawings, and cost him his Pickwick post; Dickens's principal illustrator, Hablot Browne, was luckier in being able to summon his friend, Robert Young, and older veterans for etching help.

When wood engravings became increasingly fashionable and practical from the 1840's on, Dickens's illustrators were fortunate to have the services of men like Ebenezer Landells, the Williamses, and the Dalziel brothers, who were regarded as the finest engravers of the day. But the artists were rarely pleased. Leech and Maclise, unlike the luckier Fildes, tried but failed to secure engravers of their choice for their Dickens work; Browne and Palmer went to elaborate but often ineffectual lengths to insure that their lines would be properly interpreted; Marcus Stone, like Maclise, was bitter about the engravers' ruinous effects on his designs. ${ }^{44}$ All of Dickens's original illustrators-except for his most transient one, Samuel Williams, who both designed and executed his one drawing for the author (OCS, I, 14)-doubtless would have appreciated Dante Gabriel Rossetti's satiric complaint:

O woodman, spare that block 0 gash not anyhow.

It took ten days by clock, I'd fain protect it now. 


\section{CHORUS: Wild laughter from Dalziel's workshop. ${ }^{45}$}

The Dalziels and their colleagues justifiably complained, in turn, that many illustrators (Rossetti most notoriously) lacked proper understanding of how to execute a drawing suitable for engraving on wood; and even if its engraving was satisfactory, the artist's original illustration might still be adversely affected by the subsequent proofing and printing processes. ${ }^{46}$

Whatever the compromises involved in producing the illustrations, most of Dickens's first readers accepted them as an unmixed blessing. As Mrs. Leavis has noted, they were more accustomed than twentieth-century audiences to visual presentations of political, social, and moral ideas, especially in popular prints. ${ }^{47}$ Their pleasure from literature of any kind, whether they read or were read to, was heightened immeasurably by illustrations. Only the very sophisticated early Victorian reader might have agreed with Goethe that illustrated texts placed before our eyes held the mind "in chains" or with William Wordsworth that they signaled a "backward movement" to childhood and possibly barbarism. ${ }^{48}$ Illustrations enabled most Victorians to apprehend a variety of worlds beyond their own. For rural families, even cultivated ones like the young Edmund Gosse's, they provided the only means of "realizing the outward appearance of unfamiliar persons, scenes, or things"; that is probably why Ruskin insisted that an illustration should be judged partly on whether it contained "plain facts" as well as thought. ${ }^{49}$

Dickens's illustrations, informative as well as imaginative at best, not only expanded the world of his readers, but the number of his readers, especially among the uneducated. The plates made his stories more accessible to children, a great asset since many Victorian families read them aloud every evening. The most ignorant adult auditor could comprehend the illustrations, even if the pronunciation or meaning of the words eluded him, and study them to recollect the story long after the words had faded from memory. Dickens was, of course, enormously popular with the undereducated classes. The author did not disdain this honor, and certainly the illustrations were a crucial part of it.

The illustrations were invaluable even to Dickens's sophisticated readers for other reasons. Few could wait to read the novels until they were complete, yet the part-issues protracted the story beyond ready recall. The illustrations provided continuity between the numbers. By internal structure, symbolic detail, parallels, and contrasts, the plates helped to establish the identity and mark the development of Dickens's characters, the sequence of his plots, and the nature of his themes. No wonder these illustrations were studied, as du Maurier has put it, "with passionate interest before reading the story, and after, and between." 50

The fact that the illustrations were so welcome, however, should not suggest that Dickens's language failed to do its job. Ruskin's objection to some illustrated fiction, that "it is not well to make the imagination indolent or take work out of its hands by supplying pictures of what might be sufficiently conceived without pictures," simply did not apply to Dickens. ${ }^{51}$ Illustrations may have limited the imagination in the case of less graphic authors such as Jane Austen or the Brontës or Anthony Trollope, and they may have provided short cuts for those of Dickens's readers who did not read the text carefully. But the imagination of most Dickens readers was exercised strenuously enough. His dense prose, complex plots, numerous characters, and multiple themes could only benefit from the graphic distillation of pictures. It is Leonardo da Vinci's comment on the paradoxical necessity of illustration which applies to Dickens: "the more minutely you describe the more you will confine the mind of the reader, and the more you will keep him from the thing described. And so it is necessary to draw and to describe." 52

In fact, Dickens's illustrations probably exposed more people to art than all the learned art books put together. For most Victorians, crude prints or, at the other extreme, "High Art" provided the only other means of graphic stimulation. A person who was intimidated by fashionable exhibitions, by the new National Gallery, and by erudite art criticism could exercise his imagination and his aesthetic discernment on Dickens's accessible illustrations. The response of such viewers was so enthusiastic that, with and without Dickens's approval, "extra illustrations" to the novels were issued independently of the texts with repeated success. ${ }^{53}$

The only readers to challenge seriously Dickens's illustrations were reviewers. In the years just after Pickwick, reviewers assumed that the plates were indispensable to Dickens's success and invariably commented on them as well as on the text. In the 1840 's, when Dickens's reputation was having its ups and downs, some reviewers implied that most of his early success was due to his illustrators. ${ }^{54}$ Such remarks probably helped create a climate in which Robert Seymour's heirs and George Cruikshank, all noting that the artists were veterans when they worked for Boz, began to claim excessive credit for The Pickwick Papers and Oliver Twist. Unquestionably Seymour initiated Pickwick and 
Cruikshank suggested important details for Oliver (just as Marcus Stone supplied the model for Mr. Venus and his shop in Our Mutual Friend). Nevertheless, posterity shares, with these reservations, Forster's opinion that of all the notions regarding Dickens's relationships with his first illustrators "the most preposterous would be that which directly reversed these relations and depicted him as receiving from any artist the inspiration" he always tried to give. ${ }^{55}$

Other reviewers complained that Dickens's style was unduly influenced by the presence of illustrations. As Blackwood's put it: 'The writer's 'mind's eye' becomes . . . obedient, insensibly, to the eye of his body; and the result is, a perpetual and unconscious straining after situations and attitudes which will admit of being illustrated. Thus the writer follows the caricaturist instead of the caricaturist following the writer; and principal and accessory change places." ${ }^{66}$ Indeed, at the start of his career, Dickens occasionally displayed moments of selfconsciousness about the presence of illustrations: for example, he crudely anticipated Pickwick's first club meeting for both reader and illustrator with "What a study for an artist did that exciting scene present!" (I, 3). Yet the presence of illustrations was not what made Dickens's style so pictorial. In Hard Times and Great Expectations, both of which were published initially without plates, the prose shows no decline or overcompensation in visuality. What is notable, particularly during the course of Dickens's long collaboration with Browne, as Michael Steig and others have perceived, was a roughly parallel development of verbal and graphic techniques. ${ }^{57}$ This parallelism- one which, as Steig also notes, mirrors the evolution of popular taste from caricature to realism ${ }^{58}$-indicates the author's ability to change and the artist's ability to keep pace, not the other way around. When Browne could no longer match Dickens's development-his prints becoming less "readable" as the prose became more visual-he lost his position as illustrator. Indeed, Dickens's writing became so profoundly pictorial that it was difficult for any of the illustrators of his later work to do more than represent rather than illustrate his narratives in the fullest sense.

One reviewer even urged Dickens to rid his books of illustrations for the sake of his reputation. In 1845 the London Times noted, with some justification, that by increasing the number of illustrations and celebrated artists in the Christmas books, Dickens was trying to obscure their literary worthlessness. ${ }^{59}$ But in 1846, when Pictures from Italy was published with only four small vignettes, the Times attacked the presence of any illustrations at all. "The time perhaps may have come for dismissing the crutch hitherto afforded by the painter and caricaturists, and for walking alone in the manliness and strength of proud and self-conscious reliance. The time must come, when the good public, sick of illustration, will demand that he shall rely, like his great predecessors, upon his own unaided power. Anticipate that demand, Mr. Dickens, and be your own emancipator!"60

Dickens's readers made no such demand, however, and the author voluntarily perpetuated his bondage. He knew better than the Times that most members of his audience considered the plates an invaluable bonus. He continued to work in this format not out of mere habit, but because he continued to find his own economic, aesthetic, and personal reasons for doing so valid. In 1858 , for example, just before he stopped using Browne as an illustrator, a natural moment to have dispensed with illustrations altogether, Dickens articulated yet another justification for retaining them. "I am strongly disposed to believe there are very few debates in Parliament so important to the public welfare as a really good picture. I have also a notion that any number of bundles of the driest legal chaff that was ever chopped would be cheaply exchanged for one really accessible, really humanising, really meritorious engraving. "661 It was consistent with Dickens's enduring belief in the moral efficacy of all art that he continued to have his work illustrated even after 1858 when illustrations were not as imperative as they had been in 1836. Reviewers in the Times and elsewhere tacitly shrugged and rarely mentioned the plates in Dickens's later novels; but if they took the illustrations for granted, the author and his readers never did.

Readers in our time, especially scholars, should be more grateful than their earlier counterparts for the continued presence of Dickens's illustrations. "Half the silly criticisms of Dickens need never have been written," as V. S. Pritchett has put it, had the original illustrations and illustrators been studied as closely as the author's life and text. ${ }^{62}$ For whatever their artistic merit, the original illustrations remain of special value in understanding Dickens's life and work. They are a unique form of contemporary literary criticism, and they often throw light on the author's conception of the novel and on his technique as a craftsman. Because of Dickens's close personal involvement in their creation, the original illustrations provide a unique insight into the way Dickens himself visualized his stories; certainly we cannot read Dickens as his first readers did without them. The legends and anecdotes that gathered around the subject of Dickensian illustration, often provoking sneers in the sophisticated, indicate the extent to which the original illustrations were studied and the affectionate esteem in which they and their artists were held. As the original 
illustrations were inextricable from Dickens's books, so his original illustrators were often inseparable from his life. As their art elucidates aspects of his work, so their relation- ships with Dickens elucidate aspects of the man, and their collective achievement continues to instruct and delight countless readers. 



\title{
Part I: Dickens and His Early Illustrators
}

\author{
GEORGE CRUIKSHANK \\ ROBERT SEYMOUR \\ ROBERT BUSS
}





\section{Chapter 1}

\section{GEORGE CRUIKSHANK}

It is hardly surprising, even in an age when biographers dredge for subjects, that no one has written a modern biography of Dickens's first illustrator, George Cruikshank. ${ }^{1}$ No single person has possessed knowledge (and nerve) enough, perhaps, to write comprehensively about the artist who lived so long-eighty-six years - and produced so many works with such varied subjects and techniques. Yet any history of Dickensian illustration must begin with an account, however circumscribed, of the "Illustrious George," the first artist to work with young, unknown Boz. Any future biographer of Cruikshank must be concerned with his long relationship with Dickens and its curious but distinct bipartite character: on the one hand, their literary, social, and theatrical association from 1835 to 1850 ; and, on the other, their gradual dissociation in all three spheres from 1850 to their deaths in the 1870's. Although the artist illustrated all or part of only five books written, edited, or altered by the author-a mere fraction of the nearly nine hundred books Cruikshank illustrated or the twenty-four Dickens initially published with pictures-these illustrations have kept him in the public eye more than anything else he did. More important, despite the brevity of their collaboration, which spanned just six years from 1835 to 1841 , their work together had a disproportionate effect on the careers of both men. ${ }^{2}$ It is clear in retrospect that their work together was a turning point-though in very different ways-for Cruikshank as well as for Dickens.

From start to finish, the working relationship between author and artist was characterized by a struggle for sovereignty. Such a clash was perhaps inevitable between two men so similar in interests, outlook, energies, and temperament, and it was not mitigated by their disparate ages and, initially, their disparate reputations. That Cruikshank, son and brother of artists, was the undisputed heir of Hogarth, Gillray, and Rowlandson was already a common- place observation. ${ }^{3}$ His early satirical prints on political and social topics of the day, for which he conceived as well as designed characters, plot, and dialogue, were so popular in the London of Dickens's youth that the Crown paid him not to caricature the King; his book illustrations in the 1820's and 1830's for authors, living and dead, were classics before anyone every heard of Boz. ${ }^{4}$ Even prior to their work together, Dickens insisted that no one appreciated Cruikshank's talents as highly as he did. ${ }^{5}$ Once their reputations were commensurate, however, he found the artist's challenge to his authority intolerable. Cruikshank, who found illustrating books unbearable under the limitations Dickens imposed, tried to regain his independent reputation, first through literary enterprises bearing his name, then through the temperance movement. When these efforts failed, his stature diminished even as that of Dickens increased. Gradually Cruikshank made the author a prime scapegoat for his tormented ego; even their past achievement and friendship became sources of renewed contention. Their entire relationship, in the occasionally disordered vision of Cruikshank's old age, became, to borrow a contemporary pun, "All-of-a-Twist."6

All began auspiciously enough in October, 1835, when Harrison Ainsworth's publisher, John Macrone, suggested that Dickens collect his short pieces on London life, which had appeared separately in various magazines and newspapers under his pseudonym, Boz, and publish them in a volume to be illustrated by George Cruikshank. The former employee of Warren's Blacking (for whom the ubiquitous Cruikshank had made some woodcut advertisements) ${ }^{7}$ was exhilarated at the idea. The very presence of Cruikshank's name on a title page guaranteed a sizable sale. By the 1830's, his preeminence in book illustration was so evident that Daniel Maclise had included a picture of him seated on a beer 
barrel sketching on the crown of his hat, in the "Gallery of Illustrious Literary Characters" for Fraser's Magazine (fig. 2). In agreeing to illustrate what became the Sketches by $B o z$, Cruikshank conferred on the novice author one of his first genuine honors. Aware of the artist's condescension, Dickens suggested to the publisher that a more modest title might be:

$$
\begin{aligned}
& \text { Sketches by Boz } \\
& \text { and } \\
& \text { Cuts by Cruikshank }
\end{aligned}
$$

or

$$
\begin{gathered}
\text { Etchings by Boz } \\
\text { and } \\
\text { Wood Cuts by Cruikshank }{ }^{8}
\end{gathered}
$$

The proposed titles displayed the young man's shrewdness as well as modesty. The fact that the published title referred to the author but not the artist, however, proved prophetic.

The first meeting between the two collaborators on November 17,1835 , was gratifying, especially for Dickens. Cruikshank not only wanted to study his published pieces but promised that, as far as he was concerned, the work could appear by Christmas. ${ }^{9}$ The veteran would have been kinder had he warned the neophyte about the difficulties involved in trying to coordinate their efforts with those of the publisher and printer to produce an illustrated volume in little more than a month. Deferred conferences and belated proofs were inevitable. Tension grew. Misunderstandings resulted. At the end of November, Dickens anxiously requested the list of illustrations Cruikshank intended. The artist, perhaps scribbling human and diabolic faces on a corner of the author's letter in his annoyance, complained to Macrone: he said he resented being pressed for illustrations before receiving the complete text and regretted this "unpleasant turn" of affairs. ${ }^{10}$ The author, realizing that his Sketches could not appear by Christmas, no longer rested content with Cruikshank's "good opinion" of and "kind interest" in his work. ${ }^{11}$ Irate at the apparent offhandedness of the artist, who promised one plate one week and two the next, and assuming that each plate illustrated one subject, Dickens magisterially informed Macrone that Cruikshank required the "spur."12 Then realizing that each plate actually contained four subjects, the embarrassed writer became conciliatory, assured Macrone that perhaps the later publication date would prove fortuitous, and concealed his irritation at the further delays due to the artist's refusal to be moved by imperatives of time by praising his labors in behalf of Boz. ${ }^{13}$ It was February 18, 1836, before the Sketches finally appeared.

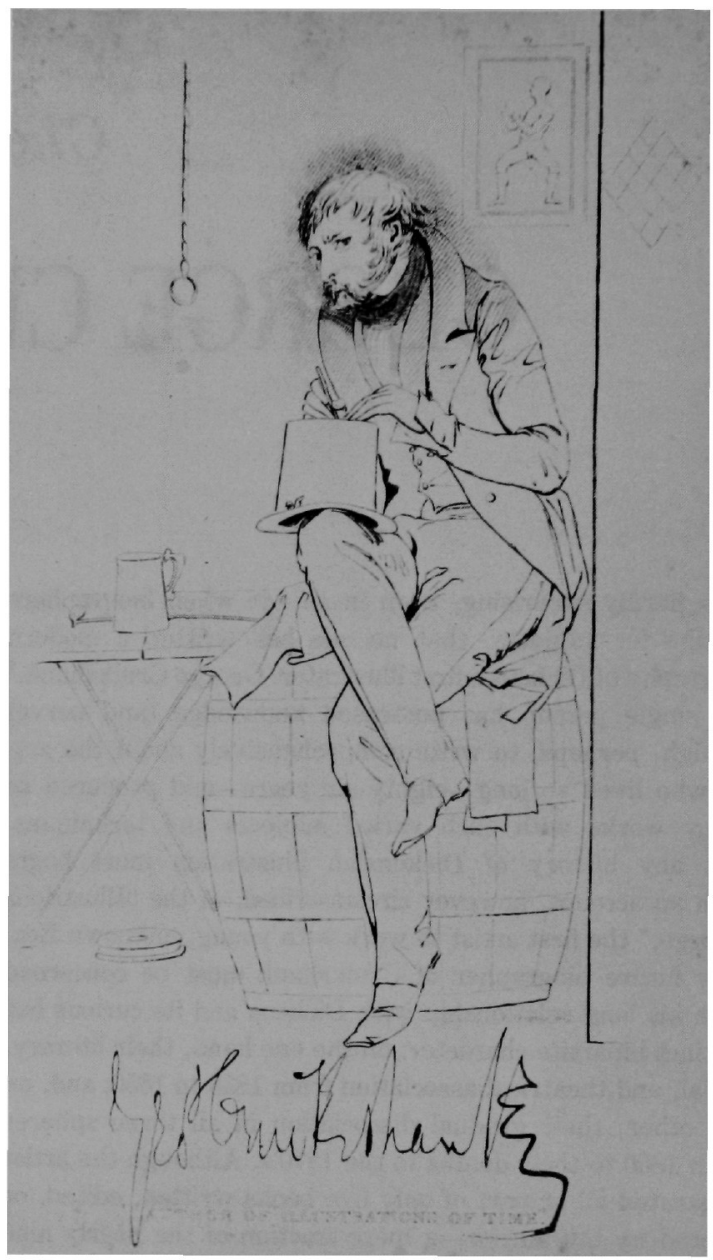

Fig. 2. Daniel Maclise, Portrait of George Cruikshank. Fraser's Magazine, 8 (August, 1833), facing p. 190. Lithograph. $8^{3 / 4^{\prime \prime}} \times 5^{\prime \prime}(22.2 \times 12.7 \mathrm{~cm})$. From the Harvard College Library, Harvard University.

If Dickens had not forgotten his differences with the artist by the time of publication, he had not forgotten his indebtedness either. In the traditional accompanying preface, which he sent to Cruikshank for his approval, he displayed his mastery of self-aggrandizement as well as of flattery. ${ }^{14}$ Slighting Macrone's role in arranging the collaboration, Dickens maintained that it was he himself who had been "naturally desirous to secure some well-known individual who had frequently contributed to the success, though his well-earned reputation rendered it impossible for him ever to have shared the hazard, of similar undertakings. 
To whom, as possessing this requisite in an eminent degree, could he apply but to GEORGE CRUIKSHANK?" (xxiii). Yet the artist's name was excluded from the title page, if not the volume spines, in later editions of the first series of the Sketches, and this preface, perhaps because it was too deferential to the artist, was superseded in all editions after 1836 (xxiii; cf. xxiv-xxix); only one of the subsequent prefaces acknowledges the appeal of the illustrations (xxv) and none mentions the artist by name. By the time they appeared, Dickens no doubt was convinced that his illustrators must be subordinates, not equals. His trials with Cruikshank must have strengthened his determination to establish control over Robert Seymour, who was working with him on The Pickwick Papers, which began to appear two months after the first Sketches. Dickens's desire for control seemed justified by the fact that Pickwick's amazing success attended his collaboration with the pliable Phiz, not with the reluctant Seymour. Cruikshank, however, a member of the old school of fiercely independent artists, chafed in any subordinate role. When he next worked with Dickens, he fought to retain control, at least over his own aesthetic domain.

Even before Boz won greater fame as the author of Pickwick, in the summer of 1836, Macrone had proposed a second series of Sketches by Boz. Dickens was willing, and Cruikshank readily consented to illustrate the intended two volumes. He apparently agreed to select the subjects for illustration with the author, instead of independently as before, when the pieces were already published, and even retained the finished portion of the manuscript in order to follow the text more precisely. ${ }^{15}$ This time, however, Dickens was dilatory. Simultaneously preoccupied with Pickwick, Bentley's Miscellany, The Strange Gentleman, and The Village Coquettes, in addition to his old Chronicle job and his recent marriage, he rarely met with Cruikshank and ultimately failed to supply enough text for two volumes of the new Sketches by Christmas. In less than a year, the "Inimitable Boz" had become better known and busier than the "Illustrious George." Such a reversal of status and its psychological effects inevitably strained their relationship.

Cruikshank, more accustomed to making delays for authors, took offense waiting for Dickens. He waspishly notified Macrone that he had undertaken another project that must be finished before he returned to Boz's; he had expected to see more manuscript, not only to select subjects at leisure, but "in order that I might have the privilege of suggesting any little arrangements to suit the Pencil"; if he could not get "good" subjects to work on, added the artist gratuitously, he would not work at all. ${ }^{16}$

Macrone forwarded Cruikshank's letter to Dickens who, not perceiving that the artist's main complaint was hurt pride, replied with a fury barely veiled with sarcasm. "I have long believed Cruikshank to be mad; and his letter, therefore, suprises me not a jot. If you have any further communication with him, you will greatly oblige me by saying from me that I am very much amused at the notion of his altering my Manuscript, and that had it fallen into his hands, I should have preserved his emendations as 'curiosities of Literature,' . . . I positively object to his touching it." 17 The author then questioned whether the work even needed any illustration, forgetting, in his wrath, that Macrone could hardly publish a two-volume work with plates in only one volume. If pictures were necessary, perhaps "his" Pickurck illustrator should provide them, Dickens suggested, with the implication that Phiz was already better known to the public than Cruikshank (and certainly more subservient to the author, as his use of the possessive suggests). Tempers eventually cooled. Work resumed. But lacking sufficient text, Macrone had no choice but to bring out the second series of Sketches in December, 1836 in a single illustrated volume-a change of plan that, given the circumstances, as Dickens impishly told Cruikshank, was an "excellent notion." ${ }^{18}$ His preface, in which the public is urged to accept the work on account of its illustrations, if on no other grounds, shows that Dickens had not altogether lost sight of the fact that Cruikshank's work was indispensable to the Sketches' success. Although the artist's name did not appear on the title page of the second series of the Sketches, it was reinstated by the time of the Collected Edition, in 1839, the version with which posterity is most familiar.

Taken together, the Sketches of 1836, which were later reorganized and published together, in monthly parts from 1837 to 1839 , and in a bound volume in 1839 , reveal nothing of the dissension-though something of the haste-that marked the course of Dickens's work with Cruikshank. ${ }^{19}$ Indeed they express all the aesthetic harmony one looks for from two talented men, who, despite differences in age and media, had much in common. Neither brought to his chosen art any formal training, but each was endowed with unusual energy, flair for self-dramatization, and a forceful public consciousness. Both were intimately acquainted with the physical, social, and moral topography of middle and lower class London in the 1830's, the setting for all of the Sketches. Indeed, the painstakingly accurate verbal and graphic descriptions of costumes, furnishings, and vehicles in scenes like 'Seven Dials' (S, V, facing p. 70) and 'The Last Cabdriver' ( $\mathrm{S}, \mathrm{XVII}$, facing p. 140) make the book a valuable quarry for historians of the period. ${ }^{20}$ 
Most important, as Professor J. Hillis Miller has persuasively demonstrated, both men were thoroughly familiar not only with popular drama and literature, but, above all, with graphics, whose conventions mold the Sketches throughout. $^{21}$

As their collective title suggests, Sketches by Boz are self-consciously pictorial. The pieces, written before Dickens ever dreamed that his work would be illustrated, owed almost as great a debt to popular graphic tradition as to Cruikshank's plates. Dickens may have been breaking fresh literary ground in taking for settings gin and pawn shops, courts and prisons, coach and boat excursions, together with the lower middle-class people who frequented them; but such unheroic subjects had long been featured in the prints of Hogarth, Gillray, and Rowlandson, not to mention those of Cruikshank himself. In order to structure and focus his own "little pictures" of London life (xxiii), Dickens appears to have studied not only the subjects of these pictorial satirists, but also their methods.

"It would require the pencil of Hogarth to illustrate ... " (T, I, 289) Boz began a description of one of his characters, thereby echoing an excuse utilized by almost every popular prose writer since Hogarth's time. Dickens, however, went far beyond the mere sentiment in his fiction, and did all he could to streteh his own medium. Admiring, for example, the economy with which Hogarth could hint at a complete sequence and extend one engraving in time if not space, he sought its verbal equivalent. In the many narrative sequences in the Sketches, Dickens achieved a "Hogarthian" ability to anticipate the final destiny of a character or object while representing only the intermediate stages; Cruikshank creatively followed suit. In keeping with Dickens's verbal portrayal of 'The Pawnbroker's Shop,' for example, as Miller and John Dixon Hunt have observed, the artist not only juxtaposes three women in different stages along the way to prostitution, but adds on a background wall a portrait of a fourth woman resembling the other three, who may have passed through the whole debased process in her own life (S, XXIII, facing p. 191) (see fig. 69). ${ }^{22}$ Indeed, Dickens's "progresses" throughout the Sketches, whether of criminals (C, XII, 272) or lovers (C, VII, 242-47) or objects (OP, VII, 41; S, VI, 75-81) are really degenerations, ending only in disintegration or death. The author, and the artist after him, depicted little change in this society that was not for the worse.

Dickens described the appearance of his characters as well as their environment in graphic detail. Yet the physical attributes of his characters, as Thackeray observed, would not have "impressed" themselves on the reader's memory were it not for Cruikshank's rendering of them. ${ }^{23}$ Indeed, despite his delineation of them in conceptual as well as visual detail, Dickens's point was precisely the insignificance of his characters. His Londoners are constantly overwhelmed by their environment; things are endowed with more importance, vitality, and permanence than people. Miller has described the various ways in which Cruikshank reinforces the point visually by surrounding his dimunitive figures with outsized background objects-often one on each side -whose stability seems more a threat than a comfort. ${ }^{24}$ Arches (S, VII, facing p. 84; S, XIX, facing p. 160), pediments (OP, IV, facing p. 22), light fixtures (S, V, facing p. 70; S, XII, facing p. 118; C, VI, facing p. 240), fireplace hoods (S, IV, 66), orchestra shells and organs (S, XIV, facing p. 126), and gin barrels (S, XXII, facing p. 182) menace some and minimize all. Some are even sealed claustrophobically behind closed doors and windows and drawn shades and curtains (S, II, facing p. 60; S, IX, facing p. 256; T, I, facing p. 288; T, VIII, facing p. 414; T, X, facing p. 458). Others, not immediately doomed by the hospital, gallows, or morgue, turn to Astley's Vauxhall, theaters, dancing lessons, and holiday excursions in escapes as futile as they are fleeting. Cruikshank appropriately underscores the transience of such activities by often portraying his characters in actions that clearly cannot be sustained, such as the open-mouthed surprise of Horatio Sparkins (T, V, facing p. 370) or the unstable postures of those Making a Night of it' (C, XI, facing p. 266). By ironic contrast, the impassive figures in the portraits that adorn many of the interiors in the Sketches not only anticipate the possible fate of those characters they so often resemble, as Miller suggests, ${ }^{25}$ but bear witness that permanence in such a society comes only through death, or perhaps, art (C, IV, facing p. 228; S, XXIII, facing p. 190 (see fig. 69); T, III, facing p. 328; and T, XI, facing p. 474). If single moments in the Sketches are comic, their cumulative effect is paradoxical and tragic.

To survive in such a society requires skill at deception and exploitation of one's self and others. Cruikshank makes this point even more explicitly than Boz. Viewed in this light, the many portraits of author and artist throughout the Sketches (title page; S, XIX, facing p. 160; C, VI, facing p. 240; C, XI, facing p. 266) become more than manifestations of Cruikshank's legacy from earlier artists, who more usually relegated their self-portraits to the background of a scene, or even of his particular sense of equality with the author. They inadvertently call attention to the fact that the two men, like many of their characters, are exploiting others for their own amusement and profit under the guise of "art." Perhaps this is what Ruskin was getting at when he cryptically called 'Public Dinners' (S, XIX, facing p. 160) 
(fig. 3) -a scene in which Dickens and Cruikshank smirk at one another while marshaling a procession of indigent orphans- "glorious" yet "withering: if one understands it. But who does? or ever did?"26

The artist had added 'Public Dinners' and other new designs to the collected Sketches by Boz when they were published in one large volume in 1839 after appearing in part-issues since 1837 (see F). In contrast to Browne's early Pickwick plates, which were improved upon being copied, and his own new drawings for the new edition, Cruikshank's enlarged copies of his old "Bozzes"-as Ainsworth dubbed his illustrations for the earlier Sketches ${ }^{27}$ -were lackluster indeed; what they gained in size they lost in vitality. By this time, however, Dickens probably was too absorbed with Oliver Twist and Nicholas Nickleby to notice or even to care. Macrone, who might have commented on the artist's diminished vitality, was no longer alive.

Even before Macrone's death, Dickens disputed whether their agreement for Gabriel Varden, as Barnaby Rudge was originally entitled, was or was not canceled. After waiving rights to this novel in return for the copyright to Sketches by Boz, Macrone ignited another conflict by planning a monthly reissue of the Sketches in green covers, exactly like those of the best-selling Pickwick Papers, a stunt that infuriated Pickwick's author and publishers. This problem was resolved when Chapman and Hall purchased the Sketches copyright and published the monthly reissues themselves.

Despite the resulting acrimony between Dickens and Macrone, when the publisher died suddenly in the fall of 1837 , leaving his family destitute, it was the author who planned a way to help. He proposed that a collection of contributions by writers and artists who knew Macrone be published for the family's benefit, and undertook the management of what became the three-volume Pic Nic Papers. Dickens himself wrote the introduction, edited two of the three volumes, and contributed the first piece. Cruikshank unhesitatingly volunteered his services. Nevertheless, it took three years before "poor Mrs. Macrone's book" was ready to be illustrated, and several months more for Cruikshank to produce two plates for it-one for Dickens's “The Lamplighter's Story" (RP, 753) and another for a contribution by Ainsworth. The Pic Nic Papers did not appear until August, 1841, almost four years after its conception. Still, Dickens was able to send $\$ 300$ in proceeds to the needy Macrone family. ${ }^{28}$

The titular similarity of The Pic Nic Papers to Dickens's first major book raises the inevitable question: why did Cruikshank not become the illustrator of The Pickwick

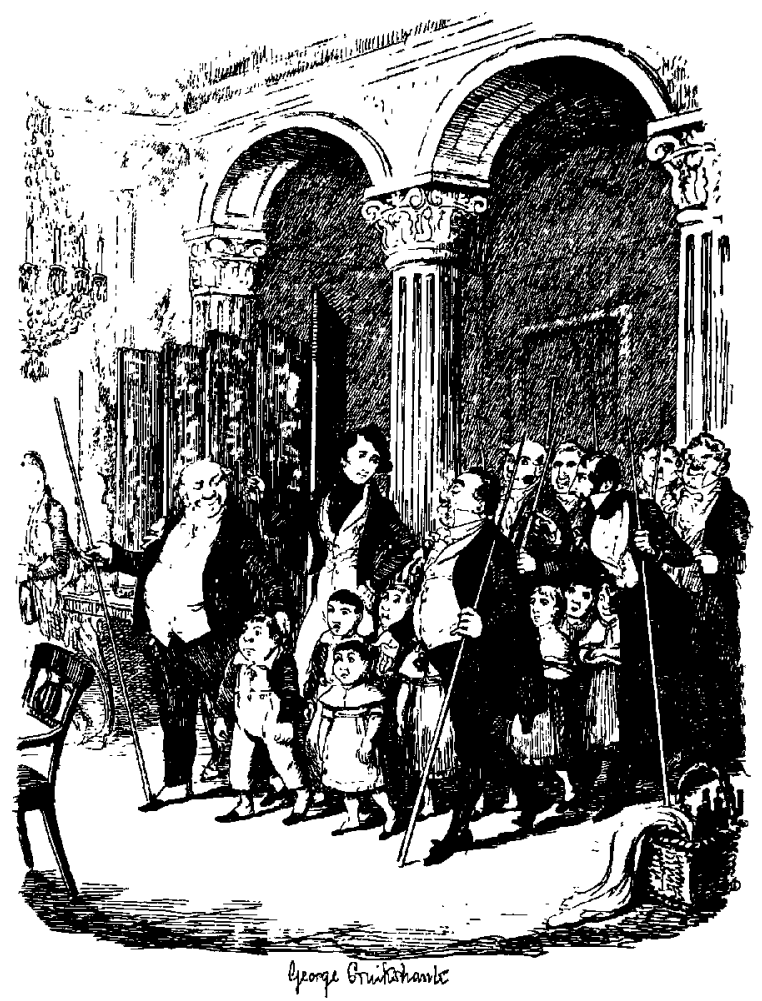

Fig. 3. George Cruikshank, 'Public Dinners.' Sketches by Boz, 8 (June, 1838). Etehing. $4 \% 8^{\prime \prime} \times 3^{11 / 16^{\prime \prime}}(11.8 \times 9.4 \mathrm{~cm})$. From the Harry Elkins Widener Collection, by permission of the Houghton Library, Harvard University.

Papers after Seymour's suicide? Not only was Cruikshank Boz's first illustrator, but he was about to go to work on the next edition of the Sketches; certainly he would seem the obvious choice. There is no evidence, however, that the matter was even broached between the two men. Dickens, pleased as he had been to have Cruikshank illustrate his maiden work, might have been unenthusiastic. His initial tribulations on The Pickwick Papers with Seymour probably strengthened his resolve never again to allow himself to be shackled by an artist's inclination. To have asked the artist of the Sketches to illustrate Pickwick might have jeopardized both his hard-won control over that narrative and his precarious relationship with Cruikshank-an artist of greater stature and force than Seymour.

Cruikshank, for his part, had undertaken other commissions between the two series of the 1836 Sketches, which he probably could not abandon or defer on short notice. In any case, the artist, famous for his representations of London, 
would hardly have been attracted to the rural setting and sporting concerns of the early numbers of Pickwick. Nor would he have been satisfied to work at Seymour's rate of remuneration, which was doubtless lower than he was accustomed to. ${ }^{29}$ Cruikshank's name might have boosted Pickwick's profits in the long run, but the poor sales of its first two issues would have prevented Chapman and Hall from paying more at this time. Cruikshank does not seem to have felt slighted at not being asked to illustrate Pickwick even after it became such a spectacular success. After Seymour's death, he apparently suggested John Leech and, perhaps, his former pupil, William Thackeray, to fill the post. Furthermore, Cruikshank was not angry when Dickens, having already selected Browne, gave both applicants short shrift, and he must have been gratified by Thackeray's attempt to thank him, perhaps, by publicly wishing that Mr. Pickwick and Sam Weller had been described "by Mr. Cruikshank's pencil as by Mr. Dickens's pen." ${ }^{10}$

As editor, from 1836 to 1839 , of Richard Bentley's new monthly Miscellany, Dickens had no choice but to work with Cruikshank again, for Bentley himself chose Cruikshank as illustrator. ${ }^{31}$ Whenever neither man's ego was very involved, their work together proceeded smoothly. When dealing with short contributions by other writers, Dickens usually indicated which were to be illustrated, but left the selection of the actual subjects to the artist. On his own short pieces, Dickens supervised Cruikshank's work more closely but still amicably. Before he even wrote "The Public Life of Mr. Tulrumble, onee Mayor of Mudfog" ( $S B B$, 536-48), he solicited the artist's thoughts about a suitable subject for a plate; in conference together, they finally settled on one Dickens considered "capital," which would show Ned Twigger in the Mudfog Hall ( $S B B$, facing p. 542) kitchen; and he even asked for Cruikshank's opinion of the finished piece. ${ }^{32}$ Under this kind of treatment, Cruikshank flourished. When Dickens later contributed a "Full Report of the Second Meeting of the Mudfog Association for the Advancement of Everything," a Pickwickian satire on the numerous learned societies of the time, the artist put forward his best efforts. He made several studies before he was satisfied with his portrayal of Mudfog's beadle in 'The Tyrant Sowster, and Real Offenders' (SBB, facing p. 572), and his ingenious rendering of an 'Automaton Police Office' (SBB, facing p. 578) left Dickens "in transports." ${ }^{\text {"33 }}$ In working on these "Mudfog Papers," not reprinted in book form until 1880, the two men worked in a harmony that was to become all too rare.

Tension began to build between the two men, however, as they began to work on Oliver Twist, featured in Bentley's
Miscellany from the second number. Dickens was now better known than Cruikshank. He no longer needed to use the artist's name to attract readers, or to put up with his delays and outbursts. Nor did he feel obliged to write deferential prefaces; indeed, neither Cruikshank nor the illustrations are mentioned in any of the three prefaces written for Oliver over the years (vii-xix). Moreover, whereas in 1835 he could not afford to live in the artist's Pentonville neighborhood, now, less than two years later, he took a house on Doughty Street in central London that must have been way beyond Cruikshank's means. ${ }^{34}$ Yet the author may still have felt insecure. He owed an incalculable debt to his early illustrators. Cruikshank had attracted public notice to Boz; Seymour had started the circumstantial chain that resulted in Pickwick; and Browne's advent had coincided with, if not caused, Pickwick's overnight success. Oliver Twist was Dickens's first planned novel-unlike Pickwick, which had grown into one. Its urban, sociological subjects particularly interested Cruikshank, who excelled in representing them, but did not hesitate to advance obtrusive as well as helpful suggestions. In a sense the author indeed would be writing up to the artist, knowing he was so well versed in this area. Yet Dickens hardly wished to be known merely as "the CRUIKSHANK of writers," as the Spectator had recently called him. ${ }^{35}$ Despite his desire for visual reinforcement (a desire he might have partly resented), the author began to act as if he had resolved to become his own illustrator in everything but actual execution of the plates. Cruikshank, accustomed throughout his career to greater independence from authors, could-and did-only seize the initiative in Dickens's absence.

Clearly but tactfully, from the start of their work on Oliver, Dickens put the artist in a subordinate position. Their plan of action was their customary one: Cruikshank was to confer with the author about subjects for the plates and, as time permitted, to submit drawings for his approval; in return, the artist was to receive the text to study early each month though he apparently preferred now, in contrast to the days of the Sketches, to confer with the author in person. In this manner, for example, the famous 'Oliver asking for more' (II, facing p. 12) was executed, a subject that Dickens correctly, if condescendingly, perceived would "bring Cruikshank out."36 Even this procedure, however, soon broke down. Increasingly, the author delayed sending the text and scheduling their meetings. He may have been overcommitted elsewhere, or he may have wished to give the artist a clean copy of the manuscript, or it may be that he wished to spare himself Cruikshank's constant suggestions. Whatever the reason, he not only often sent the text late, when at all, but he began to indicate without consulting with 
the artist the subject he wanted illustrated: in this manner Oliver's escape from the sweep apprenticeship (III, facing $p$. 20), his attack of Noah Claypole (VI, facing p. 42), and his first meeting with Fagin and his band (XVI, facing p. 112) were given to Cruikshank for representation. ${ }^{37}$ Yet the tone of their communications remains tactful and good-humored at this stage.

By this time, however, the whole enterprise threatened to collapse as relations between Dickens and his publisher worsened. In the fall of 1837 , about one-third of the way through the monthly publication of Oliver, Cruikshank took on the unlikely role of mediator between Dickens and Richard Bentley. Prior to the Miscellany's debut, Cruikshank's wrapper design had inspired the Irish writer William Maginn to compose a "Song of the Cover," which concluded:

Boz and Cruikshank want to dance,None for frolic riper;

But Bentley makes the first advance, Because he pays the piper. ${ }^{38}$

The jocular last line soon became ironic. Dickens began squabbling with the publisher about many points in their original contract, especially those which committed him to provide two novels in two years in addition to his required sixteen pages each month for the Miscellany. Before beginning Barnaby Rudge, the "first" novel, Dickens determined that Oliver, already running in the periodical as part of his monthly contribution, should also count as the second novel.

To avoid going to court over the author's attempt to make one literary work fulfill two separate obligations, Bentley accepted Cruikshank's offer to arbitrate the dispute. The artist proved a strange diplomat. Since Dickens rigidly maintained his position, Cruikshank advised the publisher to concede. He argued that the novelty-loving public would soon be "heartily tired" of Oliver Twist, and that, by accepting it as the second novel, Bentley would free himself to drop it from the Miscellany whose prospects it was likely to "injure." 39 The publisher hastily disabused him of this peculiar notion, which was probably a ruse anyway. Both artist and publisher knew full well that Oliver was a drawing card that the new periodical could hardly afford to lose. Just as Bentley told Cruikshank he would yield to Dickens's terms, however, the author gave notice that he was quitting; almost simultaneously, the bewildered Bentley received Cruikshank's declaration that there was still time to produce Oliver for the next number. ${ }^{40}$ The role of arbitrator in the battles between Dickens and his publishers was soon taken over by John Forster, now the author's closest friend. However, when Dickens and Bentley finally ceased their hostilities with a mutually satisfying agreement a year later, it was Cruikshank whom the author invited to celebrate with him. ${ }^{41}$

Soon after the temporary truce was arranged with Bentley, the procedure for choosing and inspecting the illustrations for Oliver went completely awry. Dickens supplied only a short, detailed summary-possibly supplemented by a later conference-for Mrs. Corney's tea with Bumble (XXIII, facing p. 170), and had time for only brief meetings about 'Master Bates explains a professional technicality' (XVIII, facing p. 132) and for Oliver's meeting with the Bow Street runners (XXXI, facing p. 230). ${ }^{42}$ When Dickens finally (and indisputably) allowed the artist to determine a design without consultation, for a number that was not very suggestive visually, Cruikshank perversely waived the privilege and refused to do the illustration. ${ }^{43}$

Then circumstances conspired to make the latent struggle between Dickens and Cruikshank surface, which inevitably affected the remaining illustrations. Dickens planned to tour Wales and the Midlands with Browne and Forster just as the three-volume edition of Oliver was to be published in November, 1838, in advance of its completion in the Miscellany in April, 1839. Before the author left London, he consulted with Cruikshank on the final chapters and suggested the last six subjects. ${ }^{44}$ With Dickens gone, the artist executed the remaining plates with varying degrees of indifference to the author's wishes. It made sense aesthetically to draw the lantern held by Monks in the process of destroying the evidence of Oliver's identity over rather than lowered into the well as described (XXXVIII, facing p. 288), but there seemed no compelling reason for Cruikshank to borrow the huddled pose of the condemned Fagin (LII, facing p. 410) from an earlier less dramatic moment in the text (XLVII, 359). Cruikshank represented 'The Meeting' between Nancy, Rose, and Mr. Brownlow as directed (XLVI, facing p. 352), but declined to portray the first interview between the two women alone as Dickens had specified. Instead he substituted scenes of Sikes trying to destroy his dog (XLVIII, facing p. 374) and to escape from the roof ( $L$, facing p. 394), which the author had strongly advised against illustrating: "it is so very complicated, with such a multitude of figures, such violent actions and torch-light to boot, that a small plate could not take in the slightest idea of it."45 Now openly asserting the artist's prerogative, Cruikshank went ahead and produced the plate that Algernon Swinburne, among others, so justly admired. ${ }^{46}$

Four of the six plates, the most effective ones, stressed the criminal rather than the virtuous element in the nar- 
rative. Indeed, as has long been observed, the artist often had trouble depicting sympathetic or attractive characters, especially women and children, perhaps because such tame subjects did not feature in the Hogarthian tradition. Dickens's work manifested similar difficulty differently: he often overidealized the virtuous; Cruikshank made them too ill-favored. It is not suprising, perhaps, that the eventual conflict between author and artist focused on the sentimental scene of Oliver and the three Maylies by the fireside (with Harry Maylie resembling Cruikshank), admittedly a lackluster visual climax (xvi). But by the time the dispute emerged, the plates were already etched, the text printed, and the volumes ready for delivery to the bookseller.

Dickens was so uneasy about being absent on the eve of Oliver's publication that he returned unexpectedly to London to insure that there would be no mistakes. Seeing the artist's final plates for the first time, he was dismayed. His dislike of the illustrations was doubtless colored by the feeling that Cruikshank had taken advantage of his absence to assert his independence. According to Forster's peremptory note to Bentley that aftemoon, Dickens initially wanted to exclude most of the concluding illustrations, but was persuaded that only Sikes with his dog and Oliver with the Maylies constituted "vile" and "disgusting" interpolations on the story's meaning. "The evil effects of the others, bad as they are," Forster rationalized, "will chiefly attach to Mr. Cruikshank himself." 47

Either Forster magnified the author's objections, or Dickens's temper cooled remarkably overnight. In a temperate letter to Cruikshank the next day, he said nothing about Sikes and his dog (which Forster felt resembled a "tail-less baboon" and even Thackeray thought badly drawn). ${ }^{48}$ Dickens mentioned only the final sentimental scene (xvi), and that far more tactfully than Forster had. "With reference to the last one-Rose Maylie and Oliver. Without entering into the question of great haste or any other cause which may have led to its being what it is-I am quite sure there can be little difference of opinion between us with respect to the result_-May I ask you whether you will object to designing this plate afresh and doing so at once in order that as few impressions as possible of the present one may go forth?"49

Harassed and hurt, Cruikshank objected. Loath to replace the design, he first tried to improve the original by means of stippled shadows. Finally, however, he capitulated and designed an entirely new plate showing Rose and Oliver vising the tomb of Agnes (LIII, facing p. 418). Dickens thought the pair "too old"; and certainly Rose, with her long face and pinched waist, is among the least winning of all Cruikshank's many unattractive women, though her inappropriately light-colored dress was remedied when the plate wore out in later editions of the novel. Yet the artist, aside from apparently erasing the author's marginal criticisms, made no further changes in this "Church" plate; ${ }^{50}$ at least it was more in keeping with the book's somber ending than the earlier "Fireside" plate. As if signaling victory in his fight for ascendency over his illustrators, Dickens used his real name for the first time on Oliver's title page. Cruikshank's name never appeared with the author's again except on minor works. The struggle between them, however, was to be sadly protracted in the artist's mind.

Curiously, both Dickens and Forster exempted Cruikshank's portrayal of the doomed Fagin from their general condemnation of Oliver's concluding illustrations (LII, facing p. 410). In their silence, they anticipated Thackeray, who observed of Cruikshank's Jew "let us say nothing of it, - what can we say to describe it?" ${ }^{\text {51 }}$ Other viewers have rarely been at such a loss for words. Yet the plate may reveal more about the artist than the text it purportedly illustrates. Dickens would not have faulted Cruikshank for utilizing, as he himself did in characterizing Fagin, superficial aspects of traditional Jewish stereotypes from life, literature, and art, such as the peddler in Hogarth's 'Election' series, which Hazlitt described as the "very Jew in Grain" (fig. 4), or the ones in his own works, such as the figures in 'Monmouth Street,' for example (SBB, VI, facing p. 76), in addition to Fagin (fig. 5) ${ }^{52}$ But the author
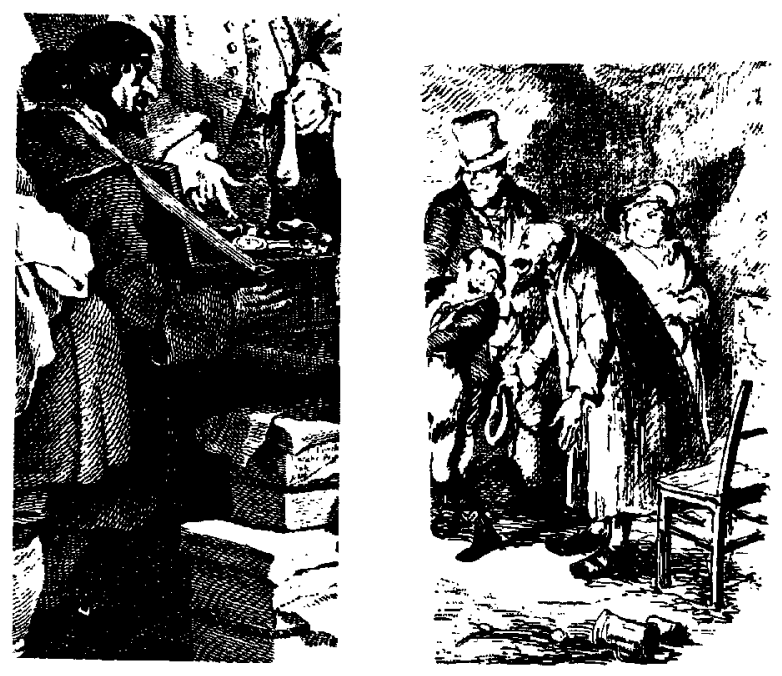

Fig. 4 (left). After William Hogarth, A Jewish Peddler. Detail from 'The Election Series,' plate 2, 'Canvassing for Votes,' February, 1757, engraved by C. Grignion from painting in Sir John Soane's Museum. Engraving, sixth state. $17^{1 / 4^{\prime \prime}} \times 22^{\prime \prime}(43.8 \times 55.9 \mathrm{~cm})$ [sheet size]. Courtesy of the Fogg Museum, Harvard University. Fig. 5 (right). George Cruikshank, Fagin. Detail from 'Oliver's reception by Fagin and the boys,' Bentley's Miscellany, 2, facing p. 430. Etching. $46 / 8^{\prime \prime} \times 33 / 4 "(11.8 \times 9.5 \mathrm{~cm})$. From the Harvard College Library, Harvard University. 
must have been disconcerted to find that Cruikshank had depicted a Fagin not staring at the ground or beating against the walls and door throughout his last night alive (LII, 409-11), which the plate was to represent, but as he had appeared earlier in the book after hearing Noah Claypole's report on Nancy's meeting with Mr. Brownlow and Rose Maylie: "[Fagin] sat crouching . . . wrapped in an old worn coverlet. . . . His right hand was raised to his lips, and as, absorbed in thought, he bit his long black nails, he disclosed among his toothless gums a few such fangs as should have been a dog's or rat's" (XLVII, 359). Even if Dickens tacitly resented Cruikshank's evasion of his final descriptions of Fagin, he must have admired the economical manner by which the artist linked the two scenes and sustained Fagin's characterization.

Aside from the plate's aesthetic and dramatic impact, later viewers found the plate to be of considerable psychological interest. As G. K. Chesterton observed, "it does not look merely like a picture of Fagin; it looks like a picture by Fagin." ${ }^{53}$ Chesterton, of course, writing in the next century, possessed hindsight as well as insight. But there is an odd physical resemblance between the artist and his best-known criminal subject, to judge by some of Cruikshank's selfportraits. In many of his innumerable representations of himself, even the ones with which he often decorated the margins of his working sketches, the artist portrayed himself as an elegantly dressed gentleman with dark hair, flashing dark eyes, and an aristocratically long nose. ${ }^{54}$ In reality, this was somewhat self-flattering. Cruikshank apparently was a small man with a swarthy complexion, dark hair, prominent eyes, and an aquiline nose, similar in features, if not in exaggerated expression, to his 1842 self-portrait of the artist scaring society (fig. 6) ${ }^{55}$ In fact, as Cruikshank informed Henry Mayhew in the $1860^{\prime} \mathrm{s}$, in one of many anecdotes surrounding his conception of the doomed Fagin (fig. 7), the Jew was a mirror image of himself. Despairing of properly depicting the criminal, he allegedly sat up in bed one morning, with his hand covering his chin and his fingertips between his lips in hopelessness. Suddenly noting his reflection in the mirror opposite, he exclaimed, "That's it, that's just the expression I want!"56 By then, Cruikshank, who never denied this story but also mentioned other living models, wanted the original for the villain's appearance to be revealed. ${ }^{57}$ For as Miller has also perceived, his art was not merely generated by external sources, whether objects, figures, or texts, but by projections from his own internal world. ${ }^{58}$ Equally applicable to Cruikshank's portrayal of Fagin may also be Hans Meyrick's explanation to Daniel Deronda in Eliot's novel: an artist, diffusing his soul in his work, "puts what he hates into caricature" (V, XXXVI).

Indeed, the artist's identification with Fagin was more
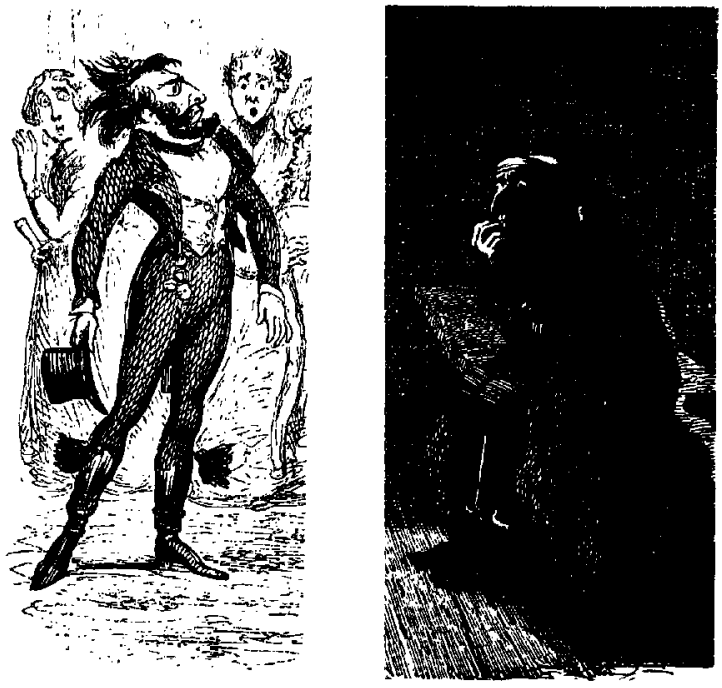

Fig. 6 (left). George Cruikshank, Self-Portrait. Detail from 'George Cruikshank frightening Society,' George Cruikshank's Omnibus, 1 (May, 1842), p. 4. Wood engraving. $358^{\prime \prime} \times 3 \% 16^{\prime \prime}$ $(9.2 \times 9 \mathrm{~cm})$. By permission of the Houghton Library,

Harvard University. Fig. 7 (right). Fagin. Detail from 'Fagin in the condemned Cell,' Bentley's Miscellany, 5, facing p. 281. Etching. $43 / 4^{\prime \prime} \times 3^{3 / 4^{\prime \prime}}(12.1 \times 9.5 \mathrm{~cm})$. From the Harvard College Library, Harvard University.

than momentary. As Dickens, in his late years, became obsessed by the murder of Nancy, so Cruikshank increasingly relished discussing and dramatizing Fagin. Cuthbert Bede was present on one of those occasions when the artist crouched "in the huddled posture of 'the Jew'-fiercely gnawing at his finger-nails, tossing his hair loosely against his head, and calling up a look of wild horror into his eyes." Cruikshank was noted for his histrionic powers, and readily transformed himself into the very essence of the villain he had so memorably delineated. At the close of his life, when claiming to have originated parts of the Dickens works he had illustrated, it might have been concluded that the artist identified even more profoundly with his most famous subject.

Until the finale of Oliver Twist, the strain between the author and the artist had no aesthetic repercussions. Both men were in their element in the Hogarthian world of lower-class London, though less comfortable in the higher social milieu of the Maylies and Mr. Brownlow. Indeed, as the preface (vii) and subtitle "The Parish Boy's Progress" suggest, Oliver was explicitly Hogarthian in much of its content and purpose. The destinies of Oliver and Noah Claypole, for example, as Hurt points out, recall the rival paths taken by the industrious and idle apprentices, and Cruikshank's composition of Oliver kneeling before the 
magistrate (III, facing p. 20) approximates that of the idle apprentice before his former fellow, now an alderman; similarly, Nancy's fortunes recall those of Moll Hackabout, and the moral degradation of the decaying neighborhood in which she and her peers live is like that of Hogarth's impoverished, criminal London. ${ }^{60}$ Oliver, in contrast to the Sketches by Boz but in keeping with Hogarth's engravings, begins to suggest, in addition, the interrelationships among the classes of society that Dickens amplifies in his later novels. Declarations that Dickens was Hogarth's heir in literature now became as commonplace as prior assertions that Cruikshank was Hogarth's graphic descendant. ${ }^{61}$

Cruikshank followed Dickens's lead as he deployed more and more Hogarthian emblems in Oliver to reinforce aspects of character, plot, and theme. Cruikshank's use, for example, of objects of art is effective, though not as profound as it was in the Sketches by Boz or as the use made of them by Phiz in subsequent novels. A graveyard scene suits the back parlor of Sowerberry the undertaker (XXVII, facing $p$. 202), and a broadside of three hanged men in Fagin's den suggests both the occupation and the destiny of its inmates (VIII, facing p. 58). The portrait of the lady who resembles the convalescing Oliver revives curiosity about his true identity, and a picture of the ministering Good Samaritan recalls both Mr. Brownlow's disinterested rescue of the boy and the persistence of the Good Samaritan theme throughout the narrative (XII, facing p. 82). ${ }^{62}$ The portrait of Mrs. Corney that hangs in her parlor suggests her vanity, and the small figure of Paul Pry on the mantle suggests both the actions and motivations of her suitor, Mr. Bumble, during the courtship scene that Thackeray pronounced "even better in Cruikshank's version than in Boz's exquisite account of the interview" (XXIII, facing p. 170). ${ }^{63}$

The background details of Cruikshank's plates, however, are less striking than their overall impression of grotesqueness - a characteristic with more numerous and positive connotations than in our day - meaning odd or exaggerated rather than weird or bizarre. "Taken all in all," commented Ruskin, despite his negative reaction to the artist's plates for Oliver, "the works of Cruikshank have the most sterling value of any belonging to this class produced in England." Baudelaire, speaking of the artist in the same breath with Goya and Breughel, termed his use of the grotesque his "mérite spécial."65 If the characters in Cruikshank's cramped centripetal etchings for the Sketches by Boz seem possessed by "la violence extravagante du geste et du mouvement," said the French poet, those in Oliver Twist manifest "l'explosion dans l'expression," especially in the many scenes involving strong but repressed emotions: ${ }^{66}$ the awed fear of the wizened youths watching Oliver ask for more (II, facing p. 12); the threatening aspect of the Maylie servants and dogs upon finding the wounded Oliver at the door (XXVIII, facing p. 213); the bemused smirks of the paupers watching Bumble's degradation (XXXVII, facing p. 274); the grimaces of Noah and Fagin conspiring (XLII, facing p. 326) (which Ruskin found the quintessence of vulgarity); ${ }^{67}$ and the despair of the condemned Fagin (LII, facing p. 410). Even the more amusing faces in the tea-drinking scene involving Bumble and Mrs. Corney (XXII, facing p. 170) and its parodic sequel involving Noah and Charlotte (XXVII, facing p. 202) are distorted by leers, and the long-faced, long-nosed visages of Oliver and Rose remain doleful even in the happiest circumstances offered by the narrative (XII, facing p. 82; XXXI, facing p. 230; LIII, facing p. 418). Henry James perceived this oddity in recalling that Dickens's novel was "all marked with that peculiarity of Cruikshank that the offered flowers of goodnesses, the scenes and figures intended to comfort and cheer, present themselves under his hand as but more subtly sinister, or more suggestively queer, than the frank badnesses and horrors." 68

It is understandable that James was as frightened by the supposedly "nice" people and "happy" moments in the plates as by the "low and awkward" ones. Certainly the artist did not sustain Dickens's idealization of the virtuous characters. Most are physically malproportioned, if not downright unattractive. If Fagin is too thin, so is Oliver. Bumble is too fat, but so is Brownlow. Nancy, whether robust or reduced, ${ }^{69}$ and Rose--like almost all Cruikshank's femalesare equally unappealing. Similarly, as viewers have noted, their quarters, whatever their status, are uniformly low, dark, and often ominous, thereby adding to the sense of suppressed energy conveyed by Dickens's prose. ${ }^{70}$ At least the young James knew where he stood emotionally while viewing an outright villain or a depressing interior, but the sense that the supposedly virtuous scenes and characters often looked, and thus might become, malevolent at any moment was unsettling. As an American, and a young and comfortable one at that, James could not yet perceive that such oddities were the least of the grotesque features in the real as well as the fictional London world. This perhaps is the point Thomas Love Peacock was making when he declared that Cruikshank's "unmatched grotesqueness" made him "a great philosopher."71

Although the period from 1837 to 1839 was the busiest of their professional association, Dickens and Cruikshank sandwiched in three other projects in addition to Oliver Twist, the Miscellany, and the new edition of the Sketches by Boz. These endeavors, though not significant aesthetically, do illuminate other aspects of the talents and temperaments of the two men. The first, a sketch portrait of the author, executed by the artist in 1837, was disappointing, given Cruikshank's unique knowledge of his subject and his talent for capturing expression (fig. 8). ${ }^{72}$ The judgment of Mamie Dickens-that the artist's portrait could never 


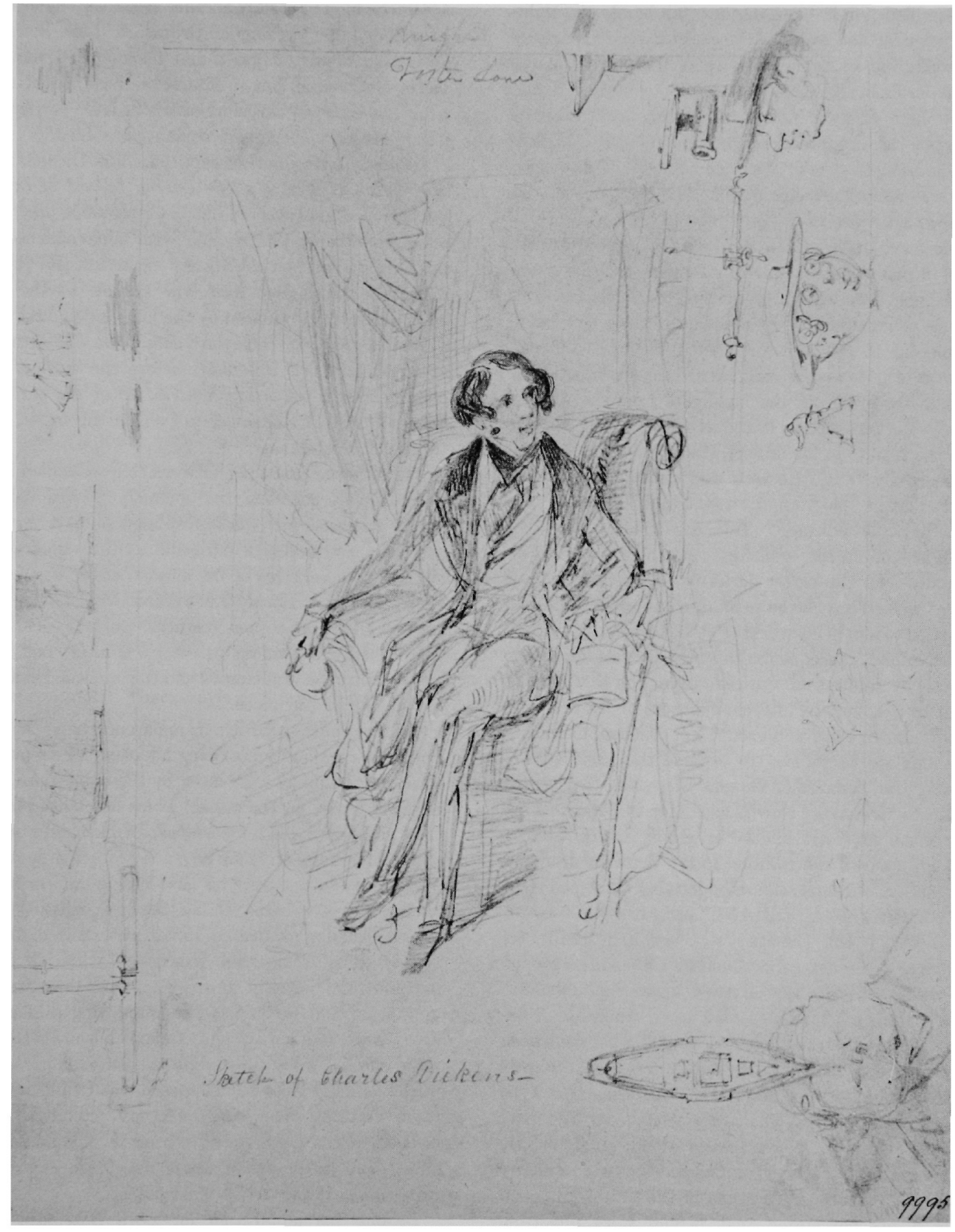

Fig. 8. George Cruikshank, Sketch Portrait of Dickens, 1837. Pencil. 9\%/ $\times 7 / 1 "(24.5 \times 19.7 \mathrm{~cm})$. By permission of the Victoria and Albert Museum. 
have resembled her father-was not too harsh: the tightfitting frock coat and oversized neckcloth were apparently characteristic of the author's effete D'Orsay dress at the time, but Cruikshank hardly captured the face of "steel" noted by Jane Carlyle, nor "the piercing eye" Bowring recalled, nor the expression Leigh Hunt thought contained "the life and soul . . . of fifty human beings.." ${ }^{\text {"73 }}$ Perhaps the artist shared Macaulay's opinion that "the best portraits are those in which there is a slight mixture of caricature."14

In February, 1838, the Memoirs of Joseph Grimaldi appeared in two volumes, edited by Dickens and illustrated by Cruikshank. Bentley had purchased the famous clown's voluminous notes after his death in May, 1837, and prevailed on the reluctant Dickens to edit them. ${ }^{75}$ Thomas Wilks had prepared a crude manuscript, and Dickens laboriously abridged it—to bring out the highlights from the "dreary Twaddle"-and provided an introduction and conclusion. He dictated the results to his father, which provoked the false rumor heard by D. G. Rossetti and still perpetrated by Grimaldi's latest biographer, that John Dickens, not Charles, did the editing. ${ }^{76}$ The Athenaeum, detecting Dickens's lack of interest in his task, questioned whether he had actually seen the clown perform. ${ }^{77}$ Dickens, who had seen "Joe" when a boy, loved to imitate him as an adult, and often alluded to him in his works ( $P P, \mathrm{~L}, 707$ and $M C$, XXII, 373 , for example), conceded that his memory was imperfect, but effectively refuted the criticism by noting that none of the great biographers-Plutareh, Johnson, or Hazlitt-had personally known their subjects. ${ }^{78}$ Yet Dickens took little pride in this work, refused to provide the same editing services for the memoirs of Thomas Eller, who had played Harlequin to Grimaldi's clown, and later insisted that he undertook the Memoirs mainly to gratify Cruikshank. ${ }^{79}$

Although his own contribution to the Grimaldi Memoirs was pedestrian, Dickens acknowledged that "the good right hand of GEORGE CRUIKSHANK" had rarely been better exercised $(C P, 1,12)$. The artist's clowns, animated by his knowledge of theater in general and by his fondness for the harlequinade in particular, certainly made the "Twaddle" palatable to the public. The Athenaeum, admiring Cruikshank's "capital" sketches, decided that he must have seen the clown; indeed he had. ${ }^{80}$ The artist had etched him in caricatures from 1807 on, and in the 1820's had portrayed him during performances. He had also belonged to The Crib, a club over which the clown had presided; he frequently visited his grave, and was to paint his likeness from memory again in 1856. Cruikshank's sense of the grotesque, combined with his perception that people were unwitting clowns, may have been overstimulated by these early antic recollections. In some, but not all, of the early issues of the
Memoirs, he, or possibly another artist, as Vogler suggests, surrounded the etching of Grimaldi's 'Last Song' with a border of distorted faces and disembodied mouths, not merely grotesque, but so bizarre, in fact, that it may have been the cause of its cancellation in later editions. ${ }^{81}$ This minor mystery, however, remains unsolved.

More satisfying but surreptitious was Dickens's connection with Cruikshank's The Loving Ballad of Lord Bateman, which appeared in 1839. Cruikshank, like Dickens, often entertained his friends with seriocomic songs. $\mathrm{He}$ particularly relished a Cockney variant of the popular old ballad of an English lord who travels to the East, is imprisoned, then released by the jailer's daughter whom he promises to marry in seven years. ${ }^{82}$ On one occasion, the artist sang "Lord Bateman" before the author who was delighted with his droll rendition. After the performance, Dickens urged Cruikshank to publish the ballad with the tune and illustrations. ${ }^{83}$

The flattered artist set to work. He welcomed Dickens's assistance in polishing the solemnly absurd ballad. The author altered a few words, replaced the last verse with a new one, and added a burlesque critical apparatus. ${ }^{84} \mathrm{He}$ obtained the services of his musical sister Fanny and her husband, Henry Burnett, to record Cruikshank's tune and mark the expression and gestures. Burnett took the music down hastily, intending to recopy it later, but the artist insisted that the crude notes and the one-sided clef added to the humor of the piece. ${ }^{85}$

In his enthusiasm, Dickens apparently sang the ballad to Thackeray without mentioning his plans for its publication. Thackeray, equally captivated by the noble Lord, etched a series of plates for the ballad, which he planned to publish. Only afterwards did he learn that Cruikshank was working on the same subject. "I am not such a fool to suppose that my plates can hurt yours," he hastened to inform his former teacher, "but warning is fair between friends." eray's plans for publication never materialized. Undaunted in any case, Cruikshank proceeded with his plans. He published the ballad in his own name, but tantalized readers by stating that neither the accompanying preface nor the notes were written by him, though he nowhere disclosed their author. Thus the Spectator, for example, found the introduction, which they supposed was Cruikshank's work, more amusing than his "ludicrous" etchings. ${ }^{87}$ Dickens considered the illustrations a triumph of comic draftsmanship. "You never did anything like those etchings-," he congratulated the artist, "never." 88

Despite his admiration for Lord Bateman, however, Dickens never publicly acknowledged his contributions to it. Disconcerted when the Morning Post mentioned him as the 
author of the ballad's introduction and notes, he begged Cruikshank to remain silent. "Pray be strict in not putting this about as I am particularly_most particularly—anxious to remain unknown in the matter for weighty reasons." ${ }^{89}$ It is possible that Dickens wished anonymity because of his agreement with Bentley not to write any other works before the long-deferred Barnaby Rudge, or because the ballad was beneath the dignity of an author who wanted serious as well as popular approval, though neither of these reasons had previously inhibited him from doing whatever he pleased. In any case, the artist kept the author's secret for almost thirty years. In $1867, \mathrm{~F}$. W. Pailthorpe, an artist who executed some of the "extra" illustrations to Dickens's novels, discovered that the literary portion of Lord Bateman was by Dickens, not Cruikshank. "Yes," the artist finally admitted, "Charlie did it for me." Even this revelation, however, was not made public until 1935.

Dickens's anonymity was sustained partly because substantial evidence was advanced to connect Thackeray with the ballad. In 1839 Thackeray was writing for Cruikshank's Comic Almanac, which was issued by Charles Tilt, the publisher of Lord Bateman - a coincidence reinforced by Thackeray's fondness for the phonetic Cockney used in the ballad, whose meter, commentary, characterization and, even, the ultimate abandonment, resembled other works by him. ${ }^{91}$ Long after the deaths of both Dickens and Thackeray, speculation continued. Thackeray's daughter, Anne, finally decided diplomatically that "the notes sounded like Mr. Dickens's voice and the ballad like my father's." 92 In 1892, however, an overturned table accidentally disclosed the illustrated manuscript of Thackeray's "Lord Bateman," which, perhaps in deference to Cruikshank, had never been published..$^{93}$ Exactly why Thackeray never published his version and why Dickens concealed his participation in Cruikshank's Lord Bateman remain enigmas.

There is less mystery, however, about the probable models for Lord Bateman in each set of drawings. At the outset of his adventures, Cruikshank's dark, lean hero resembles Cruikshank (fig. 9); Thackeray's the savagejawed Thackeray (fig. 10), though his hero passes through more physiognomic vicissitudes. ${ }^{94}$ (Another contemporary "Lord," portrayed by a later Dickens illustrator, Richard Doyle, on a sketch of a title page for yet another edition, which never materialized, resembles neither his creator nor his graphic predecessors but he is paired with a far prettier Sophia (fig. 11).) ${ }^{95}$ If Cruikshank's condemned Fagin seems partly to reflect the artist's disparaging self-image, his Lord Bateman could be said to represent the convivial aspect of his nature. To the end of his life, Cruikshank never tired of acting the roles of both these characters, originally delin- eated within months of one another. At the Greenwich dinner to welcome Dickens home from America in 1842, at the Cheshire Cheese on lesser occasions, and during intermissions at the author's amateur theatricals, the artist rendered the ballad, his coat flung over his arm, his sleeves rolled up, as he disported himself in the manner of his humorous nobleman; even in his old age, at the height of his temperance mania, Cruikshank greeted his guests in the costume of this wine-loving hero. ${ }^{96}$

With the 1841 Pic Nic Papers for the widowed Mrs. Macrone, whose husband had introduced Cruikshank and Dickens, their professional relationship came full circle and ended. Other collaborations had been suggested but never carried out. In February, 1836, for example, Dickens had been eager to talk over the artist's idea for a satire on the theater of the time, but nothing came of his enthusiasm. ${ }^{97}$ In February, 1838, Ainsworth announced that he and Dickens were about to write some tales about "ancient and modern London in a Pickwick format" with illustrations by Cruikshank and Leech. ${ }^{98}$ The only thing that materialized from this idea was Cruikshank's cover design, subsequently used for the monthly parts of Old St. Paul's (though perhaps it inspired Dickens's original plan for Master Humphrey's Clock). Some readers thought that More Hints on Etiquette, a slim volume published in 1838 with Cruikshank's woodcuts, was written by Dickens because one of the manuscript pages is in his hand, several others are in Cruikshank's, and on the backs of two more are preliminary sketches for "Oliver plucks up a spirit." ${ }^{99}$ There is nothing else in the style, substance, or pseudonym ("Pedagogue") of this mock-courtesy book that suggests the writer's hand, but, as Vogler states, there are more reasons, though not conclusive, to attribute the text, as well as the illustrations, to Cruikshank. ${ }^{100}$

Nothing came of plans in late 1839 to have Cruikshank illustrate Barnaby Rudge. Dickens was still obligated to write this work for Bentley, who was now trying to enforce its delivery by advertising its forthcoming publication. After vacillating about whether the work should be illustrated at all, in early October the author finally promised Cruikshank to have "MS by the middle of the month for your exclusive eye," and to grant him "as many consultations and preliminary explanations" as he liked. ${ }^{101}$ But by the middle of the month Dickens had decided to withhold even this longcontracted work from Bentley, which, thanks to Forster's negotiations, he was able to do. Chapman and Hall were the publishers of Bamaby when it appeared at last in 1841 as part of Master Humphrey's Clock. It was not illustrated by George Cruikshank, who was still working for Bentley's 

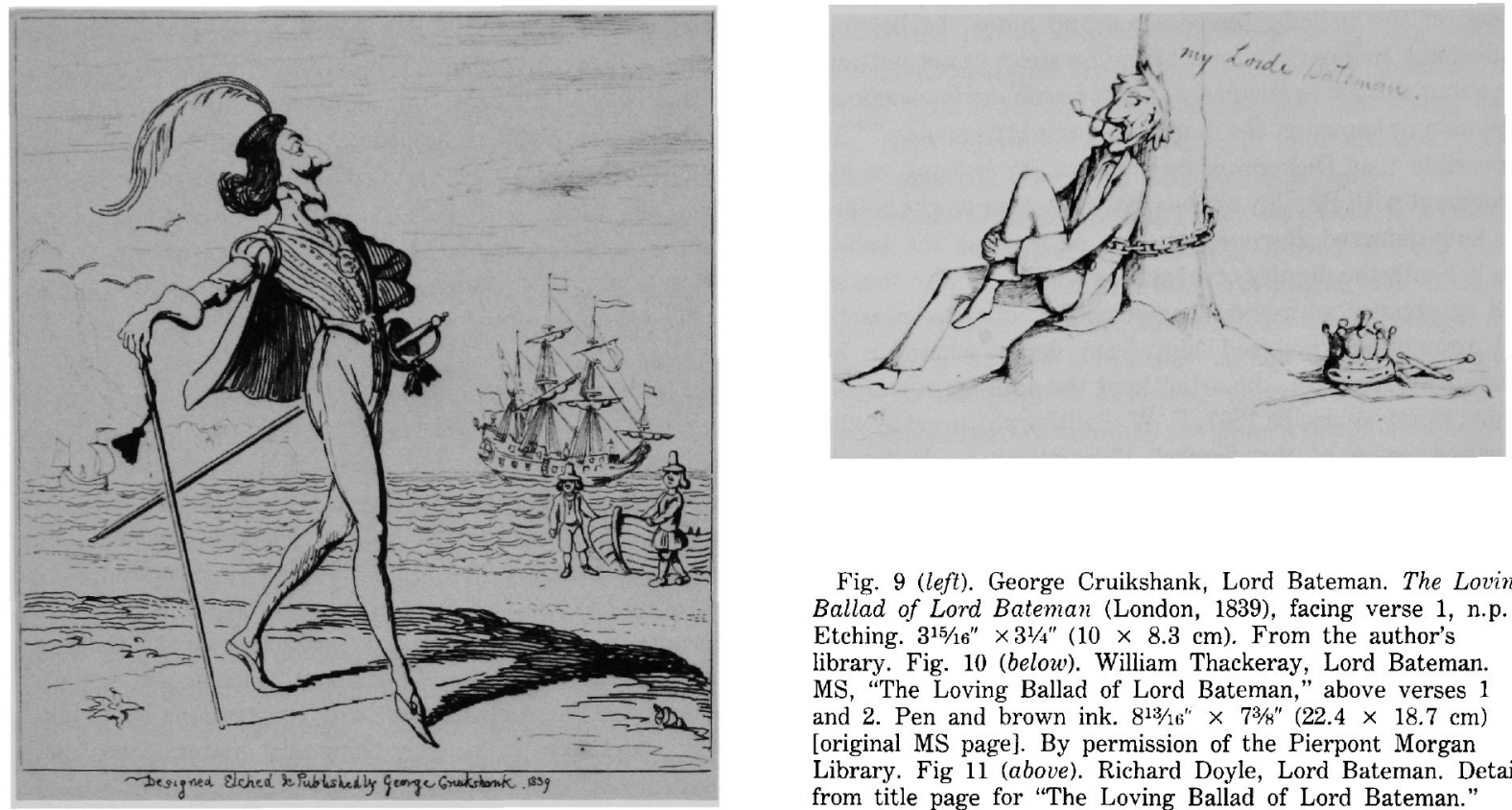

Fig. 9 (left). George Cruikshank, Lord Bateman. The Loving Ballad of Lord Bateman (London, 1839), facing verse 1, n.p. Etching. $3^{15 / 16^{\prime \prime}} \times 3^{1 / 4^{\prime \prime}}(10 \times 8.3 \mathrm{~cm})$. From the author's library. Fig. 10 (below). William Thackeray, Lord Bateman. MS, "The Loving Ballad of Lord Bateman," above verses 1 and 2. Pen and brown ink. $8^{13 / 16^{\prime \prime}} \times 7^{3 / 8^{\prime \prime}}(22.4 \times 18.7 \mathrm{~cm})$ [original MS page]. By permission of the Pierpont Morgan Library. Fig 11 (above). Richard Doyle, Lord Bateman. Detail from title page for "The Loving Ballad of Lord Bateman." Pencil. $91 / 2^{\prime \prime} \times 10^{5 / 1}(24.2 \times 27 \mathrm{~cm})$ [sheet size]. By permission of Gordon N. Ray.

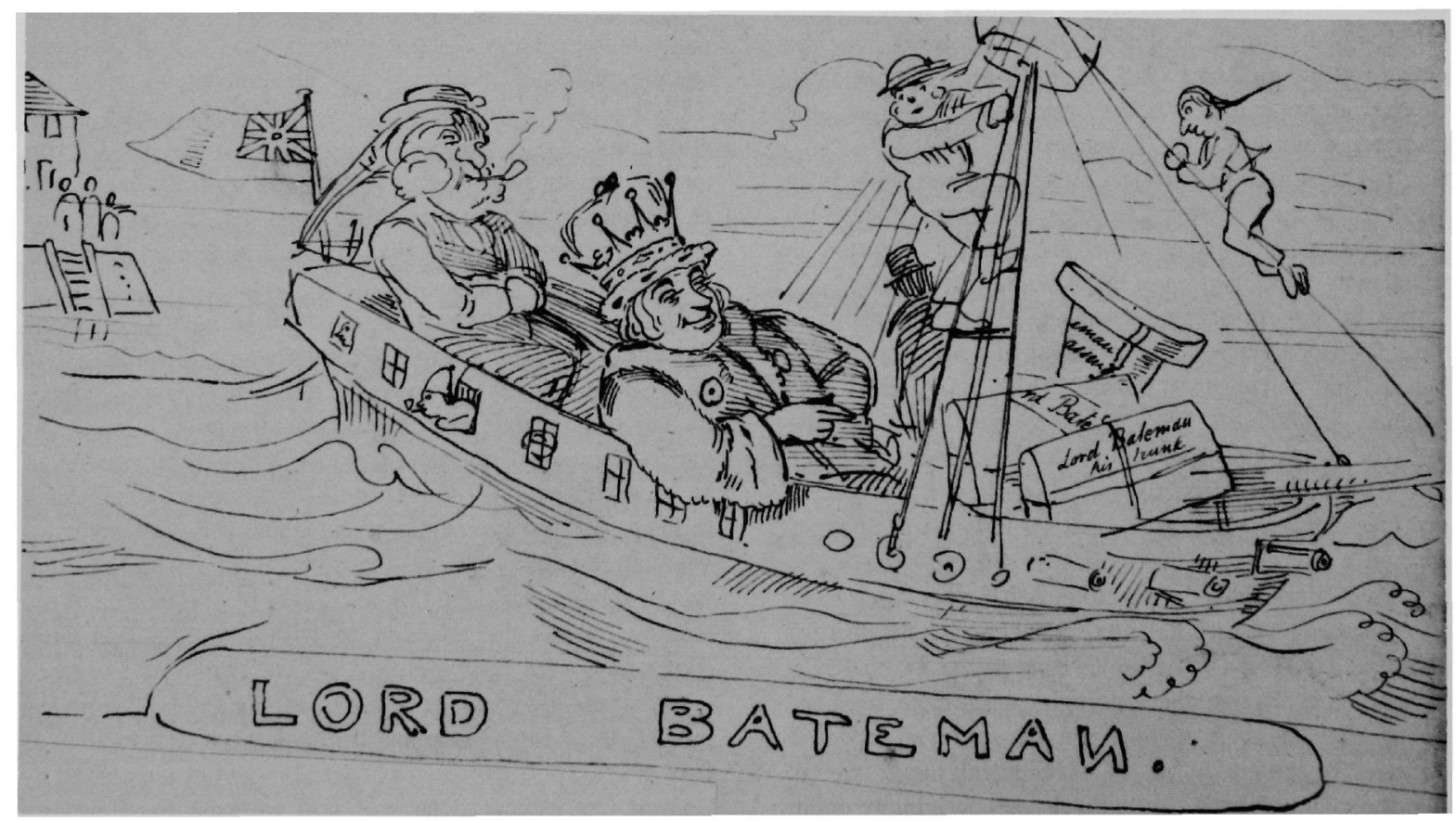


Miscellany and planning his own speculative venture, the Omnibus, but by George Cattermole who had been hired to work with Phiz on Master Humphrey's Clock. A subsequent exchange of letters in which Dickens extended his best wishes (and help) to the Omnibus and Cruikshank his congratulations on Barmaby contains no hint of bad feeling, however. ${ }^{102}$

In February, 1841, perhaps to compensate him for the loss of Barnaby, Dickens approached Cruikshank with the proposal that they create an annual, possibly concerned with lower-class children; but by that time the artist was deeply involved in the Omnibus. The conclusion of his reply to the author, however, is especially touching in view of their future relationship. "It is of no use my expressing my regret that we are not working together (as we ought to have done from the first)-and should this said speculation of mine unfortunately fail-I shall be ready to join you in any way, $\&$ work on if agreeable, to the last."103

Cruikshank's Omnibus and its successors all failed but Dickens never invited him to illustrate his books again. Yet readers and critics alike still have to be reminded that Cruikshank finally illustrated only two of Dickens's major works. After concealing his disappointment with characteristic bravado for almost three decades, the illustrator publicly consoled himself with the thought that "the other artists employed upon his works imitated my STYLE as closely as possible, and hence the public supposed that-as Charles Dickens wrote under the name of 'Boz'-that I designed and etched under the name of "Phiz."'104

Cruikshank, as we have seen, did resemble Dickens both in talents and in limitations. Had he continued to illustrate the author's books, as Austin Dobson speculated, their affinities might have become more pronounced. ${ }^{105}$ There are many Dickens characters, from Quilp and Pecksniff to Podsnap and the Billikin, that he would have portrayed perfectly. Swinburne, though he conceded that Cruikshank could not have surpassed most of Phiz's figures, wished he could have seen his rendition of the wood in which Jonas Chuzzlewit struck down Montague Tigg, or the interior of Mr. Peggotty's boathouse, or the suggestive landscape in Great Expectations. ${ }^{106}$ Cruikshank would not have matched Phiz's fidelity in representing Dickens's overidealized women and children-the little Nells, the Agnes Wickfields, and the Lizzie Hexams. Nor could he, in all probability, have kept pace with the demands of the younger author's changing style. At any rate, no matter how incomparable Cruikshank's contribution, Dickens was wise to continue working with Browne, with whom his professional relationship was more flexible and less threatening than any he could have had with the independent and egocentric veteran.

Indeed, there has been a great deal of controversy over the relative merit and importance of Cruikshank's numerically slim contribution to the body of Dickens's illustrations. An extreme detractor, W. A. Fraser, felt that book illustration had indeed advanced since the time "when any drawing signed by George Cruikshank, however atrocious, was considered good enough to illustrate the writings of the greatest master . . . England ever produced."107 On the other hand, Sacheverell Sitwell's claim that "the whole of Dickens has become visible to us through the eyes of Cruikshank" seems equally exaggerated. ${ }^{108}$ The truth, as usual, lies between the extremes, though there is no doubt whatsoever that Cruikshank's illustrations materially assisted Dickens's career. Furthermore, whatever the verdict of posterity, Cruikshank was amply repaid. His etchings for the author's Sketches by Boz and Oliver Twist were among the best of his massive but often ephemeral oeuvre. They kept the artist's name before the public longer than anything else he did, and were instrumental eventually in bringing about the present overdue reassessment of his work as a whole.

Throughout the 1840 's, despite the severance of their professional relationship, Dickens continued his association with Cruikshank on the more secure basis of personal friendship. In this sphere there was little friction between the two men, who, in spite of their difference in age, shared many interests (including mesmerism) as well as an uncommon supply of vitality. Even when their professional conflicts were at their height, their numerous dinner and theater engagements continued unabated. The author frequented the Pentonville home of the artist and his first wife, Mary Walker, gracious but sickly, and Cruikshank was always welcome among Dickens's family and friends. ${ }^{109}$

Dickens cherished and perpetuated many memories of the lively artist in his pretemperance days. There was the afternoon Cruikshank was turned away from the Pantheon aviary because he was splashed to the shoulders with mud; the morning when, reeking of tobacco and beer, he stumbled into Dickens's house at Devonshire Terrace, too ashamed to return to his own home; the Greenwich reunion after the author's American trip, which inspired him to stand on his head in an open carriage during the entire six-mile drive back to London; and the wild dinner that convinced Longfellow that Cruikshank excelled in hilarity as well as in art. ${ }^{110}$ The artist enlivened Dickens's obligatory social occasions as well. One night when Chapman and Hall were coming to dinner, for example, the author invited Ainsworth with the reassurance that the Cruiksanks were also coming so that "the anti-Bores [would] be triumphant and keep the Bores in due subjection."111

Yet when James Grant described Cruikshank as a pub-hopping heathen of eccentric character and rude man- 
ner in his 1841 Portraits of Public Characters, Dickens was more incensed than the artist himself. After reading Cruikshank's humorous rebuttal in his Omnibus, Dickens commented, "I wouldn't ha' let him off so easy."112 Indeed, the author had witnessed Cruikshank in less hilarious, less publicized moments. At the time of the wild dinners for Longfellow, for instance, the artist was soberly nursing the ailing William Hone, one of his earliest publishers and oldest friends (though, until now, estranged), who had once been arraigned for blasphemy. Cruikshank compelled the reluctant Dickens not only to meet the dying man and to attend his burial as one of the principal nonfamily mourners, but also to use his influence to secure relief for Hone's widow from the Literary Fund. ${ }^{113}$

Dickens had no other friend who responded as quickly as Cruikshank to his many pleas to help others. The artist unhesitatingly donated his time as well as his name to a committee formed to help the seven children of the drowned actor Elton; when the author solicited him on behalf of an elderly subeditor of the Morning Herald who had lost his job, he found that Cruikshank had already contributed from his own meager purse; indeed, Dickens once refused to lend the artist money to relieve a desperate Edinburgh editor, lest the chronically indebted Cruikshank become a bankrupt himself. ${ }^{114}$ Such private charity surely contributed to Dickens's premise "that Cruikshank is one of the best creatures in the World in his own odd way."115 Dickens's assessment spotlights the admirable aspect of the artist's nature. But its bemused tone, like those of all his recollections of Cruikshank's acts of charity, indicates a condescension toward the artist that deepened as the disparity between their fortunes increased-a manner hardly flattering to Dickens.

Cruikshank must have been distressed at not being offered a more prominent role in the benefit amateur theatricals Dickens staged throughout the late 1840 's and early 1850 's. His earliest ambition, like that of Dickens, had been to act. One of his family's boarders had been the well-known actor, Mungo Park; before Edmund Kean became famous, Cruikshank and his brother had acted Blue Beard with him in a neighbor's kitchen; and as a young man, Cruikshank had obtained a commission, which he never executed, to paint a scene for the Drury Lane Theatre. ${ }^{116}$ The artist never acted professionally but he, like Dickens, always loved going to the theater, just as both loved to perform, whether on or off the stage. Yet when the restless author started his amateur troupe in 1845 and proved he could be as successful "on" the boards as "between" them, he did not immediately call on Cruikshank.
Only when Stanfield resigned his part as Downright in Jonson's Every Man in His Humour in the opening production of the company, did Dickens think of inviting the artist to participate, and then only after giving his "brains a shake."117 Employing his most artful manner, the author informed Cruikshank that the play had been arranged in a casual fashion, and that much as he had wanted to include the artist in his troupe, he had lacked good roles to offer him until Stanfield volunteered to give his up if Cruikshank would take it. ${ }^{118}$ Cruikshank, either legitimately unavailable or else undeceived by Dickens's brand of tact, did not play Downright, though he and his wife did receive one of the prized invitations to the company's successful debut on September 20.

For all his fame as a mimic and comic singer, Cruikshank's main talent as an actor proved to be that of disguise. Yet Dickens soon discovered that the artist's name on the program was more important than the quality of his performance on the stage, and readily invited him to participate in the $1847-48$ benefits for Hunt, Poole, and Knowles. "In spite of all the trouble he gives me," Dickens confided to Forster, "I am sorry for him, he is so evidently hurt by his own sense of not doing well."119 The author took pains to find suitable roles and to convince the frustrated artist to take them. He chose a small "bit" in Every Man in His Humour, the brief role of Old Knibbs in Turning the Tables, and minor parts in The Alchemist, Animal Magnetism, and Love, Law and Physic; he even changed The Poor Gentleman to work in his friend. ${ }^{120}$ As a reward, perhaps, for his fine performance as Pistol in The Merry Wives of Windsor, Dickens finally offered Cruikshank his choice of parts in Used Up. After long deliberation, the artist chose the shorter blacksmith's role over that of the middleaged dandy. When his wife became ill he gave it up; when she suddenly recovered he wanted it back again. "O questa femina maladetta!" Dickens moaned to Lewes while rejuggling the cast, "O Impressario sfortunato! -ma, sempre dolce, tranquillissimo, cristianissimo, exempio di pazienza!"121

Cruikshank may have been theatrically maladroit, but he was one of the few members of the company who never lost sight of its charitable purpose. In 1847, for example, two performances for Leigh Hunt had netted only $\$ 400$, $\$ 100$ short of the sum Dickens wanted. The author decided to make up the difference by writing, from the point of view of Mrs. Gamp-the sensationally popular character from Martin Chuzzlewit-an imaginary eyewitness account of the company's railway expedition north, to be illustrated by its artist-actors. Dickens's burlesque "Piljian's Projiss" prominently features Cruikshank as the long-haired, bewhiskered 
gentleman with the hook nose and hawk eye who greets Mrs. Gamp at the station, finds her ticket, and helps her into the carriage.

'P'raps,' [says a fellow passenger], 'you don't know who it was that assisted you into this carriage!'

'No, Sir,' I says, 'I don't indeed.'

'Why, ma'am,' he says, a wisperin', 'that was George, ma'am.'

'What George, sir? I don't know no George,' says I. 'The great George, ma'am,' says he. 'The Crookshanks.' If you'll believe me, Mrs. Harris, I turns my head, and see the wery man a making picturs of me on his thumb nail, at the winder!

$(C P, \mathrm{I}: 746-47)$

The complete account was never published because the other artists involved, as Forster had feared, failed to provide the illustrations that Dickens considered essential to its success. ${ }^{122}$ Only Cruikshank fulfilled his obligation by portraying the scene in which he is supposed to be addressing the famous midwife with his hat politely raised in a picture that, as it turned out, was never reproduced in his lifetime (fig. 12).

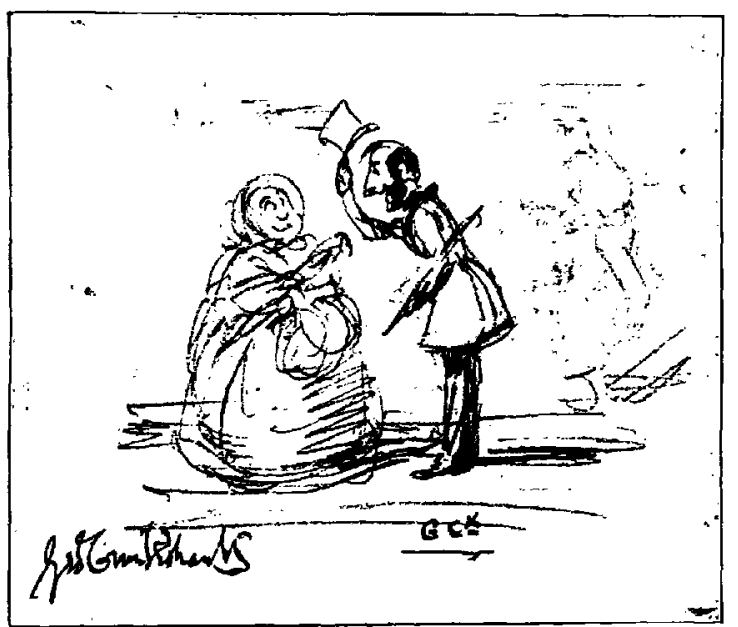

Fig. 12. George Cruikshank, Sketch of the Artist with Mrs: Gamp, 1847. Strand Magazine, 14 (August, 1897), 188. Pencil. $37 / 8^{\prime \prime} 41 / 8^{\prime \prime}(9.9 \times 10.5 \mathrm{~cm})$. By permission of the Houghton Library, Harvard University.

After 1850, Cruikshank's name was conspicuously absent from Dickens's theatrical programs, guest lists, and correspondence-a fact both men attributed to Cruikshank's intense involvement in the temperance movement at that time. Certain incidents relating to his past and present relationship with Dickens may have contributed to Cruik- shank's new mania, for it was preceded by four events that irrevocably strained the bonds between the two men: the publication of a new edition of Oliver Twist in 1846; the great success of Cruikshank's 'The Bottle' in 1847 and its sequel 'The Drunkard's Children' in 1848; the subsequent interview of Cruikshank by a journalist named R. Shelton MacKenzie in 1847; and Dickens's criticism of Cruikshank's temperance philosophy in 1848 .

In 1845 Bradbury and Evans, Dickens's new publishers, began planning a new edition of Oliver Twist to appear in monthly installments the following year. Since the story had originally appeared in Bentley's Miscellany without a wrapper of its own, it was necessary now to commission one. The publishers may have questioned whether Cruikshank would find this task wearisome or whether another artist might give this edition some novelty; but they agreed to let Dickens approach Cruikshank about doing the cover. The veteran was eager. "It is clear," the author informed Bradbury and Evans, "it would never have done to have handed it on to anybody else." 123

The artist took out his old portfolio of Oliver sketches and set to work. With what bitterness he must have contemplated their reversal of stature since his work with Dickens. "Long before Boz was heard of," the Quarterly Review had written on Oliver's conclusion in 1839, "George Cruikshank had captured a snug niche in the Temple of Fame." 124 By 1845, however, Dickens's reputation was still rising, despite professional vicissitudes and the pressures of his growing family; Cruikshank's, on the other hand, was declining, and he was beset, besides, with worries about his fatally ill wife and about his many illegitimate children. ${ }^{125}$ His name no longer guaranteed-sales on his independent ventures. George Cruikshank's Omnibus (1841-42) and George Cruikshank's Table Book (1845) had failed commercially as would George Cruikshank's Magazine (1854) and George Cruikshank's Fairy Library (1853-65). His relationships with authors and publishers invariably terminated in quarrels. Yet he obstinately refused to work for Punch, which would have provided steady employment; he had no wish to employ his impersonal style of humor in attacking individuals in the Punch manner, ${ }^{126}$ and he also was doubtless unwilling to submit to the will of editors or to share credit with other writers or artists. Meanwhile, new comic artists, like Browne, Leech, and Tenniel, all of whom were more genial than satiric, were gaining popularity. Experiment as he would with his format, technique, and line, Cruikshank never recaptured public acclaim nor financial independence.

"Neither will grudge to the other," Blackwood's would write of Dickens and Cruikshank, "the share in the fame which has justly attended their joint labors."127 But the 
proud Cruikshank, suffering in his diminished position, had already begun to think he had less than his fair share of credit for the success of his labors with Dickens, especially Oliver Twist. In fact, partly because of his fondness for the role of public benefactor, Cruikshank habitually exaggerated the effect of his own productions. According to him, his 'Bank Note' had stopped the hanging of forgers; his print of 'Bartholomew Fair' had suppressed such gatherings; his Omnibus had inspired the founding of Punch; and the advance of the temperance movement after 1850 was due mainly to his efforts. ${ }^{128}$ The gradual erosion of the artist's independence, which, in retrospect, began with his subordination in his dealings with Dickens, seems to have made him more prone than ever to overestimate his importance to the books he illustrated.

Certainly a number of critics echoed, even stimulated, perhaps, Cruikshank's own estimate of his contributions to the books he illustrated. In 1840, for example, Thackeray commented on Ainsworth's novel, Jack Sheppard: "It seems to us that Mr. Cruikshank really created the tale and that Mr. Ainsworth, as it were, only put words to it. Let any reader of the novel think it over for awhile ... and tell us what he remembers of the tale? George Cruikshank's pictures-always George Cruikshank's pictures." 129 Earlier, with regard to Oliver Twist, the Quarterly Review had wondered how much of the narrative impact was "due not to the pen but to the pencil," and Fraser's, noting the discrepancies between the graceful Oliver and his graceless education, had insisted that "the letterpress was written 'to match, as per order" the artist's wishes. ${ }^{130}$ Even Henry James was to recall that certain memorable illustrations made the book seem "more Cruikshank's than Dickens's."131 By the mid-1840's, if not sooner, the artist himself had come to share these views. With mixed emotions, then, Cruikshank composed the wrapper design for the 1846 reissue of Oliver. In accordance with Dickens's instructions, he surrounded the title with eleven vignettes of leading incidents - some based on old sketches and some entirely new. ${ }^{132}$ His past resentments over Oliver Twist and Dickens, however crudely repressed in the past, must have risen closer to the surface where they would soon manifest themselves.

The following year, Cruikshank became happily preoccupied with a very real success of his own-a series of eight large engravings entitled 'The Bottle,' depicting the downfall of a respectable household due to drink. One of the earliest purchasers in the late summer of 1847 was Dickens himself, and the series enjoyed an enormous popularity. It sold 100,000 sets in a few days, was dramatized in eight theaters, inspired Matthew Arnold to write a sonnet "To George Cruikshank," and prompted Dickens's principal illustrator, Browne, to include, as an emblematic detail as well as a bow to his older predecessor, an advertisement for it in one of his illustrations to Dombey and Son (XLVI, facing p. 636). ${ }^{133}$

Cruikshank's approach to intemperance had been prefigured in 1835 in 'The Gin Shop' in Sketches by Boz (S, XXII, facing p. 182). In the text, Dickens had set forth what remained his lasting attitude on the subject: alcoholism is the result of misery, he argued, not misery the result of alcohol. Accordingly, Dickens considered 'The Bottle' powerfully drawn, but philosophically erroneous. As he confided to Forster, "The drinking should have begun in sorrow, or poverty, or ignorance - the three things in which, in its awful aspect, it does begin. The design would then have been a double-handled sword-but too 'radical' for good old George, I suppose."134 As far as the public was concerned, however, the author kept his objections to himself, and his former illustrator enjoyed an increasingly rare moment of triumph.

The thwarted artist clutched at this timely straw of success; urged on by the leaders of the National Temperance Society, the onetime ready drinker became a fanatic teetotaler to add the force of personal example to his graphic as well as platform preaching. Certainly his volte face, not to mention his very idea of 'The Bottle' itself, was understandable on other grounds than desire for for success. As a young man, Cruikshank had watched his own father drink himself into a premature grave. And he long recalled the besotted James Gillray, one of his graphic mentors, ranting before he died: "You are not Cruikshank but Addison, my name is not Gillray but Rubens." ${ }^{135}$ During the past decade, his brother Robert had been drinking heavily and seemed to be following the same ruinous path. These specters seemed to remind Cruikshank not only of the evils of drink, however, but also of the happy period when his own career had seemed so promising. Indeed, a note of nostalgia creeps into his subsequent engravings of pubs, beer shops, and gin palaces, despite their predominant message of horror. Teetotalism, then, provided the artist's life and art with a peculiar kind of continuity as well as meaning and purpose.

Another consequence of the fame of 'The Bottle' was an interview of Cruikshank by R. Shelton MacKenzie, an English journalist friend, who later became an editor of a Philadelphia newspaper. While waiting for the artist, MacKenzie apparently examined a folder of papers for Oliver Twist, containing, among other items, a bundle of unpublished sketches and drawings. Cruikshank later explained to the curious journalist that long before Dickens's novel was begun, he had conceived of doing a series of graphic narratives, not requiring any text, on the life of a 
London thief. After seeing his sketches and listening to his suggestions, claimed the artist, Dickens had altered the plot of his recently begun story so that his hero, instead of remaining in the country, would become involved with city criminals. Cruikshank "consented," so he said, to allow Dickens to "write up to" as many of the designs as suited his purpose. In this way, he claimed credit for Sikes, Nancy, and Fagin. "My drawings suggested them," Cruikshank insisted to MacKenzie, "rather than [his] individuality suggesting my drawings." 136 In this questionable manner, the artist, emboldened by his recent success, sought to mitigate the pain of having subordinated himself in the past to Dickens's schedules, tastes, and text.

MacKenzie may have felt that Cruikshank was asserting his pride rather than the truth about Oliver's development, for he tactfully withheld this conversation from his complimentary piece about the artist and 'The Bottle,' which appeared in late 1847 , and did not mention it publicly for almost twenty years. Dickens was preoccupied at the time with, among other projects, his preface refuting the Seymours' similar claims about the origins of Pickwick -claims that may, in fact, have stimulated Cruikshank's. If he was aware at all of Cruikshank's claims, perhaps he did not want to contradict him publicly, since, unlike Seymour, Cruikshank was still alive, still his friend, and still a member of his amateur theatrical troupe. In any case, the artist did not press the matter until after Dickens's death.

In 1848, Cruikshank issued a sequel to 'The Bottle,' entitled 'The Drunkard's Children.' This time Dickens felt compelled to register a gentle protest in the Examiner. No one had a better right than Cruikshank to set himself up as a teacher of the people, the author declared, but his lesson should begin with the causes, not the effects, of alcoholism. Hogarth had never attempted a drunkard's progress, Dickens speculated, because he perceived that "the causes of drunkenness among the poor were so numerous and widespread, and lurked so sorrowfully deep and far down in all human misery, neglect, and despair, that even his pencil could not bring them fairly and justly into the light" $(C P, 1$ : 157-58). Despite the fact that Dickens lavishly praised the artistic quality of the plates, and carefully confined his criticism to Cruikshank's philosophy, the comparison was particularly well designed to deflate the artist. Long encouraged to do so, Cruikshank must have come to view himself as a latter-day Hogarth. Working in Hogarth's favorite graphic form, and sharing his desire for reform, Cruikshank craved the same creative freedom and moral authority, but could not readily achieve it in illustrations to other people's work. In an effort to achieve financial freedom as a prerequisite to creative freedom, the artist, like
Hogarth, even sacrificed some of his technical finesse: apparently both 'The Bottle' and 'The Drunkard's Children' were crudely drawn so that they might be more cheaply reproduced and widely sold. ${ }^{137}$ The unfavorable comparison with Hogarth was particularly devastating to Cruikshank and particularly convincing to readers because it came from Dickens who was known to be a friend of the artist's. Although the blow did not change Cruikshank's temperance philosophy, it was perhaps instrumental in his decision never again to utilize Hogarthian-style progresses to express it.

Nevertheless, Cruikshank did not hesitate in his early temperance speeches to capitalize on his familiarity with Dickens. The story he related on one platform was typical:

I went to take luncheon with my friend Dickens (who, I am sorry to say, is not a teetotaler); he asked me to take some wine but I told him I had taken to water, for, in my opinion, a man had better take a glass of prussic acid than fall into the other habit of taking brandy-and-water and I am happy to say that Dickens quite agreed with me, that a man had better wipe himself out at once, than extinguish himself by degrees by the soul-degrading and body-destroying enemy. ${ }^{138}$

Personally, however, Dickens remained unconvinced by his friend's conversion. Indeed, on many a lively occasion, the author attained to the condition he describes at one point in The Uncommercial Traveller: "I might have served Mr. Cruikshank as a subject for a new illustration of the miseries of the Bottle. The National Temperance Society might have made a powerful Tract of me" $(R P, 570)$.

If teetotalism infused Cruikshank's life and art with salutary purpose, however, it also functioned as a social straitjacket. At one of Dickens's parties, to cite one well-known anecdote, Henrietta Ward was about to sip her sherry when the artist suddenly snatched her glass away; he was barely restrained from smashing it on the floor by the hand of his infuriated host, who found Cruikshank's behavior particularly unforgivable in light of the bouts of inebriation he had so recently given up. ${ }^{139}$ The strain of such incidents on Dickens's friendship was only exacerbated by the artist's remarriage in 1850, after his first wife's death, to Eliza Widdison-a vigorous woman who may have inspired and certainly supported the new views of her husband, who now became a founding officer of the London Temperance League. ${ }^{140}$ When Cruikshank interpreted the infrequency of his encounters with Dickens as a sign of coolness, the author hastily attested to his "old unvarying feeling" of affection for the artist, expressed regret at the "host of small circumstances" that had prevented their meeting, and hoped soon "with one shake of the hand to dispel any lingering 
remainder" of the artist's doubts. ${ }^{141}$ Gradually, however, Dickens drifted toward less demanding companions, leaving Cruikshank to lecture strangers on the evils of drink. His early warning to the artist that involvement in Temperance societies would "keep many of [his] friends away from [his] side, when they would most desire to stand there" proved prophetic. ${ }^{142}$

The frayed ties of friendship between the two men snapped entirely in the 1850 's. ${ }^{143}$ When Chapman and Hall decided to bring out the Cheap Edition of Oliver Turst in 1849-50, Dickens insisted that Cruikshank be given the commission for a new frontispiece $(\mathrm{V}$, following p. 291), but the artist was hardly mollified. ${ }^{144}$ The trivial assignment could only have made their professional as well as their personal distance more obvious and painful. In this decade, their respective positions did not change. Dickens remained a household word while Cruikshank continued to struggle to regain lost ground as an independent, popular, and morally useful artist. Cruikshank needed a great deal of support, and the fact that Dickens, among others, could not give it wholeheartedly discouraged him excessively. The two men now communicated mainly by airing their differences on the temperance question in periodicals. Dickens continued to praise Cruikshank's art and denigrate his philosophy, and Cruikshank continued to overreact and to take these criticisms personally. In August, 1851, for example, Dickens wrote a stinging article for Household Words entitled "Whole Hogs," in which he assaulted all fanatic positions on the issues of peace and vegetarianism as well as teetotalism $(C P, 1: 379-85)$. Cruikshank did not reply immediately to this impersonal threefold critique, but he was unduly hurt the following year when Household Words, edited by Dickens, rejected a temperance pamphlet he had written. ${ }^{145}$

In 1853 another altercation arose between the two men when Cruikshank was revitalizing some traditional children's stories, (as he had done so successfully in 1827 with Grimm's tales and as Thackeray, among others, had long wished him to do again) to be issued as George Cruikshank's Fairy Library. ${ }^{146}$ When the first of the series, Hop O' My Thumb, appeared, Dickens's intimate, John Forster, enthusiastically praised the illustrations and did not mind the moralistic editing that, among other things, made drinking, smoking, and gambling the cause of the characters' misfortunes, and provided a happy ending that consisted of a ban on such activities. ${ }^{147}$ Dickens, however, was outraged that anyone should alter for any purpose the beloved stories that had enhanced his own childhood and that, he felt certain, were needed more than ever before as sources of enjoyment, imagination, and creativity.
Dickens registered his formal protest, "Frauds on the Fairies," in Household Words. Playfully yet seriously, he grieved that the "Whole Hog" of temperance who had intruded into fairyland had been driven there by "a man of genius, our own beloved friend, Mr. George Cruikshank" (CP, 1: 464). Dickens's powerful critique-an argument anticipated in the "Mudfog" papers of 1837 (SBB, 561), and amplified throughout Hard Times of 1854-was partly an impassioned plea for less realism and more fancy for children growing up in a Utilitarian age. Other Cruikshank admirers were disturbed for other reasons. Ruskin even criticized the illustrations, finding them "over-labored and confused in line"; his disappointment, rooted, like Dickens's, in childhood, stemmed from his memories of copying Cruikshank's etchings for Grimm's Tales, which he later maintained were the finest, except for Rembrandt's, ever done. ${ }^{148}$ Ruskin's criticism, however, was not published until four years later, in 1857. It was Dickens's complaint that wounded the artist. ${ }^{149}$

Yet early in 1854 Cruikshank published Jack and the Beanstalk edited in the same moralistic vein. At the same time, having gained an independent forum in the form of George Cruikshank's Magazine, he retaliated with his pen as well as his pencil. The second and final issue of his magazine concluded with "A Letter from Hop-o'-my-Thumb to Charles Dickens, Esq.," which was also printed separately as a penny pamphlet. Speaking in the guise of his fairy character, the artist accused the author of having gone out of his way to fault the editing of the fairy library. He argued that the story had not been tampered with any more seriously than the facts in Dickens's Child's History of England, which had appeared in the same year, 1853. He argued that fairy tales were constantly altered in various countries and editions, and that far from being morally attractive and instructive, they were usually immoral lessons in deceit and bloodshed. The letter claimed that Cruikshank had merely tried to convert the tales into fit "household words" by inculcating young readers with "A HORROR OF DRUNKENNESS, A DETESTATION OF GAMBLING, AND A LOVE FOR ALL THAT IS VIRTUOUS AND GOOD." 150 The bitterness of his conclusion weakened the force of his argument, however; railing against Dickens's use of the term "Whole Hogs" to describe his temperance colleagues, he insisted that the slight allusions made to their principles in the fairy texts were the only cause of offense. More humorously, Cruikshank requested that Dickens restrain his own hogs or send them to some other "market," and reinforced his point with a tailpiece in which he drove them back to Household Words (fig. 13). ${ }^{151}$ 


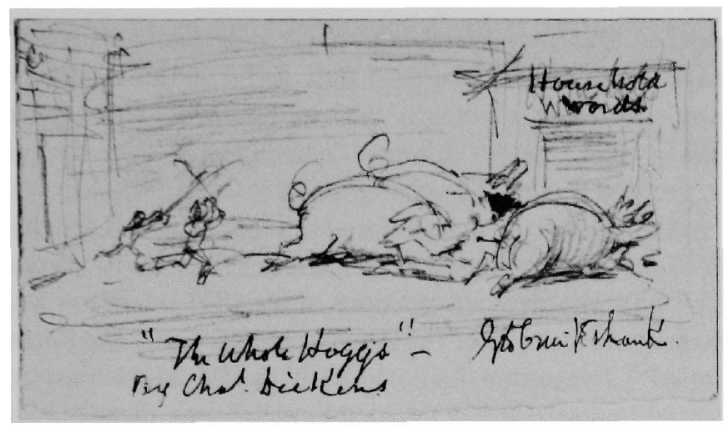

Fig. 13. George Cruikshank, Sketch for Tailpiece to "A Letter from Hop-o'-My-Thumb to Charles Dickens." Pencil with ink additions. $21 / 2^{\prime \prime} \times 41 / 2^{\prime \prime}(6.4 \times 11.5 \mathrm{~cm})$. By permission of the Arents Collections, The New York Public Library, Astor, Lenox and Tilden Foundations.

Bravely, Cruikshank issued his Cinderella later in 1854, though Dickens had parodied it, as if in advance, in "Frauds on the Fairies" (CP, 1: 465-70). Not only did the artist refuse to compromise his editing principles, but appended a note "To the Public" in which readers who might fall into the same heresies as "my friend Charles Dickens" were advised to read his "Letter" to that gentleman. ${ }^{152}$ But, for whatever reason, interest in Cruikshank's fairy tales seems to have diminished; for his next contribution, Puss in Boots, though probably completed in 1853 or 1854 , was not published until 1864. The artist probably held Dickens responsible for the hiatus; certainly he was still smarting from the author's reprimand. To Puss, he appended not only "An Address to Little Boys and Girls" but a message "To Parents, Guardians, and All Persons Intrusted with the Care of Children," both of which repeated substantially the arguments given in his reply to Dickens a decade earlier. ${ }^{153}$ When the four published tales were reissued together in 1865 , the artist had the reference to "my friend Charles Dickens" in the postscript to Cinderella altered to read "Mr. Charles Dickens"154 and retained the addresses after Puss, in this way immortalizing this particular quarrel between the former friends. Cruikshank added no more to his Fairy Library. Driven even from this imaginary sphere, he blamed his exile on Dickens.

Meanwhile, Cruikshank derived no benefits from having outlived his contemporaries. The atmosphere that encouraged what he called those "damned proraphaelite[s]," with their emphasis on brilliant color and naturalistic detail, was antithetical to his talents. ${ }^{155}$ Publishers ceased to employ him; the common reader forgot him or thought him dead already. Even when Chapman and Hall joined Bradbury and Evans in issuing the 1858 Library Edition of Dickens's works to date, it was Browne, not the original illustrator, who provided the title page vignettes for both the Sketches by Boz (xxx) and Oliver Twist (xvi).

Cruikshank, meanwhile, took other steps to recapture his lost stature and independence in the 1850's and 1860's. At the age of sixty-one, in order to help remedy his lack of formal training, he had become a student at the Royal Academy, which had denied him, and all black and white artists, membership. ${ }^{156}$ Persuaded by Clarkson Stanfield, another friend and illustrator of Dickens, to paint in oils, Cruikshank laboriously executed an epic pro-temperance canvas. But 'The Worship of Bacchus' (1863), despite Queen Victoria's blessing and Thackeray's publicity, proved a financial and hence emotional disaster. ${ }^{157}$ In contrast to Dickens, whose writings and public readings were in greater demand than he could supply, Cruikshank had so little work that Ruskin temporarily deferred his own projects to assist him. ${ }^{158}$ The futility of Ruskin's subscriptions and petitions on his behalf may not have tormented the artist's vanity as much as the commission from $\mathrm{F}$. W. Cosens to make watercolor copies of all of his illustrations for Oliver Twist, together with a title page embodying thirteen of them. ${ }^{159}$ There was scant consolation in the fact that Browne, now crippled, bankrupt, and no longer Dickens's illustrator, was similarly commissioned by the same patron at the same time to reproduce his Dickens illustrations. Moreover, the Oliver Twist matter once again was inevitably and painfully brought to mind.

Neglected, impoverished, and powerless, Cruikshank could no longer contemplate with equanimity the lionized, wealthy, and influential Dickens. Though the author now regarded him simply as an eccentric, he began to consider Dickens as an adversary. He began to blame the author for thwarting his own interests and advancement, making Dickens a public target for his own resentment. As late as 1867, as Cruikshank's long dormant frustration mounted, the author still referred to him as "my esteemed friend" -probably an unintended irony, considering its context in Dickens's final refutation of Seymour's Pickwick claims $(C P, 1: 109)$. Whereas the artist dwelt on the reversal of their careers, the author preferred to recall the fruitful results of their collaboration. "I want you to make as good a drawing as Cruikshank's 'Fagin in the Condemned Cell,"' Dickens reportedly told his last illustrator, Luke Fildes, during a discussion about the climactic scene for The Mystery of Edwin Drood. ${ }^{160}$ Even the author's death in 1870 failed to mollify the sentiments of his first illustrator. "Isn't this a frightful calamity?" F W. Pailthorpe greeted Cruikshank the day after Dickens's decease. "What! about Dickens?" the temperance artist exclaimed in a note of 
surprise that quickly became one of triumph, "one of our greatest enemies gone."161

Even before 1870 Cruikshank had started to reshape the broad outlines of his past relationship with Dickens. Subsequently, he began to distort its trivial aspects as well. He suddenly found the famous 1833 portrait of him by Daniel Maclise (see fig. 2) objectionable, partly, perhaps, because the artist became Dickens's intimate, as well as his occasional illustrator. Cruikshank not only called it a poor likeness, but now was embarrassed by the accessories of drink and tobacco in the picture, and resented having been portrayed making a sketch from a model, which, he now maintained, he never did, preferring to rely on his memory. Cruikshank seems to have completely repressed his recollection of, among other impromptu sketches, the noted one he did of Dickens in 1837 (see fig. 8), which he afterwards utilized for a figure in one of his illustrations for Ainsworth's Magazine. ${ }^{162}$

The artist even cast aspersions on his beloved Lord Bateman. He maintained that the only reason he had acknowledged Dickens's contributions to the ballad for George Reid's Cruikshank catalogue of 1871 was to make the work more profitable; he also admitted, "I so hated the fellow that I had a great mind to re-write it."163

In the editions of 1870 and 1871 , he executed this intention somewhat to the detriment of the ballad. He removed some dialect from verse $\mathrm{XX}$, suggested to the reader that Dickens's concluding verse XXI be omitted, and added three new ones to create a feeble ending in which even the Proud Porter lives happily ever after. ${ }^{164}$ To make room for his additions, and, perhaps, to further gratify his literary ambitions as well as his old hostility, Cruikshank wished to compress the musical notes of Dickens's brother-in-law, Henry Burnett, but eventually only consigned them from the front to the back of the edition and may also have had Dickens's textual notes rendered in slightly fainter print. ${ }^{165}$ Elswhere, he ambiguously asserted that Thackeray had "insisted" on writing the preface to his 1839 adaptation, thereby leaving it unclear whether Thackeray actually wrote it, or merely expressed a wish to write it, and further clouding Dickens's role in producing the ballad. ${ }^{166}$

Meanwhile, Cruikshank had resurrected his grand claims about his role in all the author's early books. Had the artist received more approbation in the past three decades - or Dickens less-perhaps he wauld not have been so assertive. He now implied that he had influenced The Pickwick Papers. ${ }^{167}$ Five months after Dickens's death, he informed W. J. McClellan, perhaps with some justification, that the bulk of the second series of the Sketches by Boz had been written from his "suggestion"; with greater reason, he asserted that one of Dickens's papers for Bentley's Miscellany was "written up to" a design of his; and, in a series of earnest overstatements, he revived his claims about Oliver Twist which, he said, was "entirely my own idea \& suggestion and all the characters are mine."168

Actually, in 1865, even before Dickens's death, R. Shelton MacKenzie had revived Cruikshank's claims to Oliver by publishing the relevant portions of his 1847 interview with the artist in an issue of the American periodical, The Round Table. ${ }^{169}$ The author had said nothing. He might not have wanted to discredit his old friend publicly any more than he already had, or perhaps he hesitated for fear of refueling the Seymour allegations which flared up again in 1866 , or of facing debate on the issue on his second American visit in 1867. It is more likely, however, that Dickens never noticed MacKenzie's article or knew about its contents. After Dickens's death, J. C. Hotten quoted Cruikshank's allegations in his 1870 potboiler biography of the author and MacKenzie elaborated upon them in his biography of the same year; in 1871, Forster tried to repudiate these claims by juxtaposing them beside Dickens's letter insisting that the artist redo the "Fireside" plate in the first volume of his monumental Life of Dickens, which spared him "the necessity of characterizing, by the only word which would have been applicable to it, a tale of such incredible and monstrous absurdity as that one of the masterpieces of its author's genius had been merely an illustration of etchings by Mr. Cruikshank!"170

The artist himself, using his letter to W. J. McClellan, pleaded his own case before the more credulous American public early in $1871 .{ }^{171}$ At the year's end, after the appearance of the first volume of Forster's biography and a Times review of it, which also dismissed any idea that the artist's plates suggested incidents in Oliver as a "ridiculous" story propagated in America, MacKenzie published a rebuttal of Forster in the Philadelphia Press while, independently, Cruikshank expanded his arguments as well as his audience in a letter to the Times. ${ }^{172}$ Shrewdly disclaiming the validity of all the circumstantial particulars of MacKenzie's memory of their 1847 interview, Cruikshank argued persuasively for the validity of its substance, citing those of his suggestions which Dickens did not adopt as well as those which he did, either in whole or in part. Indeed, there is no reason to doubt most of Cruikshank's claims in this letter: he said he had failed to convince Dickens to name the hero Frank Foundling or Steadman, but had succeeded in having the hero, after enduring the workhouse and its practices (then under investigation by friends of the artist), go to the city rather than stay in the country, and in representing him as "pretty" rather than "queer"; 173 he had described to 
Dickens the appearances and habitations of the criminal characters whose physical prototypes had appeared in his earlier work; ${ }^{174}$ he had not only performed the character of Fagin before Dickens and Ainsworth but had insisted that either the Jew or the Christian Sikes end up in a condemned cell such as the one at Newgate he had sketched before. ${ }^{175}$ Indeed, in receptive moments, the young author may well have welcomed suggestions from the knowledgeable veteran or obliged him by utilizing some of them, especially those compatible with his own conceptions; but that is a different matter, as even the artist's most partisan advocate concedes, from executing the artist's concepts as if compelled to do so. ${ }^{176}$ Cruikshank's claim, however, that he "never saw any ms. of Mr. Dickens until the work was nearly finished" was, at best, misleading and undermined the rest of his argument. Indeed, according to Ainsworth-two of whose own novels would be subjected with better reason than Dickens's to Cruikshank's claims of paternity-Dickens eventually grew so irritated with the artist's unsolicited suggestions that he did try to send him only printed proofs for illustration. ${ }^{177}$

Had Cruikshank rested his case against Dickens with his Times letter, it might have been considered more seriously by his contemporaries. Some readers criticized Cruikshank openly, and others like Forster acidly noted in private that he was "to be congratulated on the prudence of his rigid silence as long as Mr. Dickens lived."178 Stung by the tacit disbelief of the general public, and by what he considered their continuing underestimation of him, Cruikshank tried other means of strengthening his position. He requested one of his few sympathizers, the Reverend John Deane, to voice his support not only privately but publicly to the Times. ${ }^{179}$ He refreshed MacKenzie's memory about a list of proposed illustrations for a "Life of a London Thief" that he had done while Dickens was still a child, obviously hoping that the American editor would utilize it in further debate; but even if MacKenzie had access to this list, probably the one Richard Vogler claims to have recovered, he must have felt that although it, like Cruikshank's graphic prototypes, indicated long familiarity with the kinds of concerns and characters that preoccupy Dickens in Oliver Twist, it was hardly a compelling argument for the artist's having originated that novel. ${ }^{180}$ But neither Deane nor MacKenzie did anything further. It was probably at this desperate time that the artist combed through his sketches and drawings done in pencil and brown ink for Oliver and for the Sketches by Boz, labeling in fresh black ink those "first" ideas that he claimed had suggested various characters and scenes. ${ }^{181}$

Yet when Cruikshank perpetuated the controversy in an 1872 pamphlet, The Artist and the Author, he did not utilize any of this evidence. With better reason, he shifted the focus of his claims from the works of Dickens to those by Ainsworth that he had illustrated. To many, however, it must have appeared as if he conceded victory to Forster and now desperately sought recognition by advancing similar claims on the works of the lesser author. ${ }^{182} \mathrm{He}$ did, however, reassert that, while Oliver Twist was being written, he had privately explained that its "original ideas and characters" emanated from him; and he maintained that the only reason he had finally advanced his case in public was to defend MacKenzie when Forster charged him with lying, and that Dickens and Forster had not denied the account that, after all, had appeared before the author's death, only because they could not. ${ }^{183}$ In his second volume of his Life of Dickens, as in his first, but this time in facsimile, Forster refuted Cruikshank's version by reprinting the author's letter to him criticizing the "Fireside" plate-in a tone of sadness rather than outrage due to his consideration for "an original genius well able to subsist of itself without taking what belongs to others." 184

As American critics were quicker to point out than British ones, Forster evaded the issue not by refuting the specific claims of the artist. ${ }^{185}$ Yet, even had all his claims been validated and the artist's role revaluated, the magnitude of Dickens's achievement would not have been seriously diminished. The one certainty in this controversy, as with that involving Seymour, is that the extreme positions often taken by both sides obscured for more than a century the undeniable importance of the illustrator as a contributor to, if not as the moving originator of, Dickens's works.

Cruikshank also threatened to publish an explanation of the reason he did not illustrate all of Dickens's writings -one that would refiect unfavorably on the author. ${ }^{186}$ When the promised explanation failed to materialize, however, there were no snickers. No one wished to maim further the wounded pride of the formerly "Illustrious George." If his humorous antics had once made him seem a living caricature to Dickens and his circle, ${ }^{187}$ his literary pickpocketing now made him resemble a sorry burlesque of his renowned villain, Fagin. Sensing some affinity, perhaps, Cruikshank now tried to dissociate himself from the character by discrediting the story he had told Mayhew as to the conception of his illustration of the doomed Jew. Questioned by Austin Dobson at a party in 1877, he called the legend untrue. ${ }^{188} \mathrm{He}$ had never been puzzled about the climactic composition, he said, merely about whether Fagin's knuckles should be raised or depressed, a minor problem which he resolved by studying his own hand in the mirror. What struck both Dobson and the host, however, was the way the artist was dramatizing before their very eyes his resem- 
blance to Fagin, although what he wanted to convey was that his work had resulted not from an accident, but from perseverance. His grander contributions denied, he now asserted abilities that had never been questioned. Hence, when he persisted in making claims and charges, Cruikshank encountered no opposition. His rantings, which perhaps gave meaning to his distressed final years, were excused as senile foibles.

After delivering a temperance address in Manchester in . 1874, according to legend, the eighty-two-year-old artist plainly revealed the extent to which his imagination could reshape his entire relationship with Dickens. Responding to a vote of thanks accorded him by the mayor, who had referred to his work for Boz, Cruikshank implied that the only book he had illustrated was the Sketches. "You forgot Oliver Twist," prompted the official. "No," replied the artist, "that came out of my own brain. I wanted Dickens to write me a work but he did not do it in the way that I wished." Indeed, he continued, "Dickens behaved in an extraordinary way to me, and I believe it had a little effect on his mind."189 Actually, the idea that Dickens did not "do" Oliver the way Cruikshank "wished" probably reflects the real extent of the artist's participation in the novel-that of an active but frustrated colleague. His concluding reply to the mayor, however, suggests that by this time his memory could do more than distort the realities associated with Dickens that he found intolerable; it could positively reverse them. The fact that Cruikshank kept in touch with Dickens's estranged wife does not indicate that he felt in any way reconciled with Dickens, but rather that the two shared the conviction that they had been ill-used by the deceased. ${ }^{190}$

Cruikshank's obsession with the old grievance was no doubt aggravated as well as distorted at this time if, as is strongly suspected by a recent historian of Victorian temperance activities, he was suffering the added humiliation of knowing he was unable to maintain in private the strict adherence to teetotalism that was now the basis for his self-respect as well as his public respectability. ${ }^{191}$ Though the artist had designed pledge cards for the movement, he himself had never signed one; and if, as documents of the period evidently imply, he lapsed back into excessive private drinking, it was a lapse the temperance officials would certainly not wish to make public. But even they would not have taken offense at the many affectionately repeated legends about the artist's pre-temperance behavior, as has a recent defender of Cruikshank, who thereby does him a profound disservice. ${ }^{192}$ For to deny the extent of the artist's exposure to drink the first two-thirds of his life is to deny him both sympathy and credit for the necessarily fanatic struggle he made to conquer the temptation during most of his remaining years. As the aged Cruikshank must have known, it was his rabid adherence to teetotalism, not any real or imagined differences over the origin and execution of any of his work for Dickens, that had cost him the author's friendship and, eventually, his artistic reputation as well. It would hardly be suprising if, in his last difficult years, he found his temperance position no longer personally tenable.

The artist died in 1878 , too early to derive any satisfaction from watching Dickens's reputation gradually-if temporarily-sink into a scholarly eclipse while his own remained alive in the most select artistic circles. Ruskin continued to deplore the "ghastly and lamentable" manner in which Cruikshank had "cast away" his genius on the temperance movement; "how much more might and should have been," agreed Swinburne. ${ }^{193}$ But Cruikshank's pretemperance work earned him the praise of Burne-Jones, the Rossettis, Whistler, and Sickert, among others, who called him the greatest English artist of the nineteenth century, an opinion even more widely shared now, perhaps, than then. ${ }^{194}$ It is ironic, however, that the long-overdue reassessment of Cruikshank in our time has been brought about largely by the efforts of earnest Dickensians who, having reestablished the author as a giant of English literature, are now helping to reestablish his first illustrator as a giant of English art. ${ }^{195}$ 


\section{Chapter 2}

\section{ROBERT SEYMOUR}

George Cruikshank may have aided Dickens's literary ascent immeasurably; but it was Robert Seymour, his second illustrator, who propelled him to fame, albeit inadvertently. For the author, obscure at the time, working with established artists like Cruikshank and Seymour was a mixed blessing, since the difference in their relative positions made Dickens's insistence on absolute sovereignty over his story and their designs seem unwarranted. Ironically, however, it was the veteran artists for whom the relationship proved tragic. Cruikshank's gradual submission to the author contributed to his disequilibrium, and Seymour's brief involvement with him fatally unbalanced his already unsettled mind. Seymour, renowned in the 1830's for his comic sporting sketehes, is remembered now mainly for his role as the first of the three illustrators for The Posthumous Papers of the Pickwick Club, better known as The Pickwick Papers. His heirs, like Cruikshank himself, tried to enhance his fame (and their fortunes) by claiming that Seymour had originated this work of Dickens. Posterity, however, never accorded him the laurels it did to Cruikshank, whose genius has proved more enduring.

Certainly a major distinction between The Pickwick Papers and the rest of Dickens's fiction lies in the controversy over its beginnings. Robert Seymour undeniably initiated what became the immortal story of Mr. Pickwick; to what extent he originated the book remains the central problem in the record of his relationship with Dickens. A lack of reliable information about the reclusive artist further complicates the issue. "Considering the great amount of work produced by Seymour, and the widespread popularity enjoyed by him in his own day," observed the Athenaeum in 1887 , more than fifty years after Pickwick's debut, "it is astonishing that so little should be known of him in our time." Nearly a century later, we know very little more. Information about his association with Dickens still derives from the accounts of the increasingly exasperated author and his conciliatory Pickwick publisher-accounts that contradict those of the artist's hysterical widow, hostile son, and temporary Pickwick successor, Robert Buss. All of these circumstantial records were written long after the events they describe, by parties who could hardly be called disinterested. The sole undisputed fact concerning Seymour's collaboration with Dickens remains, as Forster blandly put it, that "between the first and second number of Pickwick, the artist, Mr. Seymour, died by his own hand."2

The inception of The Pickwick Papers was as rooted in Seymour's troubled past as its development was in Dickens's. The book probably confirmed the artist's long experience that each apparent success was a failure in disguise. The "posthumous" child of a Somerset gentleman, as the Victorians euphemistically described his illegitimate birth in $1798,{ }^{3}$ Seymour was poorly educated by his mother, a deficiency for which he would be publicly mocked. Apprenticed to Thomas Vaughan, a successful pattern-draftsman, Seymour soon wearied of such mechanical work and quit. That daring action seemed justified when, in 1822, the Royal Academy accepted his ambitious canvas illustrating Tasso; its rejection of subsequent canvases, however, left his desire to pursue serious painting frustrated indeed. Forced to turn to book illustration for a livelihood, Seymour quickly mastered the techniques of copper engraving; the clear, minute style he had perfected during his despised apprenticeship suited the varied and prolific demands made on it to illustrate the Bible, poetry, travelogues, or nature descriptions. But in 1827, pressures mounted again when his principal employers, Knight and Lacey, went bankrupt, his mother died, and he married his first cousin, Jane Holmeshis self-proclaimed "guiding star to fame and fortune"4 (figs. 14 and 15). When he found another steady employer, the publisher McLean, Seymour learned to etch on the newly 


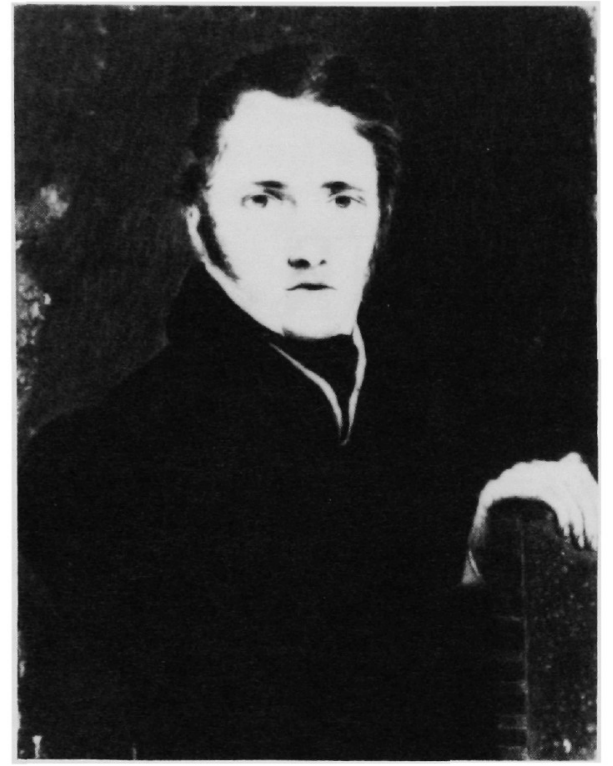

Fig. 14. Robert Seymour, Unpublished Self-Portrait Miniature. Watercolor on ivory. $35 / 8^{\prime \prime} \times 2^{3 / 4^{\prime \prime}}(9.2 \times 7 \mathrm{~cm})$. By permission of the Huntington Library, San Marino, California.

fashionable steel plates and began to specialize in humorous subjects. Insecure in these new spheres, Seymour not only imitated "HB," as Richard Doyle's father, another leading caricaturist of the time, called himself, but the style and manner of George Cruikshank as well, even affixing the nom de plume of Shortshanks to his earliest prints until Cruikshank, his neighbor in Islington, protested. ${ }^{5} \mathrm{He}$ finally discovered more original, profitable, and psychologically gratifying sources of inspiration closer at hand.

Throughout these vicissitudes, Seymour found relative peace in Islington, a rural suburb of London. Here he could work, read undistracted in his garden studio and exercise his talents as a sportsman. It was also here that he found and exploited his artistic specialty. If Islington was a convenient place for artists like Seymour and Cruikshank to live, it was also a natural spot for working-class Londoners to visit on Sundays and holidays. Seymour's published Sketches (1833-36) attest to his unabated observation of these overequipped, undertrained sportsmen pursuing cats, birds, and stray pigs on foot or on horseback. The artist's sympathies are evident in his work, the animals being far more sensitively portrayed than the Cockneys. Seymour the sportsman may have been snobbishly irritated by these absurd spectacles, but Seymour the artist made valuable use

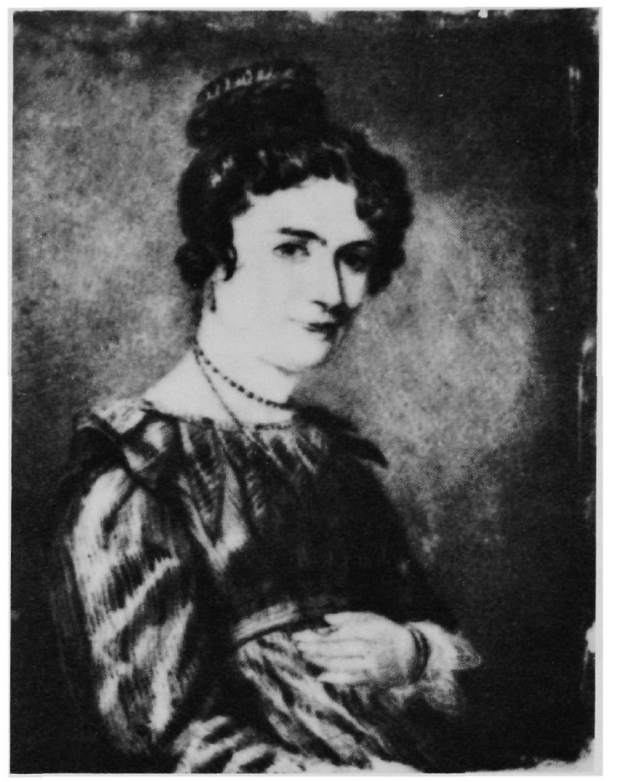

Fig. 15. Robert Seymour, Unpublished Portrait Miniature of Mrs. Jane Holmes Seymour. Watercolor on ivory. $23 / 4^{\prime \prime} \times 2^{1 / 4^{\prime \prime}}$ $(7 \times 5.7 \mathrm{~cm})$. By permission of the Huntington Library, San Marino, California.

of them; if John Leech could not see the humor in these sketches many others readily could. ${ }^{6}$ Numerous artists before Seymour had caricaiured the amateurs hunting, but none so well. This work provided him with an emotional as well as a creative outlet. He could mock others harmlessly in ways that pleased rather than offended, and that replenished his pride as well as his purse. Seymour became as preeminent in this sphere as was Cruikshank, first in political, then in literary caricature.

By the time he started Pickwick in 1836, Seymour was fully established with the public as a prolific, influential, and popular caricaturist. His fame even crossed the Channel. In 1857, when Baudelaire surveyed humorous English art, he noted after his evaluation of Cruikshank: "Il serait injuste, en parlant de l'Angleterre, de ne pas mentionner Seymour dont tout le monde a vu les admirables changes sur la pêche et la chasse, double épopée de maniaques." ${ }^{7}$ Nevertheless, he must have had misgivings about himself, for he continued to suffer from suicidal depressions. ${ }^{8}$ Perhaps Seymour shared the Ballot's fear that he was "doing a great deal too much to allow of his doing anything very well." Ironically, the very popularity of his comic plates, apparently reproduced until the impressions became smudges, must have damaged what remained of his reputation as a serious artist. 
Seymour's loftier ambitions, inflated by his wife, yet hindered by a nature that tended to shrink from contact with the world, combined to prevent him from enjoying his successs for what it was.

In 1834, at the height of his prosperity, Seymour unwittingly began his association with Charles Dickens. As one of his numerous projects, the artist was illustrating the Comic Album, a short volume of previously published extracts. One small vignette he executed-whether by his own choice or in accordance with instructions is unknown -was technically the first illustration to any of Dickens's writing. For the extract he illustrated was taken from "The Bloomsbury Christening," a Dickens piece that had appeared anonymously in the Monthly Magazine and would later be included in Sketches by Boz (T, XI, 465 [469-72] 480). ${ }^{10}$

Seymour's future collaboration with Dickens on The Pickunck Papers, however, was far more influenced by his involvement with Figaro in London the same year. Since 1831 Seymour had been illustrating, among other things, Figaro-a forerunner of Punch in that it was the first magazine, as Patten has noted, to wed journalism to caricature. ${ }^{11}$ The cheap weekly reflected the clever but abusive character of its owner-editor, Gilbert à Beckett, publisher of Cruikshank, friend of Dickens, and future Punch staffer. Figaro's chief attraction was Seymour's front-page caricature, then discussed in the feature article, a contribution that Beckett acknowledged with extravagant editorial praise. When, however, Beckett's theatrical speculations left him unable to pay the artist, who then quit, he was furious. He published Seymour's last woodcut with insults as excessive as his former praise. Not content with having hired Cruikshank's brother Robert to replace Seymour, Beckett went on libeling his former illustrator from a spurious "To Correspondents" column. Seymour has not gone out of his mind because he had none to go out of, the editor answered one sham correspondent; to another "reader" asking why Seymour could not write his own name, Beckett replied that no education could overcome the artist's innate stupidity; without his patronage, he claimed, the artist could not sell his wretched caricatures, for indeed, it was "a well-known fact, that the ideas for the caricatures in Figaro were always supplied by the Editor, he (Seymour) being a perfect dolt, except in the mechanical use of his pencil."12 It is hard to imagine from Beckett's callous treatment of the artist that the same man could, a decade later, weep so copiously over The Chimes. ${ }^{13}$

Despite the transparency of these slanders, the insecure artist acknowledged their partial validity concerning his mental instability, defective education, and lack of originality. The libels ceased when Beckett abruptly abandoned the magazine. Figaro was taken over by Henry Mayhew, who quickly restored Seymour to his former post and conspicuously advertised his name on the title page. But the damage had been done. Even Mrs. Seymour connected her husband's suicide two years later with this public humiliation at Beckett's hands. ${ }^{14}$ But, in fact, it must have been Seymour's experience with Dickens and The Pickuick Papers that confirmed his innate belief that he was indeed "a perfect dolt," even in the mechanical use of his pencil.

By 1835 , however, Seymour's pain at his Figaro humiliation had been soothed somewhat by the continuing success of his comic sporting sketches. Far from feeling that he had exhausted this imaginative vein-one in which he was unrivaled-Seymour wanted to plumb it further. He conceived a plan for a series of plates depicting the mishaps of a club of Cockney sportsmen-rather like the series R. S. Surtees had just done with such success, called Jorrock's Jaunts and Jollities (1831-34). ${ }^{15}$ The indifference of the various publishers he approached only increased his stubborn attachment to his idea, which, however derivative, he had initiated. ${ }^{16}$ Only Edward Chapman expressed interest. The young publisher liked Seymour's idea of doing "a series of cockney sporting plates of a superior sort to those he had already published" and "thought they might do, if accompanied by letterpress and published in monthly parts."17 The newly established firm of Chapman and Hall welcomed a chanee to publish work by such a popular artist.

After settling the terms of payment with Seymour, the publishers sought an author to compose an accompanying letterpress. It was only by chance, and at the end of a complex chain of circumstances, that they eventually offered the position to Charles Dickens. Chapman first proposed the job to William Clarke, whose companion text to George Cruikshank's plates in Three Courses and a Dessert had recently amused London; when he received no reply, he temporarily shelved the scheme. ${ }^{18}$ Seymour, meanwhile, was preoccupied with Thomas Hervey's The Book of Christmas for another publisher; this was not published, however, until after the holidays, and its reception was disappointing-a fact that doubtless renewed the artist's desire to see his own plan materialize. He urged Chapman to decide whether to pursue it. Chapman did not want to offend the popular Seymour, and he foresaw that the project could well make a profit, so he once again cast about for an author. At this time the new firm had begun a Library of Fiction for which they wanted a contribution from the anonymous author of the sketches that had appeared in the Monthly 
Magazine. Chapman was totally ignorant of Dickens's name, but Charles Whitehead, a former Monthly employee and newly appointed editor of the Library, managed to recollect it. ${ }^{19}$ Thus Dickens was commissioned to write "The Tuggs's at Ramsgate," which would appear in the spring with two illustrations by Seymour as part of the Library. "Having opened already a connection with you," Chapman told Dickens thirteen years later, "we naturally applied to you to do the Pickwick; but I do not think we even mentioned our intentions to Mr. Seymour."21 Time doubtless simplified Chapman's recollection of the event. It is far more likely that the publishers scanned the newly issued Sketches by $B o z$ to check on the ability of the writer whose name they did not know. And, indeed, Mrs. Seymour and Buss both maintain that they consulted the artist before approaching Dickens. ${ }^{22}$ Surely all the parties involved must have been duly impressed by the fact that the obscure author had been illustrated by the famous George Cruikshank.

On February 10, 1836, Chapman's partner, William Hall, came to Furnival's Inn to propose the collaboration to Charles Dickens. The author instantly recognized Hall as the vendor from whom he had bought the copy of the Monthly Magazine in which his first sketch had appeared "in all the glory of print" ( $P P$, xviii, and see also $D C, 622)$. Hailing the coincidence as an auspicious omen, the men quickly settled down to business. If the publisher thought that Dickens's youth and obscurity would make him wholly eager and acquiescent, he was mistaken. The writer, whose first book had just been illustrated by the best-known caricaturist of the times, was probably pleased but far from overwhelmed by Hall's proposal. On the contrary, as he recalled in his 1847 Pickwick preface, he had a good many reservations about supplying prose to go with Seymour's sporting plates (which the famous author now could express more forcefully in public than the unknown one had in private in 1836) (xvii-xix).

However much he admired the artist, Dickens feared that "writing up to" Seymour's pictures might compromise both his growing independence and his reputation. ${ }^{23}$ In the Sketches by Boz, interest had centered on the prose, giving the author at least nominal authority over the artist. As Hall presented Seymour's plan, the interest would center on the plates. Dickens's text linking the artist's plates in a coherent narrative-and hence Dickens himself-would be subordinate, a fact that hardly suited the ambitious author who already considered himself a man of letters. The proposed mode of publication did not make him any happier. In the 1830 's, a cheap "monthly something" was suitable for circulating old literary classics or new fads, but not for presenting serious new fiction. The only respectable method of publication, as Dickens's friends were quick to remind him, was the traditional three-volume novel (xix). Given his tenuous finances in 1836, however, it is probable that Dickens withheld these reservations from the publishers. He could easily have rationalized that the required letterpress, which could be executed quickly on a monthly basis, would not jeopardize his grander aspirations.

Dickens did voice his objections to the intended subject matter, however. Later, at a time when Mrs. Seymour was claiming undue credit for her husband, he claimed to have forgotten whether it was the author or the publisher who insisted on it - a notable lapse of memory (xviii). With a certain amount of condescension, he did concede that the "notion" of a club of inept sportsmen was the "best means of introducing" Seymour's plates (xviii). Unfortunately, however, despite his own birth and early upbringing near the countryside, he was nearly as ignorant of hunting and fishing as any member in the proposed club (xviii). Sporting misadventures might be Seymour's forte, but they would hardly afford Dickens scope for his own Hogarthian talents. In any case, he tellingly observed, the idea was not new. William Combe, Thomas Rowlandson, the Cruikshank brothers, Pierce Egan, and above all, R. S. Surtees had not only created series of their own, but had inspired innumerable other comic annuals and sporting magazines full of amateurs muddling through field and stream (xviii). Even at this early stage of his career, Dickens declined to act the part of William Combe to Seymour's Thomas Rowlandson, whose pictures were drawn before the text was written. ${ }^{24}$

After deriding the substance of Seymour's plan, the author reversed its raison d'être in an assured counterproposal: instead of his writing up to Seymour's plates, Seymour should illustrate his prose. "It would be infinitely better," Dickens counseled Hall, "for the plates to arise naturally out of the text" (xviii). He wished to follow his own bent, ranging freely among more varied English characters and scenes. Indeed, he was "afraid" he would ultimately do so, whatever course he might "prescribe" to himself at the start (xviii).

Hall's reaction to this interview-and what he reported back to Chapman-is unrecorded, but certainly Pickwick seems to have developed from Dickens's prose rather than Seymour's plates. Describing their conference more than a decade later, Dickens doubtless exaggerated his own initiative. Yet it is undeniable that, even as he recollected it, Dickens's response to an offer that would have flattered many better-known writers than himself was characteristic. The brash young author who had not hesitated to declare that Cruikshank required a "touch of the spur," did not intend to be subordinate to Seymour or to anyone else. ${ }^{25}$ The 
"Inimitable Boz" displayed an indomitable will and, from this time forth, his views about The Pickwick Papers indeed "were deferred to" (xviii).

Dickens regarded a collaboration with Seymour as a commercial rather than an aesthetic opportunity, and celebrated it primarily for the remuneration involved. As he wrote to his fiancée, Catherine Hogarth, after talking to Hall on Wednesday, he was to make his "estimate and calculation" before giving his decision to Chapman and Hall on Friday morning. ${ }^{26}$ The emolument was particularly irresistible because, in addition to his newspaper salary, it would enable him to marry. He did not even mention the artist, but stressed that each number, which was to contain four plates, would be written and edited "entirely" by himself. Nevertheless, when Dickens accepted the offer, both artist and publishers must have been relieved to have the project underway at last.

When Seymour and Dickens began work, each apparently was certain he was doing so on his own terms, neither aware that the other considered himself in charge; the inevitable conflicts that followed were compounded by the fact that Chapman apparently dealt with Seymour, Hall with Dickens. The publishers probably assumed that whatever problems arose would iron themselves out during the long course of publication. Indeed after so many delays, Seymour must have been gratified by the speed with which his project was to proceed. The work, nameless in mid-February, was advertised on March 26. As the notice proclaimed, the artist had "devoted himself, heart and graver, to the task of illustrating the beauties of Pickwick" (x).

Nevertheless, it became evident immediately that Seymour's efforts were at odds with Dickens's text, and the continuous strain proved almost as immediately fatal to the work as to the artist. In designing the Pickwick wrapper (see F), for instance, Seymour illustrated his original scheme, doubtless out of ignorance rather than spite for the modifications Dickens intended. The fishing and shooting scenes on the wrapper and the larger size and distinctive Gothic-style print of "SPORTING TRANSACTIONS" in Pickwick's lengthy subtitle (A Faithful Record of the Perambulations, Perils, Travels, Adventures and Sporting Transactions of the Corresponding Members), however, were in distinct contrast with the text, which never even mentioned angling and involved guns only in a humorous, rather minor way (83-85, 246-53). The unindividualized figures further suggest that Seymour designed the wrapper without reference to text. ${ }^{27}$ The artist no doubt tacitly assumed that Dickens would make the sporting incidents and equipment portrayed on the cover loom large in the story. Dickens, however, never intended seriously to involve his characters in these Waltonian recreations about which he, unlike the artist, knew so little.

Even if readers could hardly object to the inaccuracies of a cover designed before the tale was fully underway, the cross-purposes of author and artist undermined both the book and Seymour's stability from the first. The strain was evident throughout the opening number of Pickwick. In the first chapter, Dickens supposedly described the club Seymour wanted, but he failed to make any of its members Cockneys, and only one, Winkle, was even a sportsman, and he was only put in as a condescending concession to the artist (xviii). ${ }^{28}$ The detailed care Seymour lavished on the self-styled sharpshooter and his equipment in the first illustration (I, facing p. 4) was at odds with the text, which described the poet Tupman at greater length (I, 3). In fact, the text in this number provided few outlets for Seymour's special talents, although he exploited these few. Jingle's tale of "The Sagacious Dog," for example, gave him a chance to display his skill in drawing gun-toting gamekeepers, receding wooded landscapes, and beautifully proportioned animals (II, facing p. 12). If Seymour could not equal Cruikshank's urban street scenes, the older artist could never have modeled as well as Seymour the wise dog, or the horses featured in 'The Pugnacious Cabman' (II, facing p. 8) and in 'Mr. Winkle soothes the refractory steed' (V, facing p. 62) in the second number. Indeed, Seymour's animals and inanimate objects are more memorable than the Pickwickians themselves.

Dickens may have worried that Seymour would not pay due attention to his Pickwick, who was more cerebral than Seymour had intended. Still, he need not have pointed out Seymour's duty to him so baldly as he did by prefacing the description of Mr. Pickwick addressing his friends with: "What a study for an artist did that exciting scene present!" (I, 3). No artist would have passed up the scene anyway. Nevertheless, though he warmed to his task, Seymour portrayed a gathering as appropriate to any reputable Islington pub as to Dickens's text, but, somewhat unaccountably, made the hero too pompous in pose and disagreeable in expression (I, facing p. 4) (see fig. 18). Perhaps by the time Dickens complimented Seymour's portrait of Pickwick as "happy" in 1847 (xviii) and in 1868 (xxii), he was confusing Seymour's Pickwick with the more benevolent figure later created by Phiz ( $X$, facing p. 124) (see fig. 21).

For all their problems, however, Dickens readily acknowledged in 1847 that Seymour's first portrait of Pickwick "made him a reality" (xviii). The author was lucky that Seymour portrayed his hero so memorably, for his text had 

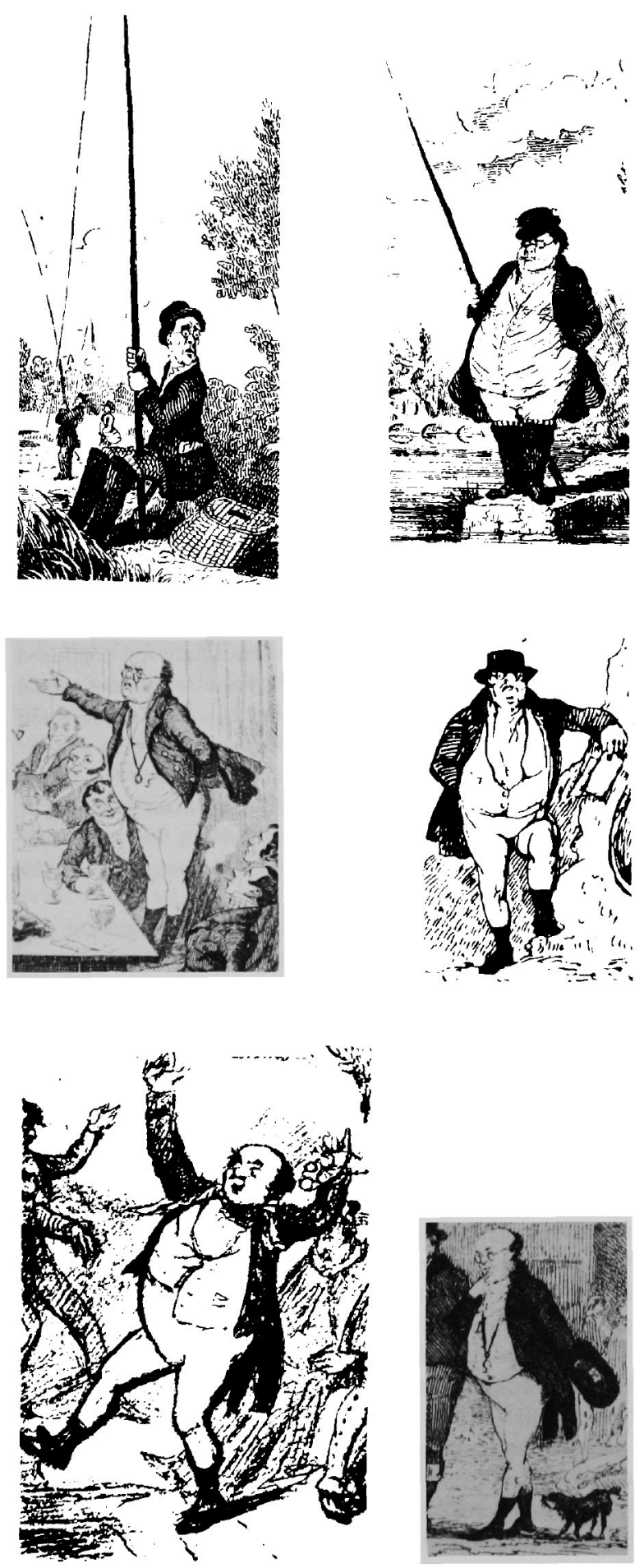

given the artist minimal help. All Seymour knew about Pickwick's appearance was that he had a bald head, beaming eyes, circular spectacles, and nondescript genteel dress; he was left to determine all the other details of face and figure. Dickens should not have been so astonished to learn from Edward Chapman in 1849 that Seymour's initial sketch showed a long, thin man, for the text had not indicated his size at all (fig. 16) ${ }^{29}$ The publisher had wisely insisted that Mr. Pickwick be fat, aware that flesh and good humor had been inextricably associated long before Falstaff; but Seymour did not need to use Chapman's plump Richmond friend that the publisher had suggested as a model. If a fat Pickwick was desired, the artist had him ready at hand. He simply selected from his earlier work one of his stock elderly Cockneys, suitably altered him, and the "immortal" Pickwick, as Dickens called him, was created (fig. 17). ${ }^{30}$ The epithet "immortal" was apt in the most literal sense, for not only had the pudgy figure already led a number of other lives in Seymour's art, but he survived basically unchanged in the hands of subsequent illustrators (figs. 19, 20, 21).

The opening numbers included other developments that could not have pleased Seymour. In keeping with the mention of Kent in the Pickwick prospectus, Dickens had the club visit his own native city of Rochester, a place entirely unfamiliar to Seymour, and thus difficult for him to represent. Then too, in his sketch of 'Dr. Slammer's Defiance of Jingle' (II, facing p. 22), the artist had drawn Slammer clenching his fist over his head; Dickens insisted

Fig. 16 (top left). Robert Seymour, Thin Prototype of Mr. Pickwick, 1833. Detail from 'Damn 'un I missed 'un,' [Richard Penn], Maxims and Hints for an Angler (London, 1833), facing p. 23. Lithograph. $5^{\prime \prime} \times 3^{\prime \prime}(12.7 \times 7.6 \mathrm{~cm})$. Fig. 17 (top right). Robert Seymour, Fat Prototype of Mr. Pickwick, 1833. Detail from 'Do ntt shew yourself to them,' [Richard Penn], Maxims and Hints for an Angler (London, 18335, facing p. 3. Lithograph. $3^{1 / 2^{\prime \prime}} \times 3^{1 / 8^{\prime \prime}}(8.9 \times 8 \mathrm{~cm})$. Fig. 18 (center left). Robert Seymour, Mr. Piikwick, March, 1836. Detail from 'Mr. Pickwick addresses the Club,' The Pickuick Papers, no. 1. Etching. $4^{\prime \prime} \times 37 / 8^{\prime \prime}(10.2 \times 9.9 \mathrm{~cm})$. Fig. 19 (center right). Robert Buss, Unused Study for Mr. Pickwick, May, 1836. Detail from sketch for title page, reproduced in Joseph Grego, Picttrial Pickwickiana (London, 1899), 1:119. Line cut after pen drawing. $6^{1 / 2^{\prime \prime}} \times 3^{\prime \prime}(16.5 \times 7.6 \mathrm{~cm})$. Fig. 20 (bottom left). Robert Buss, Unused Study for Mr. Pickwick, May, 1836. Detail from sketch for 'Mr. Pickwicf and his Friends under the Influence of the "Salmon," reproduced in Joseph Grego, Pictorial Pickwickiana (London, 1899), 1:115. Halftone facsimile after pen and pencil drawing. $41 / 2^{\prime \prime} \times 3 \% "$ $(11.5 \times 9.2 \mathrm{~cm})$. Fig. 21 (btttom right). Hablot Browne, Mr. Piikwick, June, 1836. Detail from 'First appearance of $\mathrm{Mr}$. Samuel Weller,' The Pickwick Papers, no. 4. Etching. 45/8" $\times$ $313 / 16^{\prime \prime}(11.8 \times 9.7 \mathrm{~cm})$. All from the Harry Elkins Widener Collection, by permission of the Houghton Library, Harvard University. 
that he change the sketch to show Slammer with an outflung arm-a change that even Seymour's son conceded "showed considerable sense of dramatic propriety. " ${ }^{31}$ Nevertheless, Seymour may have been offended by this first intrusion into his own sphere, for he did not sign either of the two plates for this design. To compound his difficulties, the surfaces of the steel plates to which he transferred his sketches were of such inferior quality that they broke down after a few hundred impressions, and Seymour had to do the etchings all over again, a chore that forced him to dwell on his grievances-real and imagined-when he could have been using his energies more creatively. ${ }^{32}$ This technical problem was soon remedied but too late to benefit Pickwick's first illustrator.

Seymour's problems did not end with the first number, despite the fact that, though it was not widely read or reviewed, what praise it received was mainly for its "clever and laughable cuts." ${ }^{\prime 33}$ The second number made it clearer than ever that Dickens was deliberately departing from what Seymour thought was the plan. For aesthetic as well as personal reasons, the artist may have been seriously disturbed by Dickens's inclusion of the melodramatic "Stroller's Tale" (III, 35-40). The dismal man's grim narrative about a paranoid clown drinking himself to death harshly violated the comic spirit that the artist found congenial. Seymour probably would have agreed with two later commentators who felt that the tale had "no other apparent purpose than to exhibit Boz's versatility and his independence of Seymour's designs. ${ }^{34} \mathrm{He}$ could hardly ignore the narrative; indeed, it formed so prominent a part of the number that it would have to furnish the subject for at least one of his four illustrations. He could only resent the way his initial plan kept being altered and marred by his brash collaborator. He could not have been much reassured by Dickens's insistence that "many literary friends, on whose judgment I place great reliance, think it will create considerable sensation." ${ }^{35}$ The tale did just that, though not in a way anyone anticipated.

Seymour's antipathy to "The Stroller's Tale" was undoubtedly heightened by his dual identification with its suicidal narrator as well as his wretched subject, who, in his illness, even turns against his devoted wife. The dying clown was, like Seymour, an oversensitive comic artist, compelled to make a living by amusing others; surely it is significant that Seymour's delineation of him is one of his least delicate (see fig. 22). Perhaps the subject was too close emotionally for aesthetic objectification. Baudelaire might well have cited Seymour's first sketch as an example of his "manière simple, archbrutale, et directe." ${ }^{, 36}$ Passing on with obvious relief, to judge from the freer lines, to the comic scenes in the second number, Seymour sketched Pickwick chasing his hat at the Rochester review (IV, facing p. 50), two designs illustrating the abortive ride to Dingley Dell-the one of Winkle with his stubborn horse was selected $(V$, facing p. 62) over the one of Snodgrass and Tupman falling out of the runaway chaise; and the Pickwickians cleaning up in Wardle's kitchen. ${ }^{37}$ This last drawing was never etched, for Dickens sent Seymour back to do more work on "The dying Clown.' Indeed, this plate, which Seymour had executed with such apparent distaste, utterly failed to satisfy Dickens. Chapman and Hall probably decided that author and artist, who had as yet never met, should discuss the illustration in person. If the publishers were aware of Seymour's increasing anxiety about the enterprise, there is no indication that they warned Dickens.

The author's patronizing invitation to Seymour to join him and the publishers for a glass of grog the following Sunday ("the only night $\mathrm{I}$ am disengaged") reveals his continuing ignorance of his hypersensitive illustrator. ${ }^{38}$ Dickens began his letter by expressing his pleasure at the pains Seymour was taking with their "mutual friend," clearly unaware of how inimical Pickwick was becoming to the artist. "How much the result of your labours has surpassed my expectations," the author continued in a vein condescending, if not downright insulting, to the established artist. Dickens proposed that all the Pickurick principals meet, not to celebrate the success of their project (which he unaccountably termed "most complete") but to inspect a revised sketch of 'The 'dying Clown.' "I have seen your design for an etching to accompany 'The Stroller's Tale' and thought it extremely good," Dickens elaborated, "but still, it is not quite my idea." He wanted the woman to look younger, he said, the dismal man less miserable and more compassionate, and the emaciated clown less repulsive. "The furniture of the room," he granted in conclusion, "you have depicted admirably." Seymour must have been gratified, as Edgar Johnson acidly notes, "to have it conceded that he could draw a bed and a three-cornered table, and that it was merely the people he had got all wrong." ${ }^{39}$ Certainly Dickens left Seymour no choice but to furnish him with another drawing.

One can imagine the reluctance with which Seymour accepted Dickens's invitation. Nothing could have been more disagreeable to the artist than to rework this painful subject, and then to submit it to Dickens, whom he had never met, in the presence of the publishers, who were allowing the writer so much control over his plates as well as over the plan that had initially been his. Whether, upon his arrival at Furnival's Inn, Seymour felt relieved or slighted to find Dickens's wife and brother (xxii) instead of Chapman 
and Hall is unknown. ${ }^{40}$ No record of the meeting exists, except for Dickens's comment, twenty-two years later, that Seymour "certainly offered no suggestion whatsoever" about Pickwick (xxiii).

Although Dickens approved his new sketch of 'The dying Clown' (fig. 23), Seymour must have despaired after leaving their meeting. It had become perfectly clear that the experienced artist, whose name had originally been considered the only real asset to the project, was now playing second fiddle to an obscure writer supposedly hired to concoct a story around his plates. Pride as well as the needs of his family doubtless prevented Seymour from withdrawing from Pickwick, but by remaining without protest, he tacitly acknowledged Dickens's control over the illustrations as well as the text. Although author and artist parted with an appearance of cordiality that Sunday evening, Seymour must have felt humiliated. It must have seemed to him that he was indeed, as Beckett had said, "a perfect dolt," incapable of implementing even his own ideas, a clown himself, whom people laughed at, not with.

On Monday, the perturbed artist completed his new design for 'The dying Clown,' but unfortunately, he accidentally ruined the plate he was etching it on. Time was running out. Only two of the required four illustrations were completed. It must have seemed to the artist that now even his "mechanical" abilities were failing. In desperation, he devoted most of Tuesday to doing the etching over. ${ }^{41}$ In the final plate (III, facing p. 38) (fig. 24), the woman appears as aged as before and even more haggard, and the dismal man is solicitous enough; but not only is the clown's emaciation more pronounced, his facial grimace makes him more horrifying than before, as if in reflection of Seymour's own frightened affinity with his representation. Dickens's "idea" of the plate was not realized until Phiz later altered and re-etched it, making all the characters more attractive, hence, more sympathetic (fig. 25).

The Seymours' servant girl, on her way to bed late Tuesday evening, noted nothing unusual about the artist conversing with his wife in the parlor, nor did she think anything amiss about his habitual noises in the hall early the next morning. ${ }^{42}$ But when, before breakfast, she went out for a walk, she discovered Seymour behind his garden studio lying in a pool of blood with his clothes on fire. Her screams summoned a neighboring butcher who grabbed a nearby watering can and unceremoniously doused the fire. Seymour had shot himself through the heart. The butcher found a piece of paper at the body's feet and handed it to the horrified servant. He then prevented Mrs. Seymour from entering the garden where a surgeon he had summoned confirmed that the shot had been fatal. The servant further distracted the widow by handing her Seymour's note. The artist's concluding words expressed a hope that God would grant him the peace in death that he could never find in life. The coroner's inquest, held two days later on April 22, declared the cause of Seymour's death to be "Temporary Insanity," a necessary euphemism for suicide since according to the cruel laws of the time, a verdict of felo de se would have deprived Seymour of a religious burial and his family of his estate. ${ }^{43}$

Seymour, according to Weld Taylor, who had drawn his portrait, was "a melancholy-looking man, whom nobody would have thought had so much genuine humour."44 Like Dickens's clown, the artist entertained an audience oblivious to his real nature. Only the Metropolitan Magazine perceived that "The Stroller's Tale" may have been "the one drop of bitterness which made the cup of anguish overflow." "B5 "Blame no one," Seymour charged his wife in his suicide note, but he did leave one tacit accusation, and Dickens never forgot it: when the artist's studio was searched for the illustrations for the second number of Pickwick, to be published at the end of April, "the plates were found unfinished with their faces turned to the wall." 6

Dickens learned about Seymour's death from his brother Frederick, who read it in the newspapers. What he knew of the artist's prior dealings with Chapman and Hall and what he might have sensed beneath the surface of their one meeting is unknown, but certainly he showed consternation at the news. ${ }^{47}$ Dickens may have had suspicions in retrospect that Seymour's suicide could have been precipitated by his failure to control the project he had initiated. At that point, the author may also have recognized Seymour's tragic affinity with the dying clown. But Dickens, who had never even met Seymour until after the train of events had been set in motion, could hardly have anticipated that he would shoot himself on either score. Chapman and Hall had not obliged Dickens to accept the Pickwick offer unconditionally; in fact, they hired him with full awareness of his objections. Furthermore, the artist need not have been so entirely silent about his objections. Yet the sensitive author could hardly have felt easy about Seymour's death in light of the highhandedness with which he had treated his contributions to the Pickwick venture.

Understandably, however, Dickens's anxiety about Seymour quickly yielded to anxiety about his own future. Seymour's plates had called Pickurck into existence, and the publishers' expectations for it were based primarily on the artist's name. With Seymour dead before the publication of the second number, Chapman and Hall might well decide to drop the enterprise. Instead, they decided to let Dickens 

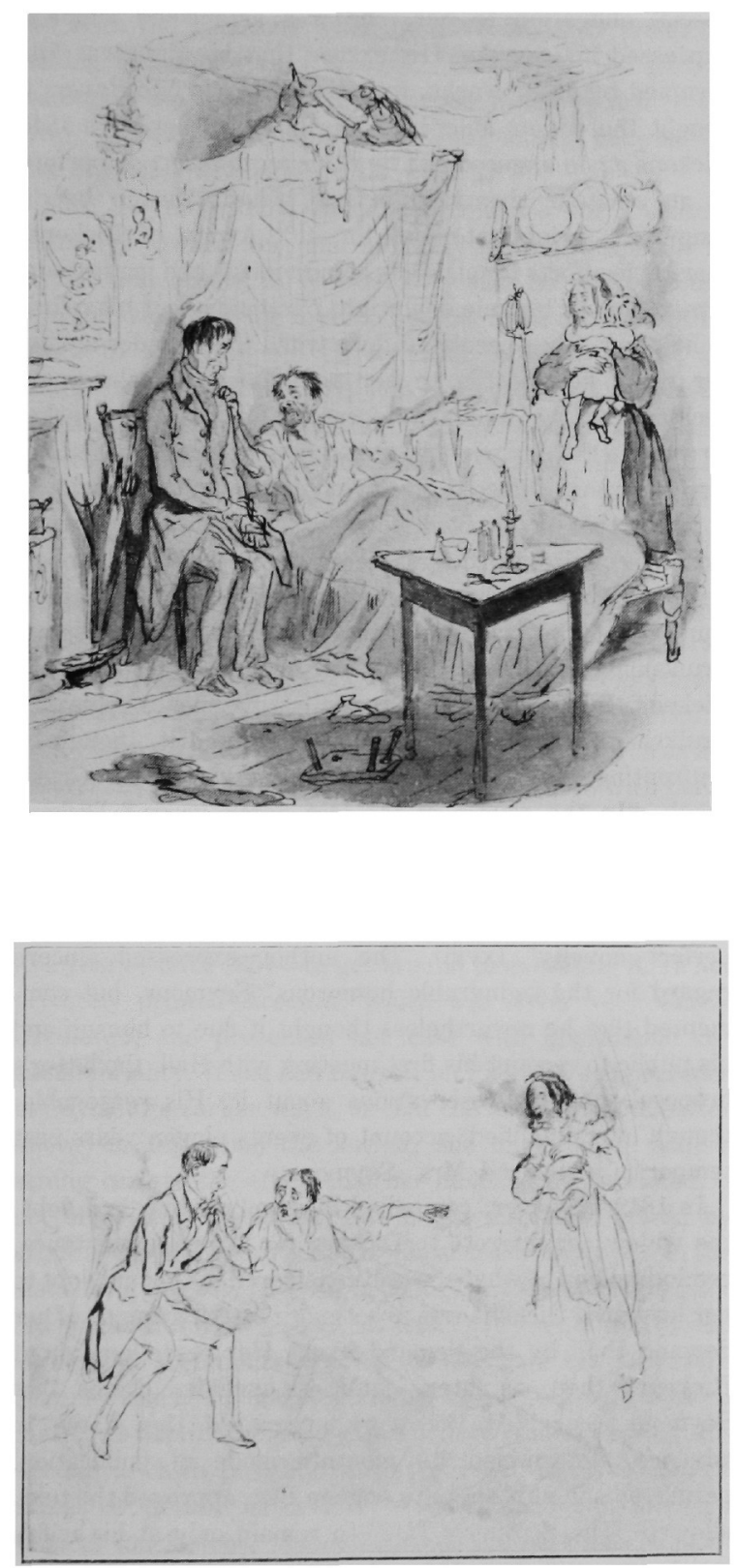

Fig. 22 (top). Robert Seymour, Unsatisfactory Sketch for 'The dying Clown.' Pencil and wash. $4 \frac{1}{1} 2^{\prime \prime} \times 3^{3 / 4} 4^{\prime \prime}(11.5$ $\times 9.5 \mathrm{~cm}$ ) [sight]. From the Suzannet Collection, by courtesy of the Trustees of the Dickens House Museum. Fig. 23 (bottom). Robert Seymour, Altered Sketch for 'The dying Clown.' Pencil. $35 / 16^{\prime \prime} \times 3 \frac{3}{4} 4^{\prime \prime}(8.4 \times 9.5 \mathrm{~cm})$. From the original in the Harry Elkins Widener Collection, reproduced by permission of the Houghton Library, Harvard University.
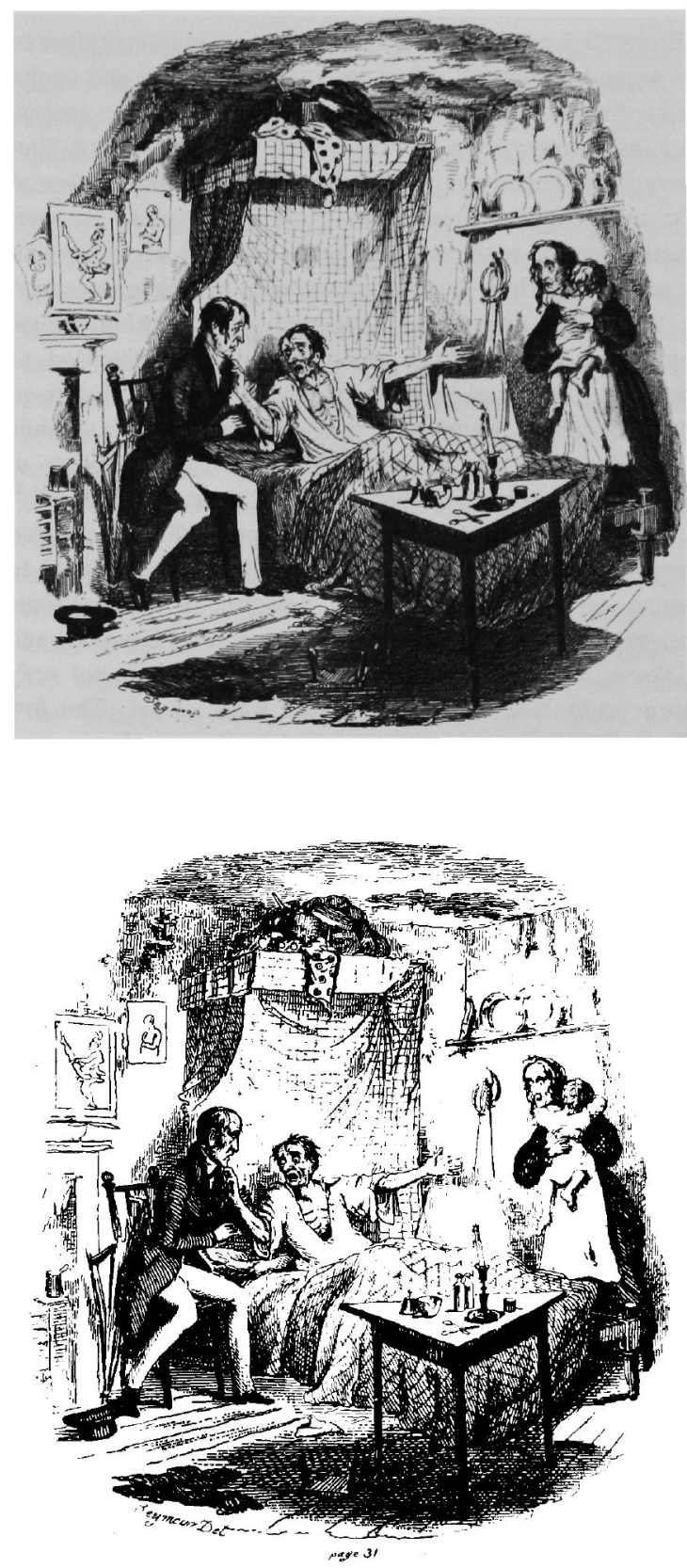

Fig. 24 (top). Robert Seymour, 'The dying Clown.' The Pickuick Papers, no. 2, facing address. Etching. 315/16" $\times$ $35 / 16^{\prime \prime}(10 \times 8.4 \mathrm{~cm})$. Fig. 25 (bottom). Hablot Browne, "The dying Clown.' The Pickwick Papers, 1st ed., 2d issue (1837), facing p. 31. Etching. $3^{15 / 1 i^{\prime \prime}} \times 3^{13 / 16^{\prime \prime}}(10 \times 9.7 \mathrm{~cm})$. Both from the Harry Elkins Widener Collection, by permission of the Houghton Library, Harvard University. 
address Pickwick's small audience in an optimistic preface to the second number. ${ }^{48}$ After eulogizing Seymour and apologizing for the fact that the issue had only three plates, Dickens summoned his bravado and heralded a new "improved" (and cheaper) plan, calling for eight more pages of text but two less illustrations. ${ }^{49}$ It remained to be seen whether or not readers would be as satisfied with this plan as was the author; for the publishers, having economized on the plates, increased Dickens's remuneration. "Poor Seymour," chorused the reviewers, whose attention to Pickwick, prompted perhaps by morbid euriosity, increased after his death. Seymour's passing was indeed a "public loss," declared the Satirist, "for with the exception of George Cruikshank, he had no 'rival near his throne." "50

Within weeks, however, the fickle public had discovered Browne (Phiz), Dickens's new illustrator, and ceased to mourn for Seymour. Indeed, relieved of the tensions generated by the incompatible approaches of Seymour and Dickens, The Pickwick Papers shortly became not only more profitable, but also a better work of art. The few efforts Dickens made to accommodate Seymour's sporting tastes had not improved the narrative. Now he had no further need to dwell in what Pickwick's earliest reviewer called "that melancholy region of exhausted comicality, in which few laughs remained." the cumbersome club machinery he had adopted in deference to the artist. Winkle endured, but Snodgrass and Tupman rarely appeared as later chapters were given over to urban concerns more in line with Hogarth's art than with Seymour's. If Seymour had lived, Dickens might have tried to maintain some tenuous semblance of his original plan, but his death freed the author to shift focus happily and irrevocably. Within weeks of Seymour's death, Pickwick reigned supreme, his figure stamped on minds, hearts, and objects throughout England.

Indeed, everyone initially involved with Pickwick prospered except Seymour's family. As the resources of his widow dwindled, her resentment of Dickens and the fortune he was making from the book increased. Reasoning that if it had not been for Seymour, Dickens would never have written Pickwick, she concluded that the author owed her an incalculable debt. Throughout the next three decades she and her son sought to collect it, first by private appeals and threats, then by public accusations. Dickens was forced to think far more about Seymour's role on Pickwick after his death than he ever had during his lifetime.

In 1840, Mrs. Seymour asked Dickens to contribute, along with other writers and artists, including Cruikshank and Browne, to a book for her relief. Convinced of Dickens's special obligation to her, she was astonished when he expressed his regrets. His excuse that his time was fully occupied by other works, including The Pic Nic Papers to benefit the widow Macrone, only incensed her. ${ }^{52}$ In 1845, Dickens again angered her by refusing to direct or perform in an amateur theatrical in her behalf, though he did compose a brief statement for it. ${ }^{53}$ Aware of Dickens's charitable efforts for all kinds of individuals and institutions, Mrs. Seymour became downright paranoid about his refusal to help her. She speculated for a while that slander against her made him hostile to her personally, but she finally decided that he was simply satanically evil. She looked forward to the day when he would be sentenced by the Lord for his wrongs inflicted on Seymour's orphans and widow.

Before that day arrived, however, she believed this world would recognize, to Dickens's eternal discredit, that Robert Seymour had been the true creator of The Pickwick Papers. Rumors of the widow's claim-which perhaps inspired Cruikshank's to Oliver Twist in the mid-1840's-reached Dickens. In direct contrast to his lasting silence regarding Cruikshank's allegation, he publicly refuted it, though by confronting Mrs. Seymour, he indirectly warned Cruikshank. "In the course of the last dozen years," Dickens wrote in his preface to the 1847 edition of Pickwick, "I have seen various accounts of the origin of these Pickwick Papers, which have, at all events, possessed-for me-the charm of perfect novelty" (xviii). The author expressed sincere regard for the "admirable humorous" Seymour, but commented that he nevertheless thought it due to himself and his public to recount his first meeting with Hall, the latter's proposal, and his reservations about it. His reasonable, though oversimplified, account of events eleven years past temporarily silenced Mrs. Seymour.

In 1849 , however, compelled by family illness and debt, the widow again wrote to Dickens for financial assistance, reminding him of what she still considered his unpaid debt to her husband. Dickens was upset more by the grounds of her demand than by the demand itself. Her assertions about Pickuick then, as later, doubtless included claims that Seymour conceived the work, prepared the plates in advance, determined its monthly mode of publication, permitted the publishers to engage Boz, approved the text, allowed "The Stroller's Tale" to remain only at his wife's insistence, and quit the enterprise after the engravers spoiled "The dying Clown."54 Dickens termed her accusations "utterly false," but was nevertheless disturbed enough to forward her letter to Chapman. ${ }^{55}$ Was his published account of Pickwick's beginnings, he asked, not strictly accurate? The publisher, drawing on his own recollections and those of the deceased Hall, replied that it was, except that Dickens 
had been too generous when he gave Seymour credit for making Mr. Pickwick a "reality." Otherwise, the partner reassured the author (who he hoped would return to the firm), "from the beginning to the end, nobody but yourself had anything whatever to do with it."

Mrs. Seymour also demanded reasons for Dickens's animosity toward her, and minutely described appeals by herself and others in her behalf which he had rejected. Dickens, vainly trying to remember all these occasions, then wrote to Mrs. Samuel Carter Hall, a family friend (no relation to the publisher, William Hall) whom the widow had mentioned as being sympathetic to his cause. ${ }^{57}$ Enclosing the letters from Mrs. Seymour and Chapman, he implicitly requested her assurance that he was innocent. Apparently Mrs. Hall affirmed Dickens's belief in his own blamelessness and the widow's audacity. Probably she also must have reinforced his suspicion that Mrs. Seymour, near deranged with grief, poverty, and envy, was desperately exaggerating her husband's Pickwick role to extort Dickens's assistance. His case substantially fortified, the author replied to Mrs. Seymour, denying her request for money as well as her assertions, and declining further communication with her. ${ }^{58}$

After she heard from Dickens, Mrs. Seymour warned him that she could call down dire consequences on his head if she were to call public attention to the affair. Dickens remained silently contemptuous of this threat, and it took the widow five years - until 1854-to get around to executing it. In her privately printed Account, which was never very widely circulated, she presented her case with implausible circumstantiality. If she had based it on Pickwick's appearance in Seymour's earlier work, or that the artist was far better known in 1836 than the author, she might have made a strong case to the effect that her husband had initiated, if not originated, Pickwick. She might also have scored by arguing that Seymour's death was at least partly due to the distasteful work he had had to do for Pickwick and Dickens's brashness and irreverence. Instead, however, she recycled all her old arguments in order to illustrate her husband's genius-which no one questioned-and Dickens's lack of charity to her. Dickens wisely refrained from disputing this Account, which possibly he never read. Mrs. Seymour's excessive detail, irrelevant or unwarranted assertions, illogical conclusions, hysterical tone, and paranoid point of view were self-defeating. ${ }^{59}$ Her gross distortion of fact, especially her drastic revision of Dickens's one letter to Seymour to make it appear that the author liked the sketch of 'The dying Clown' so much that he requested a copy for a gift, was not evident until the unaltered material was published during the Pickwick centenary in 1936, by which time Mrs. Seymour had been discredited anyway. ${ }^{60}$
In 1866 the controversy flared again, this time threatening to continue into the next generation as both widow and author turned to their eldest sons for support. When the author-publisher Henry Bohn advertised his reissue of Seymour's Humorous Sketches in the Athenaeum, the artist's son and namesake, far from welcoming a sympathetic ally, wrote the editor in a fury. ${ }^{61}$ Not only had Bohn stolen the copyright to the drawings, alleged young Seymour in the published letter, but he had written a memoir for the edition that was inaccurate about his father and that sneered at his mother's Account. He promised to provide a full refutation of Bohn's memoir and a valid account of Pickwick's origin in an edition he was preparing of his father's works. Bohn was not alone in protesting to the Athenaeum. ${ }^{62}$ Unable to remain aloof from the fray, the author of Pickwick and "of one or two other books," as Dickens sarcastically described himself, replied in another letter to the editor and stirred up the old teacup tempest. Yet again, Dickens publicly denied the Seymours' claims. The artist, he said, whom he met only once, whose handwriting he had never even seen, "never originated, suggested, or in any way had to do with, save as illustrator of what I devised, an incident, a character (except the sporting tastes of Mr. Winkle), a name, a phrase, or a word to be found in The Pickwick Papers" (CP, 1: 108-10). The editors of the Athenaeum printed a second letter from Dickens, correcting a minor factual error in his first, ${ }^{63}$ but when Seymour's son wrote a second letter to reiterate his position, they did not print it, being unwilling to carry the dispute any further in their pages. ${ }^{64}$

But Dickens, as G. K. Chesterton wryly noted, perpetuated the quarrel "as if it had been a Highland feud." between his two letters to the Athenaeum, the author wrote his oldest son Charley all about the quarrel and Mrs. Seymour's attempted blackmail. ${ }^{66} \mathrm{He}$ mentioned Chapman's supporting letter and his Athenaeum ones, written to quash the revived lies once and for all. He requested that Charley complete the record by asking his mother for her notes about that Sunday evening forty years ago when, as Dickens put it, "that poor little man and I looked upon each other for the last time" and of that Wednesday morning when Frederick Dickens reported Seymour's suicide. The uneasy Dickens wished only to spare his descendants future trouble, he told his son in apology for his overcautiousness.

Dickens's preventive measures did not cease. In $1867 \mathrm{~J}$. C. Hotten published an edition of Seymour's Sketches with a biographical memoir, the material for which must have been provided, if not actually written, by the artist's son. ${ }^{67}$ Before he left on his second American tour in 1867, Dickens gave Chapman's 1849 testimony to Forster for safekeeping 
or to use, should the occasion arise while he was gone. He took advantage of the 1868 edition of his works to revise the 1847 preface to Pickwick in order to include all the accumulated evidence against the Seymours. He wished, he said, to demonstrate "the monstrosity of the baseless assertions in question, and (tested by details) even of the self-evident impossibility of there being any truth in them" (xxii-xxiii). The controversy subsided only after the author's death in 1870, but not, perhaps, before reinvigorating the similar one instigated by Seymour's fellow Dickens illustrator, George Cruikshank.

The allegations of the Seymours, like those of Cruikshank, are not without some basis. What emerges from the welter of claims and counterclaims is that more than one person shaped the destiny of the most popular English novel of the nineteenth century. Seymour did indeed generate a plan that, through Chapman and Hall, was implemented by Dickens. The manner, however, in which Dickens developed the plan was entirely his own. Thus the problem of whether the artist or the author "originated" what eventually became The Pickwick Papers becomes one of insoluble semantics. It is hard, however, to dispute Chesterton's assertion that it was "quite easy to originate Pickwick. The problem was to write it." ${ }^{\text {" }}$ More intriguing to later generations of readers is why Dickens increasingly involved himself in a controversy that might have abated had he remained silent. Indeed, the fact that he became so indignantly exact about every detail of his Pickwick authorship suggests his inability to exorcise the troublesome specter of Robert Seymour. 


\section{Chapter 3}

\section{ROBERT BUSS}

Dickens's third illustrator, Robert Buss, also suffered from his association with the author, though less dramatically than George Cruikshank and Robert Seymour. Buss, hastily hired to replace Seymour as an illustrator for the The Pickwick Papers, was just as hastily dismissed-within a month in fact. To have missed fame by so slender a margin would have distressed any man; but to be forever remembered, if at all, ${ }^{1}$ as a failure in association with the most popular novel of the century was a fate Buss hardly deserved. Like Mrs. Seymour, Buss dwelt on these cruel ironies the rest of his life. Unlike the widow, however, he endured his misfortune in silence during Dickens's lifetime, and blamed the Pickwick publishers, not the author. When, shortly before his own death, he finally vented his indignation, he did so only privately to Forster. In fact Dickens, whom Buss never met, remained an inspiration to him throughout his frustrated career.

None of Dickens's illustrators revered him more than Buss (fig. 26). As a young artist, known for his portraits as well as book illustrations, Buss had admired Boz's first sketches in the Morning Chronicle. In 1836 he, like Seymour, even illustrated one of them when it appeared in Chapman and Hall's Library of Fiction; Seymour illustrated "The Tuggs's at Ramsgate," and Buss supplied the woodcut for "A Little Talk about Spring and Sweeps" (SBB, S, XX, facing p. 166). Chimney sweeps, as reflected in Blake's Songs, had acquired a romantic mystique during Dickens's youth. Their origins still provoked speculation and their boisterous dancing remained the only vestige of earlier May Day celebrations. Buss was fascinated by the legendary and sentimental aspects of Dickens's piece. Using straight and curving parallel lines, the artist portrayed the mythical sweeper who, kidnapped as a baby, falls asleep on his own infant bed when he is supposed to be working, and is

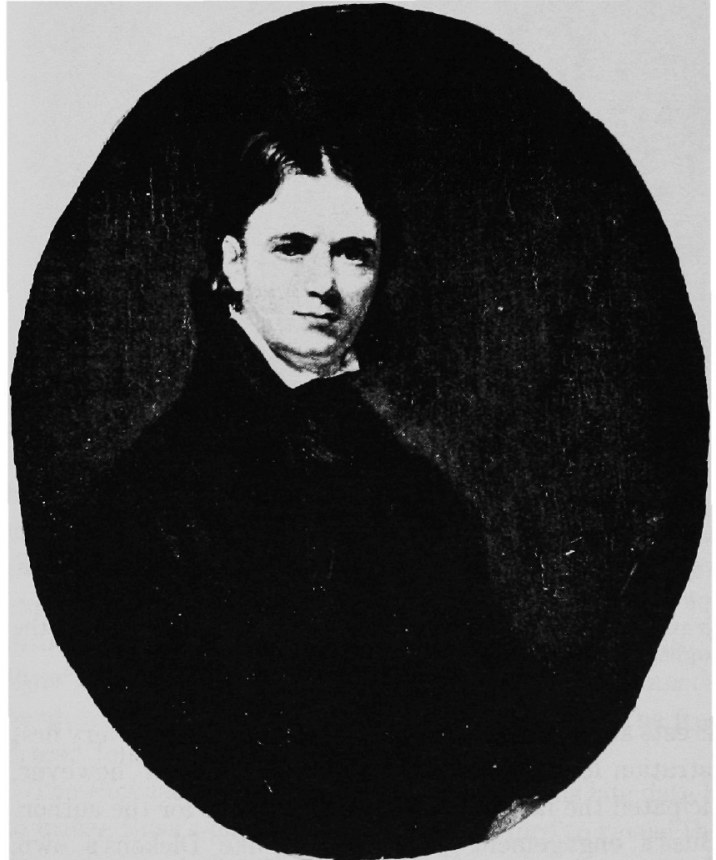

Fig. 26. Robert Buss, Self-Portrait, ea. 1837. Photograph of painting, reproduced in George Somes Layard, "Our Graphic Humourists: Robert William Buss," Magazine of Art, 26 (June, $1902), 361.4 \frac{1}{2} 2^{\prime \prime} \times 3 \frac{5}{8^{\prime \prime}}(11.5 \times 9.2 \mathrm{~cm})$. Courtesy of the Boston Athenaeum.

recognized by his mother (fig. 27). When the piece, renamed "The First of May," was reused in the second edition of the Sketches by Boz later in the year, Cruikshank found the vulgarity of the contemporary merrymaking more interesting and captured it with short, varied strokes ( $S B B, \mathrm{~S}, \mathrm{XX}$, facing p. 174) (fig. 28). The two scenes sum up the different 


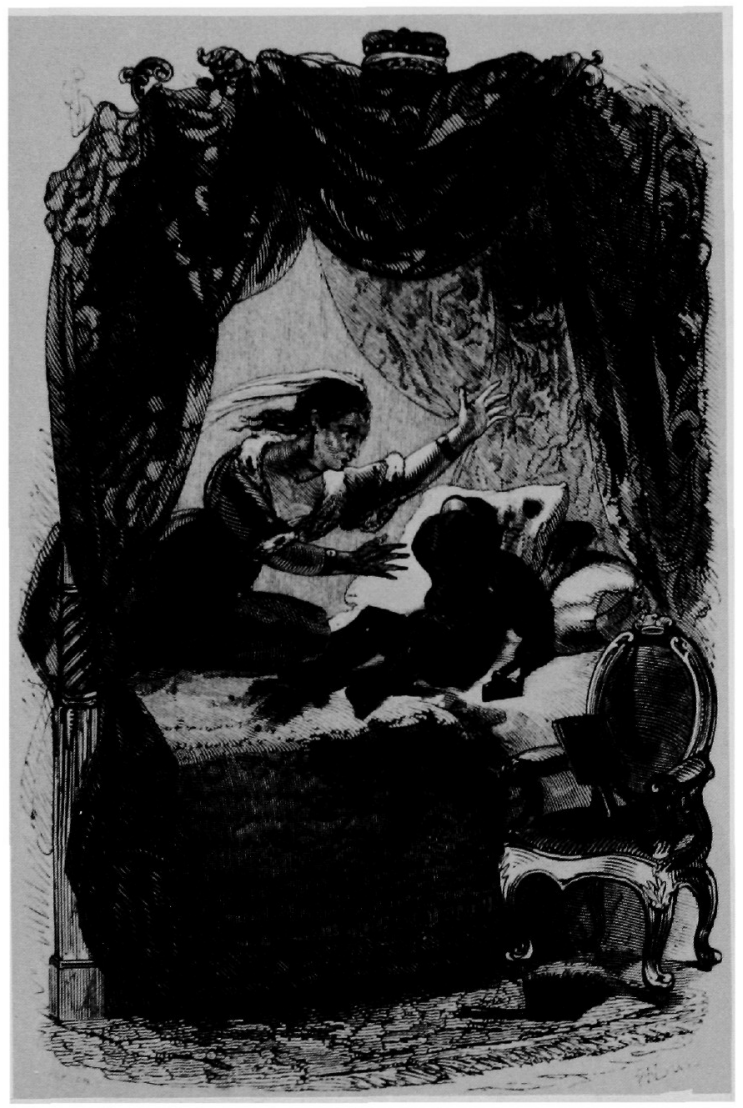

Fig. 27. Robert Buss, 'May-day in the Evening.' The Library of Fiction, 1 (June, 1836), facing p. 114. Wood engraving. $4^{3 / 4} 4^{\prime \prime} \times 3^{1 / 4^{\prime \prime}}(12.1 \times 8.3 \mathrm{~cm})$. By permission of the Houghton Library, Harvard University.

interests and techniques of the artists. That Buss's very first illustration for Dickens was so quickly repiaced, however, anticipated the fate of his subsequent plates for the author.

Buss's engagement on Pickwick, like Dickens's own, resulted from his connection with the Library of Fiction. His May Day plate had been engraved on wood by John Jackson, whose brother had engraved Seymour's wrapper design for Pickwick. ${ }^{2}$ Jackson apparently was consulted by Chapman and Hall in their urgent search for an artist to succeed Seymour. The engraver, aware of the importance of illustrations to Pickwick's survival, was stymied. Who would be available on such short notice? Who knew how to etch on steel, still a novelty, not the fashion it became after Pickwick? Cruikshank and Seymour were the only famous comic artists then capable of coping with steel plates; and even they, pressed for time, often resorted to assistance

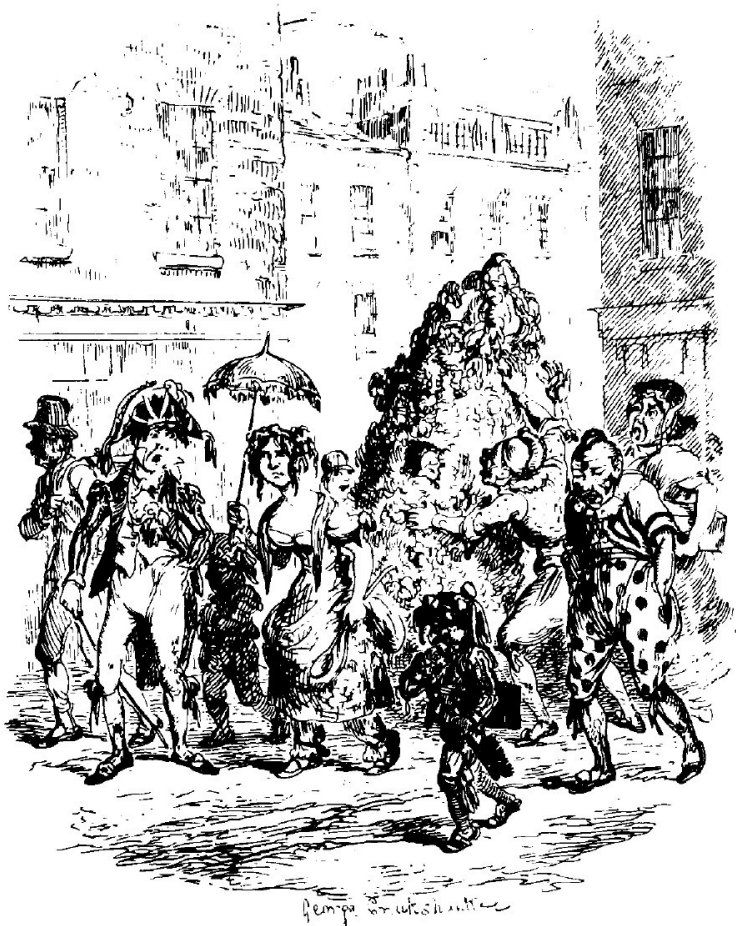

Fig. 28. George Cruikshank, 'The First of May.' Sketches by Boz, 2d series, 2d ed. (1837), facing p. 325. Etching. $3^{11 / 16 "}$ $\times 2 \% 8^{\prime \prime}(9.4 \times 7.3 \mathrm{~cm})$. From the Harry Elkins Widener Collection, by permission of the Houghton Library, Harvard University.

from engravers. Who was, in addition, familiar with young Dickens's work? The Library sketch in mind, Jackson thought of his friend Buss. Buss was familiar with Boz's work. He was steadier than Seymour and more tractable and available than the busy Cruikshank. True, Buss had never etched, though he was the son of an engraver, but he would learn quickly. Assistants could prepare the wax and resin ground and apply the tricky acids to "bite-in" his designs. Robert Buss, Jackson advised the publishers, would be a suitable successor to Robert Seymour.

Acting on Jackson's advice, Hall called on Buss, who was then working on a canvas for the fortheoming Royal Academy exhibit. The publisher's proposal that Buss "undertake the illustrations for the ensuing number of Pickwick" completely surprised the artist. ${ }^{3} \mathrm{He}$ thought his etching inexperience a serious drawback. No, Hall apparently countered persuasively, any talented artist could easily learn the process. Of course, the publishers would show "due consideration" toward his lack of etching practice. Whether "due consideration" meant less stringent judgment of his work or more generous renumeration than 
was usual was left unclear. It was also left vague whether Buss's tenure was for the "ensuing" number only or for as long as he gave satisfaction. Buss obviously assumed both that he would be well paid for his efforts and that he was likely to continue as Pickwick's illustrator throughout its publication. It was certainly clear to Buss that the publisher's plight was desperate and that his help would be invaluable. Pressed by Hall, flattered by Jackson's recommendation, awed by the reputation of his predecessor, and impressed by Dickens's writing, Buss agreed to submit a sample of his qualifications to follow Seymour.

Putting aside the Academy canvas with reluctance, Buss purchased the requisite etching tools and began an intensive period of rigorous self-training. Clearly thinking in terms of extended employment illustrating Pickwick and not just of the task at hand, he resolved to learn to etch. After studying Seymour's prints, Buss made pen and ink studies of the Pickwickians (fig. 29). Then, selecting an episode from the published second number, he drew Pickwick being forced back into the crowd by a soldier's musket at the Rochester review. Determined not to jeopardize the quality of his drawing by allowing a different hand to etch it, Buss spurned Jackson's offers of assistance and etched it himself. The novice attempted the impossible by trying to convey his accustomed bold effects of a woodcut while imitating Seymour's delicate lines. Weary from etching the steel, whose surface was so much harder (and therefore more durable) than that of copper or wood, Buss applied the "biting-in" acid only once. The result was predictably "thin and scratchy."

Even if the publishers and Dickens shared Buss's low opinion of his sample, they faced a Hobson's choice. They could continue with Buss or produce an issue without any illustrations at all. Having already halved the number of illustrations, they dared not break faith still further with their readers, few as they were. The firm gave Buss the green light. They printed his name on the Pickwick wrapper and announced that the plates for the third number would be executed by "Mr. Buss-a gentleman already known to the public as a very humorous and talented artist."

Fortunately, under the firm's "improved" plan, there were only two illustrations for Buss to prepare. Chapman and Hall had approved his sketches for two subjects: the Muggleton cricket match and the fat boy peeping at Tupman and Miss Wardle in the arbor. Again, Buss took great pains. First he studied Seymour's sketches for substance as well as style. ${ }^{6}$ Then he began to transfer the two designs to the single large steel plate from which they would be printed. He personally laid the wax and resin ground. But when he applied the etching needle to the surface, his inexperience

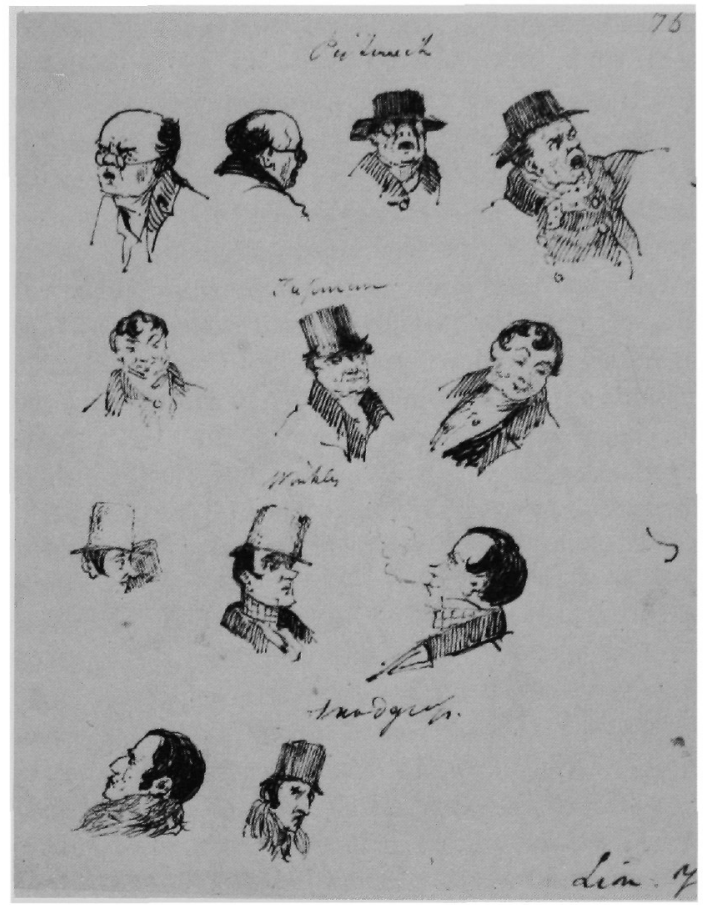

Fig. 29. Robert Buss, Unpublished Studies of the Pickwickians. Pen and brown ink. 51/8" $\times 4^{\prime \prime}(13 \times 10.2 \mathrm{~cm})$. By permission of the Pierpont Morgan Library.

became all too evident. The ill-prepared ground broke up under the needle's action. Buss did not have time to cancel the plate and re-etch it. He had to give his designs to an expert to etch them (though, addly, notations on both printed plates say they were "Drawn and Etched by R. W. Buss"). As a result of this necessary intercession of another hand, however, the published illustrations lacked the freer, firmer touch of Buss's drawings.

The Pickwick principals had no choice at this late date but to utilize Buss's plates; they could not afford to reveal their true opinion at that time. Though Buss, in retrospect, felt fairly satisfied with 'The Cricket Match' (VII, facing p. 90), his employers obviously did not. They probably found the figures oversized and angular, their poses stiff, and their expressions too uniformly open-mouthed or vacant. In any case, at their earliest opportunity they replaced not only the design but the entire subject. The 'Arbour Scene' was more to their liking (VIII, facing p. 98). By moving the fat boy from behind the amorous couple (fig. 30) to the front in a direct confrontation with them (fig. 31), Buss extracted as much comic potential from the situation as possible. But the publishers and author seem to have shared the artist's later 

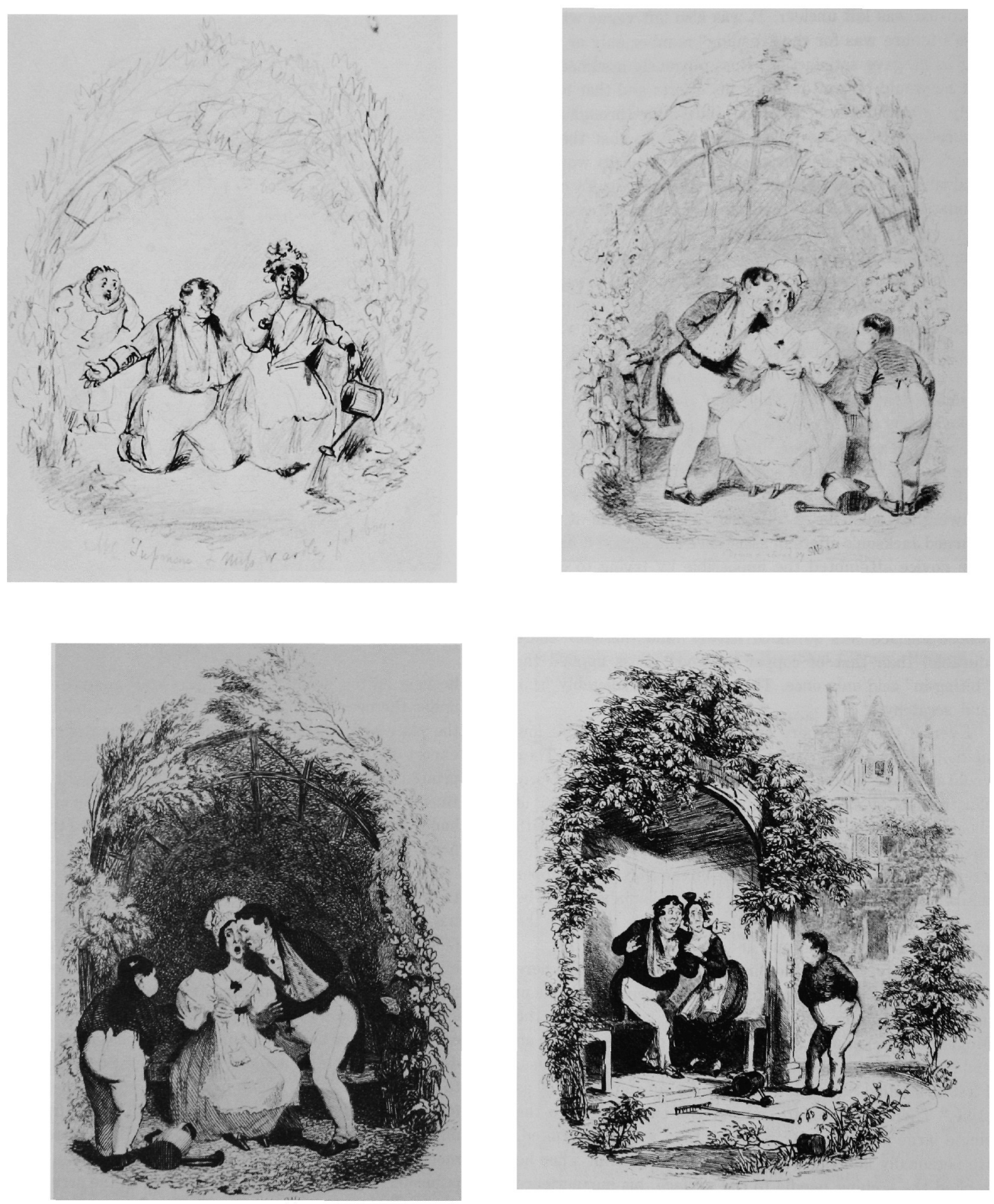


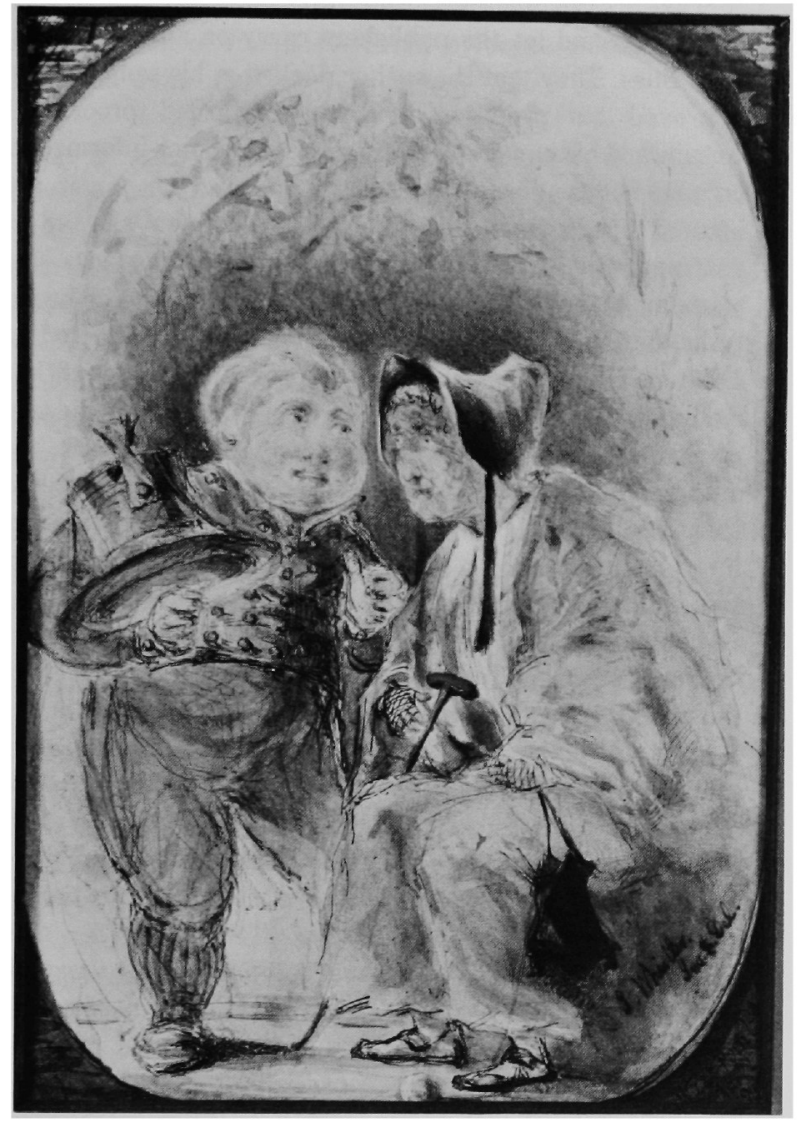

disparagement of its cramped lines and unsubtle use of light and shadow (fig. 32) - even the first letter of his signature was improperly reversed-for they had Browne redesign it completely soon after he replaced Buss on Pickwick (fig. 33; cf. fig. 34). Yet Pickwick's dwindling readership did not complain about Seymour's successor nor was he criticized by its few reviewers. One paper, one of the few even to note the new artist, declared of Boz and Buss that "the operation of the two will banish 'black melancholy' as effectually as a dose of laughing gas." Indeed, nearly twenty years later, the fat boy's revelations to old Mrs. Wardle about the antics in the arbor (VIII, 102-3) would so amuse the young James Whistler that he felt compelled to draw the scene (fig. 34 ). ${ }^{8}$

As it turned out, however, only Buss was banished. The unsuspecting artist assumed that the mere appearance of his plates indicated the publisher's tacit approval. With added confidence, reflected in the firmer draftsmanship, if not the continued expressionlessness, of all his Pickwicks (see figs. $19,20,29)$, he sketched two designs for the fourth number and even went so far as to design one for Pickwick's title page in anticipation of its later publication in hardcover. ${ }^{9} \mathrm{He}$ then returned to work on his Academy canvas while he waited to be given a deadline for the finished plates. $\mathrm{He}$ never was. While he waited, another artist submitted samples more impressive than his own in application for the post he held so tenuously. Buss knew nothing of this challenger until the publishers curtly notified him that "they had placed the work in the hands of Mr. Hablot Browne?"10

Buss was flabbergasted. He was keenly aware of the defects of his first etchings, but thought them as good as could be expected. Three weeks practice could not remedy his inexperience at etching his own drawings or at accommodating them to an expert etcher's hand, but one more month might have. He had assumed that the Pickwick principals tacitly shared his opinions. How could he have so misjudged them? Granted, the publishers had asked him to illustrate only one Pickwick number. But, almost certainly, the artist felt they had broken an implicit agreement to engage him permanently. Lacking witnesses or a written contract, of course, he could have proven nothing, had he wanted to fight for the job. His own strenuous efforts suggest that he did not regard his Pickwick assignment as a passing thing nor even a welcome opportunity to add etching to his repertoire of skills. "Is it reasonable to suppose," queried his oldest son, "that he would have consented to devote three weeks of his time, at the most valuable season to an artist, to the practice of an entirely new department of art, if it had been clearly stated that his engagement" was only temporary? ${ }^{11}$ Clearly Buss did not know another illustrator would be

Fig. 30 (opposite, top left). Robert Buss, Unpublished
Sketch for 'The fat boy awake on this occasion only.' Graphite with some pen and brown ink. $61 / 16^{\prime \prime} \times 4 \% 1^{\prime \prime}(15.4 \times 11.6 \mathrm{~cm})$ [sight]. By permission of the Pierpont Morgan Library. Sketch for "The fat boy awake on this occasion only. Graphite. $61 / 6^{\prime \prime} \times 4 \% / 16^{\prime \prime}(15.4 \times 11.6 \mathrm{~cm})$ [sight]. By permission of the Pierpont Morgan Library. Fig 32 copposite, bottom left). Robert Buss, "The fat boy awake on this occasion only:' The Pickwick Papers, no. 3. Etching. $4^{13 / 16^{11}} \times 3^{2} / 16^{\prime \prime}$ $(12.2 \times 9.1 \mathrm{~cm})$. From the Harry Elkins Widener Collection, by permission of the Houghton Library, Harvard University. Fig. 33 (opposite, bottom right). Hablot Browne, "The fat boy awake on this occasion only.' The Pickwick Papers, 1st ed., $2 d$ issue (1837), facing p. 74. Etching. 51/2" $\times 44^{1 / \prime}(14 \times 10.8$ $\mathrm{cm})$. From the Harry Elkins Widener Collection, by permission of the Houghton Library, Harvard University. Fig. 34 (above). James Abbott McNeill Whistler, Unpublished Sketch of Mrs. Wardle and the fat boy, ca. 1854. Watercolor. $8^{1 / 8^{\prime \prime}} \times 5^{9 / 16^{\prime \prime}}(20.6 \times 14.2 \mathrm{~cm})$ [sight]. By permission of Chester M. Sawtelle. 
sought, never mind found, so quickly. His chagrin naturally deepened with Pickwick's unprecedented success, which began within a month of his summary dismissal.

Certainly the publishers treated Buss very callously. After so vigorously soliciting his help, they dismissed him without a word of thanks. Buss found their idea of remuneration miserly. Did Chapman and Hall seriously think a "beggarly" thirty shillings adequate compensation for the time spent on his Pickwick work-time lost on the Academy canvas? ${ }^{12}$ Was this "due consideration"? The artist kept his hurt indignation to himself for many years. He manifested his frustration at this time mainly by locking up his etching tools and destroying many of his papers relating to Pickwick. For the rest of his life, he could not bear to have the matter mentioned in his presence. ${ }^{13}$

Chapman and Hall's behavior to Buss was shrewd enough, but morally vulnerable. It is unclear whether the firm actually intended to use Buss just for the one number but allowed him to anticipate a permanent position on Pickwick only to secure his services, or whether they planned to keep him. In either case, their vagueness facilitated a natural counterclaim: that Buss had been on trial and found unsatisfactory. Had they liked his work, they probably would not, in fact, have hired a younger, more obscure artist like Hablot Browne, despite his greater etching experience. Still, after seeing Buss's first poor sample etching, they should, in all decency, either have dismissed him with compensation, openly indicated their dissatisfaction, or decided to stand by him until he perfected his etching technique.

Business exigencies, however, doubtless superseded such genteel considerations. Despite Buss's contempt for the sum, the firm had taken his difficulties into account to some extent, for it paid him at almost the same rate as Seymour. ${ }^{14}$ Furthermore, at the moment when Buss was hired, the publishers were frantic. Their Pickwick investment, a considerable one for a young firm, threatened to yield a heavy loss. Since Pickwick's success was still thought to depend on the plates rather than the text, poor illustrations were better than none. Pressures of time prevented more advance notice to Buss or to the public of Browne's engagement. Ironically, Pickwick's diminutive audience, their real object of concern, hardly noticed all the changes of artist; and later readers were to know nothing at all of Buss's two contributions.

Dickens's role in the hiring and firing of Buss is surprisingly obscure. He apparently never met or communicated with his second Pickwick artist, despite their mutual friends, William Macready, the actor, and Clarkson Stanfield, the artist and later Dickens illustrator. ${ }^{15}$ Contrary to what became his usual procedure, Dickens stayed behind the scenes and let the publishers carry on all transactions with Buss. They, not the author, looked at his sample plate, approved his proposed designs, forwarded proof, and terminated his engagement. They kept Dickens informed, of course; not to do so might have incurred his anger and insured the artist's discomfort had he been allowed to continue. But the author's uncharacteristic aloofness suggests his utter indifference to this illustrator who he seems to have realized was temporary, though Buss did not. Had Dickens found the artist's work promising, he doubtless would have supervised every aspect of it as he later did that of Browne. Knowing Buss to be a stopgap, perhaps, the author left him to the firm's mercy, tacitly acquiescing in their dealings. Meanwhile, he devoted his spare time to interviewing other artists for Pickwick. Buss, ignorant of this duplicity, never blamed Dickens for his misfortune. On the contrary, he came to worship the author from afar.

Buss's reaction to his rude dissociation from Dickens differed in kind and degree from that of Cruikshank and of Seymour's family; the brief experience also had a permanent effect on him, although this was not immediately evident. Indeed, in the period just after his Pickwick failure, his hurt pride received considerable solace, though it proved to be temporary. He finished and sold his Academy canvas to high acclaim by the critics. Even more gratifying in the face of his Pickwick rejection, he was soon commissioned to provide etchings for books by Mrs. Trollope and Captain Marryat. “The illustrations are by 'Buss,' a young man of great talent," wrote the Observer about the former work; "George Cruikshank must look to his laurels." 16 Whereas Pickwick was, at the time he was illustrating it, an obscure work by a young journalist working for a new firm, these were books by two of the most popular authors of the day and their publisher, Henry Colburn, was eminent. These successes, however, only reminded him of how narrowly he had missed immortality with Dickens and confirmed his belief in Chapman and Hall's mistreatment of him. If he had only had another fortnight, he thought, with justification, he might have made the grade.

Ironically, Buss did get another chance to impress Dickens but again failed to do so. Early in 1837 he engraved a picture called 'The Spectre of Tappington' from a drawing by R. H. Barham's son to illustrate one of the elder Barham's Ingoldsby Legends, which appeared in Bentley's Miscellany, then edited by Dickens. Buss never knew that his idol thought he had treated a "very good subject" in a "very indifferent manner." ${ }^{17}$ But he must have noticed that, by the end of 1837 , all his Dickens illustrations-the one for Boz's Library sketch and the two for Pickwick-had been 
replaced and his name omitted from the title page of the first bound edition of Pickwick. Scant evidence remained that Buss had ever illustrated Dickens at all.

As Dickens's prosperity soared, Buss's diminished. Throughout the following decades, as if proving that his Pickwick rejection had been unwarranted, or sharing vicariously in Browne's success, Buss portrayed scenes or characters from Oliver Twist, Barnaby Rudge, The Cricket on the Hearth, The Chimes, and Dombey and Son for exhibitions. ${ }^{18}$ Dickens took no particular notice of these independent representations, which were only a few of the many his fiction inspired. After the inexplicable exclusion of his canvases from the Royal Academy exhibitions after 1854, Buss, no longer fully able to support his family by painting or book illustration, supplemented his precarious income by teaching, editing, lecturing, and writing about art. Meanwhile, in 1850, his wife and distinguished daughter, Frances, to whom he was particularly close, had founded a pioneering school for women, in which Buss began to teach branches of science as well as of art. ${ }^{19}$ In marked contrast to the Seymours, however, he never solicited Dickens's help. Indeed, the artist's admiration for the author seemed to intensify as their positions became more disparate.

Long after the Pickwick affair, Buss remained uncomfortable whenever his name was publicly connected with the book. He himself said nothing until 1871, a year after Dickens's death, when he read the first volume of Forster's Life. Referring to the problems of Pickwick after Seymour's suicide, Forster noted: "There was at first a little difficulty in replacing him, and for a single number Mr. Buss was interposed. But before the fourth number a choice had been made." 20 The official biographer's small but slighting reference revived Buss's grievances. When he retrieved and looked at his Pickwick etchings, he found them less inferior than he had remembered. Indeed their figures, which were. relatively large and naturalistic, better suited the tastes of the 1870's than the 1830's, which had favored the grotesque, and diminutive. After almost forty years, Buss was still certain that he had been mistreated by Chapman and Hall, and he wanted justice at last.

The artist decided to write Forster. ${ }^{21}$ More in sorrow than in anger, he explained the pressured circumstances of his Pickwick connection. His arguments, unlike many of George Cruikshank or the Seymours, were neither petty nor libelous. In fact, he lavishly praised Dickens, Seymour, and Browne as well as Forster, and blamed only the publishers. By his generosity to so many others, he gained sympathyand credibility-for himself. Not surprisingly, Forster's reply was cordial. He had not intended to slight Buss, he said; he had simply been ignorant of the facts. Forster promised to right matters in the next edition of the Life, but he did not live long enough to do so and Buss did not live long enough to have read it even if he had.

Buss, however, was not concerned with justice only in is lifetime or for himself. Though satisfied that Forster understood his plight, he could not let the issue rest. His anxiety stemmed only partly from the lost opportunity, the value of which hindsight had so painfully revealed. He had been aggrieved even when everyone involved with $P$ ickwick faced greater chances of bankruptcy than of immortality. Even more upsetting to Buss in his old age was the prospect that the positive achievements of his long career seemed condemned to be forever overshadowed by his fleeting Pickwick failure. As a parent, as well as an artist, he felt obligated to leave his children a complete account of the association.

"My Connexion with The Pickwick Papers," completed by Buss on March 2, 1872, but not published until 1936, is a curiously appealing document. ${ }^{22}$ The artist devotes only one-third of the statement to his own case, which convincingly, if repetitiously, stresses his trials with the etching process and his shoddy treatment at the hands of the publishers. Buss gains some historical perspective and moral credibility by devoting equal space to the two other Pickwick illustrators. His sympathetic biographical account of Seymour is filled with inaccuracies perpetuated by that family, but free of their bias against Dickens; ${ }^{23}$ in elaborating Seymour's etching difficulties, he is, of course, describing his own as well. Inevitably his discussion of Hablot Browne, his successor, is more strained. But when he discusses Browne's advantages - the support of the publishers and the appearance of the richly comic Sam Wellerhis envy is engaging in its openness. Moreover, he is sincere in his admiration of Browne's comic abilities-and of their substantial contribution to Dickens's own popularity. This private statement only partly consoled Buss's heirs, who tended to view him as a neglected genius, were repeatedly annoyed by public recollections of their father only as the unsuccessful Pickwick illustrator, and tried to counteract them. ${ }^{24}$ They were hardly gratified when time validated yet another of Buss's predictions - that book collectors would come to prize the rare copies of Pickwick that contained his two etchings. ${ }^{25}$

Had Dickens lived after 1870, he would have been surprised by the continued homage-a sharp contrast to the heightened vituperations of Cruikshank-of the illustrator he knew least. In his 1874 history of English Graphic Satire, 
for example, Buss praised Dickens's moral accomplishments throughout and even gratuitously included details about his life and taste. ${ }^{26}$ When Dickens died, Buss, now elderly and ailing himself, decided to paint the author asleep in his library chair at Gad's Hill, dreaming of his fictitious characters. Foreseeing that he might not live to complete the ambitious subject, Buss quickly modeled the setting after Fildes's famous picture, 'The Empty Chair' (see fig. 199), copied the principal figure from John Watkins's famous photograph of Dickens, borrowed, perhaps, the composition from a well-known reverie by Cruikshank, and completed a few of the characters from Dickens's later novels. ${ }^{27}$ The earlier creations, still in outline when the artist died on February 26, 1875, inadvertently added to the dreamlike appearance of the canvas (fig. 35). This final unsolicited tribute to Dickens, appropriately unfinished as was the author's own last work, came to be called 'Dickens's Dream.' A suitable subtitle would be "Buss's Dream" for now, at last, he had illustrated many of the author's major characters. In this creative way, Buss tried to overcome, if not obliterate, the painful reality of his short-lived association with Dickens.

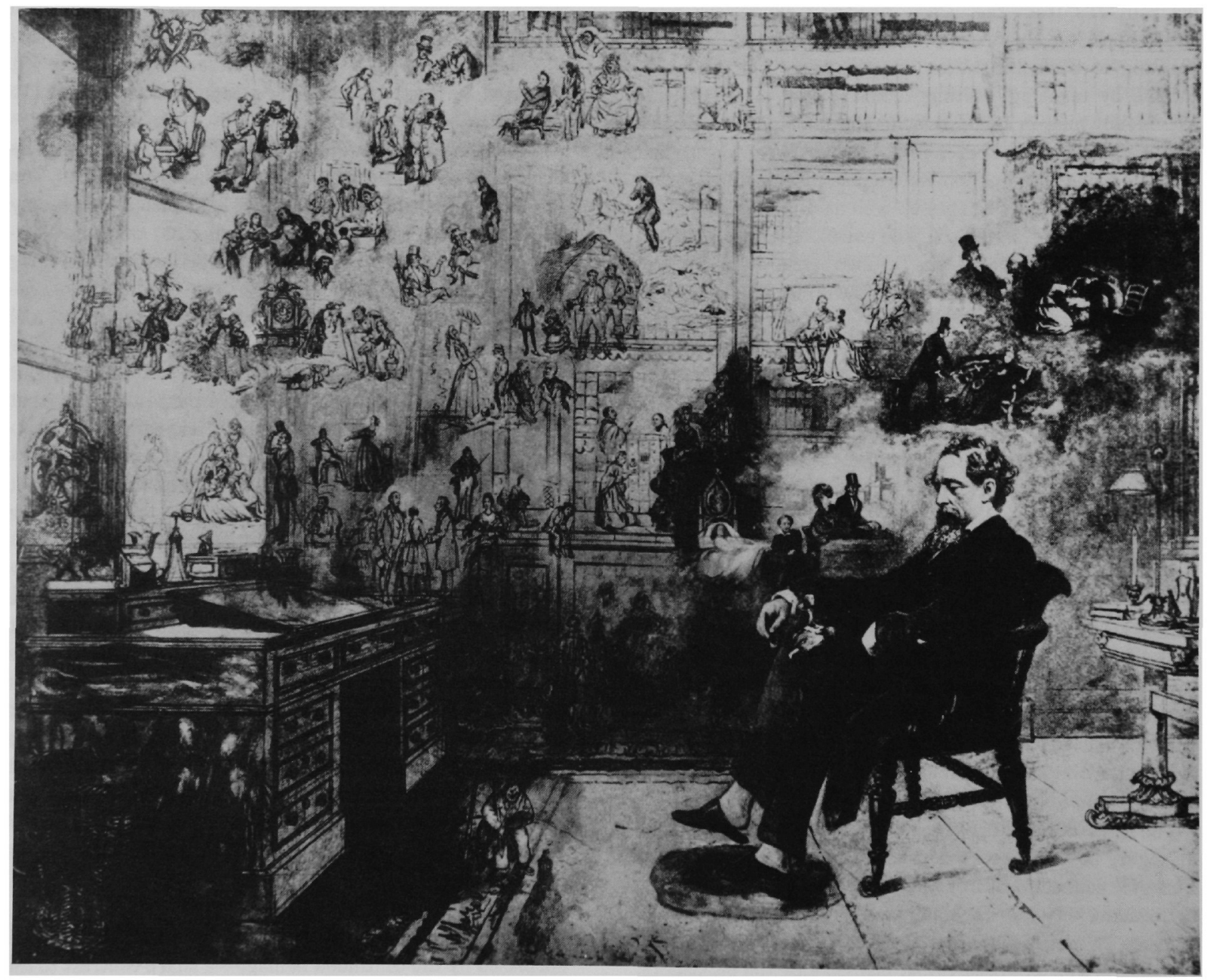

Fig. 35. Robert Buss, 'Dickens's Dream.' Watercolor. $27^{\prime \prime} \times 36^{\prime \prime}(68.6 \times 91.4 \mathrm{~cm})$ [sight] From the Tyrrell Collection, by courtesy of the Trustees of the Dickens House Museum. 
Part II: Dickens and His Principal Illustrator HABLOT K. BROWNE 



\section{Chapter 4}

\section{HABLOT KNIGHT BROWNE (PHIZ)}

I

"Can any of your readers say who Nemo is?" inquired Robert Buss's eldest son, perplexed about the signature of the two plates that originally appeared between his father's ill-fated designs and those of Phiz in The Pickwick Papers. ${ }^{1}$ "Nemo is Latin for no one," as Mr. Tulkinghorn explained in Bleak House (X, 132). What most Dickens readers still remember about the odd name is that it was the assumed name of Lady Dedlock's lover. Only a few recall that long before Bleak House, N.E.M.O. was a pseudonym briefly adopted by Dickens's principal illustrator, Hablot Knight Browne-better known by his subsequent nom de crayon, Phiz (fig. 36). ${ }^{2}$ Indeed, in 1836, his first pseudonym more or less reflected the status of the book illustrator. Often an aspiring painter did not wish to have the public come to know him as a mere embellisher of contemporary fiction. Through most of the Victorian era, Browne's distinguished work for Dickens, as well as that of book illustrators in general, helped make such anonymity unnecessary. Like the Dickens novels he illustrated, many of Browne's plates became famous in their own right. Their persistent fame, however, remains oddly distinct from Browne's stature as an artist. $^{3}$

Perhaps Browne subordinated himself too completely to Dickens to acquire a personality of his own as far as the public was concerned. Certainly Browne's first pseudonym, though he kept it only briefly, was indicative of his selfeffacing nature. Although he illustrated ten of Dickens's fifteen novels, contributing over five hundred plates, title page vignettes, frontispieces, and wrapper designs, Browne remains peculiarly obscure. Partly this is due to the relative placidity of his relationship with Dickens-a distinct change

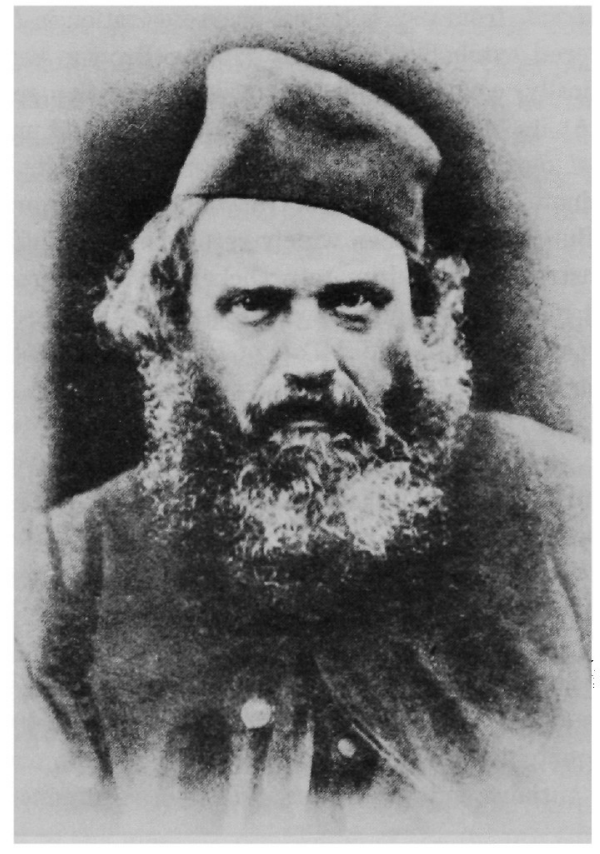

Fig. 36. Artist Unknown, Portrait of Hablot Knight Browne. Frederick S. Kitton, Dickens and His Illustrators, plate 28, facing p. 58. Photograph. 411/16" $\times 3^{13 / 16^{\prime \prime}}(11.9 \times$ $9.8 \mathrm{~cm})$. From the author's library.

from those of Cruikshank, Seymour, and Buss. Browne's personal colorlessness may make him less memorable to later generations, but it was tacitly appreciated by the 
flamboyant novelist and partly explains why their association lasted twenty-three years. ${ }^{4}$

Dickens, whose experience with veteran artists had been strained, to say the least, must have welcomed the prospect of working with an artist younger than he was, who possessed technical ability and literary sensitivity but lacked reputation and its accompanying vanities. If Browne, unlike Cruikshank or Seymour, was relatively unformed, Dickens would mold him. ${ }^{5}$ Indeed, the artist's pliability-his most distinctive personal and artistic quality-hastened both his success and his decline. Those who tend to dismiss Browne cite his "feeble" imitations of Cruikshank or his "pale" echoes of Dickens's words. ${ }^{6}$ Those who admire him argue that Browne became so sensitive to Dickens's writing that his own style and technique often appears to have assimilated and mirrored its strengths, weaknesses, and, above all, its changes. ${ }^{7}$ As the novelist shifted his emphasis from picaresque plot in Pickwick to moral theme in Chuzzlewit, from psychological characterization in Dombey to layered symbolism in Bleak House, Browne kept pace graphically, content to let Dickens's imagination spark his own. At its best, the artist's work for him lived up to the original meaning of the word illustrate-"to light up" or "illuminate," without being obtrusive or merely representative. But it has not been widely recognized nor sufficiently demonstrated that ultimately Dickens's dense prose precluded meaningful illustration altogether. ${ }^{8} \mathrm{By}$ the time of Little Dorrit in 1855 and A Tale of Two Cities in 1858, there was little left for an illustrator to depict.

Unfortunately, when his services for Dickens were no longer needed, Browne felt adrift. Isolated from the aesthetic mainstream of the 1860 's by his reclusive habits and now old-fashioned talents, he was unable to find other stimulating authors to work for, but lacked inner resources to maintain himself as an entirely independent artist. Further plagued by age and paralysis, Browne fell back into an obscurity far bleaker than that from which he had emerged, an artistic "Nemo" again. That he and Dickens had set a matchless standard for sustained collaboration between authors and illustrators provided scant consolation.

Dickens's principal illustrator did not always bend to circumstances. As a young man, he was apprenticed to Finden's, a prosperous firm of engravers of picture books, by his wealthy brother-in-law, Elhanan Bicknell (whose gracious wife and superb Turner collection attracted his Herne Hill neighbor, John Ruskin). ${ }^{9}$ Like Seymour, Browne rebelled at the monotonous, mechanical routine. With and without his employer's knowledge, he reportedly pretended to work while reading and sketching scenes from his favorite authors or covering plate margins with comic figures; when sent out to superintend long engraving operations, he often escaped to the nearby British Museum. ${ }^{10}$ In 1833, a timely award from the Society of Arts for his spirited representation of the memorable flight of John Gilpin, the comic hero of William Cowper's 1785 poem, enabled Browne to cancel his indentures before they were due to expire. ${ }^{11}$ Despite his premature departure, his engraving experience at Finden's turned out to be his only regular art training. With Robert Young, a fellow apprentice who had learned engraving techniques more diligently, Browne formed a loose partnership, and set up a studio at Number 3 Furnival's Inn.

The artist did not immediately or inevitably meet Charles Dickens, three years his senior, who occupied chambers on the opposite side of the Furnival's Inn gateway at Number 15. While the aspiring author was supporting himself by recording Parliamentary debates, Browne was attending -though with increasing irregularity- "life" classes and turning out drawings to pay his share of expenses. By the time Boz began publishing his early sketches, however, the artist began to reap the benefits of his Society of Arts medal (as well as for his work for another Finden's acquaintance, Henry Winkle, who produced three monumental volumes on cathedrals in England and Wales from 1836 to 1842). ${ }^{12}$ The Gilpin picture became Browne's carte d'entrée to Chapman and Hall, and eventually to Dickens. Accepted by the publishers for display and sale in their windows, the etching was engraved by John Jackson, Buss's friend and sponsor. ${ }^{13}$ The appealing print secured Browne a commission to provide illustrations for The Library of Fiction ${ }^{14}$ (in company with his future Pickwick predecessors Robert Seymour and Robert Buss) and for Sunday Under Three Heads, Dickens's anonymous protest against extreme Sabbatarians. While Buss was struggling with his Pickurck etchings to nobody's satisfaction, Browne, who could etch as well as draw, became a candidate for his position.

Ironically, considering that Robert Buss blamed his rejection entirely on the publishers, Dickens was allowed complete control over the selection of a new Pickwick illustrator. $\mathrm{He}$, not the publishers, dealt with the applicants-Browne, Thackeray, and belatedly, Leech-and examined specimens of their work. The author probably favored Browne from the first. He must have been pleased by the artist's sprightly woodcuts for his Sunday pamphlet $(S B B, 500,510,519)$. If the individual figures were somewhat rigid, the integration of the buildings and landscape in the background, the handling of perspective and the variety of line showed technical sophistication and each print clearly conveyed the relevant textual argument. ${ }^{15}$ Moreover, Browne's depiction of 'Winkle's First Shot' had a 
sense of line and structure clearly superior to Buss's stilted effort, though neither version was published. ${ }^{16}$ Most gratifying to Dickens, this artist was not saddled by anything equivalent to Cruikshank's vanity, Seymour's hypersensitivity, and Buss's etching inexperience. Consequently, Browne was engaged and Buss was given notice. This choice of illustrator, as Forster patronizingly put it, proved "so thoroughly justified, that through the greater part of the wonderful career which was then beginning the connection was kept up and Mr. Hablôt Browne's name is not unworthily associated with the masterpieces of Dickens's genius." 17

With Buss's fate in mind, perhaps, Browne dared not allow himself too much elation about his Pickwick employment. With the help of Robert Young, whose thorough mastery of etching techniques proved invaluable in meeting this and future deadlines-though it inspired rumors that Browne could not (rather than preferred not to) etch-the new illustrator executed the two subjects for the fourth number. ${ }^{18}$ In 'The Breakdown' of Pickwick's carriage (IX, facing p. 116), the faces and hands were crudely conceived and the horses - usually a Browne specialty-lacked tension though not grace; nevertheless, the variety of line and texture marked a great advance over Buss's version. Browne's other etching, Pickwick's meeting with Sam Weller at the White Hart, radiated charm and humor despite the tentative details of the faces and background objects, rendered with too many purposeless short strokes (X, facing p. 124). At last Dickens's hero acquired his memorable expression of benignity, in welcome contrast to the hostility and foolishness with which Seymour and Buss respectively imbued him (see figs. 18 and 19). Whatever hopes Browne had for the success of this scene in particular and of the number in which it appeared were realized to a fairy-tale extent. Indeed, the number marked, if not determined, the turning point in Pickwick's fortunes. Readers in enormous numbers took Sam and his suddenly more appealing master to their hearts. Booksellers could not keep the issue or its successors in stock, it was snapped up so fast. "It was Sam Weller that did it, and the illustrations," maintained the binder who had singlehandedly stitched the early issues of the book, which was considered a failure until the fourth number when sales so increased that he had to employ assistants to do his job. ${ }^{19}$

The Pickwick enterprise and Browne's connection with it were both secure. The success of Dickens's new character and the artist's delineation of him augured well for their future collaboration. Boz became a celebrity; N.E.M.O. a somebody. Though Browne still wished to veil his identity, in obedience to custom, his innate reserve, and, perhaps, higher artistic aims, he sought a more assertive nom de crayon. He settled on Phiz, the old humorous, colloquial abbreviation of physiognomy-an appropriate pseudonym for one who excelled in capturing facial expressions with a few deft strokes, and also a memorable and artistic signature (whose "z," like Cruikshank's "k," often resembles a comic profile). Browne's stated reason for his choice, however, proved characteristic of him and his desire to please Dickens: "Phiz," he explained, would harmonize well with Dickens's "Boz."20 Through such evidence of amiable humility, as well as of talent, Browne anchored his position with the author. When, in July, John Leech belatedly applied to replace Seymour, Dickens quickly informed him that "the plates for The Pickwick Papers are in the hands of a gentleman of very great ability, with whose designs I am exceedingly well satisfied, and from whom I feel it neither my wish, nor my interest to part."21 When, in October, Cruikshank rashly suggested alterations to the text of the second series of the Sketches by Boz, Dickens wondered aloud whether his "Pickwick man" should do those plates as well. ${ }^{22} \mathrm{He}$ never carried out his implied threat, but Browne had already become almost as well-known to the public as Cruikshank, and certainly he was more amenable to the author, as the latter's use of the possessive in denoting him suggests.

At last Dickens had a free hand with the illustrations as well as with the text. Since the procedures he evolved with Browne during their work on Pickwick never varied greatly thereafter, it is instructive to look at them closely. Stung in various ways by his trials with Cruikshank, Seymour, and Buss, the author now took inordinate pains to specify what he wanted in the illustrations and to insure that he obtained the desired result. The factor of time, not the artist's personality, proved to be the besetting problem now. Boz's first Sketches, issued separately, had been written long before their publication in collected and illustrated form was contemplated. The serial format of Pickwick and Dickens's subsequent novels, however, meant that the plates had to be created immediately after the text, if not sooner. Everyone involved in the monthly production of the twenty numbers was beleaguered by multiple deadlines. Yet no matter how busy Dickens was, he always found time to supervise the creation of illustrations. His unprecedented involvement was not due to any mistrust of Browne's ability or loyalty, but rather to his compulsion to control every aspect of his work, his awareness of the plates' importance, and the keenness of his own visual imagination. And, in contrast to the veterans who had preceded him, Browne cheerfully accepted his subordinate role. 
Dickens's communication of instructions to Browne remained a problem, however, because of the pressures of time. Browne rarely enjoyed leisurely contemplation or discussion of a finished manuscript. When Dickens and Browne were still neighbors, the author apparently would often stop in, read a portion of the number he was writing, indicate what passages should be illustrated, and discuss the points to be stressed. ${ }^{23}$ After Dickens's move to Devonshire Terrace in May, 1837, time seldom permitted even those brief meetings. "It is due to the gentleman, whose designs accompany the letterpress," Dickens generously explained in his first Pickwick preface, "to state that the interval has been so short between the production of each number in manuscript and its appearance in print, that the greater portion of the illustrations have been executed by the artist from the author's mere verbal description of what he intended to write" (xvi).

By whatever means Dickens relayed his instructions, however, he was unvarying in his insistence that he approve the artist's preliminary sketches. "Have you got the second Design from Mr. Browne," Dickens anxiously wrote Chapman and Hall concerning "The middle-aged lady in the double-bedded room' (XXII, facing p. 308), "Or is it to go on the steel, without our seeing it?"24 Doubtless this drawing, like its fellows, was submitted for Dickens's inspection before it was etched (see fig. 37). The author often returned the drawings with marginal corrections that, reflecting his confidence that his suggestions would not be resented, were tactful and free of his occasional condescension to other illustrators; indeed they seem to transfer the burden of change from the artist to the characters themselves. "I think it would be better if Pickwick had hold of the Bandit's arm," Dickens scribbled beneath the sketch of 'Mrs. Leo Hunter's Fancy-dress déjeuné,' and if "Minerva tried to look a little younger (more like Mrs. Pott-who is perfect) I think it would be an additional improvement."25 Browne, whose fealty was never overwhelmed by his discrimination, did not have the hero take the Bandit's arm but he did reduce as well as reposition Minerva to Dickens's apparent satisfaction (XV, facing p. 202). The artist was similarly selective when he altered Mr. Pickwick's 'The First Interview with Mr. Serjeant Snubbin.' He obviously tried to follow Dickens's instructions that the officer's face appear "younger, and a great deal more sly, and knowing" about the Bardell suit, but probably (and wisely) thought it more humorous to have him enter the room naturally with an unfocused gaze than to look directly at the innocent victim, as the author had wished, with a stagey compassionate smile (XXXI, facing p. 428$){ }^{26}$
When he sent Dickens his sketch of 'Mr. Winkle's situation when the door "blew-to"'-an incident reversing the stock farcical plight of the undressed heroine-it was Browne who first utilized the margin to ask whether Pickwick should remain at the window or be put in bed, and Dickens who might have made alterations in his text to suit the illustration. Pickwick should be left where he is at the first, not the second story, replied the author who also seems to have made his prose accommodate the atypically obese chairman Browne had drawn. ${ }^{27}$ Winkle should hold the candlestick above his head, not in front of him, Dickens also urged, because it "looks more comical, the light having blown out," forgetting, as had the artist, that at the moment depicted by the text, Winkle had thrown away the useless candlestick (XXXVI, 513; cf. facing p. 513). ${ }^{28}$ But when Browne too readily anticipated authorial approval, as he did for his sketch for 'Mr. Winkle returns under extraordinary circumstances' (XLVII, facing p. 660)-to judge from his request that it be forwarded to the publishers after the usual inspection, along with his usual instructions about how it was to be etched-Dickens did not hesitate to exercise his prerogative and compelled the artist to redefine and relocate Sam Weller and Mary. ${ }^{29}$ Only once did Dickens use the margin of Browne's sketch to convey approbation rather than correction. With the humorous signature "Charles his Dickens" on the last of the Pickwick sketches bearing mark minal notations, the author expressed his unqualified approval of Browne's handling of 'The ghostly passengers in the ghost of a mail' (XLIX, facing p. 686). ${ }^{30}$

No detail of position, gesture, expression, or dress was too paltry for Dickens's consideration. Indeed, when discrepancies occurred, like the one involving Winkle's light, it was usually because time and circumstance did not permit such close examination of the drawing. On a later occasion, Dickens, ill throughout the writing of the Christmas scene at Dingley Dell, and assuming that the artist was busy with 'Christmas Eve at Mr. Wardle's' (XXVIII, facing p. 390) and 'The Goblin and the Sexton' (XXIX, facing p. 396), did not give Browne the first subject for the February, 1837, number, 'Mr. Pickwick slides,' until the last minute. ${ }^{31}$ The Quarterly Review was unwittingly sarcastic when it observed that the skating scene was "brought home fully to the mind's eye without the aid of 'Phiz's' illustrative sketch" for, in fact, the artist forgot to put ice skates on any member of the party (XXX, facing p. 412) and depicts Winkle fallen, whereas in the text he has been restored to his feet before Pickwick begins slipping (XXX, 410). ${ }^{32}$ The surprise is really not that these discrepancies occurred, but that they occurred so rarely. 
Certain that Browne would never exceed his authority, Dickens willingly accorded him roles of aesthetic importance. The same man who had refused to "write up to" Seymour's plates kept Browne's particular skills constantly in mind as he created subjects, though he was under no outside pressure to do so. Understanding, but not resenting, the importance of visual aids to the success of his work, he never relegated Browne to minor subjects. The artist's contributions illustrated the climaxes of each number, and taken together, apart from the text, recapitulated the main events.

Dickens also used the plates to reinforce his own uniquely graphic conception of each number and of the narrative as a whole. Although the scheme was used only randomly in the Sketches by Boz, each number of Pickwick from the start typically consisted of a discrete prose scene, framed by the author's description, elaborated on by the participating characters, and capped by the artist's rendering of it. The entire narrative turns on visual perceptions and misperceptions from "the first ray of light which illumines the gloom" of Pickwick's earlier history (I, 1) to the time of Mrs. Bardell's ill-timed faint-“"The Pickwickians], in their turn, stared at [Pickwick] and Master Bardell, in his turn, stared at everybody" (XII, 153), to Winkle's return with Arabella - Mr. Pickwick could hardly believe the evidence of his senses" (XLVII, 660), and on to "our last parting look" at the Pickwickians (LVII, 796). Mr. Pickwick becomes heroic only when he displays insight as well as accurate ocular perception. In Dickens's later works, the author speaks less in his own voice and more through his major characters who supply interpretive as well as graphic description, but at this early stage in his career, Dickens, with the help of his illustrator, leads the reader step by visual step.

Dickens was so successful at giving Browne opportunities to make the plates as comic as possible that the pictures often appear to provide the excuse for the narrative. "How tame," observed the Quarterly Review, would be many Pickwickian situations without the artist's portrayal of them. ${ }^{33}$ The implied criticism was expanded by Barbara Hardy over a century later:

The Pickwickians and the unwilling horse, Winkle with a gun, Pickwick and the ancient stone, Pickwick in the wrong bedroom, Winkle and Pickwick on the ice-in all these comic scenes there is very little beyond an opportunity for the illustrator. . . . When a joke in Pickwick seems especially tedious and flat it often turns out to have'some justification for an illustration and this is true throughout the novel, despite the dominance of Dickens's text over the engravings of "Phiz." . . . A fat man on the ice, legs carefully apart, makes a funny picture. So does a round face, topped by a nightcap, looking out from bedcurtains while a thin lady makes a complacent and blissfully ignorant toilet. Spread out in words, neither joke is strong, and such jokes take up too much space in The Pickwick Papers. ${ }^{34}$

In later works, when Dickens tightened his structure and left Browne freer to comment on events as well as to depict them, the plates began to complement the prose on more profound levels.

As he gained confidence, Browne ventured to add graphic comments of his own, apparently independent of Dickens's text or instructions. These touches became a hallmark of his later work for Dickens. In Pickwick, for example, Browne twice added animals not specified by the text but suitable for it (when he moved to his rural home the shy Browne, like Seymour, would spend as much, if not more time in the company of animals than of people). In his first sketch of 'Christmas Eve at Mr. Wardle's,' Browne underscored the harmony of the occasion by depicting the amicable play of a cat and dog in the foreground (XXVIII, facing p. 390). When tipsy Pickwick lands in the Pound (XIX, facing p. 258), Browne, not Dickens, surrounded him with donkeys and pigs, a stroke that deepens the comedy not only because of its pictorial humor, but also because of the aptness of these symbols of stubbornness and gluttony (which contrast with the church towering overhead with its implicit promise of forgiveness). Robert Patten has noted these details as well as other Quixotic aspects of Pickwick's life, which the artist makes explicit in his suggestive frontispiece. ${ }^{35}$ On top of an armoire above the hero's head lies abandoned the kind of visored helmet and shield Cervantes's hero might have worn, a reinforcement of the text's suggestion that Pickwick's days of active chivalry have ended. He can continue his study of life more appropriately (and more wisely than the Don) from books, like the ones shown on the shelves to his right, guided in this pursuit by the illiterate Sam Weller, in this ultimate reversal of their roles.

Browne's capacity for growth, however, proved even more instrumental in his success with Dickens than his capacity for originality. The artist's ability to change and improve often equaled Dickens's own. Browne demonstrated this ability early. The demand for Pickwick increased so much during its serialization that its later plates had to be etched in duplicate, and the first twenty-one steels became so badly worn that they had to be copied over for the bound edition in 1838. Disliking slavish reproduction of any kind, as he made clear during his Finden's apprenticeship, the artist altered every one of these early plates. Noticeable immediately was his improvement on the work of his 
predecessors. In re-etching Seymour's plates, he refined them; by adding a few subtle strokes, he was able to realize fully Dickens's idea of a sympathetic dying clown for example (III, facing p. 38) (see fig. 25). He replaced Buss's 'Cricket Match' altogether and rescued his humorous conception for 'Arbour Scene' from mere caricature (VIII, facing p. 98) by including pretty details of a house and trees in the background (VIII, following p. 98) (see fig. 34). ${ }^{36}$

The same distaste for mere copying may have prompted Browne's demonstration of his striking ability to improve on his own earlier efforts. As scholars have long observed, his revisions of his own drawings and etchings for Pickwick display how much he had developed in the course of the book's publication: this is immediately evident, as John Harvey has shown, in the first three etchings for the 1838 edition, as well as in subsequent ones. ${ }^{37}$ In the artist's initial version of 'The Break-down,' for example, Pickwick has emerged from the overturned carriage with a lowered face while his attendants, holding three overrelaxed horses, look on without expression, as do the obscure Pickwickians in an ill-defined chaise in the background (IX, facing p. 116). Browne's revised version distinctly shows a shaken Pickwick, an amused postboy, and two postillions strenuously trying to control four spirited horses, while precisely delineated friends look back from their clearly drawn chaise down the road. The 'First appearance of Mr. Samuel Weller' evoked humor from the first but was so sketchily executed in places that Wardle's cane, for example, appeared broken (X, facing p. 124). For the 1838 edition, Browne not only made the minor repair, he repositioned and individualized the faces of the principals, gave sharper shadings and outline to the dog, boots, and background figures, and made the previously flat spaces in the rear balconies recede naturalistically.

The improvements Browne wrought on 'Mrs. Bardell Faints in Mr. Pickwick's arms' (XX, facing p. 154), which Harvey has amply described, are similar in kind and effect to those made on 'The middle-aged lady in the doublebedded room.' In the 1836 version, the vaguely surprised face of Pickwick peers out between his bed curtains to see a tall, spare woman with a Cruikshankian long face combing her stringy hair before a mirror; behind, her dark outer dress lies across the seat of a chair, both difficult to discern against the dark wall, which makes the white mob cap on the chair knob seem almost suspended in space (XXII, facing p. 308) (fig. 37). After Browne's revisions in 1838, Pickwick's expression shows appropriate consternation; the lady has been endowed with a more supple shape, a more natural stance, a rounder face and softer hair; on the light-colored chair behind her, now clear against the still dark wall, her pale dress is gracefully draped across the seat and a beribboned bonnet perches flirtatiously on the knob (fig. 38).

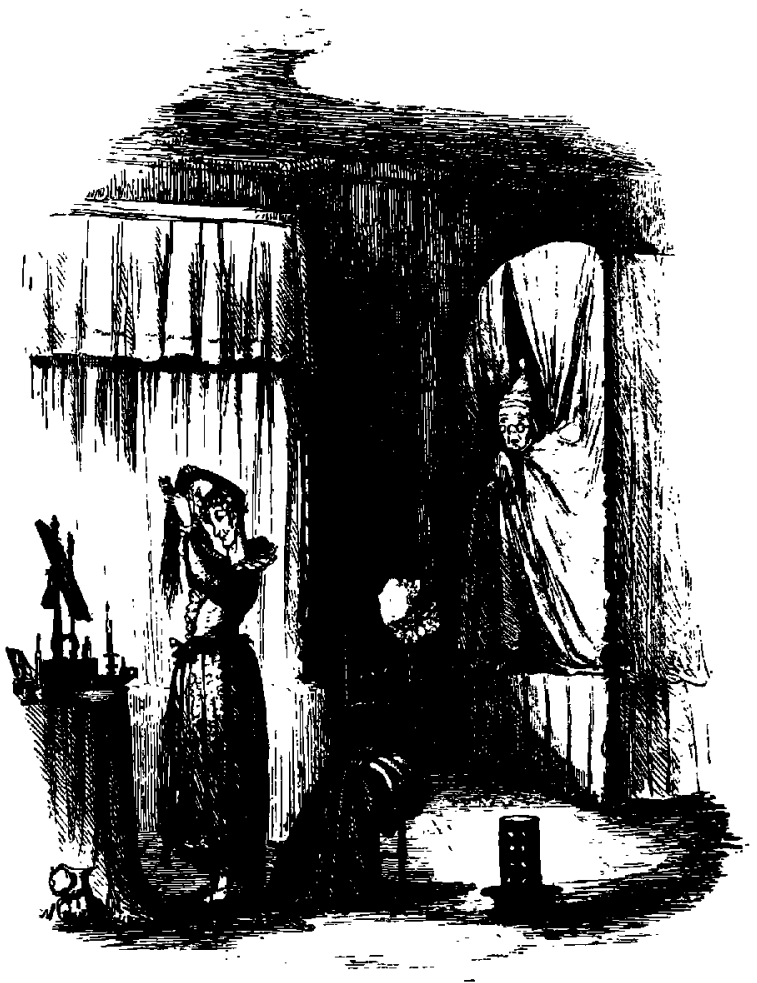

Fig. 37. Hablot Browne, "The middle-aged lady in the double-bedded room.' The Pickwick Papers, no. 8. Etching. $53 / 8^{\prime \prime} \times 3^{15 / 16^{\prime \prime}}(13.7 \times 10 \mathrm{~cm})$. From the Harry Elkins Widener Collection, by permission of the Houghton Library, Harvard University.

Browne proved equally resourceful when he confronted less humorous subjects a second time. In "The last visit of Heyling to the old man' (XXI, facing p. 292), for example, he first strengthens the lines defining the ceiling beams, window, window panes, and door in the interior in which the visit takes place. The originally effete expressions of both men become intensely dramatic as terror is added to the older face, a fierce scowl to the younger, more enlarged one. Nor does the artist's ability to surpass himself diminish in scenes involving large groups, such as the ones at Eatonswill (XIII, facing p. 172), Mrs. Hunter's party (XV, facing p. 202), the seminary (XVI, facing p. 220), the pound (XIX, facing p. 258), and at Ipswich (XXIV, facing p. 334). Almost 


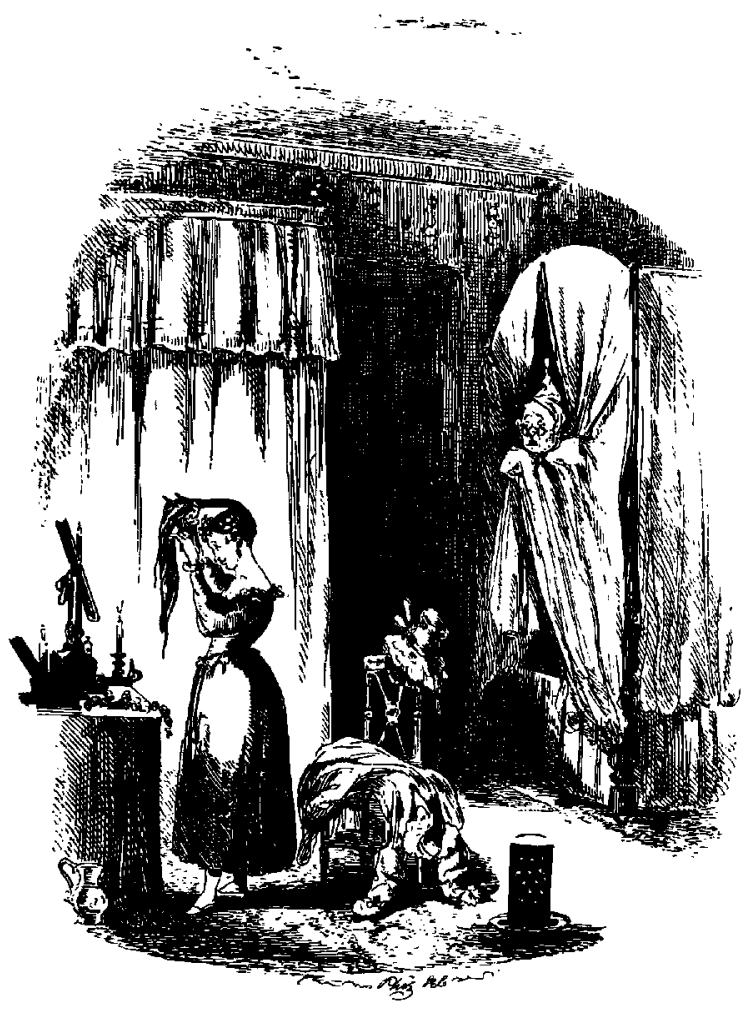

Fig. 38. Hablot Browne, "The middle-aged lady in the double-bedded room.' The Pickwick Papers (London, 1838), facing p. 233. Etching $51 / 8^{\prime \prime} \times 4^{\prime \prime}(13 \times 10.2 \mathrm{~cm})$. From the Harry Elkins Widener Collection, by permission of the Houghton Library, Harvard University.

inevitably, bodies become more distinct, faces more individualized, buildings and trees better integrated, background details more pertinent, while the black, white, and gray tones are altered accordingly to achieve or enhance these improvements. As if to underline his more confident graphic power, Browne squarely centered his famous pseudonym at the bottom of these 1838 etchings, in contrast to his habitual practice of locating it more obscurely to the left or right.

Whatever Dickens thought of these revised illustrations, if he even noticed them, it appears certain that they were inspired by the artist's initiative. The changes Browne made in his Pickwick plates, however, were curiously analogous to some of the changes occurring in Dickens's style. ${ }^{38}$ Clearly, both men drew strength from the enormous public response to their efforts. The tentative lines of Browne's early plates became clearer and more expressive as Dick- ens's prose became increasingly direct and forceful. In both drawings and text, characters became more vital, less puppet-like. Increasingly, both men omitted details that made no textual or graphic point. There is even an analogous quality to their faults-Dickens's exaggerated prose and the lack of Browne's proportion, for example, in the disproportionate size of both Pickwick and his elderly dance partner on Christmas Eve (XXVIII, facing p. 390), as well as of the cook's face in the 1838 version of the seminary breakup (XVI, facing p. 169). ${ }^{39}$ By the time they finished Pickwick, however, Browne had discerned and polished the qualities in his own art that best complemented those of Dickens.

Inevitably, of course, a few readers felt that "the loss of Mr. Seymour to the work, as far as the illustrations go, is obvious." Browne's plates not only equal to Seymour's best work but worthy of Dickens's very best scenes as well. ${ }^{41}$ With Pickwick, Browne became famous. His designs were imitated by other artists; his skills were sought by other authors and publishers. ${ }^{42}$ Also gratifying to Browne must have been Dickens's recognition of his contribution to the author's unprecedented success.

Dickens was so delighted with his new illustrator that he soon extended their collaboration into other professional and social areas. When Dickens supplied the libretto for John Hullah's operetta, The Village Coquettes, which opened in December, 1836, Browne provided the drawings on which the scenery was based. ${ }^{43}$ The Strange Gentleman, a play adapted by Dickens from one of his own Sketches, appeared on the same bill; when Chapman and Hall published it early in 1837 , Browne was invited to supply the frontispiece. ${ }^{44}$ Again, at Dickens's request, Browne supplied an illustration for Bentley's Miscellany as well as for its prospectus prior to the magazine's debut in February, 1837; the artist cleverly matched the humor of the prospectus itself-a parody of royal announcements-with a scene depicting Dickens on publishing day leading a burly porter overloaded by periodicals, fallen copies of which are eagerly snatched up by onlookers $\left(S B B\right.$, facing p. 532). ${ }^{45}$

$A$ less amusing portrait of the author appeared under the artist's sobriquet in the April, 1837, issue of The Court Magazine. This picture of the seated author, holding a portfolio while a Punch and Judy show performs in the background, was not superior to other contemporary likenesses, even Cruikshank's unflattering ones (fig. 39), and many viewers have vilified it as bad caricature. Dickens made no comment. Browne apparently repudiated any connection with the portrait, whose signature bears no resemblance to his others at this time, and which may have 


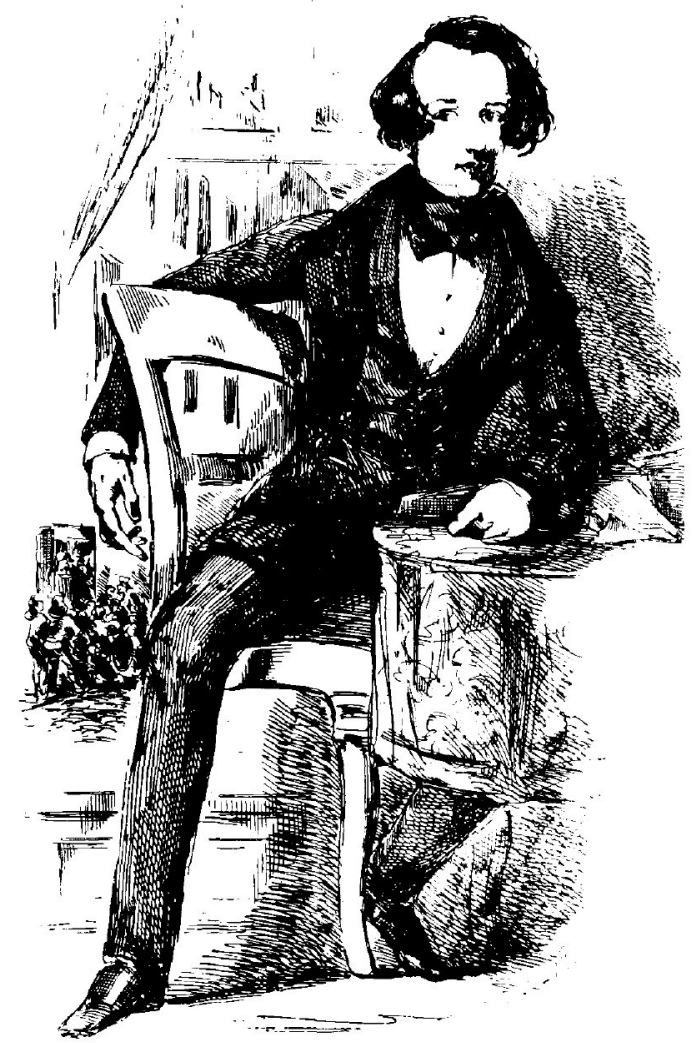

Fig. 39. Artist Unknown, Portrait of Dickens, 1837. Court Magazine and Monthly Critic, 10 (April, 1837), facing p. 185. Etching $9^{\prime \prime} \times 5^{1 / 2^{\prime \prime}}(23 \times 14 \mathrm{~cm})$. By permission of the Trustees of the British Library.

been the unscrupulous effort of someone trying to capitalize on the popularity of both author and artist. ${ }^{46}$

Also suspect, but far more entertaining and less controversial, is a watercolor representation of 'King Pickwick' that is usually attributed to Browne (fig. 40). The artist's initials appear on the drawing, but in atypically close-linked fashion. Moreover, Pickwick appears unduly red-cheeked and younger than might be expected from one who had drawn the aging man so often. Then, too, it is difficult to imagine the shy artist here, or in The Court Magazine portrait, exploiting his work for Dickens in this way at any time. Though the boisterous inscription suggests a date closer to 1836, it is possible that Browne, whose watercolors are less well-known and highly regarded than his illustrations, executed this portrait at a later date when he survived mainly on the strength of his past work for Dickens. In the absence of conclusive evidence, these questions of the picture's date, purpose, and artist must remain minor enigmas. That Browne helped to establish Dickens on a literary throne as a first-rate writer by his illustrations for Pickwick, however, remains indisputable. ${ }^{47}$

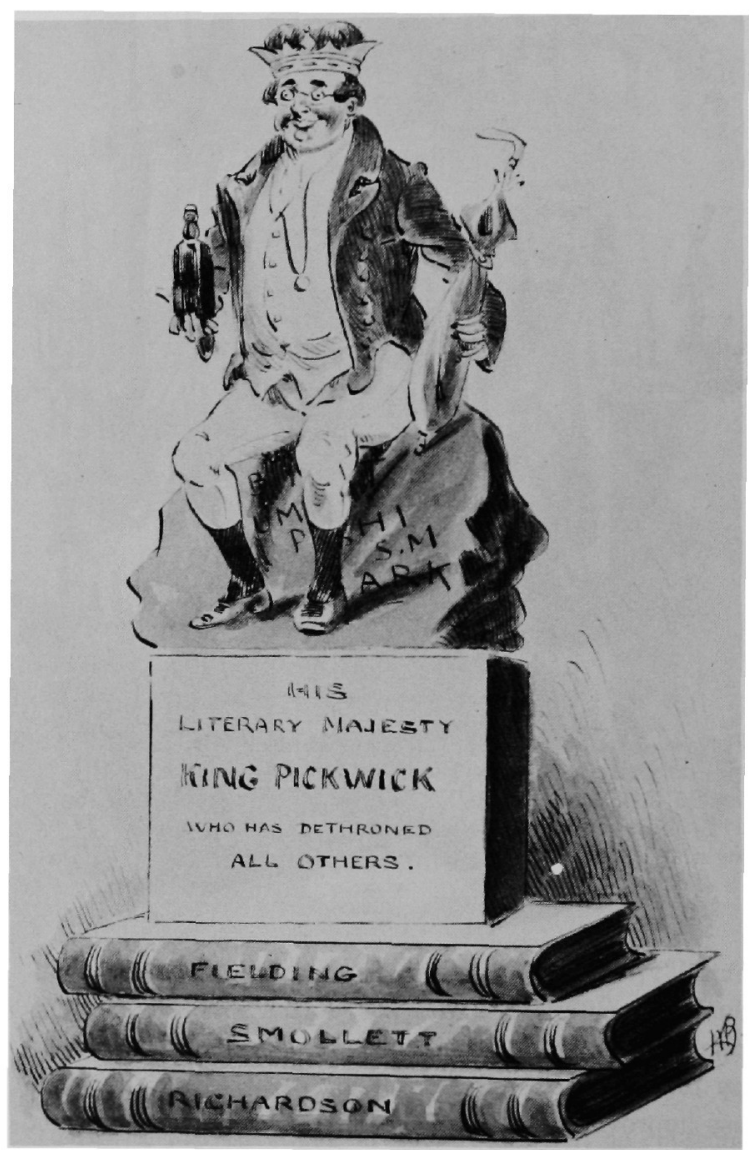

Fig. 40. Attributed to Hablot Browne, 'King Pickwick.' Pen and watercolor. $7^{11 / 16^{\prime \prime}} \times 4^{7 / / 8^{\prime \prime}}(19.5 \times 12.4 \mathrm{~cm})$. By permission of William Self.

In the spring of 1837 , Browne did produce a genuine, if unsatisfactory, portrait. The death of Dickens's young, beloved sister-in-law, Mary Hogarth, on May 7, 1837, had so upset the author that he was unable to complete the subsequent numbers of Pickwick and Oliver Twist on time. He commissioned Browne to do an oil portrait of her. The 
finished likeness, with its severe features and stern expression (fig. 41), scarcely corroborates contemporary accounts of her merry charm and loveliness; the finished portrait, however, as Dickens himself conceded, would have been worthless compared to his own idealization of her. ${ }^{48}$ Indeed, she proved more suitably enshrined in her brother-in-law's memory and in his fiction than in Browne's painting.

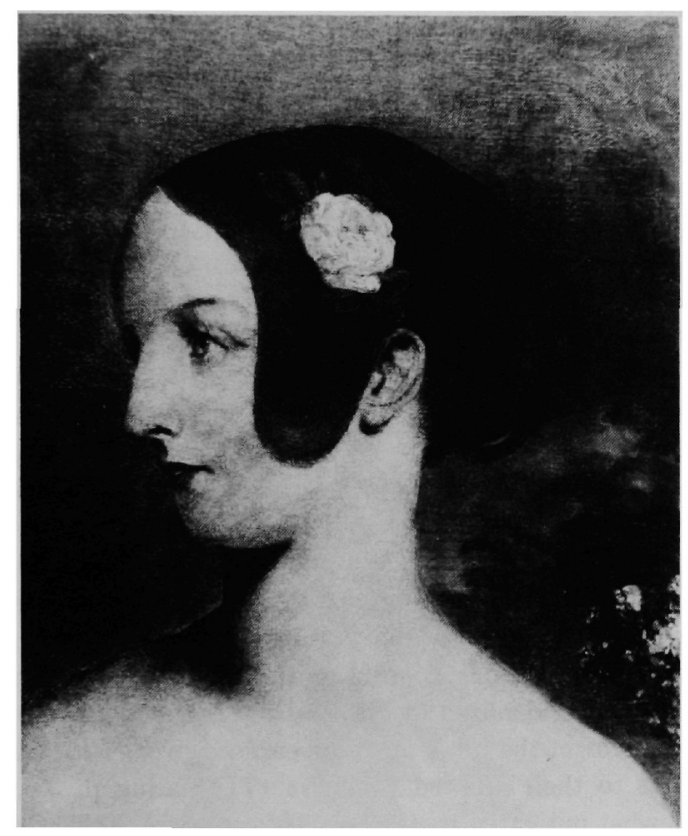

Fig. 41. Hablot Browne, Portrait of Mary Hogarth, 1837. Engraving of oil painting. $13: 4^{\prime \prime} \times 10^{3 / 8^{\prime \prime}}(35 \times 26.3 \mathrm{~cm})$ [sight]. From the Tyrrell Collection, by courtesy of the Trustees of the Dickens House Museum.

Browne's companionship on many assorted occasions was far more effective in diverting Dickens. In June the artist, together with Forster, George Cattermole, and William Macready, accompanied the author on the first of his many tours of London prisons; in July, Browne accompanied him and his wife on a more carefree excursion to Belgium. ${ }^{49}$ The shy but genial artist fitted as quietly and easily into Dickens's life as into his work, and was soon taken for granted, even overlooked, by the author's livelier intimates. His appearance, for example, at the dinner celebrating Pickwick's completion on November 18 was not noted by
Forster, Macready, or Ainsworth, though all kept careful records. If he was oblivious to Browne's social presence, however, Forster, at least, was fully aware that had it not been for the "shrewd and observant" artist's contribution to Pickwick, the dinner might have been less jubilant, if indeed, it had been held at all. ${ }^{50}$

There was never any question as to whether Browne would illustrate Dickens's next book (aside from Oilver Twist, which Cruikshank was illustrating for Bentley's Miscellany), plans for which were already under way. For both author and artist, however, Nicholas Nickleby marks a period of consolidation rather than advance. Dickens's deliberate efforts to silence his critics led him to create a tighter structure and fuller characterization. Yet the design of the resulting narrative seems more imposed than organic. Browne's illustrations, now published with engraved legends beneath them, in contrast to the unentitled Pickwick plates, reflect Dickens's self-consciousness. Too often the melodramatic progress of the narrative is approximated by the set-like interiors and puppet-like figures of the plates. Yet Browne's continuing responsiveness to Dickens, and the establishment of effective routines to accommodate the more mundane aspects of their collaboration, set the stage for a more innovative future.

The Nickleby contract was signed before Christmas, 1837 . In a search for inspiration as well as documentation, Dickens planned a tour to observe the Yorkshire "Cheap Schools" filled with youngsters-almost abandoned by their families or guardians-who too often learned little, ate less, and died young. From childhood he had heard rumors of their cruelties, and he hoped to expose and destroy them in his forthcoming novel. Browne was to accompany him in order to help transform the facts into visually memorable scenes. Deferring their journey until after the holidays, the two men worked on the Sketches of Young Gentlemen, issued anonymously as a companion piece to the Sketches of Young Ladies by "Quiz"--Reverend Edward Caswell-, published the previous year with crude plates by Browne; in 1840 Browne and Dickens would create the final piece in the series, Sketches of Young Couples. ${ }^{51}$ Uninspired by these potboilers and exhausted by Pickwick, perhaps, Browne's imagination seems to have flagged. Though carefully conceived and drawn, the plates are drawn with stiff lines and the characters seem unrefined and one-dimensional. Unfortunately, as it turned out, the quality of his Nickleby work is sometimes closer to that displayed in these minor works than to Pickwick.

On January 30, 1838, posing as friends of a widow planning to place her sons in a Yorkshire school, Dickens 
and Browne left London. Taking the route Nicholas, Squeers, and their charges were to follow, the pair began to accumulate characters and incidents for the projected novel. ${ }^{52}$ The howling storm they endured, the pretentious lady's maid they met, the legend they heard of the Five Sisters of York were all incorporated into the narrative $(V$, VI, 52-67). Inspired by a passenger carrying a letter from a parent severely lecturing his son on his refusal to eat boiled meat, Dickens created Mobb's stepmother, who was upset that her son would not eat fat. The grave of a prematurely deceased adolescent gave Dickens the idea for Smike. Attorney Barnes, who begged him to send the "widow's children" anywhere but Yorkshire, inspired the coarse but kindly John Browdie.

In fact as well as in the later fiction, their most memorable encounter was their meeting with Shaw, the prototype of Squeers. The schoolmaster's harsh voice, defective eye, and hostile attitude toward the pair, whose stated purpose he correctly doubted, were all recognizably embodied in the proprietor of Dotheboys Hall. Nevertheless, the author insisted that Squeers and his school represented a class, not an individual and, as such, was but a faint picture of the reality (xi-xii). Browne conceded only that the master in his drawings was not "unlike" Shaw.$^{53}$ In the artist's allegorical wrapper design for Nickleby, however, the only recognizable figure is that of the culprit, Squeers (facing p. xix) (see F).

The truth of the matter is that, despite the fact that the men drew inspiration and detail from real people, the characters they created did, increasingly, represent a class and serve satirical purposes. Neither the Yorkshire trip nor a later one to Wales and the Midlands ${ }^{54}$ inspired the men to anything resembling a naturalistic style. Dickens's imagination always re-created everything he saw, and Browne always felt cramped drawing from reality. Both were open to charges of distortion, being better able to depict the gross rather than the ideal. Indeed, Thackeray, in his capacity as art critic as well as colleague, publicly urged Browne to "think more and exaggerate less." exaggerated in response to Dickens's lead as well as to his own inclination. Dickens, in turn, was following a tradition of popular graphic as well as literary satire. However repulsive the author later found Gillray and Rowlandson's use of ugliness, at this time he, too, employed the powers of physical distortion for purposes of moral satire. In no other novel did Dickens create so many male characters-Ralph Nickleby, Gride, Bray, Hawk, Pluck, Pyke-who, as their names suggest, are physically as well as morally hideous. Even Cruikshank might have been taxed to individualize so many grotesques. Browne relied heavily on distorted facial expressions to convey their villainy, but effectively utilized physical height and girth as well..$^{56}$ The animal compactness of Ralph (III, facing p. 26) (fig. 42) and Squeers (IV, facing p. 32) (fig. 43), the bloated body of Master Wackford Squeers (LXIV, facing p. 830) (fig. 44), the outsized heads of Gride (XLVII, facing p. 614) (fig. 45) and Bray (XLVI, facing p. 608) (fig. 46), and the elongated physiques of Sir Mulberry, Lord Frederick, and their stooges Pluck and Pyke (XIX, facing p. 236) (fig. 47)-all parasites on society -may be unnaturally distorted, but no more so than the values and morals they reflect.

More valid and disturbing is the complaint that Browne made certain characters more grotesque than Dickens intended them to be. The author did protest, though with little effect, that Smike did not look "frightened" enough nor Squeers "earnest" enough for his purpose in "A sudden recognition unexpected on both sides' (XXXVIII, facing p. 498), yet he never objected to the artist's consistently unfair representation of Newman Noggs (V, facing p. 48; XI, facing p. 134; XLVII, facing p. 614) ${ }^{57}$ Browne never endowed Noggs with any of the innate kindness and dignity he gradually begins to display in the text, thus, in a sense, abusing his license by refusing to let the bizarre figure develop after Dickens's opening description of him (II, 8-9). Usually, however, Browne's graphic reinforcement of Dickens's benign grotesques proves flexible and accurate, as it does, for example, in the scenes involving Crummles's troups (XXII, facing p. 282) or the Dotheboys students, who are individualized by Browne better than by Dickens. The horror of the boys' aged appearance, which truthfully attests to their starved condition (VII, facing p. 90), is somewhat mitigated by the spirit of catharsis in Nicholas's castigation of Squeers (XIII, facing p. 156) and the breaking up of the school (LXIV, facing p. 830).

Both Browne and Dickens relieved the grotesqueness of the characters with touches of naturalism and beauty, as well as humor and sensitivity. If the artist did not spare Dickens's male villains, he did not, like Cruikshank, deny feminine beauty. In the background of 'Nicholas starts for Yorkshire' (V, facing p. 48), for example, two pretty, buxom chambermaids ignore their duties to watch the activity (and an admirer) below the graceful balustrade, to the fury of their homely coworker who ineffectually brandishes a mop at their shapely backs. ${ }^{58}$ When the text appealingly described "The Five Sisters of York," Browne certainly rose to the occasion (VI, facing p. 58); and in his hands, both Kate Nickleby and Madeline Bray are suitably pretty in face and figure, though often, as in the 'The Children at their cousin's grave,' they are insufficiently distinguished from one another in their pictures as in the text (LXV, facing p. 834) 

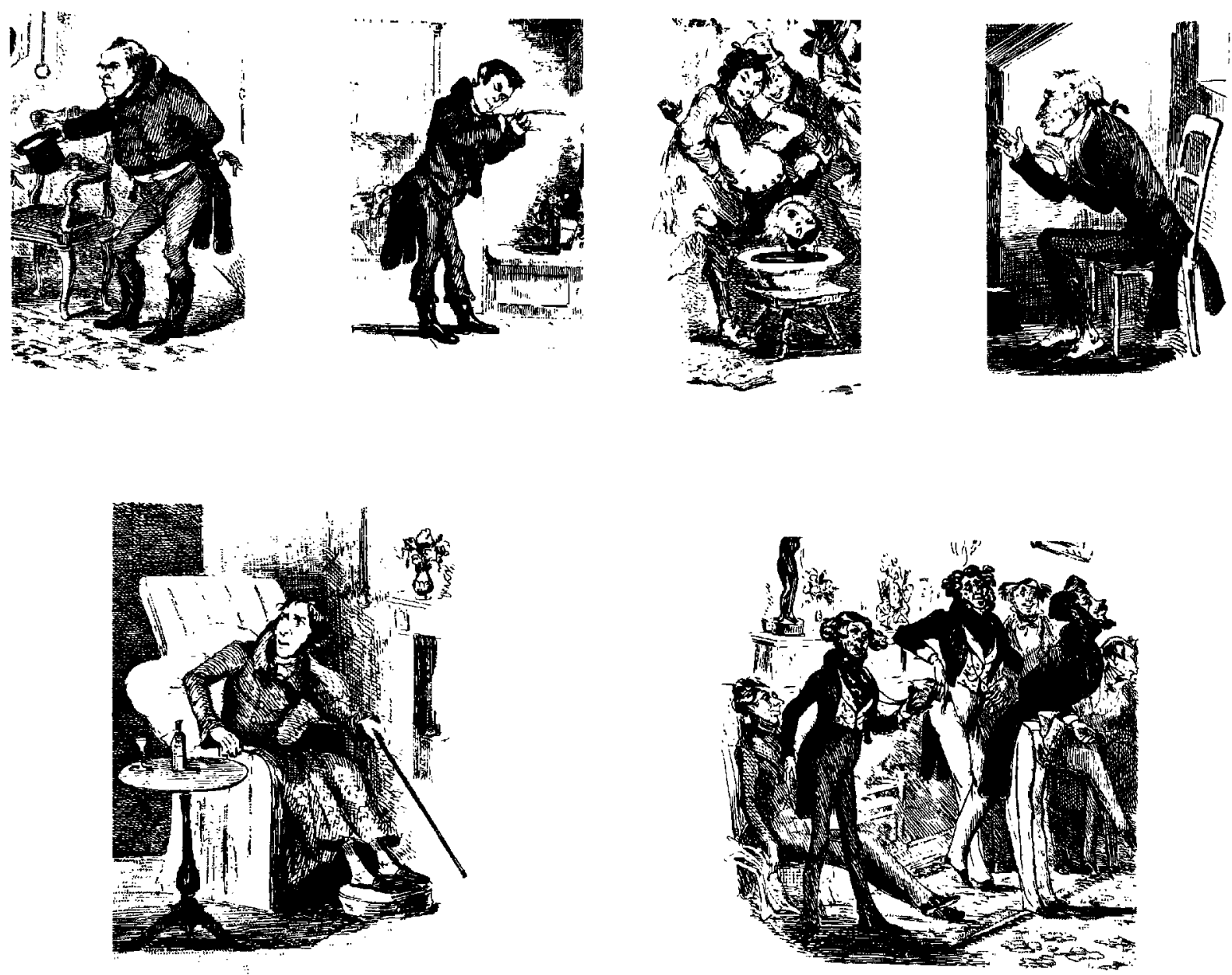

Top row, left to right: Fig. 42. Hablot Browne, Ralph Nickleby. Detail from 'Mr. Ralph Nickleby's first visit to his poor relation,' Nicholas Nickleby, no. 1. Etching. $3^{3 / 4^{\prime \prime}} \times 41_{16^{\prime \prime}}(9.5 \times 10.3 \mathrm{~cm})$. Fig. 43. Hablot Browne, Squeers. Detail from "The Yorkshire Schoolmaster at the "Saracen's Head," Nicholas Nickleby, no. 1. Etching. $43 / 16^{\prime \prime} \times 4^{1 / 8^{\prime \prime}}(10.6 \times 10.5 \mathrm{~cm})$. Fig. 44. Hablot Browne, Master Wackford Squeers. Detail from 'The breaking-up at Dotheboy's Hall,' Nicholas Nickleby, no. 19. Etching. $415 / 16^{\prime \prime} \times 43 / 16^{\prime \prime}(12.5 \times 10.6 \mathrm{~cm})$. Fig. 45. Hablot Browne, Arthur Gride. Detail from "The Consultation,' Nicholas Nickleby, no. 15. Etching. $45 / 16^{\prime \prime} \times 3 \frac{1}{1 \prime \prime}(11 \times 8.9 \mathrm{~cm})$. Bottom row, left to right: Fig. 46. Hablot Browne, Mr. Bray. Detail from Nicholas makes his first visit to the lodgings of Mr. Bray,' Nicholas Nickleby, no. 15. Etching. $4{ }^{5 / 16^{\prime \prime}} \times 4^{\prime \prime}(11 \times 10.2 \mathrm{~cm})$. Fig. 47. Hablot Browne, Sir Mulberry Hawk, Lord Frederick Verisopht, Pluck, and Pyke. Detail from 'Miss Nickleby introduced to her Uncle's friends,' Nicholas Nickleby, no. 6. Etching. $41 / 16^{\prime \prime} \times 45 / 8^{\prime \prime}(10.3 \times 11.8 \mathrm{~cm})$. All by permission of the Houghton Library, Harvard University. 
(fig. 48). ${ }^{59}$ The virtuous male characters, except for Noggs, are physically as well as morally attractive. Nicholas is an appealing hero; so are the robust Cheerybles-modeled on the brothers Grant whom Dickens and Browne had heard of from Ainsworth and met in Manchester (xii)-under whose benevolent auspices the story ends in proper fairytale fashion. ${ }^{60}$

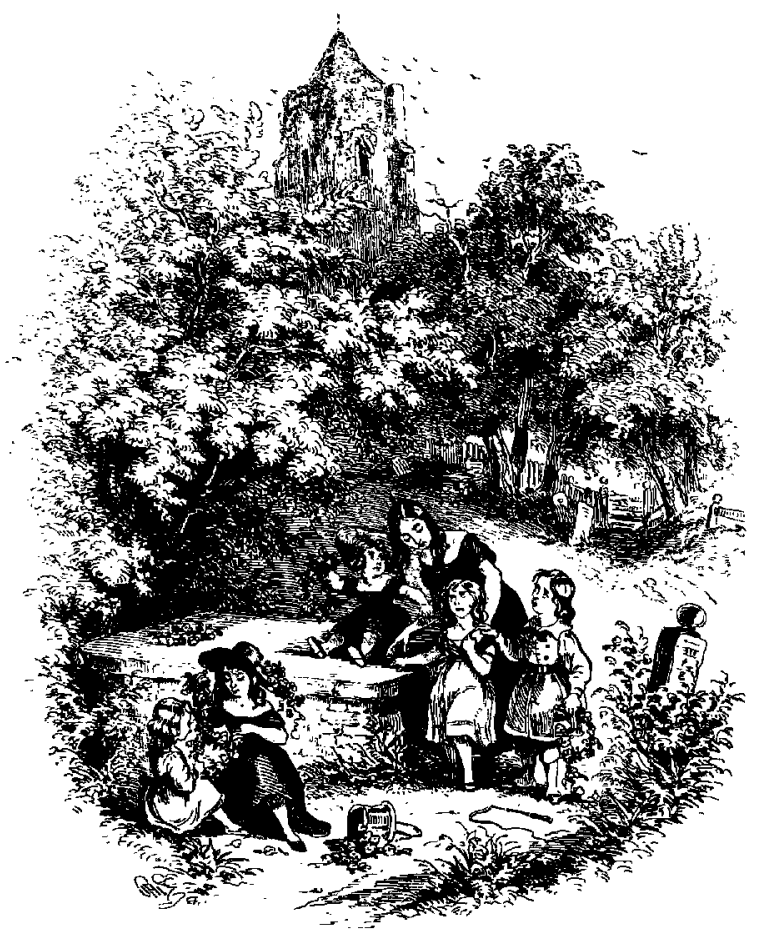

Fig. 48. Hablot Browne, 'The children at their cousin's grave.' Nicholas Nickleby, nos. 19 and 20 . Etching. $5^{1 / 8^{\prime \prime}} \times 43 / 8^{\prime \prime}(13$ $\times 11.2 \mathrm{~cm}$ ). By permission of the Houghton Library, Harvard University.

In the course of their work on Nickleby, Dickens and Browne managed to regularize their communication-no small achievement, especially considering the random quality of their contacts about Pickwick. Dickens's more carefully planned novel enabled Browne to organize his own professional life better. He was even able to draw up a timetable of his Dickens work for the publishers. Taking January as a typical month, in which, ideally, Dickens wrote his number the first ten days, the artist projected his subsequent progress.

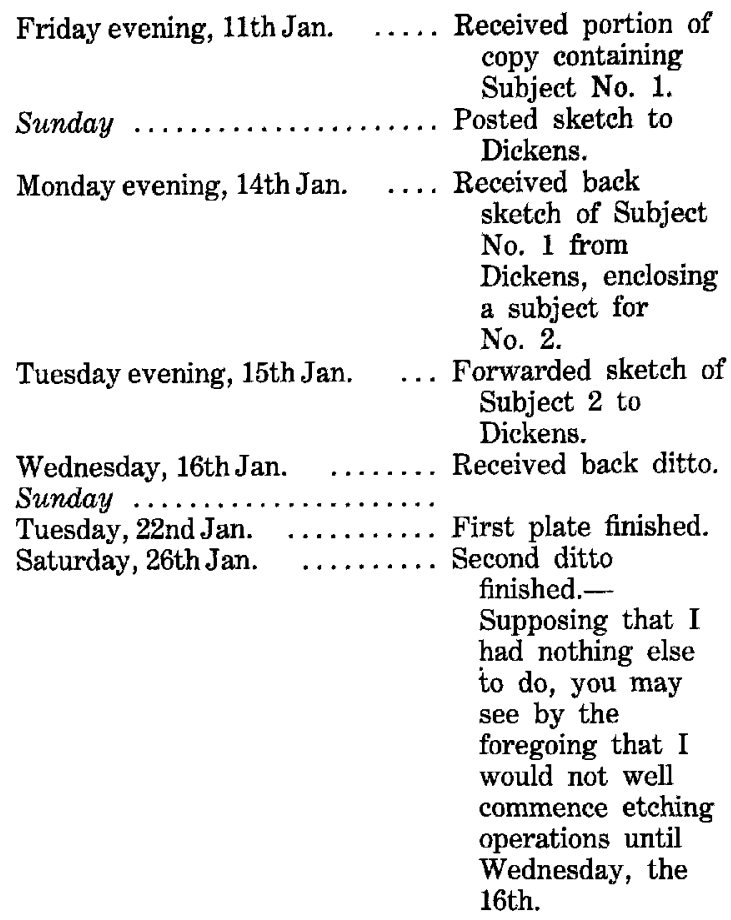

"What do you make of it?" Browne asked Chapman and Hall. ${ }^{61}$

The publishers knew all too well how oversimplified this schedule was. It did not suggest that Browne had to duplicate each steel plate two to four times. Nor did it allow for Dickens to conceive and the engravers to print a title (often ironic) as well as page numbers beneath the drawings, aids especially to those readers who later bound their monthly issues in hard covers with the illustrations in their proper place in the story. It permitted no time for Dickens to inspect and return a sketch nor for known errors to be corrected-as happened once at least when a drawing was executed before the text, and it failed to take into account unexpected developments like delays in visits or communications from Robert Young in London or the illness that incapacitated Browne for Nickleby's fourteenth number. ${ }^{62}$ Finally, it was rare that Dickens's copy was on time or that Browne had nothing else to do. Browne's association with Dickens attracted commissions for other plates at least equal in number to those he was doing for Nickleby. ${ }^{69}$ Dickens did not fear that another author would prove more stimulating to Browne than he, but the drain on the artist's inventiveness is often apparent throughout the narrative. Still, the two men wasted less time and energy on the mundane aspects of their collaboration as it became more regular. 
Unlike Dickens, who seemed inexhaustible, Browne was limited by a finite supply of energy. As the author doubtless discovered on their travels through Yorkshire, the artist never rose in the morning without the use of foree. On the eve of their trip to Wales and the Midlands, the author felt compelled to invite Browne to his home for the weekend, lest he miss the Monday morning coach. ${ }^{64}$ Socially the artist dissipated much of his strength in self-consciousness. Only during an out-of-town excursion would Browne have attended something like the Shrewsbury "bespeak" -though, when he did, he laughed, as Dickens reported to his wife, "with such indecent heartiness at one point of the entertainment that an old man in the next box suffered the most violent indignation." bled the Miss Snevellicci episodes, appearing in the current November Nickleby (XXIV, 301-17, facing p. 316) certainly contributed to Browne's hilarity. Once back home, however, it did not suit the shy artist to join Dickens at the theater, even to see the pirated stage version of Nickleby, though he must have been flattered to learn that the fine scenery was based on his sketches. ${ }^{66}$ These basic differences of temperament may have prevented greater intimacy between the two men, but it probably fostered rather than hindered their harmonious work together at this time.

It had been a most prosperous year, Dickens observed on his twenty-seventh birthday, which even Browne joined his family and friends in celebrating. ${ }^{67}$ Readers were snapping up issues of Nickleby, delighted to find again, as the Athenaeum put it, that "the characters were drawn twice over-to the eye as well as to the mind." ${ }^{\prime 68}$ Chapman and Hall were so pleased that they held a "Nicklebeian fête" on October 5, 1838. Legend has it that on such public occasions as this, the shy illustrator lurked in the corners and hid behind curtains; whether or not this is the literal truth, Brawne succeeded in effacing himself at the party. ${ }^{69}$ His reticence may have been increased by the presence of George Cattermole, Daniel Maclise, and Clarkson Stanfield, artists better established in sophisticated circles and closer personal friends of Dickens. He should have been reassured, however, by the cameo ring on his little finger, a present from Dickens to express his appreciation to the artist who had helped to assure Nickleby's success and to settle the question of whether Pickwick was but a flash in the pan. ${ }^{70}$ The fact that Nickleby was not the success that Pickwick had been may reflect, in part, the tendency of both men to flourish best in the face of challenge. Perhaps they needed fallow periods like the Nickleby one to gather strength for more innovative collaborations.

Before a word of Nickleby had been committed to paper, Dickens had already conceived a new challenge. After his interview with the kind Yorkshire attorney, the author had strolled down to the local cobbled marketplace. According to legend, an old-fashioned shop displaying the sign HUMPHREY, CLOCKMAKER, and a quaint longcase clock in its recessed doorway, caught his eye and sparked his ready imagination. ${ }^{71}$ In this accidental manner, Dickens's new project, which he titled Master Humphrey's Clock two years later, was initiated. It was to be a magazine containing legends of old England and contemporary tales in the manner of the eighteenth-century periodicals he so admired, which would appear in weekly parts, to be bound and sold monthly as well. Dickens hoped to profit from a more continuous relationship with his audience by producing a work that he need not write entirely himself. He planned on using many artists to provide not only more numerous illustrations, but decorative initial letters and head and tail pieces as well, to make the Clock as visually enticing as possible.

From the first, Dickens paid extraordinary attention to the appearance of the magazine. His early decision "to have woodcuts dropped into the text" must have been welcomed, if not suggested, by the publishers. ${ }^{72}$ The economy of this graphic process had always been appreciated by cheap periodicals. For wood blocks were not only more durable than the metal plates for etchings, but they could be printed right along with the letterpress; the slight extra expense was compensated for by the savings in distribution and binding. But Dickens's decision to adopt this format was not based simply on economic considerations. The author must have sensed what Ruskin later enunciated so condescendingly: that although some readers appreciated the "disciplined" qualities of a steel engraving, "the attention of a child [might] be excited, and the apathy of a clown overcome by the blunt lines of a woodcut." ${ }^{\text {"3 }}$ Such stimulation would be needed if a wide audience was to absorb and remember the varied fare that Master Humphrey's Clock was to offer. Crucial to this stimulation was the greater control over the integration of pictures and text that wood engravings afforded. Steel plates lacked such flexibility, since they were separately engraved and then inserted together inside the wrapper before the text, far from the passages they illustrated. Dickens was so attracted to the dramatic possibilities of an integrated arrangement that even after he had all but abandoned other aspects of the Clock, turning over the magazine to two longer narratives, The Old Curiosity Shop and Barnaby Rudge, he did not abandon his lavish pictorial plans. Indeed, the herculean pressures of providing text and supervising illustrations on a weekly basis seemed to spur him to assist his readers more visually than ever before. His instructions to his illustrators, necessarily more frequent, were just as detailed as always 
as he sought to reinforce graphically, by parallelism or contrast, the impact and meaning of his characters, themes, and descriptions.

As the Clock evolved, Dickens characteristically met this new challenge of placing the illustrations by overseeing them himself to insure that their inherent dramatic advantages, as well as the usual aesthetic ones, were fully exploited. Joan Stevens has amply demonstrated how he, not the printer, positioned the engravings to establish graphically and then recall his many characters, themes, and complex plot developments, often widely separated in time and space, and John Harvey has suggested that they often are treated as narrative units in their own right. ${ }^{74}$ Stevens has also shown that the magnitude of Dickens's achievement in this regard has been shamefully obscured by the failure of later publishers to place his engravings exactly where he wanted them. ${ }^{75}$ Placed as they were intended to be, the best illustrations perform yeoman service. At the point, for example, when Nell and her grandfather look back on the London they have fled, the picture provides a physical and emotional pause needed by the readers as well as the characters (XV, 132) (fig. 49). The view of the city, which renders verbal description of what they see unnecessary, does not replace the narrative but becomes part of it. Moreover, by bringing Pilgrim's Progress to Nell's mind at this moment $(\mathrm{XV}, 122)$, Dickens adds historical, literary and moral perspective not only to this scene, but to the entire narrative. That Browne's portrayal resembles John Martin's well-known illustration of 'The Celestial City' in Dickens's personal copy of the Bunyan allegory adds yet another dimension, albeit an extrinsic one (fig. 50). ${ }^{76} \mathrm{Had}$ this woodcut been placed at the beginning of the number, as etchings then had to be, both its immediacy of impact and its gradual resonance would have been seriously impaired.

When the Clock ceased to be a miscellany, Dickens found it both unnecessary and impractical to employ various illustrators. The still formidable task of providing pictures for the entire enterprise (except for the two provided by Williams and Maclise) fell to Browne and George Cattermole, an established illustrator of romantic fiction and a respected antiquarian painter, as well as Dickens's friend and relative by marriage. The self-effacing Browne did not object either to the presence of the painter or to the fact that his name preceded his own on the title page, though Cattermole provided far fewer illustrations. His cooperative attitude did not vary, even under the relentless pressures of weekly publication. Dickens's plan was to have each artist illustrate several consecutive numbers while the other rested. As it turned out, however, he assigned threequarters of the subjects and over half the initials to Browne,

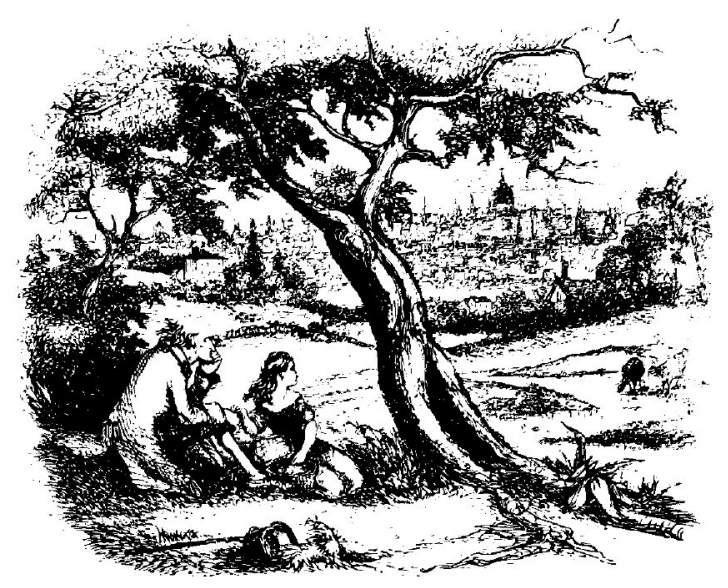

Fig. 49. George Cattermole, 'Nell and the Old Man looking back at London.' Master Humphrey's Clock, no. 14, p. 172. Wood engraving. $3^{1 / 2^{\prime \prime}} \times 41^{1 / 2^{\prime \prime}}(8.9 \times 11.5 \mathrm{~cm})$. By permission of the Houghton Library, Harvard University.

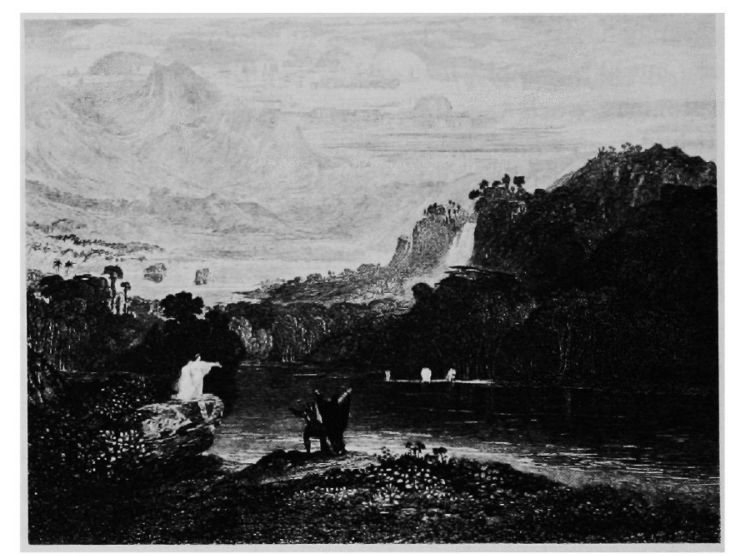

Fig. 50. John Martin, 'The Celestial City.' John Bunyan, Pilgrim's Progress (London: John Murray and John Major, 1830), following p. 213. Etching. 51/2" $\times 4^{\prime \prime}(14 \times 10.2 \mathrm{~cm})$. By permission of the Houghton Library, Harvard University.

rarely giving him a chance to relax. But the artist did not protest, even when some of the subjects meant for Cattermole were sent to him because of error, or, more often, because of the painter's indisposition or disinclination to do them. ${ }^{77}$ On the contrary, Browne must have welcomed the fact that Cattermole took on at least part of the burden.

Browne, according to his son, was less comfortable with wood techniques than with those required for steel plates. ${ }^{78}$ He often failed to make allowance in his drawings for the fact that an engraver was likely to work more extreme 
changes on a wood block than on a steel plate, since the process of cutting away wood to leave lines outstanding was more drastic and less precise than that of applying acid to metal. Whatever Browne's difficulties, however, they were not evident to Dickens or to his readers. He certainly was more expert than Cattermole, whose drawings he copied onto the wood block without complaint until the painter learned to do so himself, characteristically anxious that he do justice to his colleague's work. ${ }^{79}$

For the announcement heralding its publication by Chapman and Hall on April 4, 1840, Browne depicted Dickens opening the door of Master Humphrey's Clock, liberating the fictional characters inside ( $S B B$, facing p. 686). Readers, anticipating another Dickens novel, flocked to buy the weekly. Their disappointment at finding only elderly Master Humphrey and his friends, who were to provide continuity for the short pieces by various writers, was not appeased by the increased number of illustrations or even by the reappearance of Pickwick and Sam Weller in the second number. Falling sales reflected their refusal to rest content with anything less than a full-scale fiction from Dickens's pen. Consequently, the author decided to expand the "little child story" that he had produced for the fourth Clock number. Although Dickens himself did not lose interest in Master Humphrey (whom, he felt, Browne had delineated in "ADMIRABLE" fashion [SBB, 730]), it was little Nell who recaptured the author's audience for the periodical and ultimately absorbed Dickens's own attention. ${ }^{80}$

The growth of The Old Curiosity Shop from a short tale to a full-length narrative increased the task of the two main illustrators and the importance of their illustrations. From its inception, the story was built around simple polarities of good and evil. Dickens not only exploited them verbally as he developed his narrative, but sought to sharpen them visually by assigning Cattermole most of the serious or sentimental subjects involving the heroine, Browne the far more numerous comic or grotesque scenes usually involving the villains. Now that Master Humphrey's Clock was devoted to weekly installments of The Old Curiosity Shop, Dickens no longer sought variety, but, as Harvey has also shown, wished to maintain clear (if numerically unequal) pictorial contrast. ${ }^{81}$

Perhaps inspired by Dickens's concentrated attention, Browne relished his work in the grotesque vein; and, except for his regressive portrayal of the marchioness (LVII, 457) (LXIV, 507) (LXV, 519), began to excel at its sequential as well as its discrete aspects. ${ }^{82}$ Certainly The Old Curiosity Shop contains more interesting grotesques than does Nicholas Nickleby. They are morally as well as physically a far more varied lot. Topping the hierarchy of evil is Quilp who, unlike Ralph Nickleby, has fewer nefarious associates to blunt the effect of his singular brand of malevolence. Browne's illustrations reflect the fact that Quilp and his few cohorts are a more integral part of the narrative than their counterparts in the loosely structured Nickleby; none are gratuitous, for as Forster explains, "The hideous lumber and rottenness that surround the child in her grandfather's home take shape again in Quilp and his filthy gang."

Following Dickens's lead, as always, Browne continued to perpetuate the popular belief that physical deformity was not only laughable but also implied moral deformity, unfair as this seemed to the enlightened Thomas Hood. ${ }^{84}$ Increasingly, however, as he moved through the book, Dickens stressed Quilp's innate malformations over his external ones. Similarly, Browne's early portrayals of the dwarf stressed his physical ugliness in the old Nickleby manner (VI, 467) (fig. 51), whereas later he captured Quilp's real deformity-his moral hideousness-more subtly, by increasing the brutality of his face and figure. By the time he depicted the villain leering out of the tavern window, the words he placed on the wall to the right of the sill-MAN BEAST-seemed equally applicable to him (LX, 477) (fig. 52). ${ }^{85}$ Taken together, Browne's portrayals of Quilp-nearly one-quarter of all the illustrations in The Old Curiosity Shop -forcefully heighten Dickens's Victorian re-creation of a fairy-tale monster. So thoroughly did Browne allow his imagination to be dominated by Quilp that the face of Kit, hugging his pony after his release from prison, oddly, and perhaps accidentally, resembled that of his deceased enemy (LXVIII, 549). Cattermole was unable to enter the spirit of the villain so fully, and his characterization of Quilp is unsuitably tame (IX, 72) (fig. 53). ${ }^{86}$

The subtle brilliance of Browne's later portrayals of Quilp, especially his widely praised death scene ${ }^{87}$ (LXVII, 544), may have surprised admirers of his comic work. Indeed, the artist now began to display in a positive way the versatility that would enable him to keep pace with Dickens for so long. The author took notice. Though he continued catering to the sentimental and antiquarian tastes of Cattermole, he wisely assigned Browne many other kinds of subjects. Certainly Browne was better suited than the painter to depiet the dance at the Ladies' Seminary (VIII, 67 ), the Nubbles' theater party (XXXIX, 312), and the unemployed rioters (XLV, 359). Only he would have added the touches that would become hallmarks of his style-such as placing a sign "TAKE NOTICE! MAN TRAPS" on the wall behind Miss Monflathers and her genteel charges, thus undercutting their snobbish scorn of Nell (XXXI, 249). ${ }^{88}$ It also became apparent that Browne did as well or better than 


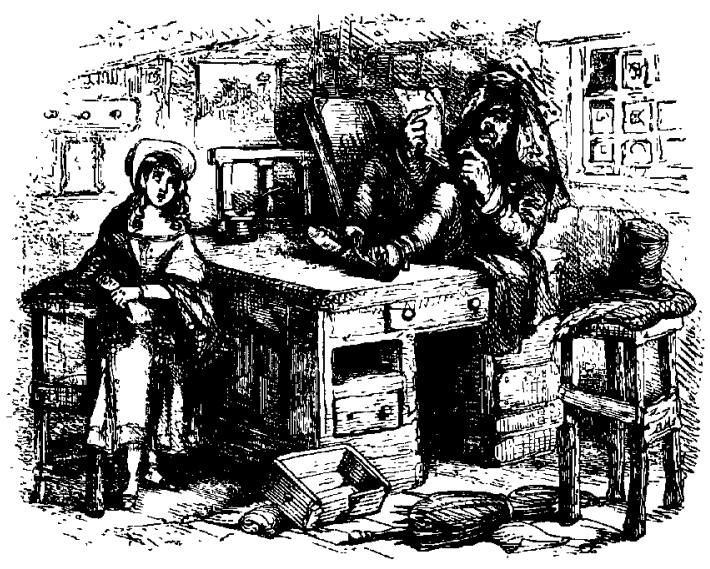

Fig. 51. Hablot Browne, 'Quilp and Nell.' Master Humphrey's Clock, no. 10, p. 109. Wood engraving. $31 / 2^{\prime \prime} \times$ $4716^{\prime \prime}(8.9 \times 11.3 \mathrm{~cm})$. By permission of the Houghton Library, Harvard University.

Cattermole, even in the latter's areas of specialty. When the painter was unable to do the frontispiece for the second bound volume of the Clock, containing the bulk of little Nell's story, for example, Browne showed himself capable of rendering the sentimental as well as the grotesque characters of the book (xiv). ${ }^{89}$ And, as shall be seen later, when Browne, a former illustrator of Winkle's Cathedrals of England and Wales, got a chance to depict gothic architecture in 'Quilp at the gateway' (XXVII, 218) (see fig. 124), he puts its symbolic features to work for the story far more

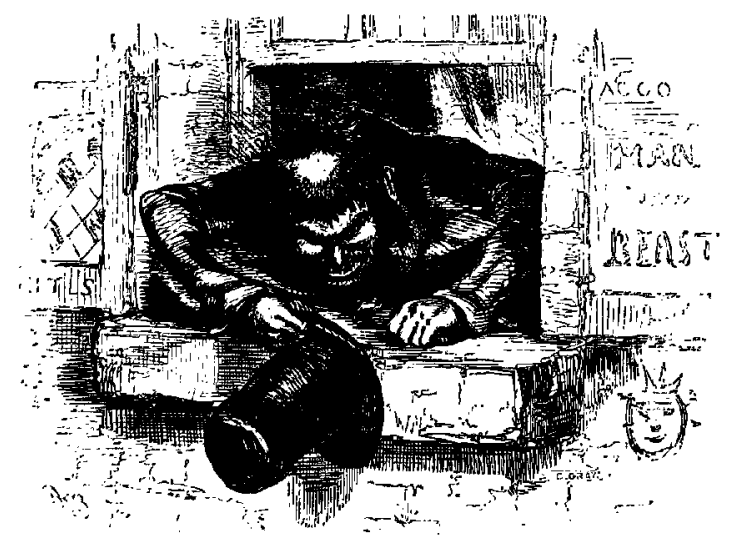

Fig. 52. Hablot Browne, 'Quilp at the tavern window.' Master Humphrey's Clock, no. 38, p. 135. Wood engraving. $31 / \mathrm{s}^{\prime \prime} \times 476^{\prime \prime}(8 \times 11.3 \mathrm{~cm})$. By permission of the Houghton Library, Harvard University. skillfully than his colleague. ${ }^{90}$ Fortunately, pressures of time prevented much comparison between the two artists.

Though he appeared to take its excellence for granted, certainly Dickens was pleased with Browne's work. The artist must have been gratified when Phiz's true identity was publicly disclosed for the first time on the title page of the first bound volume of the Clock. He himself had dispensed with his pseudonym in signing his engravings, using instead his own initials, first HB and then, perhaps due to its closeness to John Doyle's pseudonym, HKB. The artist would continue to sign "Phiz" to his subsequent etchings for Dickens's novels; but his present use of his real name seems especially appropriate, for it was during the Clock that Browne artistically came into his own, manifesting unsuspected versatility that the author would be quick to utilize in their long collaboration ahead.

Strengthened by Dickens's tacit approval and oblivious to Cattermole's favored treatment, Browne even conquered his shyness to attend with eagerness the dinners that marked the Clock's progress. In his note accepting Dickens's invitation to the first such dinner, the artist, in a rare burst of affection, expressed "a disinterested wish that, having completed and established one 'Shop' in an 'extensive line of business' you will go on increasing and multiplying suchlike establishments in number and prosperity till you become a Dick Whittington of a merchant, with pockets distended to most Brobdignag dimensions." ${ }^{91}$ Browne

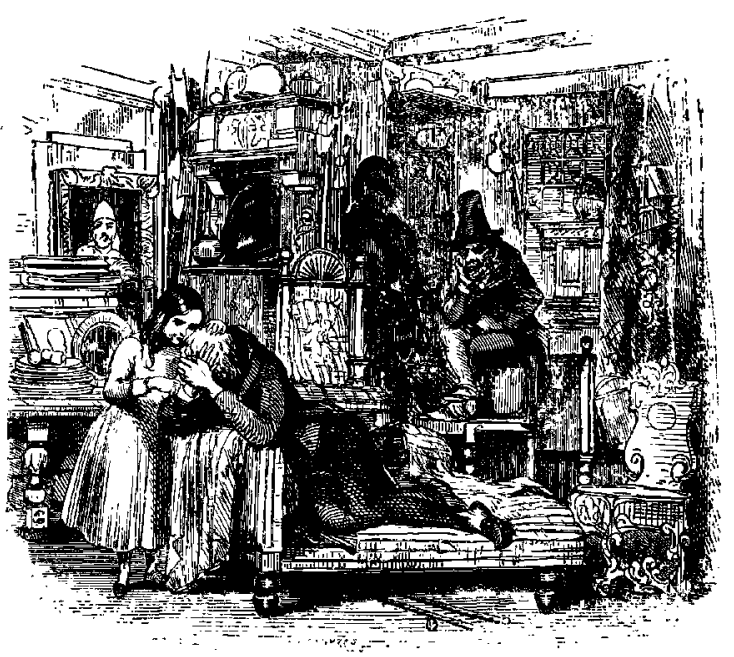

Fig. 53. George Cattermole, 'Quilp in the old Curiosity Shop.' Master Humphrey's Clock, no, 12, p. 133. Wood engraving. $41 / 8^{\prime \prime} \times 4 \% 16^{\prime \prime}(10.5 \times 11.6 \mathrm{~cm})$. By permission of the Houghton Library, Harvard University. 
well understood the author, whose constant allusions in his early works to Whittington, the English Horatio Alger, reflected his own dreams of achieving security, status, and popularity-all of which were coming true.

Dickens, having finished The Old Curiosity Shop, which marked the halfway point of Master Humphrey's Clock, could afford the momentary pause needed to finish his self-assigned obligation to edit The Pic Nic Papers for the benefit of Mrs. Macrone, the wife of his first publisher. Browne, who, along with Cruikshank and other artists, was to illustrate the work, had by now forgotten the author's request, made in 1838; it was understandable that the project had not been very "vividly" present to Browne in the busy years since. ${ }^{92}$ Nevertheless, the work, including six of Browne's illustrations, was finally published in 1841. In an irony of timing that Macrone would have appreciated, Dickens, turning his full attention back to Master Humphrey's Clock, began to fill it with installments of the long-deferred Barnaby Rudge.

The new novel-so different from The Old Curiosity Shop - that surged through the latter pages of the Clock had a stormy history. In May, 1836, the still obscure author of The Pickwick Papers had accepted a small advance from Macrone for Gabriel Varden, the Locksmith of London, and .rashly promised to complete it by November. Released from this unrealistic contract just before Macrone's premature death in 1837, he offered the incomplete story to fulfill another contract he had made with Richard Bentley. Once again, Dickens failed to deliver the work, and it became a major source of contention with Bentley, with whom he ultimately broke. In 1840, having rescued Master Humphrey's Clock from certain failure with the story of Nell, Dickens needed another narrative. Reviving the skeletal Clock machinery for a few pages to bridge the gap, the author, after changing the title from Gabriel Varden to Barnaby Rudge, finally felt motivated to proceed with that much postponed story. The gentler characters in The Old Curiosity Shop consequently bowed off stage in Browne's complex tailpiece to the story, while grotesque figures hoisted a spear with a crude flag proclaiming the title of the radically different narrative to come $(S B B, 809)$.

Despite its troubled past, Barmaby proceeded smoothly from the moment it began to appear in the Clock. In contrast to his hurried expansion of Nell's story, Dickens had had six years to ponder, draft, and even research his fictional history of the 1780 No-Popery Gordon Riots. ${ }^{98}$ His fewer major characters were a challenge to his illustrators, and his calculated placement of their work insured that the pictures would reinforce his text dynamically. Dickens continued the pattern of illustrations he had established during The Old Curiosity Shop. Throughout Barnaby, two scenes, portraying main characters or events, were allotted to each weekly number. Each monthly part included a small headpiece as well, marking key settings or incidents and an elaborate initial, sometimes purely decorative in the fashion of the time, but more often functional (which perhaps inspired Thackeray's functional use of decorative initials in Vanity Fair) ${ }^{94}$ In addition, certain significant conclusions to numbers often were underlined by tailpieces, if not full-page illustrations. As Stevens has observed, deviations from this pattern-in the Shop cut depicting Quilp's death, which appears in the middle rather than the end of a number (LXVII, 544), or the extra headpiece and initial to chapter 33 of Barnaby, in which the narrative resumes after a five-year break (267)-signaled moments of special significance. ${ }^{96}$ Dickens's awareness of the weekly text and illustrations as a composite unit was at its height throughout Barnaby. Consequently, compared to his previous work, this narrative contains fewer pictorial but inconsequential details, episodes, or even illustrations like those of Swiveller dancing (VIII, 67) or Kit gardening (XL, 317). ${ }^{96}$

Both author and artists, particularly Browne, met the challenge of providing the greater variety of styles needed for the historical, compared to the allegorical, fiction in the Clock. Dickens and Browne continued to exploit their skill at expressing the exaggerated or grotesque to render the crude characters-Gashford, Dennis, and the Protestant mob (XXXVII, 308; LXVIII, 565). They treated the Maypole rusties in their earlier humorous manner (I, 6). Throughout the first two-thirds of the narrative, however, both men were uncharacteristically restrained: Dickens's prose was plainer and more direct, and Browne's representations were uncommonly realistic. ${ }^{97}$ When, at the story's climax, Dickens really let his imagination go in describing the orgiastic riots, Browne readily caught his spirit. His designs, with their tumultuous crowds yet individualized participants, fully embodied the violent excitement of the prose (LII, 431; LXIV, 528; LXVI, 548; LXVIII, 565). Author and artist attained a unity of mood and technique at this point that would be sadly dissipated when, almost twenty years later, they next collaborated on a historical fiction, A Tale of Two Cities.

As in The Old Curiosity Shop, Browne executed the bulk of the scenes for Barnaby, this time including those involving the heroines. With few exceptions, Cattermole was again assigned the antiquarian subjects. Browne's versatile talents, Cattermole's narrower skills, and Dickens's careful coordination of both are evident throughout, but especially in their combined presentation of the novel's 
most sophisticated villain, John Chester. This character, as his name suggests, parodies Lord Chesterfield, particularly his cynical values as expressed in his letters to his son. Unlike Squeers or Quilp, this moral monster could not be portrayed mainly through body distortions or crude facial grimaces; more subtle and ironic means were required.

Examined as a whole sequence, as Dickens's illustrations should be more often, ${ }^{98}$ the woodcuts involving Chester display an impressive range of small but significant graphic touches, especially on the part of Browne. Such understated approaches are required because nothing about Sir John, whether it is his appearance or his plan to turn his son's affections from the daughter of Haredale, his impecunious, longtime, Catholic enemy, is ever revealed in a straightforward manner. The first portrayal of Sir John, done by Cattermole, is well calculated to pique our curiosity and create an aura of suspense. Cattermole provides a grand setting-the Maypole Inn's finest room-but turns the seated genteel figure away from the viewer (X, 84) (fig. 54). The next few pictures of Chester, rendered by Browne, better indicate his appearance as well as his importance. First, Sir John is lounging jauntily at the breakfast table, seen not quite full face (XV, 123) (fig. 55). Unlike most of Browne's scenes, which tend to be crowded, the figure here fills the space. The only character the artist had previously given such solitary treatment was Hugh, depicted as he dozed during his menial Maypole job (XI, 93) ${ }^{99}$ Furthermore, Hugh and Chester are linked graphically, as they will be narratively, by the artist's unusually naturalistic treatment of them both.

This link is carried out in Chester's next appearance, where he is laughing malevolently with Hugh (XXIII, 186) (fig. 56). In fact, now that Sir John is seen full face, it is clear that he somewhat resembles Hugh. This scene provides the headpiece to the fourteenth number and signals its domination by Chester in both illustrations and text. The corkscrew formed by the initial letter $T$ suggests the sinister purpose of these unlikely associates. The studied elegance with which Chester enters his carriage in the next picture (XXIII, 195) (fig. 57), after hearing the account of Hugh's mother's hanging and the empathic reaction to it by his dog, is maintained throughout his subsequent visit to Mrs. Varden's (XXVII, 222) (fig. 58). Browne makes all the listeners attentive to Sir John except for Dolly, who averts her head while the aristocrat blatantly manipulates her mother.

The very next illustration, by Cattermole, involves Chester with the story's other heroine, Emma Haredale, whose face, like Dolly's, is also averted, though not deliberately, from Chester. From the Vardens, Sir John has proceeded to the Warren in order to alienate Emma's affection from his son, Edward. "He had not gone far, or looked about him long, when he descried coming towards him, a female figure. A glimpse of the form and dress as she crossed a little wooden bridge which lay between them, satisfied him that he had found her whom he desired to see. He threw himself in her way, and a very few paces brought them close together" (XXIX, 237-38) (fig. 59). Instead of portraying Chester in the act of first seeing Emma, Cattermole takes his point of view from Dickens, and shows Emma as she looks to Chester, thus involving the viewer in the villain's machinations just as, later, Browne involves the viewer with the rioters by showing the mobs through Barnaby's eyes (LXVIII, 565). So absorbed is the viewer that he may not notice immediately Cattermole's weak suggestion of the Warren in the background or his Cruikshankian portrayal of Emma in the foreground. Browne takes up Sir John again after his mission with Emma is accomplished, and he is leaving the Maypole (XXX, 247) (fig. 60). He continues his subtle use of postures to suggest affinities and enmities between Dickens's characters: Chester's back is to us as is Hugh's, each has his left hand on his hip and his right hand raised; Joe Willet, meanwhile, turns away from the obsequies passing between his father and the departing guest, much as his beloved Dolly had turned away from Chester and her mother earlier.

In the final illustration of this sequence, which completes the establishment of the villain's nature and of the plot, Browne simultaneously suggests Chester's motivations and comments upon them. While the heartless father baldly lies to Edward about Emma, as he has to Emma about Edward, a volume of Lord Chesterfield's Letters lies open beside him, and a picture of Abraham on the verge of sacrificing Isaac hangs behind him (XXXII, 263) (fig. 61).

Five years-and many numbers-pass before Chester (now Sir John) again figures in the action. The next time we see him, Westminster Hall, as drawn by Cattermole, completely dwarfs him and Gashford during their awkward encounter with Haredale, though Chester's doffed hat clearly distinguishes him from his two old schoolmates (XLIII, 351) (fig. 62). Browne moves Sir John to the center of the consequent scuffle on the river stairs, individualizing him by a smirk as well as by his singular white coat (XLIII, 358) (fig. 63). As Chester's acts of personal vengeance become inextricable from public ones, however, he becomes increasingly vulnerable to close communal investigation.

Sir John's more significant reappearance in the headpiece to the eighteenth number, once again at breakfast (LXXV, 618) (fig. 64), has been carefully prepared by Dickens and Browne. Sir John's jaunty air at the earlier meal has yielded to one of anxiety. A contrasting note to the bedside setting 

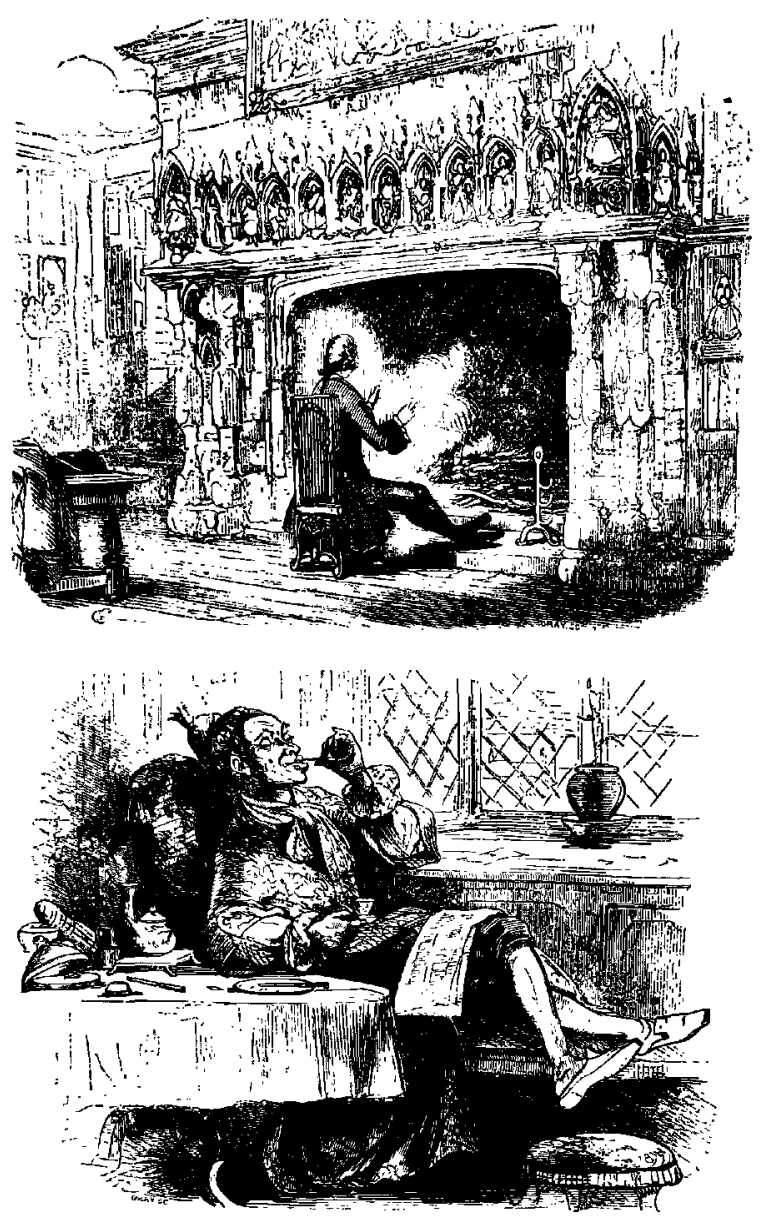

Above, top to bottom: Fig. 54. George Cattermole, 'The best apartment.' Master Humphrey's Clock, no. 51, p. 291. Wood engraving. $3 \% 8^{\prime \prime} \times 47 / 16^{\prime \prime}(9.2 \times 11.3 \mathrm{~cm})$. Fig. 55 . Hablot Browne, 'Mr. Chester lounging.' Master Humphrey's Clock, no. 54 , p. 14 . Wood engraving. $33^{1 / 4} \times 4 \frac{1}{4} 4^{\prime \prime}(8.3 \times 10.8 \mathrm{~cm})$. Right, top to bottom: Fig. 56. Hablot Browne, 'Mr. Chester dressing.' Master Humphrey's Clock, no. 58, p. 61. Wood

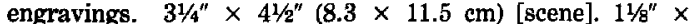
$15 / 16^{\prime \prime}(2.7 \times 2.5 \mathrm{~cm})$ [initial]. Fig. 57. Hablot Browne, 'Mr. Chester's chair.' Master Humphrey's Clock, no. 58, p. 68. Wood engraving. $314^{\prime \prime} \times 4 \frac{1}{1} 2^{\prime \prime}(8.3 \times 11.5 \mathrm{~cm})$. Fig. 58. Hablot Browne, 'Mr. Chester with Mrs. Varden.' Master Humphrey's Clock, no. 60, p. 89. Wood engraving. $312^{\prime \prime} \times$ $47 / 1 \mathrm{~b}^{\prime \prime}(8.9 \times 11.3 \mathrm{~cm})$. All by permission of the Houghton Library, Harvard University.

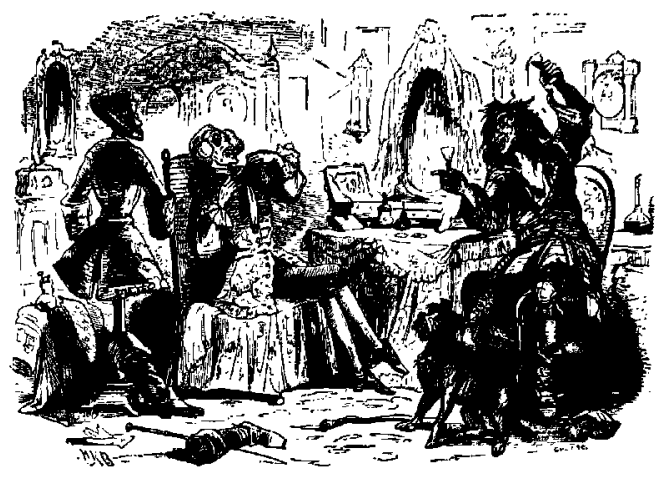

CHAPTER THE TWENTY-THIRD.
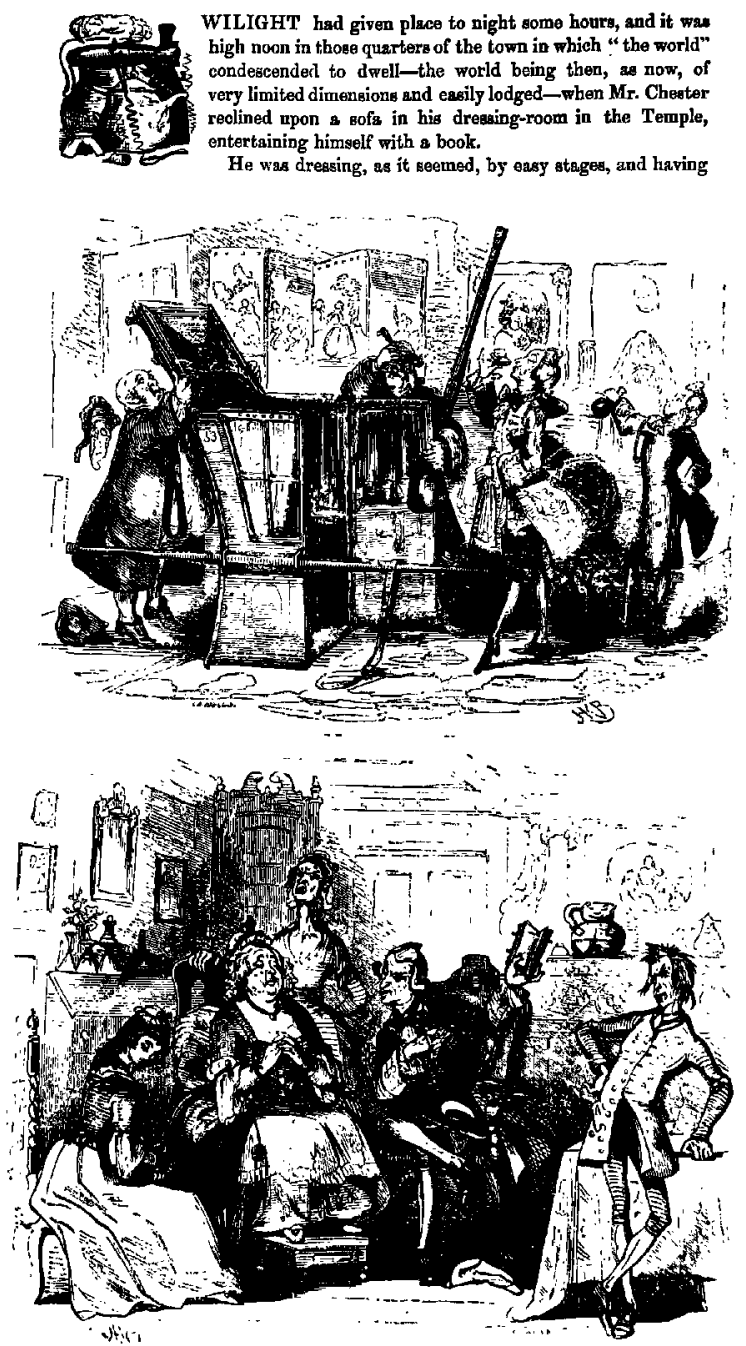

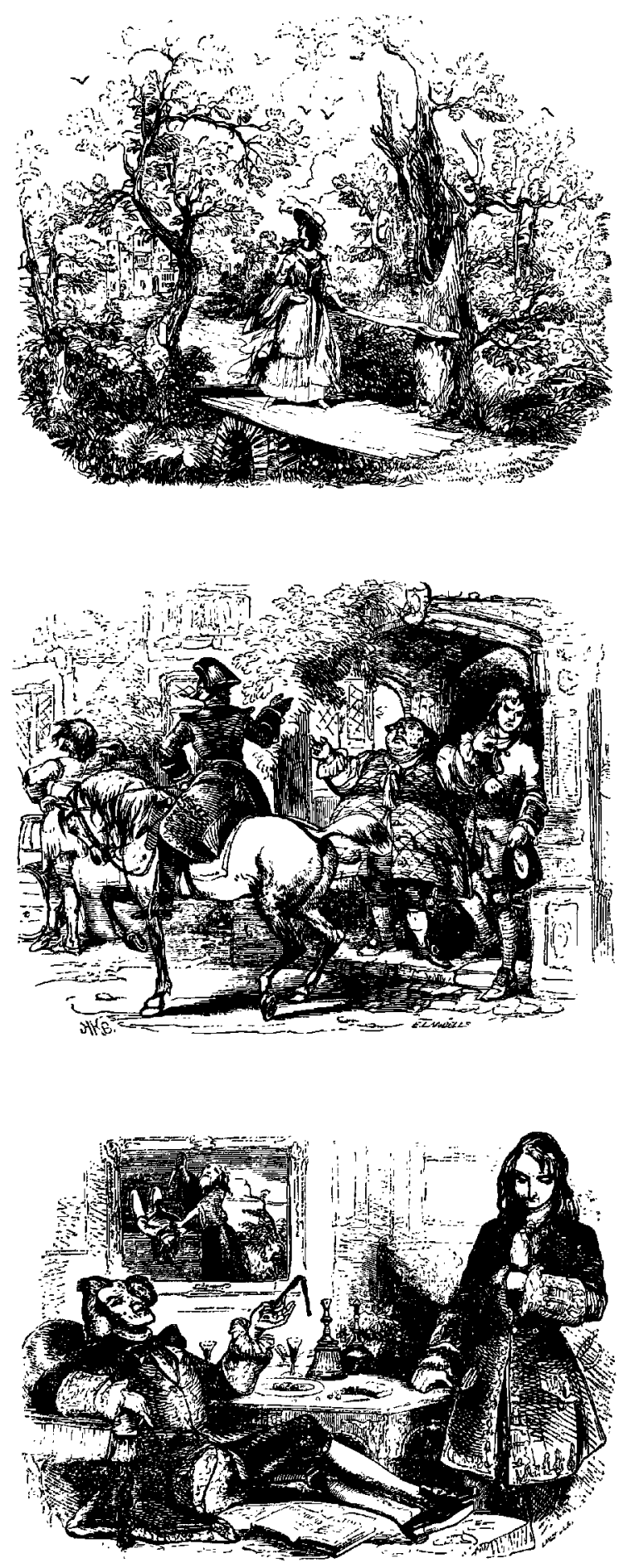
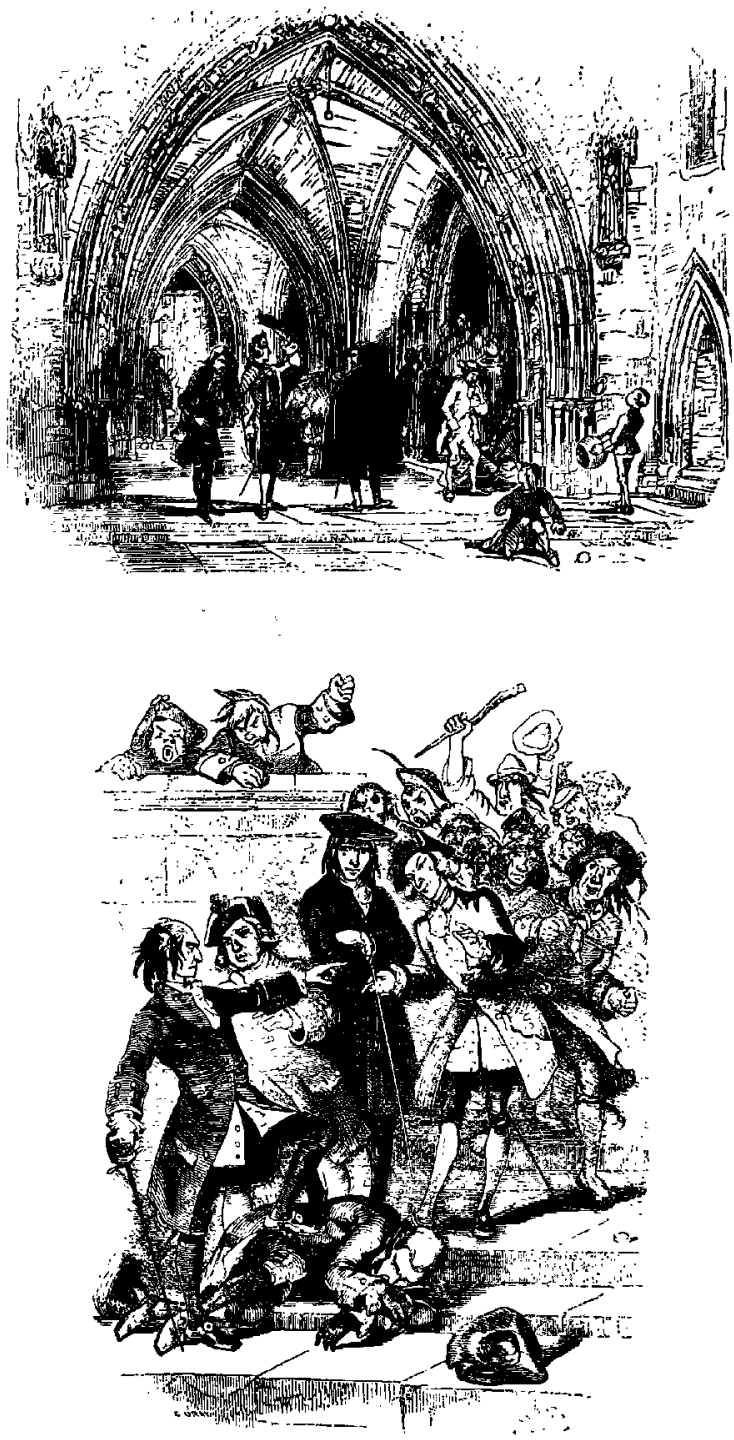

Left, top to bottom: Fig. 59. George Cattermole, 'Miss Haredale walking.' Master Humphrey's Clock, no. 61, p. 101. Wood engraving. $35 / 8^{\prime \prime} \times 4^{1 / 2} 2^{\prime \prime}(9.2 \times 11.5 \mathrm{~cm})$. Fig. 60 . Hablot Browne, 'Mr. Chester leaving the Maypole.' Master Humphrey's Clock, no. 61, p. 107. Wood engraving. $31 / 4^{\prime \prime} \times$ $4716^{\prime \prime}(8.3 \times 11.3 \mathrm{~cm})$. Fig. 61. Hablot Browne, 'Mr. Chester and Edward.' Master Humphrey's Clock, no. 62, p. 118. Wood engraving. $3^{1 / 4^{\prime \prime}} \times 41 / 2^{\prime \prime}(8.3 \times 11.5 \mathrm{~cm})$. Above, top to bottom: Fig. 62. George Cattermole, 'In Westminster Hall.' Master Humphrey's Clock, no. 68, p. 183 . Wood engraving. $3 \% 8^{\prime \prime} \times$ $41 / 2$ " $(9.2 \times 11.5 \mathrm{~cm})$. Fig. 63. Hablot Browne, 'Mr. Haredale draws.' Master Humphrey's Clock, no. 68, p. 188. Wood engraving. $47 / 16^{\prime \prime} \times 35 / 16^{\prime \prime}(11.3 \times 8.4 \mathrm{~cm})$. All by permission of the Houghton Library, Harvard University. 


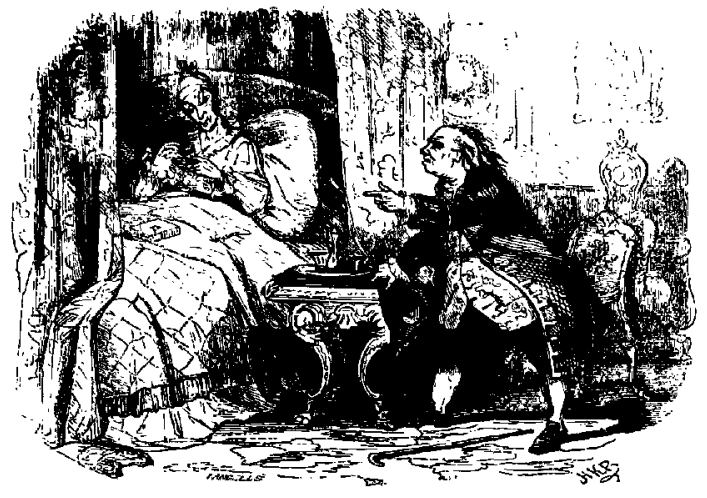

CHAPTER THE SEVENTY-FIFTH.

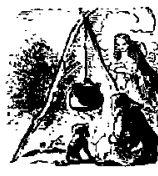

MONTH has elapsed, $\rightarrow$ and we stand in the bed-chamber of Sir John Chester. Through the half-opened window, tho Temple Garden looks green and pleasant, the placill river, gay witls boat and barge, and dimpled with the plash of many an oar, sparkles in the distanco; the eky is blue and clear; and the summer air steals gently in, filling the room with perfume. Tho very town, the smoky town, is radinnt.

Fig. 64. Hablot Browne, 'Sir John Chester's bedchamber.' Master Humphrey's Clock, no. 84, p. 373. Wood engravings. $31 / 4^{\prime \prime} \times 44^{\prime \prime}(8.3 \times 10.8 \mathrm{~cm})$ [scene]. $11 / 16^{\prime \prime} \times 1^{\prime \prime}(2.7 \times 2.5$ $\mathrm{cm}$ ) [initial]. By permission of the Houghton Library, Harvard University.

is struck by the initial design, an $A$, formed by an attractive woman, a man whose turned back prevents ready determination of his identity, and a small dog who watches a pot boiling over an outdoor fire. Gabriel Varden's presence by the bedside provides another jarring contrast. The locksmith's subsequent revelations, however, link the diner to the vagrants in the initial-Chester's gypsy mistress, who was hanged for a minor theft, their illegitimate son, Hugh, and Hugh's pet, dining on their usual harsh fare-and connect the entire scene with the first extended encounter between father and natural son. At the hands of Haredale, Sir John soon meets the violent end Hugh now wishes for him. In his tailpiece, the final illustration in the book, Cattermole follows the description of the climax of their duel quite literally (LXXXI, 677) (fig. 65), but is unable to capture the mannered malevolence that made Chester so distinctive in Browne's engravings of him and in Dickens's prose.

The three men received little gratitude from the cognoscenti for their superb coordination of graphic and textual characterization not only of Chester but of all the major figures. What contemporary praise there was of the illustrations was drowned out by the pained thunderings of Ruskin, who found the Barnaby engravings characteristic of the degraded state of popular art. According to him, Dickens's "monstrous" narrative inevitably inspired morally and

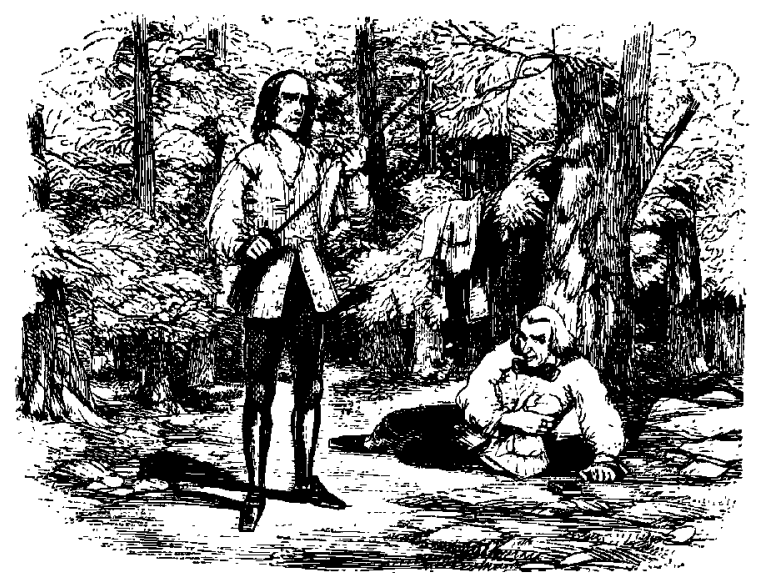

Fig. 65. George Cattermole, 'Death of Sir John.' Master Humphrey's Clock, no. 87, p. 415 . Wood engraving. $31 / 4^{\prime \prime} \times$ $4 \% 16^{\prime \prime}(8.3 \times 11.6 \mathrm{~cm})$. By permission of the Houghton Library, Harvard University.

aesthetically "ugly" illustrations, which appealed only to degraded readers.

The cheap popular art cannot draw for you beauty, sense, or honesty and for Dolly Varden or the locksmith, you will look through the vignettes in vain. But every species of distorted folly and vice-the idiot, the blackguard, the coxcomb, the paltry fool, the degraded woman,-are pictured for your honourable pleasure in every page with clumsy caricature, struggling to render its dullness tolerable by insisting on defect,-if perchance a penny or two more may be coined out of the cockney reader's itch for loathsomeness: ${ }^{100}$

Ruskin was so blinded by his flat dislike of the book that he seems to have overlooked the frequency with which Dolly (XX, 165; XXI, 171; XXVII, 222; XXXI, 250; LIX, 492; LXXI, 592; LXXVIII, 649) and her father (III, 32; IV, 41; XII, 341; LXIV, 528; LXXV, 618) are depicted. Indeed, the pictures of Dolly won the heart of her generation; she was such a popular heroine that Browne featured her in a series of separately published plates in 1848, and many other Victorian artists portrayed her on canvas. ${ }^{101}$ Ruskin's impassioned fury is indeed surprising. Browne, whose relatives, the Bicknells, had been so kind to Ruskin, might have expected better treatment; and as for Dickens, he surely tried harder than any other writer ever had to expand the moral possibilities of popular graphic art.

The especially close relationship of print and picture ended with Barnaby Rudge and the conclusion of Master Humphrey's Clock, whose varied subjects had revealed Browne's versatility in ways a single narrative might not have done. ${ }^{102}$ On top of all the other pressures of his life, the 
weekly enterprise exhausted Dickens. The overall strain, perhaps, accounts for his odd reaction to Browne's initial letter for the sixty-fifth chapter of Barnaby, a $D$ formed by Barnaby and his father as they waited for rescue in a prison archway (LXV, 533). In a letter returning the sketch to Chapman, Dickens alluded not only to the drawing, in a series of postscripts, but he also warned the publisher against his approaching marriage:

P.S. PAUSE PUT IT OFF

P.P.S. EMIGRATE

\section{P.P.P.S. -AND LEAVE ME THE BUSINESS- \\ I MEAN THE STRAND ONE. ${ }^{103}$}

It was not accidental that Browne's prison scene (one of so many in Barnaby Rudge-LVII, 481; LXII, 507; LXIII, 610; LXXIV, 613; LXXVI, 631) ignited an explosion in Dickens more amusing but no less hysterical than Ruskin's. Though remote in time and circumstance from the Marshalsea of his youth or the Newgate of his fiction, he probably was beginning to feel oppressed by two other prisons of his own creation: his marriage, increasingly unsatisfying since the death of his wife's sister, Mary Hogarth; and his work, overwhelming now that he was obligated to meet a weekly deadline and to sustain a growing reputation and family. It cannot be coincidental that Dickens's next tale of historical rebellion, A Tale of Two Cities, in 1859, was written just before he ended his marriage and curtailed the amount of his writing.

After concluding Barnaby in 1841, Dickens wound up Master Humphrey's Clock and partly followed his own advice to Chapman by planning a trip to America in 1842 . Browne was not idle during Dickens's absence. His able association with the author had won him more commissions and fame in a few years than most of his colleagues acquired in a lifetime. With Dickens away, he found time to pursue other artistic interests. One of his paintings appeared in the 1841 Royal Academy exhibit; he submitted at least one historical cartoon to the Westminster Hall competition in 1843. He also strengthened his professional and personal ties with other writers-Harrison Ainsworth, whom he had met through Dickens during their work on Pickwick and, above all, with Charles Lever. Dickens had said nothing when Lever's publishers issued Harry Lorrequer in a style and format that closely imitated his own, right down to the fact that it came out in monthly numbers and included two illustrations by Phiz. Indeed, it was Lever who worried that Browne's delineations of his hero too closely resembled Nicholas Nickleby in appearance. ${ }^{104}$ But needless to say, when Lever's publishers ran an advertisement, a copy of which appeared on the back cover of the November, 1841, issue of Master Humphrey's Clock, which quoted a reviewer's statement that he "would rather be the author of [Lorrequer] than of all the 'Pickwicks' and 'Nicklebys' in the world," Dickens was furious. When Lever invited Dickens to join Browne on a visit to Brussels, the author not only refused the invitation but protested the publishers' underhanded methods of competition. ${ }^{105}$ Yet Dickens never protested when Browne worked for competitors. He probably was convinced-with considerable justification - that his own better material and closer supervision inspired Brown to produce illustrations superior to those he provided for Ainsworth and Lever.

Browne undeniably, however, was more comfortable working with authors who were more easily satisfied with his illustrations than Dickens. Certain professional and temperamental disparities, which subtly undermined Dickens's personal relationship with his principal illustrator, had revealed themselves even before the American trip. The author liked to base even his most fantastic creations on realistic figures and locales. Browne, on the other hand, relied increasingly on his memory and imagination, and only occasionally felt compelled to study anything. ${ }^{106}$ Dickens scanned Browne's work from sketch to print with extraordinary care; the artist so lacked curiosity about the final appearance of his own work that finished numbers forwarded to him often remained uninspected for days. ${ }^{107}$ To Dickens, obsessed as he was with the importance of illustrations to his work, Browne's attitude seemed overly casual. When asked later why he had burned most of his letters from Dickens, Browne's reply was characteristic: "As they were almost solely about illustrations, I did not at the time attach any importance to them, nor did I think any one else would." ${ }^{108}$ Dickens was constantly preoccupied with making the best possible financial arrangements for himself. Browne not only rarely raised his fees, but considering his earnings sufficient for his simple rural life, despite his nine children, he often took less than he deserved. ${ }^{109}$

Dickens saw far less of Browne socially in the 1840's after the artist married Susannah Reynolds and retreated increasingly further into the countryside on account of his wife's health, their growing family, and his own leisure interests. ${ }^{110}$ Browne, like Seymour, loved fishing and hunting, recreations Dickens and his urban circle did not relish. Browne, like Charles Lamb, preferred reading plays to seeing his conception of them violated by a stage performance; hence, he was a notable exception among Dickens's friends in that he rarely joined Dickens's theater parties and never participated in his amateur theatricals. ${ }^{111}$ 
Dickens liked to travel; Browne rarely left home, except on brief excursions to the Continent or Ireland and he rarely accepted the author's invitations to join him during summer holidays. ${ }^{112}$ Yet Browne, though often shy, was not antisocial. Charles Lever's brand of effervescence, for example, apparently better dispelled the artist's reserve than Charles Dickens's (fig. 66). When Lever invited him to Brussels for a boisterous round of parties as well as work on a new novel, at the time of the Lorrequer tension, Browne not only dared to ask Dickens for his Clock subject before the weekend, to get an early start for Belgium, but requested an extra week's holiday as well. ${ }^{113}$ After another such trip to the Continent, Browne captivated the urbane Mary Russell Mitford with his unflagging store of anecdotes about his visit. ${ }^{114}$ The artist never seems to have shown himself to such advantage in the company of Dickens or Forster (who always referred to him as "Mr. Browne" and whom Browne privately called "little Dr. Johnson") ${ }^{115}$ or any of their friends. Eventually, as he moved further away from London, and further into himself, he rarely showed himself at all in artistic circles.

Personal bonds between the two men accordingly weakened over the years. Browne's children, in contrast to those of many of Dickens's other illustrators, had no affectionate recollections of the famous author. Unlike
"Uncle Bob" Young or Lever, Dickens only visited the Browne family on business; on such occasions, the artist's children caught only glimpses of an imposing figure, splendidly dressed compared to their father, who was utterly heedless of his appearance. Even from afar, they sensed the innate difference between their father and the hyperenergetic author. ${ }^{116}$

Yet Browne was to go on illustrating Dickens's major novels for almost two more decades. Dickens's 1840 invitation to George Cattermole, his elegant friend and a relative by marriage, to help illustrate Master Humphrey's Clock had not been an attempt, contrary to Buss's assertion, to "refine" Boz or "slight" Phiz. ${ }^{117}$ In the years ahead, Dickens would solicit many other artists, most of them friends, to illustrate his Christmas books, arrangements perfectly consistent with that "regard" he felt "bound to pay to Mr. Browne." 118 Indeed, the fact that Dickens did not begin to invite his more intimate and famous artist friends to collaborate with him at all until the mid-1840's, and then only on brief holiday or travel productions, suggests his high opinion of Browne's talents or at least an effort to conserve them. Certainly no one praised these holiday illustrations at Browne's expense; and doubtless more than one reader missed "the humour of the pencil of Phiz."119 Dickens's closer relationships with many of his temporary illustrators,

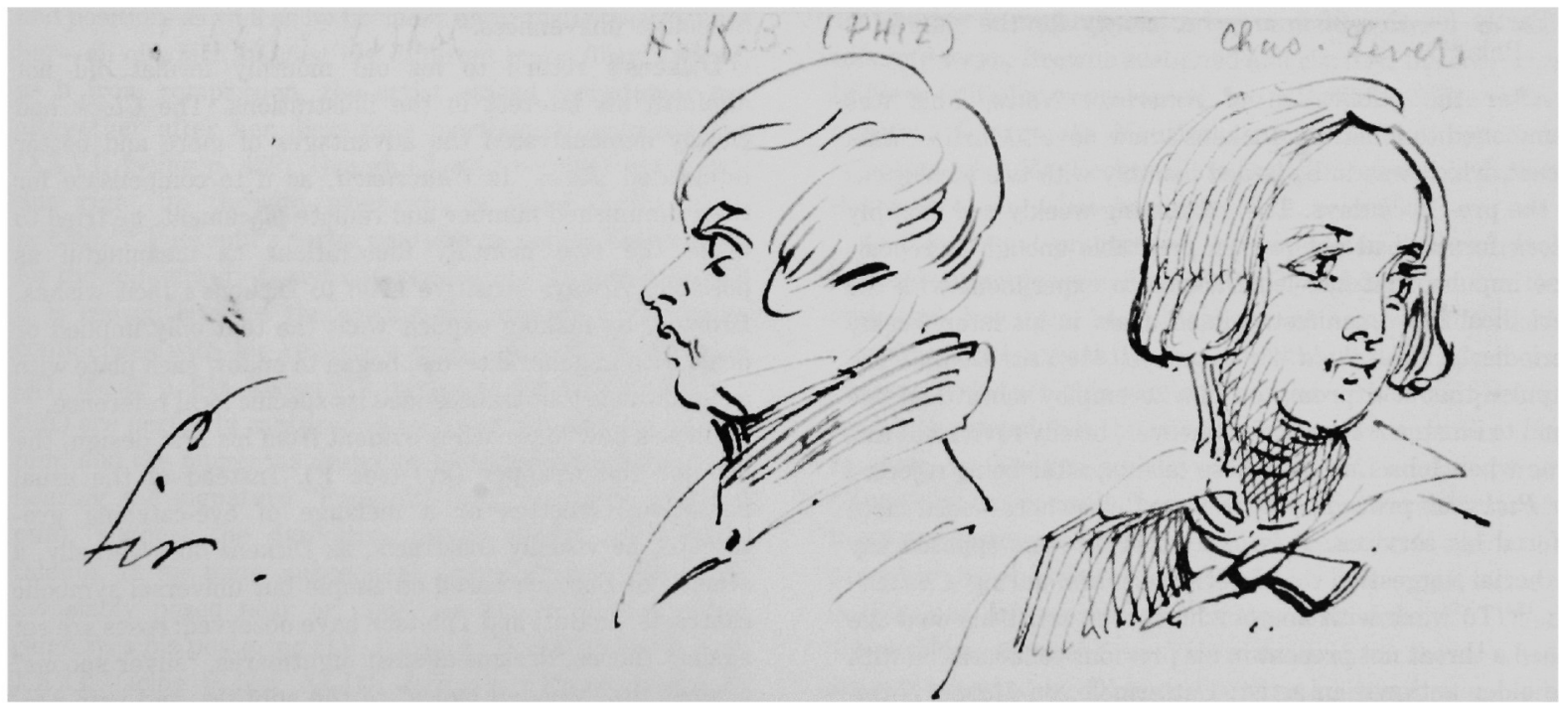

Fig. 66. Hablot Browne, Sketch of the Artist and Charles Lever. Pen and brown ink. $8^{15 / 16^{\prime \prime}} \times 55^{3 / 16^{\prime \prime}}(22.7 \times 13.2 \mathrm{~cm})$ [sheet size]. By permission of the Pierpont Morgan Library. 
however, does confirm that Dickens and Browne were always friendly but not really friends. Fond of using nicknames with his intimates, Dickens called Maclise "Mac," Stanfield "Stanny," and even the aloof Cattermole "my dear Kittenmoles"; but he never called his principal artist anything but Browne. While Dickens was writing voluminous letters from America, Browne was apparently not one of the recipients. Nor was the artist present among those many friends who welcomed the author home in June, 1842. Browne remained at Croydon, confident he would be summoned when Dickens needed him.

The author's account of his United States visit was eagerly awaited by readers on both sides of the ocean. The general expectation, according to Thomas Hood, "was that the Transatlantic Aequisitions of Boz would transpire in the shape of a Tale of American Life and Manners-and moreover that it would appear by monthly installments in green covers, and illustrated by some artist with the name of Phiz, or Whiz, or Quiz." "20 What appeared, however, was nonfietion-the journalistic American Notes-that did not contain any illustrations. Nevertheless, the piece provoked more outcry than all the earlier accounts of the New World by Mrs. Trollope, Captain Marryat, and Harriet Martineau put together. The ensuing volte-face in American regard for Dickens was facetiously reflected in the opening of "Bon Gaultier's" ballad:

We received thee warmly-kindly-though we knew thou wert a quiz,

Partly for thyself it may be, chiefly for the sake of Phiz, ${ }^{21}$

After the publication of American Notes, Phiz was summoned to illustrate Dickens's new novel, Martin Chuzzlewit, which was to be issued monthly with two etchings as in the pre-Clock days. The exhausting weekly and monthly Clock format had not proven profitable enough to repeat. The impulse that had led Dickens to experiment with the periodical form manifested itself again in his later weekly periodicals, Household Words and All the Year Round. The impulse that had prompted him to employ more than one hand to illustrate the Clock, however, briefly revived at this time when John Leech-whose talents, after being rejected for Pickwick proved so appreciated elsewhere-once more offered his services. It is likely that Browne opposed any authorial suggestion that Leech assist him during Chuzzlewit. ${ }^{122}$ To work with another humorous artist his own age posed a threat not present in his previous collaboration with the older antiquarian artist, Cattermole, on Master Humphrey's Clock. Browne could cope by himself with the requisite monthly etchings, as he had in the past on
Pickwick and Nickleby. On rethinking the matter, Dickens must have concluded it was unwise to upset his prineipal artist or subject himself unnecessarily to any extra collaborative strains. In the years to come, the author would find ample work for Leech. In the meantime, Browne singlehandedly provided the Chuzzlewit illustrations, which displayed a capacity for continued growth that approximated Dickens's own. In other respects, the author still found monthly issues sufficiently challenging. Dickens had carefully planned and even researched the historical frame and content for Barnaby Rudge. Now, going a step further, he began to structure his narrative thematically. Throughout Chuzzlewit, action and character are determined by the theme of self-interest, with Pecksniff and Tom Pinch at opposite ends of that moral scale, acting as reference points for the individuals ranged between, as Steig has suggested. ${ }^{123}$ As if the tighter structure made him feel freer, Dickens wrote with greater simplicity yet suggestiveness. Browne, as before, attuned himself to Dickens's altered approach, and reinforced it graphically. Apparently invigorated by his absence from the author and from etching for his novels, as well as his study of others' techniques, as shall be seen, the artist executed more preliminary sketches than usual, a practice that resulted in more carefully conceived designs and sharper draftsmanship. His figures, like Dickens's, were fewer in number, larger in scale, more naturalistic in appearance, yet more individualized. ${ }^{124}$ The superb quality of many of the individual etchings, whose titles were often more ironic than literal, partly compensated for their collective unevenness.

Dickens's return to his old monthly format did not diminish his interest in the illustrations. The Clock had clearly demonstrated the advantages of more and better integrated plates. In Chuzzlewit, as if to compensate for their diminished number and remote placement, he tried to make the two monthly illustrations as meaningful as possible. Always sensitive even to Dickens's tacit wishes, Browne, by making explicit what the text only implied or dealt with in general terms, began to endow each plate with a significance that transcended its specific local reference. ${ }^{125}$ Browne's new approach is evident from his first design, the one for the wrapper (xv) (see F). Instead of the usual narrative vignettes or a mélange of eye-catching grotesques, he visually constructs, as Dickens does verbally, a scheme of Fortune based on simple but universal symbolic contrasts, as Butt and Tillotson have observed: roses are set against thorns, dreams against nightmares, "silver spoons" against the "wooden ladles" of the subtitle, and vain peacocks against wise owls. ${ }^{126}$ Browne keeps the wrapper in mind throughout Chuzzlewit. For example as Steig has 
noted, in his complex frontispiece-which comes first in the bound edition but is executed last in serial publication-the roses and thorns appear again, indicating symbolically the respective fates of Pinch and Pecksniff. ${ }^{127}$

Dickens's newly restrained style might have baffled a less sensitive illustrator. But by now Browne was able to realize his intentions with more detail than the text or even the instructions suggested. The author might, for example, as he later told Frith, have had "Pecksniff in [his] eye" quite clearly. ${ }^{128}$ But his readers could not visualize this central character very readily without Browne's help, for Dickens stresses the moral significance of Pecksniff's appearance but offers few palpable visual details. The artist, unexpectedly given a free hand, did not abuse the license by gross caricature. Seizing the ironic spirit of Dickens's description, Browne clearly established the moral impostor from the outset (II, facing p. 18) (fig. 67). He wisely changed Pecksniff's cravat from white-as specified by Dickens--to black for needed visual contrast as well as to indicate the fact that the man is a widower. His clasped hands are both obsequious and complacent; his hair carefully dressed, its tuft as upright as his public facade. The poor box, ostentatiously displayed on the mantle together with a pair of scales, suggests the calculating character of his generosity. ${ }^{129}$ His daughters, by affinities and contrasts to their father, extend our perception of Pecksniff's nature. In pose and expression, Charity bears a distinct resemblance to her father-a resemblance that later developments reveal to be moral as well. Browne set Mercy apart from the pair in looks and position, as well as by his more naturalistic treatment of her-all of which suggest her different moral fiber. Indeed, as if from compassion, the artist ceased caricaturing her altogether after her disastrous marriage to cousin Jonas (XXVI, facing p. 428), though Charity receives her satiric due right up through when she is jilted (LIV, facing p. 838$).{ }^{130}$ Pecksniff's parlor provides an appropriate setting for the self-server: its self-advertisements are recalled when it is reused later as the setting for Martin's exchange of confidences with his relative's moral opposite, Tom Pinch (VI, facing p. 94). Pecksniff's righteous expression (and hair tuft) are perfectly captured in both the portrait and bust of him, and the numerous drawings of classic structures, each bearing the signature "Pecksniff fecit" (possibly an aural pun), suggest the derivative nature of his professional talents. In his many subsequent appearances, Pecksniff is invariably posed near or under an art work that either reinforces his posturing (IV, facing p. 58; IX, facing p. 140; XXXI, facing p. 502; XLIII, facing p. 670) or mocks its collapse (XII, facing p. 214 and LII, facing p. 806). Near the end, however, these artifacts, like Pecksniff's pretensions,

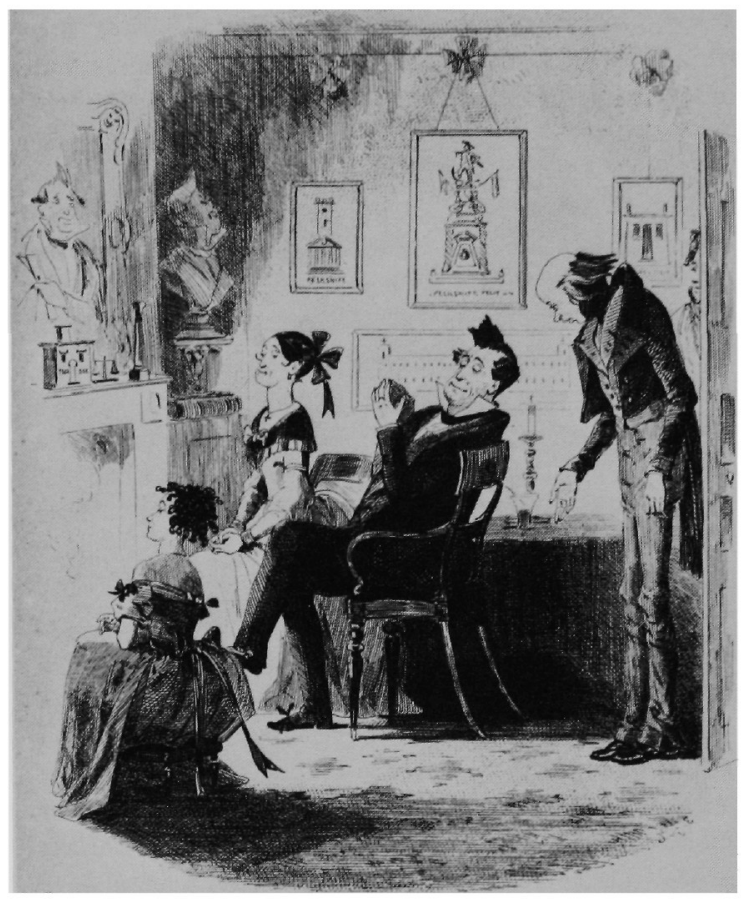

Fig. 67. Hablot Browne, 'Meekness of Mr. Pecksniff, and his charming daughters.' Martin Chuzzlewit, no. 1. Etching. $5 \% 16^{\prime \prime} \times 4{ }^{1 / 1}(13.5 \times 10.8 \mathrm{~cm})$. By permission of the Houghton Library, Harvard University.

are sparser in number and more remotely placed. In such concrete ways, Browne sustained and clarified the character Dickens initially represented too abstractly. The artist deserves George du Maurier's tribute: "One may have forgotten what Mr. Pecksniff has thought, or said, or done in this world, but what he looked like, never!"'31

As Chuzzlewit progressed, Browne often demonstrated such resourcefulness in illustrating Dickens's prose. For the first time, however, he also appears to have reinforced his own imagination with ideas from other artists, past and present. Whether this was a conscious or osmotic process cannot be proved, but the effect on his work is apparent. For example, as Steig has observed, many of his plates from Chuzzlewit on, not only the ones involving Pecksniff, testify to a more systematic and increasing application of lessons he probably absorbed from Hogarth and his heirs, most evident in his use of meaningful background detail. ${ }^{132}$ These "Hogarthian touches," as Victorians termed them, which are not specified by Dickens's text or his instructions, add relevant and succinct graphic commentary on the scenes at hand, and, in at least one instance, on the novel as a whole. 
Posters-"Last Appearance/Every Man in his Humour" and "Lost, Stolen, Strayed/Reward"-comment crudely but humorously on Mark's reluctant departure from the locale of the Blue Dragon (VII, facing p. 118). The ace of hearts Jonas reveals during his card game with Charity suggests her mistaken interpretation of his intentions (XI, facing p. 186) and withered branches testify to the quality of his ultimate marriage to Mercy (XXVI, facing p. 428). The book titles in Moddle's room-Werther's Sorrow and Childe Harold -warn of that suitor's instability (XXXII, facing p. 514), which is substantiated by his jilting of Charity, in turn confirmed by the caption "Gone" on the framed scene of a fisherman losing his catch and the picture of Aesop's dog just before losing his bone (LIV, facing p. 838); and those volumes that fall with Pecksniff in the narrative's climax (LII, facing p. 806)-Paradise Lost and Tartuffe-sum up the moral action of Chuzzleurit. ${ }^{133}$ From the first page, Dickens had stressed that the Chuzzlewit family, like all men, were direct vice-ridden descendants of Adam and Eve. To be a Tartuffe as well, like Pecksniff, is to insure that paradise in this world is forever lost. Only by ridding oneself of pride and selfishness - as Tom Pinch already has, as young Martin does in his "fortunate fall" in the American Eden, as Charity never will — can one regain a paradise of earthly love and trust.

In manifesting his new independence of the letter, though never the spirit, of Diekens's text, Browne may have fortified his initiative not only with Hogarthian devices but those of contemporary artists like Cruikshank. It has long been noted, for example, that Browne's treatment of the pawnbroker's shop (ironically called "house"), where young Martin encounters Tigg after fleeing Peeksniff's hearth, is far more than a mere representation of Dickens's description (XIII, facing p. 224) (fig. 68). ${ }^{134}$ The author had not referred to the dishevelled, tipsy laundress, probably pawning her irons to get more drink, nor the ragged musician, doubtless dependent on the violin he is about to pawn, nor the workman with the tattered hat just slipping in the door; nor had he included the Hogarthian wall decor-the pictures of a Bacchante squeezing grapes into a wine cup or a bailiff "Distraining for rent"-which suggest the common motivations of the shop's clientele. Though Browne clearly was not drawing on Dickens for these inspired details, as Steig suggests, he may well have tapped Cruikshank, who had portrayed a similar scene in the Sketches by Boz (S, XXIII, facing p. 190) (fig. 69) and included an illustrated verse "Distraining for Rent" in his Comic Almanac just three months prior to Browne's composition. ${ }^{185}$ Indeed, both artists' interiors have in common an open door with the traditional triple balls sign; a long counter and separate cubicles; a pair of clerks, one of whom writes in a large ledger; and two shabby customers-women leaning on their elbows and behatted workmen lingering on the periphery. But such similarities are inevitable if a typical shop is to be accurately portrayed. The differences between the two scenes are far more remarkable.

If Browne, in fact, studied Cruikshank's earlier composition, it evidently served only as a point of departure. He was just as aware, as was the veteran artist of the Sketches, of the disparate purposes Dickens would want the same setting to serve in Chuzzlewit. Cruikshank's design is properly static, suitable to the inherent tragic weariness of the three female customers, of different ages but similar appearance, which graphically underlines the author's point about perpetuated degradation in London life. ${ }^{136}$ Browne's composition, by contrast, is necessarily livelier. The implications of Martin's presence in the degraded shop are far less tragic-a temporary setback, not a permanent condition. The artist deepens the dramatic interest not only by providing contrastingly poignant glimpses of the more regular customers, similar to their counterparts in the Sketches, but variety of movement as well-the proprietor tilting his chair, his partner bending, the baby feeding, Tigg peering, Martin shrinking-all of which are further vitalized by a dramatic play of light and shadow. Such visual stimulation, appropriate to this moment in Chuzzleurit, would have detracted from the different point of the episode in the Sketches. It seems therefore irrelevant to praise either of these illustrations at the expense of the other. ${ }^{137}$ Whatever Browne may have learned from Cruikshank or others' treatment of familiar materials, he could be ingenious at reshaping them to his and Dickens's purposes at hand.

The artist manifested this ability elsewhere in Chuzzlewit, as did Dickens himself: in his portrayals of Sairey Gamp, which were a crucial element in her notable success, which, in turn, sustained the novel's precarious popularity. The author relied almost entirely on the midwife's manner of speech to fix her in the reader's imagination, as had Cruikshank, to a partial extent, in his verbal characterization of Sarah Toddles in his Omnibus two years before. Indeed, as Jerrold suggests, it is likely that Dickens found this character's name and manner a source of inspiration. ${ }^{188}$ But Cruikshank's numerous portrayals of his diminutive creation, whose face is completely hidden by her oversized stiff-brimmed bonnet, could scarcely have helped Browne, (though he made certain that her umbrella and glass for spirits, the traditional accessories of her profession, were inclided in his famous 'Mrs. Gamp propoges a toast' [XLIX, facing p. 758]) (fig. 70). Lacking further physical details 


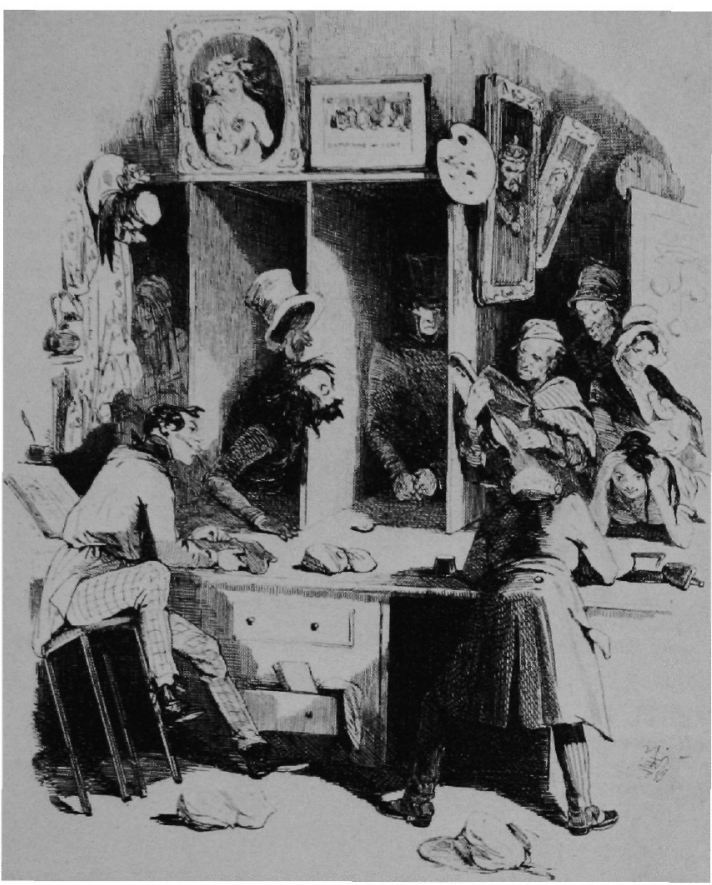

Fig. 68. Hablot Browne, 'Martin meets an acquaintance at the house of a mutual relation.' Martin Chuzzlewit, no. 6. Etching. $51 / 4^{\prime \prime} \times 4 \frac{1}{13} 6^{\prime \prime}(13.4 \times 10.6 \mathrm{~cm})$. By permission of the Houghton Library, Harvard University.

from Dickens, the artist, as John Harvey has demonstrated, probably borrowed them from Daumier, whose finer irony Thackeray had, in 1839 , publicly urged Browne to study. ${ }^{139}$ By the time of Chuzzlewit in 1843 , the artist no doubt was more familiar with the work of the French caricaturist. In 1840 he had illustrated a novel whose roguish protagonist Daumier had used in a series of caricatures throughout the previous decade (and, indeed, Daumier's conception of this rascal may well have influenced Dickens's creation of Montague Tigg as well as Browne's portrayal of him). ${ }^{140} \mathrm{In}$ 1842, four months after the final bow of Cruikshank's Sarah Toddles, but two years before the advent of Mrs. Gamp, the French artist had portrayed a memorable 'Garde-Malade' (fig. 71) that, as Harvey has shown, must have helped Browne delineate Sairey more than Dickens's generalized description of her appearance. Not only is Mrs. Gamp viewed from the same angle as Daumier's figure, but she is given from the first the same ample shape as well as a similar rugged, creased face with its shrewd expression and cleft chin (XXVI, facing p. 428 and XLIX, facing p. 758)

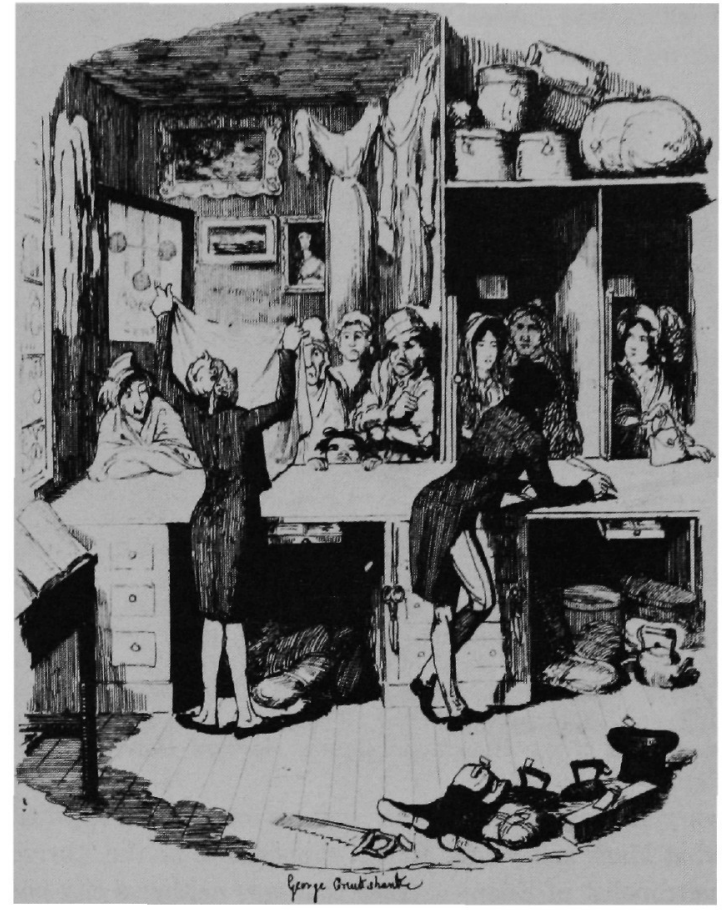

Fig. 69. George Cruikshank, 'The Pawnbroker's Shop.' Sketches by Boz, 2d series, no. 9. Etching. $41 / 2^{\prime \prime} \times 3 \frac{3}{4} 4^{\prime \prime}(11.5$ $\times 9.5 \mathrm{~cm}$ ). By permission of the Houghton Library, Harvard University.

(fig. 72). Browne was no second Daumier or Cruikshank, but from them, as from Hogarth, he displayed as great skill at adapting what he needed as did Dickens himself. Had he continued to do so as he grew older, rather than over-rely on his own or Dickens's imagination, his partnership with that author might have endured even longer than the fifteen years remaining to it.

At this stage of his career, however, the artist's imagination was fertile enough to carry on admirably when Dickens gave him minimal instructions and left him to his own devices. But the author, especially when anxious, did not perceive this yet. Readers of Chuzzlewit, disappointed at the lack of exciting characters and actions, and uncomfortable with the acid satire on domestic values, were falling away, and when the author decided to utilize more of his American experiences to spur sales, he unwisely invaded the artist's province. That Browne had never seen America should not have worried Dickens so much, as the artist's work was rarely based on strict reality. Yet the author was 

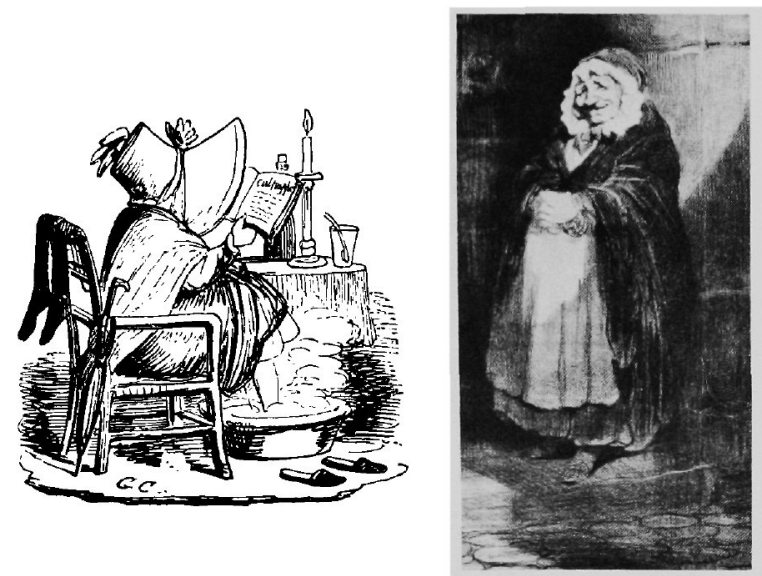

Fig. 70 (left). George Cruikshank, 'Mrs. Toddles.' George Cruikshank's Omnibus, no. 5 (September, 1841), 160. Woodcut. $1^{11 / 16^{\prime \prime}} \times 11^{13 / 16^{\prime \prime}}(4.3 \times 4.6 \mathrm{~cm})$. Fig. 71 (right). Honoré Daumier, 'La Garde-Malade.' Le Charivari (May 22, $1842)$, n.p. Lithograph. $95 / 8^{\prime \prime} \times 7^{\prime \prime}(24.5 \times 17.8 \mathrm{~cm})$. Both by permission of the Houghton Library, Harvard University.

wary of allowing Browne to trust his imagination to portray what Mark and young Martin supposed to be the "thriving metropolis" of Eden-a place that was neither a city nor a paradise-and issued unusually careful instructions. Yet, in the artist's very first illustration, which shows the adventurers studying the plan of Eden in the real estate office, Dickens failed to notice that the graceful plan itself lacked the inevitable grid structure of a new American town (XXI, facing p. 358) (fig. 73). ${ }^{141}$ Browne, however, perfectly captured the spirit of the scene with details not even mentioned by the author. The viewer, unlike the two heroes, is not too absorbed by the plan to notice the office's torn plaster and mouse, which belie the speculator's claims to posperity, and the spider web where trapped flies suggest the fate of naive buyers.

The next plate was to reveal Eden in all its squalor. Dickens described the scene at such length in his instructions that the artist was baffled. Dress, expressions, postures, actions, tools, buildings, signs, trees (both cut and uncut), the river-all were specified as if Dickens were describing the picture for the reader rather than giving instructions for it to the artist. ${ }^{142}$ "I can't get all this perspective in," Browne penciled under the précis, "unless you will allow of a long subject-something less than a mile." 143 The artist's first sketch was returned not only with the usual suggestions for alterations but with ideas about how to compress the myriad details, as well as the lines indicating the scene's desired width. ${ }^{144}$ Nothing left to his

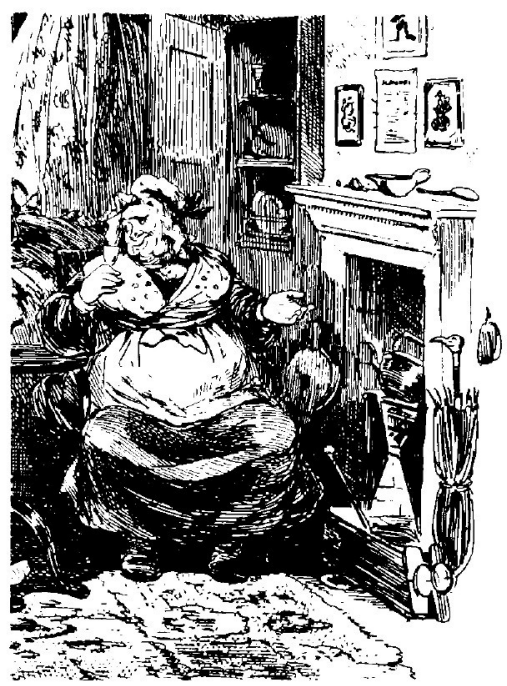

Fig. 72. Hablot Browne, Mrs. Gamp. Detail from 'Mrs. Gamp propoges a toast,' Martin Chuzzlewit, no. 18. Etching. $45 / 8^{\prime \prime} \times 4^{1 / 4^{\prime \prime}}(11.8 \times 10.8 \mathrm{~cm})$. By permission of the Houghton Library, Harvard University.

imagination, Browne produced a dutiful but uninspired picture (XXIII, facing p. 386) (fig. 74).

Browne's complicated and widely praised frontispiece for the bound Chuzzlewit volumes also reveals what he could do with a minimum of authorial guidance. Dickens concluded his narrative with an apostrophe to Tom Pinch, who, playing the organ years after the action, expresses the characters' fates in his "sounds" (LIV, 840-42). He told Browne to show Tom, the highest if colorless moral touchstone of the story, pensively playing the organ with any visual suggestion of his past that the artist wished to include. ${ }^{145}$ The artist not only indicated Tom's history by applying the rose motif of the wrapper to indicate his good fortune, but he managed to include and individualize all the leading characters and scenes - over seventy in all-in a delicate oval pattern within the confines of the small allotted space. Still, Dickens was not convinced until well into their next collaboration, Dombey and Son, that he need only provide a general summary of what he wanted in a plate, trusting Browne to decide at least some details which so often made his work transcend mere representation.

Despite the harmony of Chuzzlewit's conclusion and of Dickens's collaboration with Browne throughout, Dickens's relations with his public and with his publishers were deteriorating. Browne had often surpassed himself; Dickens swore that Chuzzlewit was the best of his works so far, but 
the fact remained that their audience had dwindled. At the first sign that it was defecting, Dickens had taken Mr. Weller's advice to Pickwick to "write about the 'Merrikins as'll pay all his expenses and more, if he blows 'em up enough" ( $P P, \mathrm{XLV}, 635)$. But the author's first fictional descriptions of America, more acidly critical than American Notes, provoked more fury than profit on both sides of the Atlantic. That many American readers were incensed was only to be expected, but even Dickens's most loyal English admirers found his account biased. Worse, it increased sales only slightly. William Hall's tactless remark about invoking the repayment clause included in the Chuzzlewit contract if profits failed to meet expectation sent Dickens into a hurt rage and precipitated his subsequent departure from the firm. Even the appearance of Mrs. Gamp, a great favorite with everybody, failed to boost profits greatly or to efface the effect of the publisher's threat, made on the very eve of her appearance. Even A Christmas Carol, despite its unprecedented popularity, failed to recoup the financial

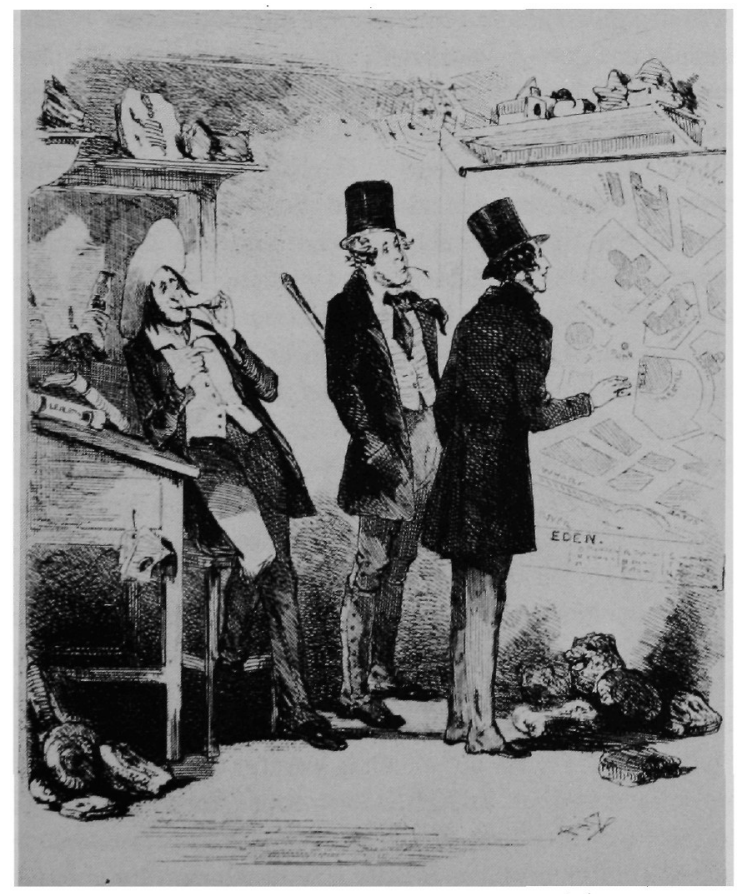

Fig. 73. Hablot Browne, "The thriving City of Eden as it appeared on paper.' Martin Chuzzlewit, no. 9. Etching. $4^{15 / 16^{\prime \prime}}$ $\times 3^{13 / 16^{\prime \prime}}(12.5 \times 9.7 \mathrm{~cm})$. By permission of the Houghton Library, Harvard University. loss. "Dickens's last book," intoned his rival, Lever, "has set the gravestone on his fame."146 His obituary, however, proved to be wishful thinking.

Dickens felt compelled to live abroad to cut down his expenses. Chagrined and concerned, he abandoned Chapman and Hall for Bradbury and Evans, and London for the Continent. In quiet Italian surroundings, however, he missed the vitality of London and the encouragement of old friends. The audience he hoped to regain seemed so remote to him that he was unable to compose even his Christmas books with his usual facility. The Chimes in 1844 and The Cricket on the Hearth in 1845 were popular but not critical successes. Dickens returned to London in the summer of 1845 to become the editor of the Daily News. His plan for the paper, as Browne wrote Lever, was that it should "extinguish, but at the same time enlighten the Times, spifflicate the Chronicle, pull down the Standard, strip the Herald, smash the Courier, gouge the Observer, and astonish John Bull." ${ }^{\text {C147 }}$ But after only seventeen numbers

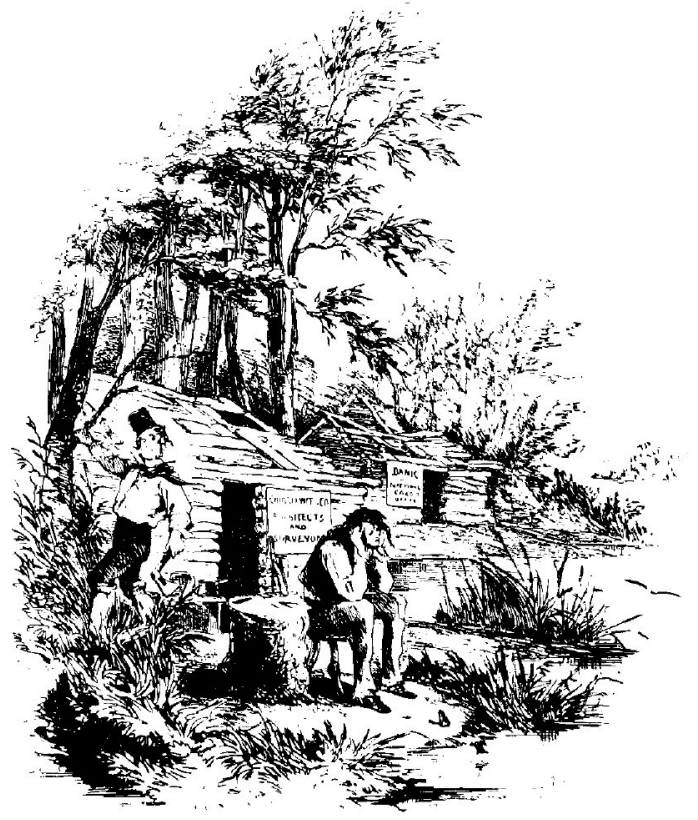

Fig. 74. Hablot Browne, 'The thriving City of Eden as it appeared in fact.' Martin Chuzzlewit, no. 9. Etching. $31 / \mathrm{s}^{\prime \prime}$ $\times 4716^{\prime \prime}(8 \times 11.3 \mathrm{~cm})$. By permission of the Houghton Library, Harvard University. 
the enterprise proved too burdensome. Dickens's Pictures from Italy, serialized in the paper prior to its volume publication, was poorly received. Once again Dickens retreated to the Continent, this time to Switzerland.

Under these inauspicious circumstances, over the summer of 1846, Dickens began Dombey and Son. Much of Dickens's anxiety about the new full-length novel, his first in three years and his first for his new publishers, manifested itself in excessive concern about its illustrations and in unusual irascibility toward his illustrator. Transferring much of his own self-doubt to Browne, he questioned the ability of the comic artist to illustrate a serious narrative. The theme of pride was to be the basis for the structure of Dombey and Son even more completely than the theme of selfishness had been for Chuzzlewit. An intricate psychological situation involving a family, rather than a single charismatic hero, was to hold the reader's interest. Anxious about setting out on what might turn out to be a profitless path, Dickens particularly wanted the illustrations to enable his public to understand his more profound purposes. There was no doubt that Browne could memorably establish clear-cut characters and actions. But could he, Dickens asked, also portray the wider range of feeling and nuance that would be present in Dombey? Could he graphically summarize more complex themes and mental states? "The points for illustrations, and the enormous care required make me excessively anxious," Dickens admitted to Forster. ${ }^{148}$ Despite-or because of-the author's anxiety, however, Browne continued to keep abreast of Dickens's development. In Dombey, and in David Copperfield and Bleak House after it, they reached the height of their collaboration together.

The problem of distance compounded Dickens's concern about Dombey. The routine he evolved to enable him to supervise Browne from afar maximized the strain on all involved. The author wrote letters from Switzerland, which, among other things, indieated the subjects for illustration, to Forster, who forwarded them to Browne in the country. The artist then sent his final sketches to Lausanne for approval. Dickens invariably had corrections and suggestions. Delays and misunderstandings were inevitable. Nevertheless, he only allowed Browne to begin to etch the plate after he had unconditionally approved the sketches, entitled them, and returned them through Forster. The etching. process was also complicated, as it had been ever since the artist moved from London in 1840. First, his London partner, Robert Young, prepared the ground and sent each plate to Browne in the country in a specially constructed box; then the artist etched it and forwarded it back to Young in the city who did the biting-in while another assistant did the lettering for the title. Neither Browne nor Forster, however, aware of the complex pressures bedeviling the author, complained about these tortuous procedures. ${ }^{149}$

Without his on-the-spot supervision, Dickens feared Browne would not work hard enough on the Dombey illustrations or else would misunderstand his intentions; and he even contemplated having the artist come to Switzerland. ${ }^{150} \mathrm{He}$ was consequently surprised when the first design, that for the wrapper, showed that Browne was "certainly interesting himself and taking pains." ${ }^{\text {151 }}$ With an incredibly complex system of contrasts (similar in shape as well as in abstract ideas to his title page for Thomas Miller's Godfrey Malvern in 1842), ${ }^{152}$ Browne allegorically portrayed the "pride goeth before a fall" moral of the narrative on the wrapper (xiii) (see F). Linking contrasted vignettes, as Butt and Tillotson have observed, is a "line of prosperity and promise [that] runs upward from the left of the centre, through the precariously balanced ledgers, to where [Mr. Dombey] sits enthroned on an office chair, on the platform of a cash box, and down through the tumbling house of cards on the right. The allegorical scenes at the foot of the design emphasize the turn of Fortune's wheel." ${ }^{153}$ The wrapper design did not commit the author to a specific plan or disclose his secrets; Florence is barely discernible and Paul's death is not revealed at all. Yet Dickens thought the design had "a little too much in it," an "ungrateful objection," as he himself admitted, but certainly in keeping with his fault-finding mood at the time; he would later recommend it as a model for the opening illustrations for each part of his fortheoming Christmas book. ${ }^{154}$

Never had Dickens been so concerned with the visual impact of an opening number. His countless directives from Lausanne reflected his fear that an undue application of graphic satire, even on comic subjects, would undermine his serious purpose. Finally settling on 'Miss Tox introduces "the Party"' as the subject for the first illustration (II, facing p. 14), Dickens particularly urged that "the Toodle family should not be too much caricatured, because of Polly," the nurse who would act in loco parentis on Mrs. Dombey's death. ${ }^{155}$ Above all, there was to be no satirizing the looks of his merchant hero, who would make his debut en famille in the second plate. What Forster termed Dickens's "nervous dread of caricature" on this score led him to suggest for the first time since, perhaps, Squeers in Nickleby a living model for the city gentleman he wanted: "The man for Dombey, if Browne could see him, the class man to a T, is Sir A-E_, of D's," he wrote to Forster; "I do wish he could get a glimpse of $A$, for he is the very Dombey." 156 The glimpse of "A" not being possible, Browne 
forwarded a sketch that portrayed twenty-nine other actual as well as imagined heads, which included examples, he noted, of the "rather bold-rather red-handsome wellmade-pompous stern-close shaved-close cut \& stuffyformal" (fig. 75). Both the effort and the humor of Browne's response seemed lost on Dickens, who soberly checked the studies he preferred. ${ }^{157}$ The artist then fashioned Dombey from a combination of the approved studies, particularly the checked specimen on the upper left, to the author's satisfaction. But his many subsequent portrayals of the hero, viewed sequentially, betray a lingering graphic confusion. ${ }^{158}$ If, in his first appearances, Dombey looks like a taller, thinner, Pecksniff without his hair tuft (III, facing p. 30; V, facing p. 54), his final ones make him resemble Trollope's Plantagenet Palliser as recently portrayed on British television (LI, facing p. 718; LIX, facing p. 840). That Dombey's carefully chosen face is rendered with an inconsistency independent of dramatic considerations (III, facing p. 30; cf. XXI, facing p. 288; cf. LI, facing p. 178 , for examples) seems to have escaped Dickens, who rested content in the knowledge that his titular hero was solemnly respectable.

Browne, proceeding with the overcautiousness Dickens was demanding, forwarded two detailed sketches of Dombey with his family, asking "whether 'twere better to have him standing thus, stiff as a poker, with a kind of side glance at his daughter (fig. 76), or sitting, as in the other?"' (fig. 77); for he had illustrated two separate but consecutive moments in the text, similar in emotional tension, if not physical activity (III, 30-32). ${ }^{159}$ They should have allayed Dickens's fear that Browne could not shift from blunt, caricature to subtle characterization. Mr. Dombey, stiffly standing to the right at Florence's entrance, might have been more imposing, but Dickens wisely chose to have him stiffly sitting in the middle, and indeed the posture and position are more suggestive of the man and his awkward relationships with his children. The merchant occupies the central position in the published illustration as in the text (III, facing p. 30) (fig. 78). His impeccable dress, faultless grooming and genteel snuff box suggest his prosperity; his pursed lips, pinched nostrils, and rigid posture his cold pride. His figure is turned toward his favored infant son in Polly's arms, who resembles him in solemn expression and upright posture. However, Dombey's eyes, as do Polly's, shift with reluctant uneasiness toward the older Florence. Halted in the tall, lighted doorway, Dombey's daughter is as excluded from her father physically by his chair back and surrounding shadows as she is emotionally by his habitual indifference to her. Her bashful face and figure, aged by its mourning dress, conveys simultaneously her yearning to join her sole remaining parent and her fear of his rejection. Directly over the heads of Polly and the baby hangs a huge, bagged chandelier, far more threatening than when it had hung on Dombey's right (see fig. 76). The fixture, earlier likened by Dickens's text to a monstrous tear (III, 23), adds a final note of ominous sadness to the unnatural group. The memorable scene is recalled in the illustrations showing Florence again entering the same door, first to be introduced to her stepmother (XXVIII, facing p. 408), then to achieve a final reconciliation with her father (LIX, facing p. 840). ${ }^{160}$ In that touching scene, Dombey is again cut off from his child by his chair back but his forlorn expression, together with the ray of sunlight linking them both, leaves no doubt about the warmth of her reception this time. 'The Dombey Family' not only perfectly illustrates the spirit of its texts but also provides points of departure and return for the developing narrative.

Readers were attracted by what they read and saw in the opening number. Florence, an appealing and sophisticated successor to little Nell, particularly engaged their affections. Dickens was elated about the favorable response. As he confided to Mitton, even Browne, "who is generally the most indifferent fellow in the world, couldn't help writing . . . a long letter about it, and saying how pleased he was," though to Forster, Dickens only remarked with condescension that "Browne seems to be getting on well."161 Both men, however, well knew how much the artist had contributed to Dombey's initial success.

In the second number Dickens relaxed his vigilant surveillance, and then regretted that he had. He did not conceal his disappointment over "The Christening Party' (V, facing p. 54) and 'Polly rescues the Charitable Grinder' (VI, facing p. 70), perhaps because both were throwbacks to Browne's (and his own) earlier comic style. The plates were so "dreadfully bad," he said, that they made him "curl his legs up" in frustration and distaste. ${ }^{162}$ They also made him unusually apprehensive about a special illustration on which he set "much store" for the subsequent issue of Dombey. The best subject for the third number, Dickens had decided, was a "quiet odd thing, Paul, Mrs. Pipchin, and the Cat, by the fire." ${ }^{\text {"163 }}$ Unaware perhaps that Browne usually made two or three sketches for each one that he sent to Lausanne, Dickens earnestly but unfairly implored the artist to think this subject worth extra effort. Shortness of time probably forced Dickens to forward the relevant text directly to the artist this once and prevented him from seeing Browne's drawing before it was etched. His reaction to the published plate (VIII, facing p. 106) (fig. 79), which he called "frightfully and wildly wide of the mark," reveals more about Dickens's hysterical mental state than about Browne's 


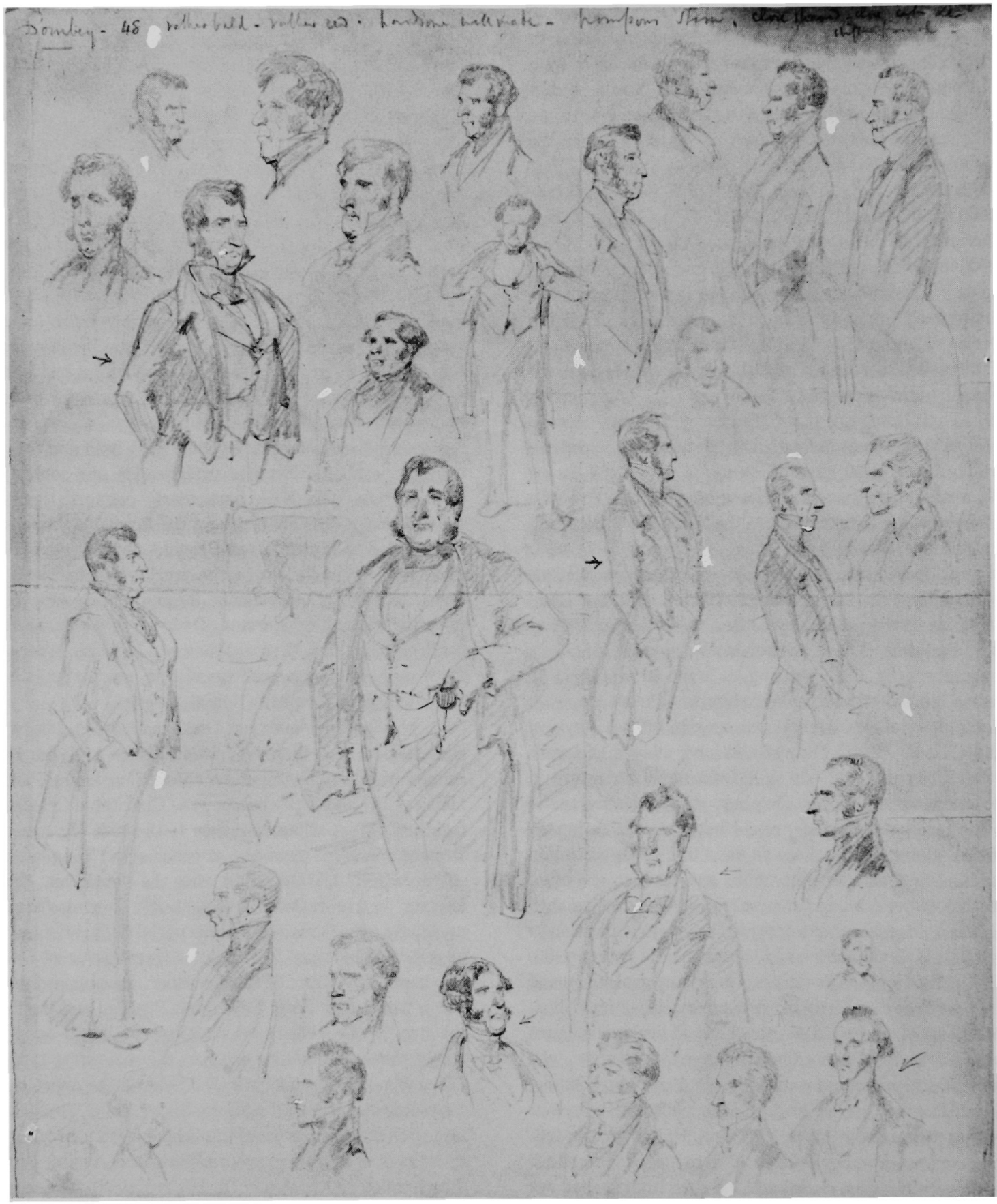

Fig. 75. Hablot Browne, Studies for Mr: Dombey. Pencil. $9^{\prime \prime} \times 73 / 8^{\prime \prime}(22.9 \times 18.7 \mathrm{~cm})$. From the Forster Collection (Library), by permission of the Victoria and Albert Museum. 


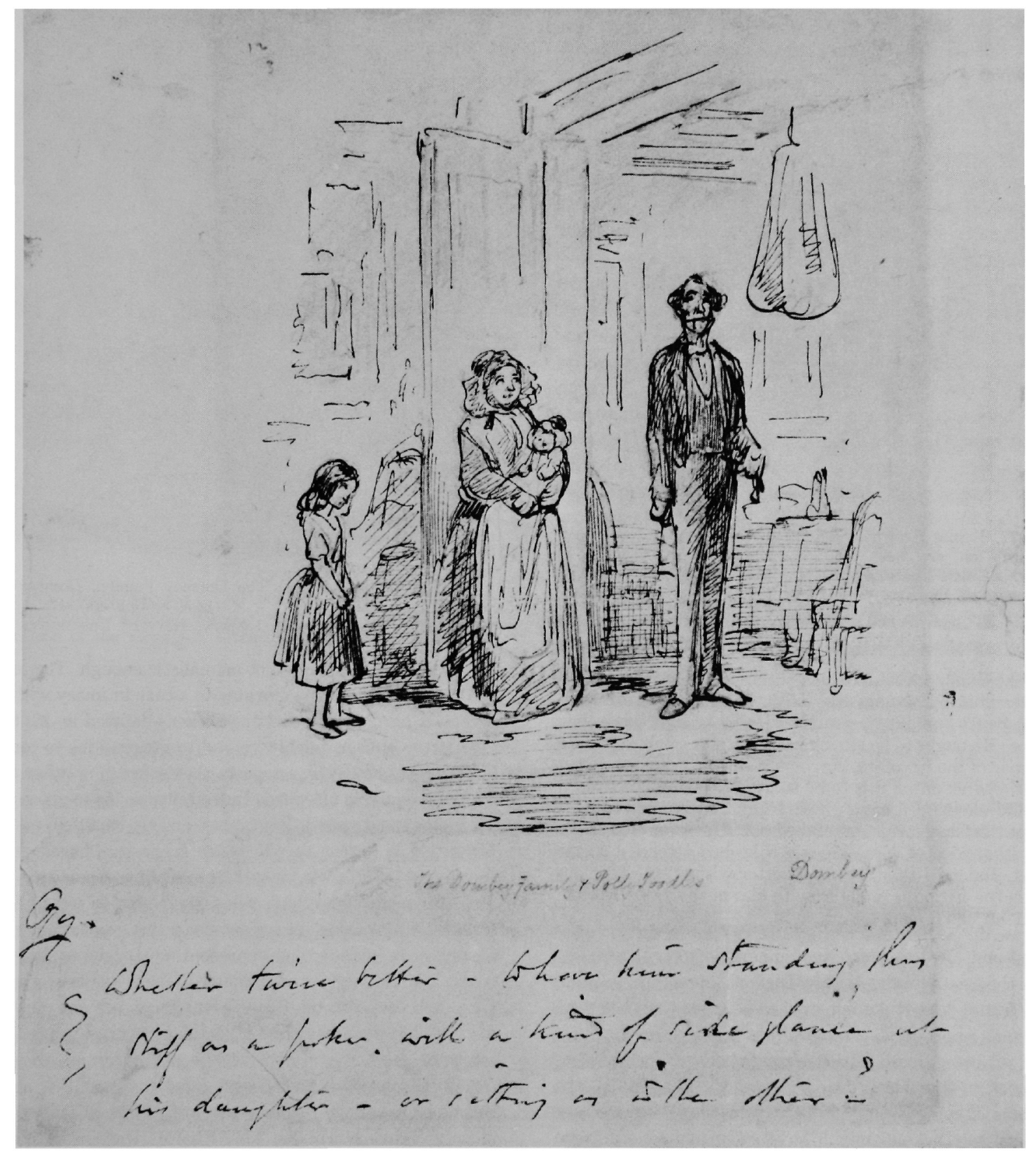

Fig. 76. Hablot Browne, Sketch for 'The Dombey Family.' Blue ink and pencil, $8^{\prime \prime} \times 6: / x^{\prime \prime}(20.3$ $\times 16.2 \mathrm{~cm}$ ) [sight]. From the Dexter Collection, Department of Prints and Drawings, by permission of the Trustees of the British Museum. 


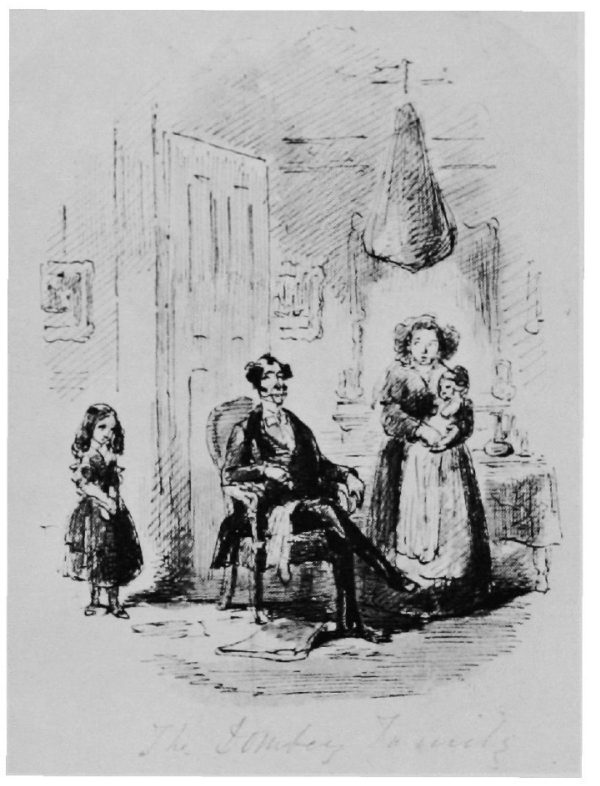

Fig. 77. Hablot Browne, Sketch for 'The Dombey Family.' Pen, black ink, and wash. $5^{3 / 4^{\prime \prime}} \times 4^{1 / 4^{\prime \prime}}(14.6 \times 10.8 \mathrm{~cm})$. From the Elkins Collection, by permission of the Rare Book Department of the Free Library of Philadelphia.

misinterpretation. "Good Heaven!” he exploded to Forster,

in the commonest and most literal construction of the text, it is all wrong. She is described as an old lady, and Paul's "miniature armchair" is mentioned more than once. He ought to be sitting in a little arm-chair down in a corner of the fireplace, staring up at her. I can't say what pain and vexation it is to be so utterly misrepresented. I would cheerfully have given a hundred pounds to have kept this illustration out of the book. He never could have got that idea of Mrs. Pipchin if he had attended to the text. Indeed I think he does better without the text; for then the notion is made easy to him in short description, and he can't help taking it in. ${ }^{164}$

'Paul and Mrs. Pipchin' was vulnerable to criticism, but not on the grounds advanced by Dickens. Mrs. Pipchin's tall, gaunt frame does make her appear younger than she was, but seems appropriate to one of her energy and appetite. Had Paul been placed in the fireplace corner, with his face shadowed by the black drapery as the text specified, the problems of composition and light would have been almost insuperable. Dickens might have complained with more justification that Browne stressed the "quiet" features of the scene at the expense of the "odd." In fact, Mrs. Pipchin is too benign, her sinister parlor too cheerful, her witch's cat

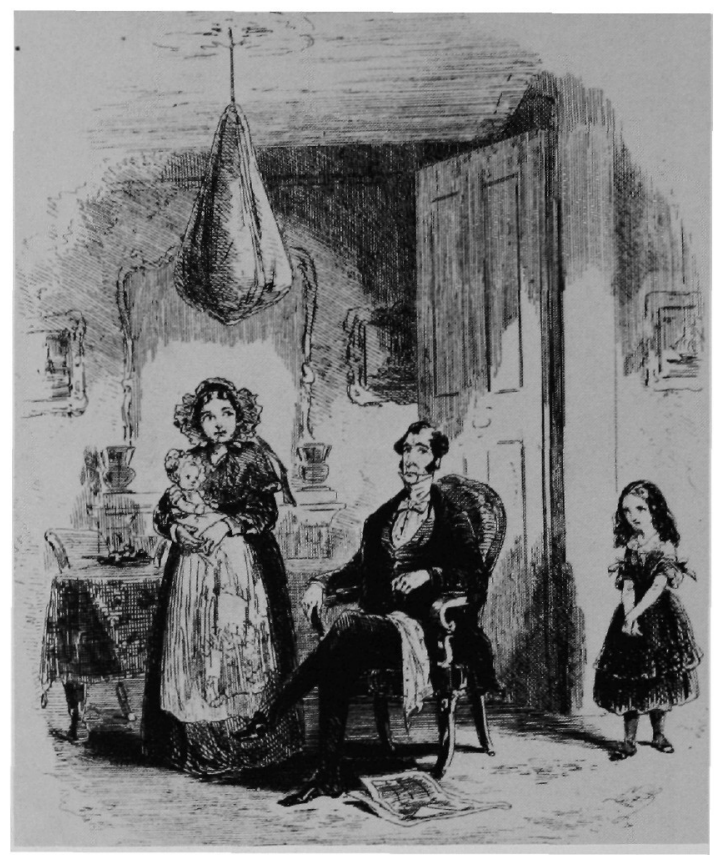

Fig. 78. Hablot Browne, 'The Dombey Family.' Dombey and Son, no. 1. Etching. $4^{15 / 16^{\prime \prime}} \times 4^{\prime \prime}(12.5 \times 10.2 \mathrm{~cm})$. By permission of the Houghton Library, Harvard University.

too tame, and her plants not animalistic enough. The effect on Paul, whom Browne elevates to a cozy intimacy with the ogress, is hardly the weird one Dickens detailed in his text.

That the author quickly veered to generalities to convey his distress, however, suggests that something other than his judgment was offended. Indeed, it was his memory that was pained and vexed. But he had not yet confided, even to Forster, the extent to which the scene was based on his recollection of his own miserable boarding experience with Mrs. Roylance, who "unconsciously began to sit for Mrs. Pipchin." 165 Browne, never privy to this revelation, could hardly have avoided misrepresenting Dickens's indelible memory of it. Forster mentioned Dickens's outburst in his Life, not to point up Browne's failings but the author's unstable mood at the time. ${ }^{166}$ Indeed, twenty years later, after the catharsis of writing the partly autobiographical David Copperfield and Great Expectations, the author selected for the frontispiece this very illustration, one out of only eight used in the 1867 Charles Dickens Edition of Dombey.

There would have been many such outbursts had Dickens remained abroad, lonely and anxious. Fortunately, the 


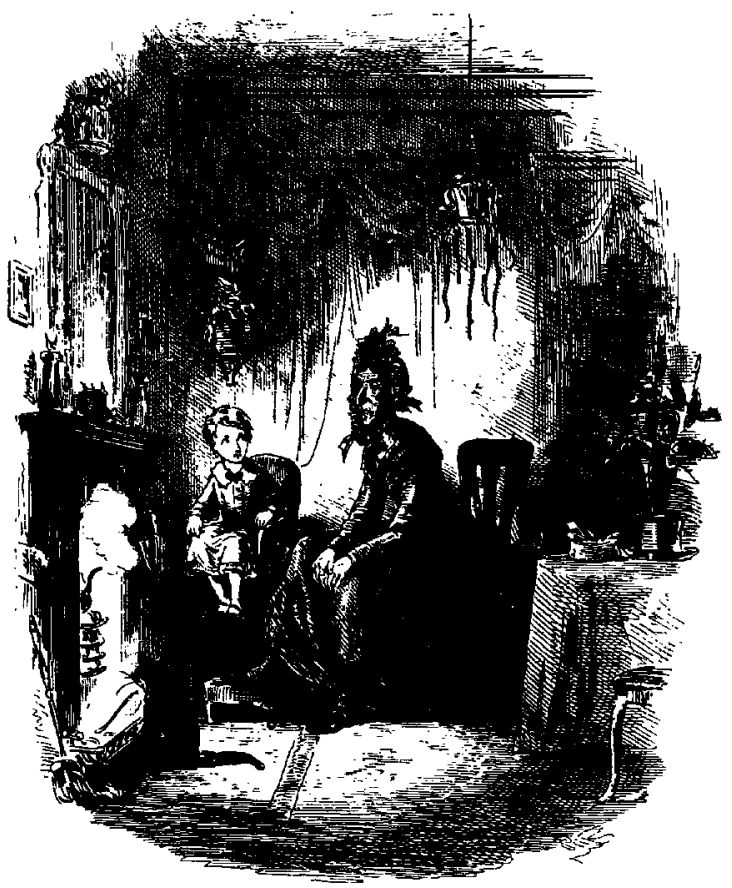

Fig. 79. Hablot Browne, 'Paul and Mrs. Pipchin.' Dombey and Son, no. 3. Etching. $415 / 16^{\prime \prime} \times 41 / 16^{\prime \prime}(12.5 \times 10.3 \mathrm{~cm})$. By permission of the Houghton Library, Harvard University.

tension was dispelled by Dickens's proposed visit to London the following month. The mere anticipation of his December holiday facilitated his writing, and this, in turn, disposed him more graciously toward his illustrator. Meanwhile, lacking time or, perhaps, beginning to perceive that Browne did better without the text, Dickens tested him by supplying only a short precis and a few explicit instructions for the scene of Doctor Blimber's students supposedly enjoying themselves on a walk. ${ }^{167}$ Freed from excessive instructions, Browne not only portrayed Blimber's traditional pedagogy in action, he incorporated a criticism of its whole mean spirit-a more difficult achievement than depicting the vicious Yorkshire school in Nickleby (VIII, facing p. 90) or the lax rural schoolroom in The Old Curiosity Shop (XXV, facing p. 199). The artist contrasts the unnatural enervation of Paul and his schoolmates with the spirited urchins somersaulting contemptuously in front of their genteel peers, and gaily flying kites and riding donkeys along the sea cliffs in the background (XII, facing p. 160). That
Browne introduced seventeen scholars instead of the ten he had explicitly requested did not bother Dickens, for he was now back in London, happily preoccupied with old friends and new ventures. He simply altered his text to read "a limited number" instead of "ten" students, and wrote his wife that "Browne's plates are much better than usual." 168

After he returned to the Continent, Dickens maintained his better humor, if not his writing facility. The subsequent Dombey numbers, however, continued to fascinate his readers. "There's no writing against such power as this -one has no chance!" cried Thackeray, throwing the number describing Paul's death onto the desk of the editor of Punch. ${ }^{169}$ The author had no time to savor such praise. He was suddenly recalled to London by his eldest son's attack of scarlet fever at boarding school. Once his child was out of danger, Dickens relished being back in London, despite the unavailability of Devonshire Terrace, which had been rented for the year, and other disruptions arising from his unexpected return. Forster and Browne, able once again to deal directly with the author, particularly appreciated his proximity and happier spirits.

Back on his native ground, Dickens tried to compensate for the irritability he had shown toward Browne. He acted far more appreciative of Browne's efforts and even abashed when his delays might inconvenience the artist. Despite his extreme busyness, Dickens's lengthy directive concerning Major Bagstock's introduction of Dombey to Edith Granger and her mother, for example, was a model of delicacy. Still wary of being misrepresented, but careful not to offend, he stressed the importance of the sketch to the narrative and his wish to inspect it, "if possible." 170 Within the week, the artist had dispatehed his sketch and received Dickens's tactful comments. The author first gently corrected two details, though admitting they were "capital in themselves"; he "grieved" that the native who pushes Mrs. Skewton around in a Bath chair (a tableau young Swinburne loved to reenact) must be in European, not native, dress; and insisted the Major must have an older, larger face. ${ }^{171}$ Otherwise, the sketch was "admirable"; the women, especially Edith, he said, were "quite perfect"; and if, for future purposes, the artist could not find the sketch of the Leamington Pump Room he had made on their Midlands trip during Nickleby almost a decade earlier, Dickens added, they might visit the spa again. ${ }^{172}$

Browne altered the sketch (XII, facing p. 288) (fig. 80) but the proposed Leamington excursion was never undertaken. Yet the fact that it was even suggested reveals the extent to which the author's disposition, rather than the 
artist's drawings, had improved since his return to London. The death of William Hall, which brought happy Pickwick days with Browne to mind rather than the painful Chuzzlewit remark, mellowed Dickens further with nostalgia. Absorbed by personal, professional, and charitable obligations, he wasted no time being querulous. In Forster's view, the artist certainly redeemed his earlier "errors" in the latter part of Dombey and Son. ${ }^{173}$ It is even clearer that as Dickens's instructions to Browne became more suggestive and less imperative, the artist responded with increased creativity.

With the introduction of Edith Granger, the most fascinating of the story's unusual number of women, Dickens began to expand the psychological scope and depth of Dombey. Some, like Mesdames Skewton, Chick, Pipchin, and MacStinger, invited caricature-indeed the only caricature Dickens permitted in this book. Most, however-Polly Toodles, Susan Nipper, Alice Brown, Florence, and, especially, Edith-all beauties of various kinds, required and received varied treatments. ${ }^{174}$ Beatrix Potter could not have been thinking of his Dombey work when she wondered "why Phiz made such a mess of some of his ladies," not the young girls but the superficially well-bred women like Edith. ${ }^{175}$ For Browne, like Dickens, now relied less and less on superficial ugliness or beauty to establish character, turning to other devices to differentiate the ladies morally and psychologically. Throughout the remaining part of the narrative, particularly in his portrayals of Edith and her comic counterpart, Mrs. MacStinger, Browne employed all kinds of Hogarthian artifacts-portraits, sculptures, posters-in a much more systematic manner than he had in his earlier illustrations for Dickens. ${ }^{176}$

Although she is the most complicated of the women Dickens had yet created, Edith must still be portrayed partly in terms of her external characteristics by the author as well as by the artist. But surrounding Edith with meaningful artifacts was an especially suitable technique for adding perspective to her character, for she is herself regarded as an artifact by her mother (as is Alice, her counterpart in so many ways [XL, facing $p$. 576]) as well as by her suitors, Dombey and his associate Carker. Dickens, more sensitive to the character-revealing potential of art since his tours on the Continent, uses artistic analogies himself to describe situations in which Edith is involved: for example, he has Carker say to Mrs. Skewton, pointing to Dombey and her daughter standing together in mutual isolation, "if you speak of pictures, there's a composition!" (XXVII, 389). ${ }^{177}$ An illustration here would be superfluous.
Nevertheless, whereas Dickens's crude anticipation of Jamesian techniques remains random, Browne employs their graphic equivalents constantly.

Dickens, himself at first uncertain what Edith's precise function would turn out to be, merely wished the artist to convey to the reader a sense of her importance. ${ }^{178}$ Thus, after her introduction to Dombey by the Major (XXI, facing p. 288) (fig. 80), Browne is temporarily limited: he can comment only on the situations in which Edith finds herself, but not on her actual character. For instance, when Edith is introduced to Florence by Dombey (at his most Pecksniffian, complete with pompous bust overhead) (XXVIII, facing p. 408) (fig. 81), the fact that she will become the girl's stepmother is suggested by the portrait, possibly of the first Mrs. Dombey, that peers out from behind its drapery, as will similar portraits at other crucial moments in Dombey's life (LI, facing p. 718; LIX, facing p. 840). ${ }^{179}$ An ominous funeral hearse suggests past as well as future events attendant on Edith's marriage to Dombey, while the Punch and Judy performance in the background parodies its quality in a picture whose special importance is signified by the fact that it is in oblong form-the first of the many that would appear in Dickens's subsequent novels (XXXI, facing p. 448) (fig. 82). ${ }^{180}$ Edith's own significance is evident by the time she haughtily appears in 'Mrs. Dombey at Home' (XXXVI, facing p. 518) (fig. 83), again, as at her wedding, slightly off-center, the vacant space in the middle suggesting the emptiness at the core of her existence. But Dickens had still not determined her ultimate fate in the story beyond her indifference to Dombey and hatred for Carker. ${ }^{181}$

By the time the two villains confer in secret, however, Dickens had decided how the three would be linked, and signaled his intention in terms so graphic that Browne's accompanying illustration was superfluous (XLII, facing p. 598) (fig. 84)-a kind of redundancy that became increasingly common in future works. Using Carker's "voluptuous" portrait that resembles Edith, the author makes clear Carker's intention to pursue her and deceive Dombey: "Blended with the look that Carker bent upon [Dombey] was a devilish look at the picture over his head, that struck upon it like a flash of lightning (XLII, 597). . . . then it shot a strange triumphant look at the picture, as appealing to it to bear witness how he led him on again, and what was coming" (XLII, 599). Since this description leaves Browne very little graphic leeway, it is hardly surprising that it is more dramatic than the illustration, in which he includes the commonplace sexual symbols 


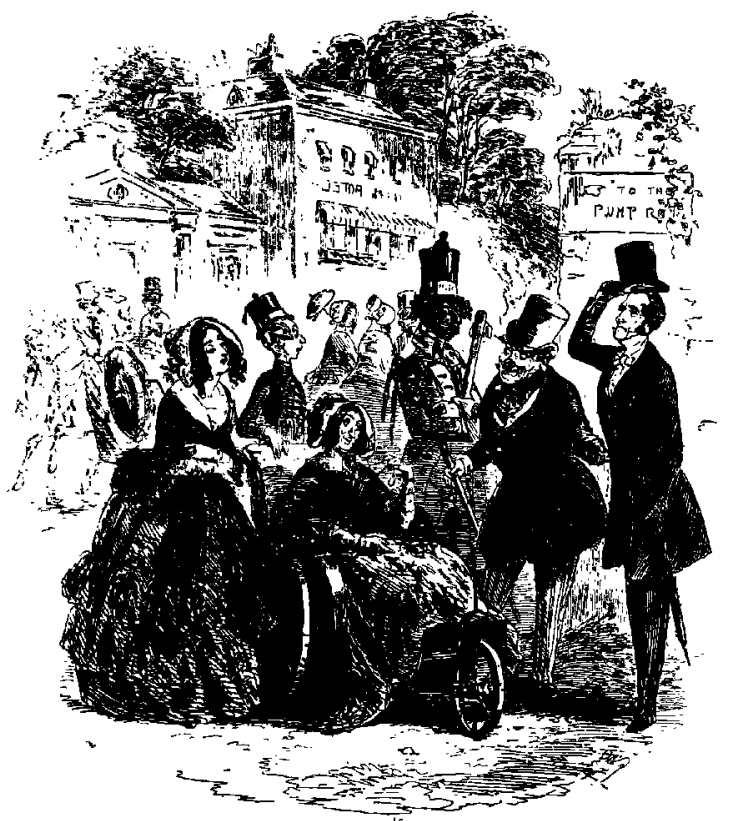

Fig. 80. Hablot Browne, 'Major Bagstock is delighted to have that opportunity.' Dombey and Son, no. 7. Etching. $5^{1 / 8^{\prime \prime}}$ $\times 4^{11 / 16^{\prime \prime}}(13 \times 12 \mathrm{~cm})$. By permission of the Houghton Library, Harvard University.

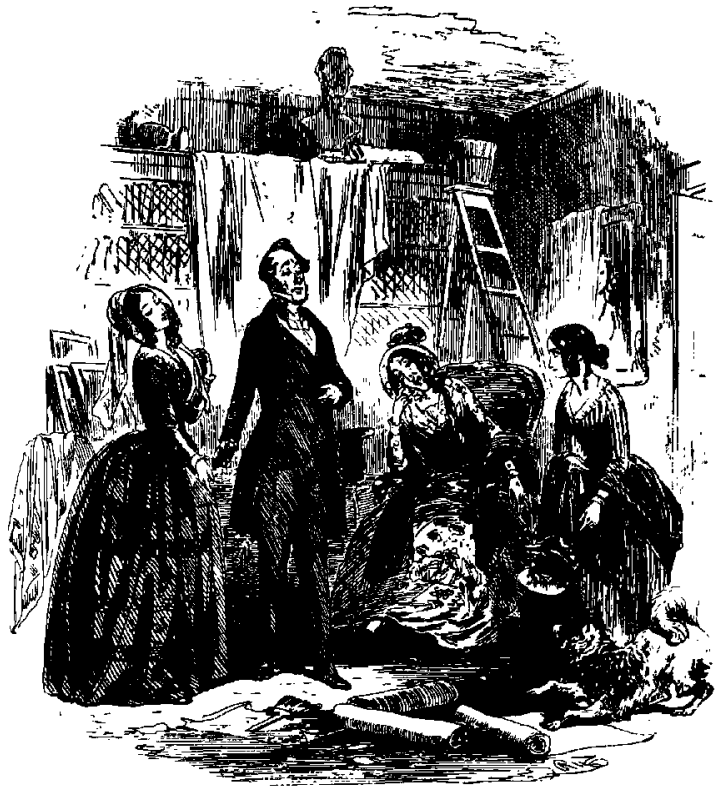

Fig. 81. Hablot Browne, 'Mr. Dombey introduces his daughter Florence.' Dombey and Son, no. 9. Etching. $45 / 8^{\prime \prime} \times$ $41 / 4^{\prime \prime}(11.8 \times 10.8 \mathrm{~cm})$. By permission of the Houghton Library, Harvard University.

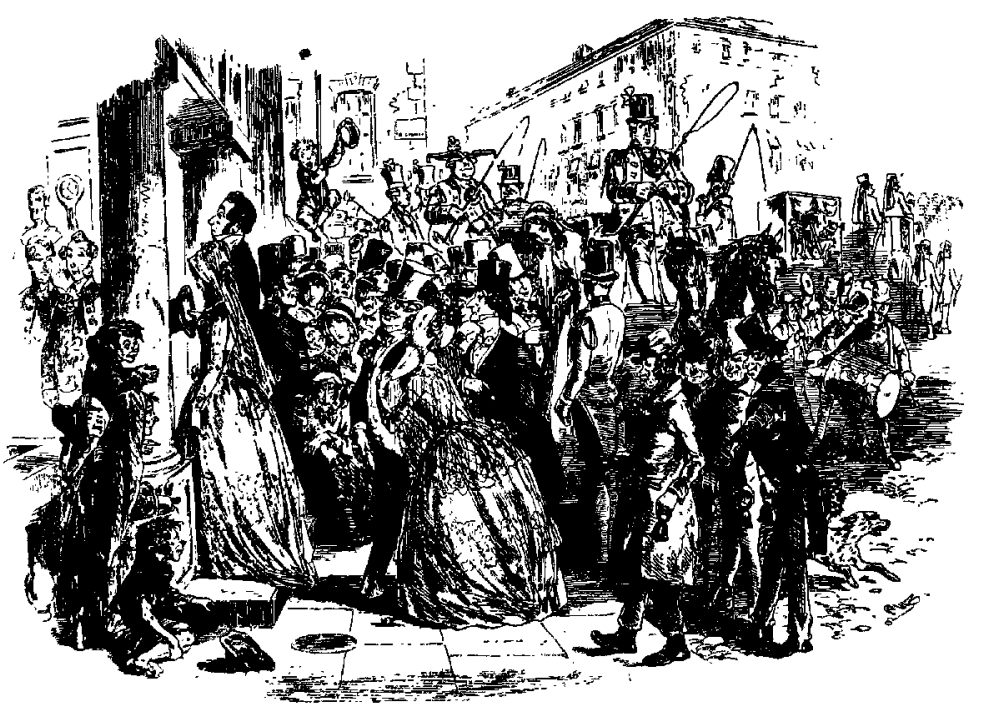

Fig. 82. Hablot Browne, 'Coming home from Church.' Dombey and Son, no. 10. Etching. 43/4" $\times \mathbf{6}^{11 / 1 \mathbf{6}^{\prime \prime}}(12.1 \times 17.1 \mathrm{~cm})$. By permission of the Houghton Library, Harvard University. 

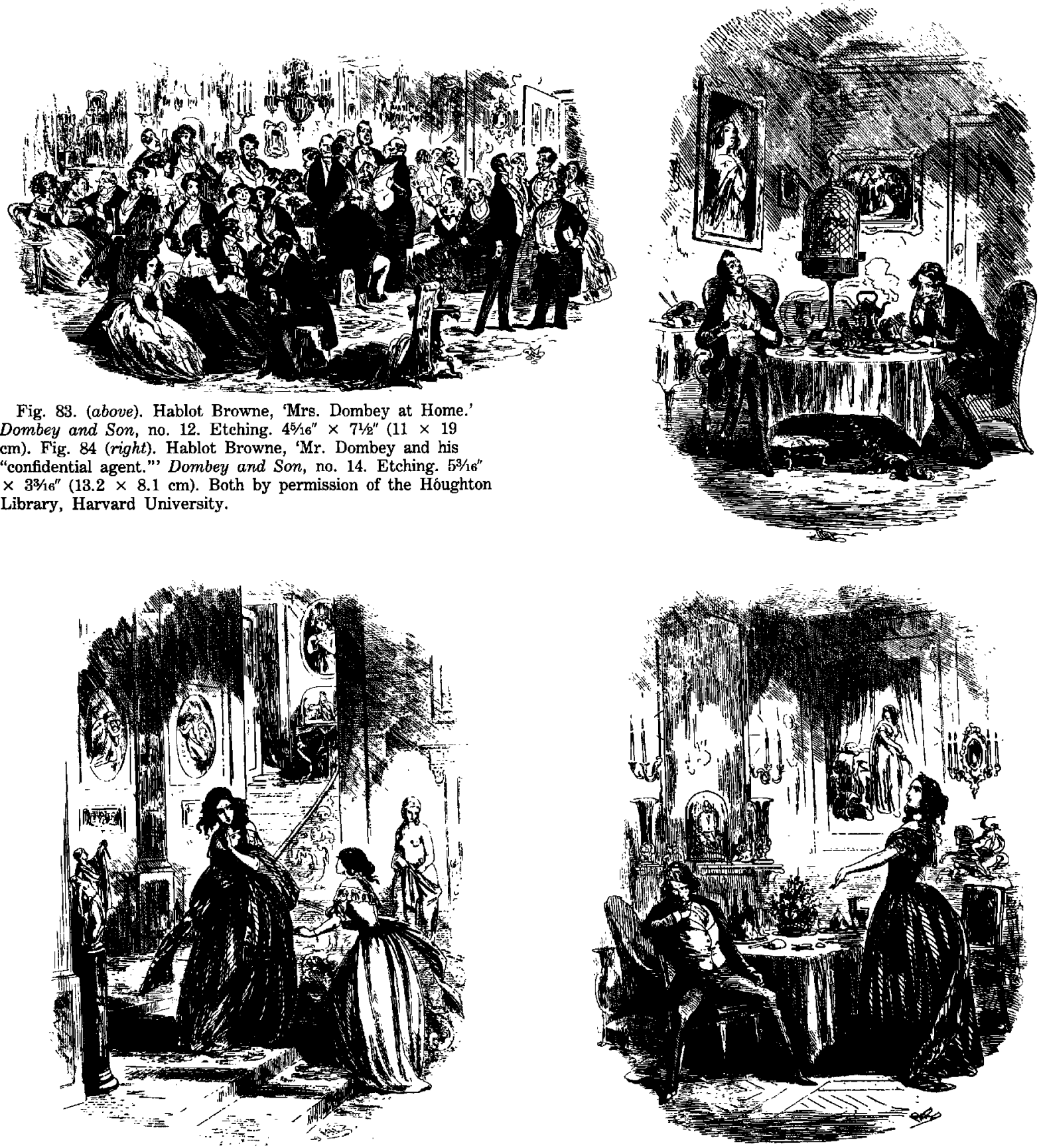

Fig. 85. Hablot Browne, 'Florence and Edith on the Staircase.' Dombey and Son, no. 15. Etching. 51/2" $\times 4 \frac{1}{16} 6^{\prime \prime}$ $(14 \times 10.7 \mathrm{~cm})$. By permission of the Houghton Library, Harvard University.

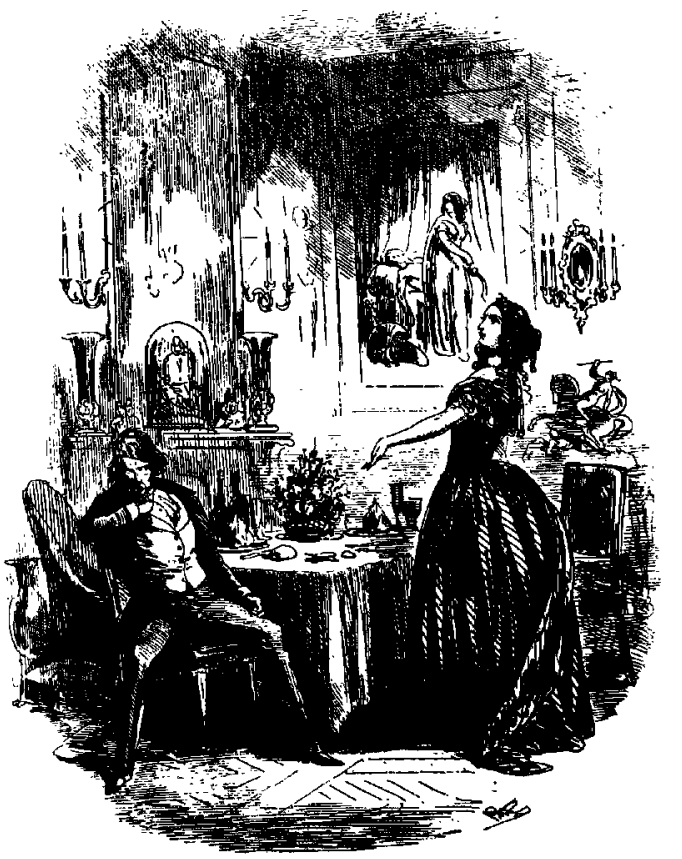

Fig. 86. Hablot Browne, 'Mr. Carker in his hour of triumph.' Dombey and Son, no. 17. Etching. $5 \% 8^{\prime \prime} \times 41 / 4^{\prime \prime}(14.3$ $\times 10.8 \mathrm{~cm}$ ). By permission of the Houghton Library, Harvard University. 
of the pierced meat and the caged bird, as he will again in 'Secret intelligence' (LII, facing p. 726). Subsequently, however, the author allows the artist to supply more clues to Edith's course of action. In her encounter with Florence on the staircase prior to her flight with Carker, for example, a series of elegant artifacts suggest Edith's conflicting feelings (XLVII, facing p. 664) (fig. 85). ${ }^{182}$ An oval portrait of a girl fondling a dove and a pair of plaques, each with a maternal angel and child, suggest her capacity and desire to be a loving stepmother to Florence. In contrast, three pieces of sculpture-a fearless Amazon (perhaps Atalanta), riding sidesaddle, a man sacrificing a woman (perhaps Agamemnon and Iphigenia), and another seminude protectively holding a small figure or objects to her body-suggest that Edith must save herself before she can save Florence lest she become another of Dombey's works of art.

Another careful Browne study, ironically entitled 'Mr. Carker in his hour of Triumph,' reveals that she will never submit to Carker (LIV, facing p. 762) (fig. 86). It is clearer from Browne's plate than from Dickens's prose that Edith has simply used Carker to escape her marriage to Dombey. The romantic objects on and above the fireplace mantel-the flickering eandles, the two pairs of amorous figurines, the clock ornamented with cupids-are at ironic odds with the unromantic events played out here. ${ }^{183}$ For Edith's untouched dishes further indicate, as Mrs. Leavis suggests, she has no thought of becoming Carker's mistress in the hotel room or anywhere else. ${ }^{184}$ Her outflung arm is not merely a theatrical gesture, but rather an expression of her dearly bought freedom in its release from its previous cramped position (see figs. 80-83, 85). The pictures of Judith beheading Holofernes and the statue of an Amazon riding over a prostrate male comment on her brave if unfeminine behavior as she undeceives Carker. Yet the sword in the picture and the raised lance in the sculpture, though they complement Edith's threatening — even castrating - gesture toward Carker, point toward her, reinforeing the fact that she pursues a self-destructive course. ${ }^{185}$ These ambiguous touches perfectly convey the moral complexity of her action. Dickens's unwillingness to pass final judgment on Edith may be suggested by the fact that she does not die after all, contrary to the author's original intention and to the usual fate of such women in Victorian fiction. ${ }^{186}$

After coping graphically with such complex dramatic situations, Browne must have welcomed the relief of a straightforward comic situation featuring Mrs. MacStinger. In his portrayal of this humorous harridan, especially her pursuit and capture of Bunsby, the artist appropriately reverts to more common and less serious artifacts. The ironic titie of the scene in which both protagonists first appear, 'The Midshipman is boarded by the enemy' (XXXIX, facing p. 558), is sharpened by the popular scenes on the wall; one, entitled 'Medusa,' shows a ship foundering in a storm (doubtless after Gericault's famed "The Raft of the Medusa,' which toured England in 1820); ${ }^{187}$ the other depicts two ships in battle. 'Another wedding,' the concluding illustration in the book (whose title, oblong form, and design invite comparison to Edith's wedding) (see fig. 81), contains even more blunt comments by the artist, by means of tattered, crudely lettered theatrical posters on the background wall advertising plays like She Stoops to Conquer and La Marriage Forcé (LX, facing p. 856) (fig. 87). In the MacStinger-Bunsby nuptials, Browne also exploits the simple poster to dramatize Dickens's portrayal of love throughout Dombey as a perpetual contest, as Steig has suggested, in which the woman-not just Mrs. MacStinger and Edith, but also Florence, Polly, Susan, Mrs. Chick, and even Mrs. Pipchin, Miss Tox, and Alice-usually wins. ${ }^{188}$

Dickens clearly appreciated the ways in which Browne had met his challenges-so well, in fact, that Henry James would refer to the narrative as "Phiz's Dombey and Son."189 Considering their inauspicious start, author and artist reached the conclusion of Dombey in remarkable accord. During the publication of the novel, Browne had been publishing independent, extra engravings of the main characters with permission of the author, whose criticisms he both solicited and adopted. ${ }^{190}$ After Dombey's conclusion, he sent Dickens some of his original sketches (whether for the novel or the separate sketches is unclear). The author vowed to treasure them as heirlooms. Browne had retained one of Paul, Dickens's favorite character, to color. Dickens, eager to have this sketch as well, added a mockmacabre warning to his note of thanks for the others, as revealing in its oblique way as the hysterical note he had sent his publisher near the end of Barnaby Rudge.

This afternoon, or Thursday, I shall be near the whereabouts of the boy in the flannel gown, and will pay him an affectionate visit. But I warn you, now and beforehand (and this is final you'll observe) that you are not a-going to back out of the pigmental finishing of the said boy, for if ever I had a boy of my own that boy is MINE!

And, as the Demon says at the Surrey, I claim my victim

$\mathrm{Ha}$ ! Ha! Ha!

At which you will imagine my going down a sulphurous trap, with the boy in my grasp-and will you please not imagine him merely in my grasp, but to hand him over. ${ }^{191}$

His fascination with Paul is only one indication of his efforts to retrieve, from the disturbing depths of his memory, the 


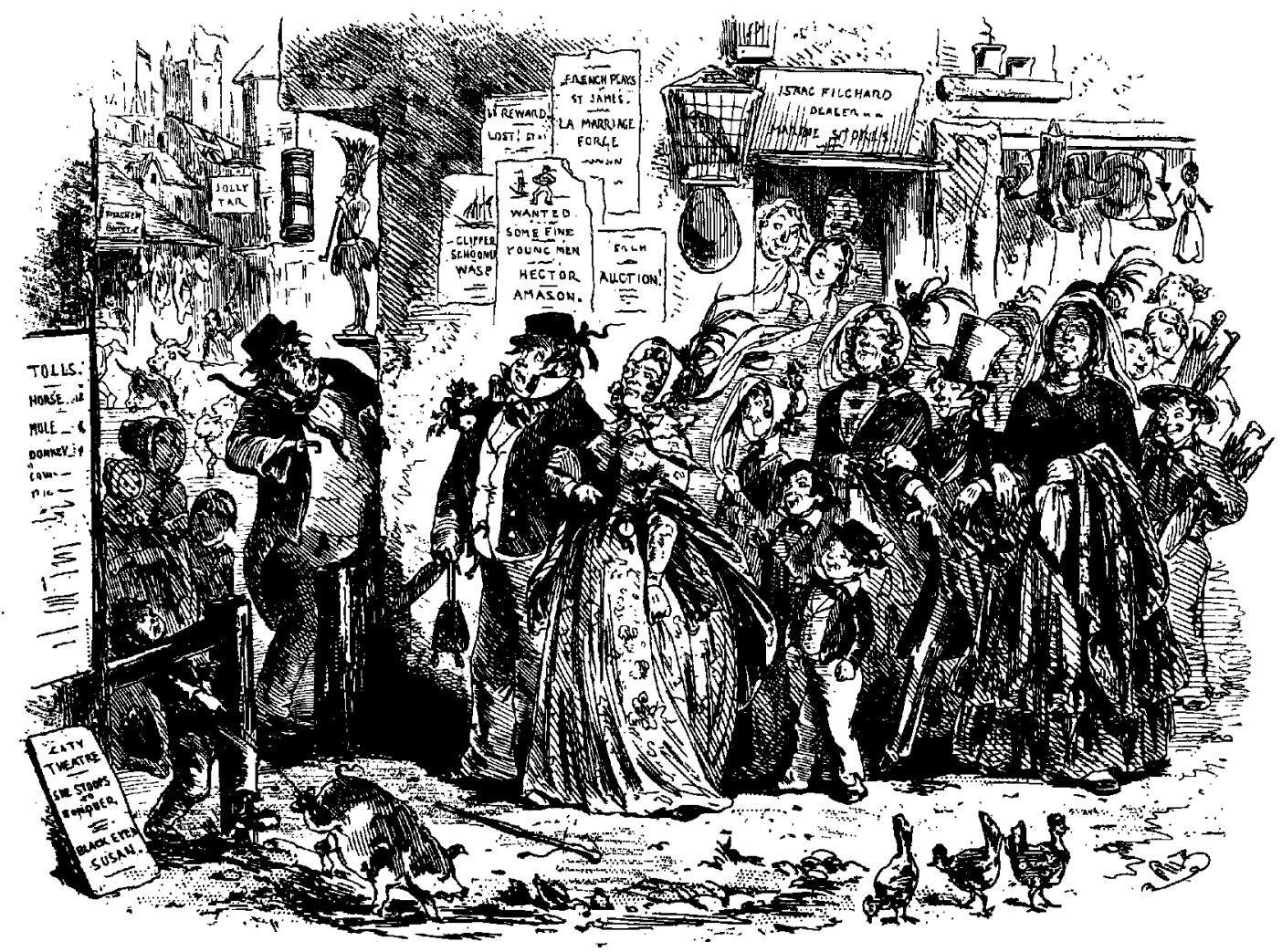

Fig. 87. Hablot Browne, 'Another wedding.' Dombey and Son, nos. 19 and 20. Etching. $4 \% 16^{\prime \prime} \times 61 / 4^{\prime \prime}(11.6 \times 15.9 \mathrm{~cm})$. By permission of the Houghton Library, Harvard University.

youngster he himself had been. In confiding details of his own childhood first to Forster and then to fiction, Dickens did not descend into any trap. Among other effects of this introspection, painfully begun during Dombey and Son and continued in David Copperfield, was Dickens's renewed creativity, and a resurgence of confidence in himself that, happily, spilled over to his principal illustrator.

When Dickens was writing David Copperfield, only Forster knew how closely Copperfield's childhood resembled that of his creator. Dickens never took Browne into his confidence, but the illustrations to this text are nevertheless unusually sensitive. As the wrapper design suggests (xiv) (see F), the artist did not know when he began what direetions the story would take. Lacking specific information about characters or incidents, Browne wisely placed a sprightly figure of Fortune overlooking a series of scenes applicable to every man from cradle to grave, placed, like those on the Nickleby and Dombey covers, in a clockwise cycle. The undefined hero is portrayed as an infant in his mother's lap, a child toddling between his mother and his nurse, a schoolboy, a suitor, a parent, a prosperous gentleman, and, though the text does not finally follow David that far, an old man beckoned to his grave. ${ }^{192}$ The artist could not portray the Murdstones, Micawbers, Wickfields, Spenlows, and Heeps, who stimulate David's inner growth, because Dickens had not yet committed them to paper, but such a generalized cover was not likely to contradict Dickens's narrative in any important way.

If conceived in distress, Dickens's "favorite child" developed in an unusually congenial atmosphere. Not only was David better known to him, but he was far more appealing to his audience than the adults who had dominated his fiction since Oliver Twist. Browne, though not personally acDickens's imagination, was nevertheless able to satisfy him. quainted with the autobiographical realities dominating 
The author's greater realism; looser structure; simpler style, and mellow tone, appropriate to a Bildungsroman, permitted à wider range of character and emotion than the objective content and the moral themes of Chuzzlewit and Dombey. With his usual sensitivity, Brown responded with suitably varied graphic reinforcement. ${ }^{193}$

The first-person narrative, another departure for Dickens, proved visually challenging for the author as well as for the artist. It took unusual empathy between the two men to portray David's memories, and, at the same time, to suggest the development of his perceptions as he tells the story. Self-contained recollections as well as resonant ones are treated with delicate economy. Browne etches David's early memory of Mr. Mell's mother listening to her son, the assistant master of Salem House, playing the flute before "she fades in her turn, and he fades, and all fades" (V, 74-75). In 'I return to the Doctor's after the party' both Dickens and Browne depict Annie prostrate at Dr. Strong's feet (XVI, facing p. 244); but the authorial insistence on the "great impression" this scene made on David suggests that the reader may wish to refer back to the picture, as David repeatedly refers back to his memory of it, gradually perceiving its problems, implications (XIX, 279), and eventual reselution (XXXV, 531). ${ }^{194}$ Even the transience of memorable moments, such as when the Peggotty clan celebrates Em'ly's engagement to Ham, functions dramatically. Browne fixes David's and Steerforth's "glimpse" of the happy group (XXI, facing p. 308), while Dickens notes the effect of their entrance: "The little picture was so instantaneously dissolved by our going in, that one might have doubted whether it had even been" (XXI, 308). Dickens can obliterate the fleeting moment with words (Steerforth will do so by his actions), knowing that Browne has given it permanence. ${ }^{195}$

Browne proved remarkably faithful to Dickens's real memories, albeit unwittingly. Considering how precise his own conceptions must have been, as they were of Mrs. Pipchin in Dombey, it will be recalled, Dickens had surprisingly few objections to Browne's sketches. He did prefer that the hero be dressed in a short jacket rather than a long coat for his first dinner out (V, facing p. 66), but only, he said, if this change could be accomplished "without altering him in any other respect."196 Browne, though unaware that the grandiloquent but improvident Micawber had been inspired by Dickens's father, nevertheless portrayed him in a manner the son deemed "uncommonly characteristic and capital."197

Not since Pickwick had Dickens been so openly appreciative of Browne's efforts. Never again would he be so pleased with the artist or with himself. The artist did labor unusually hard to capture the spirit as well as the letter of scenes and individuals. For the plate of Davy's making himself "known" to his Aunt Betsey, for example, he showed Dickens several sketches before he achieved a satisfactory balance between pathos and humor. The first two sketches showed Miss Trotwood, the most memorable of the hero's many surrogate parents, sitting flat down on the garden path in an accurate if comically undignified pose (figs. 88 and 89). The third showed the Aunt standing ereet with surprise facing her nephew. "So?" Browne queried (fig. 90). Or, "So?" he asked again in yet another version-more a caricature, which showed less of the Aunt's face but more of the boy's (fig. 90). The artist ultimately fused the designs, taking the more pathetic figure of Davy from the first two, that of the Aunt from the second pair, and a combination of details from all for the background to create a sensitive representation of the text (XIII, facing p. 190) (fig. 91). ${ }^{198}$ As Browne seemed to be taking special pains to please, Dickens was less prone to criticize him. Even when the artist turned Peggotty's boat home upside down, in contradiction of the text (III, facing p. 30), though not reality, the author said nothing. ${ }^{199}$ Dickens's affability extended to social as well as professional occasions; Browne was included in the small party instigated by Dickens to celebrate the new novel's debut, and even seems to have been prevailed upon to spend a holiday. at Bonchurch. ${ }^{200}$ In contrast to the stress surrounding their initial work on Dombey, all went smoothly on David Copperfield from the beginning.

Stimulated by Dickens's approval, Browne, more consistently and often more profoundly than in Dombey, includes meaningful details in his illustrations, which comment on individuals and episodes with which the hero becomes involved. ${ }^{201}$ In keeping with David's maturing perceptions, Browne used simple graphic accessories in the earlier scenes and more sophisticated ones in later scenes. David's aristocratic trust in people, along with other qualities, may enable him to "scramble through on hands and knees," in the grudging words of Robert Louis Stevenson, as Dickens's first real gentleman. ${ }^{202}$ But even a gentleman must learn to make proper judgments and discriminations about people and events, and to penetrate deceptive appearances. The artist, more directly than the author, enables the reader to assess David's progress in this crucial sphere.

Simple pictorial objects comment on Davy's childhood experiences, particularly those involving meals. Prints rather than parents overlook the boy's first meal at an inn (V, facing p. 66) (fig. 92). The large map on the wall, which recalls the globe on the monthly wrapper (facing p. xiv) and anticipates the map hanging behind Mr. Peggotty at the end of his search for Em'ly (XL, facing p. 578), suggests the great world that David is now encountering for the first time. Before the machinations of the "friendly" waiter are 


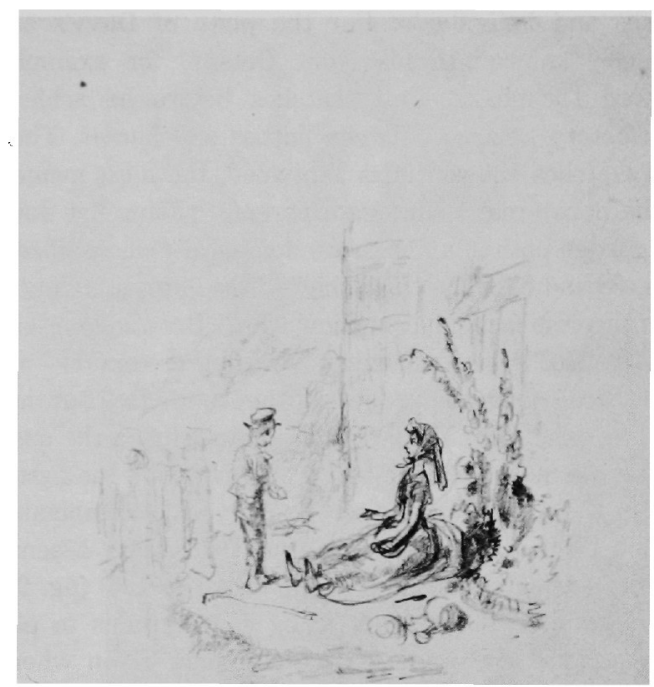

Fig. 88. Hablot Browne, Sketch for 'I make myself known to my Aunt.' Pencil. $6 \frac{1}{1 / 8^{\prime \prime}} \times 66^{1 / 2} 2^{\prime \prime}(15.5 \times 16.5 \mathrm{~cm})$. From the Elkins Collection, by permission of the Rare Book Department of The Free Library of Philadelphia.

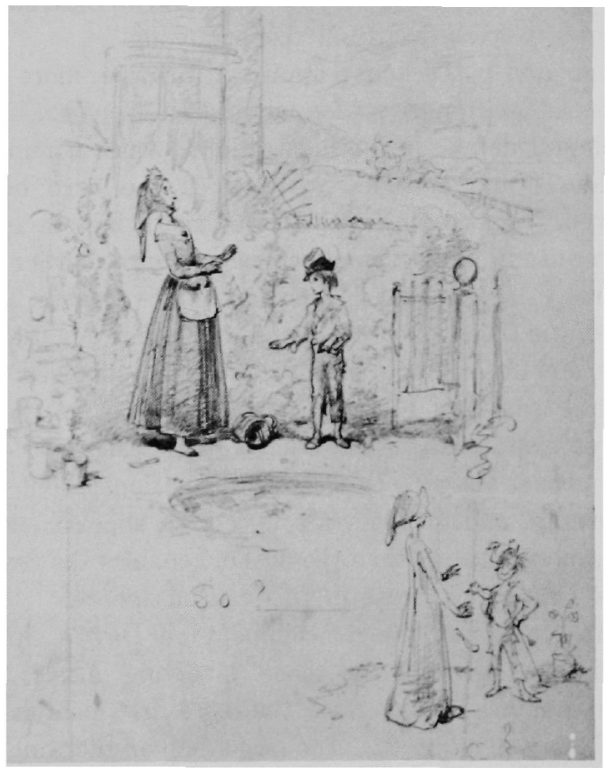

Fig. 90. Hablot Browne, Sketches for 'I make myself known to my Aunt.' Pencil. $71 / 8^{\prime \prime} \times 5 \frac{1 / 2^{\prime \prime}}{}(8.1 \times 14 \mathrm{~cm})$. From the Elkins Collection, by permission of the Rare Book Department of The Free Library of Philadelphia.

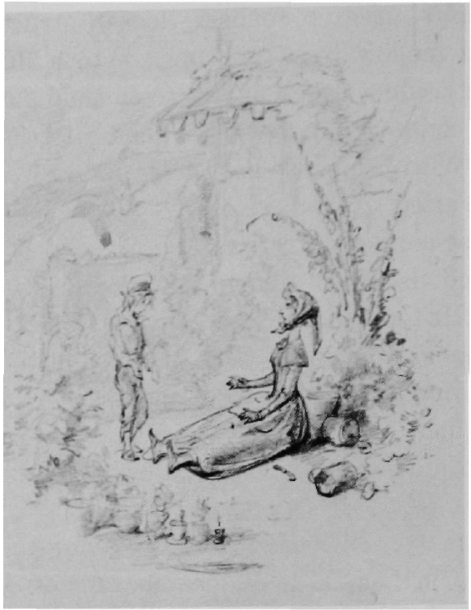

Fig. 89. Hablot Browne, Sketch for 'I make myself known to my Aunt.' Pencil. 61/8" $\times 41 / 2^{\prime \prime}(15.5 \times 11.5 \mathrm{~cm})$. From the Elkins Collection, by permission of the Rare Book Department of The Free Library of Philadelphia.

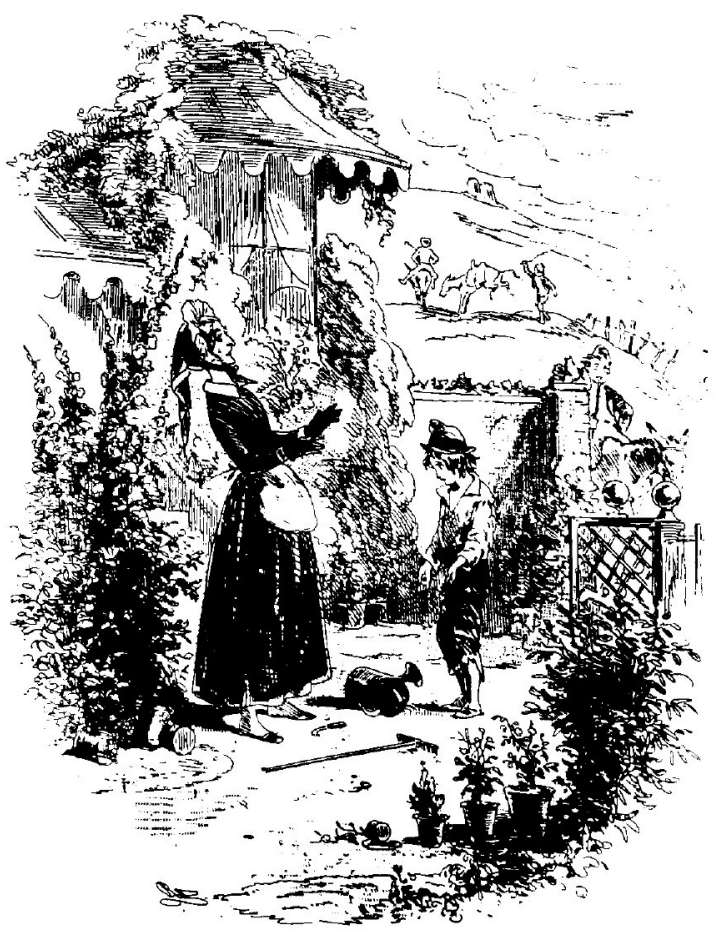

Fig. 91. Hablot Browne, 'I make myself known to my Aunt.' David Copperfield, no. 5. Etching. 55/16" $\times 4^{1 / 4^{\prime \prime}}(13.5$ $\times 10.8 \mathrm{~cm})$. By permission of the Houghton Library, Harvard University. 


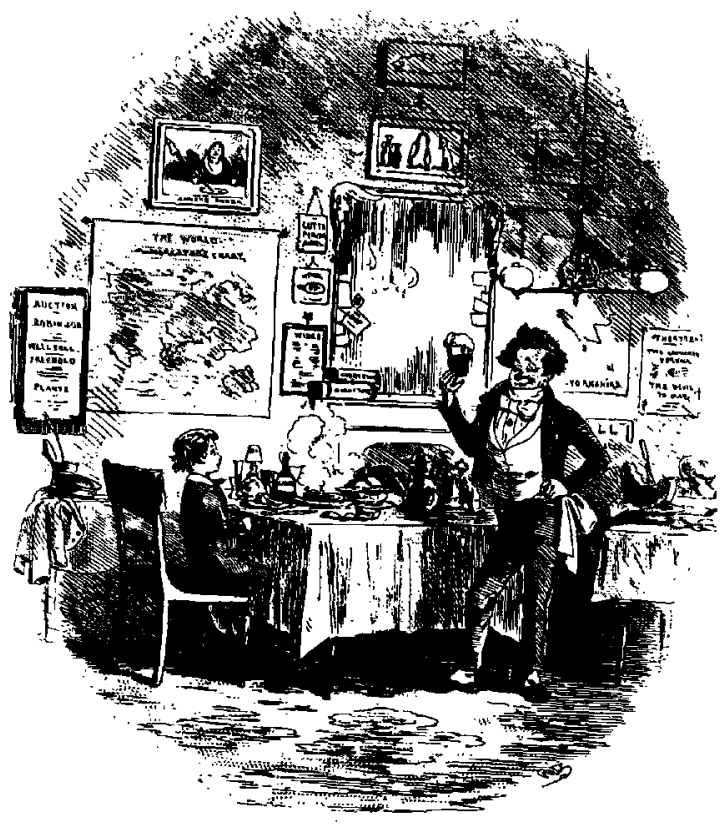

Fig. 92. Hablot Browne, 'The friendly Waiter and I.' David Copperfield, no. 2. Etching. $5^{\prime \prime} \times 47 / 6^{\prime \prime}(12.7 \times 11.3 \mathrm{~cm})$. By permission of the Houghton Library, Harvard University.

disclosed by the text, their outcome is anticipated by the other pictures on the dining room wall. That he is to be tricked out of his dinner is made clear by a scene of Sancho Panza, bewildered as the enchanter's wand draws an empty circle where his plate should be (Don Quixote, XLVII); ${ }^{203}$ by the depiction of the fable of the Fox and the Stork; and by the theater bill advertising The Devil to Pay. The reader recalls this illustration when Davy, in his blacking house days, more successfully places his "magnificent order" for a drink, though he is scarcely larger than the infant Bacchus in the pub window (XI, facing p. 160).

More sober works of art appear in 'Changes at Home' (VIII, facing p. 108) (fig. 93). Like Florence Dombey, Davy tentatively enters the living room, cut off from his family by his parent's back and that of her chair. His unsettled stance and expression is at odds with his mother's composure, his awkwardness contrasting with the graceful curves of her head, the baby's clothes and draped bassinet, and the oval frames of the pictures behind and above the pair. Unlike Florence, but like his counterpart in the framed representation of the Prodigal Son's return, Davy will be warmly included into the group. But he, like Moses, the subject of the companion scene over the fireplace, will eventually be abandoned to the care of strangers. ${ }^{204}$ This idyllic but transitory domestic moment is recalled by "The momentous interview' when it will be decided whether Davy remains with his aunt or returns with the dreaded Murdstones (XIV, facing p. 208) (fig. 94). Once more, the boy is isolated from his closest blood relation by chairbacks. And again, a Biblical picture, 'Joseph's Garment,' comments on his position, made perilous by his stepfather and ludicrous by his dress. The humor suffusing the illustration and its details, which parody those of the earlier scene, anticipates the happy outcome even before it is revealed in the text.

Browne uses all kinds of household appurtenances to characterize the experiences of the maturing hero, particularly the ones involving Dora. When David confers with

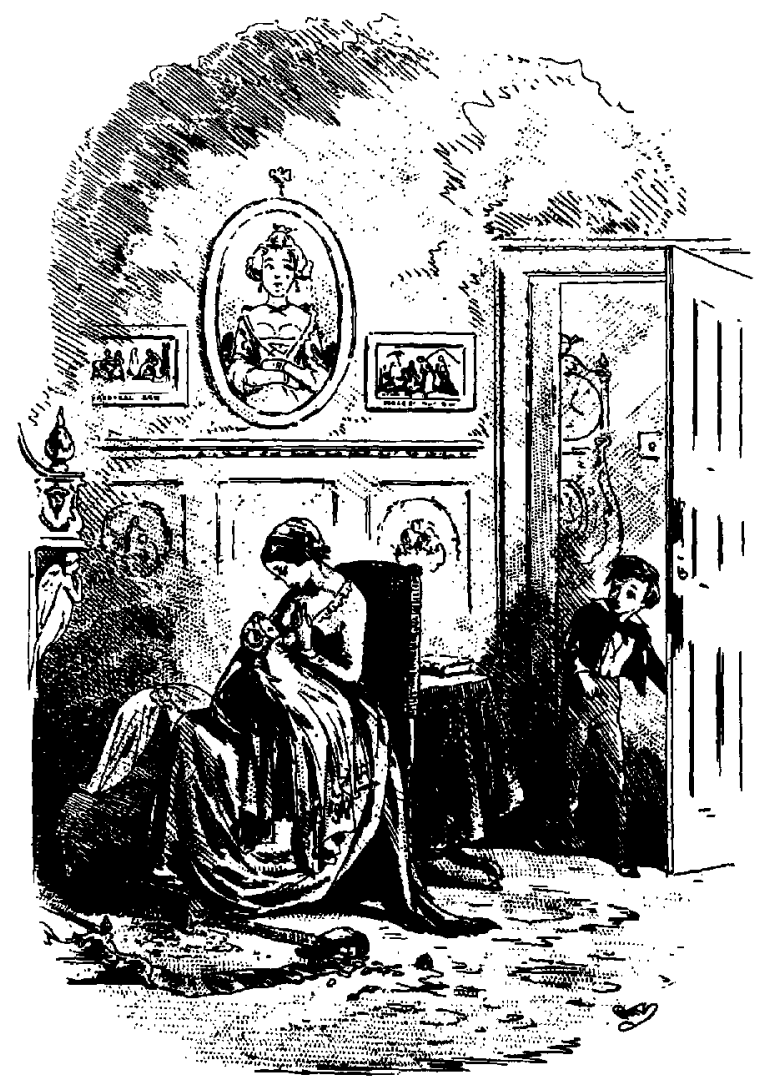

Fig. 98. Hablot Browne, 'Changes at Home.' David Copperfield, no. 8. Etching. $5^{\prime \prime} \times 31 / 2^{\prime \prime}(12.7 \times 8.9 \mathrm{~cm})$. By permission of the Houghton Library, Harvard University. 


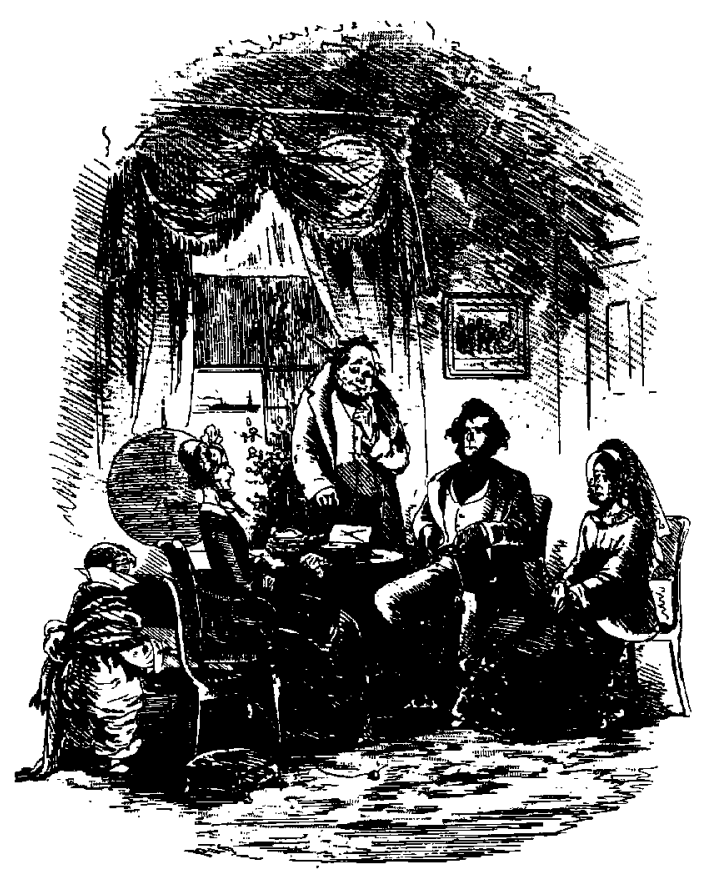

Fig. 94. Hablot Browne, 'The momentous interview.' David Copperfield, no. 5. Etching. 53/16" $\times 4 \frac{114^{\prime \prime}}{}(13.2 \times 10.8 \mathrm{~cm})$. By permission of the Houghton Library, Harvard University.

her aunts to win her hand, even the titles of the pictures on their walls-The Last Appeal,' 'The Momentous Question,' and 'Arcadia'-comment on the nature of his errand, and books-Loves of the Angels and Paradise Regained -anticipate his success (XLI, facing p. 592) (fig. 95). Other objects strewn through 'Our Housekeeping,' succinctly summed up by the jar labeled "PICKLES" prominently displayed among the scattered books on the drawing-room shelf, reveal the plight of their marriage (XLIV, facing p. 636) (fig. 96). The couple are as trapped by their own inexperience and immaturity as their caged birds. The disorder on the table sharply contrasts to the many orderly meals elsewhere in the narrative, even in David's bachelor quarters (XXVIII, facing p. 410) or the Micawbers' impoverished ones (XXXVI, facing p. 531). The cause of the chaos is Dora's dog, Jip, and, as Harvey has perceived, by dramatic analogy, its owner. ${ }^{205}$ By the dark glossiness of their hair, the softness of their bodies, and the curves of their limbs, Browne graphically equates Dora with her pet just as Dickens eventually does dramatically by having them die at the same time.

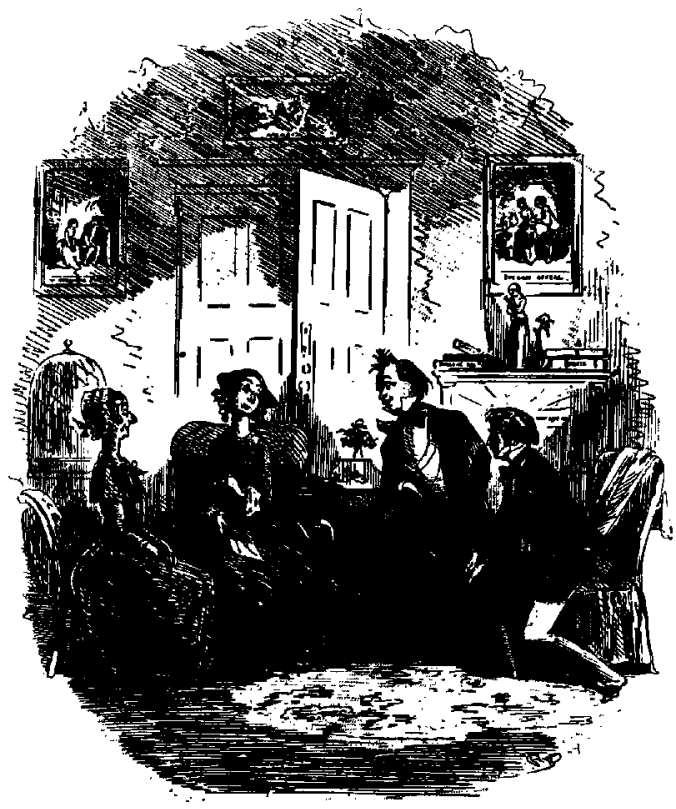

Fig. 95. Hablot Browne, "Traddles and I, in conference with the Misses Spenlow.' David Copperfield, no. 14. Etching. 53/16" $\times 47 / 16^{\prime \prime}(13.2 \times 11.3 \mathrm{~cm})$. By permission of the Houghton Library, Harvard University.

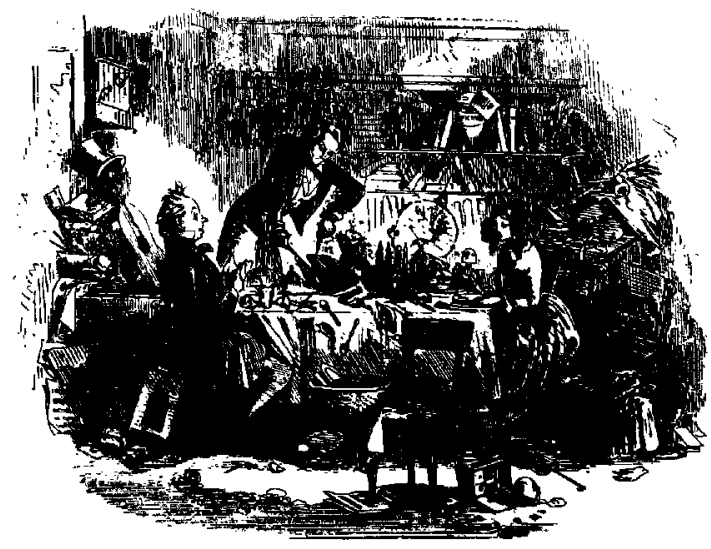

Fig. 96. Hablot Browne, 'Our Housekeeping.' David Copperfield, no. 15. Etching. 315/16" $\times 61 / 4^{\prime \prime}(10 \times 13.4 \mathrm{~cm})$. By permission of the Houghton Library, Harvard University. 
When David next appears in the same room (LIII, facing p. 762) (fig. 97), his impending bereavement is suggested by the dying dog and by many inanimate objects: the small, empty chair; the abandoned portfolio; the workless clockcase; the guttering candle; music from the Mozart "Requiem"; the broken-stringed guitar; and, in one variant of the plate, a butterfly on an inkwell. ${ }^{206}$ Behind David stands Agnes (on whom we focus because of the picture's title rather than its arrangement), with that air of decorum that will characterize their future home and life together. Dominating both at this moment, however, is the large portrait of Dora, who, significantly, resembles Clara Copperfield in childish looks and manner. ${ }^{207}$ After Agnes and David are married, the same portrait, hanging between two sculptured angels, and next to it apparently a drawing of Em'ly before her Yarmouth boat home, recall the turbulent past that made the present idyllic scene possible (LXIII, facing p. 860) (fig. 98).

David is an innocent who only profits from bitter experience. Indeed, Somerset Maugham expressed surprise that David, even after living with the bankrupt Micawbers

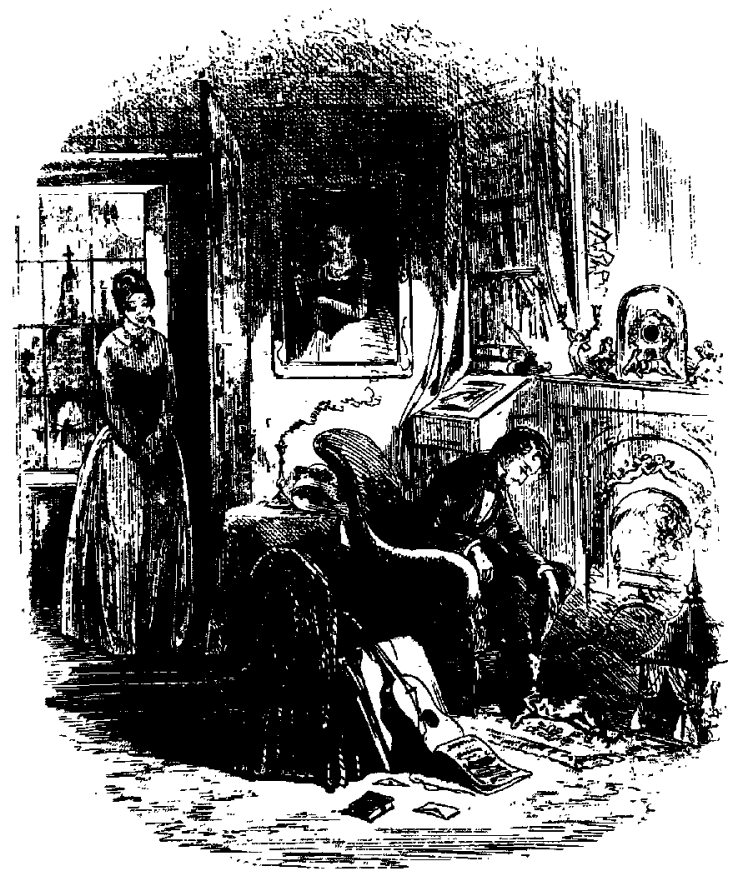

Fig. 97. Hablot Browne, 'My child-wife's old companion.' David Copperfield, no. 17, Etching. $5 \frac{5}{16} 6^{\prime \prime} \times 4 \frac{1}{2} 2^{\prime \prime}(13.5 \times 11.5$ $\mathrm{cm})$. By permission of the Houghton Library, Harvard University.

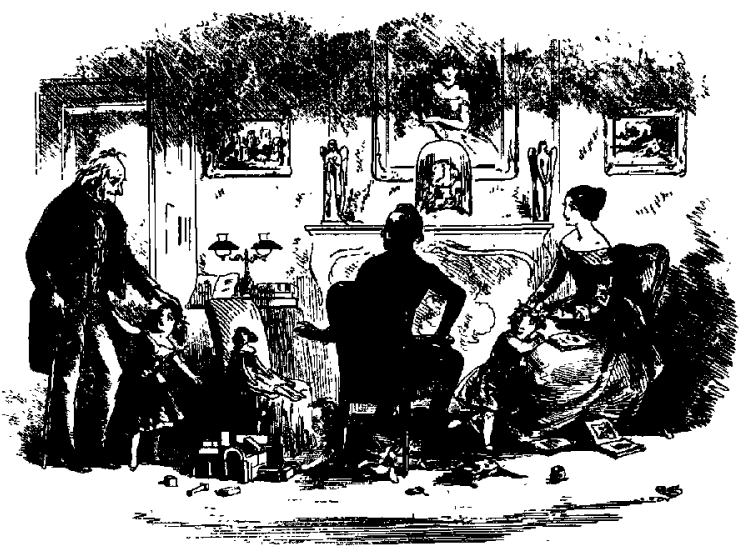

Fig. 98. Hablot Browne, 'A Stranger calls to see me.' David Copperfield, nos. 19 and 20 . Etching. $4 \% 16^{\prime \prime} \times 5^{3 / 4^{\prime \prime}}(10.1 \times$ $14.6 \mathrm{~cm})$. By permission of the Houghton Library, Harvard University.

and drudging in the London warehouse, remained such a "ninny" as to be cheated out of his coach seat (XIX, facing p. 282). ${ }^{208}$ Certainly when David took tea at the Heeps', he failed to read the threat of duplicity so obvious in the arrangement of objects beside the legal almanac on their mantle-two cats, a mousetrap, a corkserew, and a stuffed owl (XVII, facing p. 256). In this way Browne's illustrations often bridge the gap between the hero's naivete and the world's realities.

This is particularly true regarding matters of the flesh, where the artist could suggest sexual implications by postures, gestures, and lines as well as emblems, which would have offended Victorian sensibilities if put into words. When David first meets Miss Mowcher, for example, he is oblivious to her probable relationship to Steerforth, but the careful viewer of the illustration perceives that she is his procuress (XXII, facing p. 324) (fig. 99). The dwarf dramatically stands on the table, with an expression and sidelong glance of amusement, similar to Steerforth's, at David's innocence. There is a clear analogy between Miss Mowcher and the subject of the framed scene over the fireplace: Gulliver performing on a table top for the bemused Brobdingnagians. Her hair and hat feather, functioning like Pecksniff's hair tuft, link her physically and hence morally to the more complex picture over her head, apparently that of Mephistopheles observing the tryst he has arranged between Faust and Gretchen. The turbulence of her hat also connects her with the picture of a storm-tossed ship behind David's head-which anticipates Em'ly's elopement, Steer- 


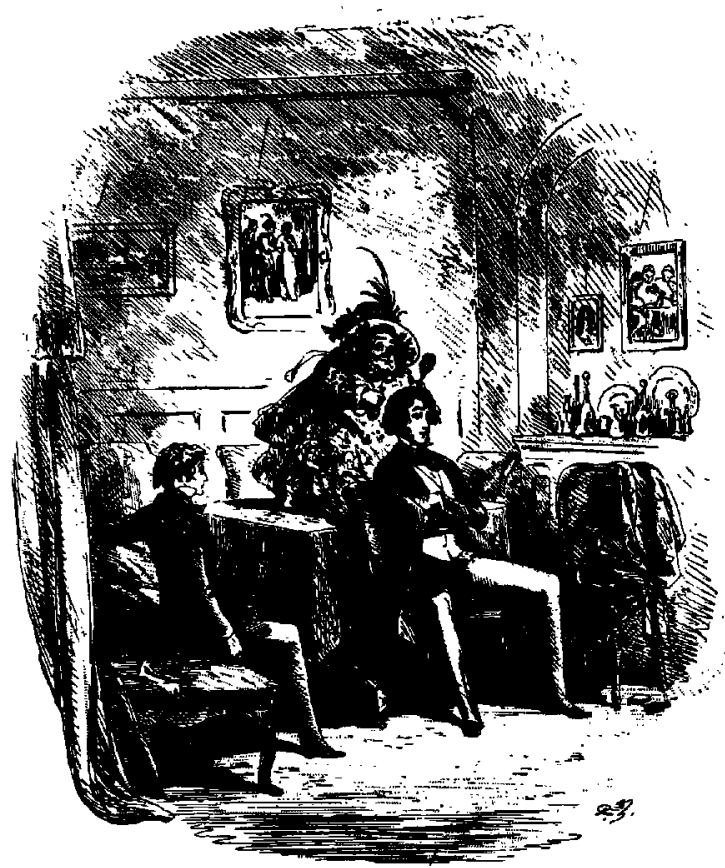

Fig. 99. Hablot Browne, 'I make the acquaintance of Miss Mowcher.' David Copperfield, no. 8. Etching. $4^{15 / 16^{\prime \prime}} \times 4^{3 / 16^{\prime \prime}}$ $(12.5 \times 10.6 \mathrm{~cm})$. By permission of the Houghton Library, Harvard University.

forth and Ham's death in an ocean storm, and Em'ly's emigration to Australia with her uncle. The Faust picture, which Harvey notes is not included in Browne's original sketch, may have.been requested by Dickens or added by Browne as a hint to the reader that Steerforth plans to seduce Em'ly with the assistance of Miss Mowcher as well as Littimer. ${ }^{209}$ The protests of Mrs. Seymour Hill-a woman who served as the physical model for the dwarf-forced Dickens to ameliorate her wickedness but Browne's unaltered plate makes clear her original function. ${ }^{210}$

Martha, the subject of the very next plate, is one of Dickens's few fictional fallen women (XXII, facing p. 334) (fig. 100). The artist not only depicts her plight more explicitly in the illustration than the author does in the text, but anticipates Em'ly's similar fate and Dickens's philosophy toward both women. As viewers have noted, he arranges the characters to approximate the figures in the mantle scene of Christ blessing Mary Magdalen. ${ }^{211}$ The picture forms the top of a triangle linking Martha, who is identified with the Magdalen by her similar posture and isolation from the group, and Em'ly, whose contrasting purity is suggested by the whiteness of her skirt. To reinforce Dickens's implicit assertion of the need and authority for forgiveness, Browne makes the heads of his characters follow an ascending diagonal line to that of Christ's in the picture (as the heads of those surrounding the dying Barkis lead to Jesus in a print of Raphael's 'Transfiguration' over the bed) (XXX, facing $\mathrm{p}$. 440). Hinting at yet another downfall is a scene of Eve's temptation, located significantly over and behind Em'ly's head, partly obscured by shadows and the door as the nature of her attraction to Steerforth is obscured in her mind and heart.

When David next sees Em'ly, her face is averted, her hair tangled and her body curved in shame like Martha's (L, facing p. 716) (fig. 101). In this scene, entitled with sad irony 'Mr. Peggotty's dream comes true,' Browne fills her shabby room with pictures alluding to her past—of small children, a fisherman, and a ship-and objects alluding to her lost virginity: the broken ewer, cracked mirror, smashed flower

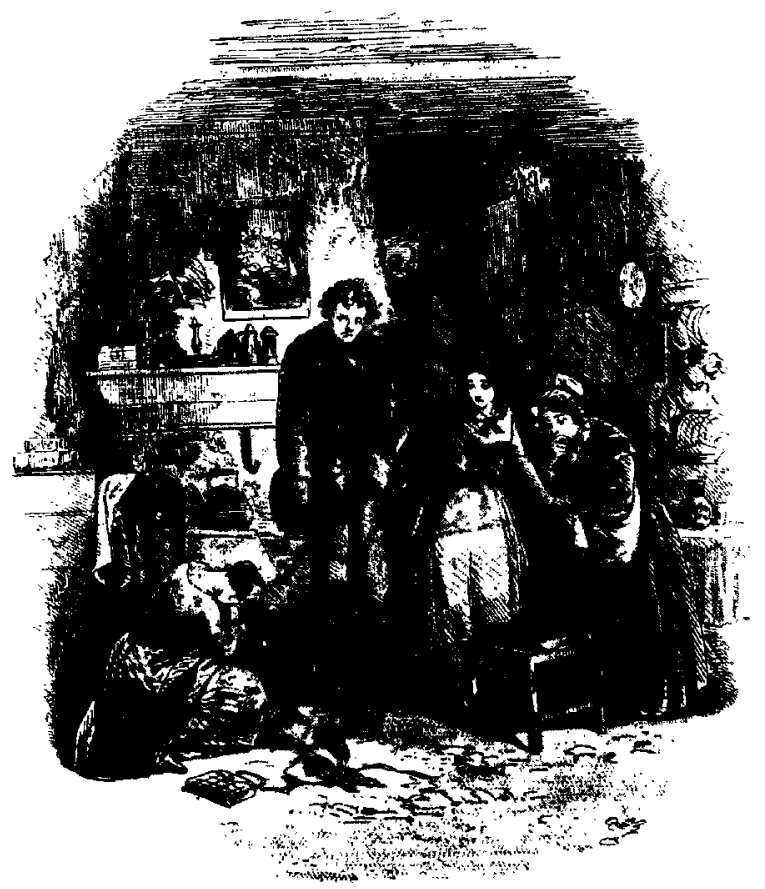

Fig. 100. Hablot Browne, 'Martha.' David Copperfield, no. 8. Etching. $5^{\prime \prime} \times 4^{15 / 16^{\prime \prime}}(12.7 \times 12.5 \mathrm{~cm})$. By permission of the Houghton Library, Harvard University. 


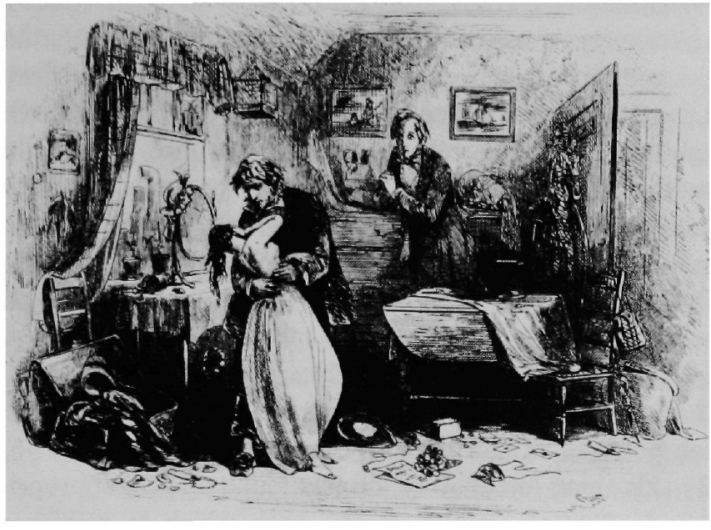

Fig. 101. Hablot Browne, 'Mr. Peggotty's dream comes true.' David Copperfield, no. 16. Etching. $4 \frac{316^{\prime \prime}}{} \times 5^{1 / 8^{\prime \prime}}(10.6$ $\times 13 \mathrm{~cm})$. By permission of the Houghton Library, Harvard University.

pot, empty envelope, discarded dance program, single dancing slipper, and abandoned bonnet and purse (like Martha's in the earlier scene). ${ }^{212}$ But as Martha was redeemed by compassion, so Em'ly will be forgiven, without having to resort, as did her friend, to the dire alternative, so memorably suggested by the artist, 'The River' (XLVII, facing p. 674). David's horrified yet compassionate expression as he watches Peggotty comfort his niece suggests he may at last have gone beyond mere sight to insight.

Both Dickens and Browne stood at the height of their reputations at the completion of David Copperfield. Many readers regarded David Copperfield in the same way Dickens did—as their "favorite child." The author found renewed inspiration as well as temporary catharsis in recreating the painful experiences of his youth. The artist not only satisfied the demands of the text and the memory that inspired it but, by means of his sensitively detailed illustrations, added incalculable psychological, emotional, and moral depth.

In David Copperfield, Dickens had begun to analyze himself. In his next novel, Bleak House, he began to analyze his society. Displaying none of the joyousness that suffused his fictional autobiography, Dickens grimly depicted a society built on a web-like foundation of exploitation, poverty, and misery, which inextricably bound together its inhabitants and their fortunes. Browne's talents were stretched to their limit as Bleak House took on more and more significance until it became a symbol of society as a whole. For the last time, the artist successfully met the challenge posed by the author's changing style and purpose. His illustrations complemented the text, not as much in specific or suggestive detail as in Copperfield, but in essential matters of artistic vision.

Dickens planned his most ambitious narrative, which even T. S. Eliot praised as his "finest piece of construction," 213 with unusual care. The new blue Bleak House wrapper, compared to the one for Copperfield in the usual green, shows that Browne was better apprised of the story's direction and spirit (xiii) (see F). Returning to a simpler paneled border of a kind he had not used since Martin Chuzzlewit, the artist picked actual characters and episodes from the narrative, which is structured by the interminable lawsuit of Jarndyce vs. Jarndyce. Chancery clearly dominates the cover, as it does society, irresponsibly dwarfing individuals it supposedly services. Across the wrapper top, as Butt and Tillotson have described, Browne unfolds an allegorical game of blindman's buff in which the Lord Chancellor, judges, and lawyers, all blindfolded, pursue witnesses for fun and litigants for cost, tripping over the woolsack and mace in the perverted process. ${ }^{214}$ In the lower corners, this kind of inhumane sport is further amplified by two scenes, one of a judge looking on bemused while two barristers play chess with clients as chessmen, and another of their colleagues opposite similarly misusing clients for their games of battledore and shuttlecock. A picture of Bleak House itself occupies the center panel, at the bottom of which stands John Jarndyce in despair, besieged by specious philanthropists. The acid satire and grim subjects of Browne's wrapper perfectly anticipate the tone and targets of the narrative to come.

Throughout Copperfield, Browne reflected Dickens's exuberance in an abundance of unsolicited graphic details; in Bleak House, his touches reflect the author's bitterness. But whereas the details for Copperfield usually lend range and depth to the first-person narrative, those for Bleak House often return to the more superficial satirical level of his work for earlier books. This time, however, in keeping with the narrative, they satirize institutions and their representatives rather than individuals and their actions. On the wall facing Jarndyce and his guests inside "The little church in the park' (XVIII, facing p. 250), for example, the artist places a memorial to a judge as if to imply the futility of escape from Chancery even on the Sabbath or in death-though the bird perched irreverently on the magistrate's stone wig adds salutary humor. Elsewhere in the narrative, not only does religion prove indifferent to institutional evils, but clergy, 
like Chadband, whose pose during his pitiless lecture to Jo caricatures that of the saint pictured behind them, perpetuate them (XXV, facing p. 356). Similarly, officers of the law pervert their function as the artifacts in Vholes's office repeatedly make clear (XXXIX, facing p. 548) (fig. 102). As the attorney enmeshes Richard more and more inescapably in the Jarndyce case, Browne's details - the legend of the fox and grapes carved in his mantle, the portrait of a nearsighted judge above, the wolves' heads below, the ironically labeled cartons stacked to the right, the butterfly net leaning against the wall, the spider web with trapped flies on the ceiling corner, the cat watching for the mouse behind the desk, the overturned wastebasket disclosing an advertisement for "fool's cap," the book opened to a plan of a maze, and the mass of tangled string next to it-all comment on his dubious brand of legal aid. As one admirer of this illustration remarked, "Who is the greater satirist of Chancery suits, 'Phiz' or 'Boz'?"'215

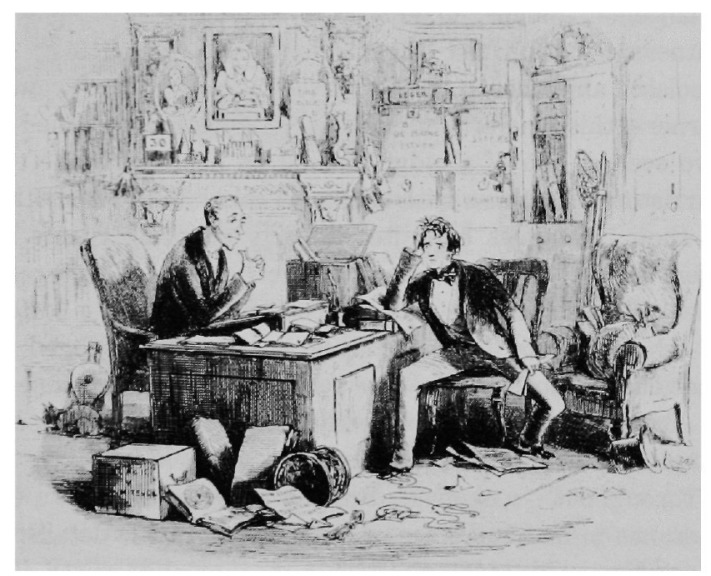

Fig. 102. Hablot Browne, 'Attorney and Client, fortitude and impatience.' Bleak House, no. 13. Etching. $41 / 8^{\prime \prime} \times 51 / 16^{\prime \prime}$ $(10.5 \times 12.9 \mathrm{~cm})$. By permission of the Houghton Library, Harvard University.

In one less sober print, Browne's unsolicited details contributed as much to Dickens's embarrassment as to his narrative satire. The author deluded only himself in thinking that Browne's picture of Harold Skimpole in 'Coavinses' was "singularly unlike" its original, Leigh Hunt, in all except superficialities (VI, facing p. 74) (fig. 103); as Macaulay observed, "surely it is by these light externals that the bulk of mankind will always recognize character."216 If Skimpole's portly figure and foolish face do not resemble the slender, sensitive Hunt, his identity is clearly betrayed by the idiosyncratic accessories in his room at Bleak House: the books and flowers; the scene of a child catching butterflies; and the sculptured "Three Graces," which suggest his three daughters as well as his tripartite credo that life should include only the beautiful, sentimental, or amusing. Such details as these, however, raised a basic problem in Bleak House. They proved best suited to comic scenes where they could lend point and even depth. But as the atmosphere in Bleak House grew more and more oppressive, they began to seem frivolous at worst, superfluous at best. The artist, perhaps perceiving this, used them less frequently in the latter portions of the narrative.

By this time, fortunately, he had found a more appropriate and effective graphic means with which to reinforce Dickens's sober portrayal of society-his so-called dark plates. Indeed, the suggestively sinister atmosphere of Bleak House is due as much to them as to Dickens's prose. The somber tones of these plates complement the action of the novel, which seems always under the shadow of impending or accomplished tragedy. The artist had already experimented with this process, which involved machine

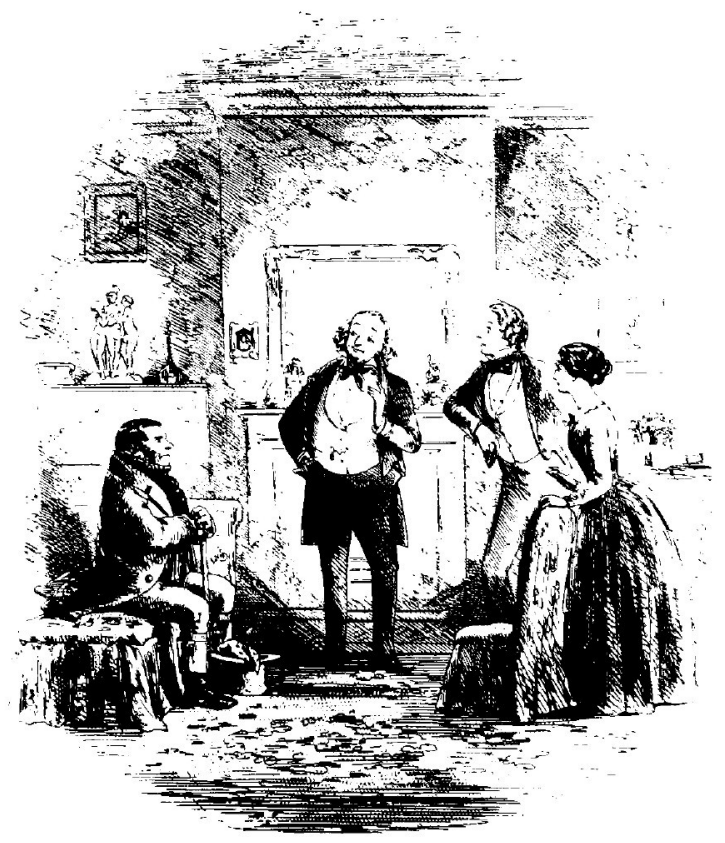

Fig. 103. Hablot Browne, 'Coavinses.' Bleak House, no. 2. Etching. $47 / 8^{\prime \prime} \times 43 / 16^{\prime \prime}(12.4 \times 10.6 \mathrm{~cm})$. By permission of the Houghton Library, Harvard University. 
ruling the entire plate with a series of fine parallel lines in addition to etching the design. Indeed, it is odd that in previous Dickens novels, Browne had singled out only Carker fleeing 'On the dark Road' in Dombey (LV, facing p. 772) and Martha standing in despair by 'The River' in Copperfield (XLVII, facing p. 674) as subjects that could benefit from the sense of ominous suspense easily provided by the technique that produced such striking contrasts of light and shadow. Perhaps, as the artist's son suggests, the first dark plate in Bleak House may well have been Browne's renewed protest against the publisher's increased duplication of his plates by lithography, which not only decreased his earnings, as no duplicate plates were required, but also blurred his fine lines. ${ }^{217}$ By mechanically ruling a plate with close lines that would blotch if transferred to stone, Browne forced the printers to reproduce it by the usual copperplate press. Whether or not it originated as a reproof, the process perfectly conveyed the mysteriousness of 'The Ghost's Walk' at Chesney Wold (XXXVI, facing p. 512) and the novel arched shape of the scene's upper portion reinforced its gracefulness. Whatever Dickens's reasons for disliking Browne's earlier "shadow-plate" in Dombey, he must have realized how ideally suited its process would be to the grimmer subjects and more symbolic style of Bleak House and henceforth encouraged the artist's initiative. ${ }^{218}$ In the remaining third of the story, most of the illustrations-some oblong, others arched, one even shaped like a pagoda-were executed in this manner.

At their best, Browne's illustrations had always complemented Dickens's texts. With apparently inexhaustible ingenuity, the artist continued correlating his visual structures and techniques with the author's changing ones. The dark plates not only reflect the novel's prevailing somber tone and atmosphere, but the oppressive dominance of the setting — both weather and structures—over the characters, an inordinate number of whom die in the story's course. As both Steig and Harvey have pointed out, of the ten dark plates in Bleak House, six have no human figures at all; of the four that do, only one figure is clearly discernible; and, moreover, the absence of people is not an inevitable result of the technique or of Browne's use of it, as is clear from the dark plates the artist executed for other authors. ${ }^{219}$ The insignificance of the characters in the artist's plates sensitively reflects their insignificance in the author's narrative, which depicts a society whose institutions dwarf, isolate, and too often destroy members. As Dickens increasingly abandoned his usual satiric devices, finding them insufficient to portray his society, so Browne gradually had to dispense with the traditional methods and subjects of graphic satire.
The dark plates, depicting the settings associated with the aristocratic Dedlocks, Tulkinghorn, their attorney, and the slum orphan, Jo, link these characters graphically as Dickens links them narratively. Utilizing light and shadow more conventionally than structure and artifact, Browne ingeniously relates Jo to all of society in his portrayal of Tom-all-Alone's (XLVI, facing p. 624), whose name nearly supplied the book's title (fig. 104). ${ }^{220}$ A garbage-filled passage leads out past a sign for a pawnshop, which fails, however, to imply even the temporary relief afforded by those previously depicted by Cruikshank (SBB, S, XXIII, facing p. 190) (see fig. 69) or Browne (MC, XIII, facing p. 224) (see fig. 68), and ends abruptly in a graveyard, which promises the only escape. Little reassurance is implicit in

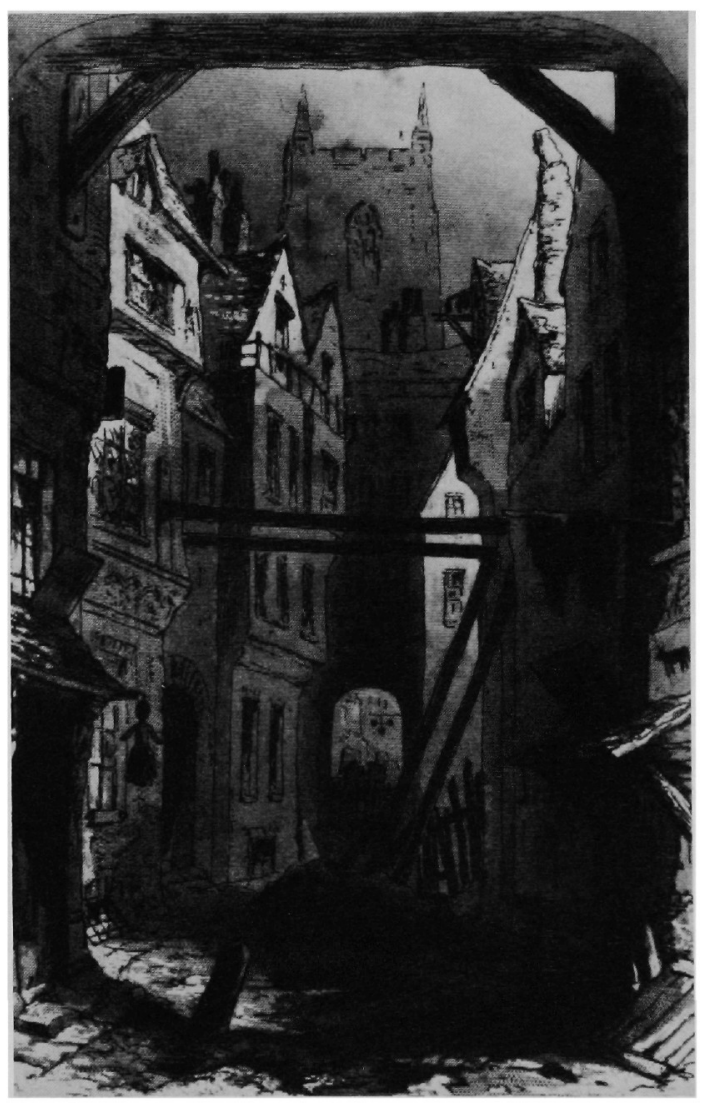

Fig. 104. Hablot Browne, 'Tom all alone's.' Bleak House, no. 14. Etching. $53 / 4^{\prime \prime} \times 334^{\prime \prime}(14.6 \times 9.5 \mathrm{~cm})$. By permission of the Houghton Library, Harvard University. 
the gray church tower which, like religion itself in Bleak House, coldly and impassively overlooks the environs, typical of impoverished London streets of the time (fig. 105). ${ }^{21}$ Browne had freely delineated church interiors with humorous details (DC, II, facing p. 14 and XLIII, facing p. $626 ; B H, \mathrm{XXV}$, facing p. 356) but he had never put sacred exteriors to such a grim use; this one recalls the similarly indifferent church in Hogarth's 'Gin Lane,' which Dickens so admired (CP, 1: 159), ${ }^{222}$ not the structures that benignly rise above Pickwick in the pound (XIX, facing p. 258) or the children playing near their cousin's grave in Nickleby (LXV, facing p. 834). No people walk or play in this urban wasteland; their presence is merely hinted at by the clothes draped over the flagless pole and a skirted stuffed doll suspended from a low roof hook, an appropriate suggestion of the condition to which the unseen inhabitants (such as Lady Dedlock's late lover) are often reduced. Similarly portrayed in dark tones are the wooden supports, which, though they brace the deteriorating buildings and, as Steig has perceived, seem to uphold the very heavens, ${ }^{223}$ are themselves rooted in the earth, surrounded by piles of human waste. As Beatrix Potter concluded, after studying Browne's masterful design, "What a sermon that little drawing preaches."224

Linked graphically as well as narratively to Tom-allAlone's is remote Chesney Wold, whose aristocratic inhabitants and environs provide the subjects of over half the total number of dark plates. Browne's exploitation of the striking light and shadow contrasts of this technique deliberately parallel Dickens's verbal devices (including the titles of the illustrations) for portraying Chesney Wold and its owners, especially Lady Dedlock. Though Browne's means are conventional, his deployment of them is sophisticated. From the first, the author leans heavily on the symbolic potential of shadow to anticipate how Lady Dedlock's adultery will affect Chesney Wold and the declining way of life it represents. He describes her portrait, which Guppy's obsessive interest has fixed in the reader's mind (VII, 87-88), in these terms: "Athwart the picture of my lady, over the great chimney-piece, [the cold sunlight] throws a broad bend sinister of light that strikes down crookedly into the earth, and seems to rend it" (XII, 152). In his dark plate, entitled 'Sunset in the long Drawing-room at Chesney Wold,' as Harvey has discussed, Browne graphically reflects the theme of light and shadow, which is used to highlight the few permitted aesthetic objects that are dramatically as well as visually essential (XL, facing p. 562) (fig. 106). ${ }^{225}$ In the center of the room, in the darkest shadow relieved only by flecks of light, stands a sculptured maternal figure attending a small cherub. At the upper left corner, face averted from

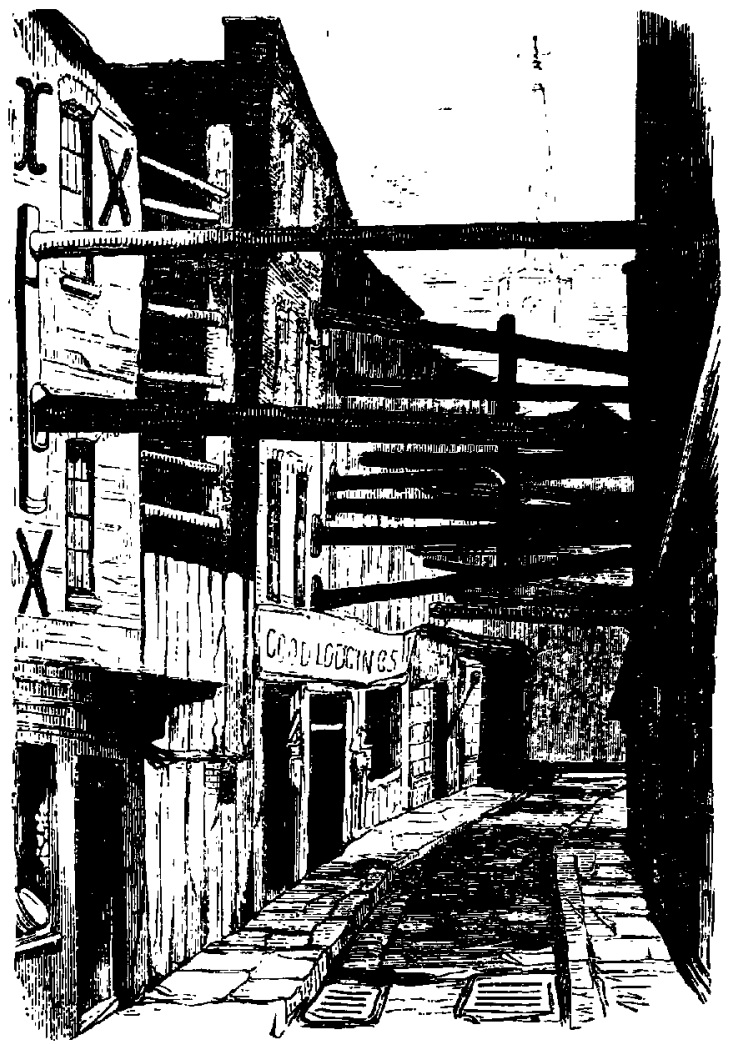

Fig. 105. John Brown, 'Mint-street, looking towards High-street, Southwark.' George Godwin, London Shadows (London, 1854), p. 76. Wood engraving. $4 \frac{5}{8^{\prime \prime}} \times 31 / 4^{\prime \prime}(11.8$ $\times 8.3 \mathrm{~cm})$. By permission of the Houghton Library, Harvard University.

the tender pair as well as from the sunlit portrait opposite of a young girl, is the portrait of Lady Dedlock. The artifacts, all linked by light, suggest what events will prove true - that Lady Dedlock turned away from her maternal duties and abandoned her illegitimate daughter to preserve her aristocratic station. But the effect of her misconduct, like the gathering shadow, here touching her pictured skirt like a stain, threatens to overwhelm her as Dickens suggests in the accompanying text. "And now, upon my lady's picture over the great chimney-piece, a weird shade falls from some odd tree, that turns it pale, and flutters it, and looks as if a great arm held a veil or hood, watching an opportunity to draw it over her" (XL, 563).

The next dark plate that features Lady Dedlock-in person this time-is entitled 'Shadow' (LIII, facing p. 718) (fig. 107), and indeed Dickens uses more and more shadow in 


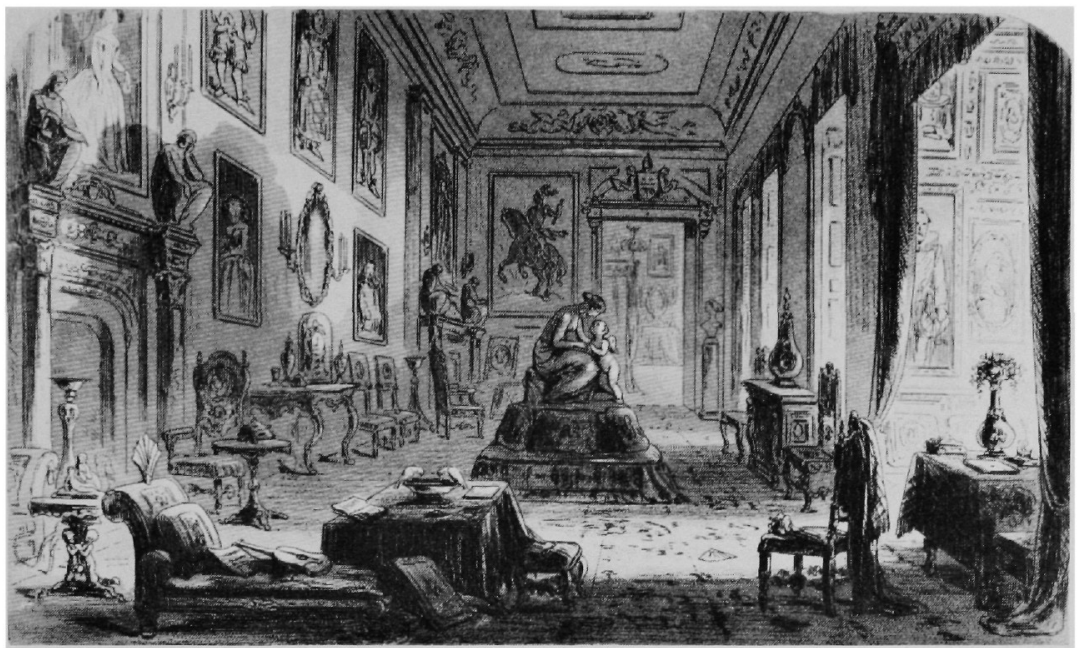

Fig. 106. Hablot Browne, 'Sunset in the long Drawing-room at Chesney Wold.' Bleak House, no. 13. Etching. 4" $\times 65 / 8$ " $(10.2 \times 16.8 \mathrm{~cm})$. By permission of the Houghton Library, Harvard University.

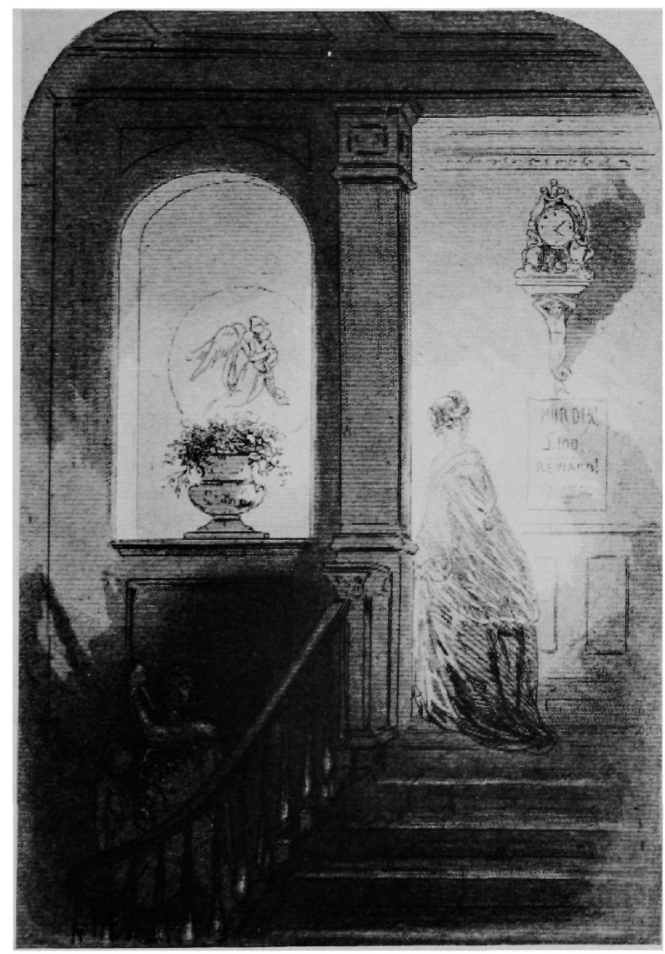

Fig. 107. Hablot Browne, 'Shadow.' Bleak House, no. 1. Etching. $55 / 8^{\prime \prime} \times 3^{15 / 16^{\prime \prime}}(14.3 \times 10 \mathrm{~cm})$. By permission of the Houghton Library, Harvard University. describing her, so that she gradually becomes equated with it. The illustration does more than afford a technical and titular contrast with the preceding scene, 'Light,' in which Esther Summerson, Lady Dedlock's selfless daughter, comforts the newly married Ada (LI, facing p. 694). In the dark plate, shadow acts as a protagonist in the implicit psychological drama, enveloping the entire staircase at Chesney Wold and all but the head and shoulders of Lady Dedlock as she mounts it. It almost blankets the maternal scene on the landing, from which her ladyship, as before, averts her head. In contrast to Edith Dombey's encounter with Florence on the stairway ( $D \& S$, XLVII, facing p. 664) (see fig. 85), a scene that invites comparison with this one, there is no acknowledged responsibility to a child to give this woman pause. Her attention is drawn instead to the area of light near the "MURDER-REWARD" poster, a reference to the recent death of the family lawyer, Mr. Tulkinghorn, as blunt as that of the figure of Allegory in the preceding dark plate (XLVIII, facing p. 662).

The next two dark plates are more exciting and mysterious. Paired by title and original placement as well as by technique, as Harvey has shown, they capitalize on the confusion created by Lady Dedlock's use of the brickmaker's wife to conceal her movements. ${ }^{226}$ The fact that the figure in 'The Night' (LVII, facing p. 766) (fig. 108) does not turn out to be her ladyship increases the ambiguity surrounding the collapsed figure in 'The Morning' (LIX, facing p. 806) (fig. 109). Perhaps it is Jenny, as Esther initially believes; 

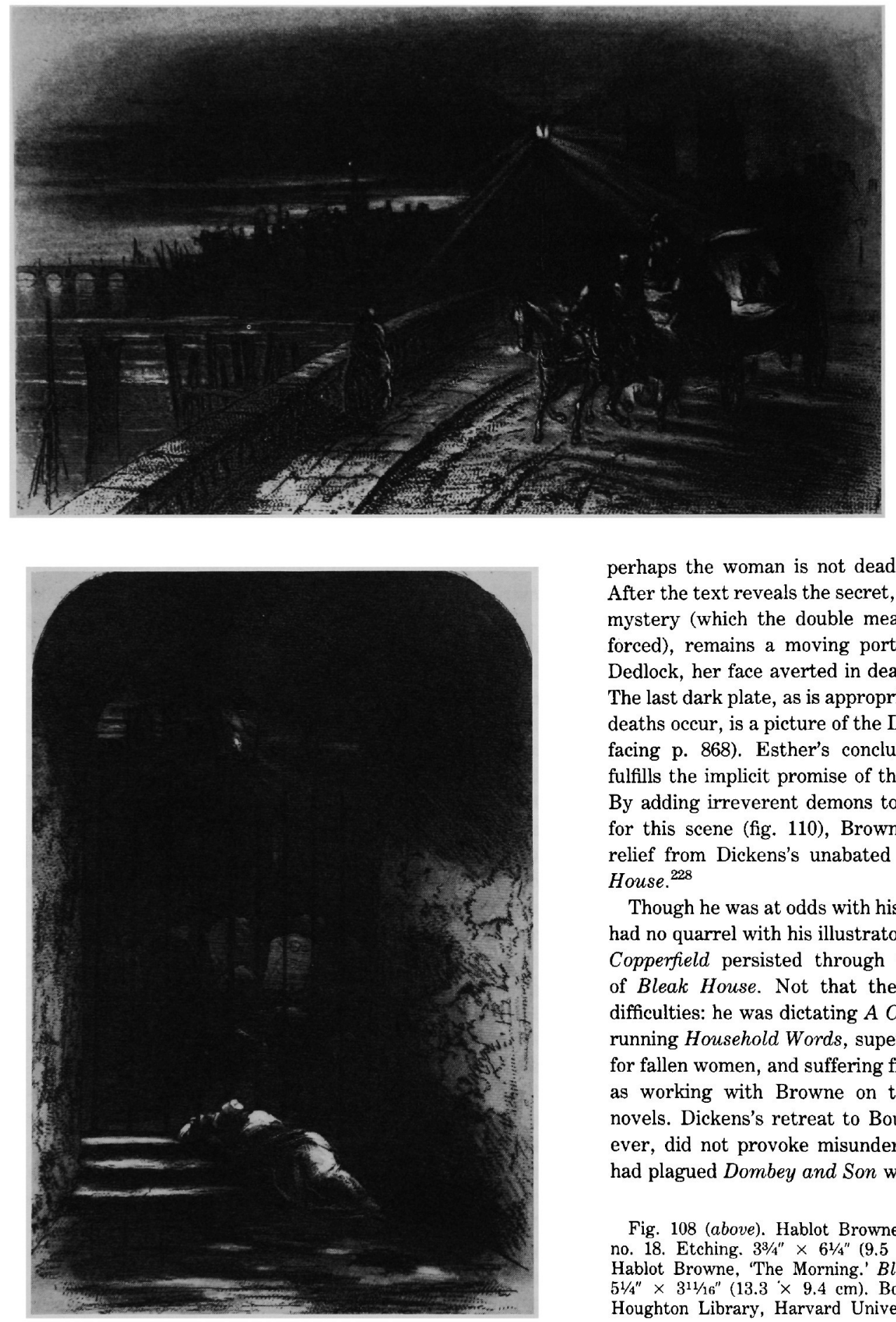

perhaps the woman is not dead, but merely ill or asleep. After the text reveals the secret, the plate, though losing its mystery (which the double meaning of its title had reinforced), remains a moving portrayal of the fate of Lady Dedlock, her face averted in death as it had been in life. ${ }^{227}$ The last dark plate, as is appropriate in a story in which nine deaths occur, is a picture of the Dedlock mausoleum (LXVI, facing p. 868). Esther's concluding epilogue only partly fulfills the implicit promise of the scene's brighter horizon. By adding irreverent demons to the margins of his sketch for this scene (fig. 110), Browne may have sought comic relief from Dickens's unabated pessimism through Bleak House. ${ }^{228}$

Though he was at odds with his society, however, Dickens had no quarrel with his illustrator. The harmonious mood of Copperfield persisted through the rigorous collaboration of Bleak House. Not that the author did not have his difficulties: he was dictating $A$ Child's History of England, running Household Words, supervising Miss Coutts's home for fallen women, and suffering from kidney troubles as well as working with Browne on this most ambitious of his novels. Dickens's retreat to Boulogne to recuperate, however, did not provoke misunderstandings of the kind that had plagued Dombey and Son when he was in Switzerland.

Fig. 108 (above). Hablot Browne, 'The Night.' Bleak House, no. 18. Etching. 33/4" $\times 61 / 4^{\prime \prime}(9.5 \times 15.9 \mathrm{~cm})$. Fig. 109 (left). Hablot Browne, 'The Morning.' Bleak House, no. 18. Etching. $51 / 4^{\prime \prime} \times 3^{11 / 16 "}(13.3 \times 9.4 \mathrm{~cm})$. Both by permission of the Houghton Library, Harvard University. 


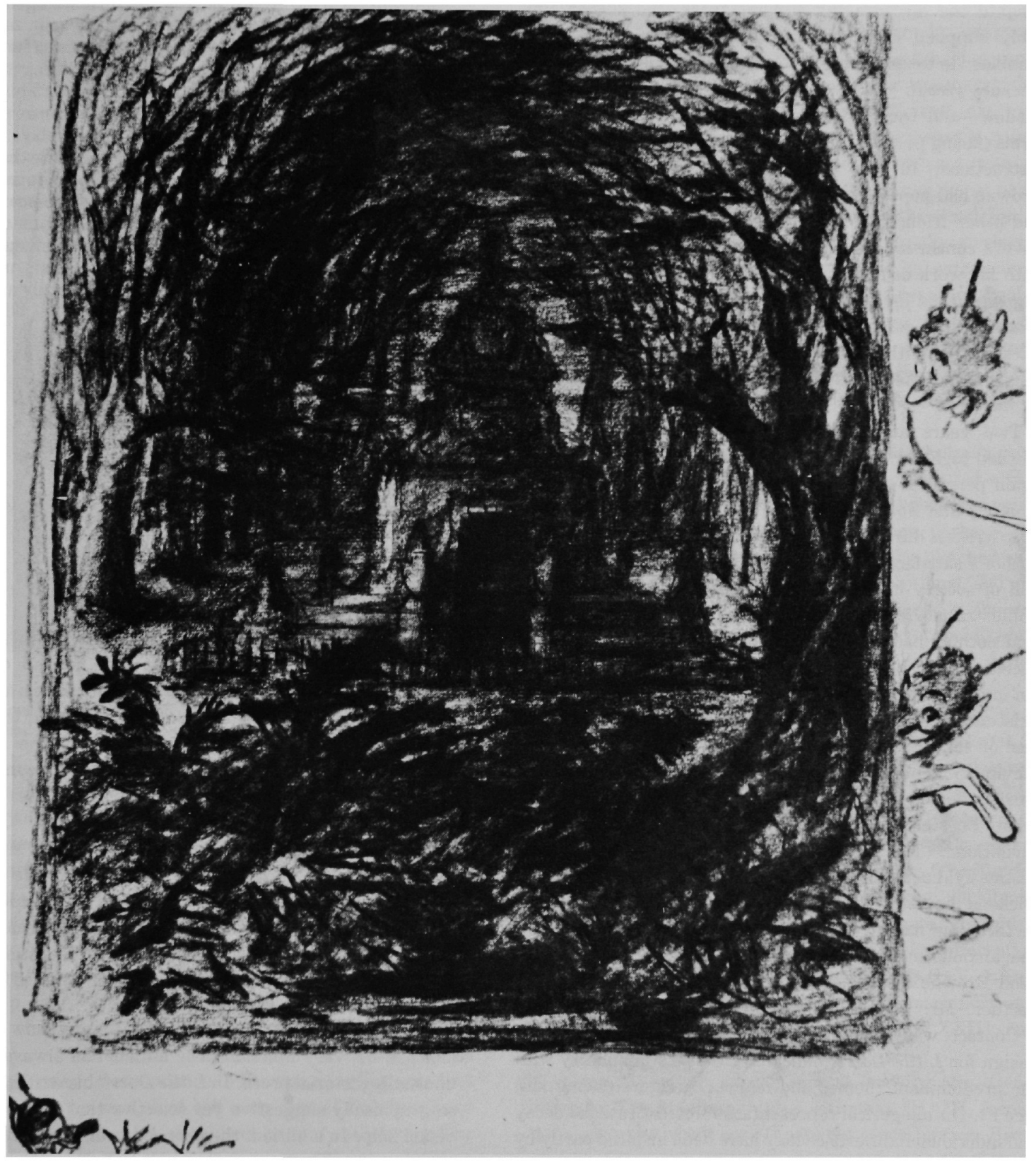

Fig. 110. Hablot Browne, Unpublished Sketch for "The Mausoleum at Chesney Wold.' Graphite. 53/4" $\times 51 / 2^{\prime \prime}(14.6 \times 14 \mathrm{~cm})$. From the Elkins Collection, by permission of the Rare Book Department of The Free Library of Philadelphia. 
Despite the discouraging circumstances, the author amicably supplied the final subjects and approved without quibbles sketches for them, for the frontispiece-a view of Chesney Wold, the bleakest house of all, enveloped in shadow-and the title vignette, showing Jo outside Sol's Arms (facing p. xviii). He gaily issued invitations, as well as instructions, to the artist-often in pidgin French. ${ }^{229}$ Browne had hoped to participate, along with the publishers and other friends, in the cross-Channel celebration of the novel's conclusion, but he must have been too preoccupied with his work or family, and could not go; a playful sketch registered his joy nevertheless at the completion of Bleak House, the most demanding of his many endeavors with Dickens. ${ }^{230}$ With this work, the two men reached the height—and the limits—of their collaboration.

Two years after Bleak House, Dickens and Browne worked together on Little Dorrit. In this book Ruskin once again perceived the "ominous palsies" he felt had afflicted Dombey and Son ${ }^{231}$ Indeed, the new novel, like Dombey, was written during one of Dickens's restless periods. The author's satisfaction with his analysis of self in Copperfield and of society in Bleak House (and in his next work, the unillustrated Hard Times) was dissipated by the realization that nothing had basically altered either in his life or in his society. Accordingly, lack of change became the besetting sin in Little Dorrit. For the characters, as for their creator, existence seems little more than confinement in a variety of real or self-imposed prisons. Some of Dickens's frustration inevitably vented itself on his principal illustrator, whose work reflected not only his own diminished ingenuity, but what Forster called the "droop" in the author's own invention. ${ }^{232}$ Matters went awry from the start. Traveling restlessly back and forth between London and France, Dickens began writing to Browne at length about his forthcoming narrative; hearing nothing about or from him, the anxious author demanded that Bradbury and Evans send Browne his Paris address and communicate with his partner, Mr. Young, about the artist's whereabouts. ${ }^{233}$

Contact was somehow reestablished, for the wrapper design for Little Dorrit indicates Browne's familiarity with the predominant themes and major characters (facing xiii) (see F). His allegorical representations of institutional decay and individual indifference may have been inspired partly by the book's original title, Nobody's Fault-a title Dickens intended as an ironic comment on the state of England in the mid-1850's. Butt and Tillotson have minutely described the complex wrapper:

Its two sides seem to typify society in decay, and images of doom are combined with complacence and self- absorption. On the left is part of a crumbling castle, on whose tottering top is seated a sleeping man in an arm chair with a handkerchief over his eyes and a newspaper on his knee. Against the castle lies a falling tree; the "supporters" of the coat of arms are rats. This is "the world" in its material aspect. Opposite stands part of a church, crowned by a raven, while a child plays leapfrog among the graves, and in a wheel-chair sits the life-indeath figure of Mrs. Clennam attended by Flintwinch. So much for "religion." Overlapping these two scenes, and extending across the bottom of the design, is a motley crowd of travellers, each clinging to his belongings, all moving different ways, colliding, harassed, unhappy. Across the top of the design is what is virtually a political cartoon. Two aged figures, crippled and half blind, lead the procession, followed by a line of dotards and a dandy; Britannia in a bath-chair, asleep, is propelled by a line of men in fools' caps, followed by a crowd of toadies, behind whom are women and children; all, save the last, are smiling insanely. The centre-piece is Little Dorrit herself, at the gate of the prison, in a shaft of sunlight. ${ }^{234}$

Browne's wrapper design well conveys the story's pessimistic mood, which connects these scenes that are not narratively related.

The reader who could continue to find that "Dickensy felicity of illustration" must have responded out of habit, ${ }^{235}$ and Browne must have found it harder to illustrate the text of Little Dorrit than of anything else he had done for Dickens. Institutions dominate individuals to an even greater extent than in Bleak House, as, indeed, the prison arch dwarfing the diminutive heroine on the wrapper anticipates (see F). The Marshalsea and the Circumlocution Office evoke vast symbols and concepts rather than concrete images. The major characters except Mrs. Clennam, perhaps - are less vivid than the minor ones like Miss Wade or Henry Gowan, and as their psychological life becomes more complex, their number and variety are reduced and the range, scope, and interest of their external actions narrowed. The dispirited atmosphere of the story is not conducive to the use of comic detail nor even to dramatic contrasts of light and shadow.

Browne's greatest problem was that by now Dickens usurped his very function. The author had always written unusually pictorial prose. In Little Dorrit his writing became so graphically suggestive yet selective that it needed little visual help. In addition, the proportion of Dickens's readers who were literate kept on increasing. ${ }^{236}$ Thus, for example, Browne's opening illustration of the Marseilles prison cell could not (and did not) add much to Dickens's description (I, I, facing p. 4) (fig. 111).

In one of its chambers . . . were two men. Besides the two men, a notched and disfigured bench, immovable from the wall, with a draught-board rudely hacked upon 
it with a knife, a set of dominoes, two mats, and two or three wine bottles. That was all the chamber held, exclusive of rats and other unseen vermin, in addition to the seen vermin, the two men.

It received such light as it got, through a grating of iron bars, fashioned like a pretty large window. . . There was a broad strong ledge of stone to this grating, where the bottom of it was let into the masonry, three or four feet above the ground. Upon it, one of the two men lolled, half sitting and half lying, with his knees drawn up, and his feet and shoulders planted against the opposite sides of the aperture (I, I, 4).

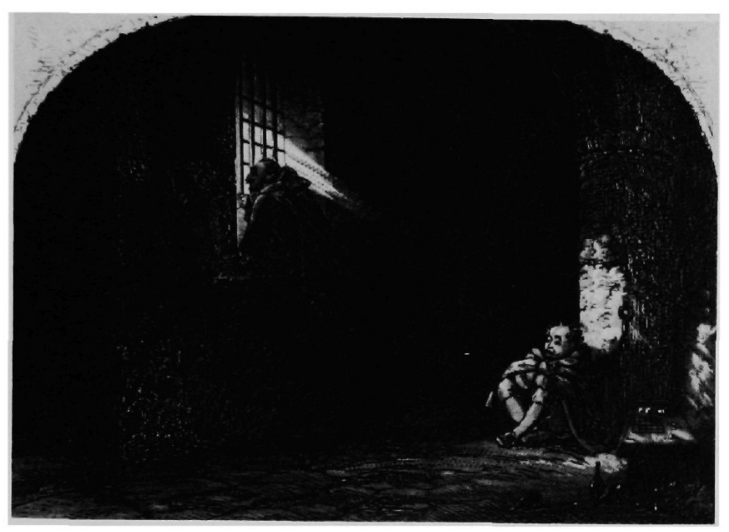

Fig. 111. Hablot Browne, 'The Birds in the Cage.' Little Dorrit, no. 1. Etching. $358^{\prime \prime} \times 47 / 8^{\prime \prime}(9.2 \times 12.4 \mathrm{~cm})$. By permission of the Houghton Library, Harvard University.

Here and elsewhere in Little Dorrit the author was, in effect, verbally fashioning his own illustrations. ${ }^{237}$ Graphic embellishment was becoming redundant, if not superfluous.

Nevertheless, the author involved himself with the actual illustrations as minutely as ever. He deemed Flintwinch receiving Blandois's friendly embrace "all right," and Mrs. Clennam's expression "capital," but insisted that her son must be "as agreeable and well-looking as possible" (II, X, facing p. 566); whereas 'The Pensioner-Entertainment' (I, XXXI, facing p. 386) could be "as characteristic as ever you please, . . . but quiet." 238 Gradually, however, there crept into Dickens's correspondence to Browne a carping note that had not been present since the early part of Dombey. Lord Decimus's hand, he said, should not be "put out" during "The Patriotic Conference' (II, XII, facing p. 578); the "baddest man" Baptist sees, he called "a leetle bit too furious and wanting in stealthiness," and the startled Mrs. Plornish appeared "too old" (II, XIII, facing p. 596); and he asks if Sparkler was, in fact, getting the tortoise-shell knife from the box in 'Mr. Merdle a Borrower' (II, XXIV, facing p. 724$)$. $^{239}$
These are quibbles compared to Dickens's objection to Browne's sketch of Mr. Dorrit just before his unexpected after-dinner speech. The artist had made him "too comic," Dickens claimed. "He is described in the text as "shedding tears' and what he imperatively wants is an expression doing less violence in the reader's mind to what is going to happen to him, and much more in accordance with that serious end which is so close before him. Pray do not neglect this change."240 Browne, of course, made the alteration, and in the final picture the former debtor, fatally strained by conflicting emotions and values, makes an extremely pathetic figure (II, XIX, facing p. 670). But not since 'Paul and Mrs. Pipchin' in Dombey had Browne so totally failed to realize Dickens's conception of a scene. In sharp contrast to his outrage about the early misrepresentation, Dickens lapsed into a critical calm-the retreat of an author who no longer expects much of his illustrator.

Browne's diminished vitality is evident technically as well as conceptually. The lines of his sketches, executed with too soft a pencil, lack precision; the designs themselves contain too many dramatically meaningless spaces, perhaps, as in the dark plates, left so the lines would not be blotched by the printer. $^{241}$ The finished etchings, conventional and dark alike, are uninspired. In the etchings made in the usual manner there are too many areas composed of rouletted dots made by a wheel that an assistant could hold. Indeed, Johannsen is convinced that 'The Travellers' is entirely the work of some unskilled apprentice (II, I, facing p. 450) (fig. 112). ${ }^{242}$ Even the eight dark plates in Little Dorrit lack dramatic impact. The artist delineated the subordinate figures and details nicely enough (I, I, facing p. 4; I, XI, facing p. 138; I, XIV, facing p. 180; I, XXVIII, facing p. 348; II, XXX, facing p. 810) and fully exploited subtle contrasts of medium light and dark tones in scenes like 'The Ferry' (I, XVII, facing p. 208), but the machine ruling, usually done by an assistant, had become too indiscriminate. The figure of Arthur Clennam, for example, is scarcely differentiated from the door and walls of his father's study (I, V, facing $p$. 58) (fig. 113), nor are the various units of machinery at the rear of the Works readily distinguishable (I, XXIII, facing p. 276). ${ }^{243}$

Even the artist's errors, such as drawing Mrs. General twice in 'The family dignity is affronted' (II, III, facing $p$. 476), seem the result not of haste but of inattention. Browne provided less dramatic interplay among the plates than he had in any Dickens story since Nicholas Nickleby. The frontispiece (ii) (fig. 114) and the title page vignette (iii) (fig. 115), which faced one another in the final monthly part as well as in the bound edition, are exceptions, as Steig has observed: ${ }^{244}$ by depicting first Amy entering Merdle's house, and then Amy leaving the Marshalsea, they link the 


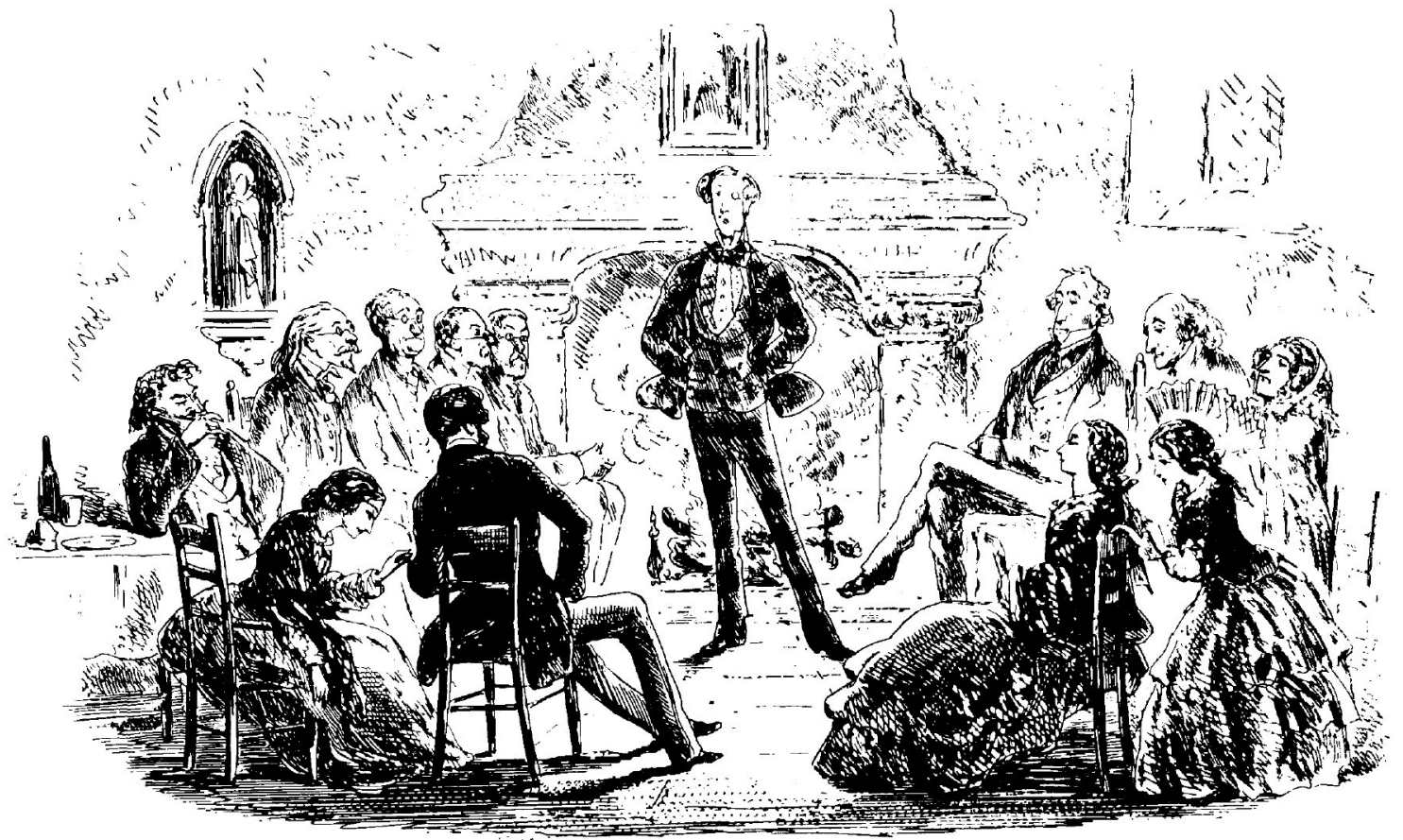

Fig. 112. Hablot Browne, "The Travellers,' Little Dorrit, no. 11. Etching. $4 \frac{1 / 8}{1} \times 615 / 16^{\prime \prime}(10.5 \times 17.6$ $\mathrm{cm})$. By permission of the Houghton Library, Harvard University.

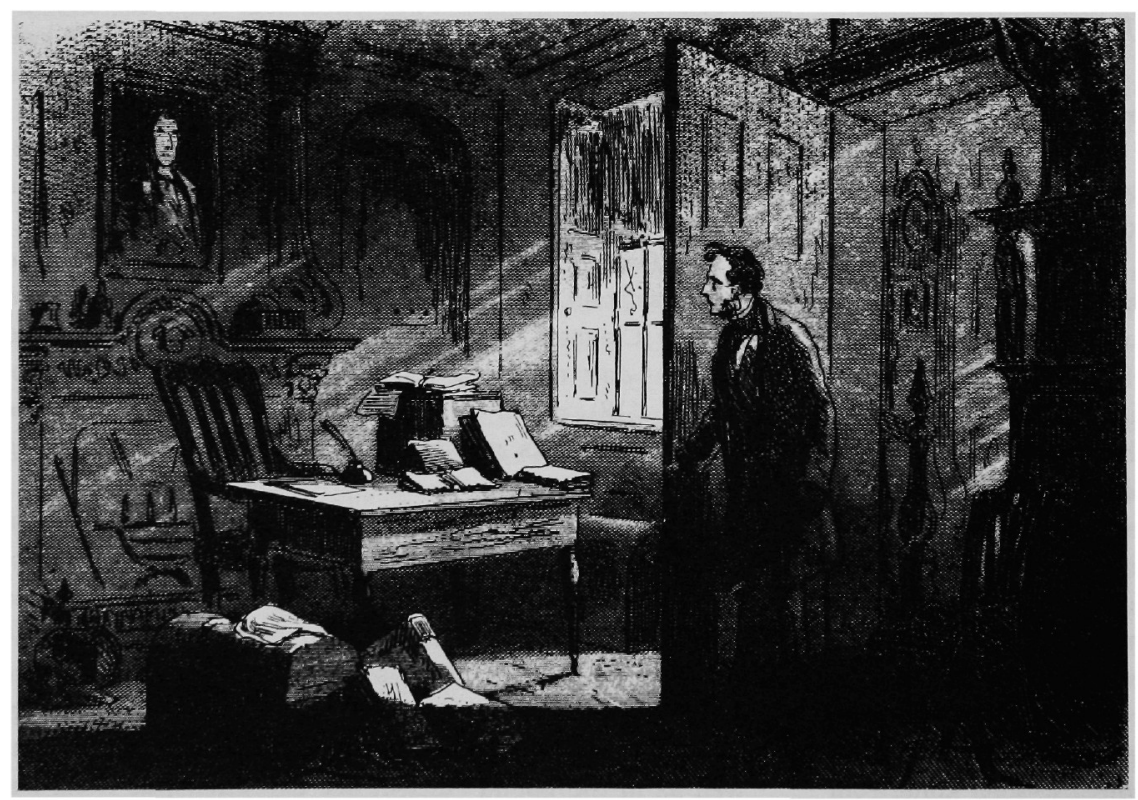

Fig. 113. Hablot Browne, "The Room with the Portrait.' Little Dorrit, no. 2. Etching. $39166^{\prime} \times 5$ " $(9$ $\times 12.7 \mathrm{~cm})$. By permission of the Houghton Library, Harvard University. 


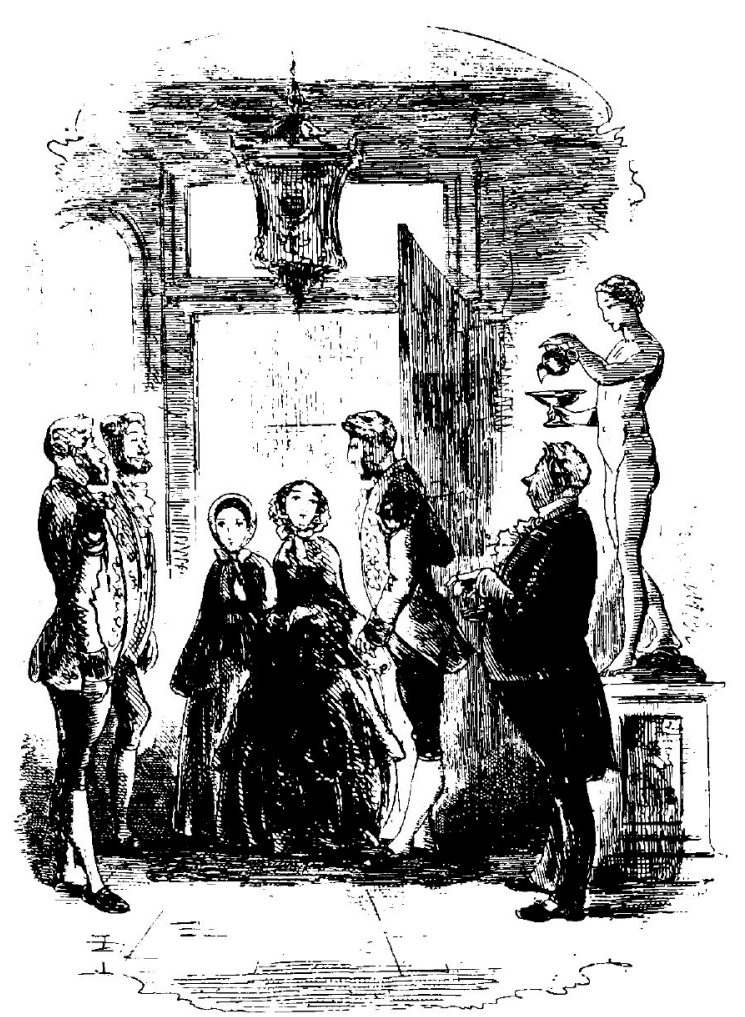

Fig. 114. Hablot Browne, Frontispiece. Little Dorrit, nos. 19 and 20. Etching. $5^{1 / 2^{\prime \prime}} \times 4^{1 / 1} 8^{\prime \prime}(14 \times 10.5 \mathrm{~cm})$. By permission of the Houghton Library, Harvard University.

prison to society at large. But this final pair cannot dispel the general impression that the plates for Little Dorrit are, at best, no better than and little different from the less memorable ones in the earlier novels. Browne may not have been insensitive to the diminished quality of his work. As he grew older, and his commissions more numerous, he occasionally forgot to sign his plates, yet, as Kitton notes, perhaps it may be indicative of his total exhaustion that he did not append his name to a single plate in Little Dorrit. ${ }^{245}$

To some extent, this failure of creativity was occasioned by Browne's usual empathy-this time with the author's own lack of inspiration. Certainly readers were relatively unmoved by the narrative, whose rebellious political views would excite a later generation of readers like Shaw and Henry Green; Henry James's comment that his own apolitical household "breathed heavily" through Little Dorrit was a characteristic contemporary response. ${ }^{246}$
Some kind of drastic change was needed, not only in the world but in Dickens's own work and life. Thus, it was not wholly coincidental that his next work, A Tale of Two Cities, concerned revolution, nor that it accompanied striking alterations in his own affairs and ultimately in those of his principal illustrator. The new fiction provided the author with a suitable creative outlet for his frustration in the years 1858-59. Revolution, as Dickens depicted it in the Tale, was the inevitable result of past stagnation but held promise of future improvement. While the story was in progress, the forty-seven-year-old author had effected some radical departures from his own past: by the story's end in 1859, he had separated from his wife of over two decades, his publishers of fifteen years, his London home, and many of his old friends. The Tale itself sharply departed from most of

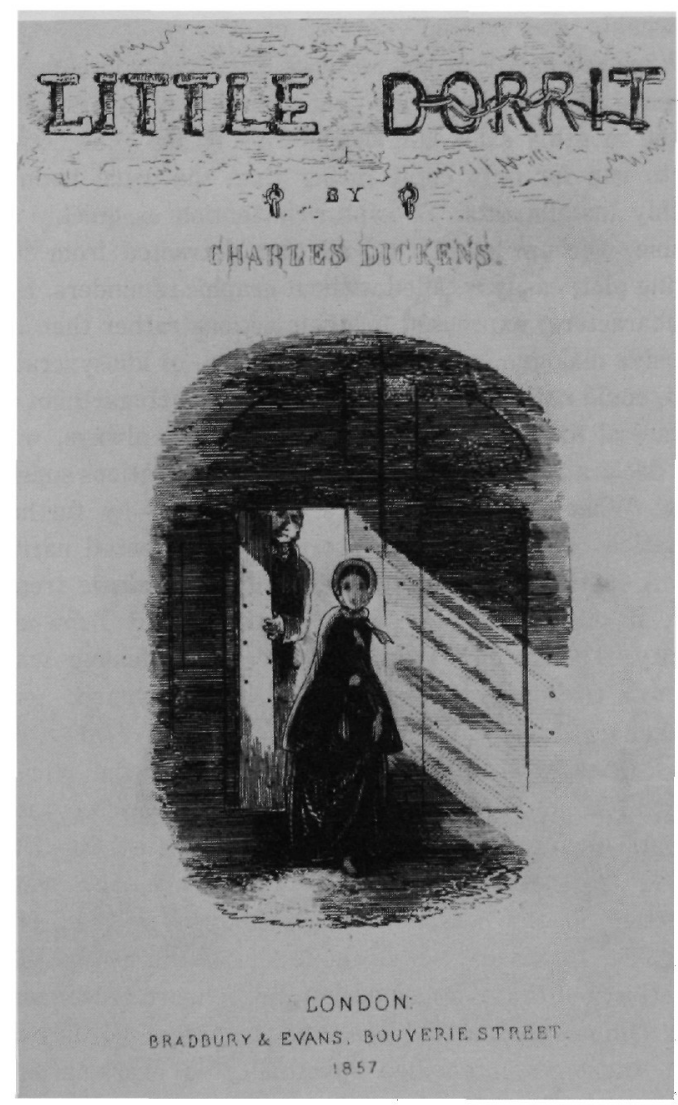

Fig. 115. Hablot Browne, Title Page. Little Dorrit, nos. 19 and 20. Etching. $35 / 8^{\prime \prime} \times 25 \mathrm{~s}^{\prime \prime}(9.2 \times 6.7 \mathrm{~cm})$. By permission of the Houghton Library, Harvard University. 
his previous fiction in its short length, simple construction, spare prose, and religious resonance. Nevertheless, nothing cataclysmic occurred between author and artist during the course of the story. The lack of usual correspondence about the illustrations, although it may have been destroyed, may also suggest that Browne was accorded an unprecedented independence due primarily to Dickens's other preoccupations and, perhaps, to a resigned acceptance of his artist's decline. For the illustrations to A Tale of Two Cities reveal, far more noticeably but less understandably than in those for Little Dorrit, that the artist utterly failed to find a graphic correlative for the author's next stage of growth. In retrospect, it is clear that Browne's days as Dickens's illustrator were, by this time, numbered.

Browne did not—or could not-follow Dickens's lead. To stimulate sales for his new unillustrated weekly, All the Year Round, the author published the Tale in it as well as in the usual illustrated monthly parts. This reversion back to the weekly and monthly format of Master Humphrey's Clock proved only a partial success. The weekly circulation rose enough to get Dickens's new periodical off the ground; but the monthly sales languished. In any case, the fiction was to run for only eight rather than the usual twenty monthly installments. To capture attention as quickly as possible, Dickens eliminated all that detracted from the exciting plot, easily recalled without graphic reminders. His few characters, expressed by their actions rather than by extensive dialogue, suggestive description, or idiosyncratic detail, could not be visually realized through Hogarthian or mechanical means. His style, as pictorial as always, was more declarative than evocative, making illustrations superfluous. What could the artist's talents add-by further distillation or reinforcement-to such a condensed narrative? A historically accurate or wholly naturalistic treatment, if either came to mind, were beyond Browne's capacity. Though previously resourceful in dealing with Dickens's challenges, this time he seemed stymied.

Dickens had planned the plot of A Tale of Two Cities enough in advance to reveal it in detail to Browne, whose wrapper design clearly depicts its main characters and incidents (facing p. xiv) (see F), but the artist failed to respond to the author's new interests as they were suggested on the wrapper and developed in the text. Though St. Paul's and Notre Dame, at the top and bottom respectively of the wrapper design, prove more consequential as symbols than actual locales in the narrative, they do reflect Dickens's intensified spirituality-a characteristic manifested in The Life of Our Lord written in 1846 for his children, but only intermittently in his fiction between the death of little Nell (OCS, LXXI, 576) and the marriage of Arthur Clennam to Little Dorrit ( $L D$, II, XXXIV, 851). But
Browne, perhaps uninspired by the less tangible emotions, or unable to portray them, provided nothing distinctive in his representations of Sydney Carton, who will be inspired to the "far, far better thing" he does in redeeming his wasted life by sacrificing it (III, XV, 363); indeed, as one viewer has observed, the artist was so indifferent to the scene as a whole that he showed Carton still wearing a wig while standing for comparison with Darnay in the crucial scene 'The Likeness' (II, III, facing p. 70; cf. p. 71). ${ }^{247}$ Furthermore, Dickens utilized his knowledge of France in the Tale to a far greater extent than he had in Little Dorrit. But the artist, who had never visited the country, clearly did not bother with architectural or sartorial details of place and period. ${ }^{248}$ Finally, the author's fascination with the French Revolution (especially as portrayed by Carlyle), which also capitalized on contemporary anti-French sentiment, was not shared by the apolitical artist. To judge from his plates, he remained unmoved even by the rush of the narrative, which reflected Dickens's own tumultuous emotions at the time.

Consequently the spirit that fired the text of $A$ Tale of Two Cities failed to animate the illustrations. Browne's indifferent work stuck out in a story so filled with exciting incidents. Perhaps the fact that his work was reproduced by lithography disheartened Browne from the first. The plates, with their thin, scratchy lines, seem hastily executed. There is little dramatic interplay among them or dramatic composition within them. The figures too often lack vitality as well as solidity; the mob scenes, for example, (II, VII, facing p. 106; II, XIV, facing p. 150; II, XXI, facing p. 208) (fig. 116) recall the stiff portrayal of the unemployed rioters in The Old Curiosity Shop (XLV, 359) (fig. 117) rather than the tense crowds of Barnaby Rudge (XLIX, 398; LXIV, 528; LXVI, 548) (fig. 118). The smaller groups are more carefully modeled but the heroes-Darnay and the Manettes, for example-look too conventional to be memorable (III, VII, facing p. 283) and the villains, like the DeFarges, look too benign to be credible (II, XVI, facing $p .178$ ). When they are suggested at all, backgrounds and interiors, previously a Browne strength, lack interest and atmosphere as well as authenticity (II, XII, facing p. 138; III, I, facing p. 244). The fact that all the illustrations are oblong, for the first time in a Dickens work, makes their superficiality more obvious. Since they contain neither draftsmanship to be admired nor detail to be studied, it is hardly worth interrupting the gripping narrative to turn the page around to view them. They are merely representations, not genuine illustrations as the artist had produced for Dickens so often in the past. The most partial admirer of Browne must concur with one of his severest critics that "the eye and the spirit are alike wearied and distressed by this exhibition of uninspiring mediocrity on the part of 'Phiz.'" 249 Again, as if agreeing 


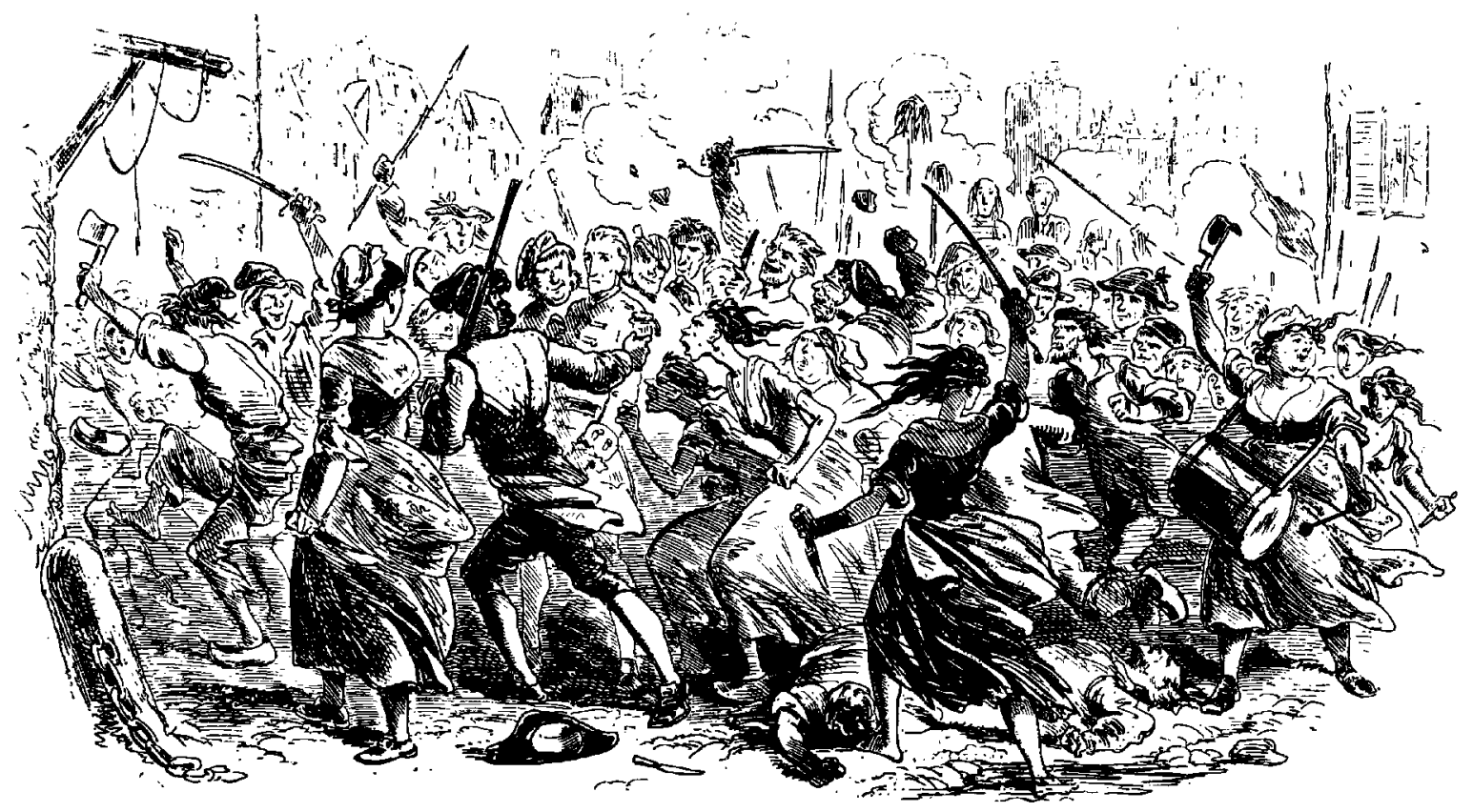

Fig. 116. Hablot Browne, 'The Sea Rises.' A Tale of Two Cities, no. 5. Etching. 33/4" $\times 73 / 16^{\prime \prime}(9.5$ $\times 18.3 \mathrm{~cm})$. By permission of the Houghton Library, Harvard University.

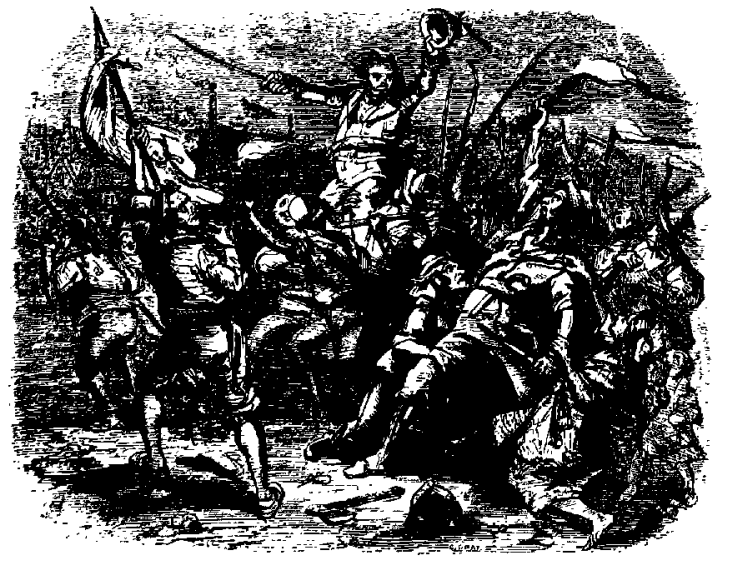

Fig. 117. Hablot Browne, 'The rioters at Moprfields.' Master Humphrey's Clock, no. 30, p. 45. Wood engraving. $3^{1 / 2^{\prime \prime}}$ $\times 4 \% 6^{\prime \prime}(8.9 \times 11.6 \mathrm{~cm})$. By permission of the Houghton Library, Harvard University.

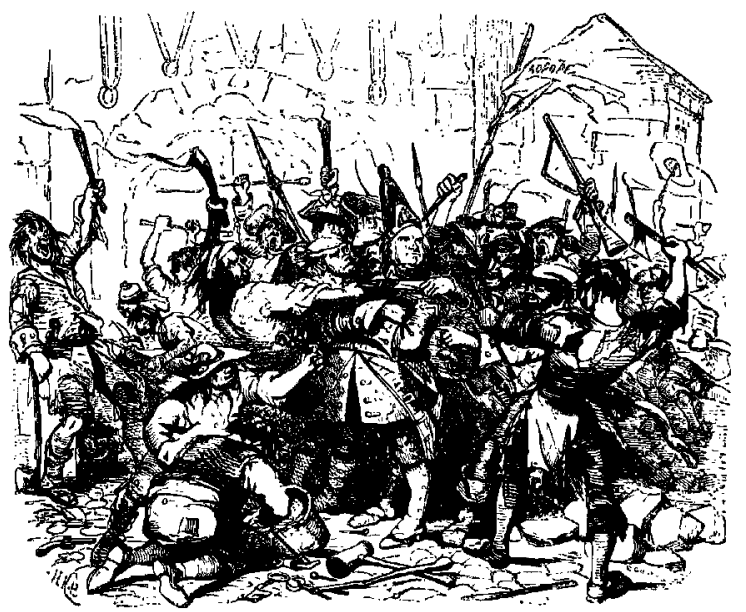

Fig. 118. Hablot Browne, 'Mr. Varden and the Mob.' Master Humphrey's Clock, no. 78, p. 309. Wood engraving. $3^{3 / 4^{\prime \prime}} \times 4 \% 16^{\prime \prime}(9.5 \times 11.6 \mathrm{~cm})$. By permission of the Houghton Library, Harvard University. 
with this assessment, Browne did not sign a single one of the plates. ${ }^{260}$

The artist's lackluster performance has never been fully explained; nor does it entirely account for the fact that Browne never again collaborated with Dickens. As it turned out, A Tale of Two Cities was the last of Dickens's works to contain illustrations by Phiz. The twenty-three-year relationship between the two men-"as suited to each other, and to the combination of a unique thing as Gilbert and Sullivan," Chesterton remarked-was severed. ${ }^{251}$ Even if the artist's work on the Tale had been satisfactory, however, other circumstances were conspiring against their continued collaboration, and indeed the break between them never manifested itself abruptly or formally.

In marked contrast to his public statements about his marital separation, Dickens said nothing about the separation from his principal illustrator either in public or to Browne himself. The artist, on the other hand, speculated endlessly, particularly after Dickens's death, about the causes for his tacit dismissal. The most obvious cause, however, was the one he did not mention. The artist's creative degeneration, as Mrs. Leavis suggests, was probably caused by physical and mental exhaustion, the cumulative result of long years of overwork and little leisure now exacerbated by tighter deadlines for the larger editions now required for the increasing number of literate readers. ${ }^{252}$ This exhaustion not only impoverished his work for Dickens and other authors but doubtless made him more susceptible to his later paralysis, which crippled him physically and professionally. But Browne never offered these considerations as an excuse for his decline, at this or any later time.

Ignoring this weariness, which was so clearly reflected in the poor quality of his work for A Tale of Two Cities, the artist dwelt instead on other events that he felt had put Dickens out of humor at the time with other associates as well as with him. A friend of the author's, Watts Phillips, for example, had used a plot very similar to that of the Tale in a play, The Dead Heart, which was staged with great success at about the time the Tale was appearing. It was the public notice of these parallels, Browne claimed, that caused Dickens to stop at the ninth number instead of at the eighteenth as usual; "All this put Dickens out of temper and he squabbled with me amongst others," the artist then concluded many years after the fact, "and I never drew another line for him." 253 Dickens may well have been chagrined at the coincidence between his plot and that of Cruikshank's close friend and pupil, but there is no record that he quarreled about it with anyone except the playwright. Nor is there any external or internal evidence indicating an unpremeditated shortening of $A$ Tale of Two Cities; the condensed narrative was concluded as planned by the author in the eighth, not the ninth number. Indeed, this is the least convincing of Browne's reasons for his own falling out with Dickens.

On the other hand, it is entirely likely that Dickens really was provoked at the time when Browne joined the staff of Once a Week, a rival periodical to his own All the Year Round, for whose opening numbers A Tale of Two Cities was written. All the Year Round resulted from a quarrel with Bradbury and Evans, the publishers and printers of Punch-which refused to publish Dickens's account of his marital arrangements-and Household Words. ${ }^{254}$ In 1859, after establishing a legal right to do so, Dickens ended Household Words, which he had edited for nine years. The furious publishers immediately started Once a Week and offered Browne a position on it. Despite the conflict of loyalties involved, Browne may have seen a chance to right an earlier wrong decision. In 1841 he had turned down a permanent position on Punch, later put to such successful use by two of Dickens's other illustrators, John Leech and John Tenniel, though he contributed to it occasionally. ${ }^{255}$ Once a Week was to be staffed by these two artists as well as by many of Punch's founders. Doubtless regretting that he had passed up the earlier opportunity, Browne could not now refuse their solicitation. ${ }^{256}$ Dickens, however, could not have been pleased to see his principal illustrator join the opposition periodical even before $A$ Tale of Two Cities was published in volume form in December, 1859, and Browne's act surely weakened the ties of loyalty between the two men.

Browne's implicit declaration of independence coincided unluckily with the death of Frank Stone, one of Dickens's Christmas books illustrators as well as an old friend and neighbor. This left Stone's son Marcus, an artist like his father, openly dependent on Dickens. In the five years following the Tale, Dickens procured small jobs for the young man on various editions of his works. "Marcus is no doubt to do Dickens," Browne correctly guessed after seeing the announcement for Our Mutual Friend. "I have been a 'good boy,"' declared the veteran, hurt that his services had not been invited, but "Dickens probably thinks a new hand would give his old puppets a fresh look or perhaps he does not like my illustrating Trollope neck-and-neck with him-though, by Jingo, he need fear no rivalry there!"257

It is inconceivable, however, that Dickens seriously objected to Browne's illustrating novels by rival authors. The artist had long illustrated the works of Charles Lever as well as many by Dickens's closer friends, Ainsworth and Bulwer-Lytton, among many others. ${ }^{258}$ Had Dickens ob- 
jected, he would not have remained silent. Indeed, it was probably the carelessness of Browne's work for Trollope's Can You Forgive Her in 1863 and 1864, rather than the fact that he did it, that reinforced Dickens's decision not to retain his services. "I think you would possibly find no worse illustrator than H. Browne," Trollope wrote his publisher. "He will take no pains to ascertain the thing to be illustrated. I cannot think that his work can add any value at all to any book." 259 To compound the insult, Trollope found Browne's etchings for the first volume of his story so unsatisfactory that the second volume was turned over to other artists, including, perhaps, Marcus Stone. ${ }^{260}$

Browne's speculation that Dickens might want a "fresh look" in his illustrations is more compelling. The artist had been illustrating his writing for twenty-three years. Though Marcus Stone's assertion that Dickens felt Browne's work had not advanced in quality or character since Pickwick is completely unfounded, ${ }^{261}$ by the 1860 's, the artist definitely belonged to an "old school" of illustrators. Public tastes and artistic techniques had changed. Earlier preferences for the grotesque, the picturesque, and the emblematic, had yielded to ones for academic realism and narrative sentimentality. New methods of duplication, such as lithography, were widening the gap between the artist's conception and the engraver's execution of steel etchings. Partly for this reason, though mainly for economic ones, steel etching was being superseded by wood engraving-a medium in which Browne was less comfortable. Younger artists like Marcus Stone, more attuned to, though not enslaved by, the dictates of the new aestheticism, would certainly give Dickens's illustrations a fresh appearance-probably one his readers would consider superior; and they could better keep pace with the grueling deadlines. For these reasons alone, the author may have decided to drop the aging Browne and his old-fashioned work even before thinking of a successor. For he must have recognized that the artist's work, even at its best, as it was from Master Humphrey's Clock through Bleak House, no longer added anything to his own everevolving prose. ${ }^{262}$

Browne put forward personal as well as professional reasons for his dissociation from the author. "I was about the last of those who knew him in the early days with whom Dickens fell out," noted the shy artist, "and considering the grand people he had around him, and the compliments he perpetually received, it is a wonder that we remained friends so long." 263 Yet the novelist had long associated with and been applauded by all levels of English society. There was no justification for Browne's implication that Dickens had become a snob, just as there was none for Robert Buss's statement that the hiring of Marcus Stone, like that of George Cattermole, was an attempt by fashionable society to "refine" the author by persuading him to banish Browne. ${ }^{264}$

However, the possibility of personal friction between the two men on other grounds cannot be discounted entirely. Dickens was unusually overwrought during the time when he was writing $A$ Tale of Two Cities. Browne, never very sociable, had grown more and more reserved-to the point of dreariness. Author and artist may well have quarreled, though whether about the Tale or Once $a$ Week or something personal is anybody's guess. For it was about this time that Browne felt compelled to excuse his inability to assist a group wanting to secure Dickens as a speaker on the grounds that "lately (Authors \& Artists will sometimes squabble), I have not been on very good terms with him."265

It is unlikely, however, that Browne was dropped as illustrator because he did not take sides in Dickens's domestic troubles, which culminated with his separation from his wife just before he began $A$ Tale of Two Cities. ${ }^{266}$ It is more plausible, as Arthur Waugh has suggested, that the author "persuaded himself that, just as he had sought comfort at home in freedom from the shackles of matrimony, so in the partnership of literature, he stood in need of a new alliance to deliver him from the bondage of himself." 267 Dickens was forcing changes on almost every aspect of his life. He had supplanted Kate with Ellen Ternan; Bradbury and Evans with their predecessors, Chapman and Hall; the ailing Maclise and Stanfield with Wilkie Collins, Edmund Yates, and Percy Fitzgerald; and Tavistock House with Gad's Hill. It seems almost inevitable that Browne should have been replaced as well. When Dickens moved from the city to Kent in 1860, he burned the accumulated letters and papers of twenty years. When Browne had moved from Croydon to the city the year before, he similarly stoked a bonfire. $^{268}$ Thus many traces of the long relationship between the two men were obliterated.

"Confound all authors and publishers," Browne wrote to his old friend and colleague, Robert Young, in a final flourish of irritation about his Dickens dissociation; "there is no pleasing the one or t'other. I wish I had never had anything to do with the lot." ${ }^{269}$ Yet he moved back to London at the close of A Tale of Two Cities to be closer to authors and publishers as well as to spark his stagnant creativity. He had some success selling sporting prints, drawing on his recollected firsthand knowledge of rural recreations. ${ }^{270}$ But his other artistic efforts, still based on his memory rather than on models, did not suit current taste for photographic realism and academic naturalism. His imagination, which had become increasingly dependent on the kind of external stimulus Dickens had provided so well, was not roused by 
other authors; and his increasing shyness further isolated him from other contacts who might have reinvigorated him. He became "a-weary of this illustrating business."271 His work reflected his fatigue. Commissions began to dwindle. Browne, though he had always lived modestly, had never bothered to put money aside, and he began to feel pinched financially. Ironically, his Dickens connection enabled him to survive the disastrous years ahead.

That later illustrators of Dickens's pre-1859 works inevitably based their conceptions on Browne's afforded scant practical or psychic compensation. In 1866, however, Frederic Cosens, a Dickens admirer and art patron, approached Browne to purchase his drawings for the author's works, but the shy artist explained that he had none, as they had been drawn directly on the plate. ${ }^{272}$ Cosens then asked him, as he had asked George Cruikshank, to make colored replicas of them all; despite his financial need, Browne named terms he thought would discourage Cosens, as he disliked the drudgery of reproduction as much as ever and, perhaps, did not want the contrast of the wretched present with the happier past. Cosens was not deterred; the two men came to terms. Shortly after accepting this commission, however, the artist was struck by paralysis, which, Micawber-like, he persisted in calling "rheumatics."273 Unable to make forefinger and thumb meet, and sometimes blind in one eye, he nevertheless labored on the replicas, drawing them with a clumsy sweeping motion of his whole arm. Whatever its signs of weakness and haste, that the commission was finished at all was not the least of Browne's Dickensian accomplishments.

The benefits of his past work for Dickens continued to alleviate Browne's misery in his final years. When the author died in 1870, the artist's bitterness yielded to regret at losing such a friend. ${ }^{274}$ In 1873 , Chapman and Hall commissioned him to provide woodeuts for their Household Edition of Dickens. After executing fifty-seven designs, his pencil lashed to his half-paralyzed hand, Browne was unable to continue. Not only his ability to work, but also the demand for his work was altogether gone. At the suggestion of Luke Fildes, Dickens's last illustrator, Browne, now sixty-three years old, petitioned the government for a pension. ${ }^{275}$ When it was denied, he was left in complete despair. "I don't know where to turn or what to do. I have at last come to a full stop and don't see my way just yet to get on again. My occupation seems gone, extinct; I suppose I am thought to be used up, and I have been long enough before the public."276 Two self-caricatures, constrasting his mood in 1837 after Pickwick with his present outlook in 1879, poignantly comment on his wretchedness (fig. 119).

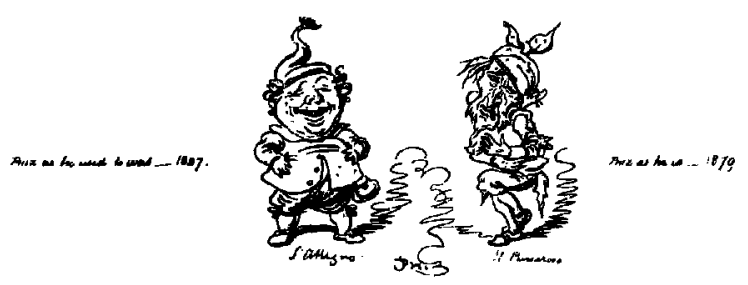

Fig. 119. Hablot Browne, "L'Allegro," 1837 and "Il Penseroso," 1879.' Frederick G. Kitton, Charles Dickens by Pen and Pencil (London, 1890-92), 2, following p. 138. Etching. 1\%16" $\times 3 \frac{5}{11}(4 \times 9.2 \mathrm{~cm})$. From the author's library.

Thanks to Fildes and other young artist friends, however, Browne received help from an unexpected quarter. The Royal Academy, which had not yet found Browne or any other black-and-white illustrator distinguished enough for a membership, awarded him the pension previously held by George Cruikshank, in recognition of his services to art. ${ }^{277}$ Thus comforted by the support and the thought that he was not totally forgotten, the artist died in 1882 . "He is not dead!" Punch insisted in its conventional verse eulogy; "there in the picture books/He lives with men and women that he drew."278 Few nineteenth-century readers would have denied that Dickens's own immortality was due in part to the memorable way in which Hablot Browne had illustrated his masterpieces; nor would they have disputed Angus Wilson's recent assertion that "for better or worse, our conception of the Dickensian world is tied up with Phiz. Who can separate Phiz's vision of Pecksniff or Mrs. Gamp, of Mrs. Skewton, Major Bagstock, of Mr. Micawber, or of Steerforth defying Mr. Mell; or indeed, in more dramatic mood, of Mr. Carker in flight, or of Tom All Alone's from Dickens's text? Indeed, when we consider Dickens's close supervision of the illustrations, who would wish us to?"279 


\title{
Part III: Dickens and His Other Illustrators
}

\author{
The Other Illustrators of Master Humphrey's Clock \\ GEORGE CATTERMOLE
}

SAMUEL WILLIAMS 



\section{Chapter 5}

\section{GEORGE CATTERMOLE}

George Cattermole was the first of Dickens's illustrators whose initial ties to the author were personal rather than professional. Since illustrating popular fiction could only detract from his reputation as a serious painter, Cattermole, like Maclise, Stanfield, and Landseer, doubtless contributed to Dickens's books for reasons of friendship, not ambition. In contrast to Dickens's earlier illustrators, Cattermole was better known to the cognoscenti than to the general public. A prominent member of the exclusive Society of Painters in Water Colours, he was England's foremost painter of scenes commemorating bygone times. Dickens was deeply attracted to the man and profoundly moved by his art. He relished the romantic, if not the realistic, aspects of "monks, cavaliers, battles, banditti, knightly halls, and awful enchanted forests"-favorite Cattermole subjects as catalogued by Thackeray; ${ }^{1}$ and he, like Ruskin, responded to the "pure, earnest, and natural" antiquarian feeling that permeated Catermole's best canvases. ${ }^{2}$ Cattermole contributed only a quarter of the illustrations for only two Dickens novels, those in Master Humphrey's Clock; yet the author said he preferred them to any of the illustrations to his earlier books. Dickens's appreciation of them probably was determined by their sentimental associations rather than their intrinsic merit. ${ }^{3}$ Nevertheless, Cattermole elicited the author's deference, gratitude, and affection as none of Dickens's more prolific illustrators was able to.

To Dickens, Cattermole, who was a dozen years older than he, embodied the essence of genteel artistic and social success (fig. 120). A shy but spirited bachelor, Cattermole had refused a knighthood, and resided in Albany chambers previously occupied by Byron and Bulwer-Lytton. ${ }^{4}$ He was welcome in the most sophisticated London circles. It was probably at Gore House, where the fashionable surrounded the Countess of Blessington and the Count D'Orsay, that the established painter met the author of The Pickwick Papers.
Dickens apparently took to him at once, and hastened to further their acquaintance through their mutual friend, John Forster. Did Forster think, inquired the author with unusual anxiety, that the artist would be interested in dining out after a tour of London prisons? ${ }^{5}$ The normally brash young writer need not have been so hesitant. Cattermole accepted this and many other future invitations with evident pleasure. ${ }^{6}$ Nevertheless, Dickens always regarded the artist as a superior being.

The two men met frequently in subsequent months, though never as often as Dickens wished. His regret when previous obligations prevented their meeting was unabashed. "Why do you always ask me to dinner on days when I can't come?" he complained upon declining an invitation from the artist after his trip to inspect Yorkshire schools for Nicholas Nickleby; "I have been engaged for next Tuesday a fortnight back, and you pick out that unfortunate day as if there were no other days in the week and no other weeks in the year." The novelist had especially wanted to accept that particular invitation since he was eager to tell Cattermole about his visit to York Cathedral because of its associations with John Britton, Cattermole's former teacher and a noted antiquarian draftsman. Dickens had entered the nave and the Verger immediately led him to the "Five Sisters" colored window. "There!" said the old man, "Mr. Britton the great artist and architect says that's the first window in all Europe; and if Mr. Britton don't know a fine window when he sees it, who does, as the Dean says." Dickens knew the encounter would interest his friend. The "Five Sisters" window with its melancholy legend and its association in his mind with Cattermole impressed him so much that he immortalized it in the Nickleby narrative (65-66).

In 1839 Cattermole became engaged to Clarissa Elderton, a distant maternal relation of the author's. Dickens was 


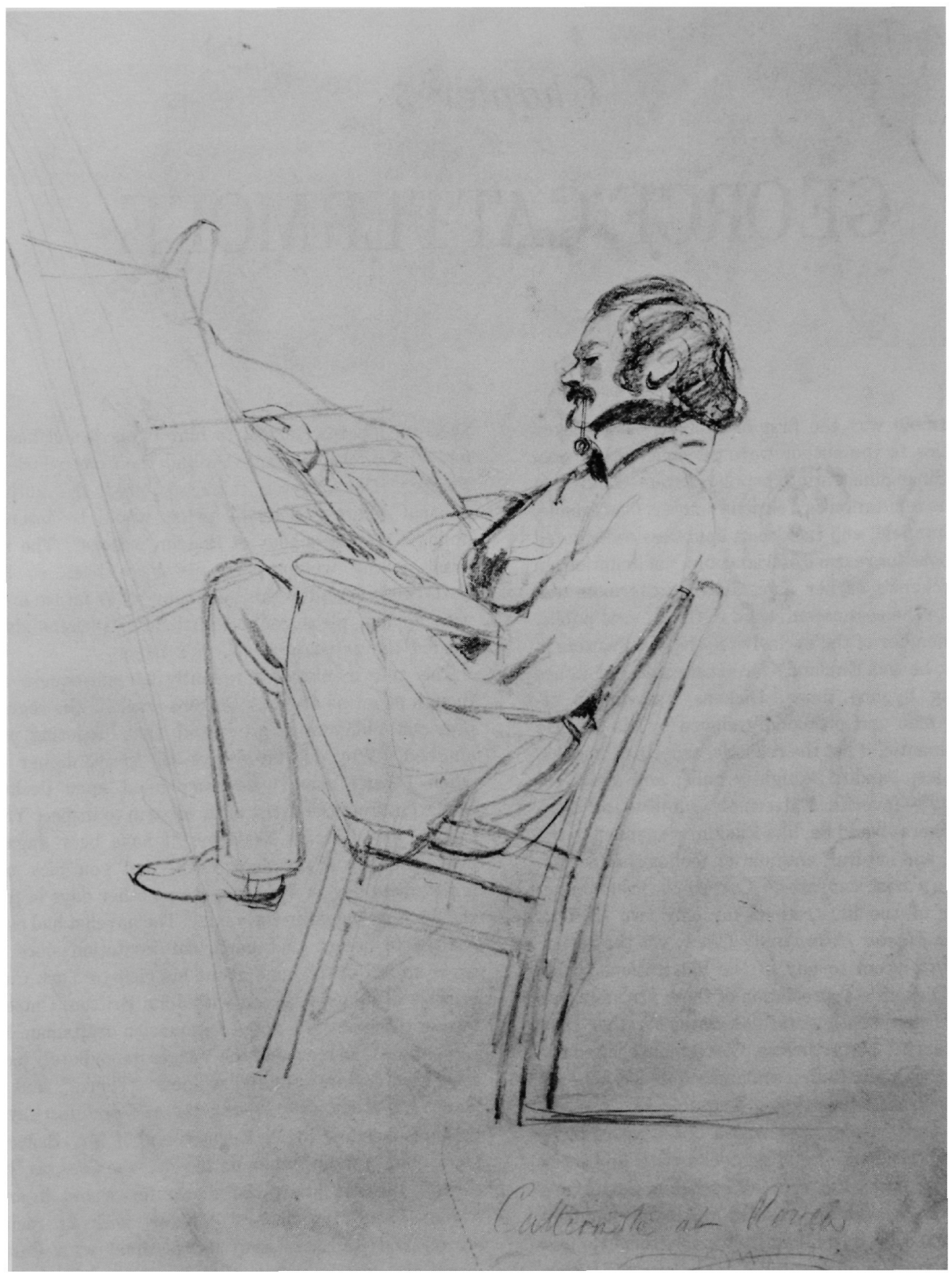

Fig. 120. Artist Unknown, Portrait of George Cattermole. Crayon. $15^{1 / 4^{\prime \prime}} \times 12^{3 / 8^{\prime \prime}}(38.7 \times 31.5 \mathrm{~cm})$. By permission of the Trustees of the National Portrait Gallery, London. 
delighted at the prospect of such a distinguished addition to his family. He also felt that the marriage could only strengthen the growing intimacy between himself and Cattermole. Indeed, the shy, sensitive artist had written to his fiancée about Dickens and his wife: "they are amongst the few friends I mark out for our future acquaintance." Although Miss Elderton had never even met her illustrious relative before her wedding on August 20, Dickens was in the forefront of the guests congratulating the couple. As the newlyweds drove away from St. Marylebone, he energetically pelted their carriage with rice and shouted his good wishes. ${ }^{10}$ The very next day, from nearby Petersham where he had taken a cottage, the novelist wrote to the couple, who were honeymooning in Richmond, assuring them of his lasting affection for them both. ${ }^{11}$

Indeed, Dickens could not do enough for the married couple. While the Cattermoles were awaiting the completion of their home on Clapham Rise, he put his pony carriage, servants, and especially his library at their disposal. He also dispatched a carpetbag full of light fiction, essays, and periodicals, which could be easily picked up and put down, and assured the couple that more substantial reading was handy at Elm Cottage should they prefer it. ${ }^{12}$ When they moved into their Clapham Rise home, Dickens gave Mrs. Cattermole an exquisitely bound volume of Nicholas Nickleby, accompanied by a charming letter of presentation, and invited her husband to the dinner celebrating the completion of Nicholas Nickleby in $1839 .{ }^{13}$

In 1840 Dickens extended his relationship with Cattermole into professional spheres by asking him to help illustrate Master Humphrey's Clock-his new periodical geared to appeal to popular tastes and purses by appearing weekly as well as monthly, embellished with wood rather than steel engravings. Since Dickens planned to include tales about London's mythical and historical past, he needed an antiquarian artist. Cattermole was superbly qualified: he had studied with Britton; his drawings had appeared in Architectural Antiquities of Great Britain from 1821 to 1823; and he had recently supplied historical landscapes and buildings from the novels of Sir Walter Scott for Leitch Ritchie's Scott and Scotland and costume pieces for the period works of Bulwer-Lytton. ${ }^{14}$ Dickens understandably felt that Cattermole's illustrations could portray the quaintness of the old settings and characters he proposed for the Clock better than his own verbal insistence could. Furthermore, Cattermole's name would undoubtedly enhance the prestige of the undertaking.

Dickens adopted a tone of jaunty self-deprecation in propounding this "mightily grave matter" to his friend. ${ }^{15}$
This unusual deference reveals how anxious he was to secure Cattermole's services. Would the artist "object," he tentatively asked, to making a little sketch of a quaint room with Elizabethan furniture and Master Humphrey's clock to head the opening page? He would not have to bother copying and cutting the drawing on wood, he promised, for these tasks would be executed by others "in first-rate style." Would he care to repeat the "joke" regularly, inquired the author, offhandedly posing his main question at last, and if so, on what terms? Dickens commented that he was also inviting Cattermole's distinguished colleague, Daniel Maclise, to contribute, but made no mention of the less prestigious Browne. The publishers, he said, anticipated great sales, and he himself could tell Cattermole more about the project over dinner; in the meantime, he submitted a written proposal, which he called "as business-like and stupid as need be."

Thus cajoled, Cattermole consented to join the "Clock works"-as Dickens nicknamed the enterprise. Although the room he drew for the headpiece contained recognizably Elizabethan furniture, its effect was not very "quaint" or "queer," and Master Humphrey's clock stood mid-wall, not in the corner as Dickens had instructed (SBB, 699); ${ }^{16}$ nevertheless, the author, delighted to have Cattermole contribute anything at all, proclaimed it "most famous." Lest the painter have lingering doubts about doing such work, Dickens rushed to dispel them. He had Cattermole's name placed first among the artists listed on the title page, despite the fact that Browne was to do a far greater number of plates, and had the publishers forward the engraved block for the artist's approval before it was cut. ${ }^{18}$ The author even offered to let Cattermole select his own subjects in the future, an option he almost never offered to his other illustrators, promising to send the proofs if Cattermole wished to choose from them. ${ }^{19}$ Finally, he later assured the artist, the publishers "will never trouble you (as they never trouble me) but when there is real and pressing occasion; their representations in this respect, unlike most men of business, are to be relied on."20

Never had Dickens been so diplomatic in dealing with an illustrator. Communicating with Cattermole, often through Chapman and Hall, he was never peremptory, irritable, or condescending as he had been more than once with Cruikshank, Seymour, and Browne. Throughout the collaboration, the author perhaps necessarily treated the hypersensitive painter as if he were doing Dickens an extraordinary favor but might back out suddenly if everything did not precisely suit him. Although Cattermole did not ask to choose his own subjects, Dickens sent. him only subjects of a picturesque nature, certain that the artist 
would like (and execute) them "best."21 When the periodical-originally conceived as a miscellany-turned into installments of The Old Curiosity Shop and Barnaby $R u d g e$, Dickens included scenes expressly with a view to Cattermole's architectural interests and skills, keeping figures to a minimum. ${ }^{22}$ He gave Cattermole every opportunity for "correction, alteration, revision, and all the other ations and isions connected with the Fine Arts."23 When he did make suggestions, he tendered them with hopes that they would not "go greatly against the grain," or with apologies to the effect that he knew the artist would realize them a "hundred times better" than he could "suggest."24 When Dickens urged haste, he never implied that Cattermole could be dilatory, but only that he or the publishers or the printers were "mortally pressed" for time. ${ }^{25}$ Although the author freely addressed the artist as "My dear George" and even "Kittenmoles," when he was giving instructions, he often sprinkled them with respectful references to "sir."26

Despite Cattermole's name and his gratifying treatment of 'picturesque subjects - the time motif on the wrapper $(S B B, 697)$ (see F); Master Humphrey's "admirable" room $(S B B, 699)$ and the stately bed of Master Graham that inspired such "glowing accounts" $(S B B, 715) ;{ }^{27}$ the Cavalier who robs Hugh of his love and life $(S B B, 720)$; and the ornate church in which Will Mark's burden is buried ( $S B B$, 771) - the Clock began to founder. Dickens planned to resurrect Pickwick and Sam Weller to join Master Humphrey and his cronies in linking short pieces, and Cattermole featured them along with the others in his complex frontispiece for the Clock's first bound volume (SBB, facing p. 689). ${ }^{28}$ But even Mr. Pickwick and Sam failed to attract readers. Here as in Pickwick, the club machinery proved cumbersome and unpopular. What the public wanted to read were longer narratives by Dickens. "Accordingly," wrote Thomas Hood, "whilst the two clubs are snugly housed-the one in the kitchen and the other in the parlour, and, as the frontispiece hints, all fast asleep-the author quietly gives them the slip and drives off to take up characters, who really have business down the road." 29 For even before the completion of the first volume, Dickens had decided to expand his "little child" story into The Old Curiosity Shop, and to revive his long-deferred novel Barmaby Rudge in order to rescue his faltering enterprise.

The expanded "business" of these characters, especially little Nell, captivated the hearts of contemporary readers. The heroine not only rescued the Clock from certain failure, but provided a creative outlet for Dickens's still unassimilated emotions about the premature death of his seventeenyear-old sister-in-law, Mary Hogarth, in 1837. The author's relief on both grounds expressed itself in excessive gratitude to Cattermole, to whom he assigned most of the illustrations involving little Nell.

A close study of Cattermole's work for The Old Curiosity Shop, however, makes it apparent that Dickens was moved more by the nostalgic associations evoked by the pictures than by the pictures themselves. ${ }^{30}$ Indeed, the artist was more interested in the heroine's picturesque surroundings than in the heroine. Assigned to do the headpiece for Nell's story, as Dickens then regarded it, for example, the artist took special pains in delineating the curiosity shop. Indeed, the interior may have been inspired by his own studio at Clapham Rise with its antique tapestries, armor, and furniture, including a prominent escritoire with carvings of "hideous, gaping, 'Old Curiosity Shop' faces." ${ }^{31}$ Cattermole took less time with Nell. The author, "more than doubtful of the child's face," which was too old-ladyish, returned it to him for further work. ${ }^{32}$ Perhaps this is why Dickens wanted Browne to execute the concluding illustration for the original short piece, and then, even after the latter was probably too busy to do it, gave it not to Cattermole but to Samuel Williams, an artist better known as an engraver. $^{33}$

At carefully spaced intervals, Dickens gave Cattermole his Shop illustrations to do (he gave Browne four times as many). Only at the end of the story, for the sequence of four engravings of Nell's transition from this world to the next, did he call on Cattermole to put forth sustained effort. Characteristically, Cattermole provided more effective settings than people. His first task was to portray Kit, Nell's birdcage in hand, arriving at the snow-covered parsonage (LXX, 568). According to Dickens's brief summary, a lighted window was to obscure the fact that the child lay dead inside; lacking the completed text, however, Cattermole forgot to draw the requisite curtain over the lower half of the window, though suspense is maintained because of the viewer's distance from it (fig. 121). ${ }^{34}$ The artist makes the parsonage the center of interest instead of Kit. Indeed, the young man, delineated from the back with parallel diagonal strokes, is visually insignificant compared to the elaborately vaulted dwelling in which Nell lies in sentimental state. But Dickens said nothing.

Cattermole's next illustration of the "dear dead child" would chill Macready, though Dickens intended it to "express repose and tranquillity and even something of a happy look, if death can."35 Yet the artist's preliminary sketches had not satisfied Dickens's detailed conception of the scene ${ }^{36}$ Perhaps he felt the picturesque semi-canopied bed was more prominent than Nell; perhaps her face failed to communicate the desired transcendence. In any case, the 


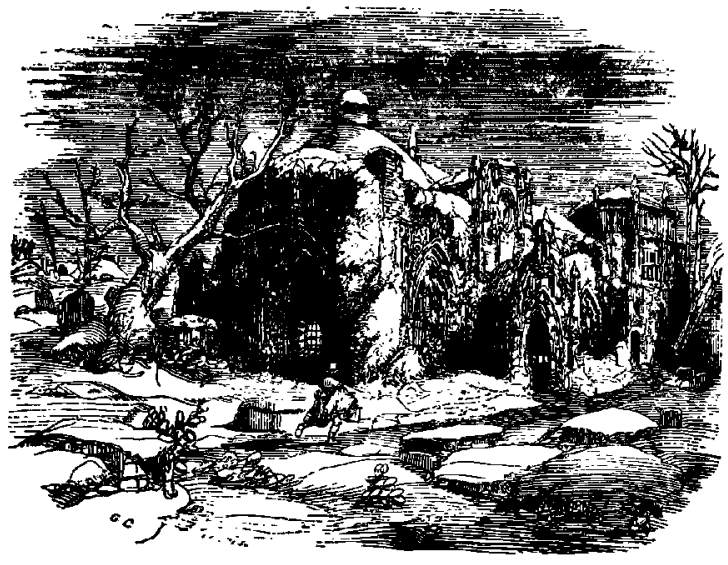

Fig. 121. George Cattermole, 'The ruin in snow.' Master Humphrey's Clock, no. 43, p. 204. Wood engraving. 37/6" $\times 41 / 2$ " $(8.7 \times 11.5 \mathrm{~cm})$. By permission of the Houghton Library, Harvard University.

author deferentially requested that the child be altered. ${ }^{37}$ Yet the modern viewer is unlikely to be moved even by the published print of the dead heroine with her broad, crudely delineated face, and her elaborate surroundings with their hackneyed symbols of immortality (LXXI, 575) (fig. 122) ${ }^{38}$ Dickens had requested the evergreens but Cattermole may have added on his own initiative the portrait of the Virgin and Child over Nell's head, the prayer book in her hand, and the open window for her departing soul with the hourglass and bird on the sill. Though the contrast between her fresh youth and her aged surroundings is stressed here as it was in Williams's picture of her first rest in the narrative, Nell herself is far less appealing in Cattermole's hands than in Williams's (I, 14) (see fig. 128).

Cattermole's greater interest in structures than in human figures is even more obvious in his final pair of illustrations for the Shop. In 'The Old Man at Little Nell's grave' (LXXII, 583), he lavishes far more graphic attention on the church interior than on the grandfather whose grief Dickens had stressed in his instructions. ${ }^{39}$ Yet the sacred clutter of the church, here as earlier (LIII, 424), does indeed recall the secular clutter of the old curiosity shop (I, 1 and 14) and makes the absence of Nell nearly as tangible as her presence was. ${ }^{40}$ Sensitive to Cattermole's evident preference, Dickens, in requesting a tailpiece that would give "some notion of the etherealised spirit of the child," downplayed the importance of human forms-"only one figure if you like."41 Cattermole did supply three angels bearing Nell to heaven, while a fourth provides musical accompaniment, yet he delineated the diminutive landscape

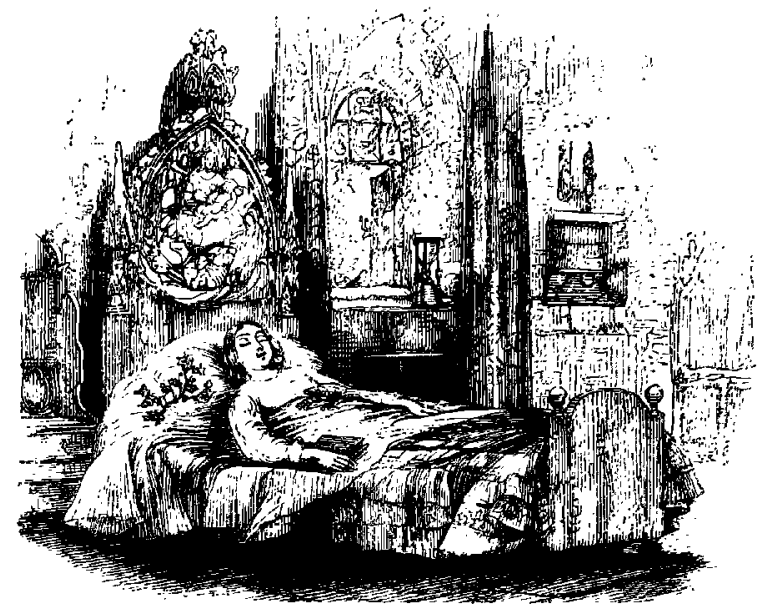

Fig. 122. George Cattermole, 'Nell dead.' Master Humphrey's Clock, no. 44, p. 46. Wood engraving. $3^{1 / 8^{\prime \prime}} \times$ $4 \frac{1}{2}$ " $(8 \times 11.5 \mathrm{~cm})$. By permission of the Houghton Library, Harvard University.

below their ascending cloud far more precisely than their vapid faces (LXXII, 593) (fig. 123). Nevertheless, Emily Dickinson would find this scene, together with the one of Nell and her grandfather comforting one another in the churchyard (LIV, 435), so fitting for her poem about "a poor tired heart" that she cut them out and sewed them with pink thread to her manuscript page. ${ }^{42}$

In general, as has been seen, Dickens apportioned out the picturesque subjects to Cattermole, the grotesque to Hablot Browne. At least in one case, however, as Mrs. Leavis has also observed, Browne proved himself more responsive not only to Nell but even to the structures with which she is associated. ${ }^{43}$ Earlier in the story, the publishers mistakenly sent Browne the subject of Nell hiding from Quilp in a gateway-one of those Dickens had included "expressly" for Cattermole. ${ }^{44}$ To judge from the superb result, 'Quilp at the gateway' (XXVII, 218) (fig. 124), Browne, a former illustrator of Winkle's Cathedrals of England and Wales (1836-38), might have portrayed the old ruinous settings even better than Cattermole. Cattermole always approached the structures in both The Old Curiosity Shop and in Barnaby Rudge from an antiquarian viewpoint, minimizing figures when he included them at all (see figs. 121, 126-28) (though never with the symbolic effect that minimizing would have in some of Browne's "dark" plates for Bleak House), ${ }^{45}$ whereas Browne more fully exploited the potential of the setting to dramatize aspects of character and plot. Here, Quilp, with his upraised stick, resembles the two stone monsters who flank the archway in a similarly menacing manner. Nell 


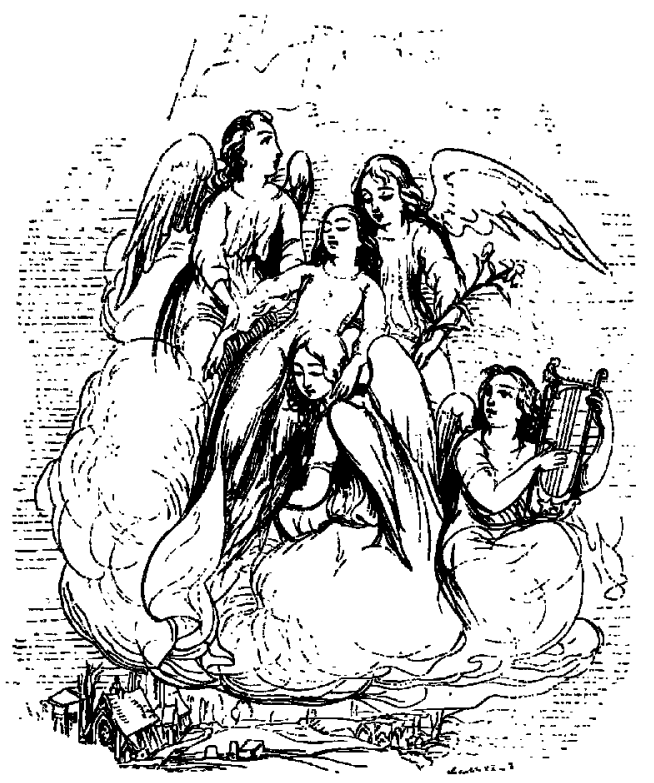

Fig. 123. George Cattermole, Tailpiece to The Old Curiosity Shop. Master Humphrey's Clock, no. 45, p. 223. Wood engraving. $33 / 8^{\prime \prime} \times 234^{\prime \prime}(8.6 \times 7 \mathrm{~cm})$. By permission of the Houghton Library, Harvard University.

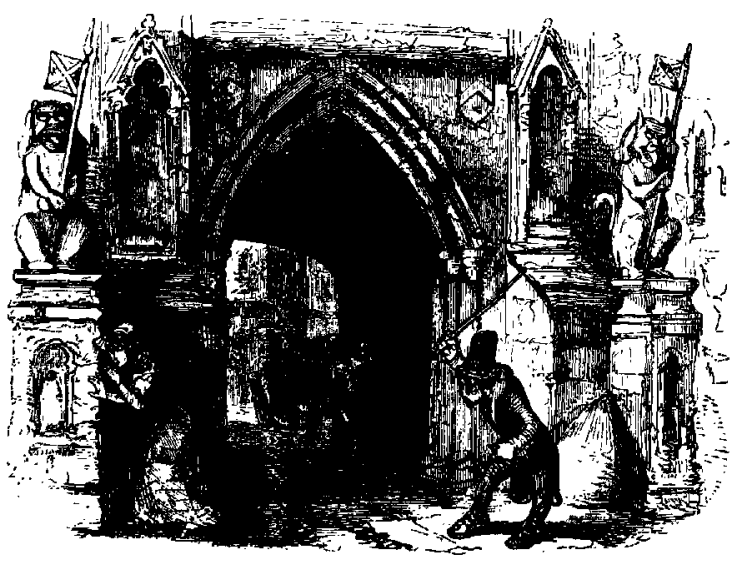

Fig. 124. Hablot Browne, 'Quilp at the Gateway.' Master

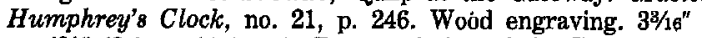
$\times 48 / 8$ " $(8.1 \times 11.1 \mathrm{~cm})$. By permission of the Houghton Library, Harvard University. cowers in the shadows of one of a series of recesses all bereft of any statues. Browne makes Dickens's point clear: that Nell has no external protection against this moral monster. As Mrs. Leavis concludes: "whether by Dickens's direction or by his own sympathetic comprehension of the text supplied him here, Phiz has supplied a visual equivalent not merely of an episode in the story, but of its meaning in the novel as a whole." ${ }^{26}$ Browne's Nell is decidedly more appealing than Cattermole's, not only here but also in his frontispiece for the published volume of the Clock containing the bulk of Nell's story (facing p. viii). But contemporary readers did not compare the two Clock artists at each other's expense, and Dickens seemed pleased with both.

All this notwithstanding, after The Old Curiosity Shop was finished, Dickens praised Cattermole's illustrations excessively. He continued to look at them, he wrote the artist, with a "pleasure" he could not "easily describe in words" because "This is the very first time any designs for what I have written have touched and moved me, and caused me to feel that they expressed the idea I had in my mind." ${ }^{47}$ Clearly Dickens had already forgotten even the few criticisms he had voiced of Cattermole's work. His response was obviously dictated by subjective factors having less to do with aesthetics than with emotions. As he was composing the Shop's final scenes, Dickens had confessed to Cattermole his heartbreak over Nell's decease, so fraught with memories of Mary Hogarth's. ${ }^{48}$ Yet the writing of the story was cathartic, and the illustrations provided him with a perfect graphic correlative for his continued idealization of his sister-in-law. By his portrayal of Nell, regardless of its artistic quality, Cattermole seemed to share and lighten the burden of Dickens's grief. Doubtless this helps to explain why Dickens thanked Cattermole so profusely for his "most invaluable cooperation" and "friendly aid"-despite the fact that he was often dilatory, disabled, or careless. That emotional as well as aesthetic help had been given, however unconsciously, by one whom Dickens regarded so highly as a painter and a friend made the tone of his appreciation border on the obsequious.

Dickens even commissioned Cattermole to make watercolors of scenes from the book, mainly those involving Nell and church graves with their inherent associations of sacred reverence. ${ }^{49}$ Upon his return from America, Dickens received the watercolors, and treated them immediately as another shrine for his worship of Mary, in spite or perhaps because of their even more elaborate concentration on picturesque objects at the expense of the characters. Once again Dickens claimed that Cattermole's work had rendered 
"the whole feeling, and thought, and expression" of his narrative to the "gratification" of his "inmost heart." 50

This period of professional collaboration on the Clock marked the height of Dickens's personal intimacy with Cattermole. As friends, relatives, collaborators, and fellow members of the Shakespeare Society and of the Portwiners, an informal group of congenial friends who often dined together, the two men spent much time in one another's company. ${ }^{51}$ They rode, walked, and dined in London and at Clapham Rise. In the warmth of the author's attention, the artist's natural reserve and coolness thawed. Dickens particularly enjoyed his visits to Cattermole's home. Its neighborhood, still old-fashioned and rural, was reached from London by omnibus, whose driver spent his waiting hours at the Charing Cross tavern from which the Clapham cabs arrived and departed; Cattermole dubbed him "Sloppy" and delighted Dickens with imitations of his Cockney speech. "It is amazing nonsense to repeat," Forster recalled, but to hear the painter imitating "Sloppy" on the subject of supposed pre-temperance experiences that he attributed to his imaginary friend Jack, "in the gruff, hoarse accents of what seemed to be the remains of a deep bass voice wrapped up in wet straw" was unforgettable. ${ }^{52}$ Cattermole's imitation inspired Dickens's invention of Mrs. Gamp and Mrs. Harris in his post-Clock novel, Martin Chuzzlewit, and the driver's nickname became that of Betty Higden's "minder" in Our Mutual Friend in 1864.

Cattermole's home on Clapham Rise perfectly suited the artist, whose dignified demeanor enabled Thackeray to imagine him presiding over Windsor Castle. ${ }^{53}$ Dickens and the other Portwiners long remembered the splendid dinners served by white-gloved servants in the painter's spacious dining room. ${ }^{54}$ After-dinner drinks were served in the drawing room, luxuriously furnished with thick drapes, Byron's carved furniture from his former Albany chambers, and wallpaper with gold bars designed by the host. Cattermole would then lead his guests down a shadowy staircase and long corridor to his studio, a room full of antiquities, where, on workdays, the artist prepared his Clock illustrations and other paintings. Here, on one of these social occasions, Richard Lane executed the studies for a profile portrait of Dickens, perhaps while the author was discoursing from one of Byron's chairs to Maclise or the Landseer brothers or Thackeray or Bulwer-Lytton on various matters of art and literature. ${ }^{55}$ Cattermole later purchased Lane's finished profile portrait of Dickens (fig. 125). Mrs. Cattermole came to cherish it, less for its

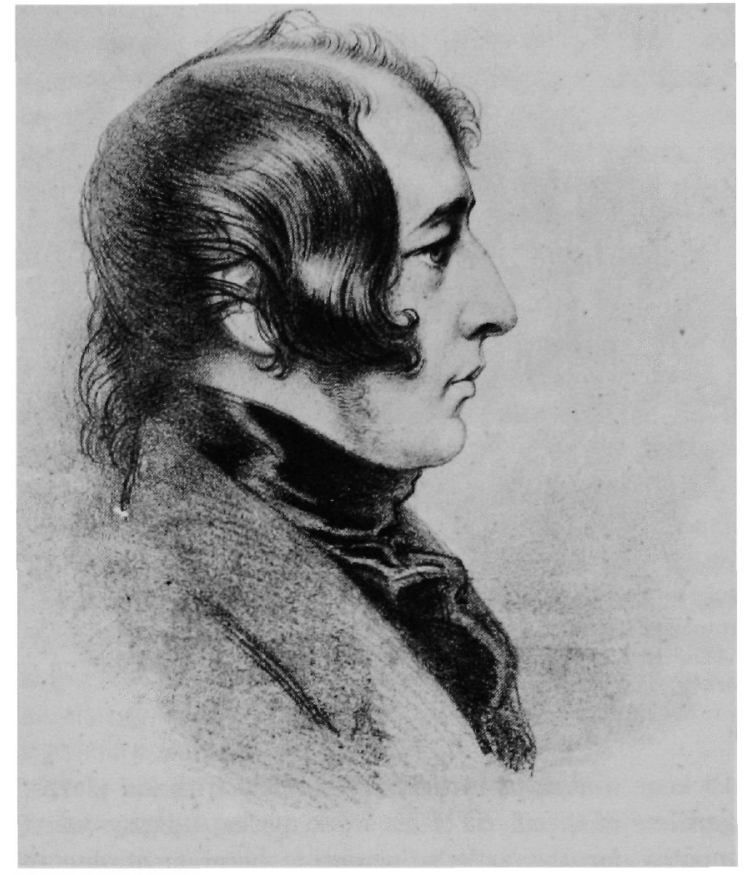

Fig. 125. Richard Lane, Portrait of Dickens, ca. 1842. Pencil and gray wash. $81 / 8^{\prime \prime} \times 6^{\prime \prime}(20.6 \times 15.3 \mathrm{~cm})$ [sheet]. Copyright reserved, Royal Library, Windsor Castle.

artistic merit than for its association with these happy days in their home, in such contrast to the extended periods of illness and debt that subsequently plagued their family.

Meanwhile, Master Humphrey's Clock ran on, and Barnaby Rudge succeeded The Old Curiosity Shop, making its public appearance on February 13, 1841. The historical fiction, set, like Scott's best novels, fifty years earlier than it was written, offered a wealth of congenial subjects for the antiquarian painter. Dickens assigned Browne the individual characters and crowd scenes, and Cattermole all the picturesque structures. The old edifices Dickens imagined for The Old Curiosity Shop, all redolent of decay and death, are memorable only collectively. By contrast; his structures in Barnaby - the Maypole Inn (fig. 126), the Locksmith's house, the Boot, the Warren (fig. 127), and Westminster Hall (see fig. 62)-function dramatically and distinctively throughout. The buildings acquire a status almost like that of characters. ${ }^{56}$ Cattermole warmed to the task so perfectly suited to his tastes. His complex curlicues, if not historically accurate, are extremely nostalgic. 


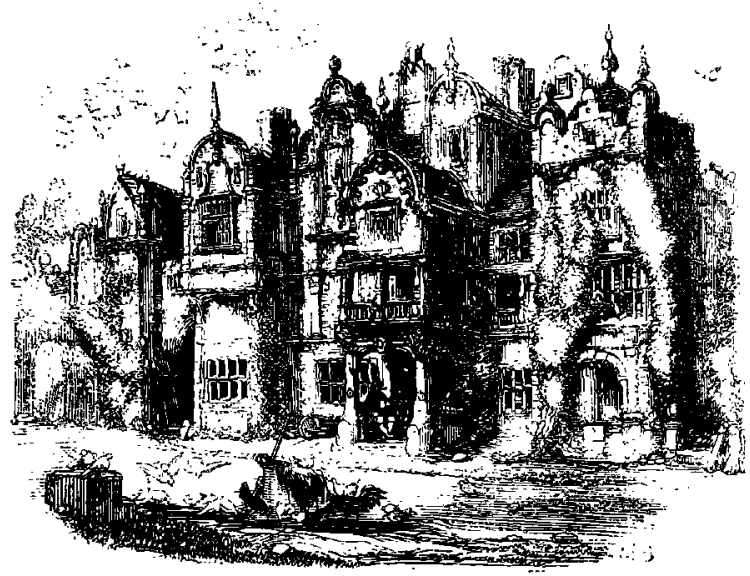

Fig. 126. George Cattermole, 'The Maypole Inn.' Master Humphrey's Clock, no. 46, p. 229. Wood engraving. $37 / 16^{\prime \prime}$ $\times 4916^{\prime \prime}(8.7 \times 11.6 \mathrm{~cm})$. By permission of the Houghton Library, Harvard University.

Dickens continued to treat Cattermole with kid gloves, regardless of the merit of his work, perhaps partly out of sympathy for the artist's increasing harassment due to illness, impending fatherhood, debt, and other commissions. When the artist drew the ornate, multigabled Maypole Inn for the opening scene (I, 1) (fig. 126), the author claimed that he was unable to bear the thought of its being cut on the block, and wished he could "frame and glaze it in statu quo forever and ever." ${ }^{57}$ In Cattermole's hands, he maintained, the scene of Chester warming himself before the Maypole's finest fireplace $(\mathrm{X}, 84)$ (see fig. 54) would be "a very pretty one." ${ }^{" 58}$ Dickens was especially helpful to Cattermole, now copying his own drawings onto the wood, in tangible ways as well. He exerted himself to procure a long block so that the Locksmith's house might "come upright as it were," when this subject, meant for chapter 7, was not executed until chapter 16 (XVI, 134), Dickens remained uncharacteristically patient, trusting that Cattermole's delineation of the "shy blinking" house with the conical roof would be worth the delay (IV, 33-34).

Dickens even concealed his disappointment when Cattermole's interest in picturesque objects did not extend to picturesque pets. He very much hoped that the painter would portray Barnaby's raven, but proposed the idea tentatively, lest it seem like an order. ${ }^{60}$ Did Cattermole fancy ravens in general? Would he fancy Barnaby's in particular? Might he like to portray the pet's maiden appearance? Certainly he was well qualified to suggest the oddness of the bird. Not hearing from the painter, Dickens

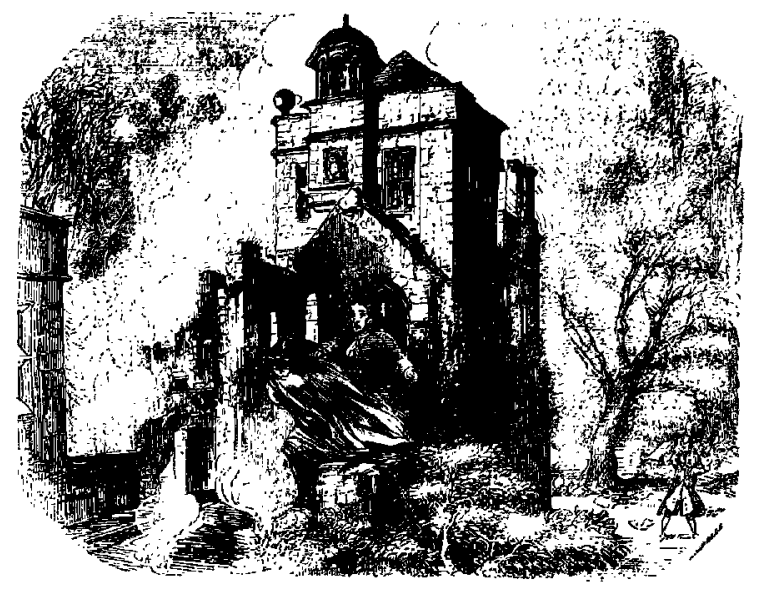

Fig. 127. George Cattermole, 'The Turret.' Master Humphrey's Clock, no. 74 , p. 264 . Wood engraving. $3 \% "{ }^{\prime \prime} \times$ $4 \% 16^{\prime \prime}(9.2 \times 11.6 \mathrm{~cm})$. By permission of the Houghton Library, Harvard University.

gently pressed him for his decision. Time was short. Browne needed instructions if Cattermole was not to do the bird. The painter finally declined the privilege of introducing the immortal Grip (XII, 105) (see fig. 147), whom even Ruskin found "perfect—like all Dickens's animals" (though it made him angrier with the rest of the narrative, which he abhorred, because he felt compelled "every now and then to open the book to look for him"). ${ }^{61}$ Even at Cattermole's delay and subsequent refusal, however, Dickens never indicated the slightest displeasure.

Cattermole had enough to preoccupy him on Barnaby Rudge without the raven. Manuscript slips, précis, and notes flew from Devonshire Terrace to Clapham Rise on each other's heels. Even from Edinburgh, where he was being lionized in June, 1841, Dickens dispatched chapters and subjects for illustrations; ${ }^{62}$ for the author was approaching the riot scenes-in which, he felt, lay all the best pictorial opportunities. Cattermole did not warm to such scenes, yet Dickens proclaimed that his portrayal of the mob wrecking the Maypole bar, while John Willet looked on with stupefaction, was "noble." 63 The author did worry, however, about Cattermole's ability to delineate the rioters' destruction of the Warren. He wanted him to delineate simultaneously one of the turrets laid open, Haredale clutching Barnaby's father-still in cloak and slouched hat as Browne had drawn him earlier (I, 6; II, 19)-and Solomon Daisy gaping from the ground below. "When you have done the subject," Dickens asked, in an unusual request, "I wish you'd write me one line and tell me how, that I may be sure 
we agree." Within a week, Cattermole sent a sketch together with a poetic explanation. He had chosen as a vantage point the roof of one of the Warren wings toward which the elder Rudge and Haredale are rushing from a small tower door. Below, on the grass, Daisy stands in amazement (though not in the darkness described in the text) and beyond are "clouds of smoke a-passing over and amongst many tall trees" and "frightened rooks, flying and cawing like mad" (LVI, 465) (see fig. 137). ${ }^{65}$ Taking unusual pains, Cattermole adequately met the challenge.

Such violent action, however, did not suit Cattermole's talents, nor his fragile temperament-especially not in his present tender mood due to the birth of his first child ${ }^{66}$ - and he executed his remaining Barnaby subjects with less success. The scene of Hugh and his cohorts fleeing from the ruined Warren in a post chaise with their lovely captives -whose presence, as Dickens suggested, is indicated only by a scarf fluttering from its window-seems to have overwhelmed him with its demands for detailed activity (LIX, 486). ${ }^{67}$ Cattermole barely differentiated the white forms of the clouds, the whirls of dust, the clothing of the abductors, the captive's scarf and the torches, all of which suggest noon rather than night and confusion rather than artistry. ${ }^{68}$

Accordingly, Dickens assigned ten of the next eleven subjects to Browne. When he next called on Cattermole to do the finale, he accompanied his request with a barrage of instructions, although he tried to soften their impact with his usual delicate manner toward Cattermole: "I have been waiting until I got to subjects of this nature, thinking you would like them best." 69 "Firstly," he asked, would Cattermole draw Lord George Gordon in his solitary prison in the Tower? The artist complied, but made the cell more interesting than its expressionless inhabitant (LXXIII, 610). "Secondly," Dickens queried, would Cattermole portray the duel between Sir John Chester, hostile but polite to the last, and Haredale, more sorrowful than triumphant at his enemy's death? Here the artist actually contradicted the text by making Haredale seem more concerned with his bloodied sword than with his enemy who expires with a graceless smirk (LXXXI, 677) (see fig; 65). Cattermole was too ill to execute the "Thirdly," a frontisplece to the novel, ${ }^{70}$ but recovered in time to produce the "Fourthly," a tailpiece representing the stopping of Master Humphrey's Clock (SBB, 817). In this scene, the artist's weariness is evident. The crutch and slippers are not where Dickens wanted them; the manuscript of The Old Curiosity Shop, to be indicated along with that of Bamaby, is not distinguishable; and the subject of the picture over the fireplace, portrayed sketchily by Browne in the third number, has become so indeterminate that viewers debate whether it is a sensuous nude or the Good Samaritan (SBB, 817). ${ }^{71}$ The artist dutifully followed Dickens's specifications for a "Fifthly," a scene showing Hugh going to jail with the old Fleet Market in the background. ${ }^{72}$ All told, however, it seems just as well that Dickens decided not to "frighten" the artist further with a "sixthly, seventhly, and eighthly."73

Cattermole continued illustrating books occasionally, but, except for a frontispiece for the 1848 Cheap Edition of The old Curiosity Shop, never again illustrated a work by Dickens, though the author repeatedly insisted to the painter that he marveled at his talents. In the $1840 \%$ s, to illustrate popular fiction, even for an author as famous as Dickens, could detract from an artist's energies as well as his reputation as a serious painter. Critics like Ruskin, perhaps alluding to Cattermole's engravings for Master Humphrey's Clock, commented more in sorrow than in anger that "no original talent, however brilliant, can sustain its energy when the demands upon it are constant, and all legitimate support and food withdrawn." 74

It is clear, anyway, that Cattermole could not have sustained the pace necessitated by Dickens's energetic temperament, work habits, and the pressures of serial publication. As the Clock progressed, the artist had become increasingly fragile under the strain of this work together with more pressing obligations. He was anxious about his growing family. He began to fall into debt, and despite "pangs and writhings of regret innumerable" borrowed money from friends, including Dickens. ${ }^{75} \mathrm{He}$ was often plagued with an ailment that, for lack of a more precise name, as he wrote the author, "I must call a disorder of the nerves." ${ }^{76}$ This malady, which often confined him to his room, contributed to his nervous, vague, and elusive demeanor. Even the robust Dickens found the effort dietated by weekly installments extraordinarily demanding (which may explain why his later periodicals, Household Words and All the Year Round, were not illustrated), and readily returned his next novel, Martin Chuzzlewit, to a monthly format to be illustrated solely by Browne. The contemporary content of Chuzzlewit would not have suited the antiquarian artist anyway.

No longer associated professionally, Dickens and Cattermole began to see less of one another socially. In contrast to the way others besieged the author, the artist held himself aloof, although Dickens continued to seek his company and solicit his talents in other spheres in the years following Master Humphrey's Clock.

In 1845, after living in Italy (where the Doria, an old palazzo, reminded him of Cattermole's quaintest pictures), ${ }^{77}$ 
Dickens returned to London and began his amateur theatrical company. Initially, he did not invite the reserved artist to join it, but when the part of Downright in the opening production of Every Man in His Humour was vacated by Clarkson Stanfield and refused by George Cruikshank, Dickens thought of his old friend and relative. His invitation was a calculated appeal to Cattermole's sense of decorum. ${ }^{78}$ The small group was to perform Ben Jonson's play, he said, with "correct" costumes and a "good orchestra" before a "strictly private" audience admitted by invitation only; furthermore, the cast included many mutual friends, including Forster, Frank Stone, and Stanfield. With a final affectionate flourish, Dickens urged the "Kittenmolian Trojan" to participate. The painter may have regretted his refusal to be more than a spectator when the debut proved such a success. For when the role of Wellbred became available for the two remaining performances, one of which Prince Albert planned to attend, Dickens more easily overcame Cattermole's probable excuses of expense, illness, and acting inability. ${ }^{79}$ After his first rehearsal, however, it was clear that the self-conscious artist needed more than reassurance. Dickens accordingly ordered his brother Frederick to practice with the artist privately. ${ }^{80}$ Thus prepared, Cattermole played Wellbred not only in the remaining 1845 productions of Every Man but retained the 'part when the play was restaged in 1847 to benefit John Poole and Leigh Hunt. ${ }^{81}$

As the artist became increasingly frail and reclusive, Dickens no longer kept in constant touch with him. Dickens's reaction to a birth announcement from the Cattermoles in 1852 reveals how infrequently the two men met, yet how eager Dickens was to renew their intimacy. He dispatched his wife and sister-in-law to Clapham Rise with a congratulatory letter stressing his pleasure in hearing from the artist. "Now don't you think," the author pleaded, "DON"T you think you could manage to dine here, at the family board, either next Sunday, or next Sunday after that, at 5 exactly? Couldn't we, if only for a novelty, meet as we used to in bygone ages? Do let us try. How can it be that Clapham Rise gets so far off?"82

The Cattermoles may have dined at Tavistock House on this occasion but not often, if ever, thereafter, If cousin Dickens found it a "genealogical poser" to name his precise kinship to Cattermole's children, ${ }^{83}$ the artist was seriously embarrassed both by his illnesses and by the problems of financing his growing family and his expensive tastes. As his nervous disorders became more pronounced, his good humor and imagination diminished, as did the quantity and quality of his paintings. He withdrew not only from society but even from the Water Colour Society in 1850; a shared award with Edwin Landseer of the French grande médaille d'honneur in 1855 and election both to the Dutch Royal Academy and to the Belgian Society of Water-Colour Painters the following year enlarged Cattermole's reputation but not his resources. ${ }^{84}$ When Dickens arrived at the Villa des Moulineaux in the summer of 1856 to work on Little Dorrit, he found the unhappy Cattermoles stranded in another of the villas let by his unhappy landlord, who complained that the artist always promised but never paid his bills. ${ }^{85}$

For the rest of the artist's life, Dickens kept track of him primarily through mutual friends. In the early 1860 's, when the artist lost his youngest daughter shortly after his eldest son, he slid into a permanent depression. When Dickens returned from America in 1868, he learned that Cattermole was seriously ill. ${ }^{86}$ Mrs. Cattermole confirmed the bad news, but assured her cousin that he was improving. Yet Dickens never saw Cattermole again, for he died on July 24, 1868.

Mrs. Cattermole was well aware, however, that her illustrious relation might do a good deal more than offer sympathy to alleviate her distress. Even before Cattermole's death, she had enlisted Dickens's aid in soliciting a pension from the Royal Academy; now she found him an indispensable help in drafting her petition for a pension from Parliament. ${ }^{87}$ Meanwhile, she held a sale of her husband's remaining canvases, and Dickens received a catalogue of the sale, but as specimens of the artist's work were already hanging on his walls, he did not greatly regret his inability to attend. ${ }^{88}$ When nothing came of the Parliament petition, the author conducted a private appeal on behalf of the Cattermoles, but it fared little better, though William P. Frith, a colleague of the late artist, unfairly felt the amount raised could have been doubled had the author not been so preoccupied with other affairs..$^{89}$ Dickens, who was never too busy to help his friends, had found, however, that Cattermole's reserve and his wife's tendency to exaggerate her misery had offended many people, who now reacted coldly to the family's plight. Finally, in mid-April, 1869, he held a meeting of the few interested benefactors, who decided to hand the collected funds over to the widow and to abandon further solicitations. ${ }^{90}$ Dickens maintained he could do nothing more for his cousin, who, though persistent, was not ungrateful. She had found the author, she said, to be a man of "magnanimous and practical sympathy"-a judgment shared by many of Dickens's original illustrators and their families. ${ }^{91}$ 


\section{Chapter 6}

\section{SAMUEL WILLIAMS}

Samuel Williams has not even been recognized as one of Dickens's illustrators until recently. However, he was well-known in Victorian publishing circles, if not to the public at large, as an engraver who could also design. For example, he not only engraved four of the illustrations provided by Browne and Cattermole for Master Humphrey's Clock but designed as well as executed the famous scene of little Nell asleep in her bedroom (OCS, I, 14) (see fig. 128). ${ }^{1}$ Williams was the only one of Dickens's artists ever to perform both these tasks. Though his tenure as designer proved even briefer than that of Robert Buss, Williams's single illustration of Nell had a greater demonstrable impact on the author than any other provided for his work.

Williams was born in 1788 in the small Essex market town of Colchester. Like most of Dickens's original illustrators, he displayed precocious artistic talent, but family circumstances did not permit him to receive formal training. Instead, he was apprenticed to a local printer named Marsden, who tried to force his skills into mechanical channels. ${ }^{2}$ Williams's inclinations, like Hablot Browne's, could not be curbed, though he followed them in his spare time, not on the job; indeed, like Miss La Creevy in Nickleby, he used to wake at dawn to pursue the "fine arts" $(N N, \mathrm{~V}, 44)$ of painting and wood engraving. ${ }^{3}$

Using techniques revived and popularized by Thomas Bewick, Williams soon became proficient enough at both designing and engraving on wood to make these skills the basis of the business he established after his unhappy apprenticeship concluded. He quickly found work, first in Colchester and then in London. ${ }^{4}$ Employers were eager to secure his dual talents. Williams had sufficient commissions to design and engrave illustrations on popular editions, such as Whittington's Robinson Crusoe in 1822 and Scott's Bible in 1831-32, to warrant training other members of his family to assist him. His brother Thomas and sister Mary Ann became respected engravers and artists in their own right; and his four sons later carried on the collective enterprise. The Williamses, along with the Thompsons, became the leading families of engravers by the late 1830 's. ${ }^{5}$

Like Seymour and Buss before him, Williams found little time to pursue his own painting (which specialized in rural scenes) as his family and business expanded. ${ }^{6} \mathrm{He}$ continued, therefore, to be better known for his contributions to the works of others than for his own. His lack of public reputation was not helped by Mary Howitt's condescending remarks after her brother William worked closely with the artist on the two dozen woodcuts provided for his Rural Lives of England in 1838: "He is a man of a curious mind, not apt in originating ideas, but quick and frequently very happy in working them out when they are suggested. He has, in his happiest designs, worked under William's eye and hand like an obedient child, and has produced some of the very best designs that have appeared in wood since the days of Bewick." Williams, hardly devoid of initiative, doubtless knew by this time how to defer to employers. This ability served him well in illustrating for Dickens.

Williams was one of the hands employed, probably by Chapman and Hall, to engrave some of the numerous designs to be "dropped" into the text of Dickens's first periodical, Master Humphrey's Clock. ${ }^{8}$ The author and his publishers naturally thought of him after deciding to use wood engravings rather than etchings for their ease of printing and placement because, as was later observed, Williams was "the first to give to periodical literature spirited and good illustrations" in this medium, often used in commercial but not imaginative work. ${ }^{9}$ Accordingly, he engraved Cattermole's illustrations of Master Humphrey's 
room for the Clock's debut $(S B B, 699)^{10}$ and Browne's portrayal of the correspondent for the second number $(S B B$, 728). He probably was to engrave the second design for the fourth number in which the Nell story, then self-contained, appeared. Browne was to furnish the design; "any subject he fancies," Dickens had instructed, but "it should have the girl in it, that's all." It is not known why Browne did not supply this drawing nor whether Cattermole, who had provided the number's headpiece, was approached and declined. With the pressure of the weekly as well as the monthly Clock schedule, the principals could lose no time in finding another artist.

Samuel Williams was the logical choice. It seems likely that he was not thought of merely as a stopgap, as Robert Buss may have been on Pickwick, but as a permanent Clock illustrator. Chapman and Hall would save time and perhaps money employing Williams, who could both design and execute his engravings, in contrast to Cattermole, who could not yet copy his own drawings onto the wood block, or Browne, who had no time or desire to do his own engraving. ${ }^{12}$ Furthermore, Dickens had wanted his periodical illustrated by a variety of artists. Browne could not take on more work; Cattermole, given his painting and his nervousness, could not be overtaxed; and Maclise had declined to participate on any regular basis, finally being cajoled into providing one design. ${ }^{13}$ Williams, with his varied skills and experience, could cope with any subject likely to arise in the miscellany. Dickens apparently thought he was hired for the Clock's duration to judge from the conclusion of his first instructions: "As Mr. Dickens hopes to communicate with Mr. Williams on many future occasions, he will not weary him with any apology for these remarks just now." ${ }^{14}$ There is no suggestion that this first written communication from author to artist would be the last.

Dickens had arranged to meet Williams at Devonshire Terrace to inspect his sketch for Nell in bed but when he was unable to keep the appointment, he sent a detailed set of stringent instructions instead. Using his most objective third-person manner, as he often did when addressing strangers, the author commented:

The object being to shew the child in the midst of a crowd of uncongenial and ancient things, Mr. Dickens scarcely feels the very pretty drawing inclosed, as carrying out his ideas: the room being to all appearances . . . exceedingly comfortable . . . and the sleeper being in a very enviable condition. If the composition would admit of a few grim, ugly articles seen through a doorway beyond, for instance, and giving the notion of great gloom outside the little room and surrounding the chamber, it would be much better. The figure on the bed is not sufficiently childish and would perhaps look better without a cap, and with the hair floating over the pillows. The last paragraph of the paper (which perhaps Mr. Williams has) expresses Mr. Dickens's idea better than he can convey it in any other words. ${ }^{15}$

Williams acted on Dickens's suggestions as readily as he doubtless had on Howitt's. Nell's face and form may still appear more womanly than childish to the viewer (I, 14) (fig. 128), but it is compatible with Cattermole's graceful portrayal of her awake (I, 1); indeed, the artist seems to have taken pains to insure continuity of his colleague's delicate style as well as their mutual subject, though Dickens had not stressed this. Nell's fair hair spreads with appealing naturalism over the pillow as the author had wished. The semi-canopied bed still appears comfortable, even luxurious, but its rounded solidity well points up the angularity and disrepair of the "grim, ugly articles" mentioned in Dickens's text (I, 14) and in his letter. Williams incorporated all these objects within the room, not beyond it, wisely recognizing the spirit rather than the letter of the author's instructions. The ghostly suits of armor and the wood and stone faces were delineated just as Dickens described them together with other disparate items that he had not-chairs, pictures, mirrors, statuary, and even a crucifix. Finally, Williams's use of bright whiteness to portray the bed and sleeping girl, in vivid contrast to the dark tones of most of her surroundings, further isolates Nell visually, just as she has been verbally-"alone in the midst of all this lumber and decay" $(I, 14)$. Whether or not William

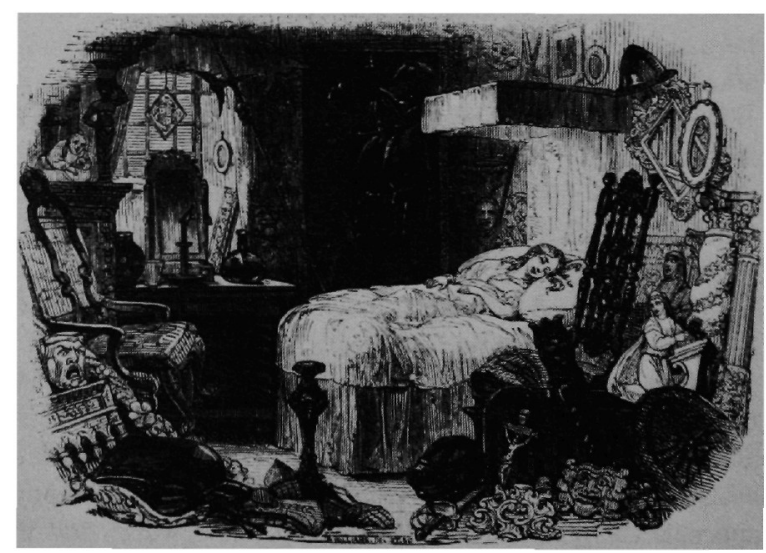

Fig. 128. Samuel Williams, 'Nell in bed.' Master Humphrey's Clock, no. 4, p. 46 . Wood engraving. $3^{1 / 8^{\prime \prime}} \times 4^{1 / 2} 2^{\prime \prime}$ $(8 \times 11.5 \mathrm{~cm})$. By permission of the Houghton Library, Harvard University. 
Linton was right in thinking the artist generally overdependent on such brilliant contrast for effect, certainly it is effectively suitable to this Dickens piece; for when it expanded into The Old Curiosity Shop, it relied heavily on traditional oppositions of light and dark. ${ }^{16}$

The hope of such collaboration, that a scene will remain in the readers' minds, even over an extended period, was realized here beyond expectation. Thomas Hood, writing anonymously in the Athenaeum in 1840, called the public's attention to Williams's illustration: "Look at the Artist's picture of the Child, asleep in her little bed, surrounded, or rather mobbed, by ancient armour, and arms, antique furniture, and relics sacred or profane, hideous or grotesque: -it is like an allegory of the peace and innocence of Childhood in the midst of Violence, Superstition, and all the hateful or hurtful Passions of the world."17 Dickens was certainly gratified by Hood's perceptions of both his original purpose in the Nell story and his intentions after it became a full-scale novel-perhaps these perceptions were clearer than his own. He manifested his pleasure in numerous ways.

First, Dickens sought the reviewer's identity and, after discovering it, wrote to express his appreciation. ${ }^{18} \mathrm{He}$ would also thank Hood publicly in his preface to the 1848 Cheap Edition of The Old Curiosity Shop (vii). In 1841, however, Dickens must have displayed marked enthusiasm about the Athenaeum review to Forster. For as Harvey has demonstrated, Forster accordingly referred to Williams's engraving in his own anonymous review for the Examiner late that year, which was recycled with scant alteration in his biography of Dickens three decades later: "In the first still picture of Nell's innocence in the midst of strange and alien forms, we have the forecast of her after-wanderings, her patient miseries, her sad maturity of experiences before its time." 19

Furthermore, at this time, Dickens made some additions to the text that seem to endorse implicitly Hood's interpretation of his thinking. These additions were necessary to replace the Master Humphrey sections that were removed from the Nell story for its separate publication in 1841. Dickens's four new paragraphs, inserted right below the Williams engraving and before his own original concluding paragraph, further reinforce the significance of the illustration as Hood had perceived it, even, as Harvey notes, echoing some of his phrases. ${ }^{20}$ Dickens's longest addition also may contain an unconscious acknowledgment of Williams's contribution in immortalizing little Nell. For readers, like the narrator, certainly possessed her "image without any effort of imagination," not only in their minds but before their eyes as well (I, 13). Surely Dickens realized what both Hood and Forster imply, that The Old Curiosity Shop retrospectively seemed as much an expansion of Williams's illustration as of Dickens's prose. ${ }^{21}$

Williams may have accomplished his task too well, however, and inadvertently deprived himself of a more lasting engagement as a Dickens illustrator. When the Clock's mixed format proved unacceptable to readers, the Nell piece developed into a novel along the lines of contrast that both author and artist took such pains to reinforce in 'Little Nell in bed.' The principals must have realized that further graphic variety was no longer necessary or desirable. The picturesque and the grotesque, whose opposition structured the narrative, were precisely the styles in which Cattermole and Browne respectively excelled. Surely this pair could meet the challenges of continuity without another hand's help. Moreover, the Clock's precariousness may have necessitated financial retrenchment; if so, Williams, as the last to be hired, would be the first to be let go.

How this message was conveyed to Williams and how he received it is not recorded. More solidly established in his craft than Buss was at the time of his Pickwick severance, Williams probably accepted his reversion to his earlier status as a Clock engraver with equanimity. He executed two more Master Humphrey designs by Cattermole ( $S B B$, $758)$ and Browne $(S B B, 789)$ with his customary competence, and then concentrated his energies on prestigious commissions such as the one to engrave the scenes for the Abbotsford Edition of Scott's Waverley novels (1842-47) and on works whose illustrations he himself designed. ${ }^{22}$ His prospering firm maintained its connection with Dickens over the years. Samuel's brother, Thomas Williams, engraved eleven of the Christmas book illustrations in the mid1840's - indeed, Maclise was furious to discover that Thompson rather than Williams was executing his opening designs for The Battle of Life in 1846. ${ }^{23}$ Thomas Williams also executed the frontispiece for the 1848 edition of the Shop, whose preface contained Dickens's thanks to Hood for what, in large part, was an appreciation of his brother's contribution to the original work (vii).

Whether the author and his publishers would have employed Samuel Williams's dual skills again cannot be known. Subsequent illustrations for Dickens's novels for the next two decades were etchings. By the time the author again used wood engravings for his illustrations, in Our Mutual Friend in 1864 and The Mystery of Edwin Drood in 1870 , Samuel Williams was dead. Yet the reason for Dickens's return to wood engraving was part of the Williams legacy in this medium, whose standards he and his family had so long upheld. His work had helped to continue the 
popular dissemination of wood engraving after Bewick's death, even when it was unfashionable or difficult to do so, and had encouraged an atmosphere in which this medium, aided by technical advances, would become the dominant one in the illustration of fiction after $1860 .{ }^{24}$ At the time of Williams's death in 1853, at least one contemporary felt that current book illustration owed its "chief force and character" to his efforts. ${ }^{25}$ And the Athenaeum felt little doubt that "whenever the history of wood-engraving in the country shall again be written, the name of Mr. Samuel Williams will be mentioned with honour." ${ }^{26}$ The same name, though devoid of legend, anecdotes, an extant likeness, or even many verifiable facts, also deserves honorable mention in any account of Dickens's original illustrators. 
The Illustrators of the Christmas Books

\author{
JOHN LEECH \\ RICHARD DOYLE \\ JOHN TENNIEL \\ DANIEL MACLISE \\ EDWIN LANDSEER \\ CLARKSON STANFIELD \\ FRANK STONE
}





\section{Chapter 7}

\section{JOHN LEECH}

But for an accident of timing, John Leech might have become the principal illustrator of all Dickens's works, not just of his Christmas books. Too late with his application to fill Seymour's vacancy on Pickwick in 1836, over the next eight years Leech earned recognition in his own right, especially after becoming an artist for Punch. His independent reputation enabled him to become a closer intimate of Dickens-for whom he worked because of friendship, not necessity-than would have been possible had he been subordinate to him from the first. Though Leech was more important to the author as a friend than as an illustrator, he nevertheless contributed immeasurably to the success of the Christmas books. There, as elsewhere, he introduced a measure of beauty into his caricatures, lending refinement to a formerly crude genre that too often equated ugliness with evil and grace with weakness. Leech's aesthetic gentility had an effect not only on fellow artists like Browne, but perhaps even on Dickens, whose own characterization grew noticeably more refined from Martin Chuzzlewit on-about when Leech began working with him. ${ }^{1}$ The artist, in turn, garnered material from Dickens's wribing for many of his best Punch cartoons. The author's affection for Leech, in contrast to that for his earlier illustrators, like Cruikshank and Cattermole, survived the vicissitudes of literary and theatrical collaboration and lasted to the end of their lives. Indeed, in return for his consistent efforts to please, Leech even elicited from Dickens a professional magnanimity that would have surprised all his artistic predecessors, except, perhaps, Cattermole.

If Leech did not become Dickens's illustrator after the Seymour-Buss period on Pickwick, it was not because he did not try. Five times he offered his services to the novelist, and five times was rejected. In the summer of 1836 , the young man had just given up the medical career that suited his parents (and the older meaning of his surname -physician) but not his own inclination to earn a living as a comic artist. His medical studies, with their emphasis on anatomical structure and proportion, proved invaluable to Leech who, like all Dickens's early illustrators, drew from memory rather than models; except for a few etching lessons from George Cruikshank, he never had any regular art training. ${ }^{2}$ In July, perhaps at Cruikshank's suggestion, Leech applied to the author to illustrate The Pickwick Papers. ${ }^{3}$ He was either unaware that two fellow artists-his old school friend, William Thackeray, and Hablot Browne -had both applied long since, or else he thought that Browne, who had been hired, might meet the same fate as Robert Buss. Dickens quickly informed him that he was very satisfied with Browne's work for Pickwick and had no desire to replace him. ${ }^{4}$

Undaunted, Leech once again approached Dickens at Furnival's Inn in late August to leave a drawing of Tom Smart and the chair, illustrating the Bagman's story then appearing in Pickwick (fig. 129). Understanding that the young artist wanted to attract the attention of Chapman and Hall in order to secure their good opinion and possibly even a post on something like their Library of Fiction, the author forwarded the sketch to the publishers with a disparaging note. "The chair's not bad, but his notion of the Bedroom is rather more derived, I should be disposed to think, from his own fourth pair back, than my description of the old rambling house" (PP, XIV, 182-83). ${ }^{5}$ His note to the artist, who "threatened" (in Dickens's words) to call again, was more tactful. ${ }^{6}$ Acknowledging that Leech's design was "extremely well conceived and executed," he said he had sent it on to Chapman and Hall, though he thought they were already provided with artists for their Library, an enterprise he himself had nothing to do with. He also repeated how pleased he was with Browne's contributions to 


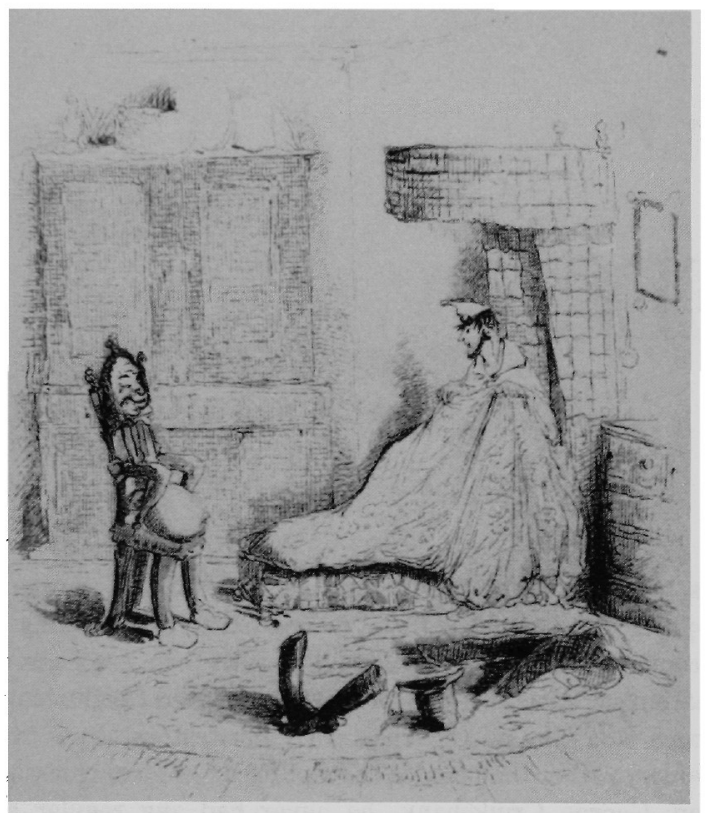

Fig. 129. John Leech, Drawing of Tom Smart and the Chair. The Pickwick Papers, ed. Charles Plumptre Johnson (London: Chapman and Hall, 1887), 2d of three inserts between p. 202 and p. 203. Pastel and colored pencil. $45 / 8^{\prime \prime}$ $\times 41 / 2^{\prime \prime}(11.8 \times 11.5 \mathrm{~cm})$. From the Harvard College Library.

Pickwick, lest Leech have further hopes for that job. The artist's efforts were not in vain; he was engaged to provide three contributions to the last two numbers of the Library (for which Browne was the regular artist), no doubt on the strength of the Bagman's sketch. ${ }^{7}$

Later in 1836 the persistent young man tried a third time to catch the attention of Dickens with a sketch of John Harley in the title role of The Strange Gentleman. Though the author liked the overall delineation of Harley, he felt the artist "had not got the face well, or the hat"-a widebrimmed type pulled down over the eyes of the smiling actor who was shown genially extending his right hand-and assigned Browne to portray Harley in the published drama. ${ }^{8}$ Even more disappointing must have been the fact that Ainsworth's idea that he and Dickens would write tales of ancient and modern London with illustrations by Leech and Cruikshank finally failed to materialize, despite plans for it from 1836 to $1838 .{ }^{9}$ Indeed, the closest Leech may have managed to come to illustrating Dickens in the 1830's was to sell a sketch of the author himself to The London Magazine, where it reportedly appeared jauntily signed "Jack Leech done it." 10
Still undaunted, Leech waited four years for another opportunity. In the autumn of 1842 he offered his services yet again to Dickens, who, recently returned from America, was preparing Martin Chuzzleurt. This time, however, Dickens confronted no novice convert from medicine but an established artist. As the successful illustrator of the Ingoldsby Legends, Hood's Comic Annual, and, above all, the new humorous periodical, Punch, Leech was now warmly received by Dickens. ${ }^{11}$ Indeed, the author always reserved his best treatment for illustrators who had earned fame independently of his own work. He now maintained that he had never forgotten meeting Leech nor lost track of his subsequent progress and expressed pleasure at the idea of employing the artist to illustrate his forthcoming novel. He said he must communicate with Browne, of course, but would let Leech know within the week how matters stood. He expressed the hope that, whatever happened, he would not lose touch with the artist again.

For some reason, however, though he had no doubts about Leech's talent, Dickens had second thoughts. He may have recalled the problems of coordinating two illustrators that cropped up throughout Master Humphrey's Clock. More likely Browne discouraged this arrangement, for he had recently turned down an offer to join the staff of Punch, partly because he disliked competing with Leech. ${ }^{12}$ At any rate, two days later, Dickens wrote Leech that there appeared to be "so many mechanical difficulties, complications, entanglements, and impossibilities, in the way" of collaboration that it was simply impractical. ${ }^{13}$ Dickens made good his social promise, however, and invited the artist for dinner the following Sunday. Over the following years, Leech dined with the author alone and en famille countless times. His gentility won Kate's affection as well as Dickens's.

Even before Martin Chuzzlewit had run its course, however, the author was able to employ the artist after all in 1843. At Dickens's suggestion, most likely, Chapman and Hall commissioned Leech to supply the illustrations for $A$ Christmas Carol, a project only partly inspired by Chuzzlewit's disappointing sales. Browne was doubtless too busy illustrating the novel to illustrate the holiday book as well; and Leech, with his graphic talent "for making one glad," as George du Maurier put it, was especially well suited to the task. ${ }^{14}$ His ability to portray both the graceful and the grotesque was needed for the Carol's unique blend of the ideal, real, and supernatural.

A Christmas Carol, like most of Dickens's Christmas books and Christmas scenes in his novels, was not explicitly related to the birth of Christ. Indeed, as Ruskin sourly 
noted, Dickens's Christmas "meant mistletoe and pudding -neither resurrection from dead, nor rising of new stars, nor teaching of wise men, nor shepherds." 15 Dickens himself regarded his holiday stories-which were so popular they created a new genre-as higher forms of nursery tales. His ideal of brotherly love, subsuming that of all religions, was, as he put it, "never out of season" ( $C B$, vii); it proved capable of affecting even the misanthropic Scrooge, just as it had his predecessor in Pickwick, Sexton Grub $(P P, 394-403){ }^{16}$ And indeed, Leech perfectly captured this transcendent but secular spirit in his illustrations for A Christmas Carol.

Certainly the benevolent little book was partly inspired by mercenary concerns. Dickens very much needed money at this time, due to his growing family and the disappointing sales of Martin Chuzzlewit. He was to pay the production costs and Chapman and Hall was to sell the book on commission. Nevertheless, to attract the largest number of purchasers, Dickens wanted the Carol to sell for only five shillings. Yet, in what seems a contradiction of principles, he insisted that it be issued with gilt edges, colored endpapers, a crimson and gold binding, a title page printed in two colors, and eight illustrations-half of them multicolored etchings, the other four black-and-white wood engravings. ${ }^{17}$

The energetic enthusiasm with which Dickens produced $A$ Christmas Carol was in sharp contrast to his agony in the same period over the writing of Chuzzlewit. Leech entered into its spirit more gingerly, however, for the graphic realization of the allegory proved problematic. The colored plates Dickens insisted on caused difficulties from the first. Leech had colored the robe of the Ghost of Christmas Present bright red before he recalled that the text described it as green (Dickens's favorite color). ${ }^{18}$ He became far more disturbed when he saw what he considered to be the poor quality of the printed colors in the four colored plates. Leech had indicated on a master print the shades he desired. Then a copyist, working from prepared tints, had colored each object separately and uniformly. The result was gay-Scrooge's bright pink chair (I, facing p. 16) and orange trousers (III, facing p. 70), the apple-red cheeks of the dancing Fezziwigs (II, facing p. 30) and the Ghost of Christmas Present (III, facing p. 38) (see fig. 141)-but crude. Leech was dismayed. Dickens sympathetically forwarded his complaints to the publishers, but thought the artist exaggerated the "evil" wrought by the copyist. "You can't think," he wrote reassuringly, "how much better they will look in a neat book, than you suppose."19

Dickens was correct. Leech's plates were received with as much critical acclaim as the author's text. The Illustrated London News, for example, thought his engravings "taste- fully coloured" and his woodcuts imbued with "the delicacy of fine etchings."20 The four colored prints provided a welcome and festive contrast to the black-and-white printed pages. The four uncolored woodcuts displayed suitable mood and expression as well as delicacy of line, whether they portrayed grotesque phantoms (I, 21), impoverished children (III, 57) or mature friends ( $V, 78)$. "Who could listen to objections regarding such a book as this?" declared Thackeray, including the illustrations as well as the narrative in his rhetorical question. ${ }^{21}$

Nevertheless, the illustrations precipitated a crisis in Dickens's life. The author discovered he had cleared only $£ 230$ on the first printing of the Carol rather.than the $£ 1,000$ he had expected. No, replied the publishers, denying Forster's charge that they had been negligent, Dickens had given his instructions, and they had faithfully executed them. ${ }^{22}$ Certainly Leech was not at fault. Nor had he been overpaid for his efforts; his total recompense for drawing and engraving the plates was just under 150 . The handpainting by others, however, accounted for a disproportionately high proportion of the total expense. The problem was simply that the modest selling price Dickens had insisted upon had insufficiently provided for the cost of such a luxurious format. Eventually, A Christmas Carol did prove profitable. Meanwhile, however, Dickens, financially devastated by the disappointing Chuzzlewit sales and meager Carol profits, in addition to his failure to recover damages from publishers who had pirated his works, broke with Chapman and Hall, and left England to retrench on the Continent.

During his self-imposed exile, Dickens planned another Christmas book, as well as travel notes about Italy and a new novel. He wanted the next holiday production to carry the same kind of message about society that he meant the Carol to have about the individual. As Michael Slater has observed, The Chimes, more directly than his previous works, dramatized his growing conviction that society's problems could not be explained away by blaming them on individual villains like Fagin, Ralph Nickleby, and Montague Tigg, but stemmed from the whole society's self-serving and self-fulfilling attitudes toward the depraved poor and from the blighted prospects it offered them. ${ }^{23}$ In further contrast to the Carol, the action of The Chimes was set on New Year's Eve rather than Christmas Eve, and dealt in social and political satire rather than moral allegory. In addition, supernatural elements, which were mainly a benign opportunity for the conversion of Scrooge in $A$ Christmas Carol, become a nightmare for Trotty Veck in The Chimes-one the reader can hardly forget despite the 


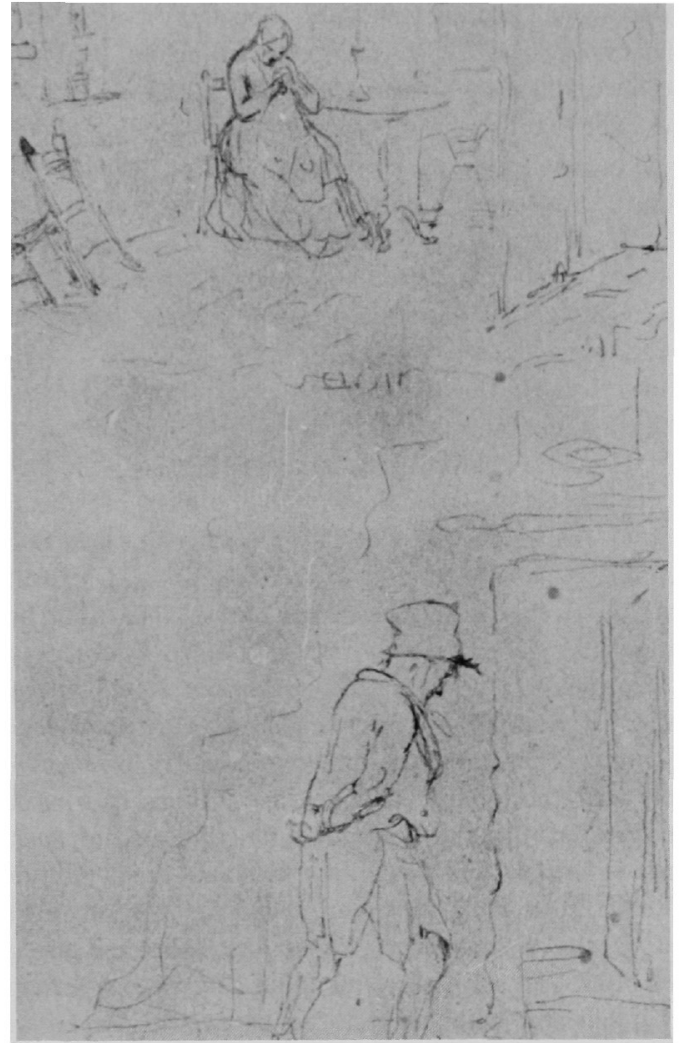

Fig. 130. John Leech, First Sketch for 'Richard and Margaret.' Pencil. $4^{11 / 16^{\prime \prime}} \times 3^{\prime \prime}(12 \times 7.6 \mathrm{~cm})$. By permission of the Castle Museum, Nottingham.

story's happy resolution. Even the charm of Leech's pictures did not dispel the grimness of the realities Dickens described.

The Chimes departed from the Carol in format as well as in spirit and substance. It contained more illustrations, thirteen rather than eight, though none of them were colored. There were not one but four illustrators, all eminent artists who might attract a still wider audience and at least, as Mrs. Leavis suggests, make each purchaser feel he had full value for his money. ${ }^{24}$ Leech provided five of the thirteen illustrations; Maclise, Stanfield, and Doyle the rest. The presence of these experienced artists lessened Leech's burden yet complicated it, for the added variety undermined visual continuity. His portrayal of Trotty Veck as a compact, genial figure with an oversized head (I, 89; II, 100; II, 112), for example, was distinctly at odds with Doyle's more youthful and conventional representation of him (III, 134).

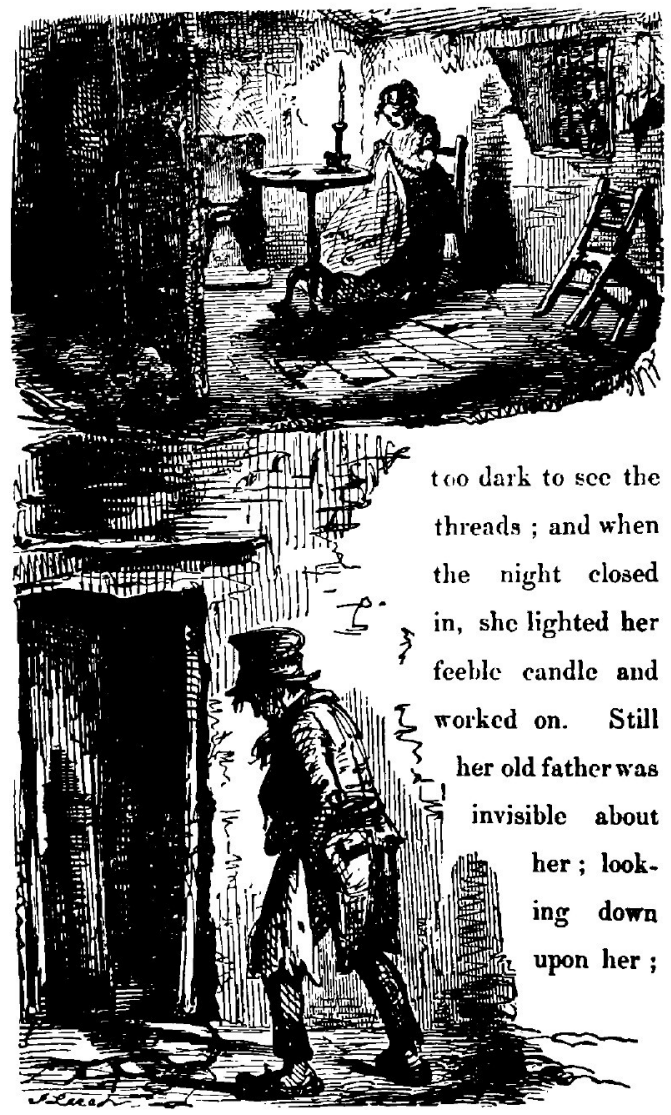

Fig. 131. John Leech, Canceled Print of 'Richard and Margaret.' Proof copy of The Chimes, p. 125, Dexter Collection. Wood engraving. $47 / 8^{\prime \prime} \times 27 / 8^{\prime \prime}(12.5 \times 7 \mathrm{~cm})$. By permission of the Trustees of the British Museum.

Moreover, Leech, always eager to please his friend, was also troubled by Dickens's absence abroad. The efforts of the various illustrators were coordinated by Forster, with whom Leech did not feel completely comfortable. ${ }^{25}$

Nevertheless, considering the real and potential obstacles, the collaboration proceeded smoothly, until Dickens returned to London to see The Chimes through the press and read it to his friends. He then noticed the second of Leech's dual scenes-both integrated within a single illustration, which became a hallmark of the Christmas books, enabling the reader to absorb two actions simultaneously - the print of 'Richard and Margaret' for the nightmare Third Quarter of The Chimes (III, 152) (figs. 130 and 131). The artist's depiction of Margaret in her forlorn garret was suitable, he must have felt, but Richard, striding home, 


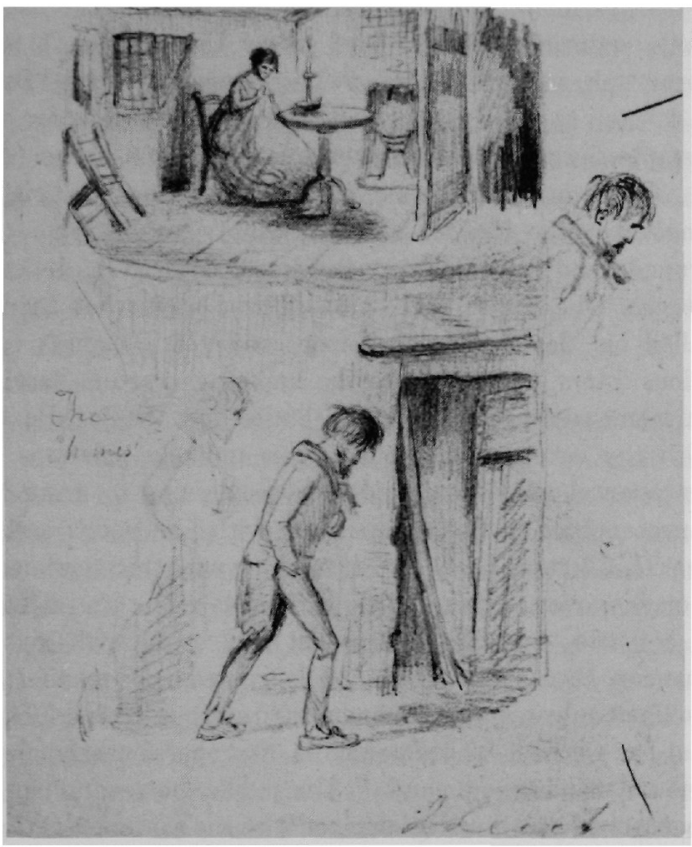

Fig. 132. John Leech, Altered Sketch for 'Richard and Margaret.' Pencil. 65/16" $\times 4 \% 16^{\prime \prime}(16 \times 11.3 \mathrm{~cm})$. From the original in the Harry Elkins Widener Collection, reproduced by permission of the Houghton Library, Harvard University.

resembled an elderly behatted nightwatchman, utterly unlike Dickens's disheveled victim of dissipation. The author hastily dispatched a tactful summons: Leech had performed "gallantly" for the new book, but they needed to discuss a "minor" but necessary alteration in one of the wood blocks. ${ }^{26}$ After a breakfast meeting with Leech (together with Doyle, one of whose cuts also failed to suit the author), Dickens, with happy appreciation for his own diplomacy, reported to his wife that "with that winning manner which you know of," he had got the artists to redo their blocks "with the highest good humour." ${ }^{27}$ Whatever his humor, Leech made another sketch (fig. 132) and altered the block overnight. Richard's bowed unshaven face and unkempt hair now reinforced the despondency of his prematurely bent fine figure (fig. 133). Dickens hastened to assure Leech how gratified he was both by the alteration and by his willing attitude. "I have the greatest diffidence in suggesting any change, however slight, in what you do-you are so ready to make it," elaborated the author, pleased yet abashed by his friend's anxiousness to please. ${ }^{28}$

The public responded to this strident holiday book almost as enthusiastically as they had to its gentler predecessor.

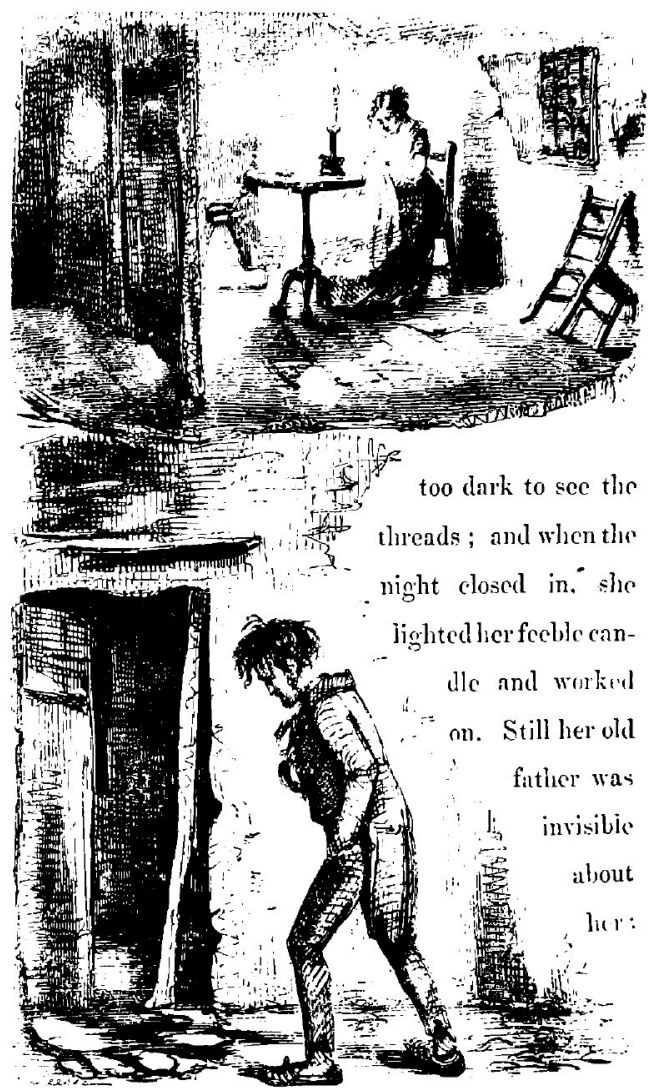

Fig. 133. John Leech, 'Richard and Margaret.' The Chimes (London, 1844), p. 125. Wood engraving. $4^{3 / 4^{\prime \prime}} \times 2^{7 / 8^{\prime \prime}}(12.1$ $\times 7 \mathrm{~cm}$ ). From the Harry Elkins Widener Collection, by permission of the Houghton Library, Harvard University.

Most praised the author in his desire to convert society, as he had Scrooge, by attacking Benthamite indifference and Tory paternalism, as he later would again in Hard Times. ${ }^{29}$ All apparently agreed that the illustrations were dramatically appropriate and skillfully executed. ${ }^{30}$ The text and the prints, especially those by Leech, revealed to many readers for the first time the beauties as well as the sorrows of the poor.

Dickens's third Christmas book, The Cricket on the Hearth, was the first to appear under the sole aegis of his new publishers, Bradbury and Evans. Even before working out the plot of this holiday production, Dickens worried about its format, so important to the work's success. "I think it is time we determined how the Christmas book shall be illustrated," Dickens wrote the firm at the end of Septem- 
ber, 1845; "if you deem it advisable to have it done as expensively as The Chimes, it may be well to communicate with Messrs. Leech and Doyle, and prepare them for what they will have to do." ${ }^{31}$ Bradbury and Evans were loath to change anything but the late publication date about the lucrative holiday books by their newly acquired author. They wanted the forthcoming volume embellished once again with illustrations by many eminent artists-Maclise, Stanfield, Landseer, and Doyle as well as Leech. Dickens immediately contacted Leech, anxious to secure his assistance. "If you are in the mood, therefore, to illustrate my poor fancies," concluded the author with excessive humility, "we will hold discourse together on the subject."32

Leech could not refuse Dickens anything. Neither did he find Dickens's fancies impoverished. The author had minimized what Slater terms the supernatural and socialconscience elements in The Cricket and omitted everything concerned with Christmas and New Year's except a winter setting. ${ }^{33}$ The result-a heart-warming idealization of Victorian home and hearth-was the most immediately popular of all his Christmas books. Its imaginative charm was partly due to Leech, who, in seven of the story's fourteen illustrations, portrayed each one of the major characters. Mrs. Leavis seems unduly serious when she charges that "the illustrations actually do the tale a disservice; their charm and quaintness underplay the text instead of confirming and reinforeing its implications as they might have done if more seriously conceived." ${ }^{34}$ For Dickens's purpose was to put his readers in a genial humor-not, for example, to examine seriously Dot Peerybingle's marriage to a much older man (a problem later taken up through Annie and Dr. Strong in David Copperfield, Dickens's longest analysis of love and marriage). In The Cricket, as Slater also observes, he simply creates a beguiling world of playthings that not even the Gruffs and the Tackletons (nor the author's own melancholy) could altogether subvert. ${ }^{35}$

And certainly Leech's illustrations sustain this optimistic spirit without falsifying the forces that threaten it. He did not shrink from portraying the Carrier's despair over the appearance of Dot's infidelity (III, 247), for example. On the other hand, he refused to let Tilly Slowboy-the only ugly woman in the narrative as well as the sole representative of the underprivileged ${ }^{36}$ - spoil a happier scene involving the Peerybingles. In a preliminary sketch for the scene, Leech evidently had included her with the couple and their baby seated by the fire. ${ }^{37}$ Perceiving that she destroyed the beauty of the fireside idyll (I, 212), however, he tactfully removed her to a separate illustration in a subsequent chapter (III, 233). Here Tilly faced no competition and could be portrayed with a dignity undiluted by laughter or pity.
Leech's final illustration contributed more to the narrative's enduring impression of gaiety than Dickens's final paragraph, surely a reflection of his depressed mood: "Even as I listen to them blithely, and turn towards Dot, for one last glimpse of a little figure very pleasant to me, she and the rest have vanished into air, and I am left alone. A Cricket sings upon the Hearth; a broken child's-toy lies upon the ground; and nothing else remains" (III, 277). Indeed, Leech's 'The Dance' (III, 276), infused with what Ruskin called his "loving wit,"38 better conveyed Dickens's conscious intent. Not only are the human characters dancing harmoniously with one another, but so does the dog, Boxer, with the cat (see fig. 163) ${ }^{39}$ This unlikely pair was no sentimental afterthought. Leech took pains to make his representation of Boxer consistent with Landseer's earlier one (II, 230) (see fig. 162). ${ }^{40}$ In keeping with the merriment, the artist even animated his own famous signature-a leech in a bottle-by adding legs that kick away with joyous abandon. By contrast, Dickens's depressed mood manifested itself not only in his concluding paragraph but in his criticism that the Carrier, whose person is disproportionately large, was not handsome enough. ${ }^{41}$ The public, however, had no quarrel with the illustrations, nor with the sentimental text, and to the chagrin of its critics, sales of The Cricket soared even beyond those of its Christmas predecessors.

In contrast, the 1846 Christmas book, The Battle of Life, contains a minimum of merriment. As the title suggests, the story is not filled with holiday spirit. The plot is improbable-a younger sister runs away from home to effect a marriage between her fiancé and her elder sister-and devoid even of seasonal crutches, set, as it is, in the spring and late fall, though snow falls at the conclusion of Part the Second (II, 349). There were neither supernatural devices not sociological appeals to reinforce Dickens's characteristic insistence on the value of home and hearth. ${ }^{42}$ Moreover, the author's circumstances-his Daily News failure, his removal to Switzerland, and the commencement of Dombey and Son, his first novel in two years-were not conducive to a mood of festivity and creativity. The pressures of Dombey, in particular, made the writing of The Battle of Life a battle indeed-one he almost abandoned.

The pictures, always such a crucial element in the Christmas books, were again complicated by Dickens's absence. Forster's coordination of Maclise, Doyle, Stanfield, and Leech was hampered by the author's anxious suggestions from afar as well as by squabbles among the artists. Forster did not receive the first two parts of the manuscript until early October. Even so, the author requested it be withheld from the illustrators until the third part arrived, 
"for it is a single-minded story, as it were, and an artist should know the end: which I don't think very likely, unless he reads it. ${ }^{\text {"43 }}$ This restriction inevitably hamstrung Forster in coordinating artists, engravers, printers, and publishers (and, as shall be seen, would fail to prevent Leech's being misled). Then, suddenly, at the end of October, Dickens suggested that the costumes in the illustrations be those of Goldsmith's period. "Whatever you think best, in this as in all things, is best, I am sure," he added soothingly. ${ }^{44}$ Despite the late date, Forster knew he had little choice but to implement this proposal.

When the completed manuscript was received, only a month remained for thirteen illustrations to be designed and sketched by four different artists, sent to Switzerland for Dickens's approval, returned, altered if necessary, drawn onto the block, and printed. Leech promised to lose no time, but he could not say how many illustrations he could produce in a week's time. "I am so embarrassed by the conditions under which I am to make my share of the drawings that I hardly know what to do at all," he despaired to Forster. "I cannot tell you how loathe I should be to cause any delay or difficulty in the production of the book or what pain it would give me to cause either Dickens or yourself any annoyance. I confess I am a little out of heart." 45

Leech finally contributed three of the thirteen illustrations (though not in the allotted time). Each one, however, compounded his earlier distress. In his first scene, 'The Parting Breakfast,' which involved most of the main characters (I, 300), he worried about his portrayal of Clemency Newsome, the faithful servant (and ancestress of Copperfield's Peggotty). Maclise had already insisted that his own earlier delineation of Clemency, whom he treated like a plumper Dot Peerybingle, be sustained in his colleagues' representations; but Leech, a master of characterization, protested that he could not "Conscientiously" make Clemency as attractive in the situation that fell to his pencil ( $I$, 295-96). ${ }^{46}$ What had impressed Leech about the servant was her comic awkwardness. "Of course I may be wrong in my conception of what Dickens intended," he explained to Forster, "but $I$ imagine the lady in question a sort of clean 'Slowboy.",47 $\mathrm{He}$ worried that readers, ignorant of his obligation to conform to Maclise's portrayal, would hold him responsible for the inaccurate characterization. Two days later, Forster received the sketch, accompanied by the artist's apologies for its "glaring" defects and for the clumsy tone of his previous letter. ${ }^{48}$ That this sketch was completed at four o'clock in the morning indeed reveals that Leech spared neither time nor comfort to show his regard for both Forster and Dickens. The controversial figure of Clemency, appealingly maternal and appropriately obscure in the background, managed to fill all prerequisites. She did not differ markedly from Maclise's characterization, or contradict Dickens's text, or compromise the artist's, own integrity.

In Dickens's three preceding Christmas books, Leech's execution of at least half the illustrations had provided some pictorial continuity. In The Battle of Life, however, the illustrations were equaliy divided among the four artists, which resulted in disparate techniques and, hence, effects. The suitably rough lines of Leech's portrayal of 'Snitchey and Craggs' (II, 318), for example, clash with the graceful curves of Maclise's 'Secret Interview' (II, 336) which, in turn, clash with the compacted strokes of Stanfield's 'The Nutmeg-Grater' (III, 353). ${ }^{49} \mathrm{~A}$ further complication was the inevitable alteration of the original drawings by the engraver. At least one observer still finds more Dalziel than Leech in the published prints. ${ }^{50}$

This, however, was the least of the problems with 'The Night of the Return' (II, 346) (fig. 134). In this final whole-page illustration for The Battle of Life, as in the others, Leech visually stressed the verbal contrasts between the upper and lower panels: while the dance proceeds in the ballroom in the panel above, a solitary couple, holding hands, are stealing out into the night in the panel below. In the process, he caused precisely the trouble Dickens tried to avoid by giving the artists only the completed text so they would know how the intricate story was resolved ${ }^{51}$ Leech apparently read only as much of the narrative as he thought essential to his purpose. Consequently, he was deceived into thinking, as Dickens intended his readers but not his artists to be, that Marion Jeddler had eloped with Michael Warden when in fact she had only run away to her aunt. Thus he erroneously included Warden in his finished block. The mistake was viewed by Dickens with particular anguish, doubtless compounded by Browne's recent misrepresentation of Paul and Mrs. Pipchin in Dombey (see fig. 79). "Of course, I need not tell you, my dear fellow," Dickens cried to Forster, "Warden has no business in the elopement scene. He was never there!"52

Yet after the initial shock of this unwelcome surprise, Dickens gave up the idea of suppressing the Leech design for what would have been the second time in their collaboration or even replacing it in future reprintings. It was not merely because publication had been expressly delayed for it. More important, he told Forster, he decided to let the print stand to avoid "the pain this might give to our kindhearted Leech"; he also realized that "what is such a monstrous enormity to me, as never having entered my brain, may not so present itself to others." ${ }^{\text {"53 }}$ If "The Night of the Return' wrongs Marion's innocence, its unaltered 
Hot and breathless as the Doctor ras, it only made
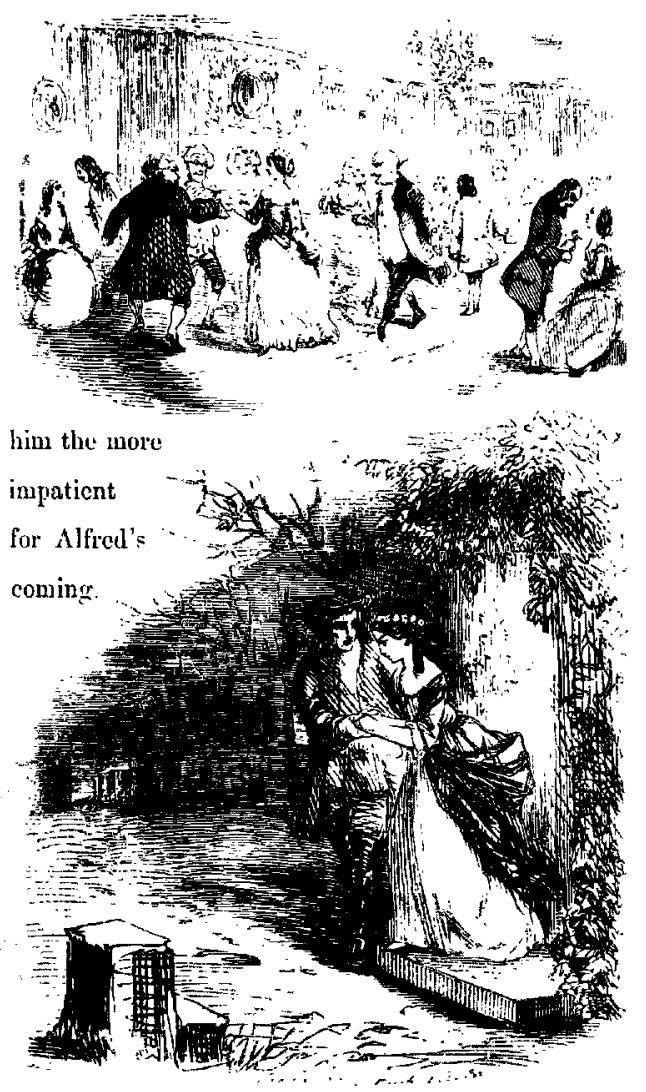

Fig. 134. John Leech, 'The Night of the Return.' The Battle of Life (London, 1846), p. 114. Wood engraving. $4^{3 / 4^{\prime \prime}} \times 22^{13 / 16^{\prime \prime}}$ $(12.1 \times 7.2 \mathrm{~cm})$. From the Harry Elkins Widener Collection, by permission of the Houghton Library, Harvard University.

presence testifies to the sensitive strength of Dickens's affection for Leech. The gesture was an especially magnanimous one at this time, when the author was so hypercritical of any shortcomings in the work of his illustrators.

Readers did not comment on Leech's error until Forster called attention to it after the death of both artist and author. ${ }^{54}$ Although Dickens praised Leech's illustrations along with all the others at the time, he later maintained that all of them "shocked me more or less," perhaps overaffected by the poor critical reception of The Battle. ${ }^{55}$ Indeed, it could be argued that the varied styles of the illustrations complicated rather than reinforced the narrative, whose plot was not as smoothly integrated as those of the earlier Christmas books, particularly the Carol. From conception to execution to critical reception, this fourth holiday production was indeed a spiritless affair.

The following year, Dickens began The Haunted Man. He structured this story around the idea of memory, a theme of all the Christmas books as well as a preoccupation rooted in his own past. ${ }^{56}$ Immersed in Dombey and Son, however, he was unable to complete the work in time for Christmas, 1847. In 1848 Dickens returned to the book. As Slater points out, he reutilized the same narrative ingredients that had made up the Carol, The Chimes, and The Cricket: an explicit Christmas setting, replete with allusions to Christ and God; scenes of ideal family happiness; a powerful embodiment of society's perpetuated wrongs in the Caliban-like boy; and even a beneficent change of heart of the main character, Redlaw, by a supernatural agent. ${ }^{57} \mathrm{He}$ could not recapture the joyous geniality of the earlier Christmas books, however, and The Haunted Man turned out to be a baffling mixture of intensity and eccentricity as it dramatized the point that painful memories are inextricable from good ones. and make men mutually compassionate.

Leech agreed to provide five of its sixteen illustrations. For the sake of friendship, he continued to tolerate strains of collaboration with other illustrators-strains that, after The Battle of Life, had led to the departure of Maclise and Doyle as regular Christmas book illustrators and their replacement by Frank Stone and John Tenniel. In return, Dickens did everything possible to make the principal illustrator of his holiday books feel appreciated, and to relieve the pressures on him. He sent Leech part one of his completed manuscript and thanked him profusely for his good opinion of it. ${ }^{58}$ Although saying he supposed that the artist would want to illustrate 'The Tetterbys' and 'The Boy before the Fire' in part two, he promised that any other subject that interested him would "do" equally well. ${ }^{59}$ When Dickens needed a break from work, he made sure the artist took one too. "All work and no play make Jack (Leech) a dull boy," Dickens prefaced his "propogician" for a day's walk along the Brighton beach; such respite, he hoped, would enable Leech to "smash the haunted man, out of hand."60 Even when haste became mandatory, Dickens lightened Leech's burden. "The time being so very pressing, and you so pressed," the author "(acting, I hope, as you would have me)" requested Stanfield to execute the concluding dinner scene-a serious scene that required more time than Leech had available. ${ }^{61}$ Dickens went on to assure Leech that he trusted there would be plenty of other comic subjects he preferred for him to portray in connection with the Tetterbys.

Such unusual authorial consideration paid off aesthet- 
ically. Leech produced some of his finest work for this cheerless holiday tale; indeed, as Mrs. Leavis has remarked, the illustrations alone must have accounted for its sales. ${ }^{62}$ The very looseness of Leech's lines in his pictures of Johnny coping with baby Moloch at home (II, 422) and abroad (III, 361) reinforces the good humor. Similarly the dark, close strokes with which he portrays Redlaw both with the Phantom (I, 401) and with the wild boy (I, 408) perfectly capture the requisite sense of strangeness, and the way he positions the child before the fireplace (III, 451) not only recalls Redlaw's posture there in Tenniel's frontispiece (380) as well as his own earlier portrayal (I, 401), but visually reinforces Dickens's linkage of the civilized man and the wild boy. ${ }^{63}$ The illustrations here display more clearly than their predecessors Leech's versatility as well as his sensitivity.

Dickens dealt with the problems of memory more directly in his confidential account to Forster in 1847 and more artistically in David Copperfield, his next novel in 1849. The Haunted Man was a necessary if crude fictional exploration. Although the short work enjoyed commercial, if not critical, success, its "Christening dinner," attended by Leech at the beginning of the new year, proved to be the last rites for Dickens's holiday books. ${ }^{64}$ He thereafter often began Christmas stories, but allowed subordinates to finish them; he published them in special seasonal numbers of Household Words and All the Year Round, but never again had one illustrated. Gradually, however, Dickens lost heart for the idealized aspects of Christmas that he, as much as Prince Albert, had perpetuated. Commencing a new series of All the Year Round in 1868, he determined to abolish even the special Christmas number on the grounds that extensive imitation was making it tiresome $(C P, 2,3)$. No longer capable of viewing the holiday season as a festive family celebration, as he had at the time of The Pickwick Papers, Dickens made it an occasion for fear in Great Expectations and for fatality in The Mystery of Edwin Drood.

Dickens's friendship with Leech did not weaken, however, after the conclusion of the Christmas books. On the contrary, it deepened as the two men shared experiences with Punch, as well as in amateur theatricals, and on family holidays. The author readily conceded that it was not Leech's illustrations for his own work but those for Punch that made him so famous, and indeed, the ubiquitous comic magazine, in which most of his work circulated, made Leech one of the best-known artists of his day. Through him, Dickens became friendly with Mark Lemon, the editor of Punch, and many of its staff members, including William Thackeray and Gilbert a Beckett, Seymour's former editor.
Dickens was often invited to the exclusive dinners at which the weekly cartoons were decided; nevertheless, the magazine rejected the only contribution he ever offered it-a criticism of the foul suburban water supply that Punch thought better criticized in pictures. ${ }^{65}$

It is testimony, however, to the familiarity of the populace not only with Dickens's work, but also with its illustrations, that the satirical artists publishing in Punch were so fond of borrowing Dickens's characters for their cartoons. Leech, in particular, adapted for Punch not only his own Dickens illustrations but those of Cruikshank and Browne as well. Henry Brougham, for example, made a fine Oliver "asking for more," the first Dickensian subject to appear in Punch, and a volatile Miss Mowcher during Copperfield's appearance; the exiled Louis Philippe perfectly travestied the condemned Fagin; soon after the publication of The Cricket on the Hearth, Sir Robert Peel figured as "A Political Tilly Slow-boy" holding "Cobden's baby" while Lord John Russell appeared as Johnny Tetterby minding his "Financial Reform" infant; and Mrs. Gamp was one of Leech's pet satiric vehicles. ${ }^{66}$ Indeed Dickens, in his humorous account of the northern tour of his theatrical company, has the midwife call Leech an "owdacious" wretch after hearing him say he had "draw'd her several times-in Punch" (which, she explains, she never touches "because of the lemon!") (CP, I, 743).

Dickens ranked Leech, along with Cruikshank, among the best caricaturists of all time. He agreed with Ruskin, William Rossetti, and Henry James that Leech, in gently satirizing contemporary politics and society, in contrast to the bludgeoning manner of earlier caricaturists, had rendered a great service to English popular art. ${ }^{67}$ In 1848, when Leech published twelve of his Punch cartoons as a series entitled The Rising Generation, Dickens, at Forster's request, readily wrote one of his rare art criticisms for The Examiner (CP, 1, 190-93). He felt the principal illustrator of his Christmas books merited special praise for being the first English comic artist to consider beauty compatible with satire. Indeed, as Steig observes, Leech undoubtedly influenced Dickens in his own movement in Chuzzlewit, Dombey, and Copperfield away from the tradition-exemplified by Rowlandson and Gillray and modified by Cruikshank and Browne-that equated humor and evil with ugliness, and toward more realism and refinement. ${ }^{68}$ The Royal Academy, however, the final arbiter of Victorian taste in art, continued to hold popular black-and-white artists in contempt, and excluded Leech, as well as Cruikshank, from its membership. Inquired Dickens sarcastically: "Will no Member and Associates be found upon its books, one of these days, the labours of whose oils and 
brushes will have sunk into the profoundest obscurity, when the pencil-marks of Mr. Cruikshank and of Mr. Leech will still be fresh in half the houses in the land?" (CP, I. 193).

Leech was among the many members of Punch enlisted by Dickens when he founded his amateur theatrical troupe in 1845. Although the artist sympathized with its charitable objectives, his participation was not wholehearted. He clearly preferred exercising his "bage vice" [bass voice], as Mrs. Gamp called it $(C P, \mathrm{I}, 743)$ in performing melancholy songs like "King Death" for his intimates, to acting before strangers. ${ }^{69}$ Yet when he played Master Matthew in Every Man in His Humour-a part he retained in many performances subsequent to its opening on September 20, 1845-Leech was praised for his fine performance by such knowledgeable theater lovers as William Macready and Robert Browning. ${ }^{70} \mathrm{He}$ tried to share Dickens's enthusiasm for costumes, rehearsals, and profits, and even made a spirited crude sketch of the author during his renowned impersonation of Captain Bobadil. ${ }^{71}$ Nevertheless, by 1848 friends watching him act the role of Slender in The Merry Wives of Windsor perceived "a ring of impatience in his voice, a kind of 'Oh, I wish this was all over!' attitude."72 Finally, although he superbly acted the part of the marquis in the next play on the program, Animal Magnetism, his nonchalance had so disturbed the company during rehearsals that Dickens had insisted he either get his part perfectly or drop out altogether. ${ }^{73}$ Essentially, it seems, Leech continued to participate in the theatricals out of affection for Dickens, rather than for the drama.

Unlike his relationships with Cruikshank, Browne, and Cattermole, Dickens's intimacy with Leech survived the trials of both literary and theatrical collaboration. In fact Leech was universally beloved. Everyone who knew him found the tall, slim, dark-haired artist attractive (fig. 135), his manner an engaging blend of gentility, melancholy, and wit, and his hospitality tasteful and elegant; even the government he so often caricatured assisted his family not only during his lifetime but after his death. ${ }^{74}$ Dickens treasured him as a friend all his life. The two had much in common. As young men, both had witnessed the collapse of their family fortunes and subsequently retrieved them by their own talents, only to be subjected to constant demands on their resources from poor relations, especially their Micawber-like fathers. ${ }^{75}$ Neither forgot his past, though both showed great gusto in enjoying the present. Whether he was walking, inspecting schools, attending the theater and concerts, watching a hanging, traveling in the countryside or on the Continent, or even being sketched by the artist (fig. 136), Dickens found Leech the ideal companion. ${ }^{76}$

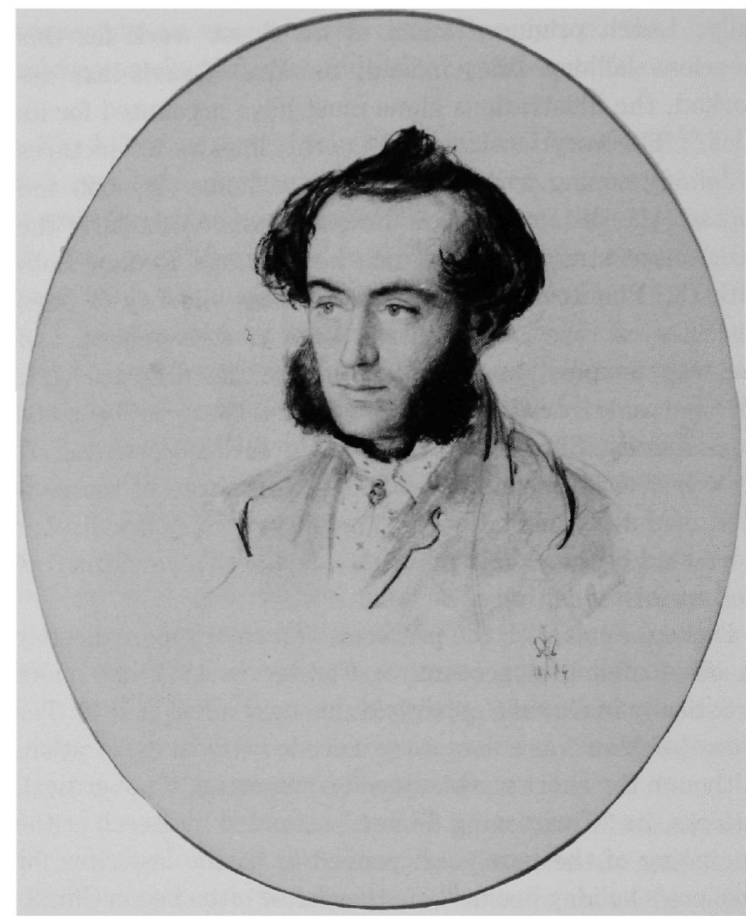

Fig. 135. John Millais, Portrait of John Leech, 1854. Watercolor. $133 \mathrm{~s}^{\prime \prime} \times 10^{\prime \prime}$ oval $(34 \times 25.4 \mathrm{~cm})$. By permission of the Trustees of the National Portrait Gallery, London.

The bonds between the two men were shared by their families. Holidays spent together, however, though their friendship survived, were a definite strain on their nerves even after 1849, when everything seemed to conspire against them. In February of that year, for example, just as the two families settled into their Brighton lodgings, their landlord and his daughter went mad; and that summer on the Isle of Wight (Leech commemorated one of their picnics in $P$ unch), the artist was knocked to the ground by a huge wave and suffered many days of sleepless agony, from which he apparently was rescued by Dickens's use of mesmerism. ${ }^{77}$ Understandably, the two families, despite their continued closeness, spent few subsequent summer holidays in each other's company. Even after Dickens's separation from his wife in 1858, which temporarily strained the author's intercourse with the artist, whom he suspected of latent sympathy with Catherine, ${ }^{78}$ Leech continued to demonstrate his fondness for the author's children. Although there were no more Christmas parties at which the artist danced the polka with Dickens's oldest daughters, 


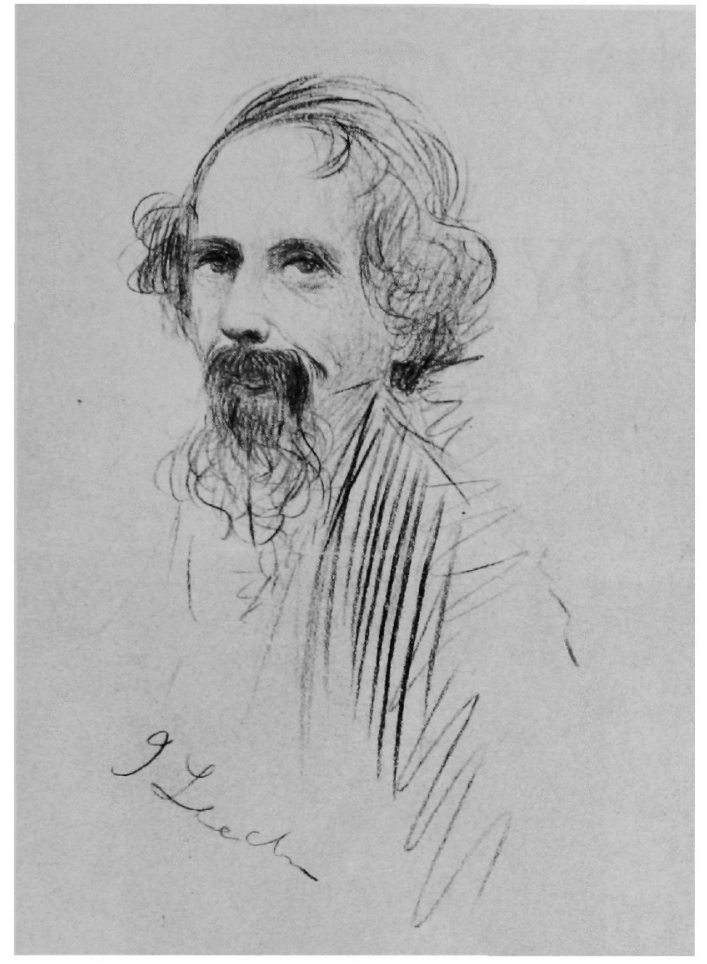

Fig. 136. John Leech, Sketch Portrait of Dickens, ca. 1856. Pencil. $67^{\prime \prime} \times 88^{\prime \prime} \times(17.5 \times 22 \mathrm{~cm})$ [sheet]. From the Gimbel Collection, by permission of the Beinecke Rare Book and Manuscript Library, Yale University. he did maintain his practice of taking Sydney, a sailor, to dinner and the theater whenever his ship was in port. ${ }^{79}$

After 1859, Dickens did not see his old friend as often. "While my readings are in hand concurrently with a Story," he explained to the artist, "I can scarcely make sure of any holiday," but afterwards "then-as we say-Yoiks!" 80 Furthermore, Leech-who, like Browne, contributed to Once a Week, the rival to the author's periodical All the Year Round ${ }^{81}$-was less sociable. Always nervous and frail, he was now suffering from acutely sensitive hearing (as did Anthony Trollope and Marcel Proust), and he was in debt, besides, from too much lending and his own extravagance. His friends urged him to visit America, but he felt unable to leave London on account of his work for Punch - though by this time John Tenniel actually was doing most of it. ${ }^{82}$ His friends then tried to make his London life more bearable by urging Parliamentary legislation against street noises, which were indeed reaching intolerable proportions; and Dickens, himself driven from Broadstairs by the din of street musicians, assigned his son-in-law Charles Collins a piece on the subject for All the Year Round that pleased Leech. ${ }^{83}$ By the spring of 1864 , Dickens thought Leech's health much improved. Nevertheless, on November 4 of that year, he joined Cruikshank, Browne, and young Marcus Stone, among others invited to the funeral he had helped Mrs. Leech to arrange. ${ }^{84}$ "This death of poor Leech has put me out woefully," he wrote Forster, explaining his temporary inability to work on Our Mutual Friend..$^{85}$ For, indeed, he shared wholeheartedly the sentiment of their mutual friend Thackeray: "Leech is the sort of man who appears once in a century." 


\section{Chapter 8}

\section{RICHARD DOYLE}

Except for John Leech, Richard Doyle provided the largest number of illustrations for Dickens's Christmas books; and like that of his Punch superior, Doyle's work, more fanciful than witty, as William Rossetti observed, also demonstrated that graphic humor could be conveyed without coarseness. ${ }^{1}$ In contrast to Leech and many of the other artists who worked on the holiday books, however, Doyle was not an intimate of the author. The artist, who was small, reclusive, genteel, even quaint (fig. 137), had been trained informally by his father, the noted political caricaturist (whose early pseudonym, H.B., often caused his works to be attributed to Hablot Browne). ${ }^{2}$ Nicknamed "The Professor of Medieval Design," Doyle, a Catholic, would have been as uncomfortable in the irreverent Dickens circle as he apparently was among the rowdy staff of Punch. ${ }^{3}$

It was his noted facility with fairies, elves, and other fantasy figures-and perhaps some urging by Leech-that prompted Bradbury and Evans, who published Punch as well as Dickens's work, to solicit Doyle's help in 1844 in illustrating The Chimes. Doyle supplied the illustration that appeared on the opening page of each quarter of The Chimes. By their position and by their inclusion of imaginary with realistic beings, Doyle's designs stressed visually Dickens's blend of fantasy and reality. The artist also took pains to accommodate his conceptions to those of his fellow Chimes illustrators-Leech, Stanfield, and particularly Maclise. His first assignment was to introduce Trotty Veck and his daughter sitting on the church steps (I, 84) (fig. 138). He initially portrayed the "weak, small, spare, old" hero of the narrative as a "very Hercules" in appearance, as well as in intention ( $I, 84)$; but after noting Leech's more accurate pictures of the workman (I, 89, 100), he modified his own characterization accordingly (II, 109; III, 134). In this first illustration, the Vecks sit beneath the soaring tower of St. Dunstan's, which Stanfield was to include later in 'The Old

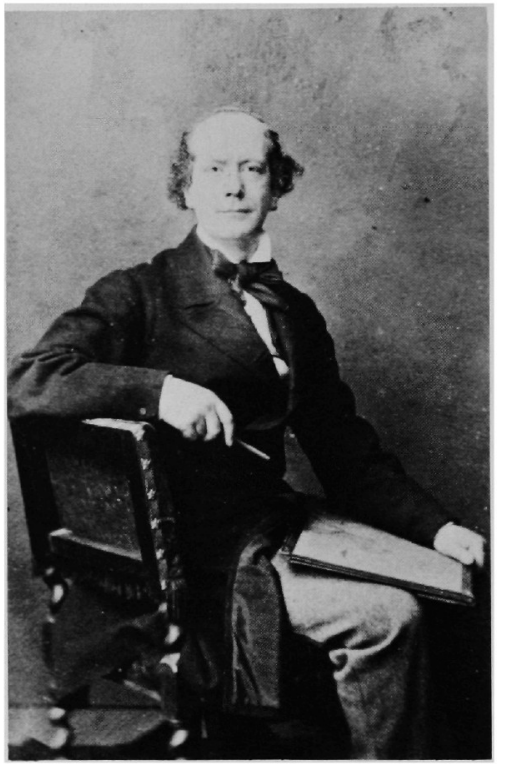

Fig. 137. John and Charles Watkins, Photograph of Richard Doyle. Album of Photographs, p. 40, no. 159, National Portrait Gallery, London. Sepia photograph. 35/16" $\times 2 \frac{1}{4} 4^{\prime \prime}(8.5$ $\times 5.7 \mathrm{~cm})$. By permission of the Trustees of the National Portrait Gallery, London.

Church' (II, 129) (see fig. 166). ${ }^{4}$ The tower, an especially suitable subject for Doyle and Stanfield, both pious men, was merely outlined by Doyle as if to provide Stanfield with direction yet freedom for his later portrayal. In keeping with Maclise's geometric use of line and shapes in the frontispiece (82) (see fig. 155) and title page (83) that preceded this picture, Doyle framed the vertical tower within the upper curve of a reversed $S$, which, in turn, is 


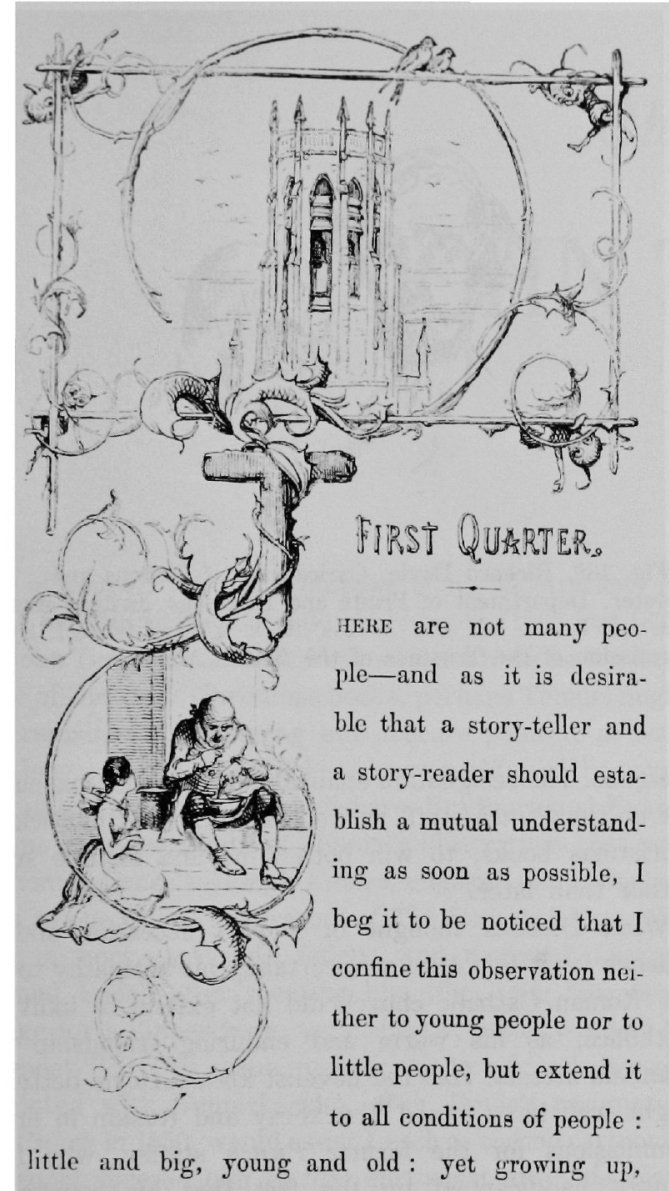

Fig. 138. Richard Doyle, 'The Dinner on the Steps.' The Chimes (London, 1844), p. 1 . Wood engraving. $4^{13 / 16^{\prime \prime}} \times 2^{13 / 16^{\prime \prime}}$ $(12.2 \times 7.2 \mathrm{~cm})$. From the Harry Elkins Widener Collection, by permission of the Houghton Library, Harvard University.

partly framed by a rectangle. Doyle's more delicate lines, open spaces, holly leaves, and merrier elves added elements of airiness, freshness, and humor lacking in Maclise's more formal, crowded designs.

Yet throughout his illustrations, Doyle kept in mind Maclise's frontispiece, with its clouds of elfin creatures emerging from bells. In the upper portions of his three remaining illustrations, he wrought variations on this theme, thereby supplying continuity to his various designs as well as consistent supernatural relief to the three scenes of despair he was asked to depict: the Vecks with the beleaguered Will Fern and his motherless daughter (II, 109); Trotty overwhelmed by his visions among the bells
(III, 134); ${ }^{5}$ and Margaret with her child at the river's edge (IV, 158). The contrast between the lightly sketched elves higher up on the plate and the firmly demarcated humans below visually established the separate realms of fantasy and reality between which The Chimes moved. For one of these pictures, Dickens rejected a preliminary sketch, which he said was "so unlike his ideas" that Doyle did it "afresh." All of the published illustrations seem so fitting, however, that even with the benefit of hindsight it is impossible to determine which one the author initially deemed unsuitable.

Dickens must have been satisfied with Doyle's contributions to The Chimes, for he had Bradbury and Evans invite him to help illustrate The Cricket on the Hearth the following year. ${ }^{7}$ Doyle agreed to provide three illustrations for this genial Christmas book, one for the beginning of each segment or "Chirp." Doyle separated the two subjects of the illustration heading "Chirp the First" by time, place, and a quaint initial letter, but gave them continuity by including a sprinkle of elves and the Peerybingle dog in each one (I, 184) (see fig. 161). The dog, seen preceding the Carrier's cart in the top picture, and snoozing by his feet before the hearth next to a parcel marked with Dickens's initials in the bottom one, proves to be Boxer, with whom Stanfield (I, 190) (see fig. 166), Leech (I, 194; III, 276) (see fig. 163), and particularly Landseer (II, 230) (see fig. 162) subsequently took great pains. Assigned the task of introducing three of the major characters-the Peerybingles and their pet -Doyle generalized them enough to permit his colleagues to add individualistic details if they wished.

In addition to his customary thoughtfulness, Doyle also displayed great aesthetic versatility. In the illustration heading "Chirp the Second" (II, 215), playful toys function as effectively as his habitual elves would have to suggest the unreal world Caleb is trying so hard to create for his blind daughter, thus making part of Leech's task easier when he came to infuse the same setting with added pathos later (II, 219). Doyle's ability to convey gloom as well as gaiety is here indicated by his scene for "Chirp the Third," in which John Peerybingle sits overwhelmed with suspicions of his wife's infidelity and oblivious to the comforting spirits around him (III, 247).

Doyle also supplied the illustrations that headed the three parts of The Battle of Life in 1846. His good nature enabled Forster to calm the egocentric Maclise during Dickens's continued absence abroad. Doyle, a mere caricaturist as far as Maclise was concerned, had already begun his first subject-the Jeddler sisters dancing around the apple tree-while the touchy Royal Academician was still trying to decide first, whether to illustrate The Battle at all, and then, whether to do his customary frontispiece. When he 
finally made up his mind to proceed, Maclise insisted that he must have the subject of the two dancing sisters for his frontispiece; consequently, Forster "shut up" Doyle's sketch for this subject. ${ }^{8}$ Doyle did not protest, though Maclise neither apologized nor thanked him. In the course of doing his three illustrations for The Battle of Life, Doyle got to try his hand at both sisters, and indeed he individualized their coloring and expression far more successfully than Maclise. Sensitive to the text, Doyle must have realized that his beloved imaginary elements would be out of place here; he allowed himself no fairy creatures and only one holly spray to ornament his scenes for Dickens's least festive Christmas book. Instead, the upper portion of Doyle's illustrations -portraying past battlefields (I, 284), abandoned corpses (II, 314), and a wagon hearse (III, 351)-force a harsh perspective on the immediate actions below. These powerful designs, however, were his last for any of Dickens's work. Perhaps he was not asked to contribute to the final holiday book in 1848; if he was, he may have been too busy, or possibly he was offended by the author's failure to express appreciation for his past work.

Dickens, away from England during most of the periods when Doyle was illustrating his Christmas books, communicated with him mainly through Forster (fig. 139) or the publishers. Even had Dickens been inclined to further his acquaintance with the artist upon his return in 1847, circumstances would have conspired against him. While the novelist was wrestling with his own emotional ghosts, prior to his work on The Haunted Man and David Copperfield, Doyle was confronting spiritual ones. His Irish Catholic heritage had long made him uneasy among his irreverent Anglican colleagues on Punch. When, in 1850, England finally legalized the existence of a Roman Catholic hierarchy within its boundaries, Punch came out vehemently against the Roman church despite Doyle's protests. The sight of one of his cartoons printed opposite the magazine's editorial, which seriously advocated trying English cardinals for treason, proved the last straw. ${ }^{9}$ Within a fortnight, Doyle

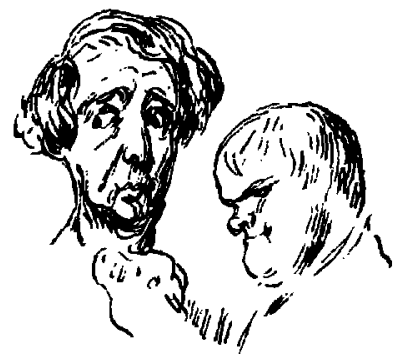

Fig. 139. Richard Doyle, Caricatures of Dickens and Forster. Department of Prints and Drawings, British Museum. Pen and brown ink. $23 / \mathrm{s}^{\prime \prime} \times 2 \% \mathrm{~s}^{\prime \prime}(6 \times 6.7 \mathrm{~cm})$ [sheet]. By permission of the Trustees of the British Museum.

resigned. His resignation enabled John Tenniel, his successor on the Punch staff, as well as on the last of Dickens's Christmas books, to win both fame and fortune sooner rather than later.

What Dickens thought of Doyle's secession and the reasons for it is not known; certainly his antipathy toward the Roman Catholic church did not extend to individual Catholics, as his warm and enduring friendship with Stanfield attests. Had the novelist known Doyle better, he might well have joined Thackeray and Ruskin in finding commissions for the former Punch staffer, who found himself handicapped by the fact that his countrymen persisted in remembering him more as a papist than as an artist. ${ }^{10}$ Ultimately, in the course of his long career, Doyle specialized in marine painting, a genre long dominated by Stanfield, his coreligionist since 1846. Here Doyle could maintain his sense of moral integrity without the slightest risk of offending anyone. 


\section{Chapter 9}

\section{JOHN TENNIEL}

It is, of course, primarily because of his illustrations for Punch and for Lewis Carroll's Alice books (1865 and 1871) that John Tenniel is famous. Yet had it not been for his work on one of Dickens's Christmas books, perhaps Tenniel might have remained a promising but obscure painter, at least much longer than he did. Dickens knew nothing of the young artist until 1848 when his publishers, Bradbury and Evans, perhaps on the strength of Tenniel's illustrations that year for Thomas James's Aesop's Fables, engaged him to replace Doyle as one of the illustrators of The Haunted Man. "He seems a very agreeable fellow, and modest," Dickens informed Leech after meeting him (fig. 140); "we must arrange for a dinner here, very shortly, when you and he may meet."1 In this casual manner the two friends became acquainted with Tenniel, who, after Doyle's resignation from Punch in 1850, would assist Leech as second cartoonist and would succeed him as first cartoonist after his death in 1864.

Tenniel concurred only half-heartedly in the auspicious train of events that followed his commission for Dickens. He regarded his graphic work merely as a vulgar means of support for his more serious efforts to paint. ${ }^{2}$ The partly self-taught artist, like Cruikshank, Browne, and Leech, drew from memory rather than models; nevertheless, he exhibited his first painting at the Royal Academy at the age of sixteen, and nine years later, in 1845, was among those selected by Prince Albert's Royal Commission to supply frescoes for the new House of Parliament." "Had Tenniel been rightly trained," Ruskin was to say of him, "there might have been the making of a Holbein or nearly a Holbein in him." After he reluctantly joined Punch, Tenniel continued to paint in oils and watercolors until the steadier magazine work inevitably preempted his time, energy, and higher aspirations. Far from bearing Dickens any ill will for his inadvertent influence on the course of his career, Tenniel did as much as anyone to keep the author's name before the public during and after his lifetime by his frequent use of Dickens's characters in his cartoons.

Tenniel contributed six wood engravings to The Haunted Man, Dickens's last and most profusely illustrated Christmas book. He took over the assignments that Maclise and Doyle had executed for the three earlier holiday books in providing the frontispiece and title page as well as the first illustration in each of the three main chapters of the story. Thus the young artist bore the entire responsibility for visually setting and maintaining the atmosphere and tone of the disquieting tale about the inextricable pleasures and pains of memory. There was no written communication between Dickens and Tenniel, only the one dinner engagement during which the author threw out "certain hints as to treatment" but "nothing more." Whether he acted on the novelist's hints or his own initiative, taken together, Tenniel's illustrations form a self-sustaining dramatic sequence.

In his use of light and shadow as well as in the mix of angelic and sinister figures in the circular black-and-white border of the yellow-tinted frontispiece (380) and within the centered circle of the title page (381), Tenniel implanted Dickens's theme that good is separate yet inextricable from evil. Throughout his illustrations for The Haunted Man he made light and shadow work symbolically as well as aesthetically. In the opening chapter, "The Gift Bestowed," the monstrous shadows cast on the wall behind the happy, fire-illuminated Tetterbys add an ominous prefatory note that is only partly relieved by the humorous Doyle-like figures in the upper portion of the scene (I, 382). In the double illustrations introducing "The Gift Diffused," the children shrink from the dark figure of Redlaw, who himself is frighteningly dwarfed by his own shadow, a long symbol 


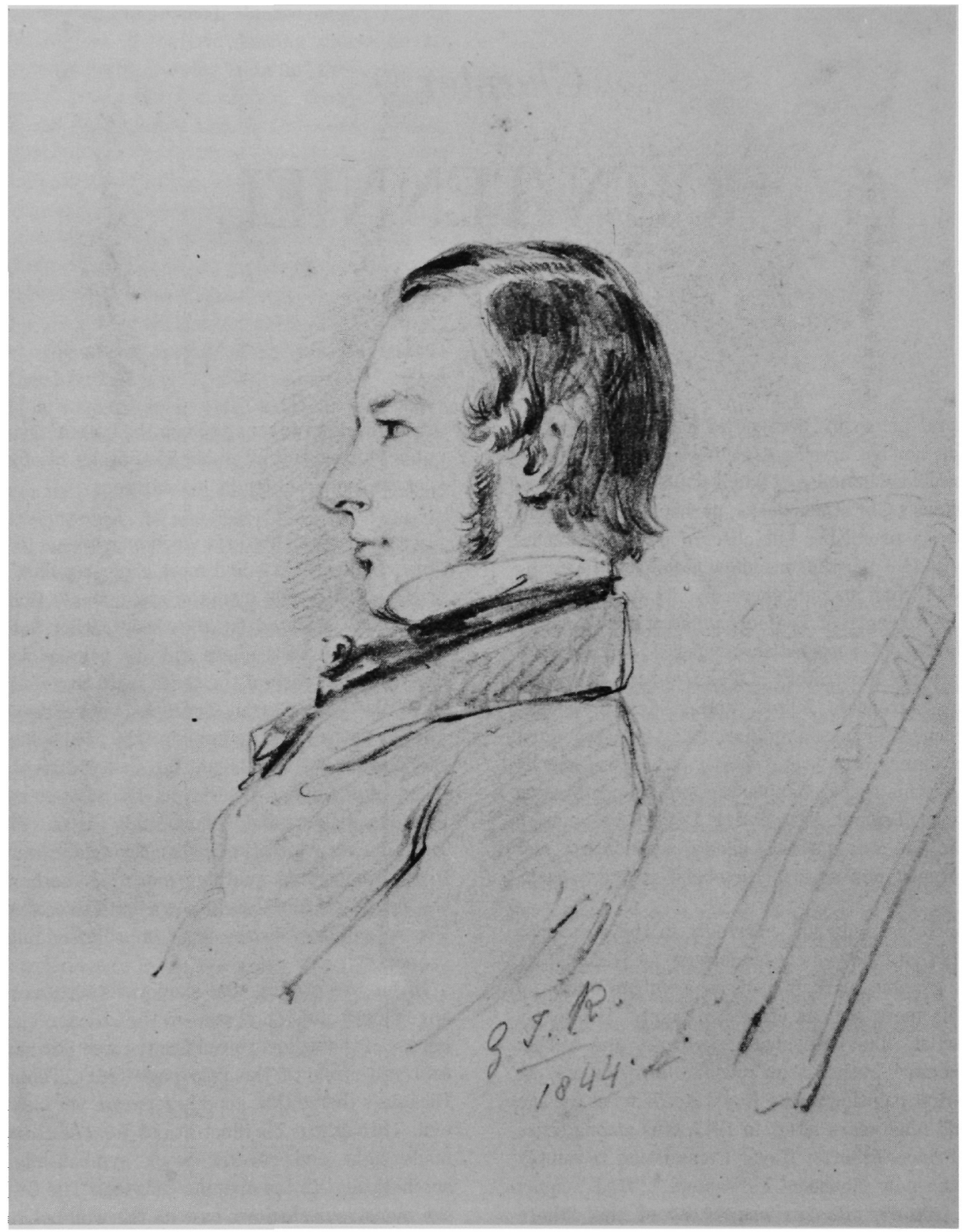

Fig. 140. G.I.R., Sketch Portrait of John Tenniel, 1844. Pencil. $6^{\prime \prime} \times 5^{\prime \prime}(15.3 \times 12.7 \mathrm{~cm})$. By permission of the Trustees of the National Portrait Gallery, London. 
of the troubled past he wishes not to recall (II, 412-13). The illustration heralding "The Gift Reversed" promises relief: the shadow of night recedes before the angels of dawn over the horizon beyond the lighthouse (III, 455). Scenes like this one, with its portentous yet graceful figures, may have prompted Ruskin's remark that "Tenniel has much of the largeness and symbolic mystery of imagination which belongs to the great leaders of classical art." ${ }^{1}$ Illustrating Dickens and Punch, however, gave the artist little scope for his grander tendencies, and cramped both by scale and by subject, they often appeared to observers like William Rossetti as mere coldness and formality. ${ }^{7}$ Tenniel himself termed his designs for The Haunted Man "poor little contributions," $"$ and, as it turned out, they were the beginning and end of his artistic collaboration with Dickens,

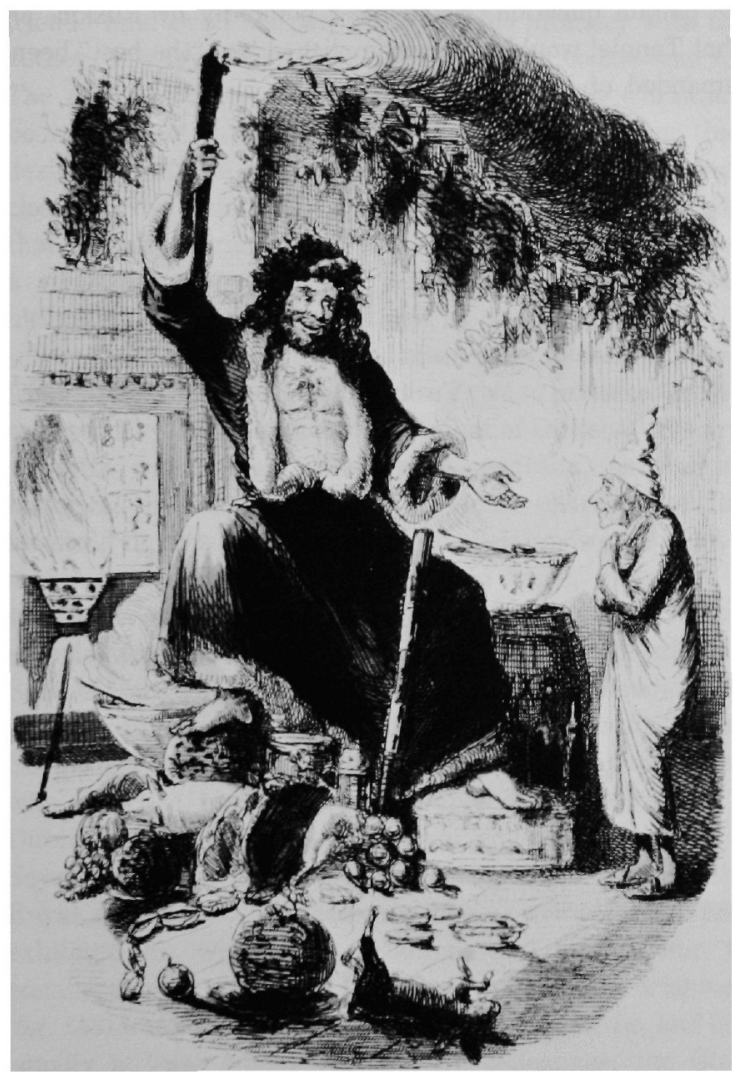

Fig. 141. John Leech, 'Scrooge's third Visitor.' A Christmas Carol (London, 1843), facing p. 78. Tinted etching. $4^{11 / 16^{\prime \prime}}$ $\times 3 \frac{1}{4} 4^{\prime \prime}(11.9 \times 8.3 \mathrm{~cm})$. From the Harry Elkins Widener Collection, by permission of the Houghton Library, Harvard University. for The Haunted Man proved to be the author's last Christmas book.

Through Punch, however, Tenniel's association with Dickens continued both directly and indirectly. Recommended by Punch editors Lemon and Jerrold for Dickens's amateur theatricals, Tenniel participated in the benefit performances of The Rent Day and The Poor Gentleman in 1850. Though cast in a subordinate role in Not So Bad as We Seem in its debut before Queen Victoria and Prince Albert in 1851 , he was promoted to the leading role when the company toured the provinces. "You have no idea how good" Tenniel was, Dickens informed the absent Forster after the final performance of Bulwer's play. ${ }^{9}$ Tenniel's distinctive bass voice was last used in the troupe's behalf in 1852 in Used Up. Meanwhile, the dignified, courteous artist-the personifica-

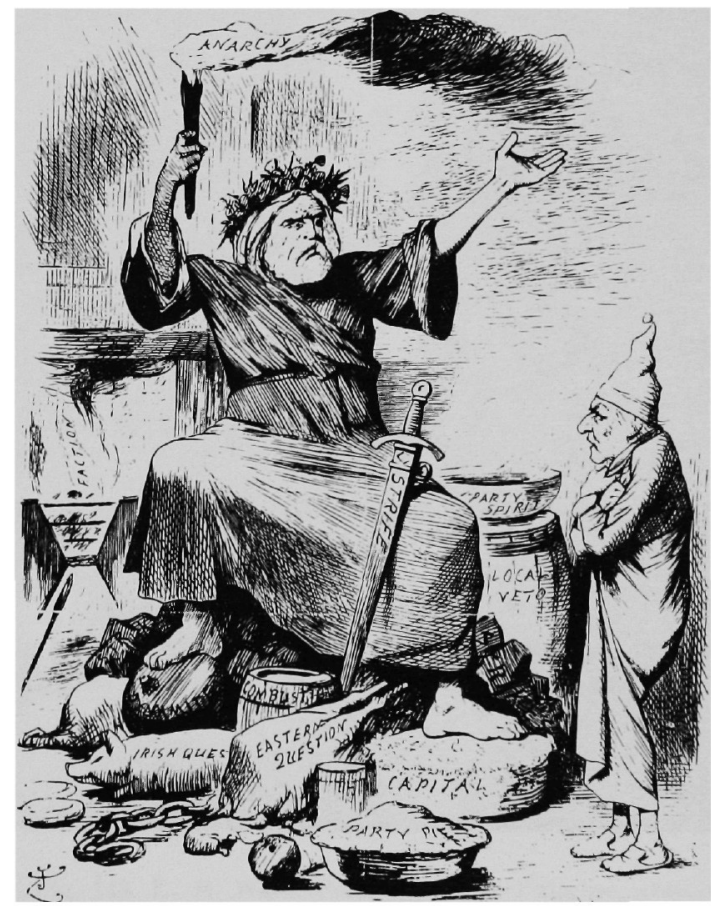

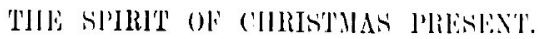

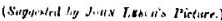

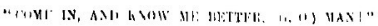

Fig. 142. John Tenniel, 'The Spirit of Christmas Present.' Punch, 105 (December 30, 1893), 307. Wood engraving. 93/4" $\times 71 / 8^{\prime \prime}(24.8 \times 18.1 \mathrm{~cm})$ [cartoon]. From the Harvard College Library, Harvard University. 
tion of an English gentleman despite his French origins and his blindness in one eye-had ingratiated himself not only with Dickens, but with his family as well, with whom he often dined at Devonshire Terrace after taking young Charley rowing on the Thames..$^{10}$

After the death of Leech in 1864 , Tenniel took charge of the political cartoons for Punch. If he diminished the element of caricature and even humor with his bold draftsmanship and large allegorical figures, he introduced nonpartisan elements of morality and respectability, as Ruskin noted, into an arena that had been openly licentious since the time of Rowlandson and Gillray. ${ }^{11}$ Tenniel extended Leech's use of Dickens's characters. In his hands, London officials became perfect Bumbles; Disraeli made a memorable Fagin; and various topical figures were cast as Sikes, Mrs. Nickleby, Smike, Mrs. Gamp, and even Mark Tapley. ${ }^{12}$ Gladstone especially served as a prime satirical target for Tenniel just as Peel and Russell had for Leech. For over three decades, Gladstone, an attentive, if not always admiring, reader of Dickens, had to submit to being caricatured as little Nell's weak grandfather, Micawber certain of "something turning up," a political Mrs. Gummidge lamenting her misfortunes with Russia and Egypt, Betsey Prig, Sairey Gamp, and, most memorably, ScroogeSadstone observing the chaotic spirit of Christmas Present (fig. 142) in grim contrast to Leech's subject fifty years earlier (III, 38) (fig. 141). ${ }^{13}$ Far from resenting this questionable attention, Gladstone, always cordial to the artist, was easily persuaded in 1893 to recommend him for a knighthood. ${ }^{14}$ Tenniel-the first humorous artist working in black-and-white ever honored in this way-was inclined to refuse it. He finally accepted it, but at the celebration utterly forgot his speech. The award doubtless recalled his early unrealized aspirations to be a painter and his lasting ambivalence about being "only" a cartoonist, for it revived the painful question, asked most pointedly by Ruskin, of what Tenniel would have accomplished had "the best" been demanded of his talent. ${ }^{15}$ 


\section{Chapter 10}

\section{DANIEL MACLISE}

Daniel Maclise's many pictures of Dickens, his family, his friends (and even his pet) testify to his intimacy with the author. His few illustrations for Dickens's books-one for The Old Curiosity Shop and several for the Christmas books, all motivated by a sense of obligation rather than desire-testify to the problems of collaboration between close friends. Indeed, the very qualities of artistic intensity that initially attracted the two men to each other proved a strain not only on their professional relationship but ultimately on their personal one as well.

The artist and the author had much in common. Both came from humble social origins. Maclise's rise to prominence was as legendary, if not as meteoric, as that of Dickens. ${ }^{1}$ His art, with its wide range of subjects - portraits, as well as historical, literary, and fantasy scenes-characterized by idealized figures (not drawn from models), powerful draftsmanship, minute detail, and polished finish, impressed a succession of influential viewers beginning with his Cork schoolmates. A friend of Dickens (and the Seymours), Samuel Carter Hall, persuaded him to abandon medicine to pursue painting-the same course as that taken by Leech. Sir Walter Scott predicted a fine future for the young man who sketched his likeness unawares during a visit to a Dublin bookstore. And John Jackson, engraver and friend of Seymour, Buss, and Browne, recommended him to the Royal Academy, which accepted him as a student in 1828, exhibited his work from 1830 on, and elected him to membership in 1835. Like Dickens, the handsome Irishman (fig. 143) was socially as well as artistically versatile, and felt equally at ease among Ainsworth's colleagues, the Gore House circle of the Countess of Blessington and the Count D'Orsay, or the staffers of Fraser's magazine. It is likely that the latter group first brought the two men together and possible that a portrait of the author as a Parliamentary reporter was one of the first fruits of their meeting (fig. 144). ${ }^{2}$

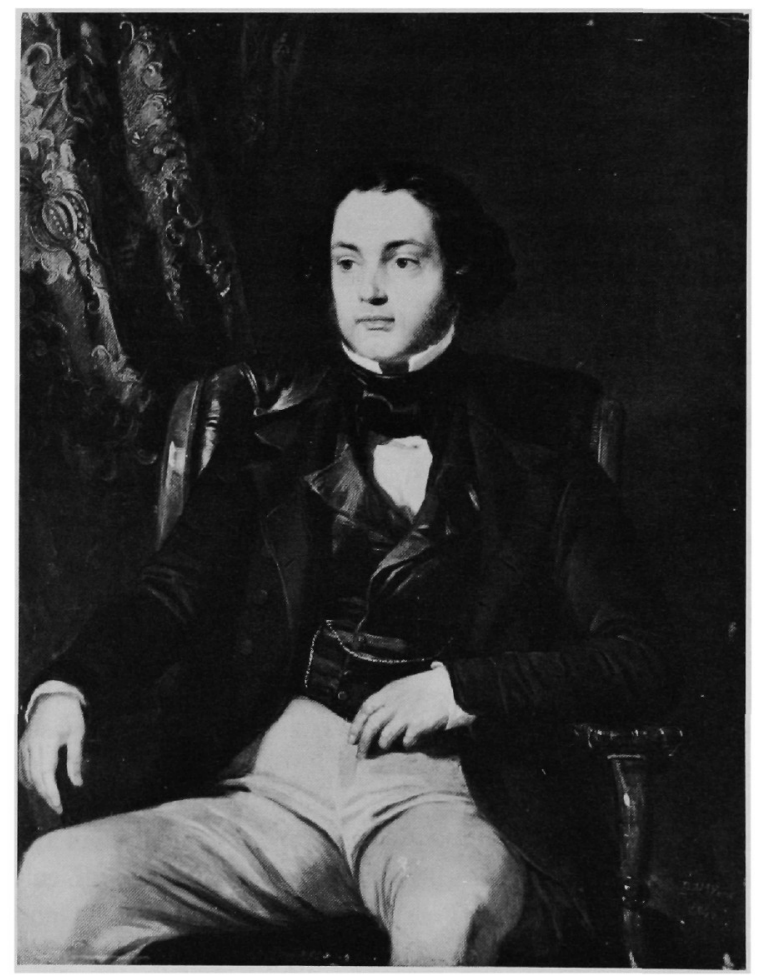

Fig. 143. E. M. Ward, Portrait of Daniel Maclise, 1846. Oil on panel. $18^{\prime \prime} \times 1378^{\prime \prime}(45.7 \times 35.2 \mathrm{~cm})$. By permission of the Trustees of the National Portrait Gallery, London.

The two men apparently took to one another at once, soon forming with Forster a close "triumvirate," which endured more than a quarter of a century. Indeed, though Carlyle may have felt that Maclise was among those friends of Dickens whose uncritical admiration "did him no good,"'; 


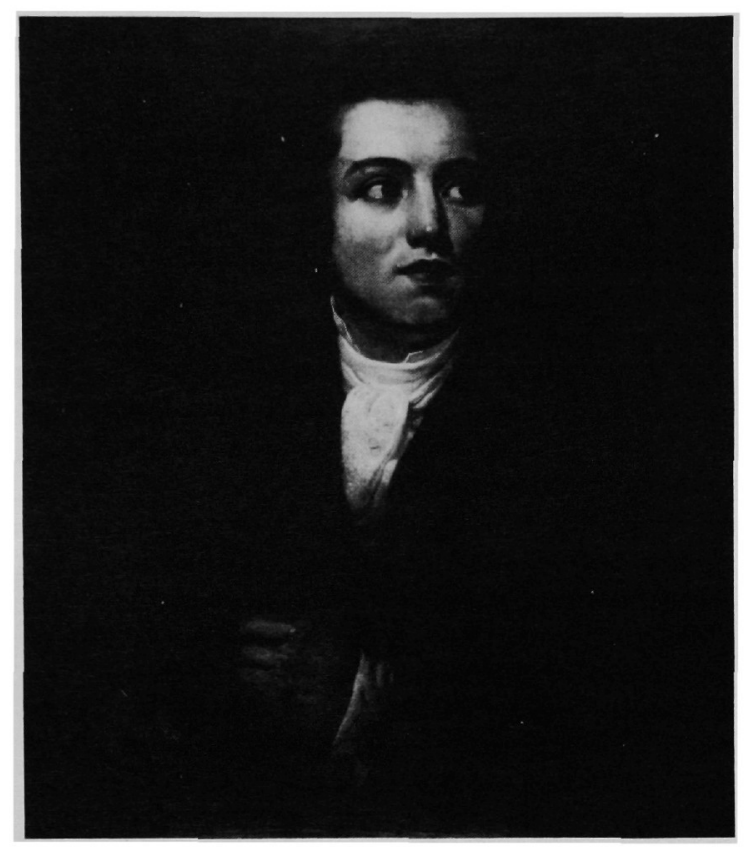

Fig. 144. Attributed to Daniel Maclise, Unpublished Portrait of Dickens as a Parliamentary Reporter, ca. 1837. Oil. 281/2" $\times 241 / 2^{\prime \prime}(72.4 \times 62.2 \mathrm{~cm})$. From the Gimbel Collection, by permission of the Beinecke Rare Book and Manuscript Library, Yale University.

the author, in awe of the artist's talents, was completely captivated by his unselfconscious charm, his ability to live wholly in the present moment-be it one of action or indolence-, his blend of shrewdness and simplicity, and his perceptive humor; Maclise, a fellow member of the Shakespeare Society as well as the Portwiners, did many canvases of literary subjects, and Dickens felt that his sensitivity to literature was such that he could well have been a writer had he wanted to $(R P, 134) .{ }^{4}$ "A greater enjoyment than the fellowship of Maclise at this period would indeed be difficult to imagine," recalled Forster; indeed, by 1840, he and Dickens agreed that "a dinner here without [the artist] seemed an absurdity." Not only dinners but the author's theater parties, charitable banquets and projects, tours for visitors, and excursions in and out of London invariably included the painter. ${ }^{6}$

Furthermore, although there seems to be no truth to the rumors that Maclise, who lived with his unmarried sister Isabella, was ever in love with young Kate Hogarth or engaged to Mary, ${ }^{7}$ the bachelor was closer to Dickens's family than a brother-in-law. The author's household sup- plied the artist with carefree domesticity, and the artist's many flirtations afforded Dickens much vicarious pleasure. ${ }^{8}$ Less inhibited with Maclise than with Forster, the author wrote him unreservedly on subjects ranging from early baldness to parental death.

Just as it was eminently appropriate that Forster should write the first comprehensive biography of Dickens, it was fitting that Maclise should paint the author's best-known portrait. "There are only two styles of portrait painting: the serious and the smirk," as Miss La Creevy explained to Kate Nickleby, "and we always use the serious for professional people" (NN, X, 116). Maclise's portrait of Dickens, commissioned by Chapman and Hall for an engraved frontispiece to Nickleby, was to be serious, unlike his humorous informal characterizations for Fraser's. Yet he had no intention of producing the typical genteel Academy likeness; moreover, Dickens was also determined that his portrait would be different. Exerting the same brand of control over the portrait as he did over the illustrations to his writing, the author "countermanded" at least one "face" before approving the final one ("which all people say is astonishing"). ${ }^{9} \mathrm{By}$ June, 1839, the finished portrait was in the hands of Finden, the noted engraver (and Browne's former employer), while Maclise and his sitter unwound from their task at Petersham. ${ }^{10}$

The sensitive portrait, unveiled at the Nickleby dinner on October 5, dominated not only the setting but also the conversation (fig. 145). Family, friends, rivals, and readers alike admired the portrait. Though, as Richard Ormond has pointed out, the pose of the man of letters seated by a table had been developed and used by Maclise in his Fraser's portraits, and elsewhere, this one managed, by its use of light as well as of line, to suggest the shrewd individual as well as the inspired author. ${ }^{11}$ Clearly, the artist "understood the inward 'Boz' as well as the outward," observed Thackeray, noting the intelligence of the eyes and the capacious forehead, the spirit implicit in the flared nostrils, and the generosity in the smile playing about the full mouth. ${ }^{12}$ George Eliot might have detested the "keepsakey, impossible face which Maclise gave him" when Forster re-engraved it in what she called "all its odious namby-pambyness" for his 1871 biography of Dickens; but most of Dickens's contemporaries found it a true likeness. ${ }^{13}$ Accordingly, in the era before photographs of celebrities, readers readily based their idea of the author's appearance on Maclise's widely reproduced portrait. Chapman and Hall owned the copyright to the canvas, which, perhaps imitating the generosity of Constable to Sir Walter Scott, they gave to Dickens. ${ }^{14}$ 


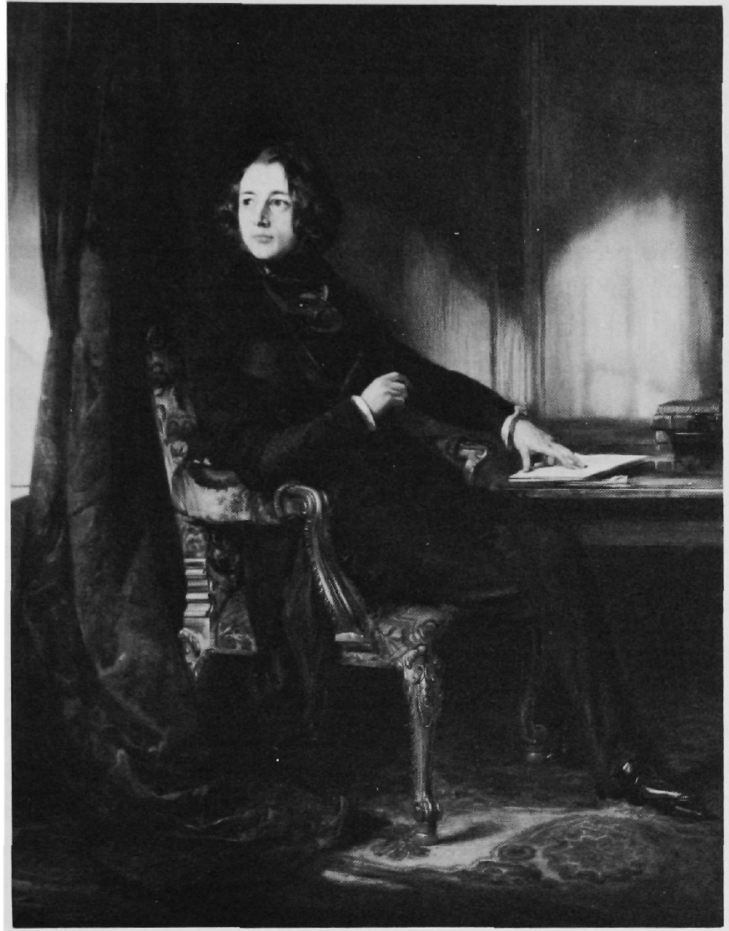

Fig. 145. Daniel Maclise, Portrait of Dickens, 1839. Oil. 36" $\times 281 / 8^{\prime \prime}(91.5 \times 71.4 \mathrm{~cm})$. By permission of the Trustees of the National Portrait Gallery, London.

Throughout the 1840 's, at the height of their intimacy, Maclise more lightheartedly documented the central characters in Dickens's private life. In March, 1841, when Dickens sent Maclise a black-bordered announcement that his pet raven Grip had died, the artist responded with characteristic wit. ${ }^{15} \mathrm{He}$ extended his sympathy both rhetorically and pictorially (fig. 146), speculating that the black raven -"the very prototype of a Byron hero-and even of a Scott,"-had committed suicide but would live forever in his owner's prose. Meanwhile, the bereaved might take comfort from his sketch of the bird's apotheosis, perhaps, as has been suggested, a caricature of Cattermole's tailpiece of little Nell borne to heaven by angels (OCS, LXXII, 593) (see fig. 123). ${ }^{16}$ As the artist had prophesied, Grip was immortalized in the next number of Barnaby Rudge (III, XII, 105) (fig. 147), and a successor was soon welcomed to Devonshire Terrace.

In 1842 Maclise provided a more sober graphic consolation for Dickens and his wife. Anxious about leaving her young children in London while they toured America, Kate

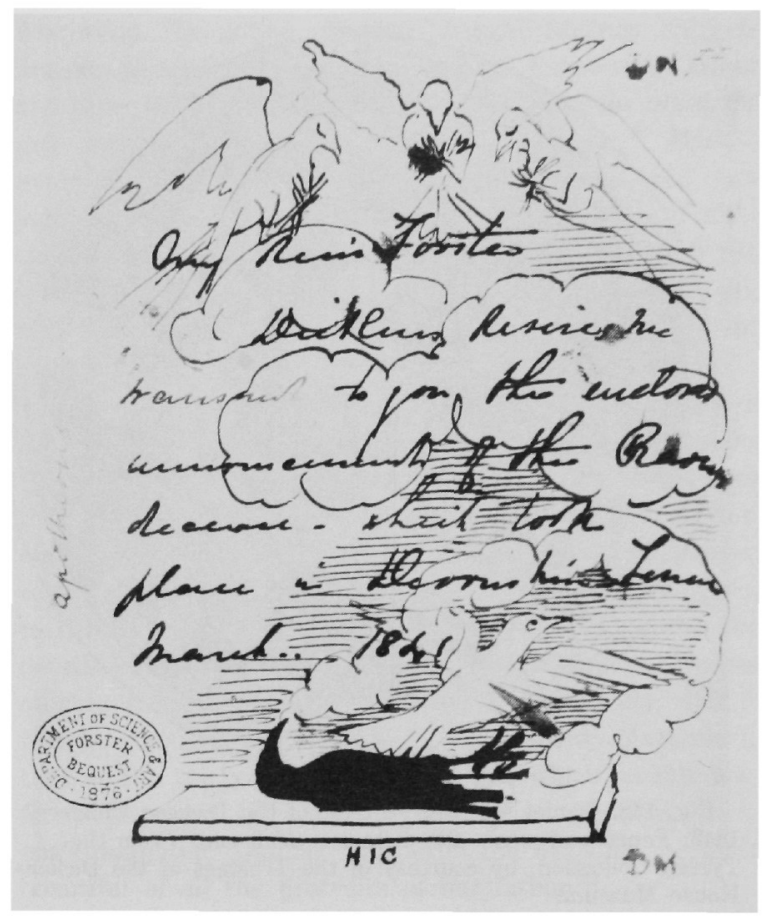

Fig. 146. Daniel Maclise, Sketch of the Apotheosis of Dickens's Raven. Letter to John Forster [March 12, 1841]. Ink. $4^{1 / 2^{\prime \prime}} \times 35 / 8^{\prime \prime}(11.5 \times 9.2 \mathrm{~cm})$ [sheet]. From the Forster Collection (Library), by permission of the Victoria and Albert Museum.

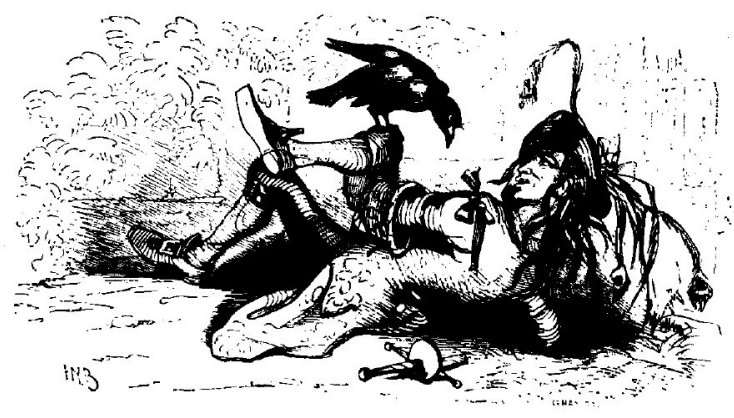

Fig. 147. Hablot Browne, 'Barnaby and the Raven.' Master Humphrey's Clock, no. 52, p. 306. Wood engraving. 21/4" $\times 4716^{\prime \prime}(5.7 \times 11.3 \mathrm{~cm})$. By permission of the Houghton Library, Harvard University.

Dickens asked the artist to make a group portrait of her four little ones. "With all my heart I will do what you wish," answered Maclise, who vowed to include even their unchristened baby, if only with "three dots and a line" (fig. 148); perhaps at this time he also made his sketch of their 


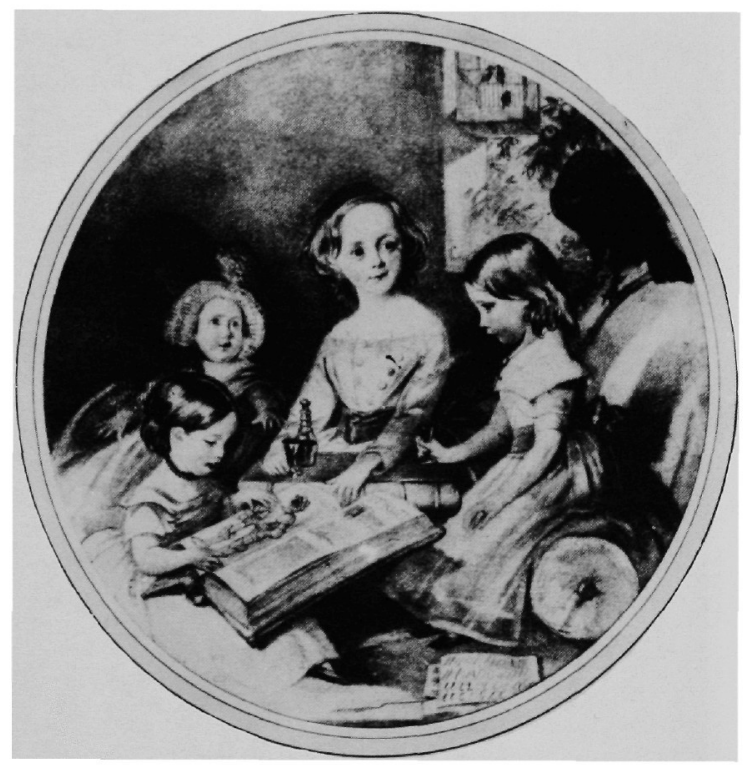

Fig. 148. Daniel Maclise, Portrait of the Dickens Children, 1842. Pencil and wash. $21^{\prime \prime}$ diameter $(53.3 \mathrm{~cm})$. From the Tyrrell Collection, by courtesy of the Trustees of the Dickens House Museum. home at Devonshire Terrace as an additional farewell memento (fig. 149). ${ }^{17}$ Throughout their American journey, according to their secretary, George Putnam, both anxious parents derived comfort from the picture of their children in which Charley and Mamie held wine glasses, while baby Walter stretched his arms behind Katie, who was absorbed in the recent edition of Strutt's Costumes; ${ }^{18}$ even Grip's successor was included, looking indifferently out the window. The charming sketch was greatly admired by their American fans, one of whom asked to have the picture as a souvenir. "Imagine such impudence! and audacity!" cried the outraged mother to Maclise. ${ }^{19}$

Much as Kate must have missed her children, she was less vociferous about it than her husband was about his longing for his close friends. Forster's lengthy accounts of his and Maclise's doings were not enough for him, and he was pained when he did not hear directly from the artist who, never a willing correspondent and presently depressed by his mother's death, may have felt that news from him would be superfluous. "Was it a necessary consequence of being out of your sight that we should be out of your mind, likewise? Oh Mac, Mac!" Dickens wrote in March, after he had been abroad only two months; "I have not yet heard from him," he sourly notified Forster in April; in May, when

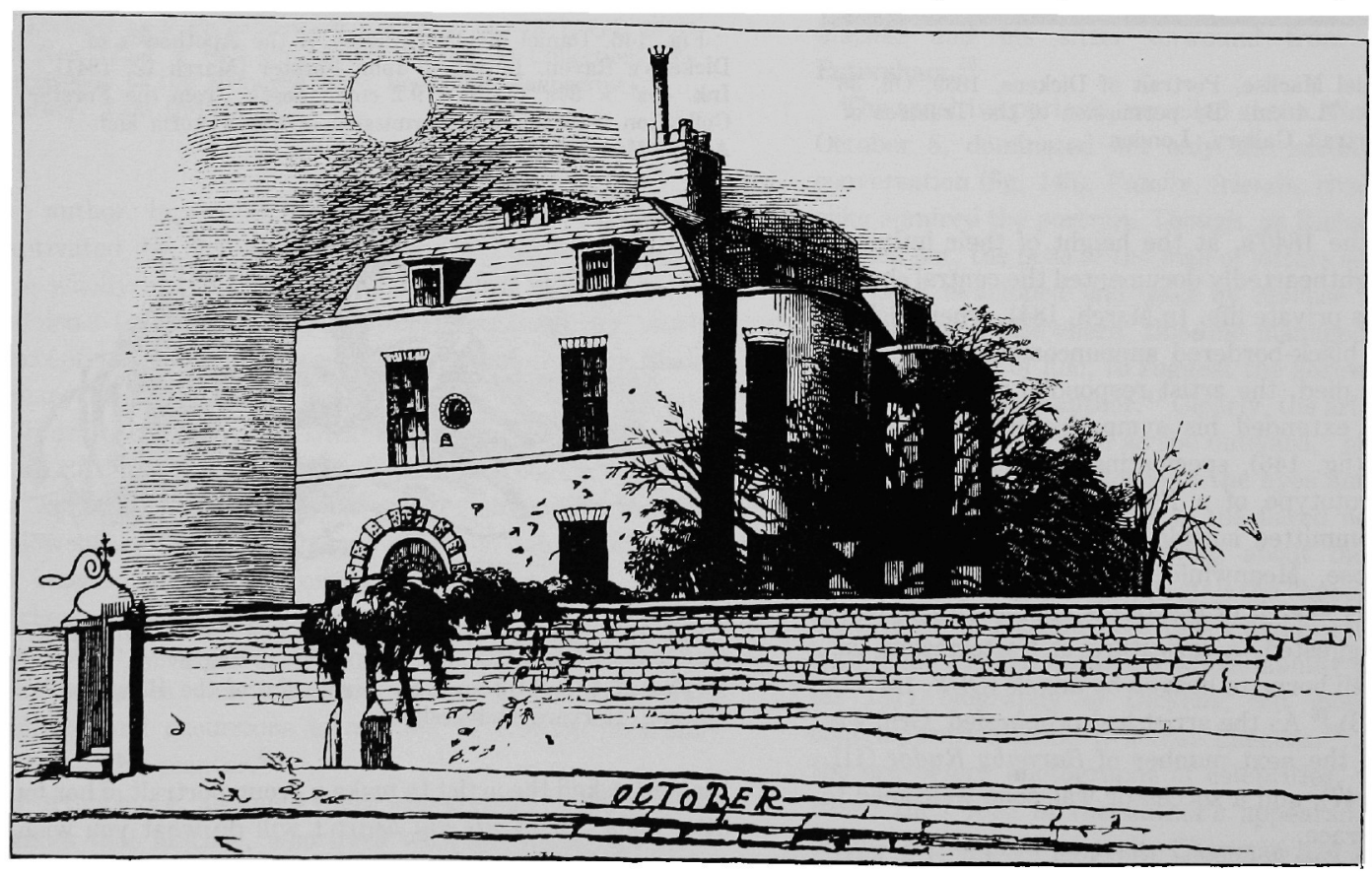

Fig. 149. Daniel Maclise, Sketch of Devonshire Terrace. Photograph of a wood engraving. $4^{\prime \prime} \times 6 \% 16^{\prime \prime}$ $(10.2 \times 16.7 \mathrm{~cm})$. From the Forster Collection (Library), by permission of the Victoria and Albert Museum. 
at last the artist did write, Dickens found his letter "as good as his painting, I swear." ${ }^{20}$ Throughout all his adventures in the New World, Dickens constantly wondered what his intimates were doing in the Old; and whenever he was traveling, be it to Boston or Broadstairs, nothing delighted Dickens more than anticipating his return. ${ }^{21}$ First he wanted Maclise and Forster to come out in the Pilot's boat when he sailed into Liverpool; then disregarding the idea of this prearranged reunion, Dickens decided instead to rush without warning into Forster's study and Maclise's studio a plan that he executed. ${ }^{22}$ Afterwards, he enjoyed an uproarious dinner at Greenwich, where he saw most of his other friends as well. ${ }^{23}$

Though soon hard at work readying American Notes for its October publication, Dickens always found time to divert himself with Maclise, whether viewing the artist's widely discussed scene from Hamlet or entertaining Longfellow. ${ }^{24}$ Then to celebrate the completion of the Notes and partly to challenge the picturesque sights he had seen overseas, Maclise, together with Forster and Stanfield, arranged a scenic journey to Cornwall for Dickens. Forster was put in charge of the luggage; Stanfield the maps; Dickens the finances; and Maclise the entertainments. ${ }^{25}$ In one of the few serious moments on the trip, Maclise was inspired by the magnificence of St. Nighton's waterfall, which he painted upon his return to. London. Into the picture, with its painstakingly detailed background of rushing falls and mysterious dark cave, he introduced a statuesque peasant maiden holding a pitcher while crossing the stream to retrieve her shoes (fig. 150). ${ }^{26} \mathrm{He}$ used as a model Dickens's fifteen-year-old sister-in-law, Georgina Hogarth, who partly filled the place in the author's household left vacant by Mary Hogarth's death.

Dickens was eager to purchase the picture before its exhibition at the Royal Academy in 1843. He knew from his experience with the Nickleby portrait that if his wish were known to Maclise, the artist would simply give it to him or sell it for a sacrificially low price. Therefore, he enlisted Thomas Beard in a "pious fraud" to purchase the painting without the artist's knowledge. ${ }^{27}$ The ruse, that one of Beard's country friends wished to purchase a work by Maclise with only one figure in it, worked. The artist, absent because of illness from the party where the author unveiled the canvas for his friends, was irate when he discovered what had transpired. "How could you think of sending me a cheque for what was to me a matter of gratification?" stormed Maclise, returning the money with regret that it had been sent at all. ${ }^{28} \mathrm{He}$ resented not being permitted to give Dickens some token of the value he attached to their friendship. "Do not be offended," begged Dickens, entreating him to accept the check in payment for so much talent and time; he would be glad to be indebted to the artist for any scrap of his work except this portrait. ${ }^{29}$ Maclise evidently found this arrangement acceptable. His two subsequent portraits of Mrs. Dickens (figs. 151 and 152), the former probably an intended companion in size if not quality to his famous portrait of her husband (see fig. 145), may have been his responses to Dickens's benevolent machinations. ${ }^{30}$

However, Dickens could hardly refuse the next sketch of family members that came from Maclise's pencil. After the Cornwall journey, the author found it difficult to get back into harness for Martin Chuzzlewit. One February afternoon in 1847, despairing at his inability to write, Dickens took his "pair of petticoats," as he called Kate and Georgina, to Richmond for supper. Afterwards, while he related the details of this salutary excursion to his friends, Maclise quickly sketched the trio in graceful profile (fig. 153). ${ }^{31}$ Forster thought all the likenesses excellent, particularly that of the thirty-one-year-old author, which he felt perfectly conveyed his look and bearing at the time; Dickens's daughter, Mamie, considered the drawing the most beautiful of all the protraits of her father. ${ }^{32}$

Events soon conspired to alter and age Dickens's youthful expression in this picture. The disappointing Chuzzlewit sales, the unexpectedly low profits from A Christmas Carol, and the birth of his fifth child precipitated a "triumvirate conference" about Dickens's future. ${ }^{33}$ He rapidly acted on the decision to leave Chapman and Hall as well as England. The novelty of a quiet, economical life in Italy quickly palled on Dickens, who sorely missed accustomed activities and acquaintances. From Albaro, he wrote to Maclise with "something of the lofty spirit of an exile-a banished commoner-a sort of Anglo-Pole," expressing his depression at being separated from his "arms and legs," as he called his two best friends. ${ }^{34} \mathrm{He}$ was more cheerful after moving to the Palazzo Pechiere in Genoa from which he could see the Mediterranean, as blue in the autumn light "as the most pure and vivid prussian blue on Mac's palette when it is newly set. ${ }^{, 35}$ In a happier frame of mind, Dickens started work on a successor to $A$ Christmas Carol. He was gratified to hear that, for the first time since 1841, Maclise had agreed to illustrate his work as well as his life.

Almost nothing had come of the novelist's original hope to have Maclise regularly join Browne and Cattermole in illustrating Master Humphrey's Clock. ${ }^{36}$ Perhaps the busy painter might have contributed more often had the Clock 


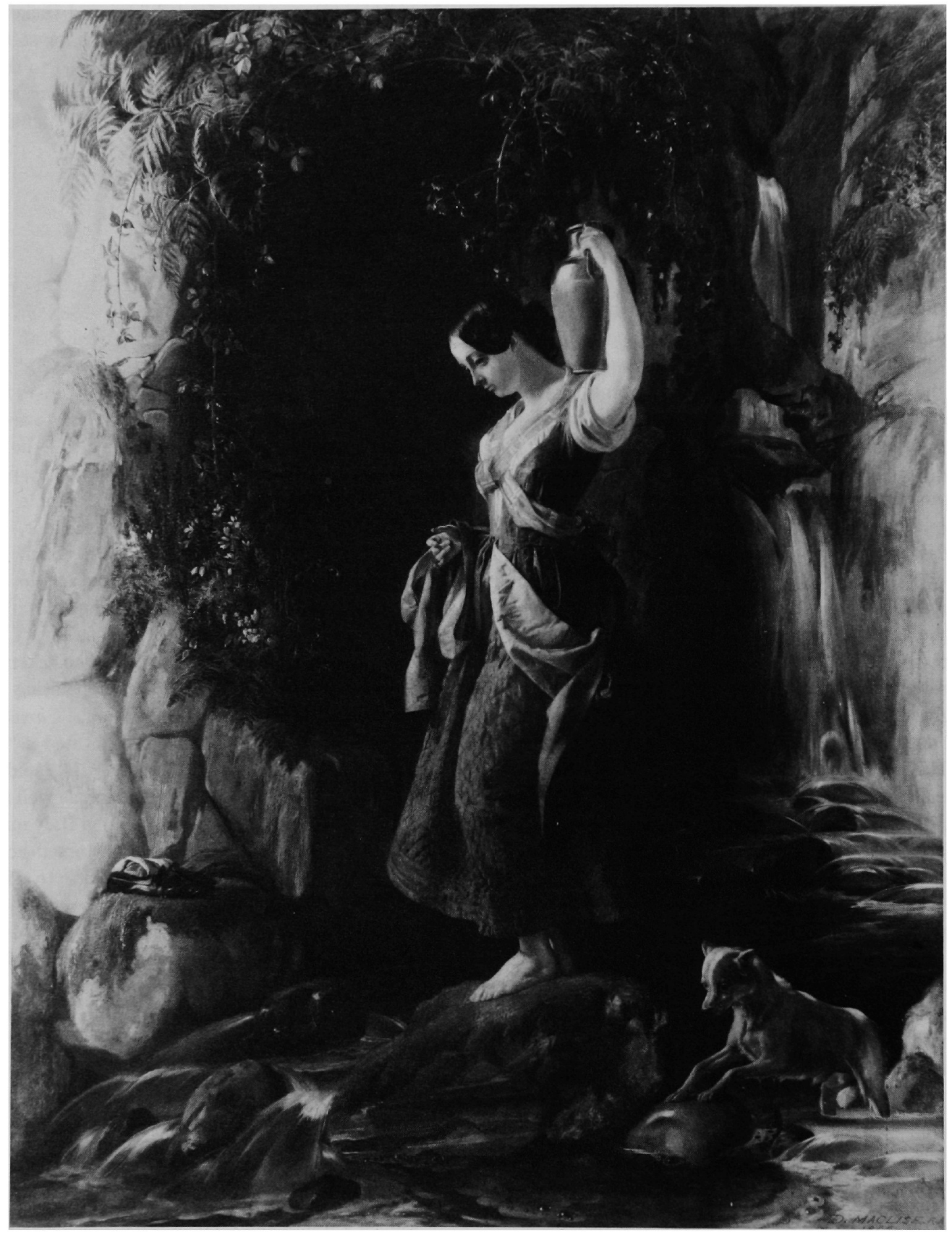

Fig. 150. Daniel Maclise, 'Waterfall at St. Nighton's Keive, near Tintagel,' 1842 . Oil. $351 / 2^{\prime \prime} \times 24^{3 / 4} 4^{\prime \prime}$ $(90.2 \times 62.9 \mathrm{~cm}$ ). From the Forster Collection (Room 104), by permission of the Victoria and Albert Museum. 


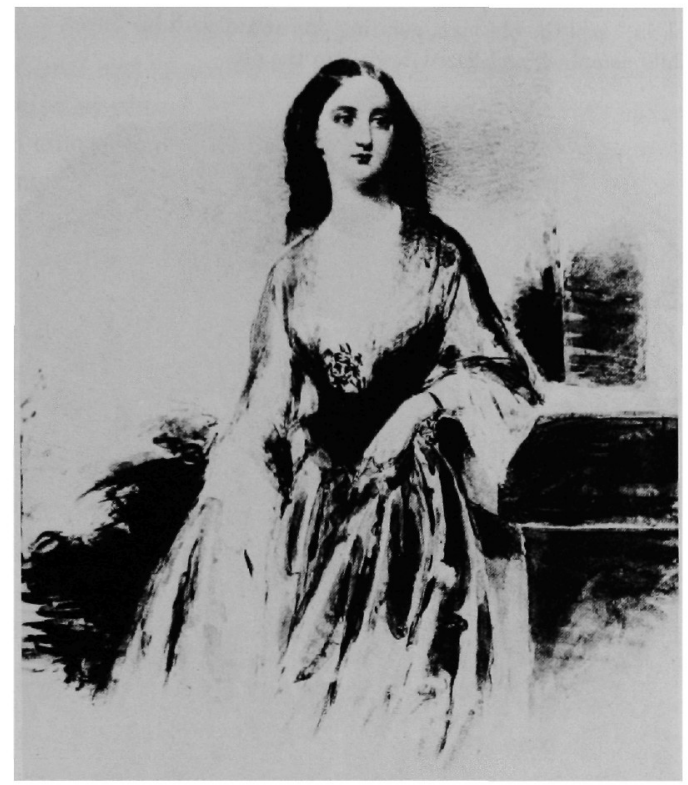

Fig. 151. Daniel Maclise, Portrait of Mrs. Charles Dickens, ca. 1846. Photograph of oil painting. $8 \% 16^{\prime \prime} \times 65 / 8^{\prime \prime}(21.5 \times$ $16.8 \mathrm{~cm}$ ). From the Tyrrell Collection, by courtesy of the Trustees of the Dickens House Museum.

continued as a miscellany. As the story of little Nell advanced, however, the artist must have indicated his willingness to try his hand at it. Dickens advanced the matter with calculated casualness. He promised to read his friend the chapter where Nell arrives at her' last earthly home-a church redolent of life, death, and resurrection -rich in graphic possibilities that, he added, "if you exert your pencil in my behalf at all, perhaps would suit you as well as any other." ${ }^{37}$ The artist evidently did not "mind" depicting the old sexton showing the child the church well underneath the bells; and Dickens not only extended " $a$ million thanks" upon his friend's acquiesence but, for only the second time in dealing with any of his illustrators, explicitly promised to accommodate the text to the illustration, if Maclise wanted to add more figures to his design. ${ }^{38}$ The artist took advantage of the author's unprecedented flexibility-he included the bell pull, but not the bells, and ignored the banal hourglass Dickens suggested, for example-and his friend let him have his way. ${ }^{39}$

Maclise's scene proved worthy of Dickens's solicitous trust; the text and illustration are truly inextricable. "Look in," the sexton tells Nell, pointing downward with his finger

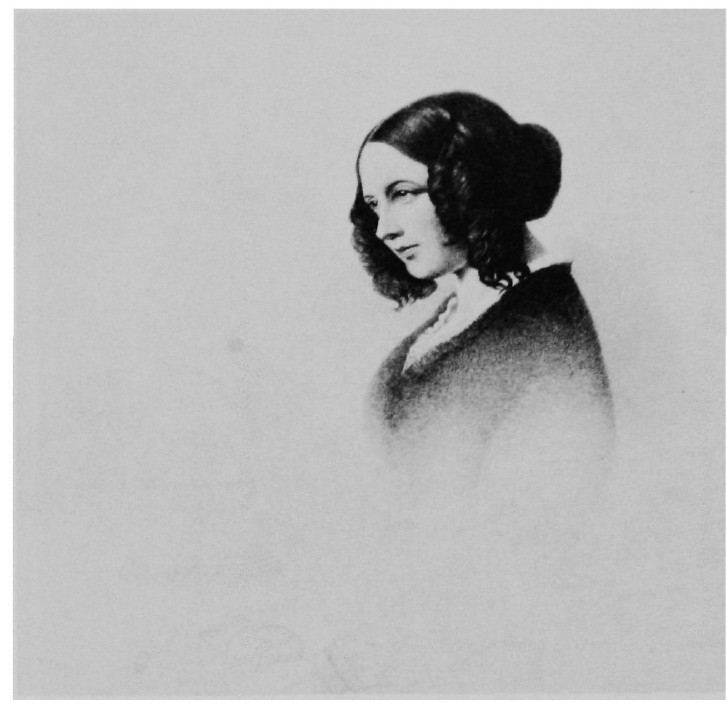

Fig. 152. Daniel Maclise, Portrait of Mrs. Charles Dickens. Engraving of painting. $43 / 4^{\prime \prime} \times 61 / 2^{\prime \prime}(12.1 \times 16.5 \mathrm{~cm})$ [photograph]. From the Tyrrell Collection, by courtesy of the Trustees of the Dickens House Museum.

toward the well (OCS, LV, 441) (fig. 154). The text breaks off, the reader confronts the illustration, and in doing so necessarily duplicates the child's lowering gaze. The downward action of the text and of the reader's head, as Harvey has also noted, is further reinforced by the artist's use of multiple verticals: the well's upper frame, tight rope and handle as well as the sexton's dress-folds, crutch and pointing forefinger. ${ }^{40}$ The sole horizontals - the tomb and sculptured effigy behind the sexton and the oval well opening-thus become more prominent and more ominous. The reader's eye, like Nell's, focuses on the well, finally moving below it only to confront the reinforeing line of text: "It looks like a grave itself" (LV, 441). Maclise's use of light and shadow similarly exploits the symbolic implications of the episode. If the text ambiguously suggests the child's fate, the artist, by making Nell's figure glow with light, and her posture follow the shape of the protective church arches, graphically anticipates that if she must be enveloped in the blackness of death, she ultimately will transcend it. The illustration not only supplies a striking finale to the chapter and number, but gives the text literal and figurative depth. 


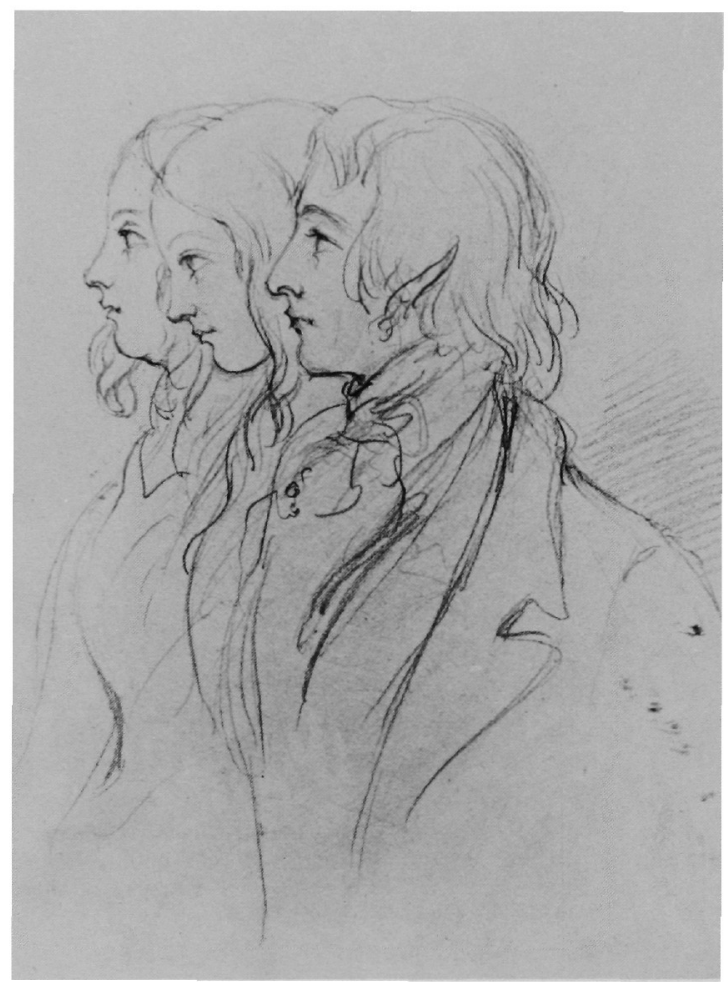

Fig. 153. Daniel Maclise, Sketch Portrait of Georgina Hogarth, Catherine Dickens, and Charles Dickens, 1843 Pencil. $77 / 8^{\prime \prime} \times 513 / 16^{\prime \prime}(20 \times 14.8 \mathrm{~cm})$ [sheet]. From the Forster Collection (Department of Prints and Drawings), by permission of the Victoria and Albert Museum.

Doubtless Maclise was too preoccupied with his own canvases to further illustrate Dickens's work at this time. Moreover, as Harvey also perceives, further random contributions to the Clock by the painter might have impeded coordination of the other principals and upset the evolving aesthetic balance between Cattermole and Brown. ${ }^{41} \mathrm{Be}-$ sides, despite his sincere appreciation of his friend's writing, Maclise did not share Dickens's fondness for girls Nell's age, whom he considered "most insipid." ${ }^{2}$ Like Ruskin, perhaps, he was more intrigued by Barnaby's raven.

For The Chimes in 1844 it was decided to depart from the format of $A$ Christmas Carol by engaging more than one artist, in order to alleviate the strain on Leech as well as to incorporate greater visual variety, and increase the number of illustrations to attract more purchasers. ("Eight illustrations," the Times noted snidely, "were thought sufficient to
"A black and dreadful place!" exclained the child.

" luook in," said the old man, pointing downward with his finger.

The child complied, and gazed down into the pit.

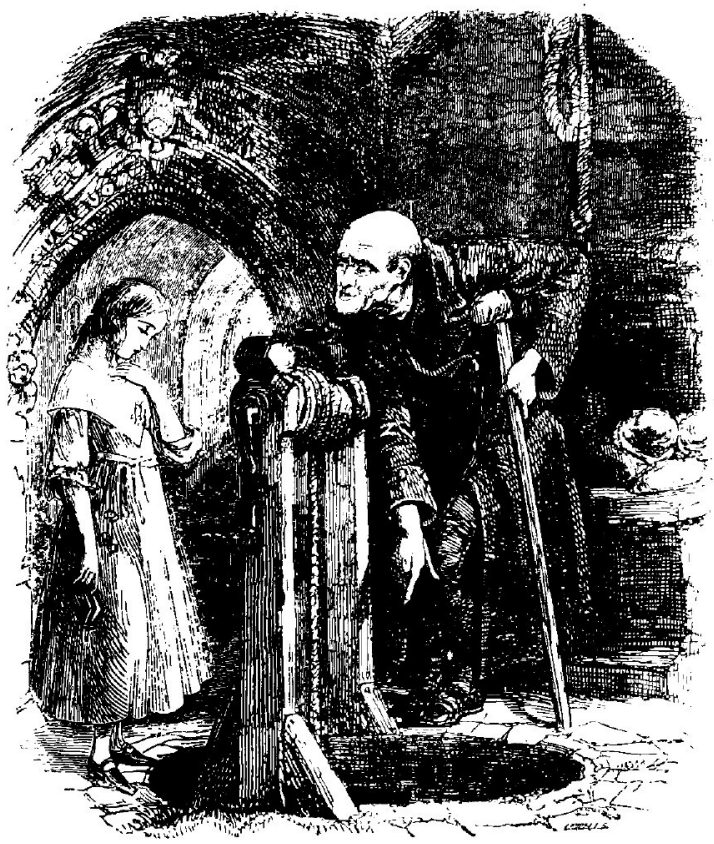

“ It looks like a grave, itself," said the old man.

"It does," replied the child.

Fig. 154. Daniel Maclise, 'Nell and the Sexton.' Master Humphrey's Clock, no. 35, p. 108. Wood engraving. 47/16" $\times 3^{15 / 16^{\prime \prime}}(11.3 \times 10 \mathrm{~cm})$. By permission of the Houghton Library, Harvard University.

make the Carol understood, twelve were necessary for the sale of the Chimes." ${ }^{43}$ Maclise readily agreed to contribute to the frontispiece and title page design for the new holiday book. He himself was fascinated by the season's secular rites, and had even made them the subject of an 1838 canvas, 'Merry Christmas in the Baron's Hall,' as well as a ballad for Fraser's that year. ${ }^{44}$ Furthermore, he probably considered that to execute two designs was the least he could do for Dickens, self-exiled on the Continent. To Forster, however, in charge of coordinating the enterprise, Maclise expressed his reluctance to be associated with such a commercial venture by complaining about the format. He found it hard, he said, to squeeze a design on one small page, being accustomed to large-scale canvases. Would Forster ask Dickens to have the width of the margin increased? A 
larger page would make the format more elegant, the artist argued more objectively. In his opinion, the appearance of the Carol had represented "the very climax of vulgarity in its mise en planches." 45 The Chimes pages do seem to have been enlarged, but so slightly as to be imperceptible to the common reader and, doubtless, unsatisfactory to Maclise. ${ }^{46}$

Maclise's designs, allegorical rather than realistic like Leech's, displayed his characteristic industry and polish. But it seems evident that he felt cramped. In contrast to the traditionally reticent frontispiece, Maclise's overwhelmed the page (following p. 79) (fig. 155); indeed the lack of any margin along its bottom suggests the printer may have had to trim the design. The forceful, somewhat geometrical composition-aptly described by Richard Ormond as an $X$-axis formed by swirling groups of elves, superimposed on the verticals and horizontals of the Gothic belfry ${ }^{47}$ - successfully strained to provide an illusion of space. Dickens, more sensitive to the substance than the technique, was charmed by the symbolism of the elves emerging from the bells, some bearing the coffin of the old year, others the infant new year, but some readers no doubt agreed with the reviewer who saw only a "monstrous mélange of kicking, sprawling nudities."48 Maclise's title page (following p. 79) is similarly playful and imaginative, with goblin figures forming many of the letters as in a medieval manuscript, according to Ormond; ${ }^{49}$ yet the five different styles of calligraphy are more visually distracting than pleasing. Nevertheless, the artist had lived up to his agreement, however reluctantly, and need feel no qualms while awaiting his friend's return.

In Italy, as in America, Dickens had become obsessed with planning his return to London. Not only was it imperative that he personally see the holiday book through publication, he rationalized to Forster, but he wished to read the completed story to his friends. ${ }^{50}$ His week-long visit in December accomplished these objectives. Maclise was present among both groups of friends whom Forster summoned on successive nights to hear Dickens read The Chimes, a moving event that helped inspire the author's later public readings. After one of the performances, Maclise made a sketch in which he managed to include a halo of light around Dickens's head and the Chimes spirits on the left-hand side, as well as to individualize the expressions of the assembled listeners (fig. 156). ${ }^{51}$ "I do not think there was ever such a triumphant hour for Charles," wrote the artist to Mrs. Dickens, to whom he sent the sketch; "every face was either extended into the broadest possible of grins, or else altogether hidden behind the handkerchief." ${ }^{22}$ The reaction of this admittedly biased audience was also shared by the general public. Sales were unaffected by criticisms like that of the Times, which found the "gross absurdities" of

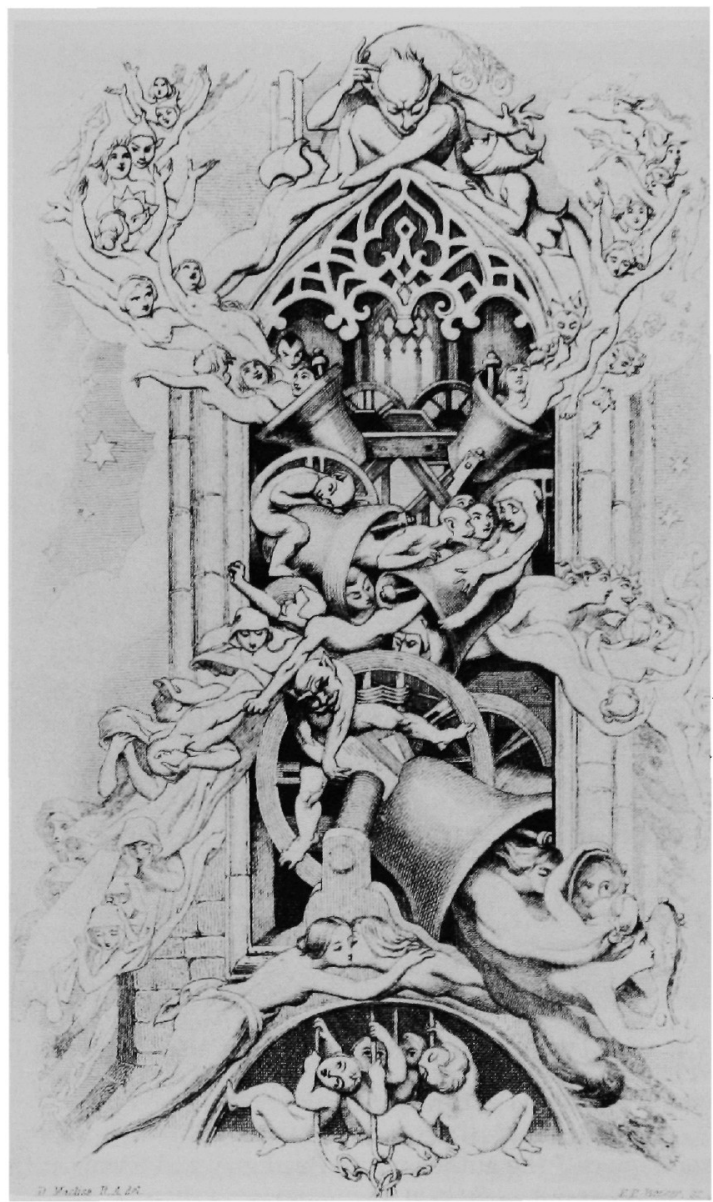

Fig. 155. Daniel Maclise, Frontispiece to The Chimes. The Chimes (London, 1844), facing title page. Steel engraving. 61/8" $\times 37 / 8^{\prime \prime}(15.5 \times 9.9 \mathrm{~cm})$. From the Harry Elkins Widener Collection, by permission of the Houghton Library, Harvard University.

the tale further perpetuated and upheld by "illustrations equally atrocious." 53

The success of The Chimes and the prospect of returning to London for good in the spring, after a reunion with the triumvirate in Flanders, ${ }^{54}$ lightened Dickens's remaining period of Italian exile. During his first months after he came home, Dickens was preoccupied with founding his amateur theatrical company. Immediately after its debut, however, he began to plan his next Christmas book. The reluctant artist delayed committing his services to The Cricket on the Hearth. "I have already given Mr. Maclise to understand that he must let me know, this week, whether he will do the 


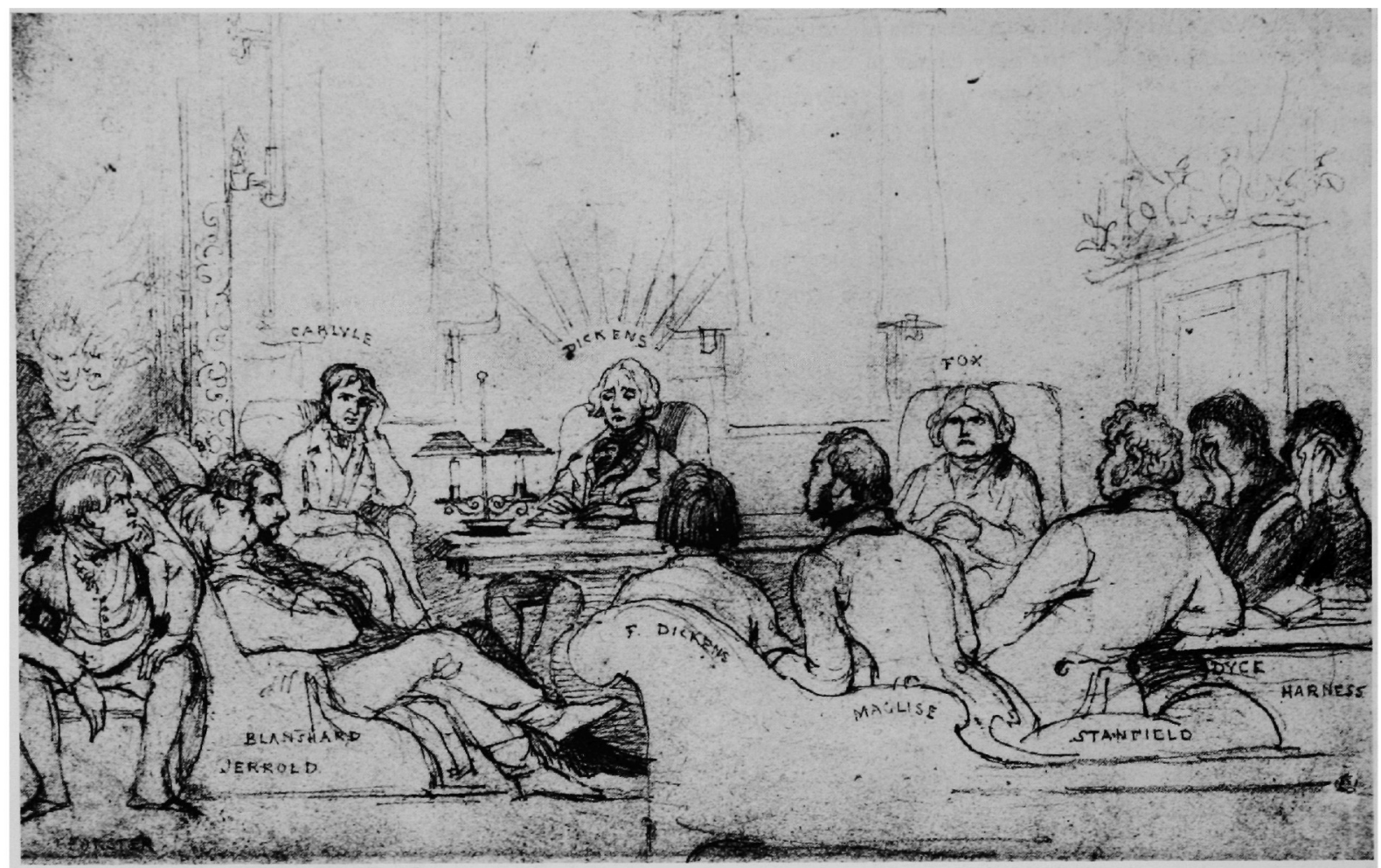

Fig. 156. Daniel Maclise, Sketch of The Chimes Reading, December, 1844. Pencil. 43/8" $\times 67 / 8^{\prime \prime}(11.1$ $\times 17.5 \mathrm{~cm}$ ) [sheet]. From the Forster Collection (Department of Prints and Drawings), by permission of the Victoria and Albert Museum.

Frontispiece," the author wrote Bradbury and Evans at the end of September. ${ }^{55}$ Still the painter vacillated. He was preoccupied now with the scenes he had been commissioned to make for the new Parliament buildings, and balked at diminishing his energy and compromising his standards on yet another commercial venture for Dickens. He argued that his illustration could add little of value to his friend's work. The author chided this self-deprecation: "Do not think so nonsensically about the value of your frontispiece. I can hardly believe you to be serious, when I know so much better, and so far above all possibility of dispute, what its value is." ${ }^{\text {"56 }}$ At last, probably after a personal conference, Dickens persuaded Maclise to provide not only the frontispiece but the title page as well.

Once again, however, the artist expressed his ambivalence about participating in this holiday enterprise by complaining to Forster about the technical arrangements. The publishers sent what seemed to the artist such a small pair of blocks for his designs that he sent them back; of the two replacements he received, he found only one satisfac- tory. Not only did the artist rage to Forster that he must have a proper block at once, but once again urged him to have Dickens insist on a still larger page to improve the book's appearance-a change that, Maclise claimed, would make him "happy for life."57 Dickens, meanwhile, chafing at Maclise's delay in producing the illustrations but unaware of its causes, demanded that the publishers see if the artist was nearly finished. ${ }^{58}$ Finally, the artist received a suitable block-one that was at least the same size as the ones for The Chimes, if no bigger-and completed his carefully structured designs to Dickens's if not his own satisfaction.

Once again, the Cricket page barely contained Maclise's frontispiece (180) (fig. 157), which was far more complex than the one for The Chimes (see fig. 155). As Ormond has shown, the artist's symmetrical structure managed to control its superabundant detail. ${ }^{59}$ Between the solid horizontals of the furniture and fire grate, Maclise centered a cricket over the fire by which the Peerybingles sit. The insect is almost lost, however, in the cloud of steam rising from the boiling kettle, which leads into the swirls of holly 


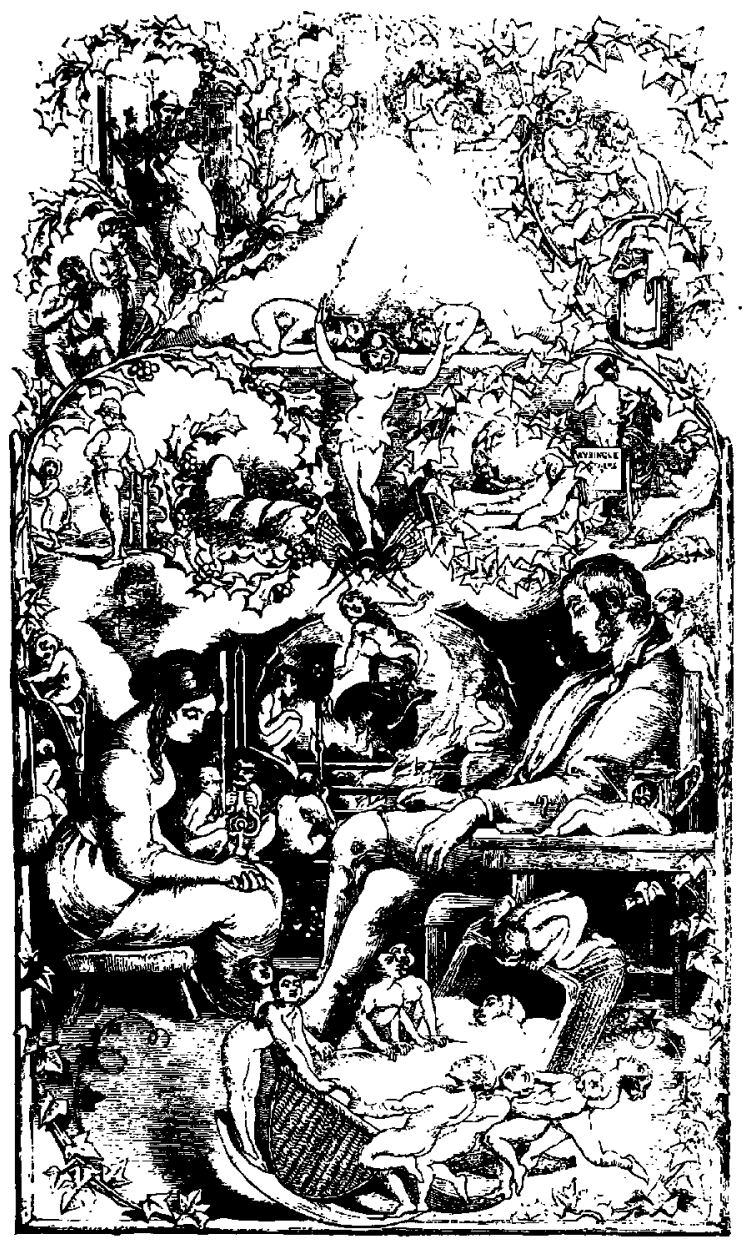

Fig. 157. Daniel Maclise, Frontispiece to The Cricket on the Hearth. The Cricket on the Hearth (London, 1845), facing title page. Wood engraving. 6\%/8" $\times 3^{13} / 16^{\prime \prime}(16.2 \times 9.7 \mathrm{~cm})$. From the Harry Elking Widener Collection, by permission of the Houghton Library, Harvard University.

surrounding ten miniature tableaux from the narrative. Meanwhile, on a strong diagonal below the couple, fairies rock their baby's cradle. The cozy claustrophobia is somewhat alleviated, however, by the lack of an enclosing linear frame around the upper third of the scene. Maclise's title page, as in The Chimes, is far simpler and more effective (181). To structure this holly-bordered design, with its sportive pudgy elves, the artist utilizes the powerful horizontals of the clock striking midnight. The ropes on which the pendulums hang somewhat obscure the letters of the title but at least the latter's clear block style does not compound this difficulty. Maclise obviously took pains with these Cricket illustrations, which, being the preliminary scenes, had to set the gentle tone for the narrative. But he got little thanks for his pains. The Cricket sold well, but the reviewers were particularly unkind to Maclise. Thackeray might term his frontispiece "one of the most brilliant specimens of the art," but the Illustrated London News deemed it inappropriately "un-English" and clearly agreed with the Times in finding the title page, with its naked spirits, "outrageous and not very decent."60 Dickens himself said nothing whatsoever. The proud artist must have regretted his efforts, so misunderstood even by sophisticated critics and only tacitly appreciated by the author.

Dickens was so caught up in his work on the Daily News, however, that he did not immediately sense Maclise's chagrin, which was no doubt exacerbated by his labors for the Parliament buildings at Westminster. The painter was helpful at the Rochester meeting about the author's future in February, 1846 when it was decided that Dickens should quit the newspaper and go abroad again to write a new novel, but his absence at the subsequent series of farewell parties was conspicuous. ${ }^{61}$ When Dickens first wrote Maclise from abroad, it was to convey his hurt at the painter's cold leavetaking rather than to recount his journey to Switzerland.

Once ahroad again, Dickens's anxiety about his future manifested itself partly in excessive concern about the illustrations for his next holiday production, The Battle of Life, as well as for Dombey and Son. Forster, again in charge of coordinating the principals in the author's absence, contacted Maclise about illustrating this Christmas story, which was to be loosely set in Goldsmith's eighteenth century rather than the present. He predictably encountered strenuous opposition. "On the whole," the artist replied to his solicitation, "I would prefer not engaging in the matter at all."62 If Forster really felt that the volume's appearance should resemble the former ones as closely as possible, said Maclise, he would accede to his request but "not at all for D," for given his recent indifference and present silence, he obviously did not "care one damn" whether Maclise contributed to the book or not. ${ }^{63}$

Nevertheless, Forster somehow elicited Maclise's sympathy for their absent mutual friend, for the artist not only agreed to illustrate The Battle but markedly altered his attitude toward its production. He agreed to execute the frontispiece if Forster would remove the subject from Doyle and save it for him. ${ }^{64}$ Since he thought a plain title page would look better than an ornate one, he offered to make another design for the narrative-whatever Forster liked: "The girls and the Doctor, Marion reading, \&c., or the lover 
of Marion's interview with her, and Clemency outside the door, \&c." promised, in any case, to keep his designs within the limit on the size of the page. Dickens knew nothing of these negotiations. Forster merely announced to him the "glad surprise" that Maclise, along with Stanfield, Leech, and Doyle, would contribute to The Battle; the artist, in turn, must have been pleased to learn from Forster that this news had made the author "jump for joy."

Dickens's obvious gratitude perhaps stimulated the artist to efforts that more than compensated for his prior reluctance. "Mac has come out with tremendous vigour in the Xmas Book," Forster reported to the author, "and took off his coat at it with a burst of such alarming energy that he has done four Subjects!"67 Maclise prepared not only his customary frontispiece and title page for the story, as agreed, but two other illustrations as well. Executing a decorated title page after all (281), he displayed his usual strong sense of structure in composing the martial figures in a $U$ curve, crossed by the strong diagonals of the clearly lettered title banner and weapons. More delicate designs were required for the frontispiece (this time readily contained within the small page) and the other two illustrations, all of which involved female rather.than fantastical figures. Yet the Jeddler sisters dancing (280) (fig. 158) and reuniting (III, 376) ${ }^{68}$ and even Clemency despairing over Marion's interview with Michael (II, 336) are all depicted in the mannered and sensuously statuesque fashion characteristic of the artist. If Maclise's portrayals of "Eve's fair daughters" wanted any "maudlin taint," as Dickens had noted earlier in mock-serious verse (CP, 2: 305), they invariably lacked charm as well. Doubtless this is why Leech despaired so at Maclise's determination to see his representation of Clemency carried through by the Battle's other illustrators. ${ }^{69}$

Indeed, Maclise's concern about the reception and reproduction of his Battle designs-ostensibly done merely to help out his friend-was more like that of an artist trying to win a reputation than of an established artist just commissioned to help redecorate the Houses of Parliament. Stung by the charge that his Cricket work smacked of the obscene, he worried particularly about his frontispiece, which depicted the Jeddler sisters dancing before an apple tree to the delight of the female onlookers, themselves ogled by two men peering over the fence (280) (fig. 158). He half-jokingly worried that a moralist like Thackeray might find it "lecherous, libinous, lustful, lewd, and loose" though he intended it to be "pure and mi-ld as the moo-n-beams." Thackeray did gently protest, but not about the licentiousness of the artist's illustrations. Rather, he thought that the

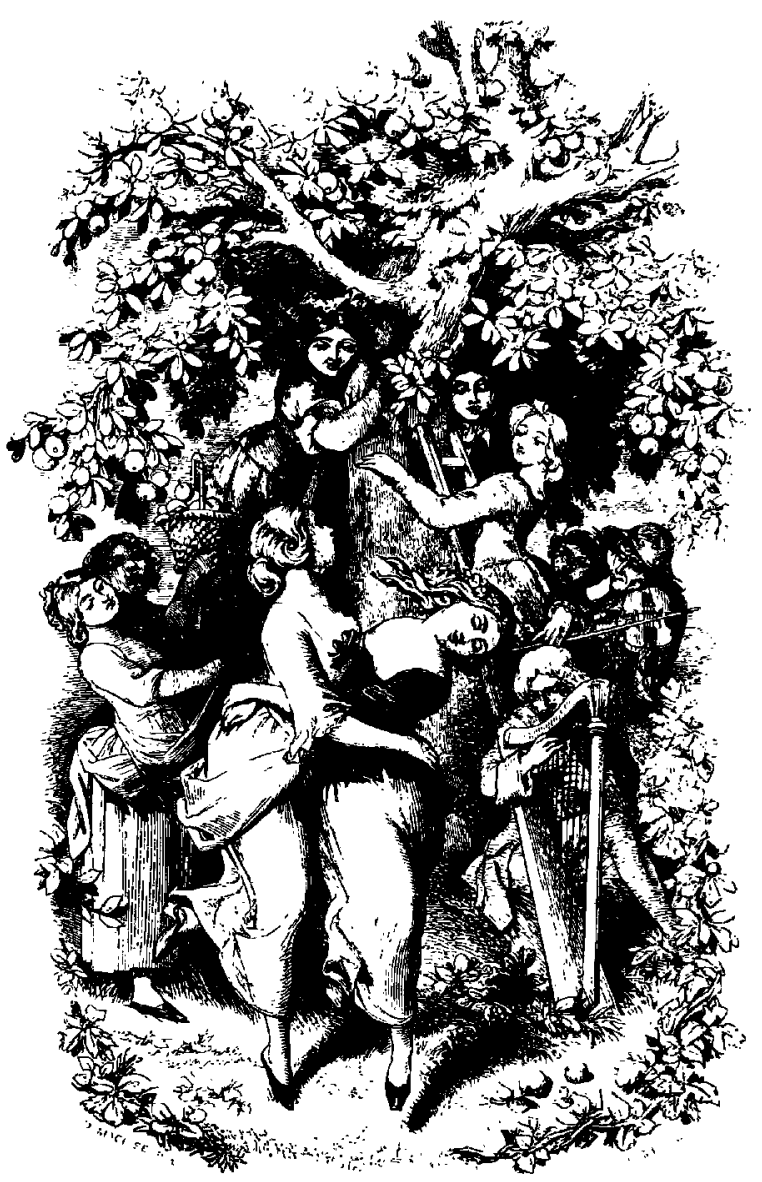

Fig. 158. Daniel Maclise, Frontispiece to The Battle of Life. The Battle of Life (London, 1846), facing title page. Wood engraving. $53 / 8^{\prime \prime} \times 31 / 2^{\prime \prime}(13.7 \times 8.9 \mathrm{~cm})$. From the Harry Elkins Widener Collection, by permission of the Houghton Library, Harvard University.

costumes, whose imprecisely old-fashioned details attempted to satisfy Dickens's desire to utilize apparel of "dear old Goldsmith's day," merely "prettified" the female characters in the narrative, as in "some of Mr. Maclise's charming designs." 71

Maclise was more seriously concerned about the reproduction of his designs. He was furious to learn that Samuel Williams's brother Thomas and the Dalziels, among the best wood engravers of the day, were unavailable, though his assigned engraver, John Thompson, was their equal. To make matters worse, he was informed that Thompson did not have sufficient "time" to do his designs justice. ${ }^{72}$ When 
the finished prints of all four illustrations predictably disappointed him, Maclise unleashed his frustration: "I am mortified and humiliated by the effect of those damnable cuts," he wrote hysterically to Forster; "I would give anything that I had kept to my original resolve and had nothing to do with the thing."73 This time, he kept his resolve. Maclise did not illustrate a Dickens work again. And Dickens, who apparently shared the artist's disappointment in the Battle illustrations, did not protest. ${ }^{74}$

The two men began to draw apart. The Christmas book illustrations had strained the artist's perfectionist standards but not destroyed his friendship with Dickens. Yet the heavy workload involved in his monumental work for the rebuilt Houses of Parliament made him less available and more prone to hypochondria and melancholy. Dickens's amateur theatricals, however, continued to provide a neutral ground for their social and professional lives. Maclise, an avid theatergoer, had originally taken a part in the opening production, Every Man in His Humour; but just before rehearsals began, he felt too shy at the prospect of facing an audience and withdrew. ${ }^{75}$ However, he never ceased to share his knowledge of period costumes with the troupe, and Robert Browning, aware that the costumes had benefited from the artist's expertise, found them all "perfect." ${ }^{76}$ At the play's debut on September 20, 1845, Maclise made the last of his informal portraits of the author; on the front of a handy play bill he sketched Forster as Kitely and Dickens as Bobadil (fig. 159). ${ }^{77}$

But even these offstage contributions ceased as Maclise became totally absorbed by his Parliament project. He did not design the garlanded title page for Mrs. Gamp's 1847 "Projiss" of the theatrical company that Dickens asked him for; and nothing came even of the artist's own proposal that he paint the company in the command performance of Not So Bad as We Seem, dedicate it to the Duke of Devonshire who had housed the production, and engrave and publish it for the benefit of the Guild of Literature and Art. ${ }^{78}$ But he was always invited to attend the group's performances and rarely missed any of them. For this and other reasons, when Queen Victoria commanded a private showing of The Frozen Deep, it was Maclise whom Dickens, too busy backstage and embarrassed by his undignified appearance, asked to greet her. ${ }^{79}$

Ironically, Queen Victoria and her consort, who had afforded Dickens and Maclise much amusement in their youth, now inadvertently hastened the dissolution of their friendship. In the early years of the "triumvirate," the author and the artist had carried on an imaginary infatuation for their young sovereign. ${ }^{80}$ Victoria was aware of "McLise" even then (though she never accustomed herself to the artist's preferred spelling of his name): on the recommendation of his fellow artist, Edwin Landseer, she had purchased some of his Academy canvases, and she gossiped with Melbourne about Maclise's affair with Disraeli's former mistress, Lady Sykes. ${ }^{81}$ After she married Prince Albert in 1840 , to the mock despair of Dickens and Maclise, Maclise occasionally was patronized by the royal pair; he painted special pictures for the queen to give her husband on his birthday, and joined Landseer, Stanfield, and six other artists in painting frescoes (his first) for the Buckingham Palace garden pavilion. ${ }^{82}$ Aware of the artist's access to royalty, Dickens loved to tease him about his impending knighthood. He also hoped, entirely seriously, that the painter, whose powers he found remarkable, would "leave his mark on more enduring things than Palace Walls." ${ }^{\text {"33 }}$

The prince consort also encouraged Maclise to produce something monumental, doubtless thinking of the unadorned walls of the new Houses of Parliament at Westminster, rebuilt after the 1834 fire. Dickens was particularly delighted when Maclise decided to compete with other artists hoping to execute the Westminster murals of British historical subjects. Such a project would provide both a challenge and an outlet for his friend's genius. The Commissioners of Fine Arts, actively led by Prince Albert, selected Maclise to design a cartoon for a mural entitled "The Spirit of Chivalry.' When it was completed in 1845 , the partisan author publicly speculated "whether the Fine Arts in any period of their history, have known a more remarkable performance" ( $C P, 1: 35)$. When the highly praised cartoon was accepted, and Maclise commissioned to paint the subject for the House of Lords, Dickens trusted that the important assignment finally would give his talented but often lazy friend a sense of purpose. The huge scope of both space and subject would allow Maclise to indulge his love of numerous and grandiose figures, yet might prevent him from overelaborating minute details. ${ }^{84}$ The commissioners were. so pleased with 'The Spirit of Chivalry' that they asked Maclise to execute a companion mural, 'The Spirit of Justice,' which he duly completed in 1849; and to begin the first two of a proposed series of frescoes for the Royal Gallery at Westminster, 'The Meeting of Blucher and Wellington' at Waterloo and 'The Death of Nelson' at Trafalgar. ${ }^{85}$ These works proved the artistic triumphs of Maclise's life, however artificial they may appear to later taste, but they also hastened his ruination.

During, and partly because of, his work at Westminster, the bachelor artist became more reclusive and hypochondriacal. ${ }^{86}$ Dickens and his other friends, also worried that his style, with its cold colors and one-dimensional figures in 




Fig. 159. Daniel Maclise, Sketch of Forster as Kitely and Dickens as Bobadil, 1845. Playbill, September 20, 1845. Ink. $10^{\prime \prime} \times 7^{3 / 4^{\prime \prime}}(25.4 \times 19.7 \mathrm{~cm})$ [sheet]. From the Forster Collection (Library), by permission of the Vietoria and Albert Museum. 
theatrical postures, was becoming more mannered than monumental, urged him to travel abroad for rest and rejuvenation, but Maclise, habitually irresolute, vacillated: he said he was too busy; he claimed he was not well; he refused to travel first with, then without Dickens. ${ }^{87}$ Though proposed trips to Italy and Ireland never materialized, the artist finally did accompany the novelist to Paris for a brief visit in 1850, and again in 1855, after which he toured Italy alone, rejoicing as each day brought him closer to home. ${ }^{88}$ Back at Westminster, however, Maclise once again confronted unbearable working conditions. He labored in a drafty, dusty hall with its seasonal heat, damp, and poisonous paint fumes. The stained glass windows cast odd patterns on his own work. He was further discomfited by the quick-drying fresco process, which, unlike his familiar oils, made his painting difficult to alter since the plaster had to be relaid to rectify any mistake. Maclise decided to resign his commission. Prince Albert persuaded him to remain. He not only promised to have the hall dusted and the colored windows removed, but he dispatched Maclise to Berlin in 1859 to investigate a new fresco technique. ${ }^{89}$ The artist, after effacing the finished portion of his fresco in order to apply the new methods he learned in Berlin, finally completed the massive Waterloo subject in December, 1861, the year of Prince Albert's death. Dickens, whose disgust at the queen's prolonged mourning was as immoderate as his despair at her marriage almost two decades earlier, failed to anticipate the devastating effects of the consort's decease on his former intimate. ${ }^{90}$

With characteristic pains, Maclise had already proceeded with the Trafalgar tableau. Although the widowed queen came to inspect and encourage his work, national enthusiasm for the Parliament murals cooled after the consort's death. In 1864 the commissioners voted Maclise payment beyond that stipulated in their original contract for his first two frescoes, but canceled all agreements for future ones without compensating the painter even for designs he had already made. Nor did they take any account of the lucrative projects he had given up during the years he had been working at Westminster. He was hardly consoled by the universal praise his murals elicited, remarking only that "nobody comes for the pictures after they are done, or wants them as far as I can see."

Ill and apathetic after his long ordeal, Maclise withdrew into almost unbroken seclusion. Even after the death, in 1865, of the spinster sister with whom he had lived, he rarely sought company, either of the old "triumvirate" or of his colleagues; the following year, he even declined an offer to become president of the Royal Academy. ${ }^{92}$ Dickens continued to praise his friend publicly $(C P, 2: 305 ; R P, 109)$ and tried to remove any grounds between them for offense. ${ }^{93}$ But, as Forster prophesied to Dickens, one day they would hear that the "wayward" life into which Maclise had fallen was over and "there an end of our knowledge of it." W4 When that day came, in April, 1870, both were nevertheless shocked. The funeral took place the day of the annual Royal Academy dinner, for which Dickens composed himself enough to eulogize his dead friend. The audience listened magnetized to his moving testimonial. ${ }^{95}$ No artist, he said, "ever went to his rest leaving a golden memory more pure from dross, or having devoted himself with a truer chivalry to the art-goddess whom he worshipped" $(C P, 2: 534)$. It was ironic and fitting that it was in honor of Maclise-the closest of the friends who "one by one" had recently "dropped" from his side-that Dickens spoke his own last words in public. 


\section{Chapter 11}

\section{EDWIN LANDSEER}

Edwin Landseer, as popular in Victorian art of the nineteenth century as Dickens was in its literature, contributed a single illustration to one of the author's Christmas books. Especially famous for his animal paintings, the artist agreed to portray the Peerybingles' dog, Boxer, in The Cricket on the Hearth. The mere fact of collaboration between these two celebrities is of greater interest than importance. Indeed, a wealth of anecdotes, here brought together for the first time, surrounds many of their meetings, revealing something of the men, if not their work together. By the time Landseer met Dickens in the late 1830 's, according to one such legend, he already admired his works, and had even incurred the wrath of his old, deaf father by reading Dickens's fiction to his life class at the Royal Academy. "What's that book?" the aged Landseer is supposed to have rasped through his speaking trumpet one evening in 1839.

“Oliver Twist," said Edwin Landseer, in a voice loud enough to reach Trafalgar Square.

"Is it about art?"

"No, it's about Oliver Twist."

"Let me look at it. Ha! It's some of Dickens's nonsense, I see. You'd much better draw than waste your time upon such stuff as that."

Whether because of such paternal watchfulness, or in spite of it, until 1967 Landseer hèld the record as the youngest artist ever to have exhibited at the Royal Academy. This early recognition proved well-founded, for Landseer subsequently became one of the most notable painters of his era. Indeed, Dickens felt about Landseer as he did about Maclise; that he could have risen to the top of whatever profession he chose, including that of a writer. ${ }^{2}$ Despite his success and his father's disapproval, the painter not only continued to read Dickens avidly, but befriended him, and, on the one occasion, even illustrated his "nonsense."
Dickens probably met the painter through the Shakespeare Society, which included in its membership the three Landseer brothers as well as the author's close artist friends, Cattermole, Maclise, Stanfield, and Frank Stone. ${ }^{3}$ Both Dickens and Edwin Landseer were frequent guests at Cattermole's elegant dinner parties at Clapham Rise. The host's son long recalled the two Portwiners descending to the studio after dinner to see his father's canvases. Dickens, his legs wide apart, would gaze at Cattermole's latest painting with admiration while Landseer stood "slowly oscillating his head with his eyes nearly closed, like a physician over a patient he despairs of," trying to impress onlookers with his transcendent, if mute, appreciation. ${ }^{4}$ The author, his family and friends enjoyed the company of the short but handsome painter (fig. 160), who was, as Forster put it, "all the world's favorite." His impeccable manners, talent for mimicry, and the confidence born of early success concealed his bouts of mental instability and preference for genteel society better than they did later on. Dickens also liked Landseer's brothers: Tom, an artist and an engraver like his father (and also deaf, but far better tempered); and Charles, a less eminent painter than his brother, who eventually became the Keeper of the Royal Academy. ${ }^{6}$ The Landseer family was equally attracted to Dickens. Even the father capitulated to his charm, providing him with interesting, if unsolicited, comments based on his first-hand youthful memories of the Gordon Riots while Dickens was composing Barnaby Rudge. ${ }^{7}$

Edwin Landseer's unprecedented success, both professional and personal, was undoubtedly due in part to the fact that he was an early and abiding favorite of Queen Victoria. He painted pictures of her pets, gave her and Prince Albert lessons in drawing and etching, and contributed, along with Maclise and Stanfield, one of the frescoes on the walls of their summer house at Buckingham Palace. "He certainly is the cleverest artist there is," asserted the young sovereign, 


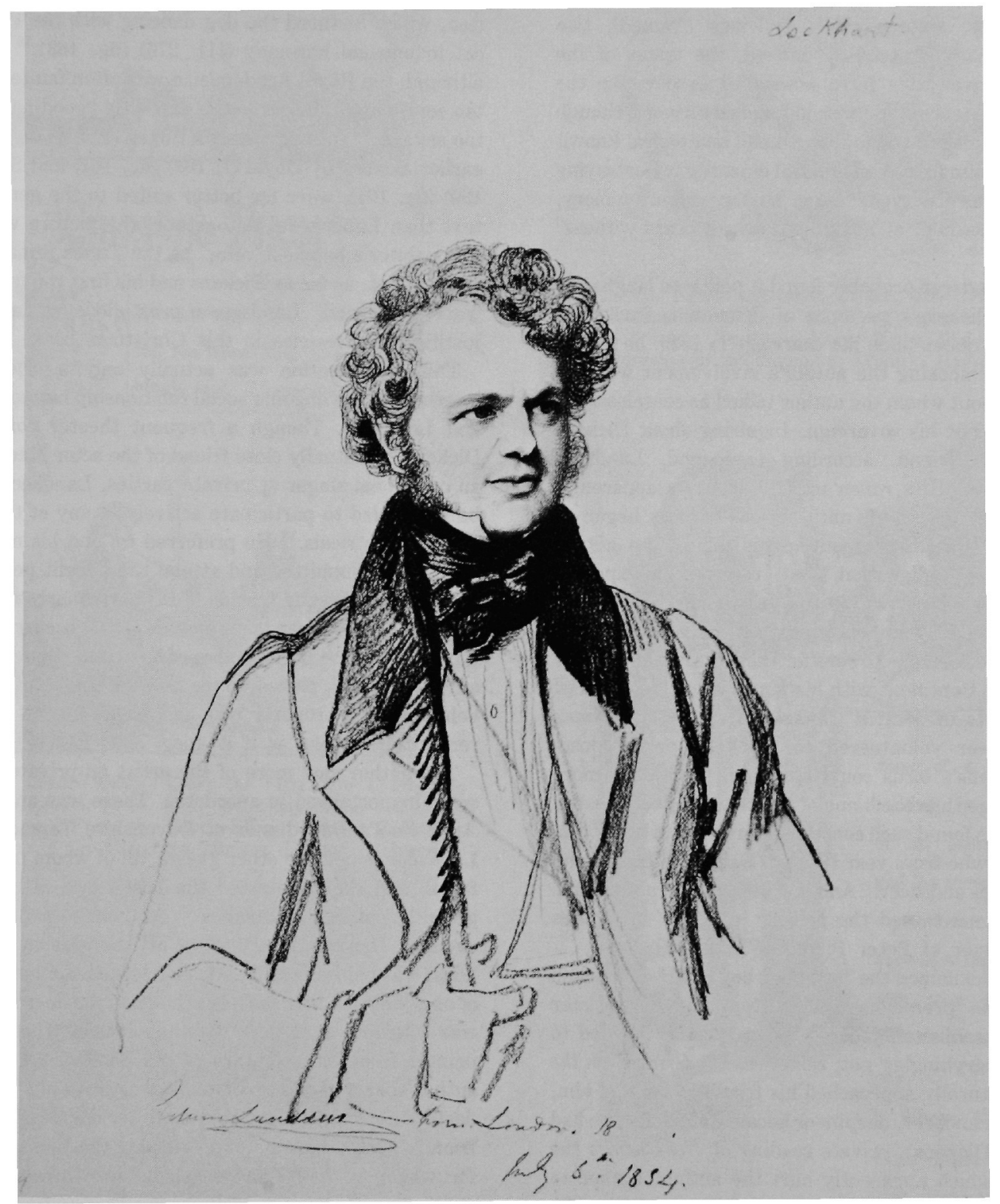

Fig. 160. Carl Vogel von Vogelstein, Unpublished Portrait of Landseer, July 5, 1834. Graphite. 71/8" $\times 9^{1 / 2} 2^{\prime \prime}(18 \times 24 \mathrm{~cm})$. By permission of the Staatliche Kunstsammlungen, Dresden. 
who, by the time of Landseer's death, owned "thirty-nine oil paintings of his, sixteen chalk drawings (framed), two frescoes and many sketches." Indeed, the tastes of the House of Hanover may have accounted in part for the continued prominence of animals in Landseer's work; though certainly he displayed a sound first-hand anatomical knowledge of many animals and an unusual empathy in portraying them as, Dickens observed, "every modern picture-gallery, and every print-shop, at home and abroad bears witness" (CP, 1: 634).

Although Landseer probably found it politic to laugh only from afar at Dickens's pretense of demented, frustrated passion for the queen upon her marriage in 1840, he felt no scruples about mocking the author's involvement with his raven, Grip, about whom the author talked as ceaselessly as he once had about his sovereign. Inquiring about Dickens from a mutual friend, according to legend, Landseer remarked, "Alas! He's raven mad!"10 His pun apparently spread and was distorted, until serious rumors began to circulate that Dickens was out of his mind. The author exhibited mock indignation, but received unexpected amends from the artist within the year. Grip died in 1841 and was replaced by an eagle, as well as a new raven. Dickens needed someone to care for them both in 1844 while he went to the Continent with his family after the financial embarrassments of Martin Chuzzlewit and A Christmas Carol. Landseer volunteered to give the pets "houseroom."11 Dickens's birds could hardly have found a more congenial refuge than the home of an artist whose sympathy with all animals found such constant expression in his works. "O Landseer, who from year to year/ Delight in beasts and birds, and dogs and deer./ And seldom give us any human vermin," Dickens teased the painter in one of his squibs after the manner of Peter Pindar (CP, 2: 305).

Landseer, nicknamed the "little dog boy" by Henry Fuseli because of his precocious ability to paint dogs, later specialized in canine subjects. ${ }^{12}$ When Dickens decided to feature the Peerybingles' pet, Boxer, in The Cricket on the Hearth, he naturally approached his friend to portray him, at least once. Landseer, despite or because of the fact he had not attended Dickens's private reading of The Chimes the year before, which apparently hurt the author, agreed to delineate the $\operatorname{dog} .{ }^{13}$ Initially undecided as to whether he should make a full-page illustration or just a vignette of Boxer alone, the artist ultimately produced a vignette showing a snarling Boxer poised among some packages (one of which, perhaps taking a hint from the initialed parcel in Doyle's scene (I, 184) (fig. 161), is playfully labeled with the author's surname) (II, 230) (fig. 162). ${ }^{14}$ Dickens passed the drawing on to Leech, who was eager to follow Landseer's characterization of the dog for his own concluding illustration, which featured the dog dancing with the Peerybingle cat in unusual harmony (III, 276) (fig. 163). ${ }^{15}$ Ironically, although the Royal Academician was often faulted for being too sentimental, he made the explicitly "good-natured" dog too savage. ${ }^{16}$ In fact, Leech's Boxer (I, 194) (fig. 163), and earlier Boxers by Doyle (I, 184) (fig. 161) and Stanfield (I, 190) (fig. 164), were far better suited to the genial holiday text than Landseer's. Altogether, the picture was "not in this painter's happiest vein," as the Times remarked in an aside. ${ }^{17}$ Yet, as far as Dickens and his first common readers were concerned, Landseer's prestigious signature alone justified its presence in this Christmas book.

This collaboration was actually only a brief working interlude in the ongoing social relationship between Dickens and Landseer. Though a frequent theater companion of Dickens, a mutually close friend of the actor Macready, and an occasional singer at private parties, Landseer could not be persuaded to participate actively in any of the author's benefit theatricals. ${ }^{18} \mathrm{He}$ preferred to lend his name to the Honorary Committee and attend the benefit performances with his aristocratic friends. ${ }^{19} \mathrm{He}$ particularly relished the memory of a legendary episode that occurred after a Tavistock House performance of Fortunio. Douglas Jerrold, a Punch writer, picked up the mask of the hero's horse, left behind by the property man and, holding it up before him, remarked, "Looks as if it knew you, Edwin!"20

The author saw more of the artist on private occasions, some immortalized in anecdotes. There was an uproarious April Fool's Day dinner at Devonshire Terrace at which Landseer joined the other guests, all of whom pretended to fall ill and then protested the host's lack of care for the growing number of invalids. ${ }^{21}$ At Landseer's, on another evening, Dickens, aware of the artist's passion for drawing lions, was neither surprised nor frightened when the corpse of one of his favorite models arrived at the door in a cart and was solemnly announced by the servant. This gift to the painter from the secretary of the Zoological Gardens, the author observed to the company, was certainly worthy of its destination. ${ }^{22}$ Dickens would more seriously compliment his friend's sympathies in "The Friend of the Lions," the proofs for which he had Landseer look over in advance of its publication in Household Words in 1856 (CP, 1: 634-38). ${ }^{23}$

Meetings between Landseer and Dickens, as both grew older, however, were not always so hilarious. Despite the painter's advance from one success to another, he became increasingly nervous, staid, and affected. Once, according to yet another legend, when Dickens invited Landseer to dinner for an early hour, knowing his tendency to be late, the artist was so shy he still could not bring himself to enter 


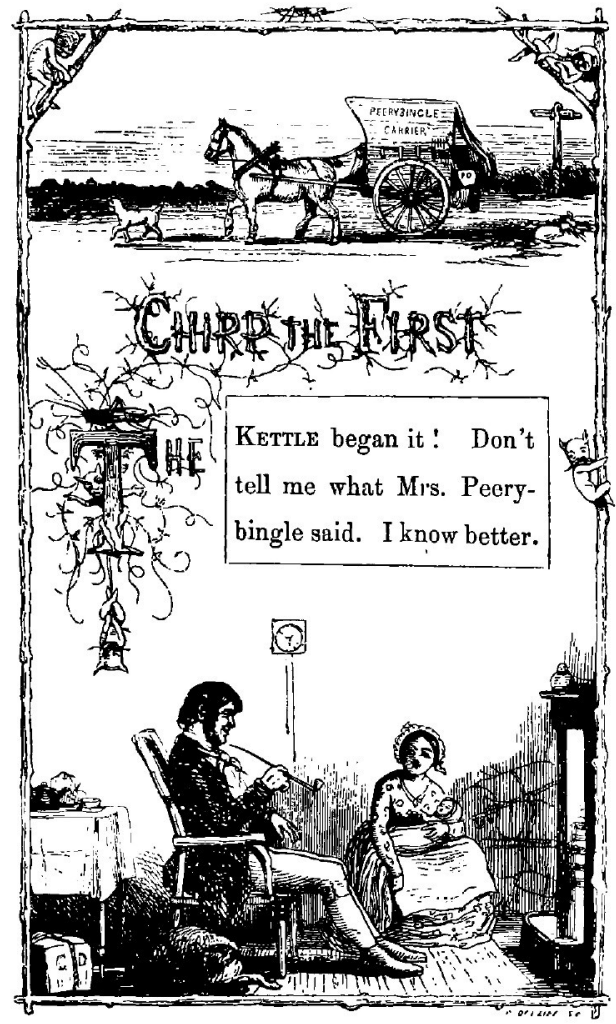

Fig. 161. Richard Doyle, 'Chirp the First.' The Cricket on the Hearth (London, 1845), p. 1 . Wood engraving. $4 \frac{1}{12} 2^{\prime \prime} \times 25 / 8^{\prime \prime}$ $(11.5 \times 6.7 \mathrm{~cm})$. From the Harry Elkins Widener Collection, by permission of the Houghton Library, Harvard University.

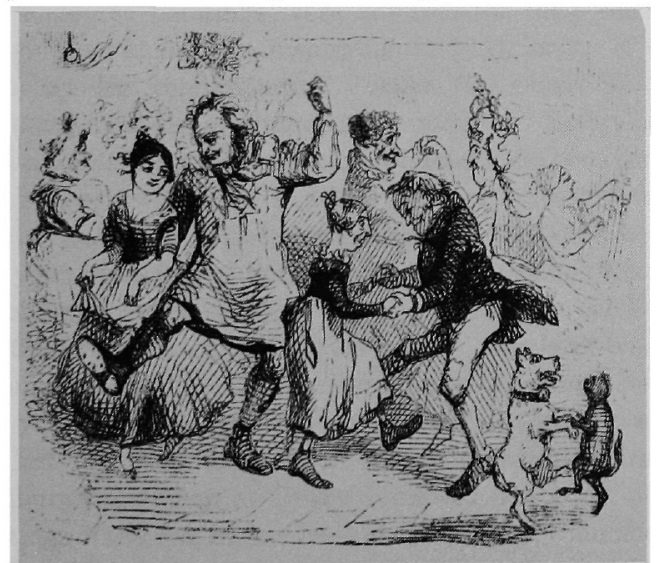

Fig. 163. John Leech, Boxer. Detail from 'The Dance,' The Cricket on the Hearth (London, 1845), p. 173. Woodcut. $4^{11 / 16^{\prime \prime}}$ $\times 2^{3 / 4^{\prime \prime}}(12 \times 7 \mathrm{~cm})$. From the Harry Elkins Widener Collection, by permission of the Houghton Library, Harvard University.

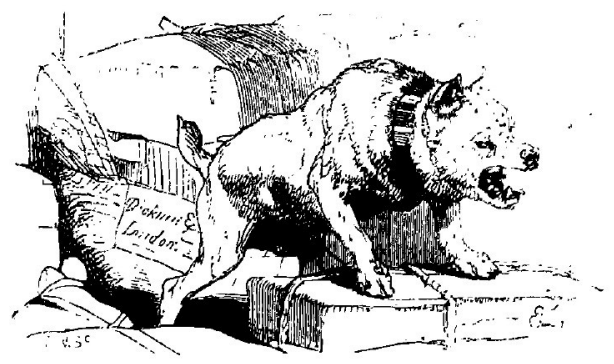

Fig. 162. Edwin Landseer, 'Boxer.' The Cricket on the Hearth (London, 1845), p. 82. Wood engraving. $11 / 2^{\prime \prime} \times 25 / 8^{\prime \prime}$ $(3.8 \times 6.7 \mathrm{~cm})$. From the Harry Elkins Widener Collection, by permission of the Houghton Library, Harvard University.

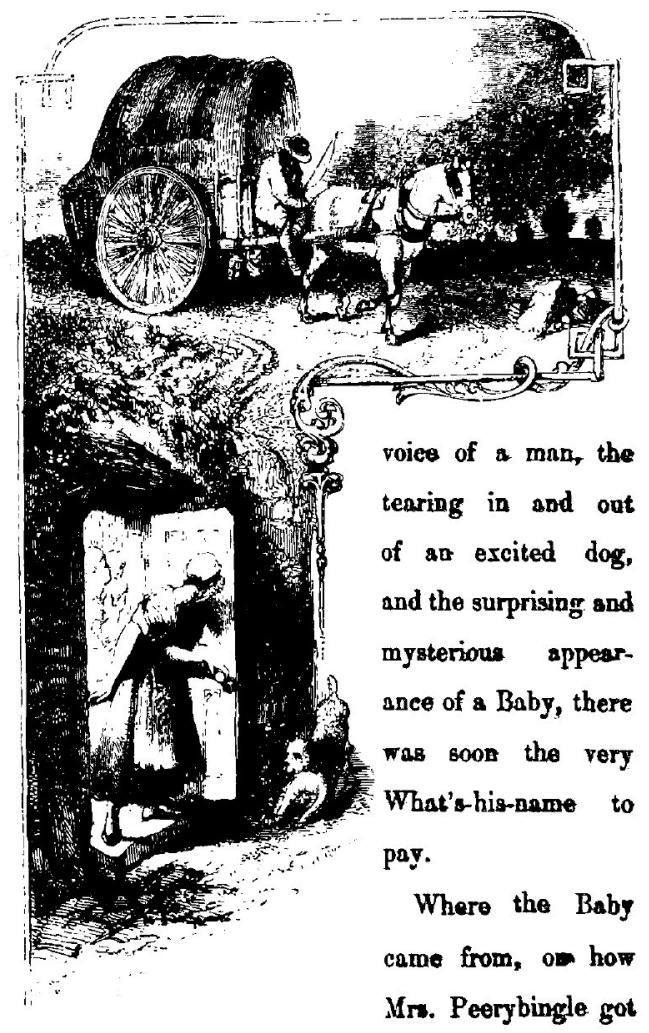

hold of it in that fash of time, I don't know. But a live Baby there ras, in Mrs Peerybingte's arms ; and

Fig. 164. Clarkson Stanfield, 'The Carrier's Cart.' The Cricket on the Hearth (London, 1845), p. 11. Wood engraving. $45 / 16^{\prime \prime} \times 2^{13 / 16^{\prime \prime}}(11 \times 7.2 \mathrm{~cm})$. From the Harry Elkins Widener Collection, by permission of the Houghton Library, Harvard University. 
the house until dinner had been served and was halfway over. ${ }^{24}$ In 1850 Landseer accepted a knighthood; at the 1855 Paris Exposition, he and Cattermole received the two grandes médailles d'honneur for English painters; and in 1865 he, like Maclise, declined the presidency of the Royal Academy. ${ }^{25}$ Yet even as his reputation widened at home and abroad, Landseer narrowed his activities. He began to drift away from Dickens's circle, doubtless put off by the author's separation from his wife and the public manner in which it was broadcast in 1858, and preferring the admiration of politer society to that of the boisterous Forster, Maclise, and Stanfield. ${ }^{26}$

Dickens and Landseer, however, always remained friends, bound by shared memories and an appreciation for each other's sense of humor. Another legend has it, for example, that after returning from an Italian trip in the late 1850 's, Landseer sent his card up to Dickens, who was sitting for a portrait by William Frith that had been commissioned by Forster. "Let's have him up," reportedly urged the author, curious to see the artist's reaction to his newly grown beard and moustache. To Dickens's chagrin, Landseer ignored his appearance. "Well, Lanny," he asked at last, "what about all this? Do you like it? Think it an improvement?" "Oh, a great improvement," Landseer replied soberly; "it hides so much more of your face."27 Such manifestations of affectionate humor became rarer, however, as Landseer sought peace through alcohol while Dickens sought excitement through public readings. When Frith's portrait of Dickens was hung at the Royal Academy in 1859, Landseer's reported reaction suggests the basic incompatibility between the men. "I wish he looked less eager and busy, and not so much out of himself, or beyond himself. I should like to catch him asleep and quiet now and then," commented the artist, whose own deterioration apparently made him appear twice his age. ${ }^{28}$ Since Dickens slept little, due to insomnia, and, when awake, was rarely quiet, the two men, despite their mutual respect and even affection, now saw little of one another. Yet there was no doubting the sincerity of Landseer's pain on learning of the author's death in 1870 , just three years before his own. ${ }^{29}$ 


\section{Chapter 12}

\section{CLARKSON STANFIELD}

"What a fine edition of Nature and Art is Stanfield," wrote Thomas Hood (quoted in $C P, 2: 47$ ) about this beloved member of the Victorian art establishment. Dickens agreed wholeheartedly. He considered the artist the finest of men as well as of friends. If the young Maclise was, for Dickens, the perfect bachelor comrade and Forster the enduring confidant, with remarkably fewer complications Clarkson Stanfield filled the role of genial older companion. The artist, nineteen years Dickens's senior, provided paternal affection, but retained a youthful capacity for spirited enjoyment as well. His few illustrations for Dickens's Christmas and travel books were as remarkable for the spirit with which they were contributed as for their aesthetic merit.

Like most of Dickens's close artist friends, Stanfield had secured his reputation before he met the author. His marine and landscape paintings were admired for their realism, though they lacked the inspiration and originality of canvases by his contemporary Turner, to whom he was constantly (and disadvantageously) compared. ${ }^{1}$ Before Dickens's parents were even married, Stanfield had been driven by his love for the sea to leave his apprenticeship to an Edinburgh heraldic painter and enter the merchant marine. ${ }^{2}$ The year Dickens was born, Stanfield was pressed into the Royal Navy where he began painting scenery for shipboard theatricals organized by Douglas Jerrold, who later became a friend of Dickens and a force in his theater group. By the time young Dickens wrote the first of his Sketches, the artist had left the navy to work as a scenery painter, first in Edinburgh and then at Drury Lane. On the basis of his paintings of the sea, he had been elected in 1832 a member of the Royal Academy, where young Ruskin used to watch him work on "varnishing" day, when exhibitors could retouch pictures accidentally damaged in moving. ${ }^{3}$ Probably the author of The Pickwick Papers met Stanfield, a fellow member of the Shakespeare Society, through Jerrold or William Macready; at any rate, Dickens was immediately captivated by the simple, burly, jovial artist with his "high lights" (as Maclise calls the knobs of brightness on the tops of his cheeks) (fig. 165), and Stanfield quickly became a lifelong member of the author's inner circle, a friend to be cherished in all seasons. ${ }^{4}$ The proliferation of nicknames over the years testified to the affection between Dickens, the son of a Navy Pay Office worker, dubbed "Philo Forecastle," "Henry Bluff," "Dick," and "Genial Oil" and the former seaman, variously referred to as "Stanfell," "Old Salt," "Old Tarpaulin," "the lad with the tarry legs," and "Messmet."

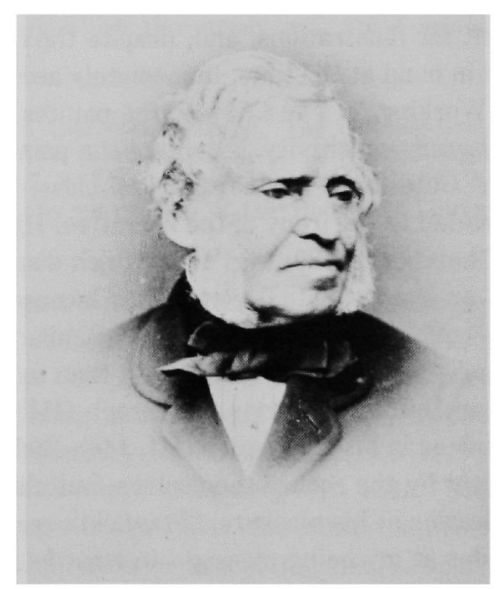

Fig. 165. John and Charles Watkins, Photograph of Clarkson Stanfield. Album of Photographs, p. 40, no. 157, National Portrait Gallery, London. Sepia photograph. $3 \frac{1 / 2^{\prime \prime}}{2} \times 2^{1 / 4^{\prime \prime}}(9$ $\times 5.7 \mathrm{~cm}$ ). By permission of the Trustees of the National Portrait Gallery, London. 
Stanfield, one of Dickens's few pious friends, consistently acted on selfless principles. Although he was very busy throughout the 1840's with his frescoes for the Buckingham Palace garden pavilion ${ }^{6}$ as well as with his Royal Academy canvases, the artist always answered Dickens's calls for help. Whether these summonses were frivolous or serious, Stanfield was heedless of their cost to his dignity, energy, or purse. When Dickens performed magic tricks at a Twelfth Night party in 1843 for his children and his friends, Stanfield's insistence on assisting him in "precisely" the "wrong way" delighted the audience; and at a celebration of the completion of A Christmas Carol in 1844, the artist willingly lent his hat in which Dickens and Forster, conjuring up a plum pudding from an empty saucepan, kindled a fire. ${ }^{7}$ Whenever he was solicited, Stanfield readily accompanied the author to the local Ragged School and the Greenwich Hospital Bazaar and the Sanatorium dinner or worked to help the General Theatrical Fund and the seven destitute children of Edward Elton, the actor, drowned in the Pegasus, and, at a risk to his health, the benefit theatricals. ${ }^{8}$

Indeed, Stanfield's generosity proved problematic for Dickens during their collaboration on four of the five Christmas books, from The Chimes in 1844 to The Haunted Man in 1848. For The Chimes, the Carol's successor, it was decided to increase the number of illustrations from eight to twelve, and-to help Leech, add variety, and attract more readers-use four illustrators instead of one. As an established artist and Dickens intimate, Stanfield was a logical artist to solicit for illustrations, and, despite the numerous works he had in hand at the time, immediately accepted the commission. Working on The Chimes, the painter revealed unexpected literary sensitivity. Adopting the point of view of Alderman Cute and his complaeent class, his two illustrations added to the irony of the narrative. His picture of 'The Old Church' (II, 129) (fig. 166), which dispenses so little charity or even spiritual comfort to inconsequential people like Trotty, is visually elegant. ${ }^{9}$ Similarly, 'Will Fern's Cottage'-more charming to look at than to dwell in, as its inhabitant bitterly informs Sir Joseph (III, 149)-is picturesque indeed in his illustration (III, 148). Dickens was pleased not only by the scenes themselves, but also by the artist's gratification at his pleasure. "Stanfield's readinessdelight-wonder at my being pleased-in what he has done is delicious," he wrote his wife upon his return to London to read The Chimes to him and other close friends (see fig. 156) and see it through the press. ${ }^{10}$

Dickens was upset, however, when the painter refused to accept any payment for his Chimes illustrations. Finally, he

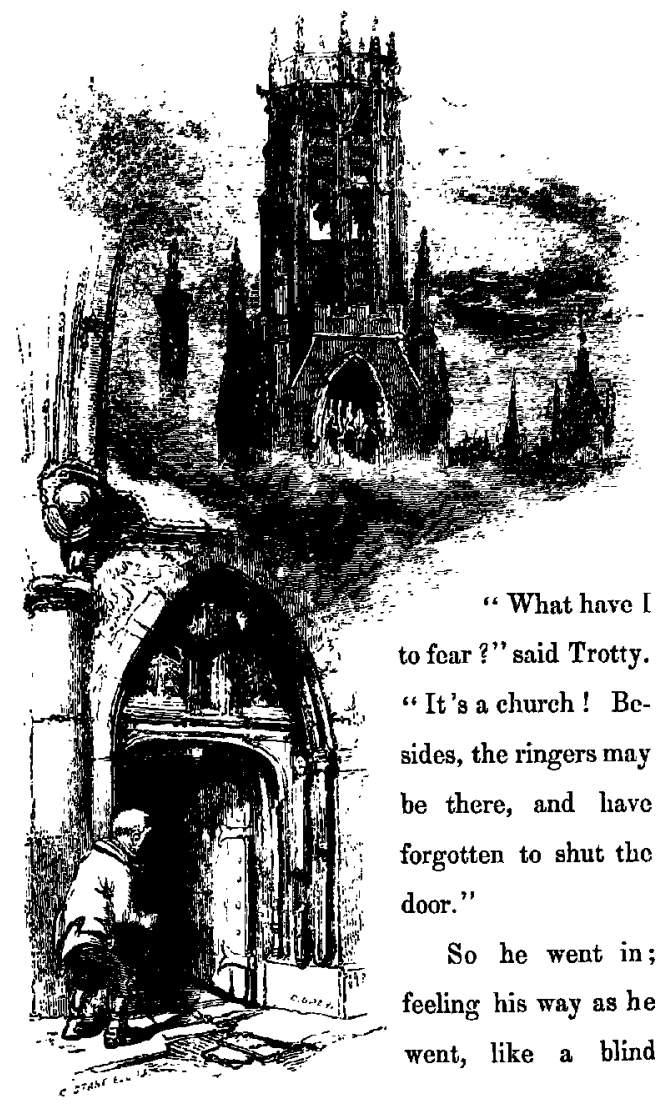

Fig. 166. Clarkson Stanfield, 'The Old Church.' The Chimes (London, 1844), p. 88. Wood engraving. $4^{11 / 16^{\prime \prime}} \times 278^{\prime \prime}(12$ $\times 7.3 \mathrm{~cm}$ ). From the Harry Elkins Widener Collection, by permission of the Houghton Library, Harvard University.

sent Stanfield a silver claret jug (at Bradbury and Evans's expense), inscribed "In Memory of The Chimes," together with a letter saying how much he wanted the artist's help on his next Christmas volume but only if he would consent to accept the publisher's check. If Stanny would not condescend to work on these terms, Dickens said, then he would have to be deprived of his talents. "What a stony-hearted ruffian you must be in such a case," the author concluded his plea. ${ }^{11}$ After similarly confuting the artist's further protests, Dickens knew he could count on him-as he never could on their mutual friend Maclise-to illustrate his next holiday production. ${ }^{12}$

Indeed, it would have appeared ungracious had Stanfield not been included among the artists for The Cricket on the Hearth. Once again, the painter was supposed to contribute 
two illustrations. ${ }^{13}$ Just at the crucial moment, however, he fell ill. The author did not visit his sick friend lest he seem to be hounding him for the illustrations; yet no sooner did Dickens hear that the artist was recovering, than Stanfield himself notified him that his drawing for 'The Carrier's Cart' was finished (I, 190) (see fig. 164). ${ }^{14}$ Dickens was thankful and relieved. He also must have found the drawing with its two panels dramatically effective-its shadows so graphically anticipating the demoralizing effect the unseen passenger above will have on the Carrier's young wife below. Stanfield was anxious to get on with his second subject, which was to head the final section of the story, and Dickens promised to "insert a full-sized Blue Bottle in the ear of the Printer" for neglecting to send him the text. ${ }^{15} \mathrm{Ul}$ timately, however, Doyle assumed the subject, perhaps to leave Stanfield freer to convalesce.

Forster was in charge of enlisting the artists for the fourth Christmas book, The Battle of Life, in 1846, which Dickens wrote in Switzerland and forwarded to Forster in London. Stanfield was, as always, willing to cooperate (even, this time, about the matter of being paid). ${ }^{16}$ If, in the course of doing their Battle illustrations, Maclise tried Forster's patience and Leech tried Dickens's tact, Stanfield inspired nothing but gratitude. His façade for 'The NutmegGrater' inn where Warden reappears to solve the mystery of Marion's disappearance six years earlier, is suitably picturesque and visually reinforces the accompanying nostalgic verbal description (III, 353) (fig. 167). His companion landscapes, entitled 'War' (I, 287) and 'Peace' (I, 291), provide a salutary, if grim, perspective on the improbable love story. "It is a delight to look at these little landscapes of the dear old boy," Dickens confided to Forster. "How gentle and elegant, and yet how manly and vigorous they are! I have a perfect joy in them."17 Even when the book's poor critical reception helped put the rest of the illustrations in Dickens's bad graces, those by Stanfield escaped his censure. ${ }^{18}$

By the time The Haunted Man, deferred in 1847, was advertised for Christmas, 1848, Frank Stone and John Tenniel had replaced the disgruntled Maclise and Doyle, but Stanfield, like Leech, loyally continued as an illustrator. At a conference at the artist's house, Dickens gave the former seaman permission to execute 'The Lighthouse' as one of his two subjects. ${ }^{19}$ Despite the fact that it is not central to the narrative, the stormy seascape proved full of dramatic interest and motion-its curved sails, clouds, and waves contrasting with diagonals of foam, rock, and birds (I, 386) (fig. 168). Stanfield's versatility is evident in his second subject, 'The Exterior of the Old College,' whose spare lines, ordered white spaces, and stark atmosphere appropri-
A LUVE storY.

$12 \pi$

thry seemed profuse of innocent and sparkling mirth, that did good where it lighted, softening neglected

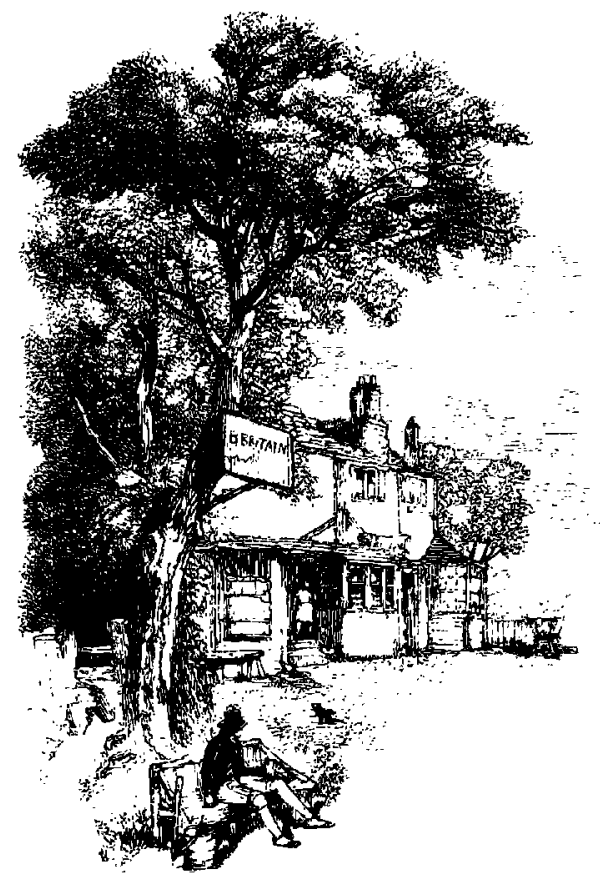

corncrs which the stealy rain could seldon reacl!, aml hurting notling.

Fig. 167. Clarkson Stanffeld, 'The Nutmeg-Grater.' The Battle of Life (London, 1846), p. 127. Wood engraving. $313 / \mathrm{s}^{\prime \prime}$ $\times 23 \mathrm{f}^{\prime \prime}(9.7 \times 7 \mathrm{~cm})$. From the Harry Elkins Widener Collection, by permission of the Houghton Library, Harvard University.

ately suggest the baleful influence of the protagonist Redlaw (II, 441). Moreover, when Leech found himself extremely pressed for time, Stanfield willingly took over and executed the concluding dinner scene in which, as the motto Lord Keep My Memory Green suggests, Redlaw finally accepts the mixed blessings of memory (III, 483). ${ }^{20}$ Still, despite the author's previous protests, the painter apparently could not be prevailed upon to accept payment; Dickens could only acknowledge Stanfield's selfless cooperation by presenting him with a pair of inscribed silver salvers. ${ }^{21}$ Throughout his work on the four Christmas books, Stanfield embodied the benevolent spirit Dickens hoped would "never be out of season in a Christian land" $(C C, \mathrm{ix})$. 


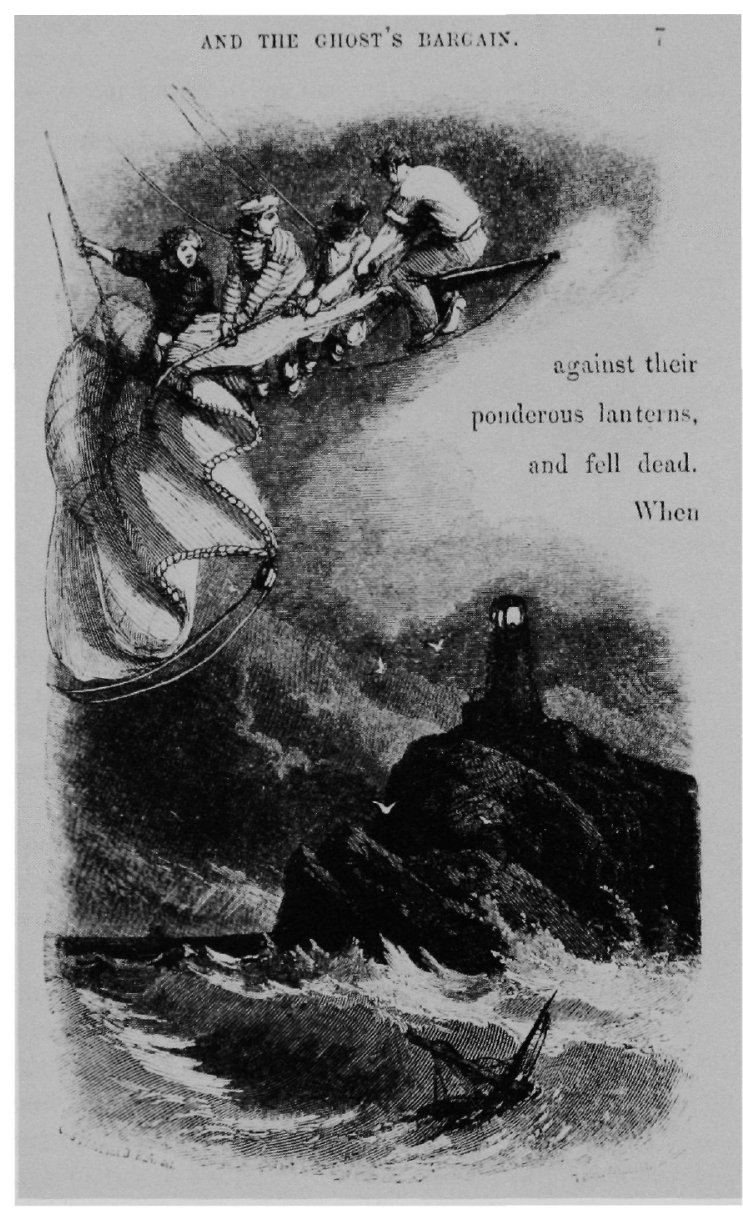

Fig. 168. Clarkson Stanfield, 'The Lighthouse.' The Haunted Man (London, 1848), p. 7. Wood engraving. $478^{\prime \prime} \times 3 "(12.1$ $\times 7.6 \mathrm{~cm})$. From the Harry Elkins Widener Collection, by permission of the Houghton Library, Harvard University.

The religious basis of the painter's selfless spirit, however, probably inhibited him from illustrating Dickens's first European travel book, Pictures from Italy. In 1846 Bradbury and Evans planned to issue in expanded volume form, after their initial appearance in the Daily News, Dickens's "Travelling Letters," which, the Athenaeum observed, revealed "not so much Italy visited by Mr. Dickens as Mr. Dickens visited by Italy."22 The author asked Stanfield, who had traveled and painted throughout Italy and had illustrated other travel books, to provide the illustrations. The artist agreed to provide about a dozen landscape and architectural designs with small figures that his son George would transfer to wood blocks in time for the book's publication in May; perhaps mindful of Stanfield's continuing ill health since The Cricket on the Hearth, Dickens advised the publishers, who were to confirm the number and expense of the wood engravings, not to "overdo the Illustration." ${ }^{23}$

When Pictures from Italy appeared, however, the illustrations were by Samuel Palmer, not by Clarkson Stanfield, whose deepening religious beliefs ultimately prevented him from contributing to it. As David Paroissien has pointed out, when the artist agreed in late February to undertake Dickens's commission, only five of the eight "Travelling Letters" had appeared, three of them about France; when he became a subscriber to the Daily News in early March and noted the increasing hostility toward the Roman Catholic church in the subsequent letters devoted to Italy, he must have felt compelled to dissociate himself from the forthcoming volume. ${ }^{24}$ Stanfield doubtless understood that the author of Barnaby Rudge, which was more anti-anarchy than anti-papist, was not attacking religious faith, devout individuals, or even church ritual, but rather their clerical abuses, which spawned what Dickens called "Catholicity" symptoms of poverty, disease, ignorance, and associated miseries throughout Ireland and parts of Switzerland as well as France and Italy. ${ }^{25}$ Indeed, a month after the publication of Pictures from Italy, the author began work on a version of the New Testament for his children (published in 1934 as The Life of Our Lord). ${ }^{26}$ But Stanfield was persuaded by other considerations of friendship and conscience. He was also friendly with the future Cardinal Wiseman, who was presently trying to restore the church hierarchy in England (and to whom Dickens refers in his introductory apologia to the Pictures) (PFI, 256). ${ }^{27}$ And he himself would shortly convert to Catholicism. Whether this step was precipitated by Dickens's book cannot be known but it was taken just five months after its publication. ${ }^{28}$ The artist understandably must have thought it improper to illustrate a work that would offend so many of his fellow believers as well as his own scruples. Accordingly, he notified Dickens of his withdrawal from this project.

"Of your decision (of course) I have not a word to say," replied the author, whose surprised pain rendered him unusually terse. "You are the best judge whether your Creed recagnizes and includes, with men of sense, such things as I have shocked you by my mention of. I am sorry to learn that it does-and think the worse of it than I did." ${ }^{29}$ This stressful interchange, however, failed to have any lasting negative repercussions on their relationship. Dickens soon began to tease Stanfield about his Papal looks, saints, and missals, while joking about his own and Forster's future conversion to Catholicism. ${ }^{30}$ Stanfield was delighted to 
continue illustrating the ecumenical Christmas books, and the friendship between the two men, firmly based on shared interests and regard, continued unimpaired.

Dickens's other travel book, American Notes, was originally published without illustrations, but for the 1850 edition the publishers wanted a marine frontispiece. ${ }^{31}$ This was morally neutral ground for Stanfield, and he was the natural choice to supply it. Not 'only was Stanfield one of the foremost marine painters of the time, he was familiar with all the stages of Dickens's journey to the New World in 1842. He had helped to plan the farewell and homecoming dinners at Greenwich; he was familiar with the contents of Dickens's letters to Forster and Frederick Dickens from America; he had heard the author elaborate on his trip during their hilarious Cornwall excursion with Forster and Maclise (and presented him with a commemorative sketch of their ascent of Logan Rock) (fig. 169); and he had reminisced about specific events with Lord Musgrave, a fellow passenger. ${ }^{32}$ For the frontispiece, Stanfield decided to portray the S.S. Britannia, the packet ship that had taken Dickens to America eight years before. The rickety vessel was the heroine of the opening chapter of American Notes, which Ralph Waldo Emerson described as "a very lively rattle of that nuisance, a sea voyage, and a pretty fair example of the historical truth of the whole book." ${ }^{33}$ As if to defy the memory of its stormy transatlantic passage, and its ignominious foundering on a Halifax mudbank, the artist showed the ship serenely entering Boston harbor $(A N$, xvi) (fig. 170).

Stanfield's execution of the frontispiece was not without technical trials. First he made a watercolor of the ship and wanted it reproduced in black and white by lithography-a reproductive process involving stone that he thought better than wood for this kind of subject; but, in contrast to their French counterparts, English publishers-and many English illustrators, such as Hablot Browne-still regarded lithography as a cheap copying process, not as an artistic medium in its own right. ${ }^{34}$ Chapman and Hall, clearly unaccustomed to such requests, forced the artist to yield to their preference for familiar reproductive methods using wood. Nevertheless, according to Dickens, who relayed the artist's subsequent complaint to the publishers, "Mr. Stanfield wonders you didn't send him a paving stone to draw upon as soon as a block in this unprepared state. ${ }^{, 35}$ Whatever Stanfield's opinion of the finished frontispiece, his watercolor for it delighted Dickens; (indeed, his pleasure must have obscured for both friends the fact that the former seaman unaccountably placed an American flag on the British ship's mizzenmast). ${ }^{36}$ When the author forwarded it to the publishers to have it copied as best they could, he

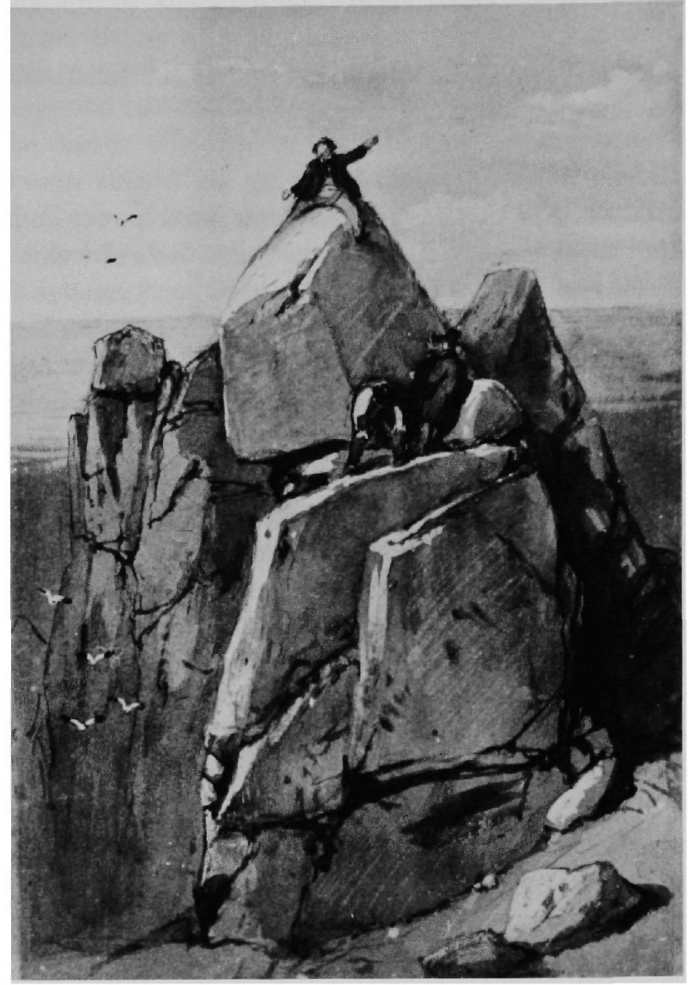

Fig. 169. Clarkson Stanfield, 'The Logan Rock, Cornwall,' 1842. Water and body color on buff paper. $10^{\prime \prime}$ $\times 67 / 8^{\prime \prime}(25.4 \times 17.5 \mathrm{~cm})$. From the Forster Collection (Department of Prints and Drawings), by permission of the Victoria and Albert Museum.

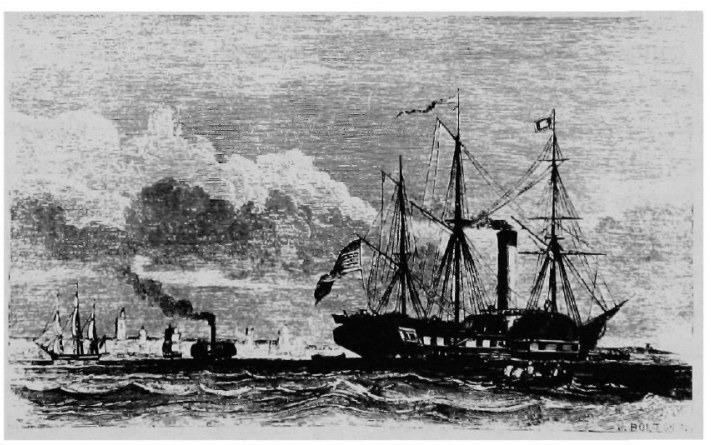

Fig. 170. Clarkson Stanfield, 'S.S. Britannia.' American Notes (London, 1850), frontispiece. Wood engraving after watercolor drawing. $3^{1 / 4^{\prime \prime}} \times 5^{1 / 4^{\prime \prime}}(8.3 \times 13.4 \mathrm{~cm})$. From the Forster Collection (Library), by permission of the Victoria and Albert Museum. 
asked that it be kept "clean" and returned to him as a souvenir of his journey and as a specimen of the work of his friend, who, as so often, refused any compensation whatsoever. $^{37}$

Stanfield apparently found serving his friends its own reward. None of Dickens's intimates worked harder on his amateur theatricals, and few relished all aspects of drama as much. He and Dickens were of one mind when it came to the stage. Indeed, their love of theater was such that it probably would have sufficed by itself to transcend all their other differences in age, religion, profession, and temperament. Both had always been inveterate theatergoers from their earliest meetings, especially when their famous friend Macready was acting. ${ }^{38}$ While on the Continent in the mid-1840's, Dickens particularly missed seeing plays with Stanfield. "When I think of how you are walking up and down London in that portly surtout and can't receive proposals from Dick to go to the theatre, I fall into a state between laughing and crying," wrote the self-exile from Albaro. ${ }^{39}$ Although their mutual distress over the uninspired state of English drama of their day did not diminish their pleasure in theater parties, it did add an intellectual impetus to the primarily charitable justification for Dickens's benefit theatricals.

In contrast to the author, the painter preferred to perform behind the scenes. Invited to play Downright in the opening production-Ben Jonson's Every Man in His Humour-Stanfield, like Maclise, became nervous and resigned the part which, after being rejected by Cruikshank and Cattermole, was played by writer Dudley Costello. ${ }^{40} \mathrm{He}$ softened the effect of his defection, however, with his masterful supervision of the sets and their construction, as well as many of the other practical aspects of production, from moving to accounting. ${ }^{41}$ In these capacities, Stanfield felt completely comfortable. Although he had given up professional scene painting after his 1832 election to the Royal Academy, he still contributed backdrops-always highly praised-for Macready's performances on occasion. His frantic activity on behalf of Dickens's plays also diverted Stanfield from recurring depression, mainly due to pain from injuries from a fall during his Royal Navy days. ${ }^{42}$ Dickens could not help worrying, however, that the strenuous demands of the theatricals and illness might prevent the aging painter from assuming these responsibilities in future performances of his troupe, for indeed he considered Stanfield indispensable. ${ }^{43}$

In one sense, Dickens need not have worried. Stanfield was reliable to the point of self-sacrifice. When, to benefit the Guild of Literature and Art, a group to aid needy artists which both men had helped to found, the company took Bulwer-Lytton's Not So Bad as We Seem on tour in 1851, Stanfield ingeniously executed Dickens's design for a portable stage. The sets, which could be set up or dismantled quickly in any large room without touching walls or ceiling, enabled the company to use concert halls and private salons instead of hiring expensive theaters. ${ }^{44}$ For performances of Wilkie Collins's The Lighthouse in 1855 in the tiny theater at Tavistock House, Stanfield roused himself from a despondent convalescence to paint not only the essential miniature interior flats but, as Dickens wished, a masterful act drop showing the Eddystone lighthouse, which he then presented to the author. ${ }^{45}$ Although illness the following year did prevent the painter from executing the sets for the first act of Collins's next melodrama, The Frozen Deep, he nevertheless insisted not only on supervising those for the remaining two acts, but worked on them himself. ${ }^{46}$ Despite his ailments, a leak that streaked one of his completed scenes, and his degenerating relations with the playwright, he went on working, standing on a plank fixed between two ladders. "Day after day, and night after night," marveled Dickens over a decade later, "there were the same unquenchable freshness, enthusiasm, and impressibility in him, though broken in health, even then" ( $C P, 2: 46)$.

Although George Bernard Shaw later deemed Stanfield a mere "scene painter who appealed to that English love of landscape which is so often confused with a love of art," Dickens shared Thackeray's regret that Stanfield's beautiful sets were constructed of such frail materials. ${ }^{47}$ After the amateur company disbanded in 1857, Dickens ingeniously cut down and hung the painter's drop scenes for both Collins's plays in the former schoolroom theater at Tavistock House. ${ }^{48}$ When he moved to Kent in 1859 , he had them carefully stored in Chapman and Hall's warehouse until they could be framed in imported French glass and rehung near the entrance hall of Gad's Hill. ${ }^{49}$ "To believe them to have been the amusement of a few mornings was difficult indeed," observed Forster, for "seen from the due distance, there was nothing wanting to the most masterly and elaborate art." ${ }^{, 50}$

This project was not Dickens's only manifestation of regard for Stanfield. While the painter labored on the Collins sets in 1855-56, Dickens was working on Little Dorrit. He decided to dedicate this novel to Stanfield ( $L D$, vii), who could hardly refuse this expression of gratitude, and sent him the proofs so he would know the ending before any other reader. ${ }^{51}$ Recalling the artist's unsparing and freely donated efforts on the Christmas books and on the frontispiece for American Notes, as well as on the theatri- 
cals, Dickens understandably found it hard to convey to Stanfield the extent of "the pleasure it has been to me to put your name on the opening page, or to leave behind us both (as I hope its being there, may), a little record important that we loved one another."

Dickens's public declaration of his gratitude to Stanfield proved timely. By the time Stanfield received his splendidly bound copy of Little Dorrit in 1857, he was no longer able to lend a hand to any of Dickens's ventures. Despite his robust appearance, the painter gradually became a chronic invalid, bedridden for longer and longer periods of time. Increasingly, Dickens's domestic upheavals and public readings after 1859 kept him away from London and Stanfield. ${ }^{53}$ Their relationship was more seriously disturbed, however, by Dickens's estrangement from their mutual friend, Mark Lemon, the editor of Punch. As a man of taste, as well as Mrs. Dickens's first representative in the negotiations with
Forster about the separation from her husband, Lemon refused to reprint in his comic magazine the author's account of his marital problems, which had appeared in Household Words and other newspapers. ${ }^{54}$ Despite his long affectionate relationship with Lemon, the author considered his refusal, perhaps insisted on by their mutual publishers, Bradbury and Evans, the treacherous act of a false friend. Stanfield was dismayed at the rift, though Dickens, in bedside visits and letters, tried to assure him that nothing could alienate him from the artist. ${ }^{55}$ After Stanfield died on May 18, 1867 Dickens hastened to honor one of his last requests, by publicly reconciling with Lemon at the graveside.$^{56} \mathrm{He}$ also assisted the artist's bereaved family and delayed printing the June number of his new magazine, All the Year Round, in order to insert a tribute to "The Late Mr. Stanfield" - "the most genial, the most affectionate, most loving, and the most lovable of men" $(C P, 2: 47) .^{57}$ 


\section{Chapter 13}

\section{FRANK STONE}

"My father must have been a remarkable man," declared Marcus Stone, like his parent an artist and a Dickens illustrator. ${ }^{1}$ In 1824, at the age of twenty-four, Frank Stone bravely quit a secure career in the family textile business in Manchester and made his way to London by painting portraits. $^{2}$ Despite his lack of formal training, his appealingly sentimental canvases of lovely ladies and gallant gentlemen attracted attention, and he soon became friendly with many of the most accomplished men of the day. Macready, to whom he was introduced by Cattermole, first thought him a clever artist but a social bore given to tedious argument, but like Thackeray, who met him at Maclise's studio, sensed that Stone would prove a loyal friend. ${ }^{3}$ Dickens concurred, in turn, with each of these judgments. Throughout Stone's involvement in his amateur theatricals, the author suffered him as a bore, but later, when Stone became his next-door neighbor as well as one of his Christmas book illustrators he came to cherish him for the devoted friend he was. If Dickens's friendship with Frank Stone was less intimate than with Leech, Maclise, or Stanfield, its development was steadier and its perpetuation through Stone's son Marcus provided Dickens, in his final years, with ties to his own youth.

It was at the genial gatherings of the Shakespeare Club that Frank Stone-one of its founding members as well as its secretary-got to know the author of Pickwick. ${ }^{4}$ Dickens's fond recollections of this short-lived group (which lasted only from 1837 to 1839 ) prompted him to invite Stone to join many of his social and charitable ventures, above all the amateur theatrical company he was forming in the summer of $1845 .^{5}$ The artist's presence among the "splendid strollers" proved a mixed blessing, however. Not content with merely acting, he put himself forward as an expert on period costumes. Dickens soon complained to Maclise, whose knowledge of costumes he did respect, that Stone's illogical and erroneous criticisms of actors' dress were more irritating than helpful: "isn't it a lamentable thing," he moaned, "that a man should bore one so, and be wrong all the time?"6 Yet the artist meant well. So when Stone begged Dickens to write him a speech to give at Manchester, to which he was returning for the first time since he had left to take up painting, the author willingly obliged. ${ }^{7}$

Dickens felt less obliging, however, when Stone, perhaps frustrated at his failure to have much impact on costumes, tried to widen his histrionic horizons. In addition to roles in the opening Jonson play and its accompanying piece, Comfortable Lodgings, he demanded a part in The Merry Wives of Windsor as soon as it was added to the company's repertoire. Stone's eagerness and his twelve-year edge on Dickens made him particularly hard to deny. "In his damnable impracticality and Bardolphian inquiry," fumed the author, the artist had "settled within himself that Shakespeare, by unconscious predestination, wrote Page expressly for him (Stone) to act, in the year eighteen hundred and forty-seven. For which, may jackasses browse on his father's grave!"8

Indeed, Stone became so preoccupied with his acting that he never did create the "fanciful" something Dickens had requested to illustrate Mrs. Gamp's "Piljian's Projiss." Nevertheless, Dickens had Mrs. Gamp flatteringly describe him as "a fine-looking portly gentleman, with a face like an amiable full moon" (CP, 1: 747-48) (fig. 171). The flattery failed to have lasting effect, however. The following season, during rehearsals for Animal Magnetism, Stone complained that the way Dickens forced him to repeat lines twenty times over if he forgot them once gave him kidney congestion. ${ }^{10}$ The author was not only unsympathetic but exasperated. Yet, as he earlier had explained to friends, he was compelled to put up with Stone who "as an artist (we are 


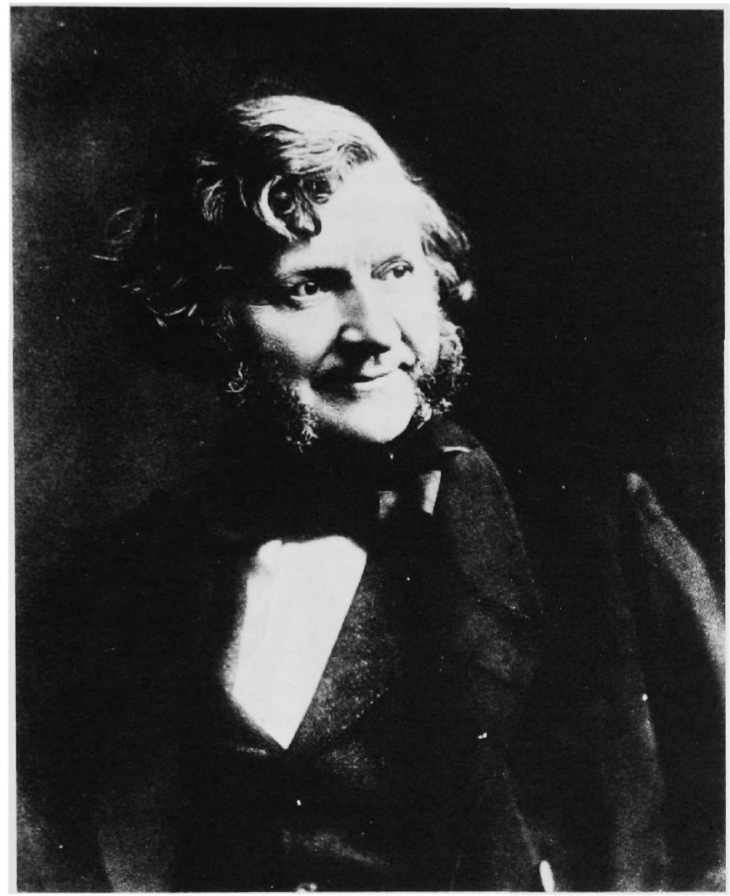

Fig. 171. Artist Unknown, Portrait of Frank Stone. Photograph. 51/8" $\times 4^{1 / 1 / 8^{\prime \prime}}(12.8 \times 10.3 \mathrm{~cm})$. Frederic G. Kitton, Dickens and His Illustrators, plate 49, facing p. 153. From the author's library.

trying to get more artists as we think it very important to the scheme) was too valuable to let go."11

Indeed, it was as an artist that Stone first earned Dickens's respect, then his gratitude, and finally the affection that characterized their later relationship. If Stone's acting afforded the author scant satisfaction, he derived only pleasure from Stone's engravings of Kate Nickleby and Madeline Bray, which were published as extra illustrations for Chapman and Hall's Cheap Edition of Nicholas Nickleby in 1848, and from his frontispiece for the Cheap Edition of Martin Chuzzlewit in 1849. ${ }^{12}$ Indeed, Dickens was so struck by Stone's ability to portray pretty ladies (or female "rococo rustics," as Thackeray called them) that he commissioned him to paint a portrait of Matilda Price, John Browdie's fiancée in Nickleby, and to help illustrate his next-and, as it proved, his last-Christmas book. ${ }^{13}$

Stone met with Dickens and Leech, still the main Christmas book illustrator, to discuss the story of The Haunted Man in $1848 .{ }^{14}$ Predictably, the painter, with his taste for attractive women, was most inspired by Milly Swidger, the redeeming angel in the macabre situation that Redlaw brings on himself by wishing away all memory of the past. The artist made proposed sketches of Milly, ornamenting the dreary college room with holly, assisted by the elderly Philip. Dickens called "CHARMING" the drawing he preferred of Milly standing on the chair rather than the floor (fig. 172), a position that stressed Philip's fragility as did his more notably stooped shoulders. "I cannot tell you how much the little composition and expression please me," the author elaborated; "Do that by all means." 15 In the final print, with its graceful and expressive curves of the old man and the benevolent woman, Stone put a small cap on Milly, who had lost her child, in deference to Dickens's wish that he include that small "matronly" sign (I, 393) (fig. 173). ${ }^{16}$

Dickens, as if making amends for his repressed irritability toward Stone during the theatricals, now overflowed with goodwill. He offered to read the second part of The Haunted Man aloud to Stone if the printer's markings made the proofs too difficult to read. ${ }^{17} \mathrm{He}$ urged him to continue depicting Milly, claiming that he was the only artist who could "really, pictorially, make the little woman whom I love," although he implied that Stone was under no obligation to do so. ${ }^{18}$ The artist duly rendered Milly again, this time graciously ministering to the sulky student Edmund Longford, who is temporarily affected by Redlaw's chilling influence (II, 435). Dickens then displayed unusual trust in the older artist. Writing from Brighton, he described a subject for the third part of The Haunted Man that would suit Stone perfectly. The Tetterbys, left contentious by a visit from Redlaw, recover their good natures from the moment that Milly, to whom the ghost has given the power of restoring memory and, hence, good humor and humanity, approaches their house. She is, as Dickens explained, "the very spirit of morning, gladness, innocence, hope, love, domesticity, etc. etc. etc. etc." 19 The author, expressing the hope that Stone would portray the scene as effectively as he had the others involving Milly, told him he need not bother sending a preliminary sketch for approval: "I know how pretty she will be with the children in your hands," he explained, "and should be a stupendous jackass if I had any distrust of it."20 Inspired by Dickens's obvious appreciation for his work, Stone completed, in record time, a scene charming enough to fulfill Dickens's fondest hopes (III, 469). ${ }^{21}$

The Haunted Man, like its three predecessors, fared better with the public than with the reviewers. Stone, the only artist who escaped their hostility, was, in fact, praised at Dickens's expense. "Were it not that Milly has been rendered 'palpable to sense' by the pencil of Mr. Frank 


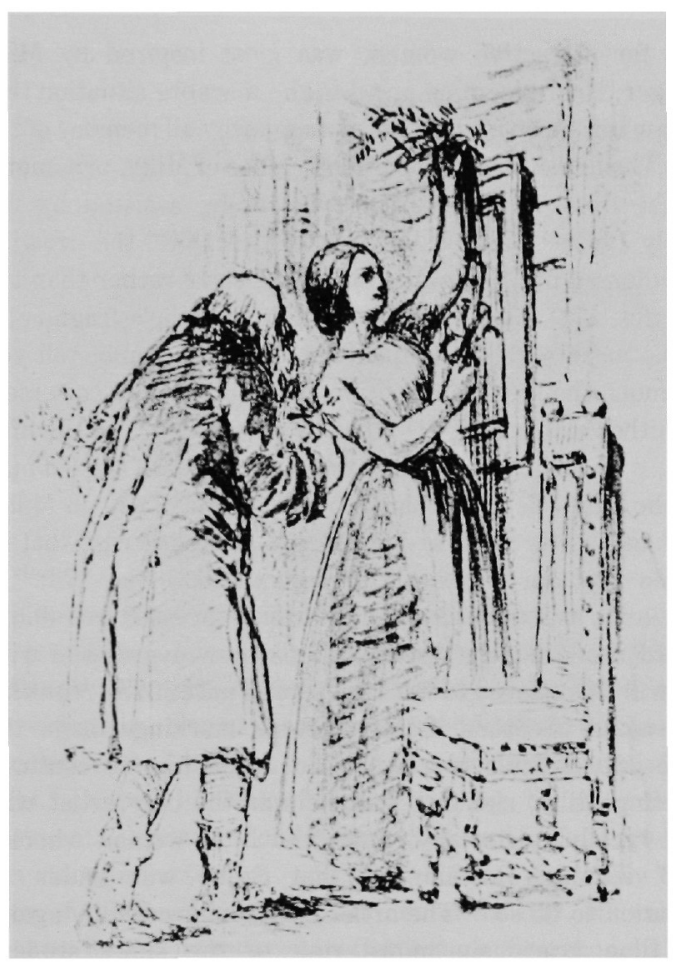

Fig. 172. Frank Stone, Sketch for 'Milly and the Old Man.' Frederic G. Kitton, Dickens and His Illustrators, plate 52, facing p. 176. Pencil and India ink. From the author's library.

Stone," observed the Athenaeum, who felt that Dickens had uncharacteristically failed to individualize his characters, "we should regard her as a quality rather than a person."22 Dickens expressed his gratitude for these illustrations by sending the artist a complete set of his works; abashed to discover later that the set he had sent did not include the Christmas books, the author remedied this deficiency shortly after the New Year at a dinner attended by Stone, which commemorated the last of his holiday volumes. ${ }^{23}$

After 1848 Stone continued to take part in Dickens's amateur theatricals, and his presence continued to be a source of some friction. But the author tolerated his idiosyncrasies with better grace. He listened patiently, for example, to a two-hour harangue from Stone interpreting his role in the production of Poole's farce, Tuming the Tables, in $1850 .{ }^{24}$ When Stone's inadequacies as the Duke in Bulwer-Lytton's Not So Bad as We Seem the following year proved a "millstone" around the company's neck, Dickens rehearsed him privately until he gave the "best" perfor-
AND TIIE GIIOST'S BARGAIN.

glistening burden in his arms, from which the quiet Mrs. William took small branches, which she noiselessly trimmed with her scissors, and decorated the room with, while her aged father-in-law looked on much interested in the ceremony.

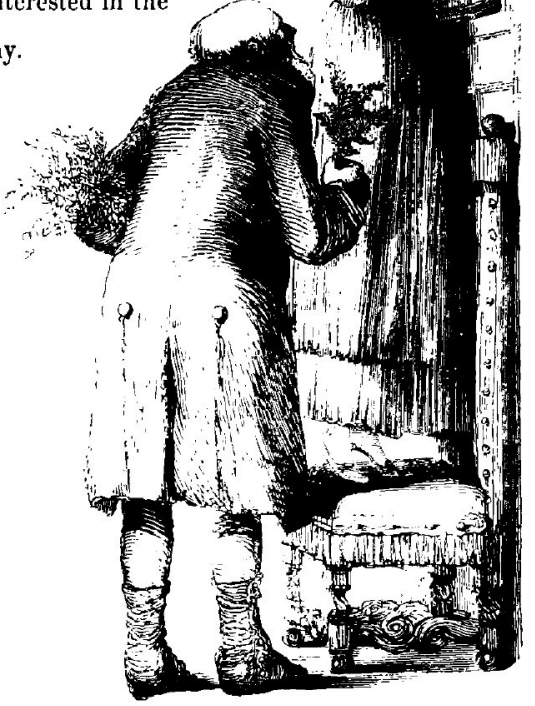

c 2

Fig. 173. Frank Stone, 'Milly and the Old Man.' The Haunted Man (London, 1848), p. 19. Wood engraving. $41 \frac{12}{12} \times$ $25 / 16^{\prime \prime}(11.5 \times 5.9 \mathrm{~cm})$. From the Harry Elkins Widener Collection, by permission of the Houghton Library, Harvard University.

mance of all. ${ }^{25}$ The author's newfound tolerance and coaching were rewarded. When the title role in $M r$. Nightingale's Diary fell vacant at the last minute, Stone took over with sufficient competence to retain the part in subsequent performances. ${ }^{26}$ Dickens did have a tendency to keep mentioning future roles that never materialized, but if Stone was hurt or impatient on that score, he never betrayed his feelings. ${ }^{27}$

After 1851 when they became neighbors, Dickens saw more and more of Stone offstage. After the death of his eight-month-old daughter Dora in April, Dickens sought to 
distract himself and his family by searching for quarters that were larger and freer from memories than Devonshire Terrace. The Stones were also moving-out of Tavistock House and into Russell House next door. After inspecting other accommodations and consulting with Henry Austin, his brotber-in-law who was an architect and engineer, Dickens decided that Tavistock House would suit him, and he authorized Stone to offer in his behalf up to $\$ 1500$ for a forty-five-year lease on it. ${ }^{28}$ The settlement negotiated, the Stones, temporarily homeless, moved into Devonshire Terrace with the Dickens family, who wanted to complete the renovation of their new quarters before moving themselves. ${ }^{29}$ Dickens, with his customary vigor, threw himself into plans to clear the Stones' debris, renovate the structure, and decorate the interior. ${ }^{30}$ When both families settled down in their separate homes, the author's continued proximity to the artist facilitated not only the inevitable conferences about gardening, rights-of-way, and taxes, but the innumerable walks, talks, and dinners Dickens always enjoyed with his close friends. ${ }^{31}$

Dickens's increased pleasure in Stone's company, however, was not wholly dictated by convenience. When away during the summer, at Broadstairs, Bonchurch, or Boulogne, the author often solicited the company of the artist, which he deemed "refreshing." ${ }^{32}$ Indeed, once he was certain of Dickens's affection, Stone became a relaxed and relaxing companion. His onstage pedantry veiled a genuine intellectual earnestness, his nervousness an unusual sensitivity toward others, and he now entered that special category of friends on whom Dickens bestowed playful nicknames. "Pump" (or "Pumpion" or "Old Tone") avidly read each number of David Copperfield, Bleak House, and Little Dorrit on its publication, and was as eager to hear about the writer's public readings as to attend his private ones. ${ }^{33}$ And "Sparkler," as Stone called Dickens, not only inspected the new associate's Academy canvases (apparently even suggesting a title for one of them) but proposed him for membership in the Athenaeum, provided letters of introduction for his Paris visit, lent books from his li- brary, and dutifully read manuscripts submitted by his literary friends. ${ }^{34}$

As the regard between them deepened, Dickens and Stone grew very fond, as well, of one another's children. Taking up where Maclise had left off, Stone adorned tbe walls of Tavistock House with portraits of members of the Dickens family. The author, previously amused by Stone's inclusion of his pet dog Timber in a canvas for the Royal Academy in 1849, appreciated more the artist's portrait of his younger brother Alfred, the pretty sketch of his older daughters. Mamie and Kate, and was especially moved by Stone's oil painting of his fifth son Sydney, nicknamed the "Ocean Spectre," which he felt captured the weirdly attractive look of inquiry in his large eyes. ${ }^{35}$ Stone, for his part, was gratified by Dickens's rapport with his own three children. The author was more paternal than neighborly to little Ellen, who occasionally attended his theatrical rehearsals with her mother (and to whom he once offered six pairs of gloves if she could guess before Mamie or Aunt Georgina which part of a story in All the Year Round was his); to Arthur (who so resembled Wallis's portrait of the dead Chesterton that his father wept on seeing it); and to Marcus, Dickens's particular favorite, who promised to become a better artist than his father. ${ }^{36}$

Throughout this decade of increasing intimacy with Dickens, Stone was plagued with heart trouble, which prevented him from pursuing his work. When, in November, 1859, the artist died, Dickens made good his promise that he would do everything in his power to help Mrs. Stone, from whom the artist was estranged, and their teenage children: he selected a grave at Highgate; arranged the details of the funeral; notified the newspapers; and immediately afterwards, concerned himself with the future of Stone's sons as if they were his own. ${ }^{37}$ Although the artist had not left his family a substantial estate, from the viewpoint of the bereaved, particularly Marcus, he had left "the splended inheritance of the friendship of Charles Dickens - a more precious inheritance than the wealth of a millionaire." ${ }^{138}$ 

The Illustrators of Pictures from Italy and

A Child's History of England SAMUEL PALMER FRANCIS W. TOPHAM 



\section{Chapter 14}

\section{SAMUEL PALMER}

When plans to have Clarkson Stanfield illustrate Pictures from Italy for its publication as a volume in the spring of 1846 collapsed at the last minute, Dickens lost no time seeking a new artist. As he informed the publishers, Bradbury and Evans: "I have thought it best to go to Colnaghi's [art gallery], and ask if they could find me any clever young artist who has been in Italy, and has brought home a portfolio of such sketches as I want. I did so on Saturday and he assures me that he has little doubt of sending some such gentleman to me tomorrow." The name of Samuel Palmer must have quickly come to Colnaghi's mind. The shy, intense landscape artist had spent two years in Italy and often visited the gallery to study the works displayed there as well as to sell his own (see fig. 174). ${ }^{2}$ Palmer exactly met Dickens's criteria and presented none of the problems raised by Stanfield; indeed his past life and work suggested that he might be an improvement in certain respects.

Stanfield, soon to become a Catholic convert, felt unwilling to illustrate a travel book containing a relentless attack on the Roman clergy. Palmer, though equally devout and deeply moved by Catholic ritual and architecture, was a Protestant whose allegiance to the Church of England was only strengthened by his stay in Italy from 1837 to $1839 .^{3}$ From an artistic as well as a spiritual viewpoint, the illustrations for the "Travelling Letters" could not have been placed in better hands. Unlike Stanfield, who was known mainly for his English scenes, Palmer attracted wider notice for his representations of Italian views than for his pastoral native landscapes, now so highly regarded. Ruskin, maintaining that he had never seen a pine nor a cypress properly drawn by anyone except Palmer, would accord him "the very highest place among faithful followers of nature" and Dante Gabriel Rossetti always remained awed by his "landscape power." Whereas Stanfield specialized in large seascapes, Palmer preferred small-scale land-

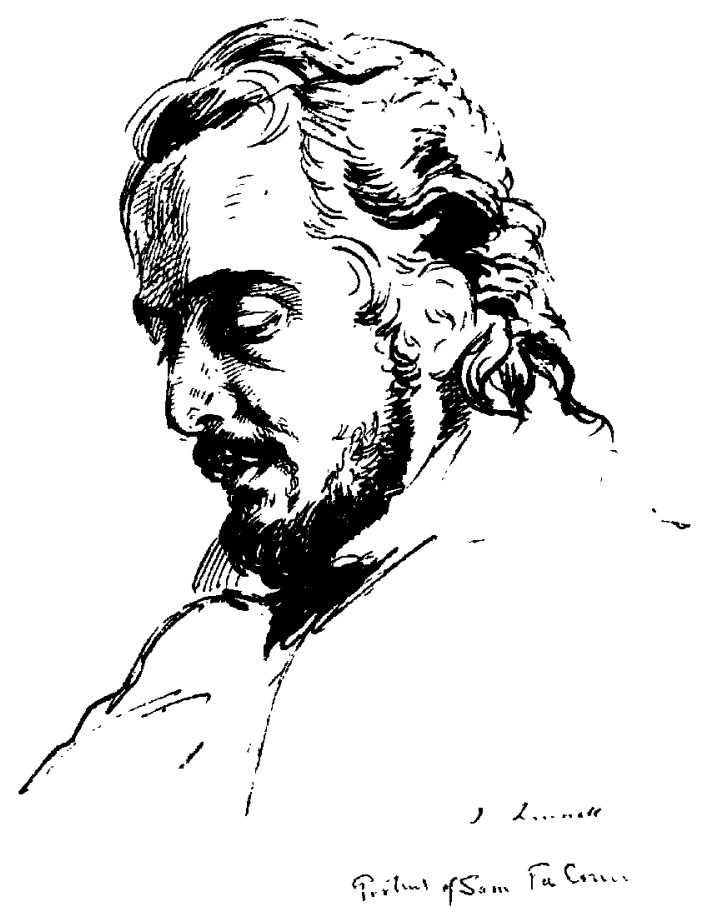

Fig. 174. John Linnell, Portrait of Samuel Palmer. A Loan Exhibition of Drawings, Watercolours, and Paintings by John Linnell and His Circle (London: P. \& D. Colnaghi and Co., January 10-February 2, 1973), plate 29, no. 88. Pen and brown ink. $1234^{\prime \prime} \times 77 / 16^{\prime \prime}(32.3 \times 18.9 \mathrm{~cm})$. By permission of P. \& D. Colnaghi and Company, Ltd.

scapes, which were better suited to book format. Moreover, since the younger artist's work, influenced by William Blake among others, did not appeal to the tastes of the time as Stanfield's did, he needed the money far more than the popular Royal Academician. ${ }^{5}$ Finally, Palmer, a self-styled 
"bookworm," in whose austere life literature and art were the chief pleasures, would be especially pleased by this commission, which Stanfield had doubtless accepted merely to please his friend. ${ }^{6}$ For Dickens's novels were apparently among the few fictional works that the younger artist read aloud to his own family; indeed, his son recalls that he could become so engrossed by the narratives that visitors might be kept waiting until he finished an episode. ${ }^{7}$

Yet Dickens and Palmer had differed radically in their reactions to Italy. At first, the artist, like the author, was homesick; if Dickens longed for London sights and sounds, Palmer missed the quiet English countryside. ${ }^{8}$ But the artist soon became fascinated by the clear light, spacious vistas, and picturesque ruins of Italy, whereas the author became obsessed with its indolence, decadence, and clerical corruption. Palmer, interested primarily in his work, could separate his aesthetic and moral judgments; Dickens, with his overriding interest in people and their institutions, could not. The author left the country with relief, though with new religious and ethnic perspectives that would manifest themselves in The Life of Our Lord, his subsequent re-creation of the New Testament for his children, as well as in the Mr. Baptist and Italian portions of Little Dorrit (1855-57) a decade later. ${ }^{9}$ The artist departed more reluctantly and found his return to cold, colorless England depressing; he could neither recapture his earlier, simpler Shoreham visions nor readily assimilate all the recent lessons of antiquity and the Renaissance. ${ }^{10}$ Dickens, aware only that Palmer knew Italy and was capable of portraying nature accurately, no doubt knew nothing of these difficulties. But if he had been aware of the artist's earlier visionary attempts to portray landscape as an expression of the Creator's mind, he would have appreciated the implicit spirituality Palmer's illustrations might add to the Pictures from Italy.

Dickens contacted Palmer immediately and set up a meeting. The artist, though eager to secure this commission, was inexperienced in the ways of the publishing world. He frantically appealed to John Linnell, his father-in-law as well as artistic mentor.

Mr. Dickens has applied to me to draw on wood vignettes of Italian subjects for a work he is about to publish (which it will be better not to mention until he advertises it as he may not wish it known) - As the time is very pressing he will (should he decide on seeing my sketches this afternoon) send the publishers to me to settle terms etc-If they ask me what I charge I shall not know what to ask-Mr. Dickens says that besides doing the drawings I shall have to oversee the blocks in their progressThey will be about this size [small sketches of a building by a lake and a boat with two figures inside, ca. $\left.2^{\prime \prime} \times 3^{\prime \prime}\right]$ and like those in Rogers' Italy-
I should wish to do them cheaply, but have not a notion about price-If you could give me a gauge by return of post I shall feel obliged \& I will come over and speak to you about it as soon as possible but at present cannot leave-expecting Mr. Dickens at 4 o'clock \& the publishers in the course of the day or tomorrow-The time when he will call is uncertain- ${ }^{11}$

When Dickens arrived at what proved to be their sole meeting, he tried to clarify aesthetic matters. He gave Palmer a memorandum book containing the "Travelling Letters," which had been published in the Daily News and which, with revisions and five added chapters, were to comprise the text of Pictures from Italy. ${ }^{12} \mathrm{He}$ also gave the artist a copy of Samuel Rogers's Italy with its elegant Bewickian vignettes engraved from landscapes by Stothard, Turner, and others; the illustrations to this volume of poetry, which had launched a fashion after their publication in 1822, were in the style Dickens wanted for his own book-small, delicate, and scenic. ${ }^{13}$ The author left all contractual details to the publishers, whom Palmer expected momentarily. ${ }^{14}$ When days passed without a word from Bradbury and Evans, the needy artist despaired; but finally a note arrived from the firm, apologizing for the delay and setting a meeting date. "There seems to have been no hitch-in the illustration business" after all, Palmer hastily informed Linnell; this news had quite "cheered" the artist and "revived" his wife. ${ }^{15}$ Though the publishers apparently reduced the number of illustrations from twelve to less than a half dozen, the twenty guineas for the designs Palmer was to provide for Dickens's book must have been welcome to his struggling household. ${ }^{16}$

Dickens's second travel work, however, like his first one on America, paid little attention to nature for its own sake. The intermittent passages that describe the landscape are as saturated with historical and moral implications as the ones describing prisons and religious festivals $(306,355,415$, for example). And although Paimer's illustrations are capable of standing alone aesthetically as pleasing Italian scenes, taken in conjunction with tbe text, they dramatize inadvertently Dickens's perception of the country as a land of physical and moral decay, unlikely to be regenerated by its political or religious leaders. Though the artist's representations of 'The Street of the Tombs: Pompeii' (438) and 'The Colosseum of Rome' (438) appear separate from the text, not integrated with it like the other two designs, they nevertheless reinforce the author's association of past ruins with the desolation of the present rather than the grandeur of antiquity. Similarly, the cypresses linking the avenue leading toward 'The Villa d'Este at Tivoli, from the Cypress Avenue' evoke their traditional associations with death as well as beauty (436). Only the concluding 'Vineyard 
Scene' (436), a suitable visual accompaniment to Dickens's closing hope that a more noble race might rise from these ruins (434), is wholeheartedly optimistic with its explicit associations of rebirth and renewal.

The published engravings may not reveal to the common reader the difficulties Palmer had with them. Eager for the commission, he did not tell Dickens that he had had little experience working with wood and probably none whatever with commercial engravers; indeed, his designs for Pictures from Italy were apparently the first book illustrations Palmer had ever done on a wood block. ${ }^{17}$ His progress on his first design, that for 'The Villa d'Este,' which Dickens wanted to head his opening chapter, was plagued by the problems of his inexperience. The artist evidently wanted to structure his composition, which had to allow the text to be dropped in, around the highly decorative letter $S$. Dickens,

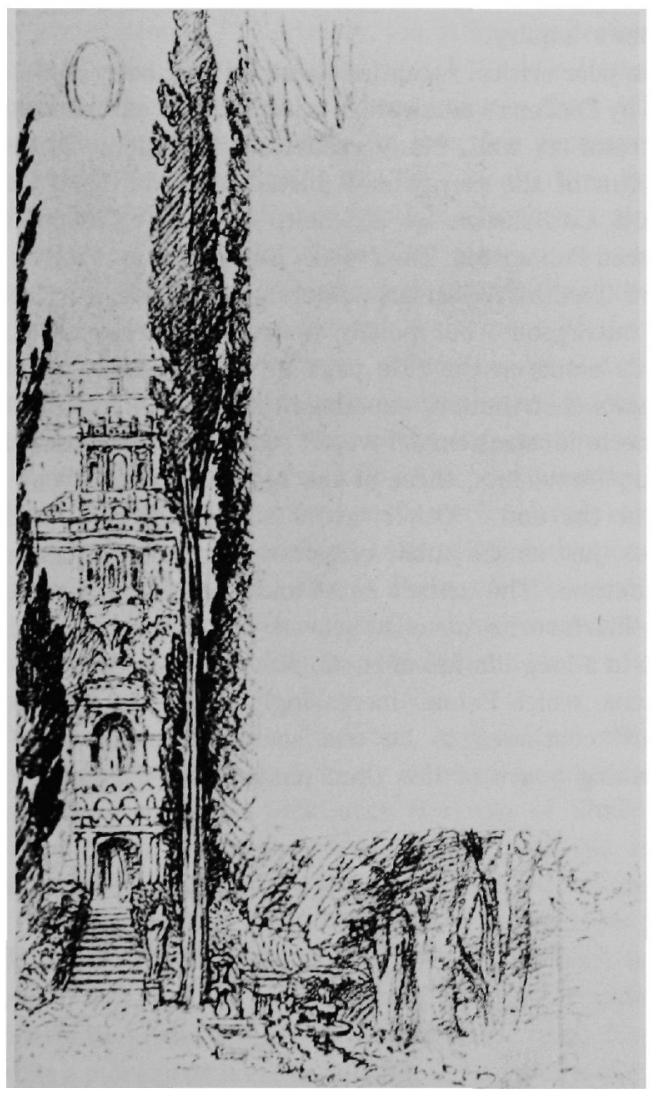

Fig. 175. Samuel Palmer, Sketch for 'The Villa d'Este at Tivoli, from the Cypress Avenue.' Frederic G. Kitton, Dickens and $\mathrm{His}$ Illustrators, plate 55 , facing p. 186. Pencil. $51 / 8^{\prime \prime} \times 3^{\prime \prime}$ $(13 \times 7.6 \mathrm{~cm})$. From the author's library. however, complained: "I am afraid I cannot comfortably manage an S. What do you say to the word 'On'? Could you possibly do that?"18 Palmer tentatively made a sketch using an $O$, but ultimately discarded it (fig. 175). Yet another preliminary portrayal of the villa proved useless because he forgot to reverse the design on the block, as he had to do for it to appear as originally drawn, and he could not adapt it to accommodate the text. ${ }^{19}$ The graceful scene that finally appeared with the unadorned $I$ of Dickens's first word If, subtly reinforced by the soaring cypresses and the slender façade of the villa (436) (fig. 176), betrays no hint of these false starts.

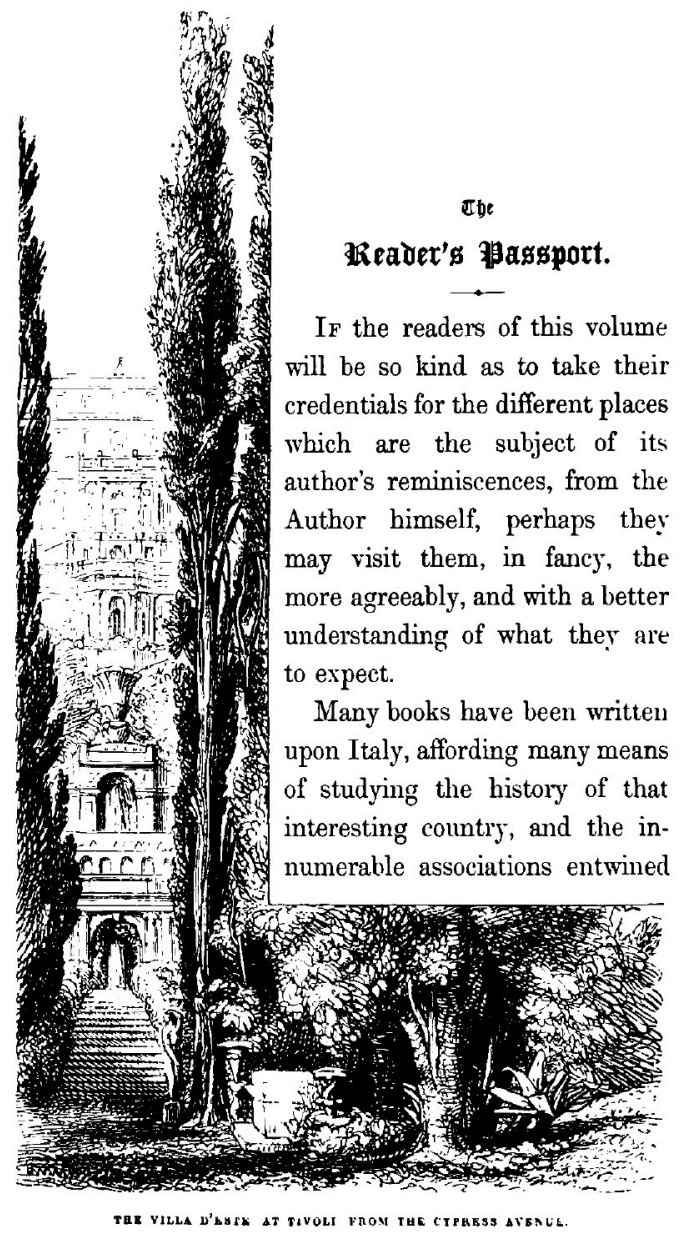

Fig. 176. Samuel Palmer, 'The Villa d'Este at Tivoli, from the Cypress Avenue.' Pictures from Italy (London, 1846), p. 1. Wood engraving. $51 / 4^{\prime \prime} \times 2^{15 / 16 "}(13.4 \times 7.5 \mathrm{~cm})$. By permission of the Houghton Library, Harvard University. 
Palmer's troubles with his illustrations, however, did not end when he designed them, since he was responsible for supervising their engraving. Though he worried that many of his subtle touches would prove untranslatable, he refused to simplify his strokes. Instead he plied the engraver with marginal notes, first on the original drawing and then on the proofs: "I wish the thin cypress to be very much as it appears on the block-not lighter" began a lengthy admonition about the 'Villa d'Este'; and "the top of the cypress is very indistinct, which greatly injures the design" headed a list of thirteen criticisms about the proofs..$^{20}$ Perhaps it was because of this perfectionism that Palmer's design for the 'View in the Campagna,' no doubt intended to illustrate Dickens's climactic account of Rome and its environs (398-99), was never published though it bears his characteristic annotations for the engraver (fig. 177). The artist's meticulous instructions here as elsewhere reveal his naïve optimism. Even an extraordinary engraver-the identity of Palmer's is unknown-would probably not have been able to translate so many minute details with the desired fidelity. As they turned out, Palmer's illustrations for Pictures from

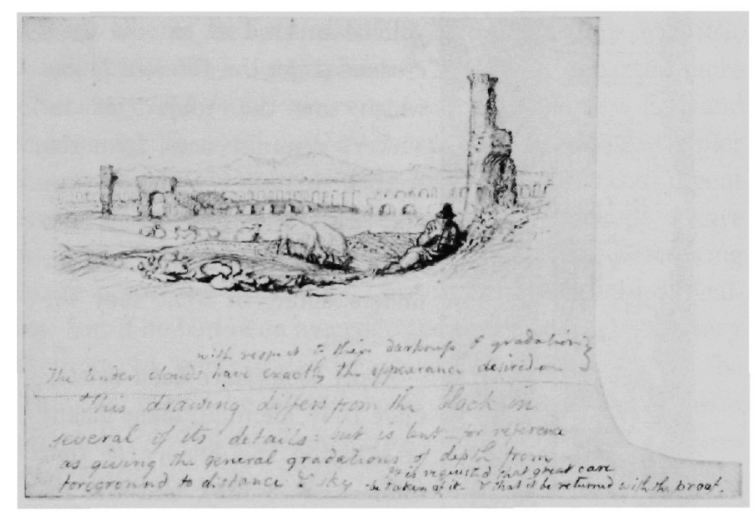

Fig. 177. Samuel Palmer, Unpublished Drawing of 'View in the Campagna.' Graphite. $31 / 16^{\prime \prime} \times 45 / 8^{\prime \prime}(7.8 \times 11.8 \mathrm{~cm})$. By permission of the Pierpont Morgan Library.
Italy are not as inspired as his representations of the same and similar subjects in media that were not dependent on another's hand. ${ }^{21}$

If Palmer was not satisfied, however, Dickens seemed to be, though he was unusually casual about the illustrations with which the artist had taken such pains. Winding up affairs in England, before setting out again for the Continent on June 1, the preoccupied author admitted he had not seen the final designs, but recalling the artist's sketches from their first meeting, he had no doubt "that they are very good."22 Perhaps this nearly total lack of communication with Dickens had prompted Palmer, despite his regrets about the engraving of his designs, to inquire whether his contributions to the Pictures would be publicly acknowledged. The author hastened to reassure him not only that he would "on no account dream of allowing the book to go to press without the insertion of your name in the title-page" but that he himself had placed it there, two days before Palmer's inquiry. ${ }^{23}$

The poor critical reception accorded Pictures from Italy, even by Dickens's admirers, ${ }^{24}$ unfortunately extended to his illustrator as well. Many readers, offended by Dickens's criticism of the clergy and mistaking it for his attitude toward Catholicism as a whole, inevitably, if unfairly, attacked Palmer too. The Dublin Review, co-founded by the future Cardinal Wiseman, understandably called Dickens's text outrageous, but pettily termed the presence of the artist's name on the title page a "miserable catchpenny"; Palmer's contribution, explained the Review, was billed as "vignette illustrations on wood" but proved to be only four "paltry" woodcuts, three at the beginning of the book and one at the end..$^{25}$ Other critics simply ignored Palmer's scenes, just as the public remained indifferent to his art in his lifetime. The artist's brief and impersonal association with his favorite novelist proved yet another disappointment in a long life full of them. Nevertheless, the works of Dickens, which Palmer increasingly alluded to and quoted from, ${ }^{26}$ continued to be one source of pleasure in the remaining years of this then unappreciated genius. 


\section{Chapter 15}

\section{FRANCIS W. TOPHAM}

"I do not know if my father owed his introduction to Dickens to his acting but have an impression that he did," recalled the son of Francis Topham; "Certainly it was the cause of their after intimacy."1 Certainly, too, it was the reason why the artist was invited to illustrate $\boldsymbol{A}$ Child's History of England, which appeared in three volumes from 1852 to 1854 with some revision after its irregular appearance in Household Words from 1851 to $1853 .{ }^{2}$ By the time he met Dickens in 1847, the thirty-nine-year-old Topham, trained as an engraver of printing before he learned to engrave pictures, was a frequent exhibitor of historical and literary subjects at the Royal Academy, a member of the elite societies of watercolor painters, where George Cattermole befriended him, and a popular book illustrator. ${ }^{3} \mathrm{He}$ was also a fine amateur actor. Forster, reviewing anonymously for the Examiner, was impressed by the "considerable force and truth" with which Topham performed one of his roles for the Artists' General Benevolent Institution productions (fig. 178) and probably called him to Dickens's attention. ${ }^{4}$ The author, always looking for artists to join his amateur troupe, subsequently asked Topham to participate in his own benefit theatricals.

Topham accepted with pleasure, and did not complain even when he was cast initially only as an understudy. Amicably enough, he took over the role of Shallow in Scotland when Leech was preoccupied with his baby's illness; replaced G. H. Lewes as Andrew in the accompanying piece, Love, Law, and Physic; and played Nym when Dickens's brother was unable to perform the part in The Merry Wives of Windsor at Birmingham. ${ }^{5}$ After managing competently in all three parts, despite short notice, Topham became a more prominent member of the company. He acted in the 1850 performances of The Rent Day and The Poor Gentleman, and earned Dickens's special praise for his characterization of Mr. Goodenough Easy in Bulwer's Not So Bad as We Seem the following year. ${ }^{6}$ Indeed, Topham proved invaluable throughout the company's northern tour in 1851 and 1852; while offstage, Dickens wrote his wife, the artist had "suddenly come out as a juggler, and swallows candles, and does wonderful things with the poker very well indeed, but with a bashfulness and embarrassment extraordinarily ludicrous." 7

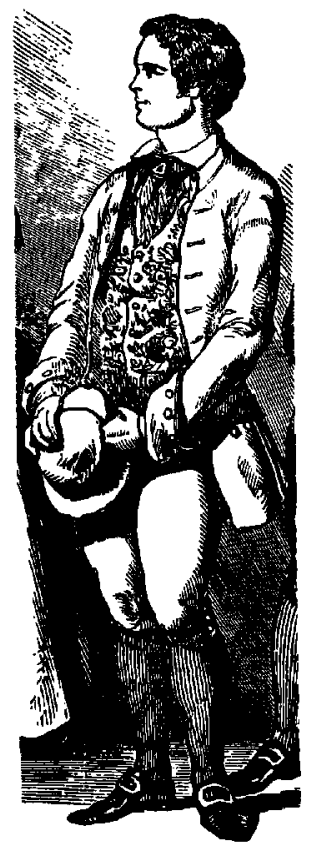

Fig. 178. Artist Unknown, Francis W. Topham. Detail of Mr. Topham as T. Homespun in 'Artists' Amateur Performance of "The Heir-at-Law," St. James's Theatre-The Epilogue.' The Illustrated London News (May 6, 1848), p. 299. Wood engraving. $5^{\prime \prime} \times 91 / 2^{\prime \prime}(12.7 \times 24.2 \mathrm{~cm})$. By permission of the Trustees of the National Portrait Gallery, London. 
Close contact with the author must have inspired Topham to select subjects from Dickens's novels, which he deeply admired, for some of his own works of art. In the autumn of 1848 the artist executed the first of his three watercolor scenes inspired by Master Humphrey's Clock, this one depicting little Nell and her grandfather making bouquets in a tent for the races; three years later he produced (and publicly exhibited) a second watercolor showing Barnaby Rudge and his mother surrounded by children as they pass through her native village; and in $\mathbf{1 8 5 6}$ he finished a third watercolor, portraying little Nell resting in the churchyard and presented it, as he had the others, as a gift to the delighted author. ${ }^{8}$

Perhaps as a result of Dickens's appreciation of the first two watercolors, Topham was invited in 1851 to provide the illustrations for the one work Swinburne, for example, was to regret that Dickens ever wrote. ${ }^{9} A$ Child's History of England, grumbled Shaw in agreement, "had not even the excuse of being childish." 10 The simplified chronicle, written or dictated to Georgina in spare moments during the composition of David Copperfield and Bleak House, was a systematic debunking of English heroes. Dickens viewed these historical figures as men, not idols, and subjected them to the same relentless moral analysis he exercised on the personages he described in American Notes and in Pictures from Italy as well as his fictional characters; few survived with either reverence or honor. The author believed his conclusions valid, if unconventional, and considered his juvenile audience unlikely to question them. Topham's elegant frontispieces, however, bely the crudely oversimplified scholarship to come. They must have delighted Victorian children and allayed the suspicions of the most skeptical parent.

Whereas Dickens intended to shock his readers, Topham hoped to provide them with two gentle visual surprises at the beginning of each of the three small volumes of $A$ Child's History. The artist conceived the idea of printing each frontispiece in "differently tinted inks," a plan that he was "confident" would produce "some new and good effect."11 Dickens presumed the publishers would not object despite the extra expense-each color had to be printed separately-and the black-and-white scenes surrounded by a warm grey-mauve border proved elegant indeed. ${ }^{12}$ Thus, for example, young Marcus Stone, to whom the author gave a presentation copy of the History, opened each volume to find a frontispiece whose border incorporated the same four vignettes: Alfred in the Neather's Cot; Canute reproving his courtiers; the boy-king Edwy and his wife Elgiva; and Eleanor and Fair Rosamonde. ${ }^{13}$ These identical borders, however, surrounded a different central subject in each volume: a young girl reading to her two siblings (cdixlii); young Alfred, the only figure accorded the status of hero in the History, reading aloud to his mother (cdli) (fig. 179); and a mother reading to her child (cdxlv). ${ }^{14}$ Dickens dedicated the book to his own children in the hope that they would be inspired to "read with interest larger and better books on the same subject" (cdxli). Topham's frontispieces, however, as striking graphically as the author's viewpoint was historically, were better received by mature readers, and indeed, they are more sophisticated in conception than the text.

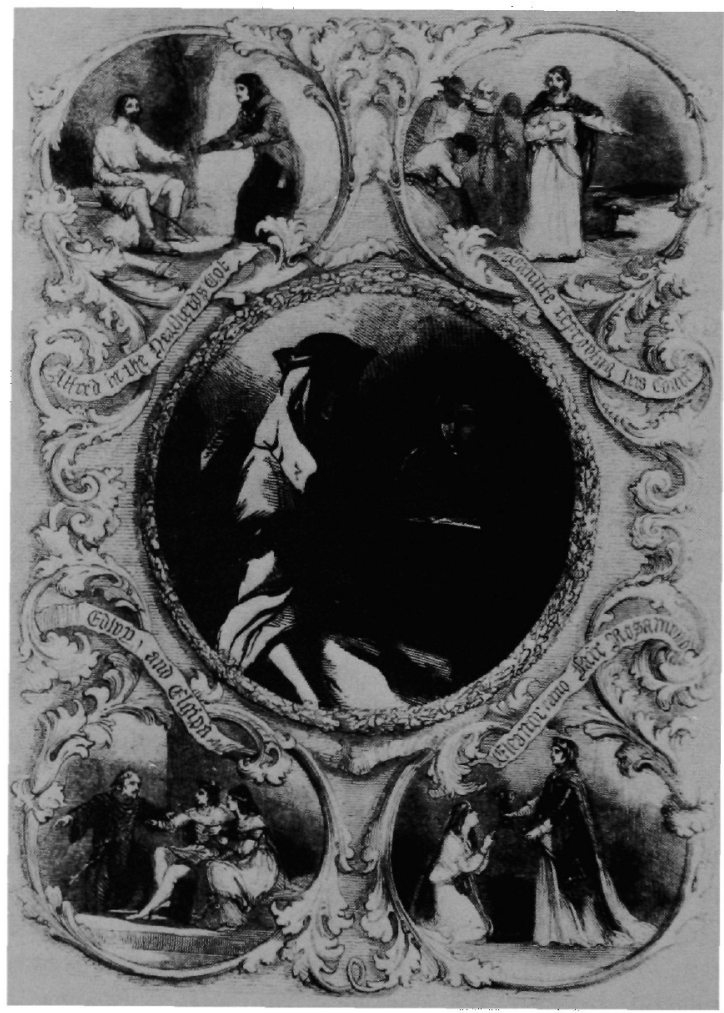

Fig. 179. Francis W. Topham, Frontispiece for $A$ Child's History of England, vol. 2. Wood engraving. 51/2" $\times 4^{\prime \prime}(14$ $\times 10.2 \mathrm{~cm}$ ). From the Harry Elkins Widener Collection, by permission of the Houghton Library, Harvard University.

Throughout this brief and busy period, Topham was becoming a friend as well as a theatrical and artistic collaborator of Dickens; further intimacy with the artist, 
however, was precluded by the artist's subsequent travels to Spain, Ireland, and the Continent after $1852 .{ }^{15}$ Abroad he found scenery and subjects more congenial to his nature than those he had found in England. His subsequent contributions to the exhibitions of the Royal Academy were praised even by such a severe critic as Ruskin for their "delicate feeling and expression," qualities already evident in his three designs for A Child's History of England. ${ }^{16}$ 

The Illustrators of Our Mutual Friend and

\author{
The Mystery of Edwin Drood \\ MARCUS STONE \\ CHARLES COLLINS \\ LUKE FILDES
}





\section{Chapter 16}

\section{MARCUS STONE}

Frank Stone's son Marcus was the illustrator of Dickens's last complete novel, Our Mutual Friend, published in 1864. It was the first time since $A$ Tale of Two Cities five years before that Dickens had had a novel illustrated for its first appearance. Although illustrations were no longer essential, as the common reader was far more literate and sophisticated than his counterpart at the time of Pickwick nearly three decades earlier, Dickens continued to want them, partly from habit, partly from a continuing belief in their efficacy ( $C P, 2: 444)$. However, he wanted them to be done by an artist who would bring new, fresh styles of observation and representation. With young Marcus Stone close at hand, he did not have to look far to find a successor to Hablot Browne. Bound by personal as well as professional obligations, the young artist would accede to Dickens's control while updating the look of his illustrations. The author's choice of Stone was not, as has been suggested, due to his insufficient awareness of new developments in art. ${ }^{1}$ But he disliked the doctrinaire standards preached by those betterknown representatives of the new aestheticism who had invaded the whole field of book illustration; John Millais, Arthur Hughes, Holman Hunt, and Dante Gabriel Rossetti, for example, would not have been willing to subject themselves either to Dickens's brand of supervision or to the Hogarthian traditions that his prose still perpetuated. For many readers, perhaps, the novelist's more sustained interest in psychological characterization in Our Mutual Friend, together with the continued visuality of his prose, rendered Stone's illustrations even more superfluous than Browne's most recent ones. But there is scant basis for the recent assertion that Dickens had lost interest in illustrations generally and in those for Our Mutual Friend in particular because Stone did not illustrate in the manner of Browne at his best. ${ }^{2}$ On the contrary, Dickens, until the last few numbers, participated as actively as he could in this collaboration, certainly more so than in A Tale of Two Cities, for example, and succeeded in eliciting from Stone the new look he had hoped for.

Young Stone was very excited about the chance to work for Dickens, a turning point in his career. As the son of a friend and next-door neighbor, he had known Dickens since he was a young boy. He never forgot the first time he had met the novelist. His hands, dirty from puttering around his father's studio, had nevertheless been warmly clasped by the famous author. ${ }^{3}$ When he was twelve years old, a scene from Bleak House-the description of little Jo sweeping the entrance to Nemo's burial ground-inspired his first attempt at book illustration. While he was sketching the scene, Stone long remembered, his father entered the room with the author: "Well now, that is very good; you will have to give that to me when it is done," Dickens observed. ${ }^{4}$ Marcus accordingly delivered the finished drawing next door to Tavistock House. Dickens was sincerely impressed by his instinctive sense of decorum as well as empathy for the subject. The author paid the boy the further compliment of sending him Browne's proof of the same subject for a keepsake and, later, an inscribed copy of $A$ Child's History of England in remembrance of the sketch that the author had "received (and preserved) with great pleasure." No one anticipated, however, that within a decade young Stone would succeed Browne as Dickens's illustrator (fig. 180).

Dickens, fulfilling his promise to do everything in his power to assist Frank Stone's family after his death in 1859, acted in loco parentis to his three children, especially Marcus. ${ }^{6}$ He persuaded them to remain at Russell House, despite his own departure from Tavistock House for Gad's Hill in Kent, in 1860, arguing that it would save money in the long run since more people would come to see Marcus's pictures in the place where they were accustomed to see 


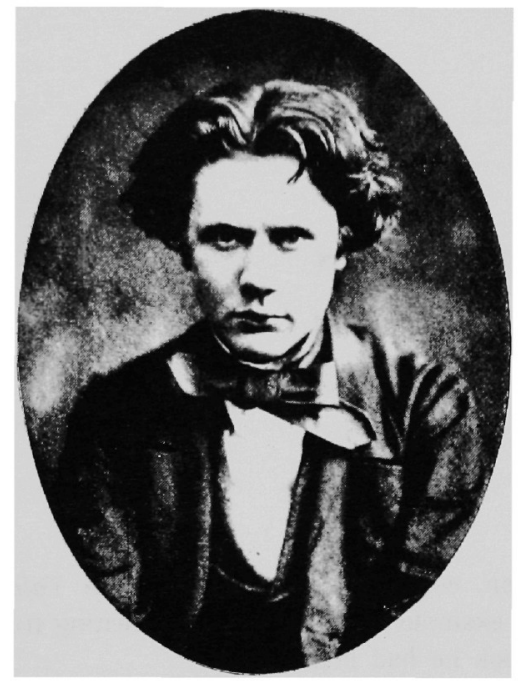

Fig. 180. Artist Unknown, Marcus Stone, 1856. A. L. Baldry, The Life and Works of Marcus Stone, R. A. (London: The Arts Journal Office, 1896), p. 9. Photograph. $3^{\prime \prime} \times 2^{1 / 4^{\prime \prime}}$ oval $(7.6 \times 5.7 \mathrm{~cm})$. Courtesy of the Boston Athenaeum.

his father's; and he explained both to Marcus and to the skeptical men sponsoring his membership to the Garrick Club that it had been Frank Stone's intention that his children, some of whom were illegitimate, should live apart from their mother after his death. ${ }^{7}$

The Stone children were as welcome in Kent as they had been in London. ${ }^{8}$ Marcus, particularly, availed himself of Dickens's hospitality, spending many Christmas and summer holidays at Gad's Hill. The author's children always relished Marcus's company, despite his increasing deafness. ${ }^{9}$ They had remembered with delight his acting in the private performances at "The Smallest Theatre in the World" at Tavistock House; now they prized his skill at drawing portraits (see fig. 187) and celebrated his feats at games in their Gad's Hill Gazette.$^{10}$ If they regarded Marcus as a brother, their father treated him as a son. ${ }^{11}$ Indeed, he often seemed to prefer his company to that of his own boys, whose achievements (except for those of Henry Fielding, his youngest son), he found disappointing. Time only strengthened Marcus's conviction that Dickens was the finest man he had ever known as well as the most "formative influence" in his life. ${ }^{12}$

Dickens had always followed and promoted Marcus's artistic progress with great interest. When, in 1859, at the age of nineteen, after an informal training in his father's studio, he had a painting of an armored knight resting under a tree accepted for exhibition by the Royal Academy, Dickens displayed almost as much pride as his father ${ }^{13}$ But Frank Stone's death in the autumn of the same year left Marcus little time to rest on his laurels. Within a week of the funeral, the author had called Marcus to the attention of prominent publishers as an "admirable draughtsman" with a "most dexterous hand, a charming sense of grace and beauty, and a capital power of observation" who was in every way "modest, punctual, and right." 14 On Dickens's recommendation, Chapman and Hall asked Marcus to contribute the frontispiece to the Cheap Edition of Little Dorrit, though he then had no experience with wood engraving techniques. ${ }^{15}$ In 1862 he received a commission to supply supplementary scenes for the Library Editions of American Notes, Pictures from Italy, and A Child's History of England; and, far more important, he received the assignment to provide the first illustrations for Great Expectations for its publication in volume form. ${ }^{16}$ These assignments, like the frontispiece Stone was commissioned to do for the Cheap Edition of A Tale of Twa Cities in 1864, were the kind that might previously have gone to Browne. Dickens, though Stone worked independently of him, must have liked the results. For by the time Our Mutual Friend was announced in 1864, even Browne was able to predict that Stone would be its illustrator. ${ }^{17}$

Stone always insisted that Dickens decided to drop Browne long before he thought of a successor for him. ${ }^{18}$ Nevertheless, the gifted son of his old friend was an inevitable choice for Dickens to make for professional as well as personal reasons. Stone, who had no ties to the Hogarth-Cruikshank-Browne tradition, would not revert to their outmoded styles, which suited the author's desire for novelty in his work as in his life. Thanks to the commissions procured for him by Dickens, the twenty-four-year-old by that time had become a fairly experienced book illustrator. He was familiar with the wood techniques that were so popular with the new artists of the 1860's and that had displaced the etchings on steel at which Browne excelled. Unlike Dickens's early illustrators, who tended to draw from memory, Stone worked from models, and his naturalistic portrayals of characters suited the academic tastes of the times. Most important, perhaps, of all, Dickens knew that the young man, so indebted to him, would not question his authority. Fully aware of how valuable the association with Dickens would be to his career, however, young Stone would nevertheless bring enthusiasm and freshness to the collaboration, qualities conspicuously lacking in Browne's last illustrations for the novelist.

Both author and artist were gratified when their professional relationship worked out as pleasantly as their social 
one. Dickens exercised control with paternal tact and interest. Stone not only accepted direction well but never abused the increasing amount of freedom Dickens allowed him. The author supervised his work closely at first, concerned that the wrapper design set the proper tone for the book. "Give a vague idea, the more vague the better," urged Dickens, who as usual wanted the comprehensive design to suggest but not reveal his complex plot. ${ }^{19}$ Despite his own frenetic schedule, Dickens conferred at length with Stone, displaying an unabated interest in every aspect of the cover from subject to layout. He praised the artist's preliminary design, which did not depart sharply either in arrangement or feeling from those by Browne (fig. 181) ${ }^{20}$ Stone had surrounded the title with generalized vignettes from the narrative, and appropriately surmounted it with a wide panorama of the Thames, which figures importantly as both setting and symbol in the narrative (and whose appearance and disappearance in the novel, Swinburne observed, coincided with the "ebb and flow" of the author's genius). ${ }^{21}$ With a "business" view to optimum legibility, however, Dickens wanted the first word of the title, OUR, each letter of which Stone had awkwardly placed between the supports of the triple-arched bridge, to be brought out into the open and made as large as MUTUAL FRIEND. ${ }^{22}$ With a view to the narrative, the author thought the inclusion of both the Inspector and the murder reward poster redundant, their significance being sufficiently suggested in the sinister moonlit view of the river. ${ }^{23}$ With a view to aesthetics, Dickens wanted the figure of the skeletal dustman, whose face he wished more "droll" and less "horrible," to be relocated on the right-hand side of the cover; the resulting space under the title might be filled with the "capital" scene of the unscrupulous Wegg reading Gibbon to the illiterate Boffin. ${ }^{24}$ It was left to the artist, however, somewhat to his surprise, to decide for himself which of Wegg's legs would be the wooden one; Stone chose the left limb. "With these changes, work away," Dickens cheerily concluded his numerous but perceptive and tactful suggestions. ${ }^{26} \mathrm{He}$ implicitly understood his young friend's predicament in executing for the first time a complex wrapper for a complex narrative as yet largely unwritten. He pronounced Stone's altered wrapper design "excellent" and worried more than the artist himself about how the Dalziels would engrave its delicate lines (see F). ${ }^{27}$ The color of the wrapper was once again green-the author's favorite color-as it had been up to the publication of Bleak House - which seemed to mark Dickens's hopes for renewal in every particular of his present life and work.

Dickens was soon prevented by the demands on his time and dwindling energies from continuing to exercise such

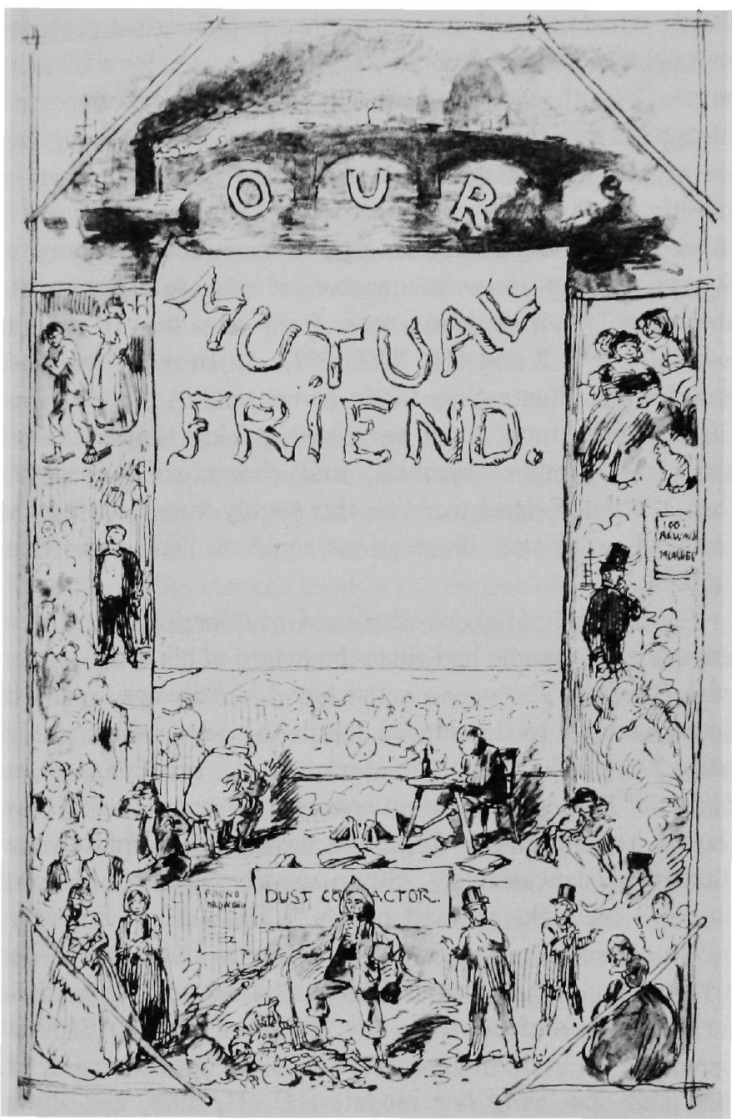

Fig. 181. Marcus Stone, Sketch for the Wrapper of Our Mutual Friend. Black ink and wash. $45 / 16^{\prime \prime} \times 3^{3 / 4^{\prime \prime}}(12.5 \times 9.5$ $\mathrm{cm})$. By permission of the Henry W. and Albert A. Berg Collection, The New York Public Library, Astor, Lenox and Tilden Foundations.

close supervision; yet the kinds of latitude he allowed Stone in the course of Our Mutual Friend reflects neither negligence nor indifference, but rather understandable trust, partly necessitated by unavoidable absences. ${ }^{28}$ His young friend was so totally dependent on the author's patronage and so free from the pressures that plagued Seymour, the vanity that tormented Cruikshank, and the competing commissions that sometimes impeded the efforts of Browne and the Christmas book artists, that Dickens must have felt he could give him certain procedural freedoms, knowing they would not be abused. Moreover, this attitude may partly reveal the author's recognition that illustrations were more ornamental than integral to Our Mutual Friend. For the first time since Master Humphrey's 
Clock, wood engravings-now more popular than etchings on steel for illustrated books-were being used for a Dickens novel. Yet the engravings, like the etchings, were not "dropped" into the text, but placed before it, thus foregoing the myriad advantages of placement that had functioned so effectively in the Clock more than two decades earlier. Indeed, the simple, linear frames surrounding many of Stone's scenes-over a quarter of the total-seem to emphasize their separateness from the text (see, for example, I, I, 2 and III, XVI, 697). As Browne doubtless found while illustrating Little Dorrit and A Tale of Two Cities, Stone must have perceived quickly that Dickens's wasteland themes, symbols, and characters throughout Our Mutual Friend were so thoroughly visualized by the pictorial prose that illustrations could do little more than embellish.

Yet certainly Dickens displayed greater involvement in Stone's task than he had since the height of his collaboration with Browne. The young artist found him always "ready to describe down to the minute details the personal characteristics," indeed "the life-history of the creations of his fancy."29 Following their procedure on Great Expectations, though one unique to Dickens's novels being written and illustrated concurrently, Stone usually selected his own subjects from the revised proofs. ${ }^{30}$ The author, however, never completely abrogated his power in this sphere. The artist invariably accepted Dickens's frequent suggestions for subjects, such as those for "The Bird of Prey Brought Down' (I, XIV, 195), Jenny admonishing her father (II, II, 269) and observing her models (III, II, 492), and Boffin digging up 'The Dutch Bottle' (III, VI, 552). ${ }^{31}$ On at least one occasion, Dickens opposed Stone's selection, objecting judiciously to his showing two interiors, each containing two people, in the same number (III, XII, 636 and III, XIV, 658 ), but it was probably too late for the artist to prepare another scene. ${ }^{32}$ Finally, the author, except when abroad, always inspected Stone's preliminary sketches, penciling any suggestions in the margin, and always wrote out the titles to be used under the final engravings (see fig. 185). ${ }^{33}$ The artist's unquestioning acceptance of his wishes, however, did enable Dickens to waive the right of inspection and approval of the final.drawings, which were accordingly dispatched by the artist direct to the engravers. ${ }^{34}$

At no point during the course of the novel, however, was Dickens's response to Stone's sketches either enthusiastic or casual in any indiscriminate way. He dispensed judicious amounts of both encouragement and correction to his young protegé. He might praise Stone's sketches for 'Podsnappery' (I, XI, 147) and 'Waiting for Father' (I, XIII, 183), as well as his portrayals of Gaffer lying dead on the windy shore (I,
XIV, 195), and of orphan Johnny "fishing" from his front door (I, XVI, 219), but he often found room for improvement. ${ }^{35}$ His admiration for the scene of Gaffer lying dead, for example, did not blind him to the fact that Mr. Inspector should not be wearing a constable's attire, and he would not give his unqualified approval for 'Miss Riderhood at Home' (II, XII, 399) until Rokesmith's false beard looked more disheveled. ${ }^{36}$ Finally, the author, accustomed to Hablot Browne's small figures, had trouble getting used to Stone's larger, more anatomically correct ones, but clearly allowed him to follow this currently fashionable perspective. ${ }^{37}$

Although Stone was strong where Browne had been deficient, the reverse was also true. Dickens's most disturbing problem with Stone was his difficulty in representing the novel's grotesque characters who were congenial neither to the artist's personal tastes, which tended towards the romantic, the domestic-in short, the conventional - nor to the academic realism of his peers. The author had to press the artist until he captured the "weird sharpness not without beauty" of Jenny Wren, whose treatment of her father epitomizes the inverted parent-child relations in Dickens's fiction in general and in Our Mutual Friend in particular (II, II, 269) (fig. 182). ${ }^{38}$ Similarly he needed to insist that Boffin's eccentric "Progress" through town in his new finery convey "an oddity of a very honest kind" that would prove endearing rather than repulsive to viewers (I, IX, 115). ${ }^{39}$ Yet Dickens's heavyhanded titling of the scene of the writhing Headstone, 'Better to be Abel than Cain' (IV, VII, 806), despite Stone's placement of a plainly labeled "Cain and Abel" picture on the wall, suggests his ill and distracted spirits after the frightening railway disaster at Staplehurst rather than any yearning for Browne's iconographical or "dark" brand of illustration. Browne at the peak of his imaginative powers doubtless would have conveyed with greater relish the morbid and grotesque: Jenny and Boffin; the dust heaps and the weir. He would have eked out far more mystery from scenes like 'More Dead than Alive' (II, XIII, 418), and far more picturesqueness from scenes like Mr. Venus's shop (the prototype for which Stone himself had discovered), ${ }^{40}$ and even, perhaps, some humor from the basically grim narrative. Perhaps Dickens, like his society in general, valued these qualities less in his maturity; and certainly the younger illustrator was more reliable than Browne might have been at capturing the myraid moods of the pretty Bella (II, VIII, 345 (fig. 183); II, XIV, 441; IV, XIII, 879 (fig. 184)), delineating the Podsnaps, Veneerings, and Lammles with compassion rather than caricature (I, X, 137 and I, XI, 147), and imparting a sense of reality based on careful study of settings, as Kitton has noted, like the Thames background in the 'Bird of Prey' 


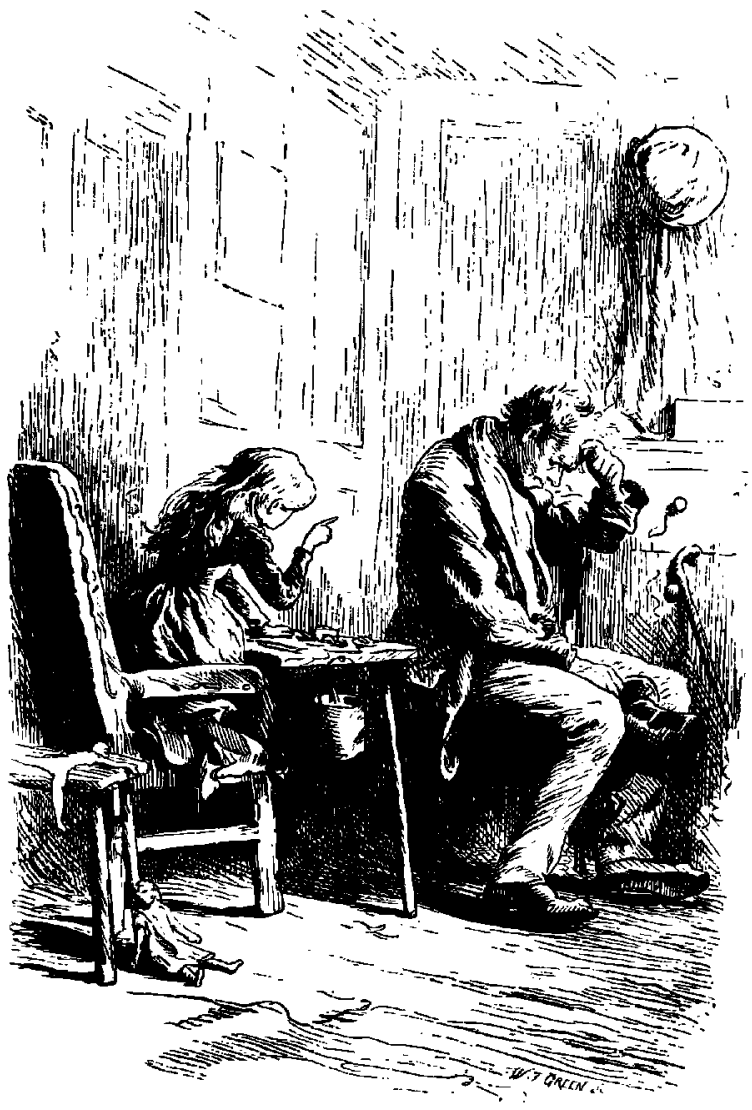

Fig. 182. Marcus Stone, 'The Person of the House and the Bad Child.' Our Mutual Friend, no. 6. Wood engraving. 53/8" $\times 3^{11 / 16^{\prime \prime}}(13.7 \times 9.4 \mathrm{~cm})$. By permission of the Houghton Library, Harvard University.

(I, XIV, 195) and the Regent's Canal lock-gates in 'Not to be shaken off' (IV, XV, 905). ${ }^{41}$

The spirit of cooperation that had characterized the relationship between the author and the artist from the beginning of Our Mutual Friend smoothed the trying period of the novel's conclusion. In June, 1865, the author, along with parts of his manuscript, in eerie keeping with its theme of death and resurrection, miraculously escaped annihilation when a train he was on derailed at Staplehurst, killing and maiming many of its passengers. Exhausted from his heroic rescue exertions and enervated by his own narrow escape from death, the author retired to Gad's Hill. Stone now had to send his sketches to him there and endure the resulting delays; he also had to cope with Dickens's last-minute change in the story-Wrayburn was not originally intended to survive Headstone's attack. ${ }^{42}$ Finally, when the shaken author went abroad to recover, Stone was left completely on his own with regard to the last four illustrations; the author could not even inspect his preliminary sketches. ${ }^{43}$ On this note of well-placed trust, partly born of necessity, Dickens wound up the final double number of his last complete novel.

Contemporary reviewers, perhaps sated by illustrations in the numerous graphic magazines that had sprung up in the 1860 's, failed to comment either on the absence of Browne's work or on the presence of Stone's in Our Mutual Friend. The artist's naturalistic illustrations, in any case, were not calculated to arouse readers or even to add dramatic interest or commentary independently of the text. Then, too, his drawings do not seem as suited to the engraving process as did those of his predecessor, Browne, or his successor, Fildes. ${ }^{44}$ For example, the engraver, given the stiff parallel strokes used in the figures of Fledgeby and Riah and the undifferentiated wash suggesting the sky in the background of Stone's drawing for 'The Garden on the Roof,' apparently was forced to provide varied lines to delineate the two men and some pattern, by means of smoking chimneys, to define the view (II, V, 312); and faced with the sketch for 'Eugene's Bedside' (fig. 185), he could further define the characters' faces-Jenny's cheek or the Reverend Milvey's features-but could do little to further differentiate the various whites of the patient's face, hands, garments, bed coverings, and hangings, and nothing to invigorate the static portrayal of a gripping climax (IV, XI, 849) (fig. 186). Accordingly, Arthur Waugh's assessment of the illustrations is typical: "Whatever the technical quality of Marcus Stone's designs, they do not take hold of the imagination; they are not easily remembered; the characters they portray are not vividly created; the old 'elfin' enchantment is gone." ${ }^{\prime 55}$ This judgment, characteristic of those who prefer the work of Cruikshank or Browne, may not have been shared by Dickens. Young Stone, while acting the perfect subordinate, had indeed given the author's book an updated look with his more realistic figures. If Dickens was displeased with Stone or with his published illustrations, he never revealed his dissatisfaction-though it must be admitted that his personal fondness for Stone might have inhibited him.

After the publication of Our Mutual Friend Dickens felt drained. In the next years, his readings, editing tasks, and a second trip to America prevented him from beginning another long novel. Marcus Stone, even after his marriage, continued to keep the author company in and out of London, and when he was not available for long periods Dickens missed him greatly. ${ }^{46}$ Throughout this decade, when many of the author's friends were dead or dying, Stone enlivened 


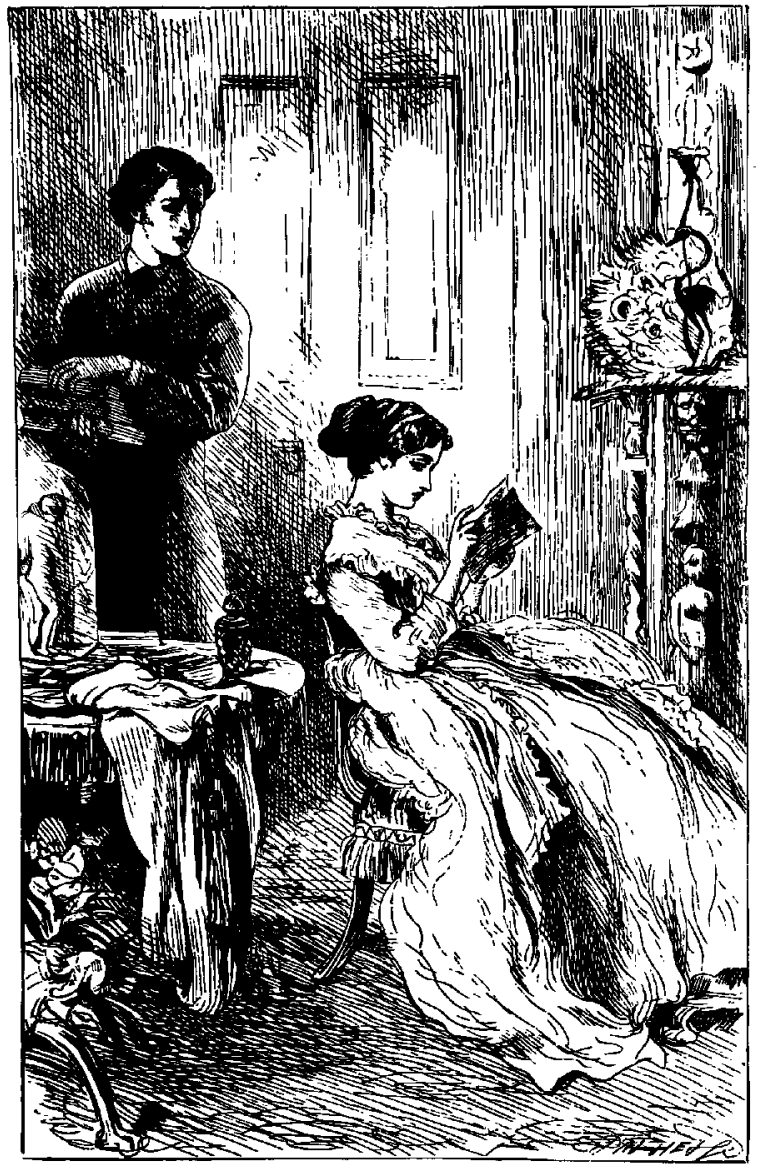

Fig. 183. Marcus Stone, 'Pa's Lodger and Pa's Daughter.' Our Mutual Friend, no. 8. Wood engraving. $5 \% 8^{\prime \prime} \times 35 / 8^{\prime \prime}$ $(14.3 \times 9.2 \mathrm{~cm})$. By permission of the Houghton Library, Harvard University.

the present while supplying a link to the author's happier past.

In 1869 Dickens felt ready to undertake The Mystery of Edwin Drood. Stone could not have objected when Dickens asked Charles Collins, his needy son-in-law, to illustrate Drood. When that unlucky artist fell ill, Stone did not step forward to prevent his contemporary, Luke Fildes, from being engaged as a replacement. By this time, in fact, Stone had probably already decided to withdraw from book illustration altogether. Even working with Dickens, the young man had felt hampered by the diminutive scale of his illustrations and by the engraver's poor interpretation of them as well as certain other unspecified "harassing restric-

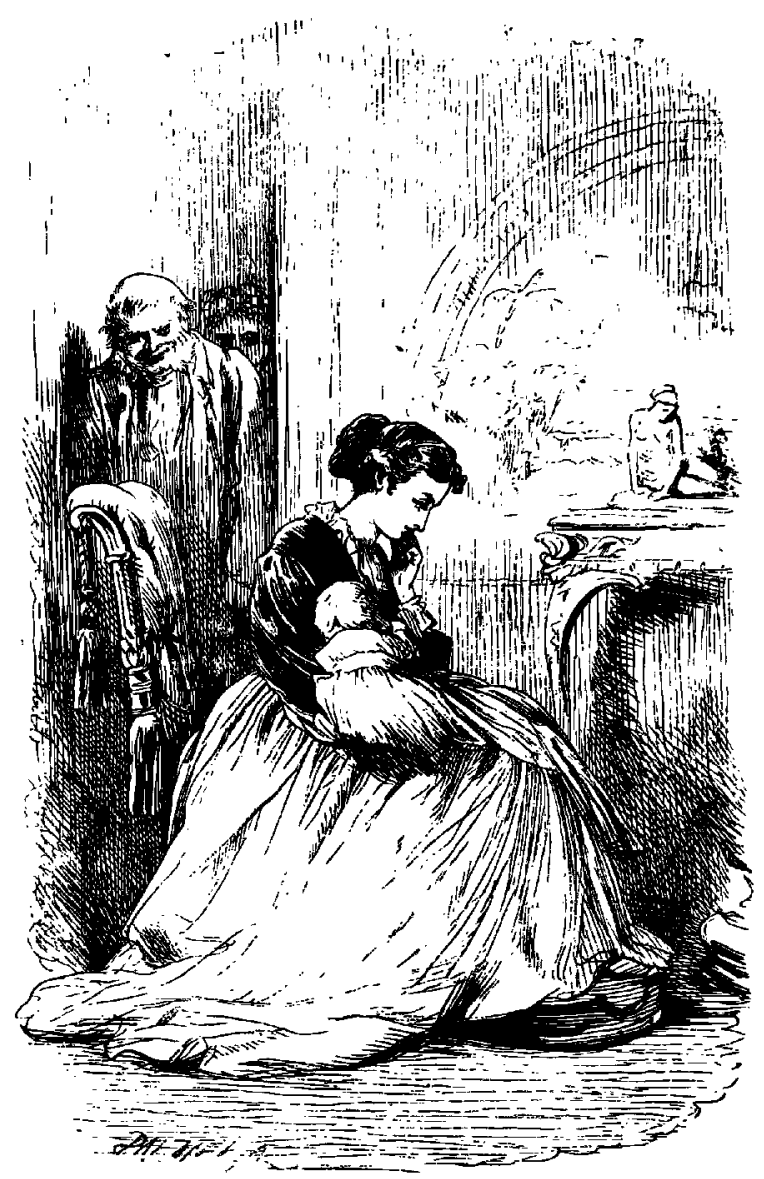

Fig. 184. Marcus Stone, 'Mr. Boffin Does the Honours of the Nursery door.' Our Mutual Friend, nos. 19 and 20. Wood engraving. $5^{3 / 4^{\prime \prime}} \times 3^{11 / 16^{\prime \prime}}(14.6 \times 9.4 \mathrm{~cm})$. By permission of the Houghton Library, Harvard University.

tions. ${ }^{247}$ His subsequent work for $\mathrm{He}$ Knew He Was Right (1868-69) completed his disenchantment, as Trollope seemed so indifferent both to the book and to Stone's efforts on its behalf. ${ }^{48}$ Stone preferred to earn what income he needed from his period narrative paintings, which recalled those of his father in their graceful style and idealized sentimental subjects. ${ }^{49}$ Indeed, the interchangeable facial expressions and cold tones that Beatrix Potter felt spoiled his paintings might certainly have been at odds-as they nearly were in Our Mutual Friend-with the graphic demands of the more sophisticated characters and their repressed passions in Drood had Stone continued to illustrate Dickens. ${ }^{50}$ 
Dickens did not live long enough to see Marcus become a fashionable and popular artist, elected to the Royal Academy in 1877. Nor did he ever know that the artist came to regard his illustrations for Dickens as the "immature" productions of his apprentice years. ${ }^{51}$ Stone always cherished their personal association, however, and appreciated

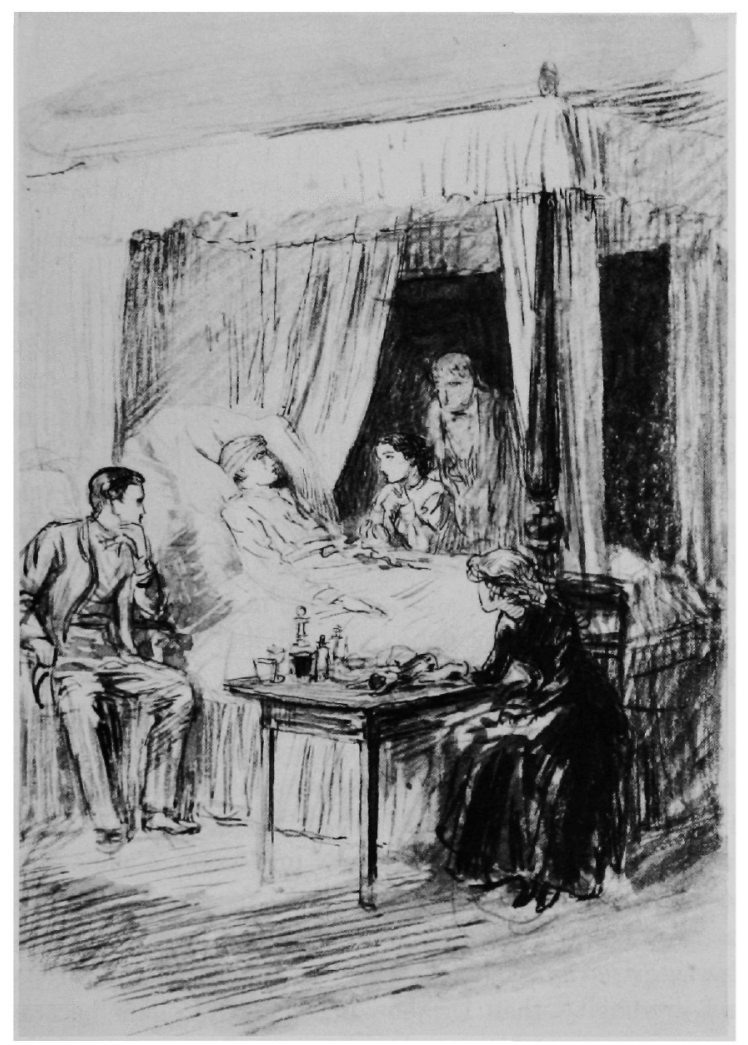

Fig. 185. Marcus Stone, Unpublished Sketch for 'Eugene's Bedside.' Our Mutual Friend, vol. 2, facing p. 247. Pen, pencil, and wash. $61 / 4^{\prime \prime} \times 4^{1 / 8^{\prime \prime}}(15.9 \times 10.3 \mathrm{~cm})$ [sheet]. By permission of the Henry $W$. and Albert A. Berg Collection, The New York Public Library, Astor, Lenox and Tilden Foundations. the fact that the author's patronage had procured for him his small niche in the Victorian hall of fame. Without that one substantial push, he might, like the artist sons of Cruikshank, Cattermole, Stanfield, Topham and, to a lesser extent, Browne, have been relegated to their present obscurity.

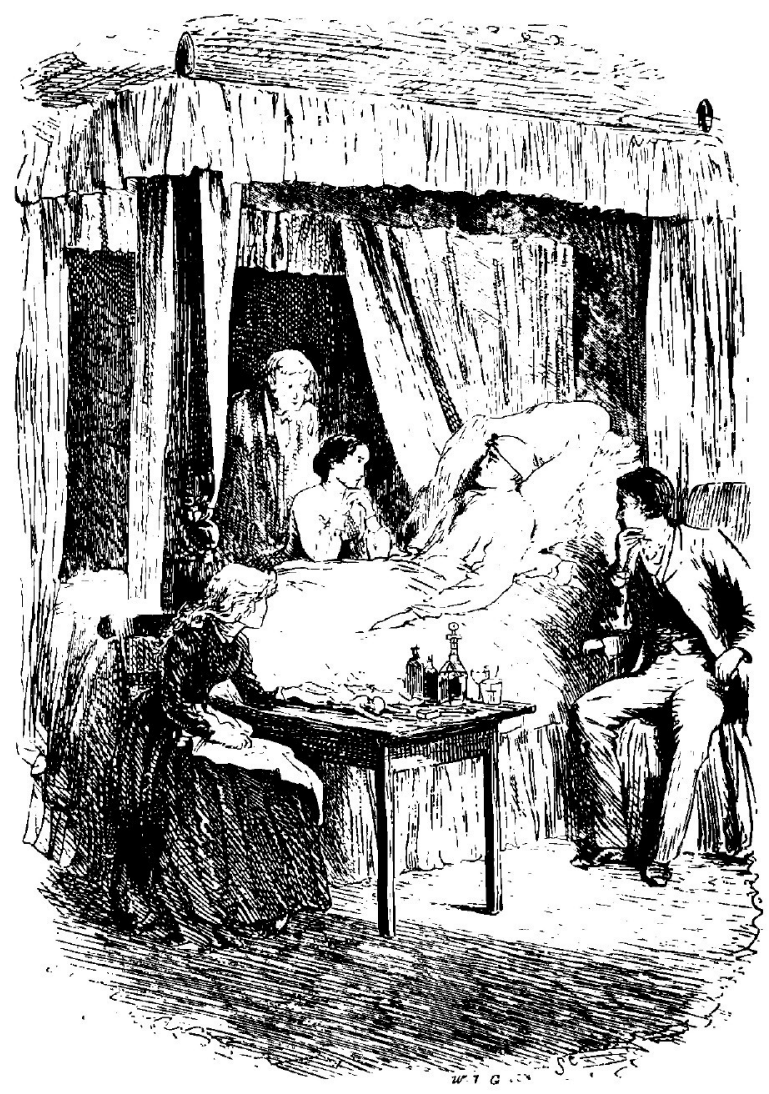

Fig. 186. Marcus Stone. 'Eugene's Bedside.' Our Mutual Friend, no. 18. Wood engraving. 55/16" $\times 33^{11 / 16 " ~(13.5 ~}$ $\times 9.4 \mathrm{~cm}$ ). By permission of the Houghton Library, Harvard University. 


\section{Chapter 17}

\section{CHARLES COLLINS}

From the standpoint of the illustrations, Dickens's last novel, The Mystery of Edwin Drood, cauld hardly have begun less auspiciously. Dickens doubted the wisdom of appointing his son-in-law, Charles Collins, as the illustrator not because of his ability, but because of his chronic invalidism. In the fall of 1869 , however, Collins felt strong enough to undertake the Drood assignment. Meanwhile, Dickens's own premonitions of mortality prompted him to include in his Drood contract a clause promising compensation to the publishers if the novel were not finished. Indeed, the author only completed one-half of the novel he planned, and its first illustrator, who survived him, completed only one design, that for the wrapper. Ironically, however, Collins's single contribution has been examined more closely and discussed more heatedly than any other illustration in all of Dickens's works.

Collins was trained as an artist by his father, a Royal Academy painter whose land and seascapes Dickens himself admired. ${ }^{1}$ The son's Pre-Raphaelite tendencies early in his career probably astonished those familiar with his father's conventional canvases, but not those who knew that like Samuel Palmer, this young man felt born out of his time and was more comfortable with anything old. ${ }^{2}$ The timid younger Collins was encouraged by mentors like Holman Hunt and John Everett Millais, whose painting of 'Christ in the House of His Parents' Dickens had singled out and derided for what he thought was a sacrilegious literalism and regressive medievalism in his attack on the PreRaphaelite Brotherhood in 1850 (CP, 1: 293-94). ${ }^{3}$ Also praised by critics like Ruskin for his "careful" technique, Collins indeed was so meticulous that painting became an unbearable physical and mental effort, and for even longer than his older friend Thackeray, he vacillated between painting and writing, for which he also displayed talent. ${ }^{4}$
Meanwhile, he had been introduced to the Dickens circle as the brother of Wilkie Collins with whom the author was becoming more intimate as his older friends either drifted away, became disabled, or died. Charles himself had become friendly with Dickens during the amateur productions of Wilkie's plays at Tavistock House. The author must have been relieved when the young artist took over a minor role on short notice in The Frozen Deep, delighted when he sketched Georgina Hogarth playing Lady Grace in The Lighthouse to her satisfaction, and, in more serious moments, stimulated by debating with him religious issues of the day. ${ }^{5}$

Finally, as he neared age thirty, Collins decided to become a man of letters. For his own sake as well as his brother's, Dickens, in his capacity as editor of Household Words and, later, All the Year Round, gave Collins invaluable aid in pursuing his new profession. Collins soon became a regular contributor to All the Year Round, writing features as "Our Eye-witness"; his work was invariably characterized by a self-conscious charm, if not by the variety and credibility that Dickens preferred. ${ }^{6}$ Collins became known as one of "Dickens's young men"- a group of rising writers, including George Meredith and Coventry Patmore-whose literary debuts were supported by the author. $^{7}$

The young man not only spent a good deal of time with Dickens, but with his two eldest daughters, especially Kate, to whom he paid particular attention (fig. 187). She, in turn, must have found the tall, slender artist with his striking red hair, blue eyes, and chiseled features attractive; perhaps his chronic timidity and melancholy made her feel needed (fig. 188). ${ }^{8}$ They became increasingly intimate while posing for a canvas by Millais (who had become a friend of Dickens's after Charles introduced them in 1855), entitled 'The Black Brunswicker,' which was displayed at the Royal Academy in 


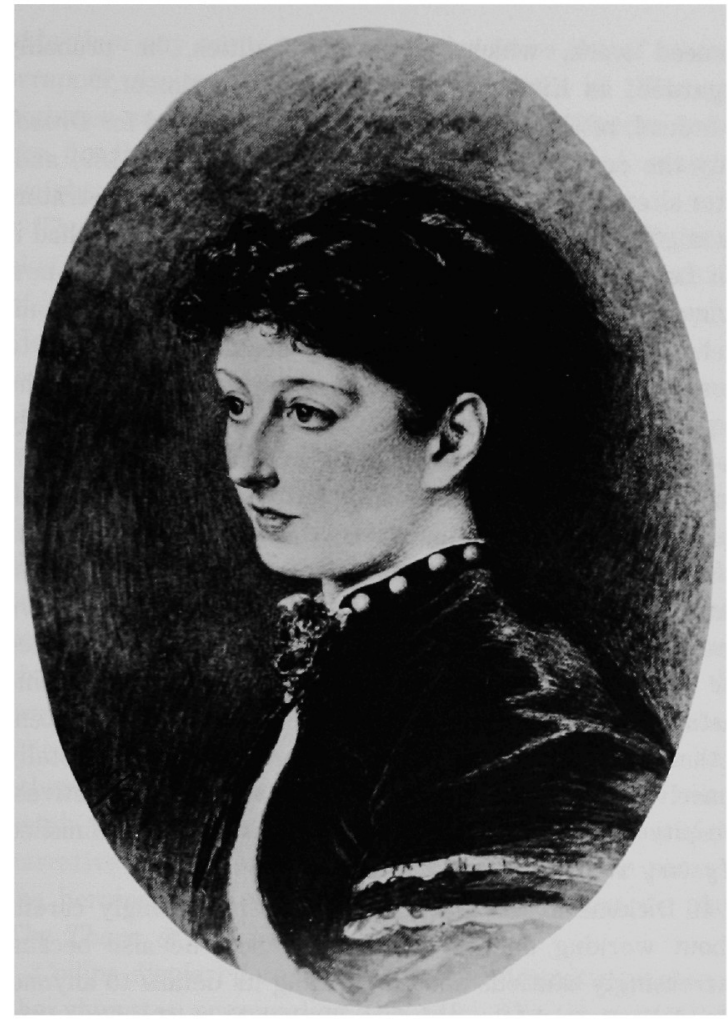

Fig. 187. Marcus Stone, Portrait of Kate Dickens Collins, 1865. Watercolor. $10^{\prime \prime} \times 71^{\prime \prime}(25.9 \times 19 \mathrm{~cm})$. By permission of Mrs. Stuart Dickens McHugh and by courtesy of the Trustees of the Dickens House Museum.

1860. ${ }^{9}$ Though she lived at Gad's Hill with her father, whom she adored, and her Aunt Georgina, she also sympathized with her mother and felt her aunt had encouraged her parents' separation in 1858. Kate became increasingly strained in the house run by Georgina, a factor that probably disposed her to accept Collins's proposal of marriage, despite her father's protests. ${ }^{10}$

Dickens found nothing personally objectionable about her suitor, whom he regarded as a good-natured, trustworthy gentleman as well as an accomplished artist and writer. ${ }^{11}$ But he sensed that Collins, nearly twelve years older than his twenty-one-year-old daughter and in chronically ill health, was not really ready to settle down, and had not really won Kate's heart. ${ }^{12} \mathrm{He}$ also may have guessed, if not known, that his prospective son-in-law was either a homosexual or impotent or both and that the marriage might never be consummated. ${ }^{13} \mathrm{He}$ barely concealed his misgivings throughout the wedding ceremony at Gad's Hill in July

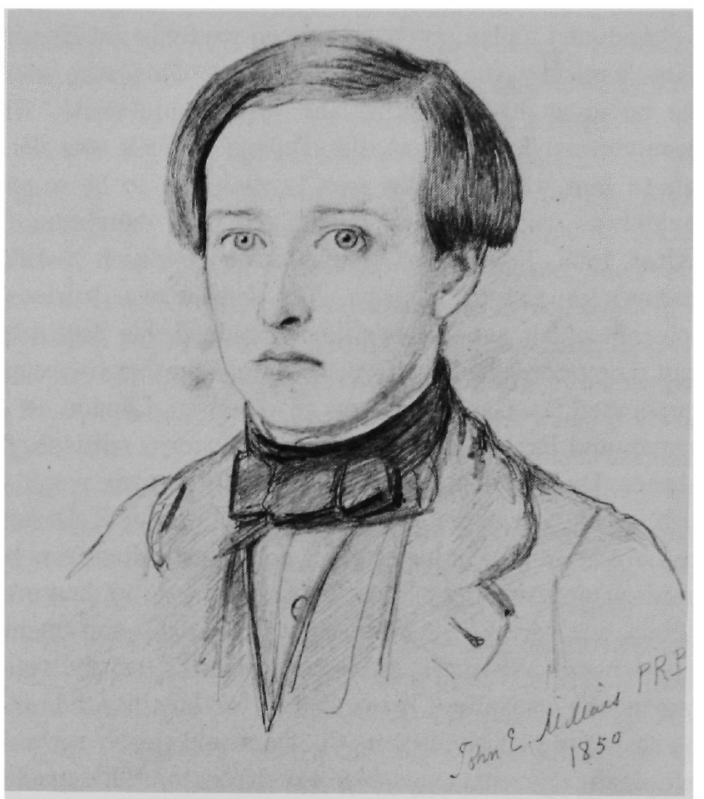

Fig. 188. John Millais, Portrait of Charles Collins, 1850. Black lead. $6^{1 / 2^{\prime \prime}} \times 5^{\prime \prime}(16.5 \times 12.7 \mathrm{~cm})$. By permission of the Ashmolean Museum, Oxford.

1860; and after the couple departed, Mamie discovered her remorseful father alone in her sister's room, his head buried in her wedding gown. "But for me," he sobbed, "Katie would not have left home."

Dickens expected the worst from the marriage. When the couple appeared happy, he acted more surprised than relieved; when either seemed poorly, he appeared more resentful than sympathetic. After the newlyweds' return from their desultory Continental honeymoon, for example, he observed with an obvious air of disbelief as well as pleasure that his daughter looked well, got on with her husband nicely, and, best of all, was not pregnant. ${ }^{15}$ The new Mrs. Collins, meanwhile, continued her own painting and, through Thackeray's fondness for her husband, which in itself would not have improved matters with Dickens, became intimate with the Thackeray family, an ironic series of coincidences that opened the way for the reconciliation of the two authors. ${ }^{16}$ Despite his feelings, Dickens nevertheless did what he could to assist the young couple. He not only concealed from his son-in-law his conviction that he was a better painter than a writer, but he contacted the publisher Murray who agreed to publish Charles's illustrated book, Cruise upon Wheels, which was based on his honeymoon travels, and he continued to display his "Eye-witness" articles prominently in All the Year Round. ${ }^{17}$ 
He abandoned a plan, perhaps formed partly in anticipation of Kate's misery, to visit Australia with Collins, who would have acted as his secretary and helped him write "The Uncommercial Traveller Upside Down." ${ }^{18}$ For it was clear, even to him, that Charles was turning out to be a good provider as well as a fine husband for his daughter.

After 1863, however, Collins's weak condition justified Dickens's persistent concern. The author was curiously intolerant of his son-in-law's illness; indeed, his pessimism about its outcome had the force of hope. Whether the couple recuperated at Gad's Hill, or resorted to London or to German and French spas in search of better conditions, for instance, Dickens remarked that probably no place would do much good; whenever Collins looked improved, Dickens commented on how exhausted his daughter looked from her ceaseless nursing duties. ${ }^{19}$ As the decade wore on, however, Collins was gradually reduced to physical and mental helplessness. When in 1868, to Dickens's barely veiled chagrin, the continuous crisis abated, his hostility did not. ${ }^{20}$ The situation was abhorrent. Collins would clearly never be well again; he was wearing out Kate; and his passive presence may have been an intolerable reminder to the author of his own ill health. Nevertheless, Collins slowly began to improve.

By the fall of 1869 Collins felt strong enough to want to try illustrating his father-in-law's forthcoming novel, which was to run for only twelve rather than the usual twenty numbers. Dickens no doubt welcomed Collins's interest. He had always appreciated his artistic ability, thought it augured well for his future, and knew that the money would help relieve the couple's financial plight. Moreover, it spared the overtaxed author having to search for a new artist for The Mystery of Edwin Drood. Marcus Stone, even if he were still interested in book illustration, would certainly understand Dickens's choice of Collins; Collins, in fact, had a better reputation among the younger generation of artists than Stone. Browne, even in the unlikely event he was reconsidered, had never fully recovered from his paralytic attack in 1867 and would not have figured as a possibility.

Dickens wholeheartedly encouraged his new illustrator but wisely proceeded with caution. He wanted him to try the cover design first and had the publishers send some old green wrappers from previous novels to help him. ${ }^{21} \mathrm{He}$ also insisted that Collins be paid at the same rate as Stone; Charles knew the amount, Dickens informed the publishers, and, as it was hoped that he would "do better-instead of worse-it would be unconscionable to offer him less."22 Bolstered by Dickens's rare encouragement, Collins com- menced work, which, given his frailties, he probably regarded, as Kitton suggests, as an experiment. ${ }^{23}$

Indeed, of the many designs Collins sketched for Drood, only the one for the wrapper was finished (fig. 189) and, after alteration, utilized (fig. 190). ${ }^{24}$ As a Dickens illustrator, he might have passed into oblivion like Robert Buss, had it not been for the author's death halfway through the new story. The tantalizing questions provoked by the incompleted narrative - was Drood really dead? what happens to Rosa? who is Datchery? - could never be resolved by the text. Frustrated readers, then as now, turned particularly to Collins's wrapper design and his initial sketch for it for clues, giving it unexpected fame. Although the only wrappers that are reliable indices to their texts are those for Oliver Twist and A Tale of Two Cities, which were issued in parts only after they had appeared in magazines, few have been dissuaded from microscopically scanning the wrapper for Drood. That most of the wrapper vignettes in this instance could, at best, suggest only scenes not yet written, actions not yet worked out, and characters not yet totally conceived, has only spurred on the would-be detectives. Despite their elaborate efforts, however, the unfinished Mystery remains a mystery.

If Dickens in his maturity became increasingly careful about working out his plot in advance, he also became increasingly cautious about revealing its details to anyone. He did not wish the wrapper design to mislead readers, though it might perplex them; and he could not allow it to restrict his narrative freedom. Accordingly, as Collins explained in 1871, Dickens revealed only "some general outlines for the scheme of Edwin Drood, but at a very early stage in the development of the idea, and what he said bore mainly on the early portions of the tale."25 The author, of course, may well have exercised even more discretion than usual to conceal the subtleties of his mystery from Charles, if one of his objectives was to excel the intricate plots of the artist's brother Wilkie Collins. Twenty years later, Fildes reported that Collins had told him he did not "in the least know the significance of the various groups in the design."26 Collins was always self-effacing, however, and Fildes's memory may have been imperfect, for it is almost inconceivable that Collins was wholly ignorant, for his wrapper depicts key characters and turning points in the plot, whose functions he must have understood to draw them at all. Indeed, though none of the wrapper vignettes finds an exact parallel in the text, each conveys the significance of particular incidents quite accurately. Moreover, as the numbers appeared, they must have shed light on Dickens's earlier instructions, and Collins should have been better 
able than any mere reader to make sense out of his own wrapper design. Hence, Collins's remarks in 1871, only eighteen months after he designed the wrapper, before the floodtide of debate about it was unleashed, must be weighted more seriously.

The sparseness of detail in Collins's much discussed sketch for the wrapper design, together with the angularity of its lines, suggests his hesitation as well as his ill health. He lacked the further knowledge of the plot, as well as self-confidence, to supply additional details. The artist drew the two figures holding back the curtains at the upper corners of his design quite tentatively, although their allegorical significance seems clear enough. The female figure overlooking the romantic scenes, involving women on the left-hand side of the wrapper, represents Love. Her male counterpart, clasping a dagger as he soberly overlooks scenes of suspicion or retribution involving only male characters, represents Hate or Revenge. Surrounding the crudely lettered title, the artist has placed bare branches. One extended branch, however, bears roses-some in bud, others in bloom-interspersed with thorns and wilted petals, suggesting the general love and death themes of the narrative as well as playing on two specifics: the name of the heroine, Rosa Bud, and the name of Bazzard's play, The Thom of Anxiety. ${ }^{27}$

Collins displayed surer graphic and dramatic touches in the vignettes surrounding the title. This is particularly evident in the scene occupying the top of the wrapper from which the others move counterclockwise. Edwin and Rosa are seen walking away from Cloisterham Cathedral with their arms linked in a manner appropriate to betrothed lovers, yet Rosa looks away in a manner that suggests alienation from or anger at her fiancé, if not selfconsciousness about Jasper's stare. Edwin seems oblivious of Jasper, who has turned away from his choir-and the harmony it represents - to regard the couple with puzzled intensity. That this exact moment is not depicted in the text is not important, for Collins has economically and accurately conveyed the disaffection of the engaged pair, the choirmaster's inordinate interest in both, and, perhaps, their differing consciousness of this interest.

In the two vignettes below and to the left of the cathedral scene, the meaning is clear, but not the identities of the characters involved. In the upper vignette, Collins depicts a graceful, long-haired girl studying the proclamation "LOST" that Jasper has posted after his nephew's disappearance. That the hair style does not resemble that worn by Rosa, or by any other woman described in the text, is tantalizing, but less important than that something or someone is missing.
As Collins asserted, "the female figure is only intended to illustrate the doubt entertained by Rosa Bud as to the fate of her lover, Drood," not necessarily Rosa herself. ${ }^{28}$

No one disputes the artist's contention that, in the lower vignette, the girl sitting on the bench in the Monk's Vineyard is Rosa accepting the attentions of another suitor. ${ }^{29}$ The identity of her fair-haired suitor, however, is provocative. Edwin, whose moustache is removed in the published wrapper design, might be redundant; Jasper is dark-haired, and Fildes illustrated the scene of his proposal to Rosa, which might have been unnecessary had it already appeared on the wrapper; and Neville's coloring is also dark, though Collins gives him a moustache in one of his trial sketches. The internal logic of the developing narrative suggested to both Charles and Kate Collins that the young man is Tartar in a forthcoming scene. ${ }^{30}$ Dickens never describes the sailor's appearance in detail, but he makes it clear that Rosa is attracted to him from the first. Fildes's oblique portrayal of Tartar in ' $\mathrm{Up}$ the River' (XXII, 247) does not disqualify him from being the suitor in this vignette. The important fact is, as the continual attempts to identify the figure indicate, that Rosa fascinates almost every man in the book, three of whom, besides Tartar, are her declared admirers.

Descending to the left-hand corner, Collins leads the viewer's gaze through a cloud of smoke, billowing from the penny-ink bottle held by the outlined figure of the Opium Woman, to a dramatic tableau at the bottom center of the wrapper. This controversial scene, which suggests a climactic point in the narrative, portrays a confrontation between two figures in a long, narrow passage, probably the cathedral crypt. The light-bearing figure is Jasper, to judge from Collins's representations of him in the top vignette and in two of the trial sketches (see figs. 190, 194). His powerful light, superfluous on the moonlit night of his furtive expedition with Durdles, would be necessary if he were about to retrieve the engagement ring from his nephew, assuming he murdered and then buried him in a quicklime tomb; the ring would be the only means by which Drood could now be identified.

The identity of the man encountered by Jasper is not at all obvious, however. The artist disagreed with those "resurrectionists" who claimed that he is Edwin, or Edwin disguised as Datchery, reaching into his breast pocket for the identifying ring before accounting for his disappearance (and Jasper's part in it, if any). Both Collins and Fildes shared the conviction of all Dickens's family and friends that Drood was dead; to resurrect him, they maintained, would hardly be an innovation for the author of A Tale of Two 
Collins's Sketch for the Wrapper of The Mystery of Edwin Drood

Known and Conjectured Actions and Identities

Female allegorical figure of Love.

Edwin and Rosa at their last meeting which Dickens later changed from inside to outside the cathedral

Poster which Jasper put up advertising loss of Edwin. Actual scene not in published text. Girl might be Rosa or anonymous onlooker with similarly light but longer hair.

Beneath branch of symbolic roses and thorns sits Rosa probably on the bench in the Monk's Vineyard, scene of her interviews with Edwin and Jasper. The Suitor, whom she seems to accept, is therefore not Edwin (whose moustache removed in final wrapper), nor Jasper (dark hair, stands near sundial); but most likely Tartar.

Princess Puffer, the Opium Woman.

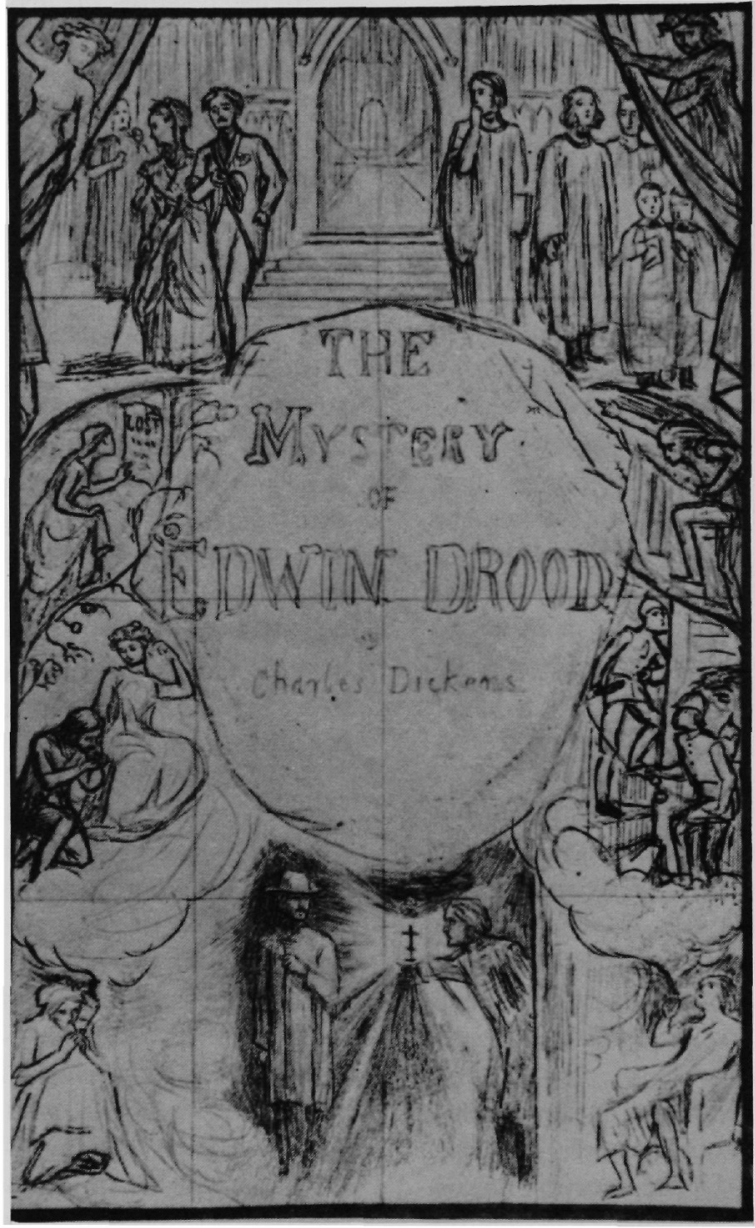

The light-bearing figure resembles Jasper above and in Collins's trial sketch 5. The figure he encounters is probably Bazzard, though his moustache makes him resemble Edwin above or Rosa's suitor; in any case, he seems distinctly masculine. The sparse diagonal lines emanating from the light suggest a long, narrow passage like the cathedral crypt.

Fig. 189. Charles Collins, Sketch for the Wrapper of The Mystery of Edwin Drood. Photograph. 57/8 $\times 33^{\prime \prime}(15$ $\times 8.6 \mathrm{~cm})$. By permission of the Trustees of the Dickens House Museum.
Male allegorical figure of Murder (or Hate, Tragedy, Death, Vengeance).

Jasper, hand at mouth, looks on pensively at the young couple. Next to him are choir members or perhaps Crisparkle and Dean.

Probably the pursuit of Drood's murderer up the winding staircase of the cathedral tower. The top figure, pointing to Jasper, is not identifiable, but is followed by local police.
Ambiguous opium-smoker of masculine size but feminine hair and nightgown-like dress. 
The Published Wrapper for The Mystery of Edwin Drood

Known and Conjectured Actions and Identities

Allegorical female figure of Love looks away from scenes sadly.

Unidentified figure behind Edwin and Rosa moved from Rosa's right to Edwin's left in front of diminished cathedral door.

The single branch of roses and thorns has now expanded to surround the title; roses dominate on left-hand side, thorns on right. The letters of the title now resemble carved wood branches.

Durdles' spade, key, and dinner bundle added; doubtless would have been instrumental in plot's resolution.

Opium Woman far better defined.
No. I.]

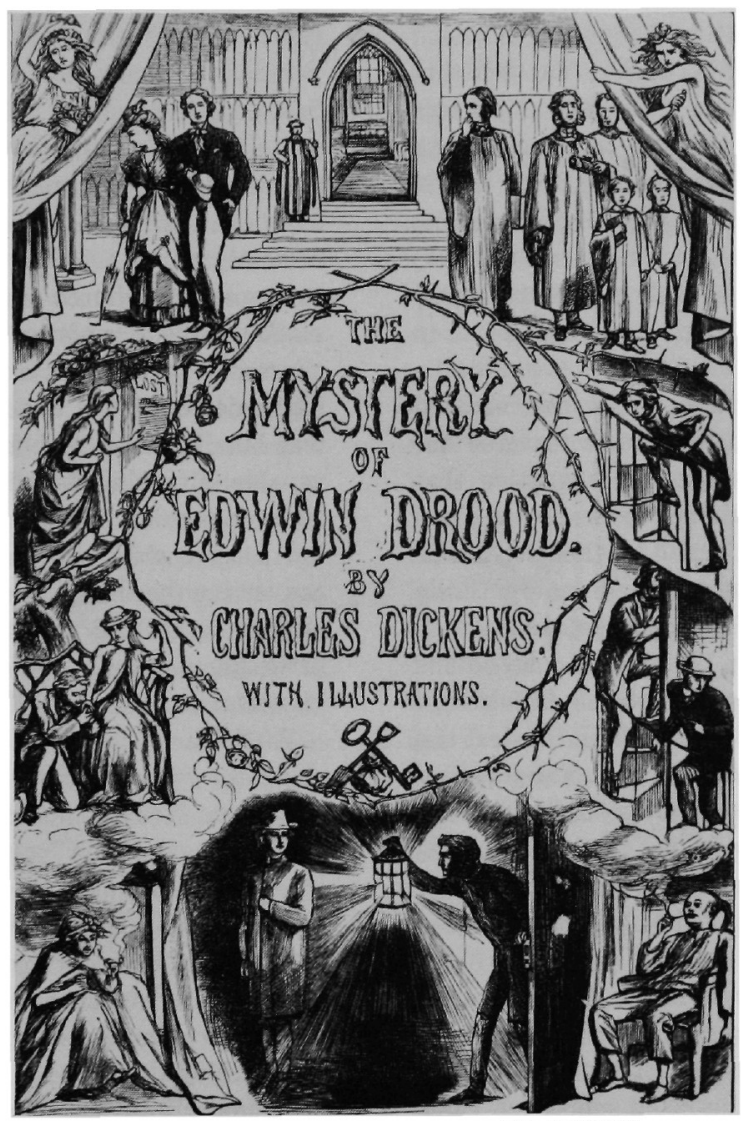

LUNDUN: CHAHAN \& HALL, 193, PICCAUILLY.

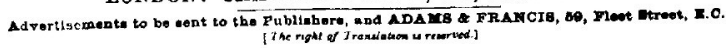

The man now bearing a lantern, instead of a light, resembles Jasper of Fildes's later illustrations rather than Collins's wrapper sketch or trial illustrations. The other figure, whose face, hair, figure now fuller, moustache removed, probably Datchery but whether Datchery is Bazzard, Helena or Edwin in disguise or a professional investigator is not determinable from this vignette. The increased beams from the lantern better obscure the dark locale.

Fig. 190. Charles Collins, Wrapper for The Mystery of Edwin Drood. The Mystery of Edwin Drood, no. 1. Wood engraving. $8^{3 / 4^{\prime \prime}} \times 5^{11 / 16^{\prime \prime}}(22.2 \times 14.5 \mathrm{~cm})$. By permission of the Houghton Library, Harvard University.
Allegorical figure of Death now resembles Amazon

The pursuit less obviously a criminal matter as the pursuers now in plain clothes. The lead figure, still significantly pointing at Jasper, is probably Neville but his light hair suggests Tartar or Crisparkle. The other pursuers probably characters in book but could be anonymous townspeople.

Opium smoker far better defined male; wearing Oriental pajamas. Probably Jack the Chinaman; or possibly one of Chinese customers of the Opium Woman. 
Cities, originally entitled "Recalled to Life," and Our Mutual Friend; ${ }^{31}$ indeed, they believed that the figure was one of the other characters in the narrative, so many of whom lead a double physical and mental life, disguised as Datchery. Except for Inspector Bucket in Bleak House, Dickens preferred amateur sleuths, personally involved with the victims or the villains of his fiction. The fact that the wrapper suggests that so many of Drood's characters could qualify to be Datchery testifies to the skill of both Dickens and Collins, though it is usually ignored in the heated arguments supporting Neville, Tartar, Grewgious, Bazzard, Helena disguised as a man, or some new character. Collins's final wrapper design, as well as the published Dickens text, ingeniously lends support at some point to each of these claims. ${ }^{32}$

Passing through another cloud of opium smoke, emitted by a figure whose sex is defined by neither features nor garments, the viewer comes to the two vignettes that ascend the right-hand side of the wrapper. In a scene probably climaxing the physical action of the plot, three policemen, following the lead of a figure energetically pointing upward, mount a winding staircase, presumably the one in the cathedral tower, though it could be the postern stairs of Jasper's gatehouse. Collins's inclusion of officers suggests a criminal pursuit, though in the text the townsfolk, not the local police, arrest Neville. The substitution of plainclothesmen in the final wrapper design must have been made on instructions from Dickens, who was trying to use the characters from the story economically, perhaps, or to obscure the status of the chase in the wrapper design.

Even in the published wrapper, however, the identity of the three figures mounting the stairs is not clear. Probably they are more closely connected to the plot than the anonymous townspeople, but Collins could supply few clues as to their individual appearances. Doubtless at this early stage in Drood Dickens had not fully conceived all the minor characters. The two lower pursuers, wearing hats, might be Tartar and Crisparkle, who, according to Collins, eventually marry Rosa and Helena. ${ }^{83}$ It would be dramatically fitting for the uppermost, hatless, light-haired figure to be Neville who, the artist claimed, was slated to die pursuing Edwin's real murderer, but Neville's swarthier coloring is insisted upon in Collins's trial sketch of him (see fig. 197) as well as in Dickens's number plans and text. ${ }^{34}$ Collins also maintained that the topmost figure is Jasper himself "pointing unconsciously to his own figure in the drawing at the head of the title. ${ }^{35}$ But if the angular figure in his wrapper sketch is the dark-haired choirmaster, the fair, bare-faced youth of the published wrapper design bears him scant resemblance.
Yet, even if Jasper does not actually lead the climactic chase, he has long consciously or unconsciously urged it on, doubtless, as Collins suggested, "in an effort to divert suspicion from himself."

Collins's first wrapper sketch clearly needed some alterations for aesthetic as well as dramatic reasons. Despite persuasive arguments to the contrary, there is far more first-hand evidence to indicate that the subsequent changes in the published wrapper were made by Collins, not Fildes; and its delicacy is more characteristic of the first artist's style than the forceful one of his successor. ${ }^{37}$ Collins was certainly well enough to round out his many angular figures; to lower the church entrance and diminish its size; to elaborate the title border into a full-scale design of roses and thorns; to give the title letters themselves the depth and dimension of carved wood; and to add Durdles's key, shovel and bundle beneath them. He certainly would have been capable of turning the allegorical figure of Love away from the scenes below her with an air of sad resignation; replacing her passive male counterpart with a threatening Amazon; converting the ambiguous features and clothing of the opium smoker opposite Princess Puffer into the recognizable ones of Chinaman Jack; and enlarging Edwin's face in the top vignette and removing his moustache.

Particularly in the bottom vignette, however, other changes were effected, probably in order to promote ambiguity. That Collins darkened Jasper's hair and expression and gave him a large distinct lantern whose reflected light better obscured the locale is straightforward enough. But by removing the moustache, lengthening the hair, and rounding out both the face and figure of the character Jasper confronts, the artist, no doubt deliberately, made its sex as well as its identity indeterminable. Collins finished his work by changing the police to plainclothesmen, whose identities are similarly indecipherable. The final wrapper design suggested yet preserved the mystery to Dickens's satisfaction; presumably the vignettes do not deliberately mislead the reader, but neither do they reveal crucial secrets. Pronouncing the design "excellent," "charming," and undeniably worth its $£ 10$ cost, Dickens preserved it in its essentials, if not in every detail, even after he engaged a new illustrator. ${ }^{38}$

It was not simply his work on the wrapper that exhausted Collins, but that in combination with his production of a number of trial sketches for the early scenes in Drood. Between September and November of 1869 , he produced not only the wrapper design, but at least eight sketches of four subjects. He doubtless worked from Dickens's manuscripts or verbal instructions, for the first proofs were not 
ready until December, by which time Collins had given up his efforts to do the illustrations. ${ }^{89}$ The similarity in subjects, if not style, between the illustrations of Collins and those of Fildes suggests either that Dickens previously designated which scenes were to be illustrated, or that the second illustrator, for the most part, simply followed the lead of the first.

On the whole, Collins's trial sketches were disappointing dramatically. His two complete sketches of the opium den, for example, despite its wonderful pictorial potential and Dickens's vivid first-hand description of it (I, 1-5), are dull. ${ }^{40}$ In both finished versions (figs. 191 and 192), Collins features Jasper in the den with the opium woman, the Chinaman, and the Lascar: in one, he stands apart as if apprehensive about his exotic but disreputable companions; in the other, he more forcefully bends over the slanted bed toward them. In a third unfinished study-previously noted but never before reproduced $^{41}$ - which is clearly related to the latter portrayal of the opium den scene, Jasper focuses intently on the Princess Puffer who looks demurely away from him (fig. 193). The Choirmaster's slightly bent figure here stands free of the frame and his semi-profile hints at a moustache, but in yet another fuller profile drawn on the same sheet, he is bare-faced once again as well as unusually expressionless. In all three sketches, the vacillations about Jasper's hair length, moustache, facial expression, and position, as well as body placement and posture, suggest that Collins had far greater difficulty than Fildes (fig. 194) in visualizing Dickens's complex hero-villain. Moreover, the opium smokers, with their graceful postures and effete faces, fail to convey any sense of their misery or degradation, and the Princess Puffer suggests a meek almswoman rather than the menacing hag Dickens described from the first.

To judge from their completeness of detail and superior finish, Collins was more comfortable with his next trio of related sketches, all focusing on a chat between the Dean and Crisparkle but varying in interesting particulars. ${ }^{42}$ In the least finished sketch, clearly done without benefit of the text, a behatted Jasper is seen in the background, walking with Tope or an unidentified chorister, toward his gatehouse near the cathedral tower. In a later textually accurate sketch, Tope lingers near, as does a dog, while the Dean and Crisparkle converse, and only Jasper's gatehouse appears in the background. In what appears to be the last sketch, the Verger actively gesticulates, the dog disappears, and the gatehouse looms more prominently behind the three men. Dickens, as Margaret Cardwell suggests, probably relegated this less dramatic subject to a later number where the more eccentric Sapsea and Durdles could be added (XII, facing p. 128); at this point in the story he wisely inserted a
Fildes illustration of Rosa and Edwin (III, facing p. 28) both to offset the disturbing effect of the opening illustration of the opium den (see fig. 194) and to attract readers to the young couple from the onset. ${ }^{48}$

Collins failed to meet the challenges inherent in the Crisparkle dinner party scene honoring the philanthropist Mr. Honeythunder and his wards from Ceylon, Neville and Helena Landless. In one of his two extant sketches, the artist statically depicts the group gathered around the dinner table in formal dress; in the other, the piano scene in which Jasper frightens his pupil, Rosa, Collins remains unable to arrange the many characters in a way that would extract the many strands of physical and psychic tension as does Fildes in 'At the Piano' (VII, 65). ${ }^{44}$

Collins's sketches, more than his wrapper design, betray an uncertainty as to concept and a rigidity of line that cannot be wholly attributed to his lack of text and health or even his understandable tentativeness about this assignment. It would have been in character for the artist to have far more difficulty satisfying himself than even his exacting father-inlaw. ${ }^{45}$ Ultimately, in the face of such mental strain as well as his physical debilitation, Collins's strength gave out and he could not continue to work. Dickens seemed sincerely regretful when he was forced to inform the publishers in late November that: "Charley Collins finds that the sitting down to draw brings back all the worst symptoms of the old illness that occasioned his old pursuit of painting; and here we are suddenly without an Illustrator! We will use his cover of course, but he gives in altogether as to further subjects." 46 Ironically, it was Millais, butt of Dickens's criticism of the Pre-Ralphaelites, but now a friend of the author as well as of the artist, who found a replacement, Luke Fildes, whose dramatic use of light and line reflected all the youthful flexibility and vitality Charles lacked. ${ }^{47}$

"No man," Forster observed of Collins, "disappointed so many reasonable hopes with so little fault or failure of his own." ${ }^{48}$ Nevertheless, Dickens, now that nothing further could be gained or hoped for from Collins professionally, was unable to conceal his renewed distaste for his son-in-law. Though plagued by his own poor health, the author could not understand an illness that led neither to recovery nor to death; nor could he understand Collins's endurance of it. ${ }^{49}$ Having long worried that his daughter's health was endangered by the double strain of nursing her husband and supporting them both by her painting, Dickens now seemed openly bent on Charles's death. At meals, a friend reported, he would look at Collins as if to say "Astonishing you should be here today, but tomorrow you will be in your chamber never to come out again." ${ }^{150}$ Such hostility was not lost on 

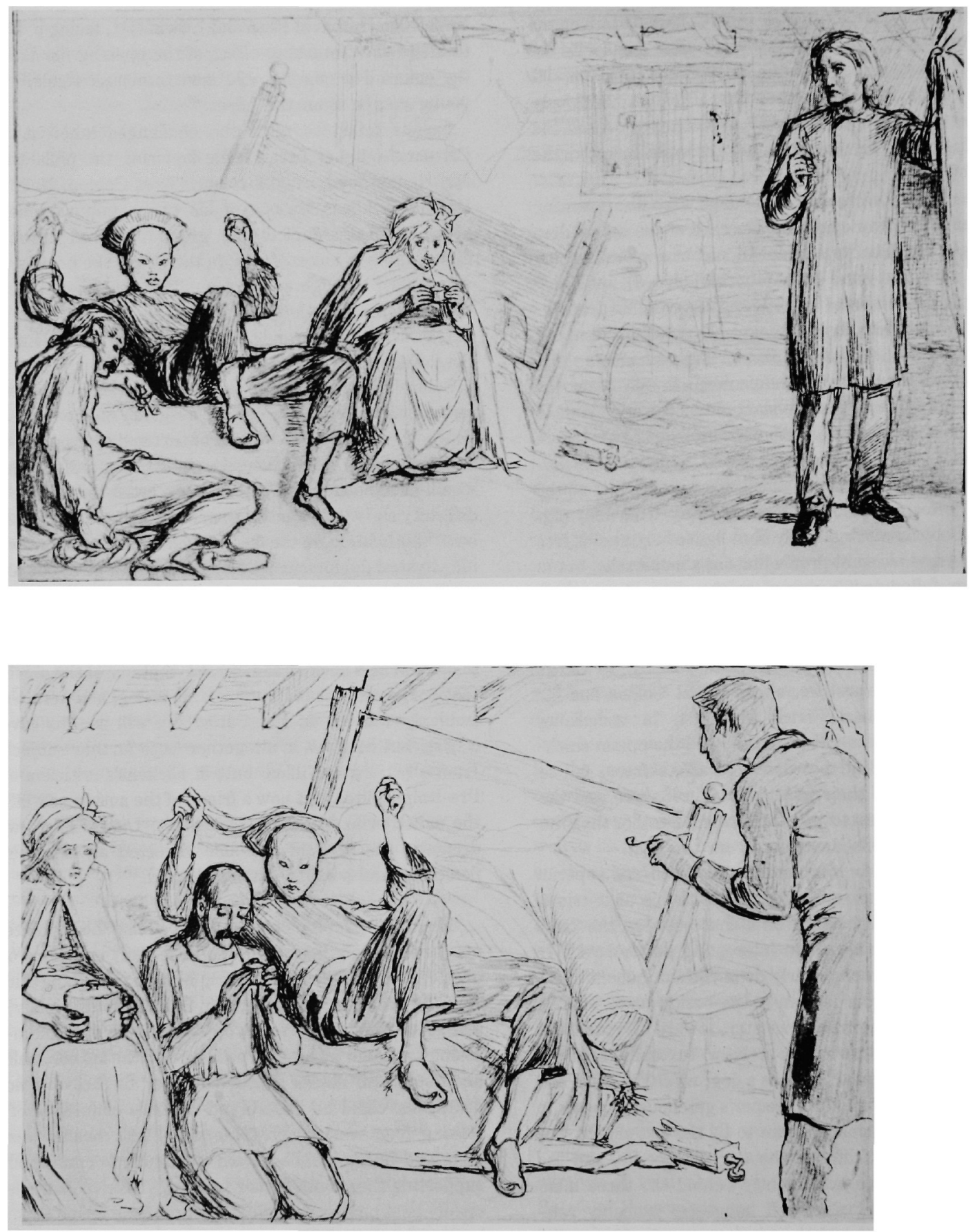

Fig. 191 (top). Charles Collins, Sketch for the Opium Den Scene. Black ink, pen, and pencil. 37/8" $\times 61 / 2^{\prime \prime}(9.9 \times 16.5 \mathrm{~cm})$. Fig. 192 (bottom). Charles Collins, Sketch for the Opium Den Scene. Black ink, pen, and pencil. $3^{3 / 4^{\prime \prime}} \times 6^{\prime \prime}(9.5 \times 15.2 \mathrm{~cm})$. Both by permission of Captain Peter Dickens. 

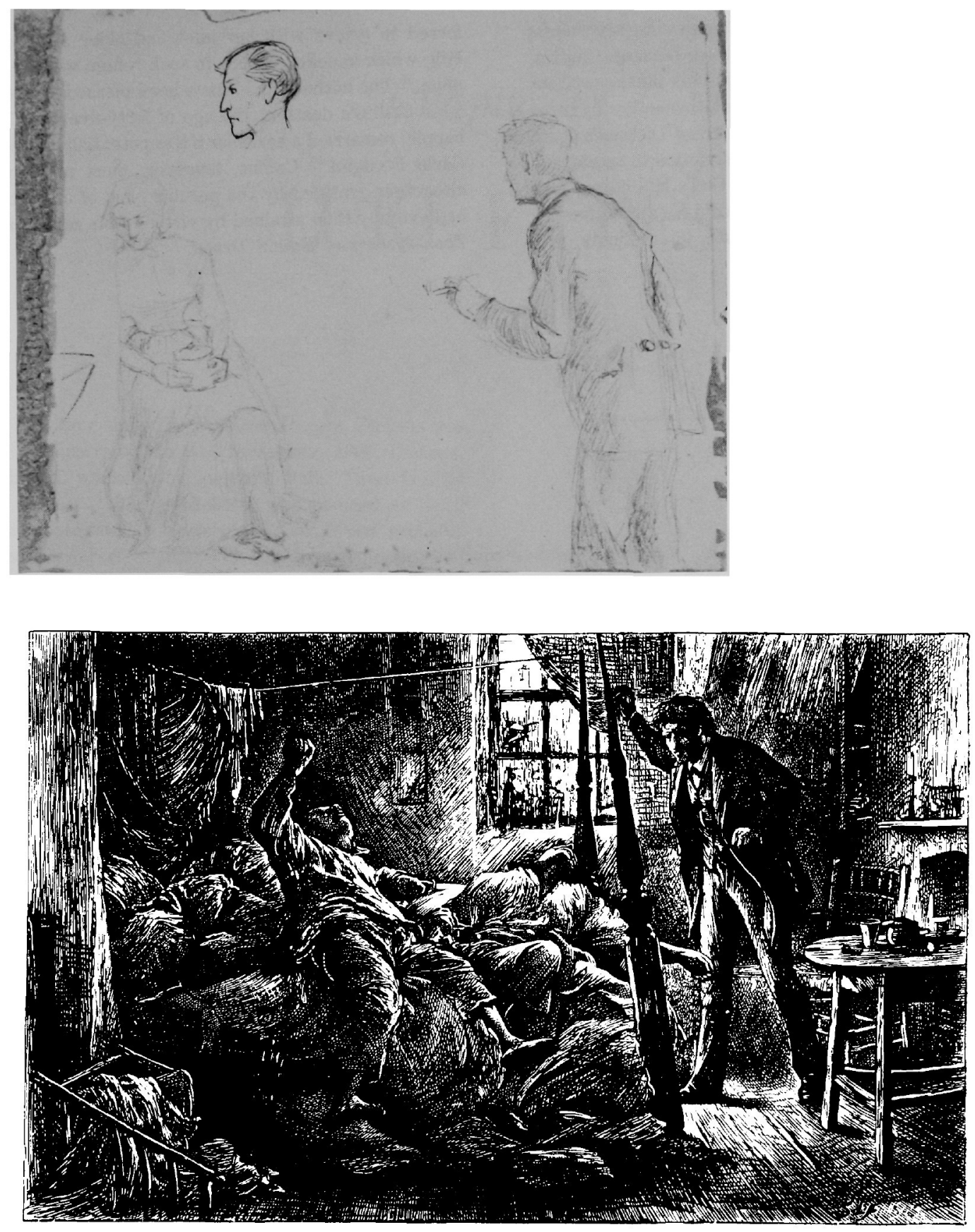

Fig. 193 (top). Charles Collins, Unpublished Sketch for the Opium Den Scene. Black ink and pencil. $71 / 16^{\prime \prime} \times 5^{3 / 8^{\prime \prime}}(18 \times 13.7 \mathrm{~cm})$ [sheet]. By permission of Captain Peter Dickens. Fig. 194 (bottom). Luke

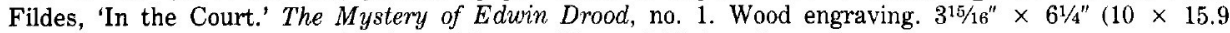
$\mathrm{cm})$. By permission of the Houghton Library, Harvard University. 
Wilkie Collins, and it, together with his own literary success at this time, further estranged him from Dickens; Charles, however, endured this treatment, like his illness, without complaint and, ironically, outlived his father-in-law by three years. ${ }^{51}$ Indeed, Collins sincerely mourned Dickens's death in 1870 and wrote an affectionate description to accompany Fildes's famous picture of Dickens's Gad's Hill library (see fig. 199). ${ }^{52}$ Yet tensions involving him did not abate after the decease of his father-in-law, for Kate, interestingly, pre- ferred to grieve with her aunt and older sister in Gad's Hill, which impelled Collins to seek refuge with Leslie Stephen. ${ }^{53}$ The author would have been pleased to know that, after Collins's death at the age of forty-five in 1873, Kate happily remarried a healthier if less potentially gifted artist, Carlo Perugini. ${ }^{54}$ Collins, however, must not have been altogether gratified by the peculiar kind of immortality he had even by then attained by virtue of his association with The Mystery of Edwin Drood. 


\section{Chapter 18}

\section{LUKE FILDES}

For the first time since The Pickwick Papers, Dickens was without an illustrator. In late November, 1869, Dickens, ailing himself, warned Chapman and Hall, "There is little time to be lost." The publishers, who planned an April publication date for The Mystery of Edwin Drood, probably were less disconcerted; they now had far more notice and experience than they had had over three decades earlier when Seymour committed suicide in the middle of the second number of Pickwick. The anxious author enlisted the aid of other artists, Millais and Frith, to help find a new illustrator; thanks to their concerted effords, Luke Fildes, a former student at the Royal Academy, was located and engaged within a few weeks (fig. 195). ${ }^{2}$ His work seemed to combine the aesthetic ideals of the new school of black-andwhite illustrators and the social consciousness of the older generation: he seemed the perfect illustrator for Dickens in every way.

While Charles Collins had been painfully executing sketches for his father-in-law's forthcoming novel, Luke Fildes had been anxiously trying to produce a memorable scene to fulfill a commission for the new (and ultimately influential) illustrated weekly, The Graphic. ${ }^{3}$ The younger artist hoped, with this scene together with the illustrations he had been commissioned to do for the English translation of Victor Hugo's L'Homme qui rit, to make enough of a mark to secure sustained employment as an illustrator, which would support his more serious efforts as a painter. Fildes's book illustrations delighted Hugo, himself a draftsman, and his wood engraving of the 'Houseless and Hungry' (fig. 196), whom he had viewed firsthand, was featured in the opening issue of The Graphic (which also contained an announcement, corrected the very next week, that Charles Collins would be Dickens's new illustrator). ${ }^{4}$ It was Fildes's Graphic subject, of dismal applicants outside the kind of workhouse that Betty Higden tried so hard to avoid dying in

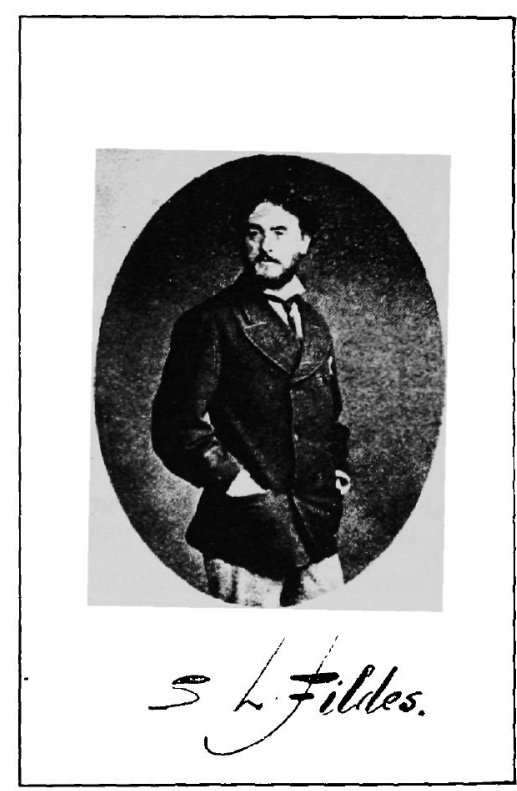

Fig. 195. Artist Unknown, Portrait of Luke Fildes, 1866. David Croal Thomson, The Life and Work of Luke Fildes (London, 1895), p. 22. Photograph. 31/2" $\times 21 / 2^{\prime \prime}(8.9 \times 6.4$ $\mathrm{cm}$ ). Courtesy of the Boston Athenaeum.

(OMF, II, X, 378), that caught John Millais's attention. "I see Millais running to Charles Dickens," imagined Vincent van Gogh, a devoted admirer of Dickens, Fildes, 'Houseless and Hungry' and The Graphic, who re-created for himself the legend of how the Drood artist was hired. ${ }^{6}$ Dickens undoubtedly was impressed with Fildes's moving scene, the kind, as Millais knew, he himself loved to depict in words.

Recalling, perhaps, the complications that had ensued with Seymour's temporary successor, Robert Buss, Dickens 


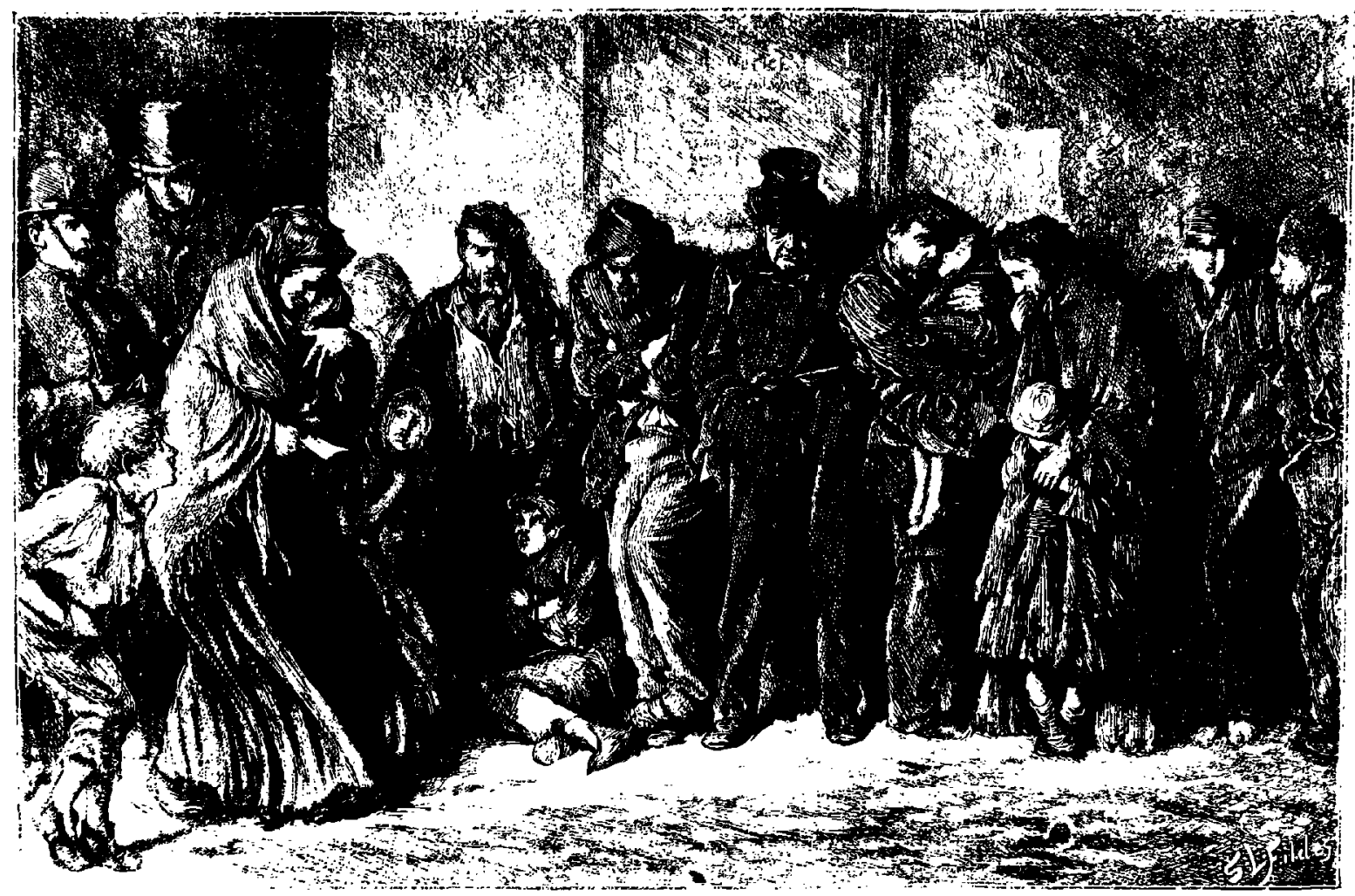

Fig. 196. Luke Fildes, 'Houseless and Hungry.' The Graphic, 1 (December 4, 1869), 9. Wood engraving. $77 / \mathrm{s}^{\prime \prime} \times 11 \% \mathrm{~s}^{\prime \prime}(20 \times 30.2 \mathrm{~cm})$. From the Deposit Library, Harvard College Library, Harvard University.

proceeded cautiously. He had the publishers contact Fildes; at their request, the artist not only dispatched specimens of his work but promised a sketch based on David Copperfield that would better display his ability to draw pretty heroines like Rosa and Helena as well as to illustrate other aspects of Dickens's prose. ${ }^{7}$ The author, already impressed by Fildes's firm draftsmanship and expressive use of line and tone, was understandably curious to see what the artist would produce for his favorite novel. ${ }^{8}$ The fortheoming sketch of little Em'ly being embraced by Peggotty after announcing her engagement to Ham confirmed Dickens's favorable opinion; "I am going to engage with a new man," he informed an American friend on January 14, 1870. "Congratulate me!" Fildes wrote to his uncle and mentor three days later.

I am to do Dickens's story. Just got the letter settling the matter. Going to see Dickens on Saturday.

Now for what I can do. This is the tide! Am I to be on the flood? My heart fails me a little for it is the turning point in my career. ${ }^{10}$
A meeting was arranged to settle other matters. The twenty-six-year-old Fildes, nervous at meeting the famous author, was put at his ease by the same paternal manner Dickens displayed toward Marcus Stone. ${ }^{11}$ Though elated at the prospect of illustrating The Mystery of Edwin Drood, the young artist honestly expressed his aesthetic and technical reservations. First, if Dickens wanted an artist who excelled in comic subjects, as had Browne, for example, he might not be suitable, for Fildes felt himself better qualified to stress the graver aspects of the author's work. ${ }^{12}$ The novelist, without disparaging his earlier artists, seemed pleased by the prospect of being taken so seriously, and he may have indicated that there would be relatively little comedy in Drood and that even those bits would serve various sober purposes. The young artist, probably at this time, also expressed concern about the usual misrepresentations of his work by engravers. He noted that engravers destroyed the artist's original drawing in the process of copying it. Fildes wished to utilize a new process, which 
Marcus Stone claimed to have made reputable, by which his drawings would be photographed onto the woodblock, enabling the drawings to be duplicated more accurately, and the originals retained to compare with the final result (and to sell later). ${ }^{18}$ Dickens had no objection to this innovation. Whatever helped Fildes would help Dickens to put his story across. The two men parted, mutually impressed. ${ }^{14}$ It seemed auspicious that this novel-one in which the plot is determined and the characters are delineated by the fact that each is endowed with artistic gifts-should be illustrated by one called Luke, after the patron saint of painters. ${ }^{15}$

Work began in earnest. Fildes received a proof of Collins's wrapper, a necessary though not binding point of departure for his own realization of Dickens's scenes and characters. ${ }^{16}$ Indeed, the text posed far more problems than the wrapper. Its distinetive plot and style-simple, yet complex, and suggestive of divided personalities, mesmerism, death, and resurrection-did not lend itself easily to illustration. The few leading characters were of more psychological than physical interest. The main action of the narrative, the probable murder of Drood, could be anticipated but not depicted. Actions, such as Crisparkle's morning swim or Neville's arrest, were not important enough to need graphic reinforcement. The symbolic prose, as well as contemporary taste, made Hogarthian or other background detail superfluous.

Yet Fildes coped effectively, better than Marcus Stone had done when confronted with similar dilemmas in Our Mutual Friend, and better than Collins would have done, to judge from his trial sketches. Fildes, of course, benefited from being a stranger, whose relationship was not complicated by the tiês binding Dickens to Marcus Stone and to Collins. Moreover Dickens, in the course of Drood, unlike that of Our Mutual Friend, was not dashing around the country or over to the Continent, communicating with his artist in brief notes. Fildes conferred with the author at Hyde Park Gate or at Gad's Hill where the scene Dickens wanted illustrated would be read or acted out; the subject having been agreed upon, with or without debate, Fildes returned to his London studio. ${ }^{17}$ Following Dickens's lead, which, in turn, reflected contemporary developments in fiction as well as art, Fildes usually portrayed only a few figures; he drew them from real life models, a technique as appropriate for Drood as Cruikshank's and Browne's numerous, smaller figures-grounded in imagination as much as actuality-had been for the author's earlier works. ${ }^{18}$ Moreover, by voluntarily but not compulsively taking some of the unobtrusive backgrounds in the outdoor scenes from actual landmarks (III, facing p. 28; XII, facing p. 128; XX, facing p. 225; XXII, facing p. 246), in keeping with his and Dickens's inclinations as well as contemporary practices, so unlike that of Browne, for example, he helped to anchor the mystery in reality. ${ }^{19}$ Though Dickens retained the right to inspect Fildes's sketches, he rarely exercised it-as his trust increased and his strength waned-and the artist simply forwarded his work to the engraver. ${ }^{20}$

The first number of The Mystery of Edwin Drood appeared in April, 1870. Fildes had ample time to study the proofs, refine Collins's early perceptions of 'In the Court' (see figs. 191-94), and conceive the meeting between Edwin and Rosa 'Under the Trees' (III, 29). ${ }^{21}$ Anxious for an assessment of the illustrations, partly, perhaps, because contemporary reviewers had increasingly ignored the pictures in his recent work, Dickens wrote to William Frith: "You will please me with what [ever] you say about my new illustrator of whom I have great hopes."22 The veteran artist confirmed Dickens's own opinion that Fildes was a sensitive interpreter of his carefully wrought story. ${ }^{23}$ Although the artist used rectilinear frames for his Drood illustrations, as had Marcus Stone so often for those for Our Mutual Friend, his scenes were powerful enough in content and technique to minimize any sense of graphic isolation. His deployment of heavy black lines and meaningful white spaces, especially in the interior or dimly lit scenes, satisfied the viewer's demand for representation while it left ample room for imagination.

In subsequent numbers, the artist continued to do imaginative and skillful work. Whether at the author's urging or on his own initiative, he wisely portrayed the psychological turning points in the mystery, particularly those involving Rosa and Jasper (who somewhat resembled Dickens at this time much as Copperfield and Pip had been his alter egos). Though Fildes did not depart very far from Collins's sketches of Rosa (see figs. 189, 194, 195), she becomes more expressive in his hands, whether sitting indifferently next to Edwin (III, facing p. 28), shrinking from Jasper (XIX, facing p. 217) (fig. 197) or gazing intently at Tartar (XXII, facing p. 246). His departures from Collins's undecided delineations of Jasper were more radical. Fildes, in seven of his twelve illustrations, rendered him in all his complexity: the manipulative teacher, relative, and host (VII, facing p. 64; VIII, facing p. 74); the thwarted schemer (XV, facing p. 172); the demonic lover (XIX, facing p. 217) (fig. 197); and the confused opium smoker (I, facing p. 2; XXIII, facing p. 263) (see fig. 193). That Jasper's appearance-his hands as well as his facial expressions and body postures (I, 3 and $\mathrm{XIX}, 216$, for example)-varies slightly each time he is portrayed suggests no vacillation on the part of the artist, 


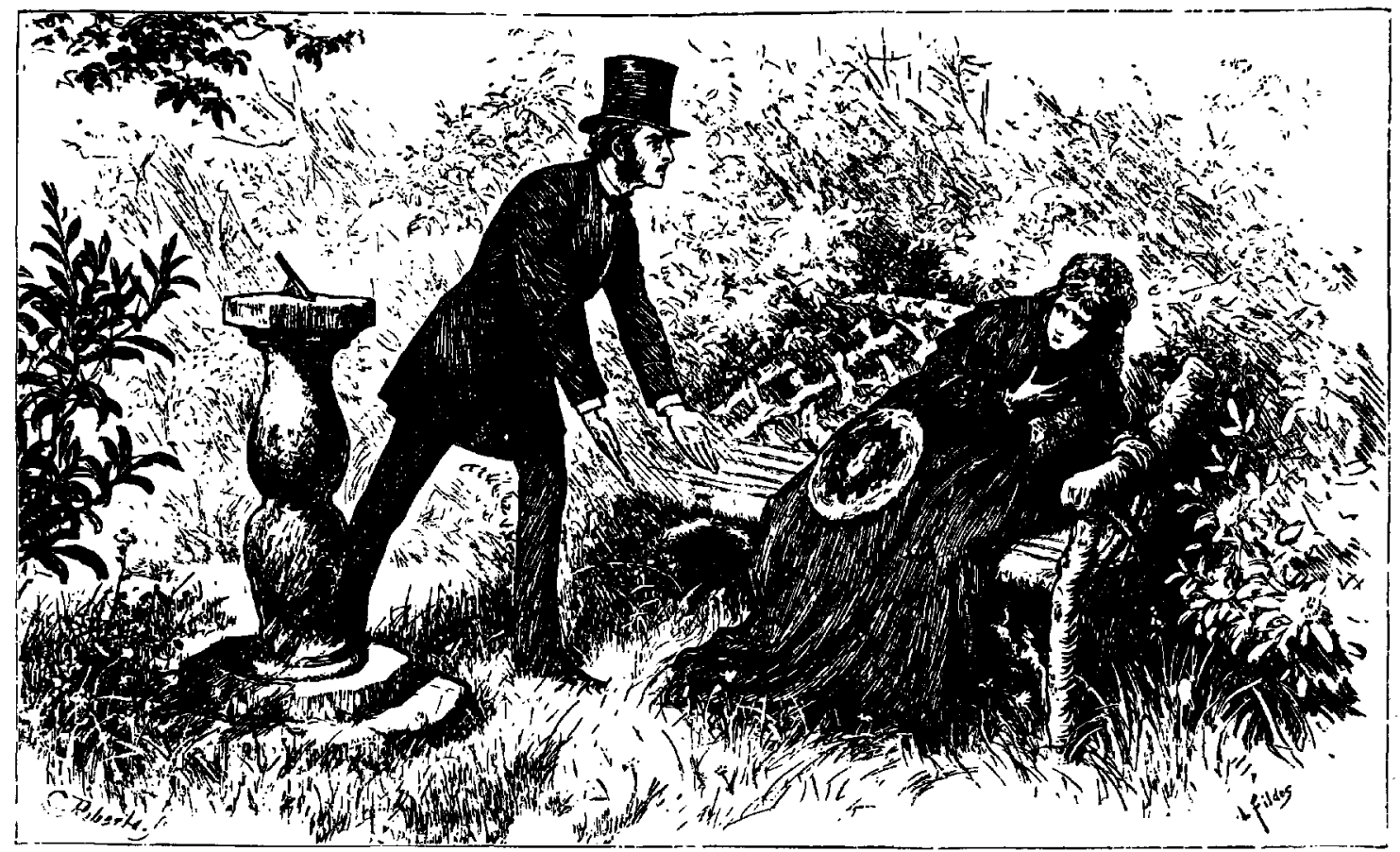

Fig. 197. Luke Fildes, 'Jasper's Sacrifices.' The Mystery of Edwin Drood, no. 5. Wood engraving. $315 / 16^{\prime \prime} \times 6 \% 16^{\prime \prime}(10 \times 16.4 \mathrm{~cm})$. By permission of the Houghton Library, Harvard University.

who made several studies for each illustration, but rather a firm graphic understanding of the development of Dickens's subtle protagonist. ${ }^{24}$ Indeed, Fildes's realization of the choirmaster, as well as of the other main characters, so gratified Dickens that he declared them "veritable photographs" of his creations, endowed with a reality that transcended mere naturalism. ${ }^{25}$

Fildes not only earned Dickens's praise and confidence but his friendship as well. The young man was charming as well as accomplished and Dickens often invited him to Hyde Park, where all was done to make him feel at home. ${ }^{26}$ Consequently Fildes had only to mention his preference to have his drawings engraved by his friend, Charles Roberts, rather than the better-known Dalziel brothers, who had done the first two illustrations, to secure the author's support in the matter with Chapman and Hall. ${ }^{27}$ In one crucial instance, Fildes even prevailed over Dickens's choice of subject. ${ }^{28}$ In the fourth number, apparently, Dickens wanted him to show Jasper mounting the dark gatehouse steps with a murderous expression on his face and a neckerchief wound twice around his throat (XIV, 162). Frustrated by not knowing the significance of such details, the artist asked why Jasper's usual small black tie should be so conspicuously replaced. Dickens, worried that he was revealing too much of his mystery too soon, reluctantly disclosed that Jasper would use the neck scarf to strangle Edwin. Fildes then dissuaded the author from having the subject illustrated at all. He convincingly argued that the gatehouse stairs would require demystifying illumination; the obvious change in neck wear would be a giveaway; and the scene was so powerfully described in words that further elucidation was unnecessary. Dickens, in another rare change of mind, yielded to Fildes's tactful and logical appeal. ${ }^{29}$

Trusting in the artist's discretion, Dickens then talked openly to him about the final projected scene in the book, which he had determined far in advance. He invited Fildes to Gad's Hill for an extended weekend visit in early June to inspect other Rochester sights for future backgrounds. On earlier visits to Kent, the artist had sketched the interior of Rochester Cathedral (fig. 198)-which would have well served the last published scene (XXIII, 271-72)-, the exterior of "Nun's House" and a characteristic Rochester street, none of which were used, but his view from the medway of the castle and cathedral did serve as an appropriate title page vignette $(v){ }^{30}$ Dickens particularly 


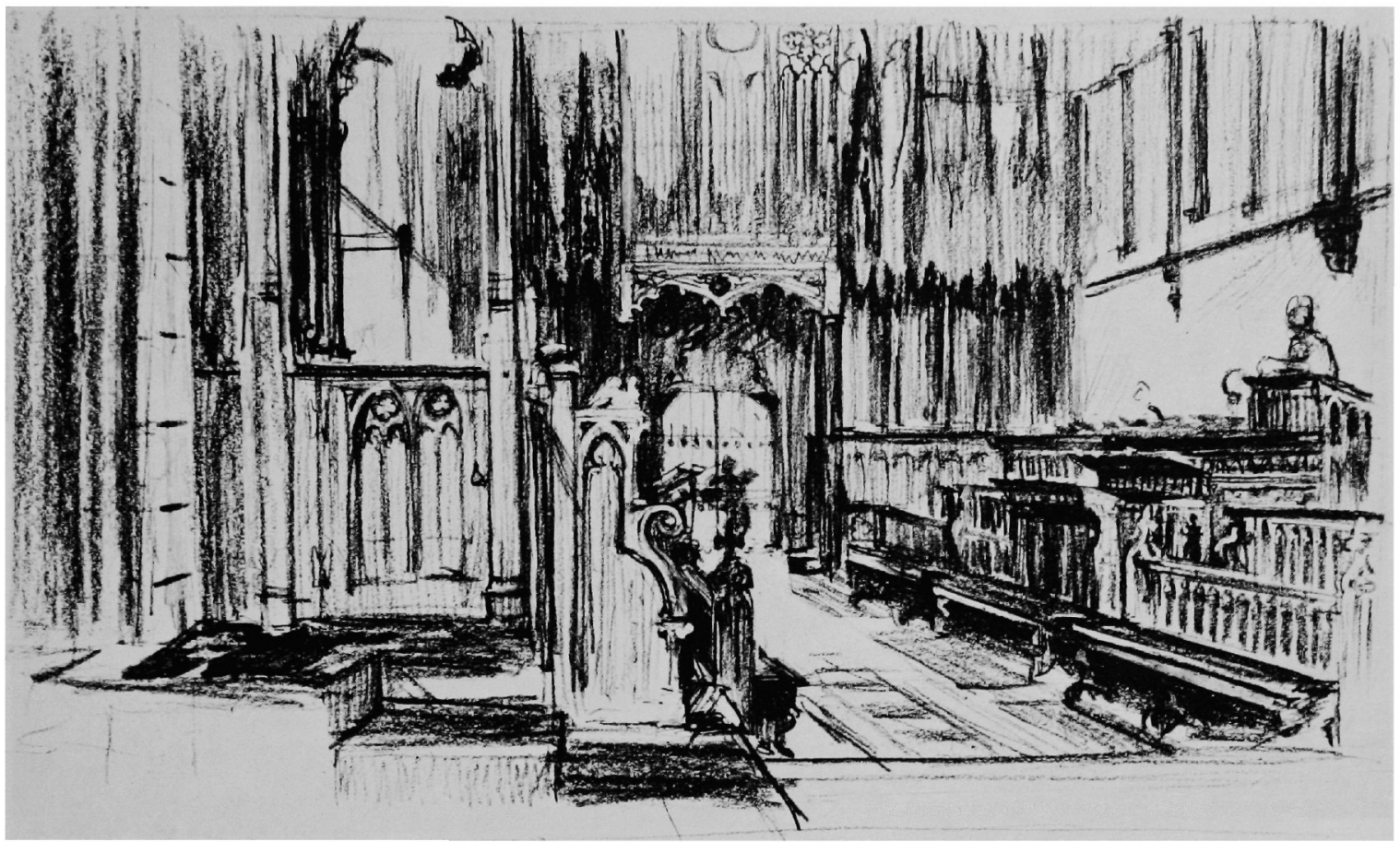

Fig. 198. Luke Fildes, Unused Sketch of 'In Rochester Cathedral.' Pencil and wash. $5^{3 / 8^{\prime \prime}} \times 8^{3 / 4}$ " $(13.7 \times 22.2 \mathrm{~cm})$. From the Gimbel Collection, by permission of the Beinecke Rare Book and Manuscript Library, Yale University.

wanted him to sketch-perhaps for the very last illustration-one of the Maidstone jails. ${ }^{31}$ It was here, according to Collins and Forster, that the author planned to have Jasper's murder confession elaborately elicited from him, perhaps by opium or mesmerism, just before his own death, and delivered as if he were talking about someone else. ${ }^{32}$ Fildes "might do something better than Cruikshank," Dickens encouraged the artist, alluding to the famous drawing of the condemned Fagin. ${ }^{33}$ This intimidating challenge, which might have invited invidious comparisons or plagiarism charges, was never taken up, however. While preparing on Friday, June 10, for his weekend visit, Fildes saw the newspaper with its announcement of Dickens's death the day before; for personal as well as professional reasons, Fildes was devastated by the news, for Dickens had treated him, as he had Marcus Stone, like a son. ${ }^{34}$

Only three numbers of Drood had been published. Engravings had not been entirely determined for the remainder of the text that was already written. Forster subsequently assembled Dickens's manuscript for publication, while Fildes selected, completed, and entitled the illustrations for it himself. The sudden deprivation of direct authorial inspiration and supervision-and consequent turmoil-may account for the uneven quality of the last six engravings compared to the first six. The four illustrations involving Rosa, for example, are disappointing. Fildes, better at rendering a few characters at once, nicely spaced the girls bidding farewell to Rosa at Miss Twinkleton's but hardly differentiated them either from one another or from the heroine, who is identified mostly by her central position in the picture (XIII, facing p. 143). ${ }^{35}$ The way Rosa shrinks from Jasper during his proposal is too theatrical, even in terms of this melodramatic scene (XIX, facing p. 217) (see fig. 196); ${ }^{36}$ and the badly defined foliage against which she retreats recalls the similarly ill-defined wall against which she almost disappears when Jasper earlier frightens her at the piano (VII, facing p. 64).

Fildes's early reservations about his ability to represent the lighter moments in Drood were somewhat substantiated 


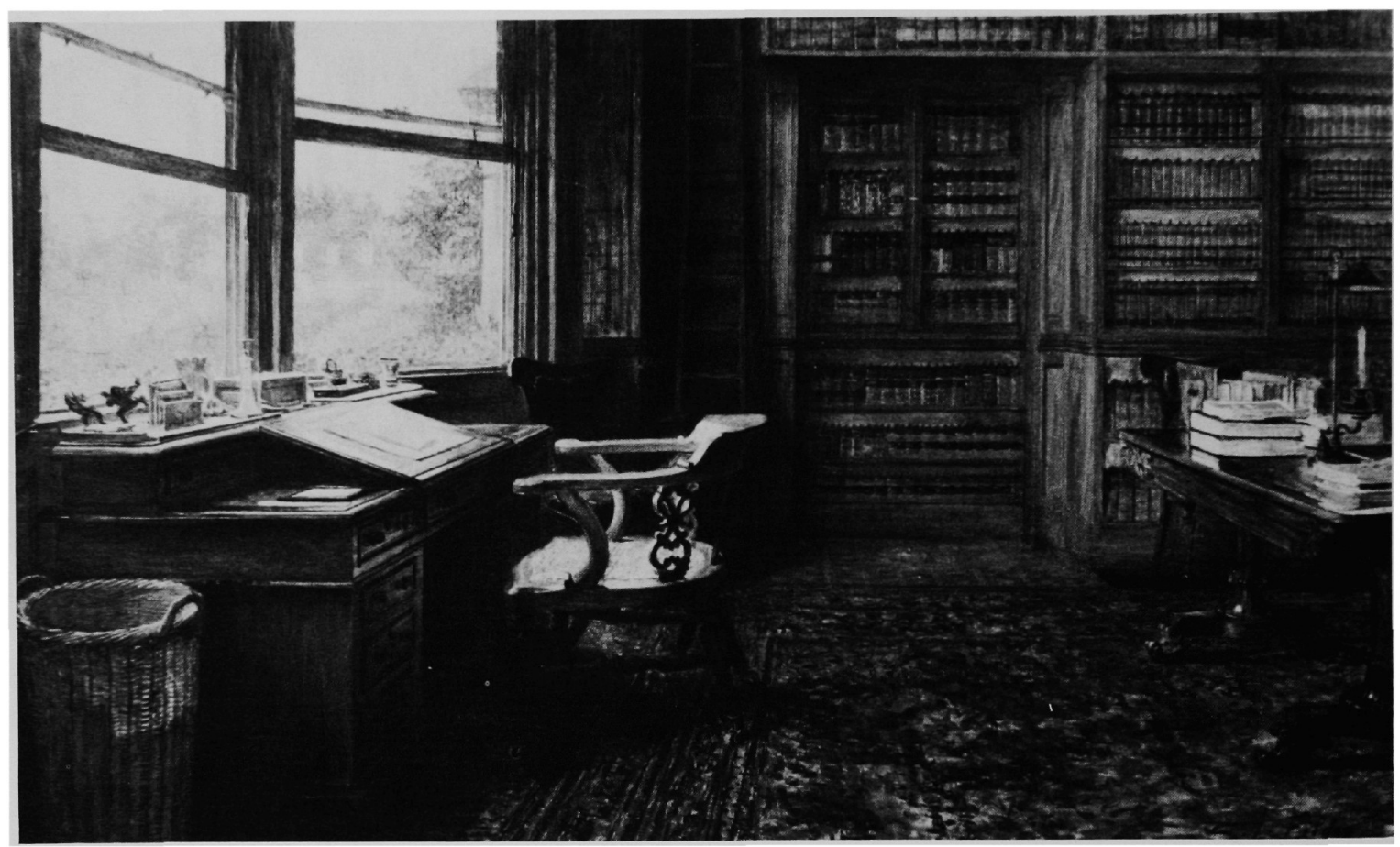

Fig. 199. Luke Fildes, 'The Empty Chair.' Watercolor. $15^{\prime \prime} \times 251 / 4^{\prime \prime}(38.1 \times 64.2 \mathrm{~cm})$. From the Elkins Collection, by permission of the Rare Book Department of the Free Library of Philadelphia.

after the author's death. ${ }^{37} \mathrm{In}$ 'Mr. Grewgious experiences a new Sensation,' a scene of Rosa and her elderly guardian at Staple Inn after her flight from Cloisterham, Fildes's choice of sentimental subject is dramatically questionable though appealing (XX, facing p. 225). ${ }^{38}$ Similarly, his representation of their subsequent ride 'Up the River' with Tartar and Lobley is unsatisfying (XXII, facing p. 246). Dickens had wanted Fildes to portray the recognition scene between Crisparkle and Tartar originally in the fifth number, but Forster's rearrangement of the text delayed Tartar's introduction until the sixth number (XXI, 231). ${ }^{39}$ Not only did Fildes show poor judgment in not waiting to illustrate that more interesting confrontation later, but his execution of the principals in the river excursion is flawed: Rosa appears too intense to be enjoying herself as the text maintains she does (XXIII, 246); Grewgious appears inexplicably stockier on sea than on land; Tartar, seen mainly from the back, is hardly memorable; and his man, Lobley, whose fully revealed face resembles a bemused kindly monkey, dominates the romantic idyll. ${ }^{40}$ The artist, as he himself anticipated, better displayed his talents in the grimmer scenes involving Jasper, whose prone body is surveyed by the suspicious Grewgious in one picture (XV, facing p. 173) and by the eavesdropping Opium Woman in another (XXIII, facing p. 263). In fact, these two illustrations, with their striking use of firelight and shadow as well as their expressive representation of hands as well as faces, make the viewer wish that Fildes had had the opportunity to deal with the full tragic depths of a completed Dickens novel. ${ }^{41}$

After the author's death, Dickens's family, friends, and even his former illustrators became closely involved with Fildes. Concerned that Drood's termination might adversely affect the career of the personable young artist, the Dickens family encouraged him in many different ways. After the Westminster funeral, they invited him to Kent in belated fulfillment of the novelist's wish. When he showed interest in Dickens's desk, with its odd assortment of cherished objects, Georgina gave him the memorandum slate, quill pen, and a piece of blue stationery to keep..$^{42}$ The family granted permission for his watercolor portrayal of the library, including Dickens's desk, to be engraved for The Graphic, where it appeared with the title, 'The Empty 


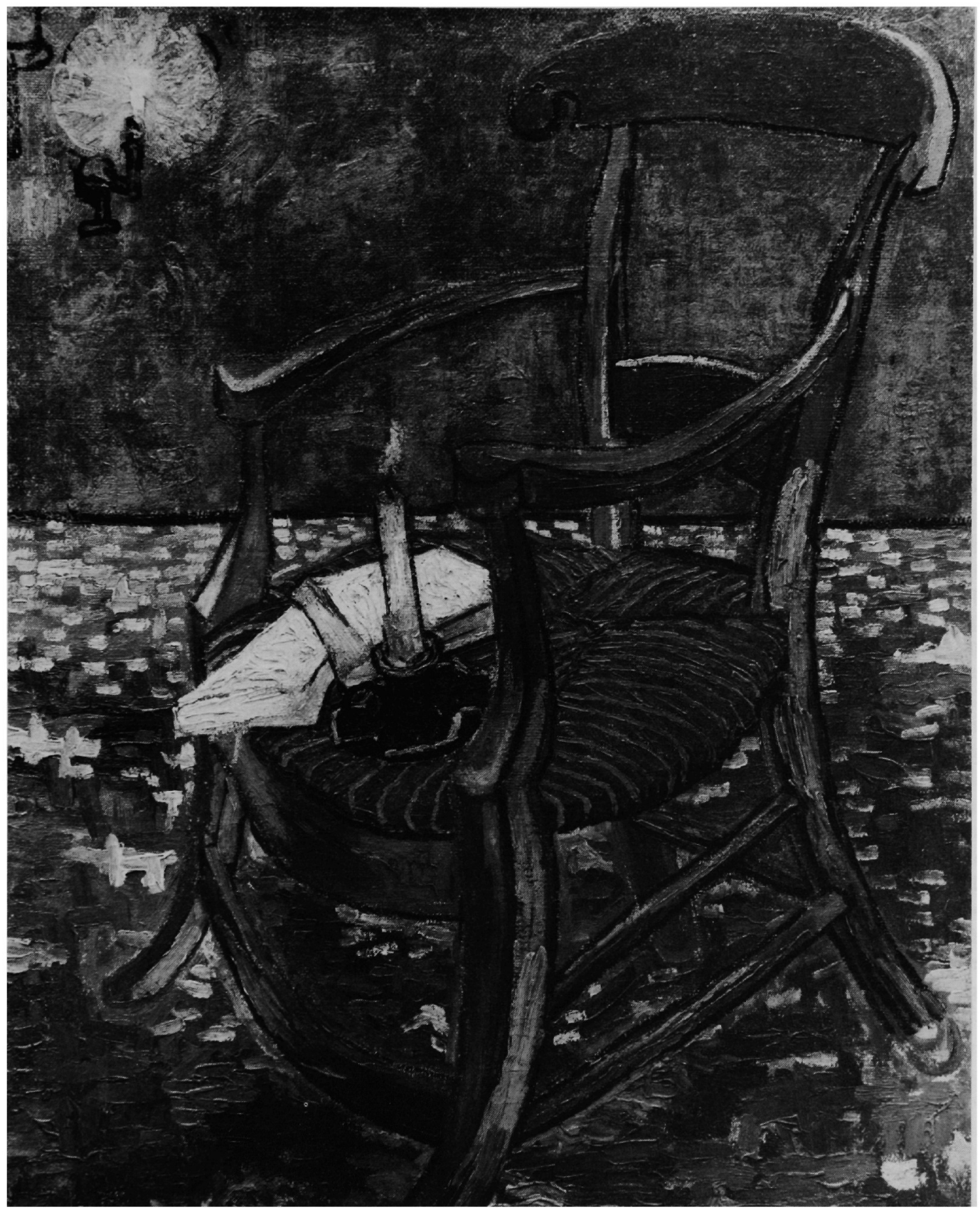

Fig. 200. Vincent van Gogh, 'Gauguin's Chair,' 1888. Oil. $355 / 8^{\prime \prime} \times 283 / \mathrm{s}^{\prime \prime}(90,5 \times 72 \mathrm{~cm})$. By permission of the Stedelijk Museum, Amsterdam. 
Chair' (fig. 199). ${ }^{43}$ It was greatly admired by many, but none more so than Vincent van Gogh, whose 1888 painting of 'Gauguin's Chair' it apparently influenced (fig. 200). ${ }^{44}$

Fildes's Graphic engraving was accompanied by Charles Collins's description of Dickens. ${ }^{45}$ Indeed Collins, far from appearing to resent or envy Fildes, was particularly helpful. He introduced him to his brother Wilkie, some of whose works, as well as ones by Lever, Reade, and Thackeray's daughter, Anne, among others, Fildes subsequently illustrated. ${ }^{46}$ Collins also introduced him to Millais, whose illustrations in the 1860's had inspired Fildes to work for periodicals but who now encouraged him to rent a studio, concentrate his energies on painting just as Marcus Stone was now doing, and advised him as to subjects for paintings that might be of interest to the Royal Academy; indeed, one of his subsequent paintings, 'Simpletons,' which was displayed at the Royal Academy in 1873, was entitled by Collins and his wife. ${ }^{47}$ Even after Collins died in 1873, Fildes continued his friendship with Kate and her new husband, Carlo Perugini, and other members of the Dickens family; in later years, he painted Kate's portrait, as well as that of her younger brother, Henry, and also gave her his sketch of "The Empty Chair. ${ }^{48}$ Meanwhile, Forster commissioned him to do a watercolor of Dickens's grave in Westminster Abbey to be engraved for the third and last volume of his biography of the author. ${ }^{49}$ By 1877 , just seven years after Dickens's death, Fildes was successful enough as a painter that he could resist the entreaties of Lewis Carroll, who admired the pictures for Drood so much that he was very eager to have Fildes illustrate the successors to the Alice books. ${ }^{50}$

Ironically, the subject of 'Houseless and Hungry,' which had led to his Drood commission, once again proved to be the vehicle for Fildes's continuing professional advance. While redesigning the composition for his 1874 Royal Academy canvas, now re-entitled 'The Casuals,' Fildes was astonished to learn from Forster that Dickens had not only witnessed but described just such a scene of unfortunates waiting in the frigid weather outside the workhouse for a night's lodgings ${ }^{51}$ The artist, stunned by this coincidence that the novelist himself had forgotten, secured permission to quote Dickens's powerful description beneath the title of his work in the Royal Academy exhibition catalogue; his forceful painting attracted such crowds that police and barricades were necessary to control them. ${ }^{52}$ This triumph, together with less sensational successes in painting portraits, in which he subsequently specialized, insured his eventual election to the Royal Academy. The news of this honor was brought to him in 1879, in another twist of fate, by Marcus Stone, himself recently elected to the Royal Academy; in fact, the two former Dickens illustrators remained neighbors and friendly rivals throughout their careers. ${ }^{53}$ Yet the Drood artist was not so absorbed by his own success as to remain unmoved by the plight of Dickens's principal illustrator, Hablot Browne, for whom he helped to procure an Academy pension to relieve his last wretched days. ${ }^{54}$ If, in his own old age, Fildes grew bored with the works of Dickens, at least he never forgot that he owed him much of his subsequent good fortune. ${ }^{55}$

Throughout his life, Fildes was plagued by Dickens enthusiasts, especially those trying to track down the ending of The Mystery of Edurin Drood-an enterprise they pursued with a tenacity never displayed by admirers of Mrs. Gaskell, Nathaniel Hawthorne, and Thackeray, whose last works were also unfinished. ${ }^{56}$ The artist, however, contributed little information that readers could not deduce for themselves. ${ }^{57}$ But the multiple ironies of the situation made further inquiry irresistible. Just as Dickens's first novel still provokes controversy about its origins, his last work provokes controversy about its ending. In both disputes, any position must be based in part on the testimony of the illustrators and their families as well as on a minute examination of their drawings. The problem of Drood's conclusion, like those of Pickwick's genesis, may never be resolved conclusively. That they still engage readers after more than a century, however, testifies to the novels' transcendent power. Thus this account of Dickens and his original illustrators comes full circle with the author, not the artist, having, as always, the last word. 


\section{Conclusion DICKENS AND THE DECLINE OF THE ENGLISH ILLUSTRATED NOVEL AFTER 1870}

As the publication of The Pickwick Papers in 1836 marked the rise of illustrated popular fiction in England, so Dickens's death in 1870 heralded its gradual decline. Paradoxically, the unprecedented success of Dickens and his original illustrations may have hastened the reversion of illustrated new fiction to its present pre-Pickwick status, and the technical, economic, sociological, and aesthetic conditions that fostered its rise also accelerated its degeneration. The advantages of illustrations had outweighed their disadvantages throughout the Victorian era for most novelists, as well as publishers, artists, and, above all, readers. In the twentieth century, however, in America and on the Continent as well as in England, illustrations tend to be regarded as more trouble than they are worth by these principals. Yet the recent revival of interest in Dickens's original illustrations, which had previously shared the fate of illustrated fiction generally, is encouraging. Whether present interest reflects nostalgia for the past, renewed scholarly interest in every aspect of Victorian England including Dickens, anticipates a new era of book illustration, or will remain an isolated phenomenon remains to be seen.

The world Dickens passed from in 1870 , in contrast to the one he entered in 1812, was deluged with graphic material, especially illustrations for new fiction. As costly methods of reproducing drawings, etchings, and engravings yielded to cheaper photomechanical techniques, illustrations became increasingly accessible, in color as well as in black and white, and in daily as well as weekly and monthly doses. ${ }^{1}$ Publishers provided the public with a proliferation of illustrated fiction in one-volume hardcovers and periodical serials, which were beginning to drive out the shilling monthly parts and the three-decker novel. Eventually, however, illustrations for new popular but serious fiction, which Dickens's success had helped popularize, lost their novelty and no longer guaranteed higher sales.
As the twentieth century progressed, illustrated new fiction suffered from the decline of serial publication, which minimized publishers' risks, as well as from rising labor costs and competition from photojournalism, movies, and television. Now, as before 1836 , publishers do not commission illustrations for the promising literary classics of the future, but for the established ones of the past-and then usually only for a limited luxury edition-and for children's books and for gift books that, like the old annuals and "keepsakes," are meant to be looked at rather than read. ${ }^{2}$ Illustrations may appear on dust jackets or paperback covers to attract buyers, as illustrations posted in booksellers' windows used to do, but they rarely appear in the text itself; exceptions, of course, are comic strips for the near-illiterate which Gabriel Garcia Márquez, for example, has termed the "apotheosis of the novel" (the illustrated novel, one might add). ${ }^{3}$ Even publishers who agree with William Morris that the illustrated book, because it combines so many arts and gives such pleasure, should "remain one of the worthiest things towards the production of which reasonable man should strive" know that his view is more idealistic than economically realistic. ${ }^{4}$

That "the Dickenses of today may go unillustrated," as Lynton Lamb put it, "may not be a source of regret among contemporary authors." Most serious novelists no doubt would prefer to do without illustrations, even if publishers encouraged them, since in recent decades, as before Pickwick, the vehicle for fiction with the greatest appeal for the educated elite has been the unillustrated bound volume. Illustrations have usually been associated with serialized or short narratives appearing in popular but not intellectually prestigious magazines (themselves now defunct or in danger of extinction). Though Pearl Buck's second husband, as editor of Asia, included illustrations with most of his wife's books that appeared there before and after The Good Earth 
(1931) in serial or complete form-as did Collier's, Ladies' Home Joumal, Good Housekeeping and other less cerebral magazines-as editor and then president of the John Day Company, he never continued this practice in the subsequent hardcover editions. Similarly, Ernest Hemingway's novella, The Old Man and the Sea, first appeared complete in Life magazine on September 1, 1952, with blue-tinted drawings by Noel Sickle; for its debut in volume form, however, Scribner's, no doubt with the author's acquiescence, omitted any illustrations.

The nature of the fiction written by major authors after Dickens undoubtedly contributed to the demise of illustrations. Dickens's narratives lent themselves especially well to graphic representation; those of his successors usually did not. As George du Maurier summed up the situation by 1890: "If the disappointed author says to [his illustrator], 'Why can't you draw like Phiz?' he can fairly retort: 'Why don't you write like Dickens?" "F For despite the fact that following the Pre-Raphaelites ut pictura poesis once again became the ideal of verse, serious fiction followed a different path. The naturalistic narratives of George Gissing, Arnold Bennett, and John Galsworthy, for example, doubtless made imaginative illustrations inappropriate and realistic ones superfluous. ${ }^{7}$ The later introspective stories of $E$. M. Forster and Virginia Woolf with their psychological plots, stream-of-consciousness monologues, and symbolism, together with the increasingly egocentric and abstract prose of their successors, still seem to render illustration virtually inconceivable. No wonder Harvey concludes that "in respect of illustration the modern novel has a withered limb."

Even authors after Dickens, with comparable pictorial imagination and style, worried that illustrations would date, misinterpret, or in some other way limit their prose conceptions. Others openly feared competition from contributions to their books by another artist working in another medium. Henry James, for example, on whose youthful mind Dickens's first artists had perhaps made too indelible an impression, permitted his travel books but never his mature fiction to appear with drawings. ${ }^{9} \mathrm{He}$ grudgingly admitted Alvin Colburn's photographs into the New York edition of his works only as frontispieces and only after reassuring himself that they would contribute in as different an aesthetic medium as possible, so that their reference to "Novel or Tale should exactly be not competitive or obvious."10 "Anything," James further explained, "that relieves responsible prose of the duty of being, while placed before us, good enough, interesting enough, and, if the question be of picture, pictorial enough, above all in itself, does it the worst of services, and may well inspire in the lover of literature certain lively questions as to the future of that institution."11 Similarly, Thomas Hardy increasingly excluded all illustrations from the collected editions of his novels except for photographic frontispieces and a regional map drawn by him. ${ }^{12}$ None of the first or standard editions of Joseph Conrad's fiction seem to have been illustrated in his lifetime, nor were any of James Joyce's, except for the extravagant edition of Ulysses, issued by the Limited Editions Club in 1935, with drawings and etchings by Matisse.

Furthermore most of the later novelists, whatever the content and style of their prose, would not have wished to spend endless hours with artists and illustrations. Lacking Dickens's enduring belief in the value of illustrations, they also lacked his energy, authority, and interest in coping with all the professional and personal aspects of collaboration with another artist. Leo Tolstoy, had he lived closer to urban art centers, might have proved an exception, to judge from his wholehearted involvement in the illustrations he commissioned (despite the advice of intimates) for War and Peace (1867-69) by M. S. Bashilov as well as those for Resurrection (1899) by Boris Pasternak's father Leonid. ${ }^{13}$ But few authors, if any, would have been willing to worry about their artists' egos, preferences, infirmities, or lack of experience, as Dickens did, not to mention the deadlines of engravers on top of those of publishers and printers. Consequently many authors became increasingly remote from illustrators as well as the illustration process. It is a suitable paradox that the one author who, in one period of his career, surpassed Dickens's professional involvement with an artist and the original illustrations to his work - even providing sketches for guidance-is far better known for his plays. Bernard Shaw's childhood ambition to paint surfaced not only in his early art criticism but in his later absorption with every aspect of the wood engravings John Farleigh provided for The Adventure of the Black Girl in Her Search for God (1932) and in Short Stories, Scraps and Shavings (1933). ${ }^{14}$ In our day, however, there seems to be no evidence to disprove Harvey's blanket assertion that "one does not imagine a novelist taking any interest in the illustrations of his work, if it has any illustrations."15

In such a discouraging atmosphere, it is not surprising that the remarkable nineteenth-century author-artists -Blake, Lear, and W. S. Gilbert, who illustrated their own verse; Thackeray, du Maurier, Greenaway, and Potter, who illustrated their own fiction; Ruskin, Rossetti, Hopkins, Beardsley, Whistler, the ubiquitous Morris, and the young Beerbohm, all of whom displayed (usually separately) verbal as well as graphic facility-left no reliable heirs, especially in novel illustration. Whether in reaction to the illustrated narratives of their youth, now commonplace, or fearful of 
meeting the new aesthetic standards, even those authors with artistic skills revealed them sparingly, when at all, and rarely in their important works. They seemed to agree tacitly with Lewis Carroll, who, after himself illustrating the presentation manuscript of Alice's Adventures Under Ground, preferred to let a professional like Tenniel, in this instance, supply the pictures for the published version. ${ }^{16}$

Thomas Hardy, for example, though an able draftsman, willing to illustrate some of his published poems (though apologetically) and to instruct an illustrator with sketches, never supplied more than a map for his own novels. ${ }^{17}$ The versatile Samuel Butler, despite extensive training to be an artist, always separated his mature paintings from his important prose, as did that later iconoclast, D. H. Lawrence. ${ }^{18}$ Other novelists with graphic facility applied their talents sporadically when at all. The impulse that prompted young Henry James to take art lessons led to verbal, not graphic, "pictures" of people and places, and art reviews; Robert Louis Stevenson, despite prolonged holidays near the flourishing Barbizon painters in Fontainebleau, never reproduced his amateur landscape sketches in his lifetime; Kipling, an artist's son, provided the pen drawings for his Just So Stories (1902) but did not follow further in his father's footsteps; H. G. Wells was content to let his comic "picshuas" adorn only letters and presentation copies of books to friends, letting professional artists cope with those of his fictions that were illustrated; Evelyn Waugh put his brief art training to use in only one of his many novels, the Decline and Fall (1929); and Wyndham Lewis, who studied at the Slade School of Art, illustrated the fiction of others, but not his own. ${ }^{19}$

The situation abroad was no more encouraging. Although amateur draftsman Victor Hugo did not hesitate to supply frontispiece designs for some of his novels, a later writer like Thomas Mann might supply drawings as well as text for his proposed (but never published) Picture Book for Good Children but not for Buddenbrooks (1901), which was being written concurrently. ${ }^{20}$ In America, which never boasted a tradition of author-artists except in children's fiction, writers with artistic inclinations have similarly separated, hidden, or disparaged them. E. E. Cummings, who considered himself an artist as much as a poet and an occasional fiction writer, published his art separately from his writings, except for one playful collection of stories (1930). ${ }^{21}$ William Faulkner refused to allow the later reproduction of the stylized illustrations of his university days, for in his maturity he displayed his graphic talents only to his family and close friends. ${ }^{22}$ In our day, Kurt Vonnegut defensively announces his compulsion to "scrawl pictures of a Nazi flag and an asshole and a lot of other things with a felt-tipped pen" rather than suggesting that he may be providing his own illustrations in Breakfast of Champions (1973) in order to break out of the strict bind of print. ${ }^{23}$

Book illustration, always an arduous craft, remained financially unrewarding for most artists, despite and then because of the plethora of illustrated matter in the decades after Dickens's death, just as it had been before 1836. Even if a major novelist wished to publish his work with plates, and even if his publishers agreed to the extra expense, doubtless he would have had trouble finding an established artist willing to take on the work unless, like Dickens, he could persuade on grounds of friendship. There were few contemporary counterparts to Cruikshank and Seymour, willing to illustrate an unknown "Boz." Many Victorian artists, as Graham Reynolds has observed, were "sturdy materialists" in their lifestyle as in their painting. ${ }^{24}$ No doubt they took heed when Cruikshank and Browne, among the first and most successful artists to earn a living largely from book illustration, died neglected and poor. Younger men continued to illustrate books and periodicals, but primarily to get started in more lucrative painting careers - the route followed by Marcus Stone and Luke Fildes. And newly established painters like John Millais could supplement their incomes better by illustrating periodicals, which paid higher commissions than did book publishers. ${ }^{25}$ Meanwhile, those artists content to remain illustrators could earn a more secure living by contributing to some of the many illustrated periodicals partly spawned by the fabulously successful part-issues of Dickens and his fellow novelists. And the situation has not changed greatly in our day, despite the decline of the illustrated magazine.

The illustrator of current fiction probably reached his highest status during Dickens's lifetime, reverting gradually to his previous humble status after his death. When du Maurier was illustrating in the last quarter of the century, he was surprised and upset by an apparently unbridgeable gulf of snobbishness between illustrators and more traditional artists, and grieved that his dream of black-and-white art to rival painting would not be realized. ${ }^{26}$ The artistnarrator of Henry James's "The Real Thing" probably spoke for most of his colleagues when he explained: "My illustrations were my potboilers; I looked to a different branch of art to perpetuate my fame." "27 Some painters, like Luke Fildes, paid lip service to du Maurier's aspirations: "It may be said, scoffingly, that the Art of the Illustrator is but the Art of the Multitude. Be it so. But he who by earnest and sincere efforts, arrests, stirs, or gives pleasure to the many does good work, perhaps great work."23 But the former illustrator declaimed from the security of the Royal Academy, the center of Victorian art patronage which, 
despite Dickens's best efforts in $1848(C P, 1: 193)$, did not elect an exclusive practitioner of black-and-white art to full membership until $1956 .^{29}$

Yet a more élitist du Maurier prophecy, voiced at the beginning of the so-called golden age of English illustration in the 1860's, was validated in his lifetime. "A day is coming when illustrating for the million (swinish multitude) a la Phiz . . . will give place to real art, more expensive to print and to engrave and therefore only within the means of more educated classes who will appreciate more." ${ }^{n 0}$ In the 1890 's this day arrived for at least a few gifted illustrators, who considered themselves designers and craftsmen as well, but its arrival had less auspicious implications for the future of illustrated popular fiction. Oscar Wilde was especially fortunate in securing for The Picture of Dorian Gray some designs for the cover and preliminary pages by Charles Ricketts, who also joined Charles Shannon in illustrating the short stories in The House of Pomegranates (1891); although the new fiction of most of his contemporaries was also often issued with plates, most of their artists are more obscure today. ${ }^{31}$ The most esteemed illustrators of the nineties -Beardsley, Walter Crane, Hugh Thomson, and E. J. Sullivan, to name a few in addition to the two aforementioned-generally seem to have put their most memorable efforts into editions of classic fiction and esoteric verse for intellectuals and collectors, or into books for children. ${ }^{32}$ The plates dominated the text, as they were designed to do, but their success undermined earlier traditions of book illustration, which depended more heavily on the integration of picture and prose and comprehension by a broadly based audience.

The status of the popular book illustrator was hardly higher abroad. In Europe, such artists were accorded even less prestige, as book illustration for the masses had never flourished there as it had in more industrial England. Leo Stein, impressed by the young Spanish artist he had met in Paris, commented in 1913: "Picasso is to my belief an illustrator by his gifts, one of the greatest who was ever born, but illustration in our day is anathema." ${ }^{33}$ When Continental artists like Picasso and Marc Chagall did do illustrations, not as an inferior but as an alternative and optional way of working, they were the real features in limited luxury editions of dead-authors, usually poets. ${ }^{34}$ In the United States, Andrew Wyeth refused to contribute a lithograph even to a book about his own works because he felt that the standing of his father N. C. Wyeth (1882-1945) as an original artist and painter had been irreparably damaged by his prolific book illustrating. ${ }^{35}$

Ironically, the technical advances that made illustrated fiction so widely available in the nineteenth century doomed it in the twentieth, benefiting book illustrators far less than publishers, authors, and readers. ${ }^{36}$ Some illustrators profited from their steadier employment on periodicals or from the wider distribution and consequent popularization of their scenes, thanks to processes that reproduced more copies at less cost. But most found it harder to attract attention and all must have felt a diminished sense of public mission. It was harder to appeal to the more jaded imaginations of the increasingly sophisticated post-Dickens audiences, whose appetite for realism and information was better satisfied by photographs. And although the new photomechanical processes reduced discrepancies between the artist's drawing and the final reproduction, his lesser involvement both demoralized him and devalued his work. The late Victorian revival of more personal but anachronistic procedures, by Morris at his Kelmscott Press and especially by Ricketts and Shannon at the Vale Press and Lucien Pissarro at the Eragny Press, held as one of its aims a restoration of the union between an illustrator's conception and execution of his work; but this union, a necessity when Dickens was writing and Seymour, Cruikshank, and the young Browne were illustrating, has proved too costly a luxury. ${ }^{37}$ Moreover, whatever process is used, artists of all times and countries have invariably protested the quality of their reproduced designs. Virginia Woolf discovered this truth when her sister, Vanessa Bell, viewed the carefully wrought prints of her woodcuts for Kew Gardens (1919) and made a vow (not kept) never to work for the Hogarth Press again. ${ }^{38}$

As if to compensate for their increasingly frustrating lot, some post-Dickens illustrators appear to have practiced a weird kind of revenge. Driven by technological developments and the taste of the times into the hands of the late Victorian "Art for Art's Sake" movement, which as Mrs. Leavis has noted, placed a premium on illustrations conceived as pictures in their own right, they became more self-consciously independent but less willing to help authors. ${ }^{39}$ Even before Dickens's death, in an 1868 article not written but certainly approved by him, All the Year Round observed that early Victorian illustrators had set an author's best scenes before the reader, whereas contemporary ones seemed more interested in representing scenes that would reflect their own abilities. ${ }^{40} \mathrm{Du}$ Maurier apparently was atypical in wishing he had been able to consult Hardy more often for The Hand of Ethelberta (1876) illustrations to better portray his conceptions; in the same year, Trollope was bitterly complaining that "an artist will frequently dislike to subordinate his ideas to those of an author, and will sometimes be too idle to find out what those ideas are." By the start of the twentieth century, in the aftermath of 
the egocentric nineties, veteran G. S. Layard observed that the average illustrator acted curiously superior to an author's minimal requirements: "He either does not read the episodes that he is called upon to illustrate, or, if he reads them, he does not grasp their meaning, or, if he grasps their meaning, the meaning does not meet with his approval. At any rate, he constantly makes a hash of the whole thing." 42 Whether such egocentricity was cause or effect, the notable achievements of Victorian and early Edwardian illustration, even before the devastating effects of the First World War, were gradually petering out.

As in the days before Pickwick, the author of new illustrated fiction, whether in book or magazine form, was usually subordinate to, as well as remote from, his artist. Shaw felt compelled to remind one of the most outstanding illustrators of the 1930's that illustration involved much more than "making a picture and sticking it into a book." The continuing relevance of his admonition is reflected in the following recollected interchange shortly after the Second World War between Evelyn Waugh and the editor of a popular magazine, who was publishing one of the author's short stories with a single illustration.

"This illustration is by the very best artist in the country.'

'What did you pay for it?'

'2,500 dollars.'

'But you could have got a real picture for that.'

The editor then said, 'What's more, this illustration is about the story. Often they have nothing to do with it.' 'Why?'

'Artists as important as [Al Parker] are so busy they don't get around to reading what they illustrate. Maybe they have a secretary make them a synopsis. Then maybe they get mixed. We can't control artists as important as [Al Parker], ${ }^{44}$

It seems clear that successful illustrators today are no more willing than formerly to be "the ballyhoo guy to bring people into the author's tent," as Arthur Brown, who illustrated some of 0 . Henry's and Fitzgerald's short fictions, has put it. ${ }^{45}$

If the serious common reader in the century after Dickens's death had continued to want his new fiction illustrated, publishers, authors, and artists, whatever their reservations, would have met the demand. But in the years following 1870, English readers, now almost wholly literate, were flooded with pictorial fiction, which first expanded the tradition of novel illustration, as Mrs. Leavis has noted, but ultimately impoverished its educative and amusement value. ${ }^{46}$ Readers could absorb the realistic contemporary scenes more easily than those of the earlier illustrators, whose anatomical idiosyncrasies and Hogarthian subtleties had provided previous generations with food for thought and comment for extensive periods. ${ }^{47}$ Some readers, their imaginations now besieged with images, more readily agreed with Henry James that pictures, at best, were like a "perpetual nudging of the elbow" which interrupted the story and, at worst, were "impertinent" and "illicit" shortcuts to it. ${ }^{48}$ Others preferred something left to their imaginations in serious fiction or considered illustrations to be juvenile. Indeed, children became the only fiction readers for whom books were regularly illustrated. And even they, when grown, sometimes apologized for their youthful indulgence in them. In this vein, for example, Gertrude Stein defensively recalled her initial exposure to picture books, "but books all the same," she insisted, "since pictures in picture books are narrative."49

Meanwhile, the technological advances that enabled illustrated fiction to reach such a wide public in the Victorian era soon engendered other visual diversions, which cut down on reading time. Competition from movies and television, as. well as increased travel opportunities, further encouraged cavalier attitudes toward illustrations in fiction. Their decline was consequently inevitable. Just as the vitality of the eighteenth-century print passed into the illustrated novel and the narrative painting of the Victorian era, so did that vitality pass in the twentieth century into film.

Dickens's original illustrations have, on the whole, fared better in the century since his death than most illustrations of the period. Late Victorian publishers would not have dared to issue his work without some plates-usually reproductions of the originals, sometimes fresh designs by a surviving original artist, or, occasionally, a new hand altogether ${ }^{50}$ Most late nineteenth-century readers shared $\mathrm{du}$ Maurier's nostalgic recollection of Dickens's creations, which for them had been "fixed, crystallized, and solidified into imperishable concrete by those little etchings in that endless gallery, printed on those ever-welcome pages of thick yellow paper." ${ }^{21}$ As the century waned, however, so did near universal appreciation of Dickens and his original illustrations. Young Beardsley, like Whistler and no doubt many budding artists of the period before him, cut his teeth on subjects from the novels, but only to amuse himself and his intimates in idle moments. ${ }^{52}$ Contemporary art historians pronounced the early Dickens illustrations "rubbish," the later ones inconsequential. ${ }^{63}$ When even an admirer of Dickens as knowledgeable as George Gissing, himself a novelist who had written a study of the author and edited the Rochester edition of his works (1900-1901), confessed that he only enjoyed a few of the original designs, publishers 
must have realized it was time to call a halt. ${ }^{54}$ Accordingly, between 1916 and 1937, no editions of Dickens's collected novels appeared with the original illustrations. ${ }^{55}$ No one protested these unadorned editions and readers like $\mathrm{C}$. S. Lewis would doubtless have preferred them, for he remembered Dickens "with a feeling or horror engendered by long poring over the illustrations before I learned to read."

Even as an adult, Lewis still thought Dickens's first illustrations "depraved" but Graham Greene perhaps best expressed the consensus of the Depression generation, whose scholarly interest in the author was beginning to revive though their distaste for the original prints persisted.

It would be well if we could forget the Phiz and Cruikshank illustrations that have frozen the excited, excitable world of Dickens into a hall of waxworks, where Mr. Pickwick perpetually turns up the tails of his coat, and in the Chamber of Horrors, Fagin crouches over an undying fire. His illustrators, brilliant craftsmen though they were, did Dickens a disservice, for no character any more will walk for the first time into our memory as we ourselves imagine him, and our imagination after all has just as much claim to truth aqs Cruikshank's. ${ }^{57}$

Filmmakers, however, who adapted many of Dickens's novels in the 1930 's and 1940 's, did not share this view, relying heavily on the original illustrations for the appearance of their characters, costumes, and sets. ${ }^{58}$ The cinema (and now television), whose techniques Dickens both anticipated and infiuenced, ${ }^{59}$ have probably kept the author's name before the general public more than the novels themselves, thus preparing the ground for the subsequent popular revival as effectively as did the seminal essays of Edmund Wilson and George Orwell for the scholarly one ${ }^{60}$

Aided by publishers, literary scholars and students today realize, as did most of their Victorian counterparts, that Dickens's original illustrations are indispensable to a comprehensive understanding of his time and his texts, even if poorly reproduced, incorrectly positioned, or aesthetically uncongenial. ${ }^{61}$ Accordingly, editions of Dickens that repro- duce the first prints - the limited Nonesuch (1938), the Oxford New Illustrated hardcovers (1947-58), the scholarly Clarendon volumes (1966- ), and the Penguin paperbacks (1965- ) have been or are still being issued. It may be that Dickens's renewed popularity has generated interest in everything related to his life and work. The original illustrations seem, however, themselves to have survived the vicissitudes of taste and time as well as the narratives they initially accompanied.

Even casual readers of Dickens have always recognized Pickwick, Fagin, and Scrooge in pictures, if not the names of the artists who first portrayed them. For better or worse, consciously or not, our conception of Dickens's work seems irrevocably tied to the representations of it by the artists with whom he worked so closely. Few Dickensians have ever permanently welcomed their re-creations by later artists, no matter how technically superior or aesthetically appealing. ${ }^{62}$ Indeed, it seems, as Percy Fitzgerald perceived long ago, that

there is a curious mystery, or it may be finality, in this connection of original illustrations with the text, from which, bad, indifferent or good, they are not to be divorced. They have been engendered with it; they have come in response to the author's ideal; he at least has accepted them. They have been produced under his prompting and direction. Such are strong recommendations; but a more important cause for their acceptance is that the reader has come to know the characters and scenes in this shape. The newer designs have no authenticity, and are distasteful because strange. ${ }^{63}$

A modern reader's claim that he "would disembowel anybody who proposed a Dickens with any except the original illustrations" is a crude but increasingly representative opinion in our day. ${ }^{64}$ The most powerful and enduring reason for our cherishing Dickens's original illustrations, however, may well be our recognition that the remarkable confluence of history, technology, and personality that made them possible is unlikely to occur again. ${ }^{65}$ 


\section{Appendix}

\section{DICKENS AND \\ HIS WOULD-BE ILLUSTRATOR}

WILLIAM THACKERY

While interested London circles gossiped about Robert Seymour's suicide, William Makepeace Thackeray thought about applying to fill the vacancy he had left on The Pickwick Papers. ${ }^{1}$ In early 1836 , the young man still planned to become a painter rather than a writer: he had practiced etching at Cambridge under Robert Buss's friend, Mr. Roe, an engraver and printseller; and after he came to London, where he was befriended by artists like Frank Stone, Maclise, Cattermole, and other future Portwiners, he studied with his longtime idol, George Cruikshank, who doubted that his pupil, an ingenious wit but a poor draftsman, had the requisite patience to become an artist. ${ }^{2}$ It was probably at Cruikshank's urging that the aspiring artist applied directly to Dickens for the Pickurick position. The commission to write Pickwick had enabled Dickens to marry Catherine Hogarth; aside from the boost it would give his professional aspirations, Thackeray hoped to become its illustrator in order that he might wed Isabella Shawe.

Dickens opened his door at Furnival's Inn to the tall, bespectacled stranger (fig. 201), who quickly got down to business. Having brought two or three specimen drawings, Thackeray left them for Dickens to inspect. ${ }^{3}$ One legend, of doubtful veracity, maintains that Thackeray parted from
Dickens thinking he had been hired and celebrated his success over dinner with his colleague, Hablot Browne. ${ }^{4}$ It is much more likely that Dickens studied the designs, one of

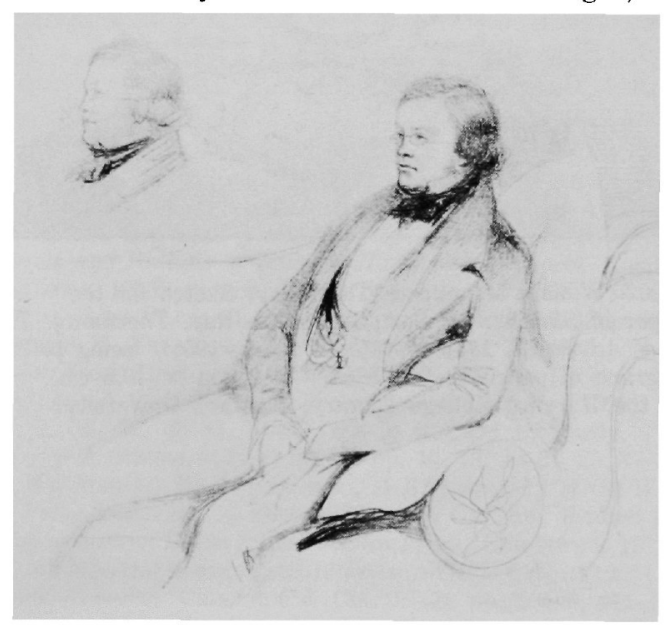

Fig. 201. Daniel Maclise, Sketch Portrait of William Makepeace Thackeray, 1835. Lewis S. Melville, William Makepeace Thackeray (London, 1910), 1, frontispiece. Photogravure after a pencil sketch. $314^{\prime \prime} \times 315 / 16^{\prime \prime}(8.2 \times 10$ $\mathrm{cm})$. From the Harvard College Library, Harvard University. 
which may have been for the Sketches by Boz wrapper (fig. 202). If so, he probably would not have admired the center figure, perhaps a gross caricature of "Boz," and the bottom mask anticipated those in the border around 'The Last Song' in Grimaldi's Memoirs, usually attributed to Cruikshank, that was quickly suppressed. ${ }^{5}$ Noting their crude lines and grotesque faces-so different from Seymour's relatively

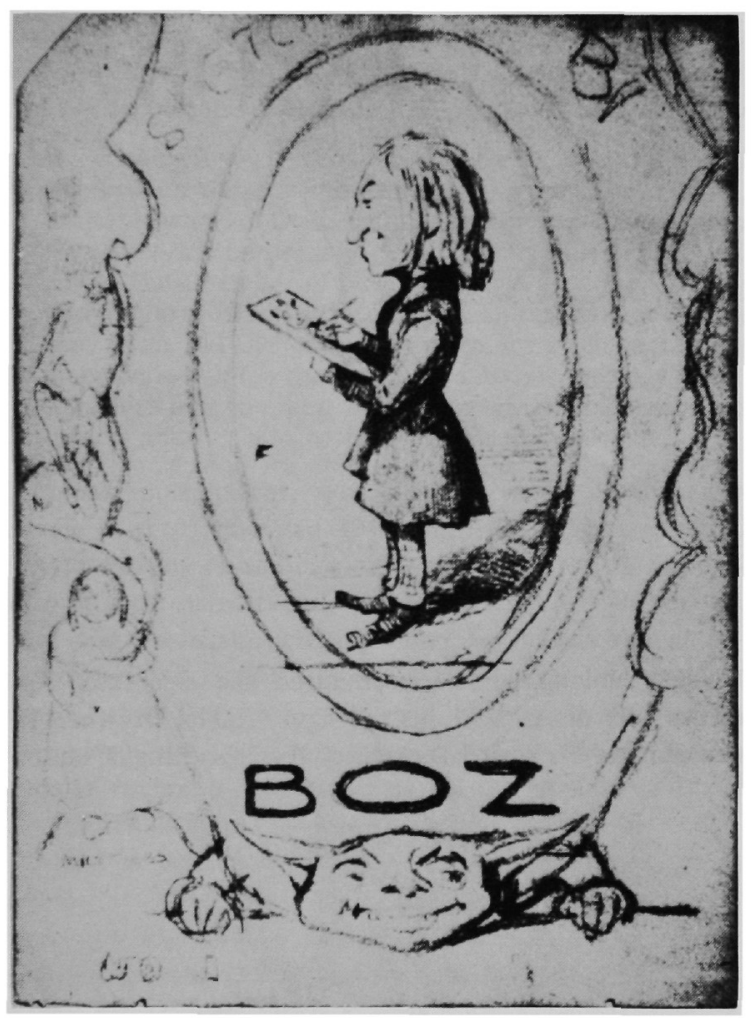

Fig. 202. William Makepeace Thackeray, Sketch for the Wrapper of Sketches by Boz. Gordon N. Ray, Thackeray: The Uses of Adversity, 1811-1846 (New York, 1955), facing p. 238. Photograph of pencil sketch. $5^{1 / 2^{\prime \prime}} \times 4^{1 / 8^{\prime \prime}}(14 \times 10.5 \mathrm{~cm})$. From the Harvard College Library, Harvard University. realistic and carefully detailed ones-Dickens understandably must have decided Thackeray would not be a suitable illustrator for Pickwick.

It would have been characteristic of Thackeray, however, upon learning that Browne had been selected to illustrate The Pickwick Papers, to be among the first to congratulate him. ${ }^{6}$ Meanwhile he wrote nothing of his disappointment to Isabella Shawe, mentioning only that they would not be parted long. ${ }^{7}$ He subsequently began to vacillate between the professions of painting and writing: Macready, who encountered him at the Garrick Club, thought that Thackeray, having exhausted his funds, was about to settle in Paris as a painter; Cruikshank, however, recalled his saying that he might "presently break out into another element and stay there." Indeed, the following year Dickens accepted one of his stories, "The Professor," for the September issue of Bentley's Miscellany. ${ }^{9}$ Ironically, the very success of the Dickens work he had failed to illustrate provided him with an ideal, commercially viable medium for his combination of verbal and graphic talents, which the influential Count D'Orsay apparently made voguish at this time.${ }^{10}$ In a little more than a decade, after the appearance of Vanity Fair in 1847-48, Thackeray became Dickens's chief competitor as a writer of serial fiction, which he often illustrated himself. ${ }^{11}$ This rivalry inevitably sharpened the acrimony between the two authors during the Edmund Yates-Garrick Club controversy; they were finally reconciled through Kate and Charles Collins's friendship with the Thackerays. ${ }^{12}$

Just before their differences peaked, however, Thackeray, rising in response to Dickens's toast to literature at the Royal Academy banquet in May, 1858, alluded to their first encounter as "Mr. Pickwick's lucky escape," in humorously recalling that "unfortunate blight" to his early prospects that influenced his decision to become a writer. ${ }^{13}$ Their fabled early meeting was recalled as briefly but more soberly by Dickens in the opening of his Cormhill Magazine tribute after the death of his main literary rival in $1863(C P$, 1: 97-101). ${ }^{14}$ By that time, it had long been apparent that Dickens's rejection of Thackeray's artistic services had turned out to be a stroke of rare good fortune for the English-speaking world. 


\section{NOTES}

\section{Introduction}

1. Pilgrim, 4:679-80 and n. 4, Forster, [?December 12, 1846].

2. Kitton, $D I$ p. vili, and Arthur Waugh, "Dickens and His Illustrators," Retrospectus and Prospectus: The Nonesuch Dickens, p. 9 (also known and hereafter cited as Nonesuch Dickensiana).

3. The criterion here is "complete," for $S B B, P F I$, and $C H E$, as shall be discussed in the relevant chapters, have a different history of publication than the other CD works cited, all of which first appeared with illustrations in substantially final form. The individual $S B B$ were published separately without illustrations (see Pilgrim, 1:692-94) before being issued collectively with illustrations (see John Eckel, The First Editions of the Writings of Charles Dickens, pp. 11-16). PFI had five chapters as well as illustrations added for its publication in book form following its appearance in installments in the Daily News in 1846 (see Eckel, p. 126); whereas $C H E$ gained illustrations but was reduced by eight chapters for its 1852-54 publication in three volumes, each of which appeared after the comparable material ran in Household Words from 1851 to 1853 (see Eckel, p. 128).

4. Kitton, $D I$, lists only sixteen illustrators, as he mentions Williams in his Cattermole chapter and includes his discussion of Charles Collins, the first illustrator of $E D$, in his chapter on his successor, Luke Fildes. In this study, Williams and Collins are given chapters to themselves.

5. For discussions and charts on literacy, see Laurence Stone, "Literacy and Education in England, 1640-1900," pp. 119-21, which was called to the attention of the author by Martha Vicinus, who also pointed out other contemporary sources of visual material; Ian Watt, The Rise of the Novel, pp. 35-59; Leavis, p. 333; and Louis James, Fiction for the Working Man, 1830-1850 (London: Penguin, 1974), pp. 1-12, 82.

6. For the most useful of the many recent discussions of Dickens and Hogarth, which include references to earlier comparisons, see Harvey, pp. 44-75; John Dixon Hunt, "Dickens and the Tradition of Graphic Satire," Encounters: Essays on Literature and the Visual Arts, ed. John Dixon Hunt, pp. 124-40; and Nancy K. Hill, Visual Art in the Imagery of Charles Dickens, pp. 146-85.

7. See Herbert Cahoon, "The Author as Illustrator," p. 69, and Harvey, p. 69.

8. For written descriptions of this activity, see [William Makepeace Thackeray], "George Cruikshank," pp. 6-7; Richard Doyle, Dick Doyle's Journal, 1840, pp. 149-50; Henry Vizetelly, Glances Back through Seventy Years, 1:123; and C. R. Ashbee, Caricature (London: Chapman and Hall, 1928), p. 47. For relevant prints, see Gillray's 'Very Slippy-Weather,' reproduced in Draper Hill, Mr, Gillray the Caricaturist, frontispiece, and 'Honi Soit Qui Mal Y Pense,' August 21, 1821-attributed in Mary Dorothy George, Catalogue of Political and Personal Satires; Volume $X$, $1820-1827$, p. 233 , to [?T. Lane] but possibly by one or more of the Cruikshanks-in The Attorney-General's Charges against the Late Queen (London: G. Humphrey, [?1821]), copies of which are in the Meirs Collection and in the British Museum.

9. For example, see Harvey, pp. 2, 51-52, 159; Hunt, Encounters, pp. 128-29, 132; and Leavis, pp. 334-35.

10. Swift, "The Legion Club," The Poems of Jonathan Swift, ed. Harold Williams (London: Oxford University Press, 1958), 3:839, 11. 221-30. Ironically, in 1730-31, Hogarth illustrated a translation of Pierre Desfontaine's The Travels of Mr. John Gulliver, Son to
Lemuel Gulliver and provided a frontispiece for Fielding's Tom Thumb, according to Ronald. Paulson, Hogarth's Graphic Works, 1:263-64, nos. 218 and 220 .

11. See Hanns Hammelmann, Book Illustrators in EighteenthCentury England, pp. 34, 56, 71. See also T. S. C. Eaves and Ben D. Kimbel, Samuel Richardson: A Biography (Oxford: Oxford University Press, 1971), p. 188, for the author's disappointment about the frontispiece he wished from Hogarth for the second edition of Pamela.

12. Lamb, "T. T. Stothard, Esq.," The Complete Works and Letters of Charles Lamb, pp. 554-55; Ruskin, "The Cestus of Aglaia," The Works of John Ruskin, 19:138; and Hardy, unpub. ALS to J. W. MacKail, Christmas Eve, ?1924, The Beinecke Rare Book and Manuscript Library, Yale University, which granted permission for this paraphrase.

13. See Harry Stone, "Dark Corners of the Mind: Dickens's Childhood Reading," 313-15; and J. Hillis Miller, "The Fiction of Realism: Sketches by Boz, Oliver Twist, and Cruikshank's Illustrations," pp. 34, 43-44.

14. This is a central argument in the present discussions of Seymour and Cruikshank, as it was the author's earlier articles, " A Melancholy Clown'-The Relationship of Robert Seymour and Charles Dickens" and "All-of-a-Twist': The Relationship of George Cruikshank and Charles Dickens," and seems now to be widely accepted. Edmund J. Sullivan, The Art of Illustration, pp. 208-10, notes that the practice of writing "up" to drawings lingered on until well into the 1860 's

15. See Robert L. Patten, "Pickwick Papers and the Development of Serial Fiction," and J. A. Sutherland, Victorian Novelists and Publishers, pp. 21-22, for a useful discussion of serial publication generally and $P P$ in particular, and Harvey, pp. 12-18; cf. Leavis, p. 332, who says that by the second decade of the nineteenth century, novels were expected to be illustrated.

16. Letter to Robert Cadell, March 26, 1831, The Letters of Sir Walter Scott, 11:483, n. 2 (hereafter cited as Scott, Letters).

17. A useful summary is provided by Michael Steig. "Martin Chuzzlewit's Progress by Dickens and Phiz," DSA 2:119-20 (hereafter eited as Steig, "MC's Progress"), and Sutherland, p. 21. For complete bibliographical details about each author mentioned, see Harold Locke, A Bibliographical Catalogue of the Published Novels and Ballads of William Harrison Ainsworth (London: E. Mathews, 1925), passim; Lionel Stevenson, Dr. Quicksilver: The Life of Charles Lever (London: Chapman \& Hall, 1939), pp. 297-301; Richard H. Shepherd, The Bibliography of Thackeray (London: Elliot Stock [1880]), pp. 29, 35, 43, 46, 48, 50; Michael Sadleir, Trollope: A Bibliography (London: Constable \& Co., 1928), pp. 34, 37, 55-56, 72, 83-84, 91-92, 108-9; Richard L. Purdy, Thomas Hardy: A Bibliographical Study, pp. 10, 13, 20-21, 25, 37-38, 69, 88, 94; Maurice Buxton Forman, A Bibliography of the Writings in Prose and Verse of George Meredith (London: Printed for the Bibliographical Society by Dunedin Press, Edinburgh, 1922), pp. 22, 46; M[orris] L[ongstretch] Parrish, Wilkie Collins and Charles Reade (London: Constable \& Co., 1940), pp. 205-6, 214-15, and Victorian Lady Novelists (London: Constable \& Co., 1933), p. 17; Sadleir, Nineteenth Century Fiction: A Bibliographical Record Based on His Own Collection (New York: Cooper Square Publishers, 1969 [reprint of 1951 edition]), 1:230-46; and Oliver Warner, Captain Marryat, A Rediscovery (London: Constable, [1953]), pp. $195-96$. 
18. See Lever, letter to Spencer, December, 1838, quoted in Edmund Downey, Charles Lever: His Life in His Letters, 1:107, and Ainsworth, quoted in [Robert Smith Surtees] and Edward D. Cuming, Robert Smith Surtees, p. 247, both of which are also quoted in Harvey, p. 8; and "The Cricket on the Hearth," the Times (London) (December 27, 1845), 6.

19. Letter to Rappard, [March, 1883], The Complete Letters of Vincent Van Gogh, 3:374; and see also Philip Collins, ed., Dickens: The Critical Heritage, pp. 5-6; and [David Masson], "Pendennis and Copperfield: Thackeray and Dickens," North British Review 15 (May, 1851): 70-71.

20. Forster, p. 720.

21. Noted by Steig, "MC's Progress," p. 241, but first called to the author's attention in Patten's remarks at the MLA Seminar on Dickens and the Graphic Arts, December 28, 1972, New York City.

22. Notes to item no. 73, Yale University Library Gazette 37 (October, 1962):67.

23. See Joan Stevens, "Woodcuts Dropped Into the Text," pp. 127-28, and the discussion of $M H C$ in chapter 4 below.

24. See CD's memoranda for $D C$ quoted in John Butt and Kathleen Tillotson, Dickens at Work, p. 167, and Edgar Rosenberg, "A Preface to Great Expectations," DSA 2:304-6 (though this blank is not included in the Nonesuch edition). Professor Harry Levin pointed out to the author that Proust, in "A Propos du 'Style' de Flaubert," Chroniques, ed. de la Nouvelle revue français (Paris: Librairie Gallimard, [1927]), p. 205, notes that Flaubert made similar, though more extensive, use of a blank space in L'Education sentimentale (1869). Of course, Laurence Sterne, in Tristram Shandy (1759-67) had utilized much earlier not only blank spaces but a blank page, two black pages, and dots, dashes, and italies to visually reinforce his unique narrative.

25. See Forster, p. 69, n. 74 .

26. Henry James, preface to The Golden Bowl in The Art of the Novel, p. 333.

27. For example, see Scott's problems with Turner in letter to Robert Cadell, August 1, 1831, Letters 11:492, n. 3.

28. See figures provided in Harvey, pp. 186-88, for example.

29. Thackeray, [M. A. Titmarsh], "May Gambols; or, Titmarsh in the Picture Galleries," p. 711.

30. See Laurence Senelick, "The Dreamer Awakened," DS 2 (September, 1966): 155; and see also van Gogh, letter to Rappard, [September-October, 1882], Complete Letters 3:330-31.

31. George Bernard Shaw, preface to Great Expectations by CD, p. $x$.

32. See also David A. Roos, "Dickens at the Royal Academy of Arts: A New Speech and Two Eulogies," Dick. 73 (May, 1977): 100-107.

33. See Kitton, $P+P$, passim, and $D I$, pp. 243-48; B[ertram] W. Matz, ed., Dickens in Cartoon and Caricature, passim; and, for example, [Walter Dexter], "Dickensian Peeps into 'Punch," Dick. 31 (Autumn, 1935): 264-66 to 35 (Summer, 1989): 175-79.

34. See J[ohn] H[arrison] Stonehouse, ed., Catalogue of the Libraries of Charles Dickens and William Thackeray, pp. 125-28, and Kate [Dickens] Perugini, "Charles Dickens as a Lover of Art and Artists," pp. 129, 164.

35. Parallels between Henry Gowan in $L D$ and Thackeray, CD's would-be illustrator in 1836 and literary rival in 1855, have been noted but are largely discounted both by Edgar Johnson, Charles Dickens: His Tragedy and Triumph, 2:892, and by Gordon N. Ray, Thackeray: The Age of Wisdom, 1847-1863, pp. 156, 458 n. 35 (hereafter cited as Ray, Thackeray, 2).

36. CD's removal of an allusion to the destruction of Maclise's portrait of Sir John Soane is noted by Patten, "A Proposal for an Annotated Edition of the Works of Charles Dickens," DSN 2 (December, 1971): 109 and is discussed in [Edward Keneally], "Daniel Maclise, R.A.," p. 605, and in ALS to Keneally, inserted in Maclise's unpub. MS "Autobiography," October, 1846, np, at the library of the Royal Academy, London.

37. For example, see NL, 3:778-79, O'Driseoll, May 18, 1870.

38. NL, 2:700, Forster [October, 1855], which is quoted and discussed in Harvey, pp. 165-66; and see also van Gogh, letter to Theo, nd, Complete Letters, 1:479; Monroe Engel, The Maturity of Dickens, p. 24; and Ira B. Nadel, "'Wonderful Deception': Art and the Artist in 'Little Dorrit,"' Criticism 19 (Winter, 1977): 17-33.

39. Forster, p. 475.

40. See Percy Muir, Victorian Illustrated Books, p. 109, and A[lfred] L[ys] Baldry, The Life and Work of Marcus Stone pp. 14-15.

41. George Eliot, letter to Leighton, [? June 4, 1862], The George Eliot Letters, 4:40; see also Charlotte Brontë, letter to W. S. Williams, March 11, 1848, in Clement $\mathrm{K}$. Shorter, The Brontës: Life and Letters, 1:402.

42. For example, see Maclise's letters to Forster, nd, quoted in Kitton, $D I$, pp. $163-64$, complaining about the small page size for $T C$ and $C H$, and NL, 2:223, Chapman, July 22, 1850, for CD's relayed complaint from Stanfield about the surface of the block for $A N$. For a good general discussion of these and other technical problems, see Harvey, pp. 182-86, 190-94.

43. The specific technical problems encountered by CD's artists will be taken up in more detail in the relevant chapters. For the present, however, on Cruikshank, see Lynton Lamb, Drawing for Illustration, pp. 5-6, quoted in Leavis, p. 361; on Seymour, see Thomas Hatton and Arthur $\mathrm{H}$. Cleaver, A Bibliography of the Periodical Works of Charles Dickens, pp. 18-19, and Albert Johannsen, Phiz: Illustrations from the Novels of Charles Dickens, p. v; on Buss, see Robert Buss, "My Connexion with The Pickwick Papers," pp. 122-26 (hereafter cited as Buss "My Connexion with $P P ")$; on Browne, see typical letter from Browne to Robert Young, [ca. 1845], quoted in Thomson, p. 235, and Young, quoted in Kitton, $D I$, p. 64, and Beatrix Potter, entry for December 15, 1883, The Journal of Beatrix Potter from 1881 to 1897, p. 57, who says that Browne's drawings for $D S, D C$, and $B H$ are much better than the prints, usually acknowledged to be among the best done by him for CD.

44. On Leech, see letter to Forster, November 18, 1846, quoted in Kitton, $D I$, p. 44, in which the artist requested Linton (but got Dalziel), and see also pp. 146-47, in which George du Maurier and Ruskin are quoted about the poor engraving generally of Leech's drawings, and Kitton, John Leech: Artist and Humourist, p. 58, for the artist on the subject; for Maclise, see quote and letter to Forster, nd, in Kitton, $D I$, p. 167, concerning the engravers and engraving of his designs for $B L$; for Fildes, see NL, 3:766, Chapman, March 14, 1870, about his request, which was granted, for his engraving friend Charles Roberts; cf. Kitton, DI, pp. 212-13, who nevertheless finds the result disappointing compared to his drawings; for Browne, see letter from Edward Chapman to $\mathrm{CD}$, partly quoted in M.S. [Michael Slater], "Car]ton Bequest, Dickens House," Dick. 70 (January, 1974): 46 , which mentions Browne's determination to have every line cut, and unpub. ALS from $H K B$ to Charles [undecipherable], nd, at Princeton (AM 19684) saying "See what a gash the brothers Dalziel made!" (quoted by permission of the Princeton University Library); for Palmer, see his explicit, often impracticable instructions to the engraver, quoted in Kitton, $D I$, pp. 185-87; and see unpub. ALS, CD to Marcus Stone, February 29, 1864, in the Morgan Library for the author's concern about the engravers, and the artist's complaints about them in Kitton, $D I$, p. 201. 
45. Rossetti, quoted in Frank Wietenkampf, The Illustrated Book, p. 156, and see David Bland, A History of Book Illustration, p. 259, for the causes of Rossetti's sarcasm and the Dalkiels' version in $n .46$ below.

46. See [George and Edward Dalziel], The Brothers Dalziel, pp. $86-87 n_{\text {., }}$ and Muir, pp. 6-7.

47. See discussion in Leavis, p. 333.

48. Goethe, quoted in E. H. Gombrich, "The Cartoonist's Armoury," p. 139, and Wordsworth, "Illustrated Books and Newspapers," The Poetical Works of Wordsworth, ed. Thomas Hutchinson (London: Oxford University Press, [1964]), p. 383.

49. Edmund Gosse, Father and Son, ed. William Irving (Boston: Houghton Mifflin, The Riverside Press, [1965]), p. 198. See also Frederic Harrison, Autobiographic Memoirs (London: Macmillan, 1911), 1:6 and Ruskin, letter to Tennyson, July 24, 1857, Works, 36:265.

50. du Maurier, "The Illustrating of Books from the Serious Artist's Point of View," p. 350.

51. Ruskin, Works, 19:139.

52. Da Vinci, quoted in Bland, p. 15

53. See Kitton, $D I$, appendix, pp. 227-42, for examples. However, there is no full account of the illustrations that accompanied the Ameriean publications of CD's works.

54. See, for example, [Richard Ford], "Oliver Twist," p. 102; and "Charles Dickens and His Works," pp. 399-400.

55. Forster, p. 475.

56. [Samuel Warren], "Dickens's American Notes for General Circulation," Blackwood's Edinburgh Magazine 52 (December, 1842): 785.

57. Steig, "Dickens, Hablôt Browne, and the Tradition of English Caricature," pp. 219-33 (hereafter cited as Steig, "English Caricature"), was the first to make this point explicit, and it is an implicit assumption in the discussions of Browne in Harvey, pp. 103-60, and Leavis, pp. 332-71, among others.

58. Steig, "English Caricature," pp. 220, 232.

59. "The Cricket on the Hearth," the Times (London) (December 27, 1845), 6 .

60. "Pictures from Italy," the Times (London) (June 1, 1846), 7. 61. CD, letter to Augustus Thiselton, June 12, 1858, quoted in William J. Carlton, "Dickens and the Artist's Benevolent Funds," Dick. 63 (January, 1967): 10, reprinted in slightly varied form in $C P, 2: 444$.

62. V. S. Pritchett, "Books in General," p. 145.

\section{Chapter 1: George Cruikshank}

1. Cf. Ada Nisbet, "Charles Dickens," p. 70. Blanchard Jerrold's Life of George Cruikshank remains the only full-scale account of the prolific artist who, according to his most noted bibliographer, Albert M. Cohn, George Cruikshank: A Catalogue Raisonné, illustrated 863 books and produced 1,251 separate prints. The record of his life apparently proved too much for even the artist to record: G. A. Sala, "George Cruikshank: A Life Memory," p. 545, mentions that his wife was revising and editing an autobiography but the preface to Drawings by George Cruikshank Prepared by Him to Illustrate an Intended Autobiography, np, indicates that only "the present plates and other disconnected memoirs and jottings," some of which are in the Borowitz collection, survived of this plan. The new general work by Hilary and Mary Evans, The Man Who Drew the Drunkard's Daughter, called to the author's attention by Laurence Senelick, and scholarly biographies in progress by Jonathan Hill and Robert L. Patten may remedy this situation and integrate the many disparate studies of the artist that have appeared since the mid-1960's. In addition, John Wardroper's The Caricatures of George Cruikshank, called to the author's notice by Patten, and works reportedly in progress by William Feaver, Michael Steig, Richard Vogler, and possibly others should also add to our knowledge of aspects of Cruikshank.

2. Cf. Richard Vogler, "Cruikshank and Dickens: A Reassessment of the Role of the Artist and the Author," PULC 35:90, who notes the small number of works but not their significance in the lives of both men, particularly the artist.

3. See, for example, Miller, "Fiction of Realism," pp. 51-52; Harvey, pp. 19-31; and Ronald Paulson, "The Tradition of Comic Illustration from Hogarth to Cruikshank," PULC 35:35-60.

4. Noted by George, Catalogue, 10:xli; Draper Hill, Mr. Gillray, the Caricaturist, p. 120 and n. 2; and William Feaver, "Cruikshank: The Artist's Role," in George Cruikshank. Exhibition Catalogue, Victoria and Albert Museum, February 28-April 28, 1974, p. 11 (hereafter cited as $V+A$ Cruikshank Catalogue). See also Harvey, pp. 30-34, who discusses the artist's earlier autonomy and his subsequent efforts to retain it as a book illustrator, and Anthony Burton, "Cruikshank as an Illustrator of Fiction," PULC 35:93-128.

5. Pilgrim, 1:89, Macrone, [November 7, 1835].

6. Coined by Watts Phillips, letter to Dr. Ord, December 31, 1873, reproduced in E[mma] Watts Phillips, Watts Phillips: Artist and Playwright facing p. 103, in alluding both to his leg ailment and to the contemporary controversy about whether Cruikshank or CD originated OT. Buss, English Graphic Satire p. 160, says that Phillips was the artist's only pupil; cf. evidence in Moncure Daniel Conway, The Autobiography of Moncure Daniel Conway, 2:6, that Thackeray also studied with him.

7. See Cohn, George Cruikshank, p. 173, no. 591, and p. 352, nos. 2092-96, and noted also in Thackeray, Vanity Fair, ed. Geoffrey and Kathleen Tillotson (Boston, 1963), p. 207n.

8. Pilgrim, 1:82 and n. 1 [?.October 27, 1835].

9. Ibid., 94, Macrone, [November 18, 1835].

10. Ibid., 100 and n. 2, Cruikshank, [November 30, 1835], and $102, \mathrm{n} .2$, which appears to be the same item as the two-page draft ALS from Cruikshank to Macrone, nd, in the Berg Collection, partly quoted in Charles Dickens, 1812-1870: An Anthology, ed. Lola Szladits, p: 17 (hereafter cited as Szladits, Berg Anthology); cf. Vogler, "Cruikshank and Dickens," p. 68, who maintains that Cruikshank "did not like to select a subject for illustration from the reading of a completed text."

11. Pilgrim, 1: 102, Cruikshank, [December 8, 1835].

12. Ibid., Macrone: 110 [December 21, 1835] and 111 [December 22, 1835], and see 701, Cruikshank, [December 21, 1835].

13. Ibid., 112, Macrone, [?December 26, 1835]; 120, Catherine Hogarth, [?January 22, 1836]; and 122, Cruikshank, [?February 1,1836$]$.

14. Ibid., 116 and n. 2, Cruikshank, January 7, 1836.

15. Ibid., 181, Macrone, [?October 6, 1836].

16. Ibid., 183, n. 1, October 11, [1836] and see 691, ?Macrone to ?CD, [?early December, 1836].

17. Ibid., 183, [?October 19, 1836]; ef. Vogler, "Cruikshank and Dickens," pp. 78-81, whose speculation that Cruikshank could have influenced the majority of the illustrated sketches in the second series of $S B B$ fails to reckon with this letter.

18. Pilgrim, 1:200, [November 28, 1836].

19. Kitton, $D I$, pp. $7-8$, notes some careless discrepancies between picture and text.

20. Kitton, $D I$, p. 6 , predicted their historical value and Sacheverell Sitwell, Narrative Pictures, p. 20, and Miller, "Fiction of Realism," pp. 46-47, confirm it. Patten informed the author that 
Guilland Sutherland's essay on the changing character of London as revealed in Cruikshank's work will appear in the forthcoming Victorian Artists and the City, ed. F. S. Schwarzbach and Ira B. Nadel (New York: Pergamon Press).

21. See Miller, "Fiction of Realism," pp. 45, 53-64, to whose suggestive discussion of the $S B B$ the one here is obviously indebted.

22. Ibid., pp. 63-64, and Hunt, Encounters, pp. 128-29.

23. Thackeray, "George Cruikshank," p. 53.

24. Miller, "Fiction of Realism," pp. 55-64, also notes, and in greater detail, many of the objects, the activities, and the unstable postures mentioned in this discussion.

25. Ibid., pp. 63-64.

26. Ruskin, letter to C. S. Howell, September 2, 1866, Works 36:512. See also Waugh, A Hundred Years of Publishing, facing p. 38; cf. Waugh, Nonesuch Dickensiana, p. 24, who discusses whether or not the lead figures are the publishers, and Cohn, George Cruikshank, p. 122, no. 405, who notes that on the title page of William Hone, Facetiae and Miscellanies (London, Published for William Hone by Hunt and Clarke, 1827) is a woodcut of the artist sitting with the author at 'The Library Table' in Ainsworth's Magazine (April, 1842), 186, as does G[eorge] S[omes] Layard, George Cruikshank's Portraits of Himself, pp. 13 and 35, respectively.

27. Quoted in S. M. Ellis, William Harrison Ainsworth and His Friends, 1:278. For further discussions of the differences between the two sets and possible reasons for it, see Steig, rev. of Miller, "Fiction of Realism," and Borowitz, "George Cruikshank," DSN 3 (December, 1972): 114; Harvey, "George Cruikshank: A Master of the Poetic Use of Line," PULC 35:143-44; and Paulson, "Tradition of Comic Illustration," p. 59.

28. See Pilgrim, 1:372, Cunningham, February 12, 1838; 2:151 and n. 2, Cruikshank, November 17, [1840]; 169, n. 2; 273, Shoberl, April 27, 1841; 282, Cruikshank, May 13, 1841; 287, [Colburn], May 27, 1841; and Forster, p. 167. Cruikshank's work proved to be his last for CD to appear in their lifetimes, as his 1847 drawing of Mrs. Gamp was not published unitil 1897.

29. See Harvey, p. 187, for figures from which it can be deduced that Seymour received more than $\$ 4$ per plate but probably far less than Cruikshank's 12 guinea rate.

30. Thackeray, "George Cruikshank," p. 53.

31. See Kathleen Tillotson, ed, Oliver Twist by CD, p. 392 and n. 1 (hereafter cited as Tillotson, ed., OT), and Pilgrim, 1:223, n. 3 for Edward R. Morgan's role in the selection.

32. Pilgrim, 1:198, Cruikshank, [?November 26, 1836]; 202, Bentley, [November 30, 1836]; and 206, Cruikshank, [December 5, 1836]; ef. Vogler, "Cruikshank and Dickens," pp. 81-82, whose argument supporting the artist's later assertion that CD's text followed his plate inexplicably ignores these last two letters, which may imply the opposite, whereas his continued omission of CD's letter of December 5, 1836, which states that his text for the $B M$ piece is enclosed, also undermines his further assertion that the fact that the original plate title for the piece reads "Tom" rather than the correct "Ned" Twigger may reflect Cruikshank's "ignorance of, or indifference to" the text rather than the more plausible haste, carelessness, or faulty memory on the part of the author, printer, or artist.

33. See Kitton, $D I$, p. 25, and Pilgrim, 1:418, [?July 19, 1838].

34. See Pilgrim, 1:99, Catherine Hogarth, [?November 30, 1835], which notes that the cheapest quarters CD saw in Pentonville were $\$ 55$ yearly, and John Greaves, Dickens of Doughty Street (London: Hamish Hamilton, 1975), p. 16, who notes that the Doughty Street residence cost about $\$ 80$.

35. "Second Series of Sketches by Boz," Spectator 9 (December
26, 1836): 1234. Harvey, pp. 33-34, also utilizes this quote in his longer discussion of this problem.

36. See Pilgrim, 1:221, Cruikshank, [January 9, 1837] and 224, Bentley, [January ?18, 1837].

37. See ibid., Cruikshank: 234, [February ?8, 1837] and 319, [October ?13, 1837]. See also a note from Cruikshank to CD, June 15,1837 , quoted in Kitton, $D I$, p. 14; cf. its use by Vogler, "Cruikshank and Dickens," p. 72, to support his assertion that the artist was more than equal with $C D$ during $O T$ despite weightier evidence to the contrary, and ef. Leavis, who mistakenly asserts that the artist, with two exceptions, "took no directions from the author" (p. 340) and, without explanation or qualification, that "Cruikshank was allowed to send drawings for Oliver Twist direct to the press without Dickens's being able to stop them on the way" (p. 353), which indeed happened, as shall be discussed, but only at the end of the novel when CD was out of town. A more valid example of Cruikshank's initiative might be the unpub. sketch in the Meirs Collection of Oliver following at Bumble's heels, which is not mentioned by $\mathrm{CD}$ but which may have been an alternate sketch for the chapter subsequently illustrated by 'Oliver escapes being bound apprentice to the sweep,' as it represents a later moment in that chapter (OT, 4:27), or perhaps it was a subject conceived by the artist after reading the text but before receiving $C D$ 's final instructions.

38. William Maginn, "Song of the Cover," quoted in Kitton, DI, pp. 9-10. For more information about CD's relations with Bentley, see Royal Gettman, A Victorian Publisher: A Study of the Bentley Papers, pp. 98-102, and Patten, Charles Dickens and His Publishers (Oxford: Clarendon Press, 1978), which was not available at the time of writing.

39. Pilgrim, 1:307-8, n. 4, Cruikshank to Bentley, September $15,1837$.

40. Ibiid., p. 308, Bentley, September 16, 1837; p. 309, Cruikshank, [September 16, 1837]; and p. 308, n. 1, Cruikshank to Bentley, [September 16, 1837], a draft of which is in the Meirs Collection (AM 13427).

41. Ibid., p. 436, Cruikshank, [September 20, 1838], and see 3:13-14 and n. 5 for a summary of Cruikshank's own difficulties with Bentley.

42. Ibid., Cruikshank: 353, [?mid-January, 1838]; 329, [?November, 1837]; and 396, [April 16, 1838]; and see Vogler, "Cruikshank and Dickens," p. 71, for further discussion on 'Mr. Bumble and Mrs. Corney taking tea.'

43. Pilgrim, 1: 426 (2), Cruikshank, [?August, 1838]; and see Tillotson, ed., OT, pp. 393-94, n. 6 .

44. Pilgrim, 1: 441 (2) and n. 3., Cruikshank, [?October 20, 1838]; and see Tillotson, ed., $O T$, p. 392, n. 7.

45. Pilgrim, 1: 440 and n. 1, [?October 6, 1838].

46. Swinburne, Charles Dickens, p. 13.

47. Pilgrim, 1:451 n. 1, Forster to Bentley, November 8, 1838.

48. Ibid., and Thackeray, "George Cruikshank," p. 19.

49. Pilgrim, 1:450, Cruikshank, [November 9, 1838]; cf, Graham Everitt, English Caricaturists and Graphic Humourists of the Nineteenth Century, p. 198, and Waugh, Nonesuch Dickensiana, who says that the artist "agreed at once" (p. 26). See also Steig, "Cruikshank's Peacock Feathers in Oliver Twist," which suggests an interesting but overly subtle reason for CD's rejection of the "Fireside" plate. The Cruikshank Collection at the V + A has both the rejected drawing (9995.D) and proof (9996.11).

50. See William Glyde Wilkins, "Variations in the Cruikshank Plates to Oliver Twist," Dick. 15 (April, 1919): 73, which also reproduces the "Church" drawing, now in the Berg Collection. See also E. D. H. Johnson, "The George Cruikshank Collection at 
Princeton," PULC 35:17 (hereafter cited as Johnson, "Cruikshank Collection"), who notes a folded sheet in the Meirs Collection that he describes as containing a rough sketch for the "Fireside" plate and four rough sketches for the "Church" plate, and suggests, as does Vogler, Cruikshank and Dickens: A Review of the Role of Artist and Author, p. 244 (hereafter cited as Vogler, Cruikshank), that the artist had these alternate designs in mind from the outset. It is not apparent, however, that this sheet does contain an alternate "version" of the suppressed plate, but rather it looks like a transitional sketch from it to the "Church" plate, showing a vestigial Rosa seated, her right arm extended protectively toward the standing Oliver (cf. the other sketches, which show both standing), as if Cruikshank at least wished to salvage the postures of the pair from the "Fireside" plate but found it unsuitable for Rosa to be seated in church. Vogler, Cruikshank, p. 244, suggests that the "Fireside" plate might have been Cruikshank's reversion to an earlier idea rejected by $\mathrm{CD}$, which might explain the author's anger; if Johnson's assertion is correct, it might help explain the artist's reluctance to execute a finished drawing of a subject he had already considered and rejected for whatever reason. The unusually crisp, clean sheets, which contrast markedly with Cruikshank's usual scraps, inevitably torn and browned with age (as is the original drawing for the "Church" plate, for example), might also suggest the possible, if farfetched, conclusion that the artist drew these sketches later to bolster his claims to $O T$ just as he added words to that effect to some of his early sketches for $S B B$ and $O T$, because the letter rejecting the "Fireside" plate was the main proof in Forster's argument against any of the artist's claims, as will be discussed below. The paper's watermark yielded no further clues about the dating, however.

51. Thackeray, "George Cruikshank," pp. 57-58.

52. William Hazlitt, "On Hogarth's Marriage à la Mode," in The Complete Works of William Hazlitt, 4:30; see also Miller, "Fiction of Realism," p. 52 and n. 2; Edgar Rosenberg, From Shylock to Svengali, pp. 116-37; and Vogler, "Oliver Twist: Cruikshank's Pictorial Prototypes," DSA 2:108-12. There are sketches of the condemned Fagin in both the Forster and Gimbel collections but whether for the first or 1846 edition of $O T$ is difficult to determine.

53. G. K. Chesterton, Charles Dickens, A Critical Study, p. 112; ef. Harvey, p. 210, and Burton, "Cruikshank as an Illustrator of Fiction," pp. 123-24, who intelligently qualify this widely quoted remark in their discussions of it. See also Sylvère Monod, "Confessions of an Unrepentant Chestertonian," DSA 3:224, who shares Chesterton's "very poor" opinion of the OT illustrations.

54. See Layard, George Criikshank's Portraits of Himself, passim. See also Jerrold, p. 221 n., and Johnson, "Cruikshank Collection," pp. 24-25, for added comments about the artist's propensity for self-portraiture; George William Reid, A Descriptive Catalogue of the Works of George Cruikshank, 1:1 and n. 1, who reports the artist saying in 1871 that many of his self-portraits were done at the instigation of his publishers but, given the late date, when his claims on CD and others were being advanced publicly for the first time, this justification sounds somewhat defensive; Steig. "A Chapter of Noses: George Cruikshank's Psychonography of the Nose," who notes that Cruikshank tends to use "Jewish" noses in his comic self-portraits and straight noses in his serious ones (p. 315); and James Grant, Portraits of Public Characters, who notes that the final " $K$ " in the artist's signature forms a human profile with the nose "having a peculiar prominancy assigned to it" (2:250).

55. For more objective representations of Cruikshank's appearance, see photographs of him in the Meirs Collection (AM 20354) and descriptions of him by Henry and Augustus Mayhew, eds., The Greatest Plague of Life (London: David Bogue, [1847]), pp. 11-15; George Eliot, letter to Mr. and Mrs. Charles Bray, May 4, 1852,
Letters, 2:23-24; Vizetelly, 1:106; and Edgar Browne, Phiz and Dickens, p. 23

56. Quoted in George Hodder, Memories of My Time (London: Tinsley Bros., 1870), pp. 107-8, Jerrold, pp. 152-63, and widely elsewhere. The Department of Prints and Drawings, British Museum, has a self-portrait of Cruikshank sketching himself in the mirror, described in Lawrence Binyon, Catalogue of Drawings by British Artists and Artists of Foreign Origin Working in Great Britain, 1:281, no. 2(a).

57. See Cruikshank, "The Origin of 'Oliver Twist,'” and Jerrold, p. 152 .

58. Miller, "Fiction of Realism," pp. 50-51.

59. Quoted and discussed in Jerrold, p. 152. See also the artist's accounts of his impersonations in "The Origin of 'Oliver Twist," " and in The Artist and the Author, p. 5.

60. Hunt, Encounters, p. 132.

61. See, for example, [T. H. Lister], "Dickens's Tales," p. 77, also quoted in Stephen Wall, ed., Charles Dickens: $A$ Critical Anthology, p. 47.

62. Noted by Patten, "So Much Pains about One Chalk-Faced Kid'-The Clarendon Oliver Twist," DS 3 (October, 1967):165 (hereafter cited as Patten, "So Much Pains").

63. Thackeray, "George Cruikshank," p. 57, and see Steig, "MC's Progress," pp. 120-21, for further discussion on Paul Pry.

64. Ruskin, "Modern Grotesque," Works, 6:471.

65. Baudelaire, Oeuvres complètes, ed. Y.-G. Le Dantec (Paris: Gallimard, 1958), p. 751, which has been widely quoted and discussed, along with other of the poet's remarks.

66. Baudelaire, p. 751

67. Ruskin, "Modern Painters," Works, 7: 349-50.

68. James, "A Small Boy and Others," Autobiography, p. 69, and see a similar observation about all of CD's illustrated characters by C. S. Lewis, Surprised by Joy: The Shape of My Early Life (London: Geoffrey Blos, 1955), p. 145 (also quoted in "One Man's Meat ..." Dick. 71 [September, 1975]:177), which is discussed in the Conclusion and in $\mathrm{nn} .56$ and 57 there.

69. For further discussion on Cruikshank's varying portrayals of Nancy, see Tillotson, ed., OT, pp. xxxv-xxxvi, and Steig, "Cruikshank's Nancy," Dick. 72 (May, 1976): 87-92.

70. Miller, "Fiction of Realism," p. 55, makes a similar point in regard to $S B B$, whereas Patten, "So Much Pains,"” p. 164, and Burton, "Cruikshank as an Illustrator of Fiction," p. 127, who also sees other kinds of patterns in the artist's plate (pp. 124-26), focus specifically on interiors in $O T$.

71. Peacock, "The New Year," Works, 7:250.

72. See Pilgrim, 1:248, Beard, [April ?12, 1837] and Kitton, $P+P, 1: 17$. Variants of this sketch are in the Berg Collection, reproduced in Kitton, $P+P, 1$ :following p. 15, and in Szladits, Berg Anthology, p. 2; the one engraved by Pailthorpe in the Gimbel Collection (cf. Richard Ormond, Early Vietorian Portraits, 1:143, which mistakenly locates it at the Dickens House), reproduced in Kitton, $P+P$, 1: facing p. 17; the Dexter Collection, Department of Prints and Drawings, Volume 1 [Dex. 322 and 323]; and still others are mentioned by Kitton, $P+P, 1: 17-18$, who finds difficulty in immediately recognizing any resemblance.

73. All are quoted in Kitton, $P+P: 1: 19$ (Carlyle and Hunt), $3: 28$ (Bowring), and 47 (Mamie Dickens), and widely elsewhere.

74. Quoted in Layard, George Cruikshank's Portraits of Him. self, title page.

75. See Pilgrim, 1:326 and n. 5, Bentley, [October 30, 1837] and 337, Bentley, [?December 5, 1837] and Forster [December 6, 1837]. 
76. See H. T. Mackenzie Bell, "Memoirs of Grimaldi"; cf, Forster, "such modifications or additions as [CD] made having been dictated by him to his father" [italics added] (p. 104), which is misread by Richard Findlater, Grimaldi: King of Clouns "to him by his father" [italics added] (p. 228), which leads him to conclude that the father, not the son, did the editing.

77. [John Hamilton Reynolds?], "Memoirs of Joseph Grimaldi (Second Notice)," p. 165.

78. Pilgrim, 1:382-83, subeditor of Bentley's Miscellany, [March 1839]; cf. 386, Bentley, [?March 12, 1838]. For reports of CD's imitations of Grimaldi, see George Dolby, Charles Dickens as 1 Knew Him, pp. 39-40; Annie (Adams) Fields [Mrs. James T.], Memories of a Hostess, p. 165; and Edward F. Payne, Dickens's Days in Boston (Boston and New York: Houghton Mifflin Co., 1927), pp. 229-30.

79. See Pilgrim, 1:687, Ellar to CD, September 1, 1839, and 586-87 and n. 3, Ellar, September 27, 1839; NL, 2:215, Britton, May 9, 1850; K. J. Fielding, "Charles Whitehead and Charles Dickens," p. $141 \mathrm{n}$., who notes that Whitehead revised and added to it for Bentley's 1846 reissue; and Findlater, who justly concludes that "it was not Dickens but Grimaldi who suffered most from its [first] publication" (p. 229).

80. Athenaeum (March 3, 1838), p. 165; and see also John F. Dexter, "Hints to Dickens Collectors," Dickens Memento, p. 15; Jerrold, pp. 106, 232-33; Sitwell, Narrative Pictures, pp. 19, 68. For representations of Grimaldi by Cruikshank, see Cohn, George Crikshank, pp. 94, no. 279; 96, nos. 286-87, 289; 249 , no. 880 (in the Meirs Collection, as is another unpub. watercolor, 1838 , according to Johnson, "Cruikshank Collection," p. 11); 258, no. 962; 321 , no. 1825 ; and 353 , no. 2104.

81. 'The Last Song' is reproduced in Layard, Suppressed Plates, facing p. 40, and in Cohen, "All-of-a-Twist," plate 5, following p. 172. For a discussion of the border, see Vogler, Cruikshank, p. 86 .

82. The fullest account of "Lord Bateman" and Cruikshank, CD, and Thackeray's participation in it remains that provided by Anne Lyon Haight, "Charles Dickens Tries to Remain Anonymous: Notes on The Loving Ballad of Lord Bateman," which, however, suffers from its inaccessibility in a rare journal and its lack of pagination; $c f$. her pre-1939 sources, also listed here. Haight notes that the artist says he heard the ballad from a character whom he commemorated in 'Bandy Tom Singing the Ballad of Lord Bateman,' reproduced in Drawings by George Cruikshank, plate $13, \mathrm{np}$, and in $A$ Handbook for Posterity, no. 18, np, and that F. W. Child, ed., English and Scottish Popular Ballads, 2:454-83, lists fifteen versions of the ballad, including Cruikshank's, but omits the latter's distinctive Cockney, making it resemble Thackeray's version, discussed below. Haight locates other versions and Vogler, Cruikshank, pp. 103-5, reprints yet another in the Clark Library, a broadside, which is far closer to Cruikshank's than, for example, the 1790 broadside "Young Baker" that is mentioned as a possible prototype by Cohn, "Loving Ballad of Lord Bateman, 1839." Child, pp. 457-58, notes the traditional ballad's connection with the legend of Thomas à Becket's parents, as does Slater, reviewing a 1969 reprint (London: J. M. Dent) of the Cruikshank version, Dick. 66 (January, 1970): 60-61; cf. Gordon N. Ray, The Illustrator and the Book in England from 1790 to 1914 , who says that the ballad "is not necessarily as primitive as it purports to be" (p. 87).

83. According to Walter Hamilton, George Cruikshank: Artist and Humourist (quoted in Jerrold, pp. 204-5, and referred to in Haight), the artist sang the ballad at a dinner of the Antiquarian Society (p. 57). Pilgrim, 1:636, diary entry for December 11, 1838, notes that $\mathrm{CD}$ attended a dinner with Cruikshank at the Antiquaries [sic] Club, doubtless the same organization; cf. Edgar Johnison, Charles Dickens, 1:260, who says the artist first sang the ballad to CD at Elm Cottage in the summer of 1839, forgetting that the ballad was published in June of that year.

84. Pilgrim, 1:552, Cruikshank, [?May, 1839], quoted also in Haight.

85. Burnett, quoted in Kitton, $P+P, 2: 137$, and mentioned in Haight.

86. Letter to Cruikshank, May ?, 1839, The Letters and Personal Papers of William Makepeace Thackeray, ed. Gordon N. Ray, 1:380-81 (hereafter cited as Thackeray, Letters) and quoted in Haight; cf. Hamilton's version, p. 57 (quoted in Jerrold, pp. 204-5), which says that Thackeray also heard Cruikshank sing the ballad at the Antiquarian Society dinner and expressed a desire to print and illustrate the ballad but was "warned off" by the artist at that time. There seems to be no basis for the suggestions tentatively advanced by Charles P. Johnson, "The Loving Ballad of Lord Bateman," Athenaeum (January 21, 1888): 86, that Cruikshank set his sketches aside and helped the young Thackeray by supplying a preface and notes and polishing up the verses, or by S[idney] Hodgson, "The Ballad of Lord Bateman," that Thackeray allowed Cruikshank to redraw his designs.

87. "The Loving Ballad of Lord Bateman," Spectator (June 8,, 1839): 568.

88. Pilgrim, 1:559, [July 3, 1839].

89. Ibid., 559 and $\mathrm{n}$. 3, which quotes the notice in the Morning Post (July 2, 1839): 5. See also Slater, ed., The Catalogue of the Suzannet Charles Dickens Collection, p. 232, lot 204 (hereafter cited as Slater, Suzannet Catalogue), who notes that the artist wrote above the ALS "Mem get the MS. from Printer," which may suggest that the MS bore CD's handwritten corrections, and Hodgson, (cited by Haight), who notes the existence of a draft of the captions for the ballad's illustrations in CD's handwriting, which the artist followed when etching the plates.

90. Quoted in Walter T. Spencer, "Loving Ballad of Lord Bateman, 1839," and in Haight.

91. See, for example, Sala's comparison of the Proud Young Porter to James de la Pluche in Jerrold, p. 206, and Charles P. Johnson's comparison of its meter to that of the 1848 "Little Billee" and its commentary to that of the 1829 "Timbuctoo" in "The Loving Ballad of Lord Bateman," p. 86, both mentioned in Haight, as well as Trueman's comparison of its offhand invention and ultimate neglect to "The Three Sailors of Bristol City," quoted along with Johnson's comparisons in Anne Thackeray Ritchie, "Comment on Lord Bateman: A Ballad," pp. 126-28.

92. Ritchie, "Comment on Lord Bateman," p. 125.

93. Ibid., and in Haight. The Thackeray MS is at the Morgan Library and is reproduced in Ritchie, "Comment on Lord Bateman," pp. 124-28.

94. See, for example, Cruikshank's self-portrait in the Department of Prints and Drawings, British Museum [1974 (201a)] and the portraits of Thackeray in Ormond, Early Victorian Portraits, 2:np, especially nos. 911,913 , and 916 , which resemble one another more closely than do the sequential representations of his Lord Bateman.

95. Ray, The Illustrator and the Book, pp. 87-88, reproduces and discusses Doyle's title page, comparing it with the comparable scene from the Cruikshank ballad, which is also reproduced.

96. See letter to Mrs. Elliott, July 11, 1842, Memorials of Thomas Hood, ed. Daughter [Mrs. F. F. Broderip] and Son [Thomas Hood] (London: E. Moxon, 1860), 2:125, which notes that

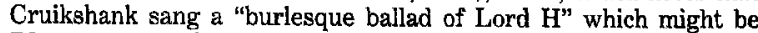
B[ateman] as J. W. T. Ley, The Dickens Circle, p. 130 (hereafter cited as Ley, Circle) suggests; Jerrold, pp. 206-7; theater program for "The Rent Day" and "The Poor Gentleman," May 18, 1850 , reproduced by permission of the late Noel Peyrouton in Cohen, "'All-of-a-Twist," plate 9, facing p. 336; 'W. Teignmouth Shore, 
Charles Dickens and His Friends, pp. 79-80, who maintains that the artist could not sing but was encouraged in these performances by his second wife; and Haight.

97. Pilgrim, 1:122 and n. 1, Cruikshank [?February 1,1838 ].

98. Letter to Crossley, February 8, 1838, in Ellis, 2:332 (quoted in Pilgrim, 1:358-59, n. 5).

99. See Kitton, "Pseudo-Dickens Rarities"; cf. Eckel, p. 205, and discussion in Vogler, Cruikshank, pp. 106-10. The MS, which the author has not seen, is in the Huntington Library.

100. Vogler, Cruikshank, p. 110.

101. Pilgrim, 1:589, and n. 4 [?October 3, 1839].

102. Pilgrim, 2:Cruikshank, 276 and n. 1, May 2, 1841, and 340 , July 21, 1841, and unpub. ALS from Cruikshank to CD, April 10, 1841, Huntington Library (HM 18480), paraphrased here by permission.

103. See Pilgrim, 2:151, n. 2; Cruikshank, 213 and n. 4, February 17, 1841 ; and 213 , n. 5, letter from Cruikshank to CD, February 27, 1841.

104. Letter to W. C. McClellan, November 12, 1870, quoted in Wilkins, "Cruikshank versus Dickens," Dick. 16 (April, 1920): 81; cf. slightly different draft of November 11, 1870 in the Elkins Collection, quoted in Vogler, "Cruikshank and Dickens," pp. 77-78. See also letter from Cruikshank to ?, nd, partly quoted in Sister Lucille Carr, comp., A Catalogue of the VanderPoel Dickens Collection at the University of Texas, p. 20, no. A139 (hereafter cited as VanderPoel Catalogue), explaining that he did not illustrate PP; Waugh, Nonesuch Dickensiana, p. 22; and V. S. Pritchett, "Books in General," p. 142; ef. eds., Dick. 38 (June 1, 1942): 129

105. Austin Dobson, "Illustrated Books," p. 155.

106. Swinburne, Charles Dickens, pp. 13-15.

107. W. A. Fraser, "The Illustrators of Dickens. George Cruikshank," Dick. 2 (May, 1906): 122. See similar views in Percy Merriman, letter to eds., July 7, 1906, Dick. 2 (August, 1906): 222-23, and Gleeson White, English Illustration, 'The Sixties': 1855-1870, pp. 18-19; cf. Kay White, 'Cruikshank, 'Phiz,' and Modern Taste," Dick. 2 (September, 1906): 239-40.

108. Sitwell, Sitwell, and Sitwell, "George Cruikshank," p. 248.

109. For their social activities with $C D$, see relevant entries under Cruikshank and his wife in Pilgrim, 1:717; 2:513; 3:650; 4:740; and future Pilgrim volumes. For information about the first Mrs. Cruikshank, see David Borowitz, "George Cruikshank," p. 78.

110. See Jerrold, pp. 221-22; Pilgrim, 3:292, Felton, July 31 , 1842, and 409, Longfellow, December 29, 1842; and Henry Wadsworth Longfellow, The Letters of Henry Wadsworth Longfellow, 2:482, letter to Forster, December 15, 1842, and 495, letter to Freiligrath, January 6, 1843.

111. Pilgrim, 1:358-59, [January 25, 1838].

112. Ibid., 2:276-77, and nn. 2-5, and 277, n. 1, Cruikshank, May $2,1841$.

113. See Jerrold, pp. 71-72; Pilgrim, 3:337 and nn. 3-5, Forster, [October 5, 1842]; 366 and nn. 2-6, Literary Fund, November 12, 1842; and 453 and in. 5-6, and 454 and nn. 1-4, Felton, March 2, 1843; cf. W[illiam] Robertson Nicoll, Dickens's Own Story (London: Chapman \& Hall, 1923), pp. 147-70, which tries to correct CD's colorful account of Cruikshank's behavior at the funeral.

114. See Pilgrim, 3: Cruikshank, 528-29, July 26, 1843, and 534, July 31, 1843; and Jerrold, p. 224.

115. Pilgrim, 4:380-81, Coutts, September 17, 1845; see also 353, Cruikshank, August 13, 1845, and 494, Cruikshank, February $12,1846$.

116. See Jerrold, p. 19, and Borowitz, "George Cruikshank," pp. 74-76.
117. Pilgrim, 4:363, Forster, [August 22, 1845]

118. See Pilgrim, 4: Cruikshank, 361-62, [?August 22, 1845] and 364-65, August 27, 1845; and 365, Cattermole, August 27, 1845.

119. Quoted in Ley, Circle, p. 22; ef. Forster, p. 456, whose use of initials to disguise CD's references to the actors makes CD's comment about Cruikshank, for example, equally applicable to Leech or Frank Stone; yet cf. Pilgrim, 4:462, n.3.

120. See NL, 2: Cruikshank, 28, June 8, 1847, and 61, November 26, 1847; and programs and cast lists in Kitton, $P+P, 2: 108-11,124$.

121. NL, 2:110, July 9, 1848, and see 107, Cruikshank, July 1 and 3,1848

122. See NL, 2: 47-48, Forster, August 4, 1847, and Forster, pp. $458-59$.

123. Pilgrim, 4:392 and n. 5, September 29, 1845.

124. [Richard Ford], "Oliver Twist," p. 102.

125. See Browne, p. 23, and Borowitz, "George Cruikshank," pp. 88-90, on the artist's family situation, and Harvey, "George Cruikshank," pp. 145-48, for the effect of recent professional reversals on his art.

126. See Jerrold, pp. 200-201.

127. [John Paget], "George Cruikshank," p. 219.

128. See Jerrold, pp. 147-48, and unpub. ALS, Cruikshank to John T. Atkinson, April 6, 1865, Huntington Library (AM 15985).

129. Thackeray, "George Cruikshank," p. 53.

130. [Ford], "Oliver Twist," p. 102, and "Charles Dickens and His Works," Fraser's, pp. 399-400.

131. James, Autobiography, p. 69.

132. A description in CD's hand of the vignettes to be placed around the title of the 1846 OT wrapper is in the Berg Collection; a sketch for the wrapper is in the Gimbel Collection; and the wrapper itself is reproduced in Szladits, Berg Anthology, p. 44.

133. See Ruari MeLean, George Cruikshank: His Life and Work as a Book Illustrator, p. 34, and Arnold's tribute "To George Cruikshank," Early Poems, Narrative Poems, and Sonnets, p. 8 (reprinted in Jerrold, p. 255).

134. NL, 2:52, September 2, 1847; and see Louis James, "An Artist in Time: George Cruikshank in Three Eras," PULC 35:165-68, for further discussion of 'The Bottle.'

135. Quoted in Jerrold, pp. 241-42.

136. Quoted from the account given by [R. Shelton MacKenzie], "Philadelphia"; cf. Tillotson, ed., OT, who says it is not in this publication "as stated by Hotten and others after him" (p. 393, n.3). See also Pilgrim, 1:367, n. 3, about MacKenzie and Cruikshank's letters to MacKenzie, October 15 and November 1,1847 , in the Historical Society of Pennsylvania, quoted in Vogler, Cruikshank, pp. 121-22, about granting permission to reproduce scenes from 'The Bottle' in the London Journal 6 (November 20, 1847): 177-82.

137. See letter to Feuillet de Couches, December 3, 1847, Beinecke Library (quoted in Harvey, p. 31, in his discussion of Cruikshank's doomed search for independence, pp. 30-34).

138. Quoted in Jerrold, pp. 241-42.

139. Henrietta Ward, Memories of Ninety Years, p. 117, and see Shore, pp. 79-80, for this and other anecdotes and Jerrold, pp. 256-77, for a detailed description of the artist as a muscular teetotaler.

140. See Dawson Burns, Temperance History (London: National Temperance Publication Depot, [ca. 1889]), 1:339 and 358, and Norman Longmate, The Waterdrinkers: $A$ History of Temperance (London: Hamilton, 1968), pp. 134-35. For further details about Eliza Widdison Cruikshank, see Jerrold, p. 223; Evans and Evans, p. 140, and see photograph of her and Cruikshank on p. 187; and an oil portrait in the Cruikshank Collection at the $\mathrm{V}+\mathrm{A}$, reproduced in 
W. H. Chesson, George Cruikshank, facing p. 112.

141. NL, 2:301, April 25, 1851.

142. Ibid., 71, February 15, [1848].

143. Cf. Waugh, Nonesuch Dickensiana, p. 23, who asserts that their friendship continued throughout CD's life.

144. NL, 2:206, Chapman, February 13, 1850.

145. Ibid., 398, Cruikshank, June 23, 1852.

146. Thackeray, "George Cruikshank," p. 10. See Harry Stone, "Dickens, Cruikshank, and Fairy Tales," PULC 35:213-47, for a more detailed account of the Fairy Library.

147. Forster, "George Cruikshank's Fairy Library: Hop o' $M y$ Thumb and The Seven League Boots."

148. Ruskin, "The Elements of Drawing," Works, 15:222 23.

149. According to Cuthbert Bede, "A Reminiscence of George Cruikshank and His 'Magazine."

150. George Cruikshank's Magazine 1 (February, 1853): 78. A draft of Cruikshank's "Letter" is in the Meirs Collection (AM 20606).

151. George Cruikshank's Magazine 1:80.

152. Cinderella (London, [1854]), p. 31.

153. Puss In Boots (London, [1864]), pp. 28-40.

154. See Cinderella in George Cruikshank's Fairy Library (London, [1865]), p. 31, where there is awkward space where the longer word was; this change is aiso noted by Hamilton, George Cruikshank, p. 34, as well as by Stone, "Dickens, Cruikshank, and Fairy Tales," p. 240.

155. Quoted by du Maurier, letter to his mother, [January, 1861], The Young George du Maurier: A Selection of His Letters, p. 29.

156. See Jerrold, pp. 280-81; of Burton, "Cruikshank as an Illustrator of Fiction," p. 115, who states that the artist began attending R.A. classes in his seventies.

157. See Thackeray, "Cruikshank's Gallery," the Times (London) (May 15, 1863): 6; and Jerrold, pp. 289-98, for a detailed account of the exhibition and its reception.

158. See Ruskin, Works: 18:xlix; 36: letters to C. A. Howells, 502 and n. 3, February 24, 1866; 503, March 27, 1866; 504-5, April 2, $1866 ; 506-7$, April 9, 1866; 510, July 4, 1866; 516, [September], 1866; 17:414, diary entry, April 11, 1867; Reid, Catalogue, p. 193 and n. 1; and unpub. ALS, Cruikshank to Ruskin, June 21, 1867, in the Berg Collection.

159. The Meirs Collection has a copy of a petition for a civil pension for Cruikshank (AM 17399) and the Cosens watercolors, in the Morgan Library, are reproduced in Cruikshank's Water Colours, ed. Joseph Grego, pp. 1-109.

160. Quoted in Kitton, $D I$, p. 214, and widely elsewhere.

161. Quoted in Spencer, "Loving Ballad of Lord Bateman, 1839," and widely elsewhere.

162. See Kitton, $P+P$, 1:17 n.; Harvey, p. 162; and 'Mayley's Visit,' Ainsworth's Magazine 4 (July, 1843): facing p. 12 (the similarity of the subject's name to the family in OT may have suggested the sketch to Cruikshank).

163. Quoted in Spencer, "Loving Ballad of Lord Bateman, 1839," and in Haight.

164. Cf. Haight; and Cohen, "All-of-a-Twist," p. 338, whose imprecision in saying that verse XXI was "cancelled" is noted in Vogler, Cruikshank, pp. 101 and 114, n, 10. But Vogler's omission of the artist's bracketed suggestion to the reader between CD's verse XXI and his own three new verses makes his pronouncement that verse XXI is included in the 1870 edition "as usual" equally misleading.

165. Haight quotes Cruikshank's handwritten instructions on the proofs for the 1870 edition, dated November 25, 1869: "The notes to be compressed in order to make room for the 2 pages required for the additional verses," but may partly err in asserting that the notes "were relegated to as inconspicuous place as possible to make way for the artist's own verses" as both were eventually accommodated, the notes in their previous place.

166. Quoted in Pilgrim, 1:536, n. 1.

167. See Kitton, $P+P, 1: 17$.

168. Quoted in Wilkins, "Cruikshank versus Dickens," p. 81, which differs slightly, especially in its lack of underlined emphases, which softens the tone, from the ALS draft of November 11, 1870 in the Elkins Collection, quoted in Vogler, Cruikshank, pp. 135-36, and which is utilized substantially as written by Mackenzie, "George Cruikshank vs. Charles Dickens," p. 2. For a detailed consideration of the whole so-called Cruikshank-CD controversy, particularly concerning OT, see Harvey, pp. 199-210, and Vogler, Cruikshank, pp. 115-76, which is less useful for its strained arguments in support of the artist than for its quotation in full of most of the relevant but obscure documents, also utilized throughout the present discussion as well as in preceding parts of the chapter, which are essential to a full discussion of the complex issue.

169. R. Shelton MacKenzie, "Philadelphia."

170. See [John Camden Hotten], Charles Dickens, p. 27; R. Shelton MacKenzie, Life of Charles Dickens, pp. 164-65; cf. Forster, pp. 112-13 and n.

171. Cruikshank, "A Bit of Literary History."

172. See "Forster's Life of Charles Dickens," the Times (London) (December 26, 1871): 4; MacKenzie, "George Cruikshank vs. Charles Dickens"; and Cruikshank, "Origin of "Oliver Twist."

173. See Burton, "Cruikshank as an Illustrator of Fiction," p. 121, n. 37, about the hero's name; Harvey, pp. 202-4; cf. Vogler, Cruikshank, pp. 149-57, about the 1836 workhouse inquiry; and "Charles Dickens and His Works," Fraser's 21:399-400, about OT's appearance.

174. See Sala, "George Cruikshank: A Life Memory," p. 558, n. 1, and Vogler, "Oliver Twist: Cruikshank's Pictorial Prototypes," p. $98-118$.

175. See Tillotson, ed., $O T$, p. xxii, and Harvey, pp. 205-9.

176. See Vogler, Cmikshank, p. 44.

177. Jerrold, pp. 148-49.

178. See, for example, The Evening Standard (December 30 , 1871): 4, col. 5; cf. unpub. draft reply by Cruikshank in the Meirs Collection (AM 15985) and The Graphic (January 6, 1872): 7, col. 1-2; cf. draft reply by Cruikshank, though not in his hand, January 10,1872 , in the Morgan Library, both of which are quoted by Vogler, Cruikshank, pp. 144-46; and Forster, quoted in Waugh, Nonesuch Dickensiana, p. 27.

179. See letter to Deane, January 3, 1872, Elkins Collection and letter from Deane to Cruikshank, February 6, 1872, described in Sales Catalogue No. 14, issued by Jantzen, Toll Gate, Lewes Road, East Grinstead, Sussex (July, 1959), first called to the author's attention by Vogler, Cruikshank, pp. 155-57, which quotes. both items.

180. See letter from MacKenzie to Cruikshank, January 4, 1872, in the Arents Collection, quoted in Vogler, Cruikshank, pp. 136-37, and a final ALS draft from Cruikshank to MacKenzie, January 21, 1872, in the Arents Collection; cf. Vogler, "Cruikshank and Dickens," p. 65, who notes only the first letter and taxes Tillotson, ed., OT, p. 394 and n. 4, for noting two. A fair copy of the ALS from Cruikshank to MacKenzie, January 22, 1872, is in the Historical Society of Pennsylvania and is quoted by Vogler, "Cruikshank and Dickens," pp. 73-74, who also discusses the "List," pp. 74-75, and reproduces it in Figs. 14 and 15, following p. 46. 
181. See Cruikshank's sheet of pencil sketches, tipped into a Widener Collection copy of OT, vol. 3 , inscribed in ink by the artist: "Sketches for 'Oliver Twist'-suggestions to Mr. C. Dickens-the Writer-George Cruikshank," quoted in A. S. W. Rosenbach, A Catalogue of the Writings of Charles Dickens in the Library of Harry Elkins Widener, p. 92 (hereafter cited as Rosenbach, Dickens Catalogue) and here by permission; the artist's inscription in ink on a sheet of sketches for $O T$, including some for the imprisoned Fagin: "First idea and sketch for Fagin in the Condemned Cell_-" in the Cruikshank Collection (9555.J), reproduced in Kitton, $D I$, plate 14, facing p. 26, and discussed as such on p. 15; cf. Harvey, pp. 205-9, who argues convincingly that these sketches were done for the 1846 OT wrapper; and the artist's inscription on a sheet of sketches for $S B B$ : "Some of these suggestions to Chas. Dickens \& which he wrote to in the second part of Sketches by Boz," in the Cruikshank Collection (9995.Q), reproduced in Kitton, $D I$, plate 7, facing p. 12, and briefly diseussed in Charles Dickens: An Exhibition to Commemorate the Centenary of His Death, June-September, 1970, p. 13, No. C11 (hereafter cited as $V+A$ Dickens Catalogue).

182. See Harvey, pp. 34-42, and Vogler, Cruikshank, pp. 162-76, for discussions of Cruikshank's more valid claims on the works by Ainsworth that he illustrated.

183. Cruikshank, The Artist and the Author, pp. 4-5, 15; a draft copy of this pamphlet is in the British Museum. In the Bradburn Collection is a letter to an unidentified editor, March 4, 1878, written by William Merle (the "A.B." who wrote the supporting letter of April 22, 1872 included at the end of The Artist and the Author, p. 16, probably at the artist's request), which affirms that Cruikshank did mention his contributions to CD during the course of their work; Merle is discussed and his letter, not seen by the author, is quoted in Vogler, Cmikshank, pp. 158-62.

184. Forster, p. 475, and CD's letter to Cruikshank, fac. between pp. 476 and 477 .

185. See, for example, "Mr. Forster's 'Life of Dickens,' Vol. II," Nation 16 (January 9, 1873): 29, and "Recent Literature," Atlantic Monthly 31 (February, 1873): 238-39, which were first called to the author's attention in Vogler, "Cruikshank and Dickens," pp. 84-86, who notes and quotes them both.

186. Letter to McClellan, quoted in Wilkins, "Cruikshank versus Dickens," p. 81.

187. Pilgrim, 4:380, Coutts, September 17, 1845.

188. Letter from Dobson, April 2, 1872, quoted in Jerrold, pp. $153-54$.

189. Quoted in Kitton, $D I$, p. 23.

190. The Meirs Collection contains unpub. ALSs between Cruikshank and Mrs. CD of January 4, 1866 (AM 17778) and April 25,1872 (AM 13947) as well as an unpub. list including her name among those who are to receive a copy of The Artist and the Author. The Borowitz Collection contains a guest list of the Cruikshanks' silver wedding anniversary party which includes Mrs. CD, reproduced in Borowitz, p. 91.

191. Dr. Lilian L. Shiman has shared with the author her informed speculations about Cruikshank's probable reversion, based on her inspection of contemporary documents for her study of the temperance movement, "Crusade Against Drink."

192. See Vogler, "Cruikshank and Dickens," pp. 87-89.

193. Ruskin, "The Cestus of Aglaia," Works, 19:77, and Swinburne, p. 15.

194. See William Rossetti, Fine Art Chiefly Contemporary, p. 278, and Sitwell, Sitwell, and Sitwell, "George Cruikshank," p. 247.

195. Cf. Vogler, "Cruikshank and Dickens," p. 62 and passim.
Although it is true that many of the scholars now working on Cruikshank became interested in him through their work on Dickens, it is also obvious-as the other articles in PULC 35 attest-that they have become fascinated by the artist for his own sake but were rarely biased against him in CD's favor in any case, as Vogler suggests.

\section{Chapter 2: Robert Seymour}

1. [Charles P. Johnson], “'Pickwick' and Its Illustrators," p. 737.

2. Forster, p. 77.

3. See Layard, "Robert Seymour," DNB 17:1266; cf. [?Robert Seymour, (son)], "Life of Robert Seymour," p. 3 (hereafter cited as [?Seymour, (son)]), who says nothing about his illegitimacy.

4. Mrs. Jane Holmes Seymour, An Account of the Origin of the Pickwick Papers, p. 214, reprinted in William Miller and E. H. Strange, A Centenary Bibliography of The Pickwick Papers pp. 189-214, which is the edition to which the page citations will refer (hereafter cited as Mrs. Seymour). The miniatures here reproduced doubtless are the subject of the ALS from Robert Seymour (son) to ?, February 25, 1891, at the Huntington Library.

5. See George, Catalogue, 11:xlvii; [?Seymour, (son)], p. 4; Henry Bohn, introduction to Seymour's Humorous Sketches, p. v; and Kitton, DI, p. 31. See also Harvey, p. 30, for Gillray's influence.

6. W[illiam] P[owell] Frith, John Leech, His Life and Work, 1:101; cf. the positive assessment made by George, Catalogue, 11:xlvii, quoted in Patten, "Portraits of Pott: Lord Brougham and The Pickwick Papers," Dick. 66 (September, 1970): 216 (hereafter cited as Patten, "Portraits of Pott"); and Louis James, "Pickwick in America!" DSA 1:64-70.

7. Baudelaire, p. 750 .

8. See "Coroner's Inquest," the Times (London) April 22, 1836):7; ef. [?Seymour, (son)], p. 8, who stresses the artist's even temperament.

9. Quoted in George, Catalogue, 11:xlviii.

10. See 'The Omnibus,' Seymour's Comic Album, p. 89, and Kathleen Tillotson, "Seymour Illustrating Dickens in 1834," Dick. 59 (January, 1958):11.

11. Patten, "Portraits of Pott," p. 216.

12. Beckett, "To Correspondents," Figaro in London 3 (November 15, 1834): 184, climaxes weekly insults from (August, 30), 137 to (December, 27), 205; cf. puffing in (January 11), 5 to (August 9), 126, examples quoted in Cohen, "A Melancholy Clown," 253, n. 15 , and 254 , n. 16.

13. Pilgrim, 4:234, Mrs. CD, December 2, 1844.

14. Mrs. Seymour, pp. 204-5; cf. A. W. à Beckett, The à Becketts of "Punch," pp. 36-42.

15. See Engel, Maturity of Dickens, pp. 75-77, for parallels between $P P$ and the popular Surtees work, whose "Nimrod" club $C D$ alludes to in his later $P P$ prefaces (xviii, xxii), and Harvey, p. 14, for the lesser influence of Pierce Egan's works.

16. Mrs. Seymour, pp. 190, 197, mentions Monerieffe and Mayhew, and Robert Seymour (son), "Seymour's Sketches," p. 398, Spooner and McLean, but, oddly, not to support their case that Seymour originated $P P$. None of these publishers, however, later mentions seeing Seymour's plan after CD made it famous.

17. Letter to CD, July 9, 1849, quoted in Forster, p. 74; cf. Mrs. Seymour, pp. 189-91, who says that her husband was prevented by illness from writing the text himself and that it was he who insisted on publication in monthly parts, not two volumes as Chapman and Hall wanted.

18. See Vizetelly, 1:16 and n., on Clarke's prior obligations; $c$. 
Mrs. Seymour, pp. 191, 221; Bohn, 'Biographical Notice of Robert Seymour," p. vii; and Buss, "My Connexion with PP," p. 114, who suggests that Leigh Hunt and other light essayists turned the job down.

19. See Fielding, "Charles Whitehead and Charles Dickens," pp. 141-52.

20. Kitton, $D I$, pp. $45-46$, notes that the fat man in Seymour's first illustration in The Library of Fiction (London, 1836), 1: facing p. 10 (SBB, T: IV, facing p. 343) is said to be a self-portrait; cf. Weld Taylor's widely reproduced portrait drawing, whose original is in the Widener Collection copy of Mrs. Seymour's Account, facing title page, and the artist's self-portrait miniature (see fig. 14), which portray a far thinner man. See also Vogler, Cruikshank, p. 80, who notes that Cruikshank simply recopied the first of Seymour's two illustrations in reverse for the $1839 S B B$ and cites it to indicate the former artist's indifference but fails to account for his redrawing of the second of Seymour's illustrations [Library, 1: facing p. 17; cf. $S B B$, facing p. $352(2)]$.

21. Quoted in Forster, p. 74.

22. Mrs. Seymour, p. 191, who says she urged CD's selection because of his reported poverty; [?Seymour (son)], p. 7; and Buss, "My Connexion with PP," pp. 114-15.

23. See Weld Taylor, quoted in Kitton, $P+P, 3: 4$, for CD's expressed admiration of Seymour.

24. See Robert R. Wark, ed., Rowlandson's Drawings for "The English Dance of Death" (San Marino, Calif.: [Huntington Library Publications], 1966), p. 6.

25. Pilgrim, 1:110, Macrone [December 21, 1835].

26. Ibid., 128-29, February 10, 1836.

27. Joseph Grego, ed., Pictorial Pickwickiana, 1:12-13, also notes these discrepancies, as do others, and Samuel W. Lambert, When Mr. Pickwick Went Fishing, pp. 8-12, uses them to indicate that the Pickwickians existed visually in Seymour's work long before CD, much as prototypes have been shown to exist for $O T$ in Cruikshank's work, but they are strangely ignored by the Seymours in their arguments.

28. Cf. Mrs. Seymour, p. 203, who says Winkle was already in the club.

29. Quoted in Forster, p. 76; cf. Waugh, p. 21, whose statement that $\mathrm{CD}$, not Seymour, was shown Chapman's fat friend is unsubstantiated. [Abraham Hayward?], "The Posthumous Papers of the Pickwick Club . . Oliver Twist," p. 497, also notes CD's vague description of Pickwick.

30. The following have been suggested as prototypes by Seymour for a fat Pickwick:

1. [Richard Penn], Maxims and Hints for an Angler (London: J. Murray, 1833), facing p. 3, reproduced in Lambert, facing p. 4, and also noted by Kitton, $D I$, p. 38; Walter Dexter and J. W. T. Ley, The Origin of Pickwick, p. 21; Butt and Tillotson, p. 64, n. 2; and Pilgrim, 1:136, n. 1. [Penn], facing p. 23, reproduced in Lambert, facing p. 60, has a figure remarkably like Browne's Sam Weller and the thin fisherman here may suggest how Seymour first conceived Pickwick, which is discussed further by Kathleen Tillotson,

"'Pickwick' and Edward Jesse," p. 214.

2. Seymour, New Readings of Old Authors, 6:np, reproduced in Lambert, facing p. 30, also noted by Dexter and Ley, p. 21.

8. Thomas K. Hervey, The Book of Christmas (London: William Spooner, 1836), facing p. 82, reproduced in Lambert, facing p. 22, also noted by Dexter and Ley, p. 21, and Pilgrim, 1:136, n. 1.

4. Seymour's Sketches, plate 114, and Seymour, The Heiress, plate 2, are suggested by [?Seymour (son)], p. 7, but
Mrs. Seymour does not use them to support her version of PP's origin.

31. ALS to Augustin Daly, March 26, 1889, in the Widener Collection copy of Mrs. Seymour's Account, following title page, quoted in Rosenbach, Dickens Catalogue, pp. 27-28, and the original corrected sketch is inserted between pp. 8 and 9 . See also Leavis, p. 339 , for comments on this illustration.

32. See Hatton and Cleaver, pp. 18-19; Johannsen, p. v; and Harvey, pp. 183, 185.

33. "The Library of Fiction, The Posthumous Papers of the Pickwick Club," p. 233.

34. Butt and Tillotson, p. 68; cf. Patten, "The Art of Pickwick's Interpolated Tales," p. 357. Mrs. Seymour, p. 192, says that her angry husband allowed the tale at her request.

35. Pilgrim, 1:145-46, [April 14, 1836], the ALS of which is inserted between pp. 6 and 7 in Mrs. Seymour's Account in the Widener Collection.

36. Baudelaire, p. 750 .

37. 'The Runaway Chaise' and 'The Pickwickians in Mr. Wardle's Kitchen' are reproduced in Grego, Pictorial Pickwickiana, 1:87 and 89 respectively.

38. Pilgrim, 1:145-46, [April 14, 1836].

39. Johnson, Charles Dickens, 1:137.

40. Cf. ibid., who says "Hall, it appears, must have been [present]."

41. CD, address, $P P$ No. 2, before the illustrations, reprinted in Dexter and Ley, p. 52 , states this as fact, either as an educated guess or as an effort to enhance the number's interest; cf. Mrs. Seymour, pp. 192-93, 202; [?Seymour (son)], p. 8; and Seymour (son), letter to Daly, quoted in Rosenbach, Dickens Catalogue, pp. 27-28-all of which insist that the artist was working on another project, as if to obscure his problems with 'The dying Clown.'

42. This account is based on "Coroner's Inquest," the Times (London) (April 22, 1836),7; “Seymour's Inquest," Bell's Life in London (April 24, 1836), np; and Leslie C. Staples, "Where Robert Seymour Died," Dick. 13 (October, 1917): 265-66; cf. most commentators, from Buss, "My Connexion with PP," p. 119, to Johnson, ed., $P P, 1: 138$, who maintain that the artist blew his brains out.

43. Emile Durkheim, Suicide: A Study in Sociology, trans. John A. Spaulding and George Simpson (New York: The Free Press, 1966), p. 328, and Alfred Alvarez, The Savage God: A Study of Suicide (New York: Bantam Books, 1973), p. 46, discuss the punitive English suicide laws before 1870.

44. Weld Taylor, quoted in Kitton, $P+P$, 3:4.

45. "The Posthumous Papers of the Pickurick Club," Metropolitan Magazine 16 (June, 1836): 46-47; cf. a scholar quoted in [Dexter], "Pickwick Illustrators," Dick. 32 (Summer, 1936): 163, who says that Seymour blew out his brains after CD asked him to redo 'The dying Clown' and advertised for another illustrator.

46. NL, 3:465, Robert Pusey, April 3, 1866. Grego, Pictorial Pickwickiana, 1:71, repeats the legend that the final 'Clown' drawing is stained with Seymour's blood.

47. According to Burnett, quoted in Thomas Wright, The Life of Charles Dickens, p. 85.

48. Reprinted in Dexter and Ley, 57, and widely elsewhere, but, oddly, not in the Nonesuch $P P$.

49. Thomson, Life and Labours of Hablôt Knight Browne, "Phiz," p. 83, says that the publishers considered this format even before Seymour's death.

50. "The Posthumous Papers of The Pickwick Club, No. 2," Satirist (May 1, 1836): 138.

51. "The Posthumous Papers of The Pickwick Club, No. 1," 
Atlas 11 (April 3, 1836): 220. See also Patten, ed., introduction to The Pickwick Papers by CD, p. 16.

52. CD's refusal, nd, is quoted by Mrs. Seymour, p. 196.

53. According to ibid., p. 196; Pilgrim, 4:418, Challenor, October 28, 1845; and information supplied by the late William Carlton in letters to the author of January 28 and February 18, 1967.

54. Mrs. Seymour's 1849 letter to CD is not available but it is likely that she uses the same arguments, if in briefer form, that she later employed in her 1854 Account, which is discussed below.

55. Quoted in Forster, p. 76.

56. Ibid. CD had left the firm in 1843 after difficulty over $M C$ and A Christmas Carol, which are discussed below, returned in 1859, and in his 1868 PP preface acknowledged Chapman's contributions to the realization of $\mathrm{Mr}$. Pickwick's appearance (xxii; cf. xviii).

57. NL, 2:163-64, July 18, 1849; and see also Mrs. Seymour, p. 195, and Samuel Carter Hall, Retrospect of a Long Life, p. 393, for memories of $\mathrm{CD}$.

58. Mentioned by Mrs. Seymour, p. 198, who says that his letter was written "in a great fright."

59. Some characteristic statements from her Account are as follows: "Mr. Dickens edited a work called the Pickuick Papers, which was originated solely by my husband in the summer of 1835 , and but for a cold (which brought on a severe illness) which he caught on the Lord Mayor's day, on taking his children to view the procession from the Star Chamber, would have been written as well as embellished by himself" (p. 189). "An unprecedented sale took place for the second number of the Pickwick Papers, the deluded public believing that they were purchasing the last designs of their favorite artist" (p. 195). "Had there been no Mr. Seymour, Pickwick Papers would not have been written; but had there been no Dickens, they would have been written notwithstanding" (p. 195). "[Seymour] needed not the pen of a Dickens to fame him, and afterwards to asperse his memory by falsely saying he left his family unprovided for, and calling him the caricaturist, and saying other things equally obnoxious and untrue" (p. 213).

60. CD's letter to Seymour, cited above in Pilgrim, 1:145-46 [April 14, 1836], the version used by Mrs. Seymour, pp. 191-92, and yet another edited by Seymour's son, "Seymour's Sketches," pp. 398-99, who quotes only the opening complimentary sentences (cf. [?Seymour (son)], pp. 7-8, who quotes the letter in full though makes it seem earlier in date) were all reprinted together in Dexter and Ley, pp. 92-95, 98.

61. Seymour (son), "Seymour's Sketches," pp. 398-99. He, according to Bohn, and his sister, according to J. Challenor Smith in an unpub. letter to William Carlton, 1926, made available by Cariton in a letter to the author of January 28, 1967, sold prints of their father's works, which they considered their property, and resented Bohn, who owned many of Seymour's works, for trying to profit from them as well.

62. Bohn, "Seymour's Drawings," p. 464. See also Eilis, Ainsworth and His Friends, 1:174-75 and Waugh, $A$ Hundred Years of Publishing, p. 83, for Ainsworth's similar dispute with Bohn over his use of Cruikshank's illustrations for The Tower.

63. The existence of $\mathrm{CD}$, letter to $\mathrm{E}$. Walford, July 28,1858 , partly quoted in Carr, VanderPoel Catalogue, p. 19, No. A 112, suggests that $C D$ often received correspondence citing the Seymours' claims, which may account for his punctilious correction of his letter to the Athenaeum (March 31, 1866): 430, in the next issue of the Athenaeum (April 7, 1866): 464, to place Seymour's death before "the next twenty-four" pages of $P P$ were written rather than "the next three or four," as Seymour's sketch of "The Pickwickians in Wardle's kitchen,' reproduced in Grego, Pictorial Pickwickiana, 1:89, which illustrates an episode on p. 50 of the originial $P P$, indicates.
64. (Eds.), Athenaeum (April 7, 1866): 466.

65. Chesterton, p. 72.

66. Letter, April 4, 1866, quoted in Charles Dickens the Younger, introduction to The Pickwick Papers by CD (London: Macmillan, 1893), pp. xxviii-xxix, who adds that his mother's notes were destroyed but that she and his uncle "confirmed" the letter in "every particular."

67. [?Seymour (son)], pp. 3-6. The book, subtitled $A$ Complete Collection of One Hundred and Eighty Humorous Designs appears to be the "complete edition of the one hundred and eighty sketches" by Seymour that the son said he was publishing in his letter to the Athenaeum (March 24, 1866): 399. The unsigned preface, usually attributed to Hotten, a prolific but unscrupulous publisher, recalls the son's Athenaeum letter in style as well as substance. Furthermore, only Seymour's son was familiar enough with both Bohn and Mrs. Seymour to contradict the former and to omit or explain the least credible statements of the latter.

68. Chesterton, p. 79 .

\section{Chapter 3: Robert Buss}

1. For example, L[ouis] F. Cagan, "Robert Buss," DNB, 3:492, does not even mention his role in PP. See also [Dexter], "Pickwick Illustrators," Dick. 32 (Summer, 1936): 163, who cites a completely garbled sequence of CD's artists that omits Buss entirely; and Sitwell, Narrative Pictures, p. 22, who cites him as an example of an artist who, because he was not associated with a Dickens, failed to attain the fame he deserved.

2. See Mason Jackson, "How I Engraved the Cover of 'Pickwick," " p. 516, which supplied much of the information used in the account below, and Buss, "My Connexion with PP," pp. 121-22.

3. See Buss, "My Connexion with $P P$," p. 122. Much of the following description of what ensued is based on the artist's version, which stands largely uncontradicted by other accounts.

4. Ibid., p. 125. The original drawing for 'Mr. Pickwick at the Review,' in the Morgan Library, is reproduced in the Victoria (or Jubilee) Edition of $P P$ (London: Chapman and Hall, 1887), 1:51, and in Grego, Pictorial Pickwickiana, 1:109. See also Johnson, ed., PP, 1:140 and n. 26; cf. Waugh, One Hundred Years of Publishing, p. 24

5. Address, $P P$, No. 3, following the illustrations, is reprinted in Dexter and Ley, pp. 57-58, and widely elsewhere but not, inexplicably, in the Nonesuch $P P$

6. See F. Gordon Roe, "Seymour, The 'Inventor' of 'Pickwick," p. 155, and Patten, "Portraits of Pott," p. 205, who suggest that 'The Cricket Match' is based on the artist's popular design, 'The Cricket Match (Maximo-rotondo Crobble bowled out),' in Sketches by Seymour, 1, no. 8. The fat boy in Buss's 'Arbour scene,' which is discussed below, may be based on Maximo-rotondo as well.

7. "The Posthumous Papers of the Pickwick Club, No. 3," Bath Herald 45 (June 11, 1836): 4, quoted in Dexter and Ley, p. 78. Here, the reviewer put the artist's name in quotes, thinking it a pseudonym and even in the review of the 4 th no. in 45 (July 9, 1836): 4 , in which Browne's plates first appear, continued to think PP illustrated 'by "Buss," the collaborator of "Boz," as does W. S[awyer], "The Pickwick Papers," pp. 34-35. Meanwhile, the reviewer of "The Posthumous Papers of The Pickwick Club," Metropolitan Magazine 16 (June, 1836): 76, quoted in Dexter and Ley, p. 76, stated that $P P$, no. 3 , contained illustrations by "R. W. Boz" and even as late as 1936 a newspaper, mentioned in Dexter and Ley, p. 56, stated that Buss committed suicide because of his failure to satisfy $C D$ and the publishers.

8. According to his fellow cadet at West Point, later Brigadier General Charles G. Sawtelle, in a written account given to the 
author by his grandson, Chester M. Sawtelle, "The situation appealed to Whistler's sense of humor and dropping the book he made a sketch of the interview which he afterward elaborated in a water color drawing which he presented to me." Doubtless such diversions contributed to the artist's imminent dismissal from West Point in 1854. This drawing was first called to the author's attention by Anne Blake Smith.

9. See Kitton, DI, pp. 52-54, for a list and description of Buss's eight $P P$ designs, used and unused, and Grego, Pictorial Pickwickiana, 1:108-19, for reproductions of six of them, five of which are in the Morgan Library. N.B. that the subject of Buss's two designs for $P P$, No. 4-Mr. Wardle and his friends under the influence of "the Salmon" and 'The Break-down'-are retained by Browne, but that the subject of 'Mr. Winkle's First Shot,' portrayed by both artists, reproduced in Grego, 1:106, 161, was not used in $P P$

10. Buss, "My Connexion with $P P, "$ p. 129.

11. Rev. Alfred G. Buss, "R. W. Buss," p. 331.

12. Buss, "My Connexion with $P P$," pp. 127-28, and see n. 13, below.

13. According to his grandson, Rev. F. Fleetwood Buss, quoted in Dexter and Ley, p. 141.

14. See Buss, "My Connexion with $P P$," pp. 127-28, 133, and Forster, p. 82, n. 92; cf. Ley, "Robert William Buss: A Tribute to an Unlucky Artist," Dick. 6 (March, 1910): 71, who reprints the artist's account book, which reveals he received 30 shillings for each of his drawings and etchings, only slightly lower than the 35 shilling rate paid Seymour, according to [?Seymour (son)], Seymour's Sketches, p. 8.

15. See Layard, "Our Graphic Humourists: Robert William Buss," p. 363, and Ley, "Fair Play for Buss," Dick. 28 (Autumn, 1932): 262

16. See Dexter and Ley, pp. 147-50, who discuss Buss's illustrations for Mrs. Trollope's The Widow Married, published by Colburn in 1840 , not 1836 , as is here stated, and p. 150 , for Frederick Marryat's Peter Simple (1837); and see also "Captain Marryat's Novels . . Peter Simple," Observer (February 5, 1837): np, quoted in Josephine Kamm, How Different from Us, p. 16, which makes it clear that the reviewer thinks the artist's real name is a pseudonym, and "Biographical Note," in Michael Sadleir, ed., Peter Simple by Captain Marryat, 1:xiii, quoted in appendix, n. 10 below, which gives the history of the execution of the illustrations of this edition. Buss also provided eleven illustrations for the initial serial publication of Ainsworth's James the Second: Or the Revolution of 1688 (1847), which is mistakenly entitled Court of King James II in "A Note on R. W. Buss," ibid., 1:xii.

17. Pilgrim, 1:230, Bentley (January 28, 1837). The engraving appears in Bentley's Miscellany 1 (February, 1837): facing p. 191.

18. See Kitton, $D I$, pp. 54-56, for accounts of Buss's scenes from $B R$, reprodsced facing p. 54, from two of the $C B$, and from $D \& S$, reproduced facing $p$. 56. The Arents Collection contains some sketches from $O T$.

19. See ibid., pp. 56-57; Kamm, p. 43; and Annie E. Ridley, Frances Mary Buss and Her Work for Education, pp. 54-65 and 74-75, for praise of his teaching by former students as well as his relationship to this daughter.

20. Forster, p. 77.

21. See Ley, "Buss's Pickwick Pictures: An Important Letter," Dick. 32 (Spring, 1936): 101-4, for Buss's letter of December 11, 1871 and a summary of Forster's reply as recalled in 1907 by Buss's eldest son.

22. The whole document was reprinted for the first time in Dexter and Ley, pp. 109-38.
23. For example, Buss, "My Connexion with $P P$," p. 110, not only makes Seymour the originator of $P P$, but the legitimate son of Vaughan, the pattern maker. Buss's grandson, Rev. F. Fleetwood Buss, according to Dexter and Ley, p. 14, feels Buss got his information about Seymour from his family. Mrs. Seymour, p. 195, mentions Buss's kind reply to her 1840 appeal.

24. Buss's three children actively sought public justice for their father. Using the artist's 1872 statement, they got Kitton to alter his remarks in $D I$, p. 51 ; cf. Kitton, Phiz (Hablot K. Browne): $A$ Memoir, pp. 9-10; persuaded Charles $P$. Johnson to include its main points in his introduction to the Victoria edition of $P P, 1$ :xi-xiii, as well as in his anonymous "Pickwick' and Its Illustrators"; and inspired Ley to write many articles sympathetic to the artist in The Dickensian (6:33-37 and 71-75; 28:258-64; and 32:101-4, all cited above). His grandson, Rev. F. Fleetwood Buss, probably wrote "A Note on R. W. Buss," in Sadleir, ed., Peter Simple, 1:xí-xii, which gives a factual summary of the artist's career noting his contributions to $P P$, but not their reception, and gave Dexter and Ley permission to publish the statement in full in 1936 . See also n. 26 below and Kamm, pp. 16-17, 43.

25. Buss, "My Connexion with $P P, "$ p. 135.

26. Buss, English Graphic Satire, esp. pp. 82-84, 87, 155, 171-72.

27. See Rev. F. Fleetwood Buss, "Dickens's Dream; The Last Picture of R. W. Buss," Dick. 28 (Autumn, 1982): 265-66. (In 1928, Rev. Buss wrote to thank Ley, Secretary of the Dickens Fellowship, for his fair treatment of the artist in his articles and to offer the painting to Dickens House, where it now hangs.) See also the discussion and nn. $43-45$ in chapter 18 below; NL, 2:437, Coutts, December 25, 1852, for an incomplete account of CD's sitting for Watkins; and Cruikshank's 'The Triumph of Cupid,' from The Table Book 1 (January, 1848): facing p. 1, reproduced in Jerrold, facing p. 210, and in Layard, Cruikshank's Portraits of Himself, p. 49, for a similar composition that may also have inspired Buss.

\section{Chapter 4: Hablot Knight Browne}

1. Rev. Alfred G. Buss, “R. W. Buss,” p. 451.

2. Browne, p. 1, notes there is no circumflex over the o in Hablot, but the addition persists. There is no excuse, however, for calling the artist Hoblot K. Brown as does Chesterton, p. 74.

3. Harvey makes a relevant point: "Like the novels they illustrate, his plates have acquired the status of classics. Yet, unlike the novels, and unlike most classies, they have almost no reputation" (p. 103).

4. This now commonplace observation, implicit in all nineteenth-century accounts of the artist, was first made explicit in Ley, Circle, pp. 36-37.

5. See Ley, Circle, who notes, "Phiz was ideal in this way" (p. 36), and Harvey, who similarly asserts: "The great advantage of $\mathrm{H}$. K. Browne was that with his youth, inexperience, and receptive and malleable character he was ideal for Dickens's purpose: he was still unformed" (p. 34).

6. See, for example, Sitwell, Sitwell, and Sitwell, Trio: (pp. $247-48$ ) "Cruikshank . . . was only followed in feeble imitation by 'Phiz'"; and Feaver, introduction to $V+A$ Cruikshank Catalogue: Phiz supplied "pale, nervy echoes of [CD's] words" (p. 18).

7. This argument, implicit in the writings of most nineteenthcentury commentators, even briefly stated in Everitt, p. 247, and Browne, pp. 272-73, for example, has recently been made explicit by Steig, "English Caricature," pp. 220-33, Harvey, pp. 103-60, and Leavis, pp. 332-71, and is now widely accepted, except for a few holdouts like Ray, The Illustrator and the Book, who feels "Phiz ... . went on repeating himself, though at a high level, 
throughout his career" (p. xxiii). The discussion below and passim is obviously indebted to these early and recent elaborations. There is, however, disagreement about which novel first displays notable interplay between text and illustration (Steig, "English Caricature," pp. 223-24, says $M C$; Harvey, p. 160 , and many others say $D \& S ; M H C$ is suggested below), and about which first show signs of decline (Leavis, pp. 359-60, says $B H$; Steig, p. 220, suggests TTC; most other commentators suggest $L D$ ).

8. For example, Harvey notes that in $L D$ "Browne has ceased to respond to what is new in Dickens's writing and it would seem from the slipshod drawing that he has ceased to be interested" (p. 160), but does not further explain what is "new" in CD's writing or "slipshod" about Browne's plates. Leavis does get closer to the mark with her assertion that in parts of $L D$, "Dickens is here his own illustrator" (p. 363).

9. See Thomson, pp. 18-19, 237-39, and Browne, pp. 62-63.

10. According to Thomson, p. 20, and Kitton, Phiz, p. 8, but see also John Buchanan-Brown, Phiz!, Illustrator of Dickens' World, p. 10 (hereafter cited as Buchanan-Brown, Phiz.).

11. R[obert] H[arrison], "Hablot Knight Browne," $D N B$, 3:46, and Kitton, Phiz, p. 8, say the artist received a Society of Arts medal for the best illustration of a historical subject in 1832 and another one for Gilpin "later"; cf. Thomson, p. 21, Kitton, $D I$, p. 60, Grego, Pictorial Pickwickiana, 1:133, and others who maintain that only the first medal was given to him in 1833 for his portrayal of Gilpin.

12. For further details on Browne's work for Winkle's undertaking, see Thomson, pp. 20, 203-4; Grego, Pictorial Pickwickiana, 1:143; and Browne, pp. 4-7.

13. For John Jackson's role in advancing Browne's career, see Mason Jackson, "How I Engraved the Cover for Pickwick," pp. 516-17, and Grego, Pictorial Pickurickiana, 1:133; cf. Kitton, DI, pp. 62-63, and Browne, p. 10, for a similar role claimed by John Fennell, Finden's supervisor.

14. Kitton, $D I$, p. 62 , discerns a prototype of Tony Weller in the illustration for E. Mayhew, "John Smith," The Library of Fiction, 1: facing p. 293, and there seems to be a Quilp prototype in the illustration for Maurice Harcourt, "The Pleasure Party," in 2: facing p. 86.

15. Harvey, p. 105, also discusses these illustrations, relating them to Browne's early $P P$ plates.

16. Reproduced in Grego, Pictorial Pickwickiana, 1:161. See also Kitton, $D I$, who quotes Fennell: "I . . . induced him (H.K.B.) to reproduce Buss's two illustrations (viz., The Cricket Match and The Fat Boy Awake on this Occasion only), which I sent down to Chapman \& Hall" (p. 62), but notes that there seems to be no illustration extant by Browne of the first subject and although the second subject might have been a specimen originally, it probably was not executed until later in 1836 when Brown designed a substitute for Buss's original plate.

17. Forster, p. 77.

18. See Thomson, p. 92, and Kitton, DI, 63-64, among many others, for the widely circulated legend about how the pair spent the whole night preparing these $P P$ subjects. Buss, "My Connexion with $P P$," pp. 132-33, argues that Browne knew no more about etching than he himself had, which is surprisingly accepted without qualification by Dexter and Ley, pp. 149-50 and by [Johnson], "Pickwick' and Its Illustrators," p. 737. Cf. the more valid argument that Browne could etch (vide the prize for the Gilpin etching) but had little inclination and less time for the long process of biting-in, stopping-out, rebiting, etc., as explained by Mason Jackson, "Pickwick' and Its Illustrators," pp. 766-67, and "How I Engraved the Cover for 'Pickwick," pp. 516-17, Kitton, DI, pp. 63-64, Grego, Pictorial Pickwickiana, 1:142, and Browne, pp. 4,
167, among others. That Browne was not indifferent to how his drawings were etched can be seen in his instructions concerning 'Mr. Winkle returns under extraordinary circumstances' ( $P P$, XLVII, facing p. 660), quoted in Thomson: "The outlines of the figures I have etched with a broad point intentionally: bit them slightly, that they might not be too hard, especially Pickwick" (p. 95).

19. Quoted in Kitton, $D I$, p. 65 , and Browne, pp. $7-8$, and widely elsewhere.

20. Letter to James Cook, March, 1859, quoted in John Dexter, "Hints to Dickens Collectors," Dickens Memento, p. 11. CD dropped "Boz" by the time of OT and Browne, though retaining "Phiz" on his etchings, when they were signed at all, used variants of his initials on his woodcuts (HB in the first part of OCS, and then-perhaps because of confusion with Dickie Doyle's father, John, who also used $\mathrm{HB}$-used HKB in $O C S$ and $B R$ ). See also Thomson, pp. 22-23 and n., Kitton, $D I$, p. 65, and Browne, p. 25, for further discussion of these signatures, which often confused readers; $O E D, 7: 783$, for definition of Phiz; and Potter, entry for December 15, 1887, Journal, p. 57, and Harvey, p. 184, for characteristic praise of Browne's ability to depict faces.

21. Pilgrim, 1:168, [?August 24, 1836].

22. Ibid., 183, Macrone, [?October 19, 1836].

23. See Thomson, p. 63, and Kitton, DI, p. 67.

24. Pilgrim, 1:184, [?October 19, 1836].

25. Ibid., 163, Browne, [mid-August, 1836]; the sketch is reproduced in Grego, Pictorial Pickwickiana, 1:187. See also Kitton, $D I$, p. 70, and Patten, "Portraits of Pott," pp. 220-22, for further discussion of this plate, its alterations, and the reasons for them.

26. Pilgrim, 1:222, Browne, [January, 1837]; the sketch is reproduced in Grego, Pictorial Pickwickiana, 1:205, and its alterations noted in Thomson, p. 94, and Kitton, DI, p. 70.

27. Pilgrim, 1:242, Browne, [mid-March, 1837]; the sketch is reproduced in Grego, Pictorial Pickwickiana, 1:215. Thomson, pp. 94-95, and Kitton, $D I$, p. 71, suggest that CD altered the text.

28. Pilgrim, 1:242, Browne, [mid-March, 1837]. Kitton, DI, p. 71, notes this discrepancy between picture and text.

29. The original sketch, now facing p. 605 in the copy of $P P$ in the Berg Collection, and the altered sketch are reproduced in Grego, Pictorial Pickwickiana, 1:225-27; Browne's instructions are quoted in Thomson, p. 95, and in n. 18 above, and CD's are in Pilgrim, 1:294, Browne, [?mid-August, 1837].

30. This sketch is reproduced in Grego, Pictorial Pickwickiana, $1: 229$.

31. Pilgrim, 1:195, Chapman and Hall, [?November 15, 1836].

32. [Hayward?], p. 497. See also Kitton, $D I$, pp. 67-68, who notes this and other discrepancies between plate and text in $P P$, and Hunt, Encounters, pp. 130-31, who discusses the influence of Gillray and Cruikshank on CD's Christmas scene.

33. [Hayward?], p. 497.

34. Hardy, The Moral Art of Dickens, pp. 88-89.

35. Patten, "Boz, Phiz, and Pickwick in the Pound," and "The Art of Pickwick's Interpolated Tales," provides detailed discussions respectively of Christian and Quixotic values in $P P$.

36. Browne, pp. $245-46$, makes the same point in his discussion of the artist's integral use of backgrounds here and elsewhere in his CD illustrations.

37. Thomson, pp. 81-82, and Kitton, $D I$, pp. 66-67, make this point briefly; it is implicit throughout Johannsen, $\mathrm{pp}$. 3-43, who reprints and annotates the states of these $21 P P$ etchings and passim all of Browne's duplicate etchings for CD's novels; and is explicit in Grego, Pictorial Pickwickiana, 1:149-99, who repro- 
duces a few of the etchings in their first and second states, together with their sketches, and in Harvey, pp. 105-10, who fully restates the point in discussing Browne's first three $P P$ plates, which has influenced the discussion of them below.

38. Harvey makes a similar point- "All these characteristics [of Browne's evolving style] have their equivalents in those features of Dickens's writing that were most conspicuously his own" (pp. 109-10)-but lets the reader infer the special aspects of these changes.

39. Kitton, $D I$, p. 68, notes the first example and four others.

40. "Literature," John Bull 16 (September 11, 1836): 295; and see also anon. revs. of "Posthumous Papers of The Pickurick Club, Nos. 16, 18, 19 and 20," The Idler and Breakfast-Table Companion (1837), quoted in Miller and Strange, pp. 175-77.

41. [Forster], "The Pickwick Papers, no. XV," p. 422.

42. See Harvey, pp. 111-12, for one such imitation, and Johannsen, pp. 78,173 , for other commissions given to Browne during and after $P P$.

43. See Browne, p. 149.

44. See Pilgrim, 1, Harley: 214, [December 19, 1836] and 216-17, [?December, 1836]. The Berg Collection has an unpub. sketch by Cruikshank for The Strange Gentleman, which may have been rejected in favor of Browne's.

45. See Pilgrim, 1:228 and n. 5, [?E. S. Morgan], January 26, [1837], and 228-29 and nn. 2-3, Bentley, [January 28, 1837]; and Kitton, $P+P, 1: 23-24$.

46. See Layard, Suppressed Plates, pp. 27-28; cf. Kitton, $P+P$, 1:23, who argues that Browne "undoubtedly did it." See also a pencil drawing of $\mathrm{CD}$, ca. 1840, attributed to Browne in the Charles Dickens Birthplace Museum, Portsmouth, reproduced in its guidebook, "The Birthplace of Charles Dickens," p. 8; however, the uncertain and atypically wide-spaced $\mathrm{H} \mathrm{K} \mathrm{B}$ signature, as well as the fact that a line has been drawn through it as if to cross it out, makes this attribution very suspect.

47. Miss Nellie Clark at Walter T. Spencer, Ltd., which acquired the drawing before Spencer's death in 1936 and allowed its reproduction in Dick. 32 (Winter, 1935-36):9, for the $P P$ centennial, was unable to provide further information about its origins or provenance in her reply of April 22, 1977 to the author's inquiry.

48. Pilgrim, 3:483-84, Mrs. Hogarth, May 8, 1843; and see Pilgrim, 1:65, n. 3, for other recollections of Mary Hogarth.

49. Pilgrim, 1:277, and n. 3, Forster [June 26, 1837], and 280-81, Forster, July 2, 1837.

50. Forster, p. 94. See also Pilgrim, 1:331, n. 1, who notes Browne's presence; cf. Ley, Circle, pp. 37-38 who says he was not there.

51. Thomson, p. 117 , and Kitton, $D I$, p. 74 , note the similarity between the third design here ( $S B B$, facing $p .658$ ) and the portrayal of the Kenwigses (NN, XXXVI, facing p. 468).

52. See accounts of this trip in Pilgrim 1:365-66, Mrs. CD, February 1, 1838, and 632, diary entry, February 2, 1838; Forster, pp. 127-28 and n. 128; and especially T. P. Cooper, With Dickens in Yorkshire, pp. 71-74, 90-104, to whose details the discussion below is indebted.

53. According to Browne, pp. 11-12. See also Pilgrim, 1:481, Mrs. S. C. Hall, December 29, 1838; Cooper, p. 75; and Kitton, DI, pp. 75-76 and n. 1-who also notes that Browne's portrayal of a pettifogging attorney in Punch 2 (February, 1842):66, resembles Squeers. Cf. Thomas Wright, The Life of Charles Dickens, pp. 125-26, who protests CD's portrayal of Shaw. The question of sources aside, Angus Wilson, The World of Charles Dickens, p. 138, feels that Datheboys Hall is more memorable from Browne's illustrations than CD's text.
54. See Pilgrim, 1:447-48, Mrs. CD, November 1, 1838, and p. 471, n. 1, and Richard Renton, John Forster and His Friendships, pp. 224-25, for details of their Midlands trip.

55. Thackeray ["T"], "Parisian Caricatures," p. 304; and see also Everitt, p. 336; Browne, pp. 246-47; and Waugh, Nonesuch Dickensiana, p. 28, who show similar concern about Browne's tendency to exaggerate; of. Chesterton, who says "no other illustrator ever created the true Dickens characters with the precise and correct quantum of exaggeration" (p. 74), and E. H. Strange, "The Original Plates in Nicholas Nickleby," Dick. 29 (Summer, 1933): 227.

56. Steig, "English Caricature," makes a similar point about the evil $N N$ characters "whose villainy is pictorially expressible in the grimace and the stunted shape" (p. 223), but he does not elaborate further.

57. See Pilgrim, 1:513, Browne, [February, 1839]; Kitton, DI, p. 77, who doubtfully suggests that the sketch for 'A sudden recognition unexpected on both sides' (XXXVIII, facing p. 498) was altered after and in accordance with CD's criticisms before the plate was etched; and Fraser, "The Illustrators of Dickens: Hablôt K. Browne," Dick. 2 (July, 1906): 183 (hereafter cited as Fraser, "Hablôt K. Browne"), who also notes the over-gross portrayals of Noggs.

58. Browne, p. 245 , also notes the beauty, if not the humor, of this detail.

59. du Maurier, "The Illustrating of Books," p. 371, argues that Browne's women, though pretty, are generally indistinguishable, whereas Kitton, $D I$, p. 77 , even denies that the artist has made the $N N$ heroines pretty.

60. See Kitton, $P+P, 2: 137-38$, who suggests that Henry Burnett was the model for Nicholas (who also resembles the young CD); and Pilgrim, 1:471, n. 1, which provides further details about the Grants.

61. This schedule is reprinted in Thomson, pp. 233-34, summarized in Pilgrim, 1:549, nn. 1-2, and is the obvious, if unacknowledged, basis of the discussion in Nicholas Bentley, "Dickens and His Illustrators," pp. 214-15. It is also interesting to compare Browne's more general rural routine, described in Browne, p. 29, with that of Cruikshank's urban one, described in Jerrold, p. 22.

62. See Pilgrim, 1:560 and n. 1, Browne [early July, 1939] and 2:51, and n. 4, Augustus and Mrs. De Morgan, April 12, 1840, on the errors in "Great excitement of Miss Kenwigs at the hair dressers shop' (LII, facing p. 690), and Kitton, DI, pp. 76-77, who notes other discrepancies in other plates; Slater, Suzannet Catalogue, p. 266, Lot 281, who quotes an unpub. ALS, nd, from Browne to Bob [Young not ?Buss as is suggested], saying he cannot come tomorrow, "some blocks having come in wanted, as usual, in a violent hurry"; and Strange, "Original Plates in Nicholas Nickleby," p. 227, who mentions Browne's illness, the notice for which is not reprinted in the Nonesuch $N N$.

63. See Johannsen, p. 78, for Browne's other commissions at the time of $N N$.

64. See Pilgrim, 1:444, Harley, [?October 24, 1838] and 435, Forster, [?September 18, 1838].

65. Pilgrim, 1:448, November 1, 1838.

66. See ibid., 460, Forster, [?November 23, 1838].

67. Ibid., 640, diary entry, February 7, 1839.

68. "Nicholas Nickleby," Athenaeum (March 31, 1838): 229.

69. See Kitton, $P h i z$, p. 12, and $D I$, p. 117, and Johnson, Charles Dickens, 1:265; cf. Browne, pp. 241 42 , on Browne's legendary shyness.

70. See Pilgrim, 1:455, Edmonds, [?November, 1838] and 645, cheque-book counterfoil, November, 301838. 
71. See Cooper, p. 39, and Pilgrim, 1:358, n. 5, whose description of Ainsworth's project for illustrated tales of old and new London in collaboration with $\mathrm{CD}$, though it never materialized, suggests an earlier germinating idea for $M H C$.

72. Pilgrim, 2:7-8 and n. 1, Cattermole, January 13, 1840. N.B. that CD uses the term "woodcut" although, in fact, the illustrations for $M S C$ are wood engravings. Reynolds Stone, quoted in Jane Taylor, "Reynolds Stone, Engraver," Vogue (London) (July, 1977), offers a clear explanation of their differences: "For a woodcut the cutting edge of the tool comes towards you and you bang the top with your left hand. For engraving the graver goes forwards, away from you, while the left hand holds the block, so helping guide the engraver. This gives much more fluidity" (p. 118).

73. Ruskin, "John Leech and John Tenniel," The Art of England, Works, 33:351; and see Edward Fitzgerald, letter to Barton, 1844, Letters of Edward Fitzgerald, 1:174, and Sam Weller and Mr. Stiggins's discussion of woodcuts in PP, XXVII, 366, which more often appeared in the cheapest literature of the time.

74. See Stevens, 115-29, to whom all discussions of the $M H C$ illustrations, including the one below, must be indebted, and Harvey, p. 115, one of whose examples is further discussed in the $V+A$ Dickens Catalogue, p. 38, F 14.

75. See Stevens, 113-15, 129-33.

76. See Pilgrim, 4:717, for CD's inventory of books in 1844, and Stonehouse, p. 16.

77. See Pilgrim, 2:110 and n. 3, Cattermole, [?August 7, 1840]; 197, Cattermole, January 28, 1841; 206 and n. 3, Cattermole, February 9, [1841]; 218-19, n. 3, letter from Browne to CD, [?March, 1841]; 352 and n. 3, Cattermole, August 6, 1841; and 378 and n. 3, Cattermole, September 12, 1841. Kitton DI, p. 81, notes the inevitable discrepancies between the OCS text and illustrations-all by Browne.

78. See Browne, pp. 164-66; cf. Jackson, "How I Engraved the Cover for 'Pickwick,'" p. 516. See also letter from Chapman to $\mathrm{CD}$, partly quoted by Slater, "The W. J. Carlton Bequest," Dick. 70 (January, 1974): 46, and unpub. ALS from Browne to Charles [?], nd, at Princeton (AM 19684), cited above in n. 44 to the Introduction.

79. See Pilgrim, 2: Cattermole: 8 and n. 7, January 13, 1840; 12 , [?January 21, 1840]; and 206 and n. 4, February 9, [1841]; cf. Kitton, $D T$, who says that Cattermole's designs were copied on wood "by a practical hand" (p. 123).

80. See Pilgrim, 2:38, Browne, [? March 6 or 7, 1840]; the sketch is reproduced in Kitton, DI, facing p. 72. See also Patten, "The Story-Weaver at His Loom: Dickens and the Beginning of The Old Curiosity Shop," in Dickens the Craftsman, ed. Robert B. Partlow, Jr., pp. $44-51$, for a full account of the origins of OCS.

81. This point, implicit in Leavis, p. 344, is explicit in Harvey, pp. 117-18, 125.

82. Kitton, $D I$, notes that "the terrible-looking creature intended for the Marchioness, in the [57th] and [65th] chapters, would never have developed into the 'good-looking' girl, as she really did, according to the text" ( $p$. 80) and Stevens notes that she is more properly "romanticized" (p. 130) in Browne's depiction of her for the 1848 Cheap Edition of OCS, which is reproduced in Steig, "Phiz's Marchioness," DS 2 (September, 1966): 141-46, who discusses her whole graphic history.

83. Forster, p. 152, and see his earlier version in his anonymous review for The Examiner (December 4, 1841): 772, both of which are discussed and quoted in Harvey, p. 124.

84. [Thomas Hood], "Master Humphrey's Clock, Vol. I," p. 888.

85. Harvey, pp. 121-22, 180, makes some similiar observations about this scene and Leavis makes a relevant point about an earlier scene: "the animal nature of Quilp's face and body-attitude in goading the chained dog opposite him brings out the inferiority of the animal to the human in ferocity and malice" (p. 345).

86. Browne calls Cattermole's Quilp "lifeless" (p. 260) but erroneously implies that he provided more than one representation.

87. 'Quilp's corpse' has been praised for its "horribleness" by Thomson, p. 116; for its "emotional reinforcement" of the text by Stevens, p. 124; for its effective placement by the $V+A$ Dickens Catalogue, p. 40, F 19 (d); and is compared to Whistler's Thames studies by Kitton, Phiz, p. 26 (but not in DI, p. 81) and to Doré by Fraser, "Hablôt K. Browne," p. 179, who is otherwise critical of all Browne's work for OCS in particular and for CD in general.

88. Kitton, $D I$, p. 81 , and Leavis, p. 346, also note this detail.

89. See letter from Browne to CD, [?March, 1841], quoted in Pilgrim, 2:218-19, n. 3, and Leavis, who comments on Browne's "mawkishness in representing Nell" (p. 346), but in a bottom note concedes that this observation mainly pertains to Cattermole's contributions. Leavis is similarly unfair and partly mistaken when she remarks "It was not expected that 'Phiz' could tackle satisfactorily the scene where Nell travels through the industrial Midlands in chapters XLIV and XLV" (pp. 346-47), as Browne portrayed only the second of the two scenes (XLV, 359), which CD describes in unusually abstract language to make his moral and emotional point.

90. This engraving is discussed in chapter 5 below.

91. Quoted in Pilgrim, 2:244, n. 1.

92. Browne, letter to CD, nd, quoted in Kitton, $D I$, p. 115.

93. See Pilgrim, 2:244, n. 1, Browne to CD, nd; 295, n. 1; and 417-18, John Landseer, November 5, 1841.

94. See Harvey, pp. 82-89, for a discussion of Thackeray's use of initial letters. The whole subject of Browne's use of initial letters in $M H C$ deserves far closer examination than the brief mentions below provide.

95. See Stevens, p. 124.

96. See Stevens, who, in making the same point, notes the same first example and suggests still another-Kit 'At the play' (XXXIX, 312).

97. Harvey, p. 126, makes the same observation; cf. Steig, "English Caricature," speaking of $O C S$ as well as $B R$, who says "(Browne) did not deviate from his tendency to distort comic and villainous characters' faces into a limited variety of stagey expressions" (p. 223).

98. Both Burton, "Cruikshank as an Illustrator," pp. 110-11 and 124-28, and Steig, "MC's Progress," pp. 121-22, state this point before their respective examinations of the $O T$ and $M C$ plates as sequences, as well as discrete compositions.

99. See Sylvère Monod, "Rebel with a Cause: Hugh of the Maypole," DS 1 (January, 1965): 15-16 and n. 1, who further discusses Hugh's representation and notes Browne's minor discrepancies in depicting him and Joe Willet, as does Kitton, DI, p. 82 .

100. Ruskin, "Ariadne Florentina," Works, 22:467-68, and see Fraser, "Hablôt K. Browne," pp. 179-80.

101. Kitton, $D I$, pp. $243-47$, notes portrayals by Buss, Charles Green, Edgar Hanley, and includes additional material on the most famous one by W. P. Frith. Doubtless, as Kitton said even then, there are others.

102. Cf. Steig, "English Caricature," "The woodcuts in [OCS and $B R$ ] do less than justice to Browne's talent" (p. 223).

103. Pilgrim, 2:384 and n. 3, September 16, 1841.

104. See W. J. Fitzpatrick, The Life of Charles Lever (London: Chapman and Hall, 1879), 1:228, n.; Pilgrim, 2:399-400, n. 3; and the figure on the right in 'The Supper at Father Malachi's,' Harry Lorrequer, 2, which resembles Nicholas. 
105. See Pilgrim, 2:399-400 and n. 3, Lever, [?early October, 1841].

106. See Thomson, pp. 237-38; Browne, p. 300; and Kitton, DI, pp. 107, 114, who notes that for one illustration, 'The lonely figure' ( $B H$, LVI, facing p. 762), the artist did visit a limestone pit to study the appearance of the huge crushing wheels.

107. See Browne, p. 290.

108. Quoted in Fitzpatrick, 2:51, n., and in Thomson, p. 150; and see also letter to Cosens, December 6, 1877, paraphrased in Slater, Suzannet Catalogue, p. 281, lot 311 .

109. See letter from Forster to Browne, nd, quoted in Browne, p. 237, and Pilgrim, 4:620, n. 2; Thomson, pp. 29-30; Kitton, DI, p. 116; Alan Horsman, ed., Dombey and Son by CD, p. 870 (hereafter cited as Horsman, ed., D\&S); and especially Harvey, pp. 187-88, who supplies figures from $P P$ to $L D$.

110. See Pilgrim, 1:227 and n. 3, Forster, [June 26, 1837]; diary entry, January 11, 1838; and 526, Beard, [March 13, 1839], about the glass shade of the artist's table lamp, which may relate to and help date the letter from Browne to Beard, nd, which playfully mentions plans by CD, Forster, and others for a party in his new quarters, quoted in the Anderson Galleries Catalogue, No. 325, January 9-11, 1918, shown to the author by the late Noel Peyrouton; cf. Browne, pp. 26, 43-44, who notes the effect of Browne's remoteness.

111. See Browne, pp. 107, 184, who quotes a letter from Browne to Lever, [ca. 1845], about CD's theatricals that betrays no hurt feelings whatsoever.

112. See Thomson, p. 238, and NL, 2:169, Forster, [September, 1849] and 471-72, Browne, June 29, 1853.

113. Letter from Browne to CD, September, [1841], quoted in Pilgrim, 2:399-400, n. 3; and see Lever's remarks about Browne's illustrations contributing to the "uproarious" character of his own work, quoted in Thomson, pp. 28-29, and Everitt, pp. 336-37.

114. Letter, January 10, 1852, quoted in Browne, p. 15.

115. See Forster, pp. 77, 94, 123, 132; cf. 142, an exception, and Browne, p. 238.

116. See Browne, pp. 46, 235.

117. Buss, "My Connexion with PP," p. 134.

118. Pilgrim, 3:359; Leech, November 5, 1842.

119. "The Chimes," Illustrated London News 5 (December 21, 1844): 395 . This periodical commissioned an un-Dickensian 'Christmas Carol' scene by Browne for 27 (December 22, 1855): 736, as is noted by John Suddaby, "Dickens's Pen Pictures of the Seasons, Part II," Dick. 7 (September, 1911): 243.

120. Thomas Hood, "Boz in America," New Monthly Magazine 66 (November, 1842): 396.

121. [Sir Theodore Martin], ed., "The American Apostrophe to 'Boz,'" The Book of Ballads, p. 52.

122. See Pilgrim, 3: Leech: 358-59, November 5, 1842 and 361 and n. 3, November 7, [1842].

123. See Steig, "Martin Chuzzlewit: Pinch and Pecksniff," p. 181; and Harvey, who describes the theme as "the growth of selfishness from small beginnings" (p. 136).

124. Steig, "English Caricature," pp. 223-24, and Harvey, pp. 130-31, make similar observations about the changes in both author and artist.

125. Harvey makes a parallel observation: "If [the illustrations] were freed from an exact dramatic context they could express more of the whole drama; they could mean more" (p. 129).

126. Butt and Tillotson, p. 93, fail to discem any narrative line connecting these details, however.

127. Steig, "MC's Progress," pp. 119-49, discusses these (124-25) and all the $M C$ illustrations in iconographic detail, which has proved useful in the discussion below.

128. Quoted in W. P. Frith, John Leech, His Life and Work, 2:89. See also Forster, p. 558, and $V+A$ Dickens Catalogue, p. 43 , who discuss Samuel Carter Hall as a possible model for Pecksniff.

129. Steig, "MC's Progress," p. 126, also notes these details and their significance.

130. Leavis, p. 347 , also notes Browne's altered portrayal of Mercy.

131. du Maurier, "The Illustrating of Books," p. 350, Kitton, $D I$, p. 87 , however, feels that the plate is badly executed and that the fact it is unsigned seems significant, and on p. 89 suggests that Tom Pinch may have been a belated addition to the scene to judge from his portrayal in the first sketch.

132. Steig, "English Caricature," pp. 226, 228, notes the increasing number of what he prefers to call "conceptual allegorical details" in the plates for $M C(9), D \& S(11)$ and $D C(18)$ which contrast with their lesser number in earlier-PP (1), $N N$ (3), OCS (3), $B R$ (1)-and later- $B H$ (7?) and $L D$ (3)-novels.

133. See ibid., p. 227, which also notes the function of these two titles as well as the framed pictures in the scene of Charity's jilting.

134. Everitt, pp. 344-45, and Steig, "MC's Progress," p. 132, make the same observation but their interpretation of the characters differs in several details from that of each other and the discussion below.

135. Steig, "MC's Progress," p. 132.

136. See Miller, "Fiction of Realism," pp. 63-64, and Hunt, Encounters, pp. 128-29.

137. Leavis, pp. $341-42$, makes such a comparison on aesthetic grounds only, praising Browne's "vivid" scene at the expense of Cruikshank's "static" one.

138. Jerrold, p. 110. Mrs. Toddles was introduced in the Omnibus (with which $C D$ was familiar, according to Pilgrim 2: Cruikshank: 276 and n. 1, May 2, 1841 and 340, July 21, 1841) in the issue for September, 1841, p. 160, and endured to the magazine's literal end in January, 1842, 299-300, the last pages of the last issue. Jerrold also suggests another model for Mrs. Gamp in a Cruikshank lottery puff in January, 1818, but his lack of specificity makes it difficult to tell which of the many puffs of that same date designed by Cruikshank he has in mind. The Queen (Cohn, George Cruikshank, p. 301, 1397) in the puff dated January 23, 1818 or Mrs. Swilltub (Cohn, p. 303, 1505) in the puff dated January 12, 1818 or the Hostess (Cohn, p. 302, 1450) might be possibilities as might the figure in 'A Comical Thought' for Swift, not listed in Cohn, but contained in Lottery Puffs, vol. 2, in the Widener Collection.

139. Harvey, pp. 131 -34 , to whose discussion the one below is obviously indebted, also quotes (p. 132) Thackeray's advice in " $\mathrm{Pa}$ risian Caricatures," p. 304.

140. See Harvey, p. 131 , for further details of this 1840 novel by George Reynolds, Robert Macaire in England, and Gordon McKenzie, "Dickens and Daumier," pp. 273-98.

141. Kitton, $D I$, pp. 87-88, notes other more minor discrepancies. between picture and text.

142. Pilgrim, 2, [August 15-18, 1843], 542-43, and reprinted in Butt, "Dickens's Instructions for Martin Chuzzlewit, Plate 18," pp. 49-50, and in Harvey, pp. 134-35, who also discusses the Hogarthian quality of CD's details.

143. Quoted in Pilgrim, 3:543, n. 1.

144. Ibid.

145. The $M C$ frontispiece and its instructions, quoted in "Dickens's Instructions to Phiz," Dick. 17 (January, 1921): 94, and in Pilgrim, 4:140 and n. 5, Browne, [?June, 1844], has been discussed at length by Steig-in relation to the $M C$ wrapper, and in its own 
right-in "MC's Progress," pp. 132, 143-45, and in relation to Tom Pinch's role in the story in "Martin Chuzzlewit: Pinch and Pecksniff," p. 18. It also has been widely praised by Kitton, $D I$, p. 85, Browne, p. 72, and even Fraser, "Hablot K. Browne," p. 183, among others, for the reasons given in the discussion below.

146. Quoted in Lionel Stevenson, Dr. Quicksilver: The Life of Charles Lever, (London: Chapman \& Hall, 1939), p. 154.

147. Quoted in Fitzpatrick, 2:51, who has regularized the punctuation; cf. the ALS at Princeton (AM 19311).

148. Pilgrim, 4:586, [July 18, 1845].

149. For the procedures on Browne's end, see Kitton, $D I$, pp. 90 , 92, 99, and Browne, pp. 82, 166-67. CD's usual routine is sufficiently indicated in his letters from Forster quoted in the discussion below.

150. See Pilgrim, 4:604, De La Rue, August 17, 1846, paraphrased by Horsman, ed., D\&S, p. 866 .

151. Pilgrim, 4:620, Forster, [?September 6, 1845].

152. Noted by F. Gordon Roe, "Talking of Dombey," pp. 177-78.

153. Butt and Tillotson, p. 93. See also the $V+A$ Dickens Catalogue, p. 83, I 3, for a good summary of the wrapper's content, and Horsman, ed., D\&S, pp. 570-71, 866, for a discussion of the wrapper and its relation to the frontispiece.

154. See Pilgrim, 4:620 and n. 3, Forster, [?September 6, 1845]; cf. ibid., 4:649, Forster, [October 26-29, 1845].

155. Ibid., 4:586, Forster, [July 18, 1845].

156. Pilgrim, 4: Forster: 586 and n. 3, [July 18, 1845] and 596 and n. 1, [August 2, 1846]; and see also Forster, p. 475, and Leavis, pp. 348-49, for further discussion of CD's excessive anxiety.

157. Cf. Kitton, DI, p. 98, who says that the artist checked the preferred studies but the ink of the checks differs markedly from the pencil used by Browne in his notations at the top of the original sheet.

158. Kitton, $D I$, p. 92 , also briefly notes this inconsistency.

159. See Pilgrim, 4:599, Forster, [August 7, 1846], for CD's original concept of the scene. Harvey, pp. 137-39, whose discussion of this illustration has informed the similar discussion of it below, as have the remarks in Leavis, pp. 350-51, notes that the published etching better illustrated the later moment but is placed, according to its original page number, opposite the earlier one. Harvey perhaps overstates the already considerable achievement of both artist and author by implying that this discrepancy may have been deliberate. More likely, it occurred because no one noticed it, which would be understandable given the distance between the principals, or because the two scenes are only one page apart, as Harvey notes, p. 138 and Horsman, ed., $D \& S$, implies, pp. 865-66, or perhaps it was a printer's error, as happened with plates 14 and 15 of $P P$, whose page numbers were transposed as Johannsen, p. 28, has noted.

160. John R. Reed, "Confinement and Character in Dickens's Novels," DSA $1: 45$, also notes the interplay between three scenes, and Leavis, pp. 35-51, also notes the parallelism between the first and last seene.

161. See Pilgrim, 4:613, Forster, [August 30, 1846] and 615, Mitton, August 30, 1846; CD may have heard from Browne after writing Forster from Lausanne and mentioned it to Mitton while writing from Rosemont later that day.

162. Quoted in Forster, p. 478; and see also Pilgrim, 4: Forster: 613, [August 30,1845] and 628, [October 3, 1845] for CD's hopes and doubts about the christening scene.

163. Pilgrim, 4:653, Forster, [November 4, 1845]. Browne's sketch is in the Elkins Collection.

164. Ibid, 671, Forster, [?November-December, 1846], and widely quoted elsewhere.
165. CD quoted in Forster, p. 27. See also Forster, pp. 478-79; Browne, pp. 85-87; Leavis, pp. 351-53; Horsman, ed., D\&S, p. 866; and Pilgrim, $4: 671$, n. 4 , for further commentary on this memory. A preliminary sketch of the scene, reproduced in Horsman, ed., D\&S, facing p. 866, is in the Dexter Collection, British Museum, and another is in the Elkins Collection.

166. Forster: "The result was not satisfactory; but as the artist more than redeemed it in the later course of the tale . . . the mention of the failure here will be excused for what it illustrates of Dickens himself" (p. 478).

167. Pilgrim, 4:677-78, [?December 6, 1846] and reprinted in NL, 2:18-19, ?March, [1847], an evident misdating as the text and plate had already been published in the 4th number in January, 1847.

168. See Horsman, ed., $D \& S$, pp. 867 and 142, n. 1, and Pilgrim, 4:681, Mrs. CD, December 19, 1846. See also Kitton, DI, pp. 95-96, one of many observers who notes this discrepancy between CD's instructions and Browne's sketch, and Leavis, pp. 354-55, who discusses the scene in detail.

169. Quoted in George Hodder, Memories of My Time (London: Tinsley Brothers, 1870), p. 277; cf. Ruskin, "Fiction, Fair and Foul-II" Works, 34:275, n. See also Patten, "The Fight at the Top of the Tree: Vanity Fair versus Dombey and Son," Studies in English Literature 10 (Autumn, 1970): 739-53.

170. NL, 2:17-18, March 10, 1847. The Berg Collection contains many sketches by Browne of Edith, as well as of Paul, Florence, and Alice, but whether they are studies for $D \& S$ or for the illustrations later issued separately is hard to determine.

171. NL, 2:19-20, March 15, 1847, and see Mrs. Disney Leith, The Boyhood of Algemon Charles Swinburne (London: Chatto and Windus, 1917), p. 8.

172. NL, 2:19-20, March 15, 1847; and see also Kitton, DI, p. 98, and Horsman, ed., $D \& S$, p. 869 , for further observations on this illustration.

173. Forster, p. 478 , quoted in n. 166 above.

174. Browne, p. 274, also notes the unusual number of women in $D \& S$ and the variety of graphic treatments consequently required.

175. Potter, entry for December 15, 1883, Joumal, p. 57, an assessment with which Thomson, p. 135, would agree; cf. du Maurier "The Illustrating of Books," p. 371.

176. [Kentley Bromhill], "The Illustrations to Dombey and Son," Dick. 38 (September 1, 1942): 219-21, 39 (December 1, 1942): 48-51 and 39 (March 1, 1943): 57-60, notes many of these artifacts as does Steig, "Iconography of Sexual Conflict in Dombey and Son," DSA 1:161-67, in far greater interpretative detail; both have contributed to the discussion below.

177. Leavis, pp. 25-26, also quotes this interchange in her relevant discussion of this scene and, pp. 334-35, n. 4, notes, among other Hogarthian parallels, one between it and Hogarth's Marriage à la Mode, as does Hill, Mr. Gillray the Caricaturist, p. 183.

178. Letter to Browne, nd, quoted in Kitton, DI, p. 93.

179. Steig, "Iconography of Sexual Conflict in D\&S," p. 164, also notes the recurring portrait but assumes that they all represent the first Mrs. Dombey. If so, Browne's interiors are unusually inconsistent if it is assumed that the room in which the portrait appears is meant to be the same one: the portrait is first placed on the empty wall to the right of the door (XXVIII, facing p. 408), then over the mantel (LI, facing p. 718), and finally next to a large bookcase next to the door (LIX, facing p. 840), and is draped in its first two appearances but not in its last; moreover, the hair of the lady in the first portrait seems longer than it is in the second portrait, whereas its length in the third is indeterminate. Reed, "Confinement and Character in Dickens's Novels," p. 45, suggests that these last two portraits are of Edith. 
180. See Harvey, pp. 139-41, who discusses this scene in detail, and Steig, "Dombey and Son: Chapter XXI, Plate 20," pp. 124-27, who discusses the significant presence of Alice's mother, Mrs. Browne, in it.

181. Letter to Browne, nd, quoted in Kitton, $D I$, p. 93, yet see NL, 2:55, Forster, September 19, 1847 (dated November 19, 1847 in Forster, p. 483), which indicates CD's intention of having Edith die.

182. See [Bromhill], "Illustrations to D\&S," p. 58, Johannsen, p. 289, and Steig, "Iconography of Sexual Conflict in $D \& S$," pp. 163-64, who also note and discuss the various artifacts in this scene.

183. Steig, "Iconography of Sexual Conflict in D\&S," pp. 164-65, also discusses the identity and significance of these and other objects in the scene.

184. Leavis, p. 356, who also discusses this scene, especially its melodramatic content and techniques, in detail.

185. This castration idea is implicit in Leavis, p. 356, and explicit in Reed, "Emblems in Victorian Literature," pp. 28-30, and in Steig, "Iconography of Sexual Conflict in D\&S," p. 165.

186. Cf. NL, 2:55, Forster, September 19, 1847, and cf. Steig, "Iconography of Sexual Conflict in $D \& S$," pp. 165-66, who says that the frontispiece reflects CD's ambiguity about Edith, who alone of all the major characters is assigned no literal or allegorical fate, but the $D \& S$ frontispiece is intended more as a summary of the action, as discussed in Horsman, ed., $D \& S$, pp. 870-71, than as an anticipation of its consequences.

187. See Lorenz Eitner, Géricault's Raft of the Medusa ([London and New York]: Phaidon, [1972]), pp. 62-65, called to the author's attention by Robert Patten, which describes its tour in London. Harvey also notes the dramatic relevance of this picture, though not its historical significance, p. 141.

188. See Steig, "Iconography of Sexual Conflict in D\&S," pp. 161, 166-67.

189. James, Autobiography, p. 39.

190. See NL, 2:3, Browne, January 5, 1847, for example.

191. Ibid., 100, Browne, June 13, 1848. Horsman, ed., $D \& S$, p. 870 , says that Browne gave $C D$ all but one of his original sketches; ef. Kitton, $D I$, pp. 99-100, who notes that Georgina Hogarth had no memory of them. The sketches are in the Elkins, Collection.

192. The $D C$ wrapper inevitably has been similarly described in similar terms by Kitton, DI, p. 106, Butt and Tillotson, p. 115, [Bromhill], "Phiz's Illustrations to David Copperfield," Dick. 40 (December 1, 1943): 47, and Steig, "The Iconography of David Copperfield," p. 2, and "MC's Progress," p. 124.

193. Cf. Kitton, $D I$, who feels that Browne did not "quite rise to the occasion" (p. 102).

194. Harvey, pp. 144-45, similarly discusses this sequence, though in greater detail, while Steig, "Iconography of $D C$," pp. 16-17, notes Annie's position and dress as well as Dr. Strong's artifacts.

195. Harvey, pp. 143-44, makes essentially the same point in his longer discussion of this scene; Steig, "Iconography of $D C$," p. 11, notes Steerforth's disproportionate height; and Geoffrey Hemstedt, Some Victorian Novels and Their Illustrations, pp. 68-69, notes Steerforth's sinister centrality in the design.

196. Quoted in Kitton, DI, p. 105, who also notes that David's little white hat resembles that which $C D$ wore as a boy, and, pp. $105-6$, notes other changes made in the original sketches.

197. NL, 2:173, Forster, [September, 1849].

198. Thomson, pp. 46-53, 128, Kitton, DI, pp. 104-5, and Steig, "Iconography of $D C$," p. 6, also discuss the evolution of this plate, whereas Leavis, p. 359 , n. 2, notes conflicting opinions about it.

199. See Kitton, DI, p. 103 , and Browne, p. 277 , who notes the existence of boat homes in upright and overturned positions. The Meirs Collection contains a sketch by Cruikshank of an upside-down boathouse (AM 20612).

200. See NL, 2:151, Browne, May 4, 1849, and 315, Forster, June 1, 1851; and Forster, p. 528.

201. See Leavis, pp. 358-59, who provides useful general remarks on this point. [Bromhill], "Illustrations to $D C$," pp. 47-50, 83-86; Steig, "Iconography of $D C$," pp. 1-18, and Hemstedt, pp. $65-94$, comment on many of these details in each $D C$ plate, which has benefited the discussion below.

202. Robert Louis Stevenson, "Some Gentlemen in Fiction," Scribner's Magazine 3 (June, 1888): 766-77.

203. Johannsen, pp. $314-15$, notes that the picture is labeled 'Sancho Panza' in variant A, but not B, as does Steig, "Iconography of $D C$," p. 5, who discusses the iconography of the scene in detail and in "MC's Progress," pp. 122-23, notes parallels between it and Hogarth's 'Sancho's Feast.'

204. See Steig, "Iconography of $D C$," p. 6, who suggests that this picture also relates to Davy's discovery of his baby brother, and Leavis, pp. 50, 359, who further discusses the plate as a whole.

205. This analogy is explicit in Harvey, p. 151, and implicit in Leavis, pp. 54-55, whereas Steig, "Iconography of $D C$," p. 16, and Hemstedt, pp. 87-89, note that Mr. Murdstone's dog, though not illustrated, becomes the symbolic equivalent of its owner.

206. This detail is also noted by Johannsen, p. 382 , and the others are also commented on by [Bromhill], "Phiz's Illustrations to $D C$," p. 85; Steig, "Iconography of $D C$," p. 16; and Hemstedt, pp. 87-90.

207. Leavis also notes and discusses this parallel, but erroneously asserts that Browne shows "Clara-like portraits of Dora over the mantelpiece in every interior Dora figures in" (p. 54); it does not appear in 'Our Housekeeping,' for example (see fig. 96), the scene that is most important for Dora's characterization, and when it does appear, as discussed above, she is not physically present.

208. Somerset Maugham, "Charles Dickens," Atlantic Monthly 182 (July, 1948):56.

209. See Harvey, pp. 148-49; ef. Steig, "MC's Progress," i. 361, n. 19 , who insists that the artist may have added the detail later. This scene is also discussed by Leavis, p. 74, and Hemstedt, pp. $69-70$.

210. See Forster, p. 548, and Browne, pp. 48-49, who further discuss Mrs. Hill's role.

211. See [Bromhill], "Phiz's Illustrations to $D C$," p. 50; Harvey, pp. 147-48; and Hemstedt, pp. 69-72, who also note this meaningful arrangement of the figures, and whose discussions of the plate as a whole have helped the one below.

212. [Bromhill], "Phiz's Illustrations to $D C$," p. 85; Steig, "Iconography of $D C$," pp. 12-15; and Hemstedt, pp. 76-77, also discuss this plate in detail, and Kitton, $D I$, pp. 105-6, notes that Rosa Dartle was included in Browne's sketch, reproduced in plate 34 , facing p. 84, together with other differences between the $D C$ sketches and plates. 525.

213. Eliot "Wilkie Collins and Dickens," TLS (August 4, 1927):

214. Butt and Tillotson, p. 195. The $V+A$ Dickens Catalogue, p. 66, provides a good summary of the complex wrapper.

215. See [Bromhill], "Phiz's Illustrations to Bleak House," Dick. 40 (September, 1944): 193, whose notation of the details here and in all the $B H$ illustrations has proved helpful in the discussions below; cf. Leavis, p. 360 and n. 1, who finds the old Hogarthian mode here inappropriate. Kitton, $D I$, p. 108 , notes the differences between this plate and Browne's original sketches as well as other differences between other $B H$ sketches and plates, and text and plates, pp. 106-7, and Steig, "The Critic and the Illustrated Novel: Mr. Turveydrop from Gillray to Bleak House," pp. 55-56, discusses 
Browne's use of spider webs in $B H$ and elsewhere in CD's works. 216. See NL, 2:382, Forster, March 7, 1852; Macaulay, journal entry, December 23, 1859, in George Trevelyan, The Life and Letters of Lord Macaulay (London: Oxford University Press, [1932]), 2:397-98; and Browne, pp. 94-104,for further details about the Leigh Hunt-Harold Skimpole parallels.

217. Browne, pp. 290-91. See also Thomson, pp. 233 and 25; Harvey, pp. 185-86, 191-92; Muir, p. 96; and Horsman, ed. D\&S, pp. $870-71$.

218. See NL, 2:63, Forster, December 21, 1847, and Horsman, ed., $D \& S$, pp. 870-71. Yet the "dark" plates are satirized in "A Browne Study," p. 112 (first called to the author's attention in Steig's remarks at the MLA Seminar on Dickens and the Graphic Arts, December 28, 1972), reproduced in Dick. 65 (September, 1969): 44; are ignored by Leavis, who feels that Browne has failed to convey "the atmosphere that is special to each Dickens novel" (p. 359); and are dismissed as "more or less an admission of failure" by Robert Kaufman, The Relationship between Illustration and Text in the Novels of Dickens, Thackeray, Trollope, and Hardy, p. 103.

219. See Harvey, pp. 151-52, and Steig, "English Caricature," p. 229, and "Structure and the Grotesque in Dickens: Dombey and Son, Bleak House," p. 326.

220. See Forster, p. 568, n.

221. The Southwark scene was first called to the author's attention in the $V+A$ Dickens Catalogue, p. 68, I 23 (b).

222. Steig also notes the Hogarth parallel in "English Caricature," pp. 230-31.

223. Ibid., p. 231.

224. Entry for December 15, 1883, Joumal, p. 57; cf. Ruskin, "The Guild of St. George Accounts, 1884," Works, 30:155, who feels the plate's "practical result fails because of its dramatic purpose."

225. Harvey, pp. 155-57, notes that "a play of light and dark is one of Dickens's main resources in presenting Lady Dedlock" and that portraits and paintings play a "large part" in $B H$, points that have proved suggestive in the discussion below.

226. See Harvey, pp. 153-54, and Thomson, p. 135, who deems 'The Morning' one of Browne's very best plates.

227. Relevant here is Steig, "The Iconography of the Hidden Face in Bleak House," DS 4 (March, 1968): 19-22, and Kaufman, p. 77, who shows that even the artist got his subjects and titles confused.

228. Steig, who first called this sketch and its location in the Elkins Collection to the author's attention during and after his remarks at the MLA seminar cited above in $n$. 218, suggested that the marginal figures mock $C D$ and/or $B H$. Browne added a similar demon, pushing a boat carrying Peggotty and the artist, on a certificate of authenticity for the Cosens $D C$ drawings, to be discussed below, now in the Gimbel Collection, and described in the Yale University Library Gazette 37 (October, 1962): 73, no. 97.

229. See NL, 2:471-72, June 29, 1853, and letter from $C D$, Juil-ly [sic] 6, 1853, quoted in Browne, pp. 293-94. Philip Collins, $A$ Critical Commentary on Dickens's 'Bleak House', pp. 12-13, discusses the frontispiece.

230. The sketch is accompanied by a note, reproduced in Thomson, p. 240, and in NL, 2:814, nd, between letters of December 9 and 11 , 1856, which implicitly relates it to $L D$, which is far less likely than $B H$, given the much gayer mood and greater distance between author and artist at the latter's conclusion.

231. Works, 24:275, n.

232. Forster, p. 623.

233. NL, 2:698, Wills, October 19, 1855.

234. Butt and Tillotson, pp. 224-25, and also the description by
[Sir James Fitzjames Stephen], "The License of Modern Novelists," Edinburgh Review 106 (July, 1857): 130, and J[ohn] C[owie] Reid, Little Dorrit (London: Edward Arnold), p. 14. Harvey Sucksmith, ed., Little Dorrit by CD may also be helpful on this and other $L D$ matters but was not available in time to be consulted in this study.

235. "Little Dorrit," The Knickerbocker 50 (August, 1857): 188.

236. See Laurence Stone, "Literacy and Education in England," pp. 119-21, for rising literacy figures at this time.

237. Leavis, p. 363, makes the same point, using the text and illustration of 'The family dignity is affronted' ( $L D$, II, III, facing p. 476), which is mentioned later in the discussion below.

238. NL, 2:810, November 8,1856 , and letter to Browne, July 2, 1856, quoted in Thomson, pp. 141-42, and see Angus Wilson, The World of Charles Dickens, pp. 283-84, who praises the latter illustration, as does Leavis, p. 362, who deems it the only one that succeeds in capturing the text's essence.

239. NL, 2:814, December 6, 1856-and see Frederick Willis, "Phiz and 'Little Dorrit,"' Dick. 26 (Spring, 1930): 152, and NL, 2:839, March 6, 1857.

240. Letter to Browne, February 10, 1857, quoted in Thomson, p. 142, and in Kitton, $D I$, pp. 110-11.

241. The original sketches for $L D$ were seen at Dickens House on April 1, 1973, thanks to the former curator, Marjorie Pillers, and justify a similar opinion of them expressed by Browne, pp. 296-97.

242. Johannsen, p. 437. See also Bentley, "Dickens and His Illustrators," p. 211, who condernns 'Urider the Miscroseope' (I, II, facing p. 20), and Thomson, p. 141, who complains about 'Reception of an old friend' (II, XVIII, facing p. 654).

243. Steig, "English Caricature," pp. 231-32, makes the same observation about the first example (as did perhaps the artist, author, or etcher, to judge from the improved contrast in its duplicate version, reproduced in Johannsen, p. 423; cf. p. 422) but not the second (which displays the same problem in both versions reproduced in Johannsen, pp. 432-33).

244. Steig, "English Caricature," p. 232; and Leavis describes the "very memorable" title page vignette as "Blake-like" (p. 358, n. 1), and as "half-way between a popular emblematic cut and a Blake-like symbolic vision" (p. 335).

245. See Kitton, $D I$, p. 109 , and Johannsen, p. 418 , who lists the many other commissions being filled by the artist before and during $L D$, which may have made him indifferent to these matters, minor and major alike, in his work for $L D$.

246. See Shaw, preface to Great Expectations, p. xiv; James, Autobiography, p. 69; and Henry Green, Living (London: Hogarth Press, 1948), pp. 55, 159, 161.

247. See Frank A. Gibson, "The Saddest Book," Dick. 60 (January, 1964): 32, and Cyril C. C. Kenrick, "Errors of Illustrators," Dick. 39 (December 1, 1942): 98.

248. Thomson, p. 147, Kitton, DI, p. 112, and Browne, pp. 297-98, also make this observation.

249. Fraser, "Hablôt K. Browne," pp. 182-83; and see also " $A$ Tale of Two Cities," Saturday Review 8 (December 17, 1859): 743. Yet L.C.S. [Leslie Staples], "Phiz," Dick. 53 (May, 1957): 116, is unfair when he insinuates that the TTC etchings were so bad that they were excluded from Johannsen, for as the latter had explained, p. $v$, only one set of the TTC plates was drawn so it was pointless to reproduce them.

250. Kitton, $D I$, p. 111, of course, also notes this omission.

251. Chesterton, p. 74.

252. See Leavis, pp. 360-61, and Browne, pp. 43-44, 158-59.

253. Letter to Walter Browne, nd, quoted in Kitton, $D I$, pp. 111-12. See also Andrew Kirby, "Watts Phillips, A Man of Letters," pp. 400-401; Browne, pp. 221-26; and Ley, Circle, p. 39. 
254. See Ley, "Boz and Phiz," Dick. 11 (June, 1915); 152-53, and Arthur Allchin, "An Illustrator of Dickens: Hablot Knight Browne ('Phiz')," p. 393.

255. See Allchin, p. 393; Browne, p. 269; M. H. Spielmann, The History of 'Punch,' p. 451; and Richard G. G. Price, A History of Punch, p. 43.

256. See Thomson, p. 245, the entry under Once a Week in the index, for Browne's contributions.

257. Letter to Robert Young, nd, quoted in Kitton, DI, pp. 112-13, and widely elsewhere.

258. See Johannsen, pp. $78,173,241,309,327,418$, who lists Browne's other work concurrent with that for CD; Thomson, pp. $149-71,172-79,180-83,203-15,216-24$, for his work for Lever, Ainsworth; . Smedley, and other authors before and after 1860 respectively.

259. Letter to George Smith, August 12, 1864, in Trollope, The Letters of Anthony Trollope, ed. Bradford A. Booth (London: Oxford University Press, 1951), p. 157 (hereafter cited as Trollope, Letters); and see also Thomson, p. 218, Kaufman, pp. 297-312, and Ray, The Illustrator and the Book, p. 79.

260. This minor literary mystery merits more attention than can be given here. Trollope, letter to Smith, August 12, in Letters, 242, says that the last ten numbers are being illustrated by a lady named Miss Taylor, who had already done the first two drawings-a statement that Sadleir, Trollope, A Bibliography, p. 56, and others have accepted without question. Booth, p. 242, n. 1 and the author have been unable to identify this artist. Buchanan-Brown, p. 25, asserts without qualification that the woman artist was Mary Ellen Edwards, who unquestionably did illustrate The Claverings for its erialization in The Cornhill Magazine (1866-67) and in the published edition (London: Chapman and Hall, 1866); she is discussed by Forrest Reid, Illustrators of the Sixties (London: Faber \& Gwyer, [1928]), p. 261. Thomson, p. 218, says that Trollope turned the second volume over to "other artists," which may be the closest to the truth. For although the title page of the last nine numbers as well as that for the first bound edition of the novel (London: Chapman and Hall, 1864), simply states "With Illustrations," that for the second edition, which has the identical scenes, reads "By 'Phiz' and Marcus Stone." The signatures complicate the matter further. The two drawings that accompany part XI, and were presumably done by Miss Taylor, are unsigned; the signature that does unmistakably appear on at least one of the two drawings each for parts XII-XVIII can be read either as an embellished "T" or an " $E$ " though Mary Ellen Edwards, to judge by her signature on the plates for The Claverings, used a plain "MEE"; the four plates for the final two numbers are not signed and could well be by Stone, who was also illustrating $O M F$ at this time in a similar style. Whether Miss Taylor, Mary Ellen Edwards, and/or Marcus Stone contributed to this work is not clear, nor whether the women's names were used to cover up Stone's participation to avoid displeasing CD or hurting Browne-a subterfuge less necessary in 1866 , one would have thought-cannot be determined without further investigation.

261. Quoted in Ley, Circle, pp. 149-50, and widely elsewhere; and see also Kitton, $D I$, p. 112, and Harvey, pp. 160-61.

262. Cf. Harvey, who maintains that it was likely that "up to the end Dickens wanted the kind of illustrations that Browne had provided for Dombey and Copperfield, although this was no longer available either from Browne or anyone else" (p. 166).

263. Quoted in Allchin, pp. 389-90; cf. Ley, Circle, p. 38, who quotes it but protests its veracity.

264. Buss, "My Connexion with PP," pp. 133-34.

265. Letter to $\mathrm{Dr}$. Carpenter, partly quoted and discussed in Harvey, pp. 164, 227-28, n. 10. Yet if the April, 1861 dating of a lighthearted note from $\mathrm{CD}$ to Browne, quoted in Browne, pp. 52-53, is correct, then the two had not altogether ceased friendly communication after TTC.

266. Suggested by Allchin, p. 391, who is quoted in Ley, Circle, pp. $38-39$.

267. Waugh, Nonesuch Dickensiana, p. 42.

268. See n. 108 above.

269. Letter, nd, quoted in Kitton, DI, p. 113.

270. See Browne, pp. 303-4, and R[obert] H[unt], "Hablôt Knight Browne," $D N B, 3$ (London, 1917), 46, who notes that Leech envied Browne's facility in drawing horses, a talent noted also by Kitton, $D I$, pp. 87-88.

271. Letter to Walter Browne, nd, quoted in Kitton, Phiz, p. 19.

272. Cosens's account of this transaction is quoted in Kitton, $D I$, p. 118, and has been utilized in the discussion below. Broane's PP watercolors for Cosens are in the VanderPoel Dickens Collection at the University of Texas, according to Carr, VanderPoel Dickens Catalogue, p. 23, A-157, the illustrated certificate for which is reproduced in Thomson, p. 79 , and some for $D C$ are in the Gimbel Collection, according to Yale University Library Gazette 37 (October, 1962): 73 , no. 97.

273. This euphemism is used in an unpub. ALS, December 4, 1867, in the Dept. of Special Collections, University Research Library, UCLA, and elsewhere, as quoted in Thomson, p. 32, who, pp. 31-34, provides further details about Browne's illness, as does Buchanan-Brown, p. 28.

274. See Kitton, $D I$, p. 113. The artist's appearance in these years is suggested in the engraved frontispiece in Thomson and the photographic frontispiece in Browne.

275. See Thomson, pp. 32-33, for the memo prepared by Browne for Young to put into proper petition form and his letter of thanks to Young on July 28, 1878.

276. Letter, March, 1878, quoted in Kitton, DI, p. 116.

277. See Thomson, p. 333; Kitton, DI, p. 117; L. V. Fildes, Luke Fildes, R.A.: A Vietorian Painter, pp. 53-54; and unpub. ALSs, Henry Wells to Fildes, January 14, 1879, and Browne to Fildes, February 15, 1879, in the Forster Collection, which were called to the author's attention by Anthony Burton.

278. "Phiz," Punch 83 (July 22, 1882): 34.

279. Angus Wilson, The World of $C D$, pp. 133-34, which seems a modern echo of the observation by du Maurier, "The Illustrating of Books," p. 350, quoted in the Conclusion below.

\section{Chapter 5: George Cattermole}

1. Quoted in Lewis Marvy, ed., Sketches after English Landscape Painters, np and in Pilgrim, 1:277, n. 6.

2. Ruskin, "Modern Painters," Works, 3:220-21, and see 46, n., and 603 .

3. Harvey makes a similar observation: "the deeply-felt beauty must rather inhere in the associations of reverence and sanctity that gather around ancient religious buildings" (p. 119).

4. See Kitton, $D I$, p. 121, and [William] C[osmo] M[onkhouse], "George Cattermole," DNB, 3:1233. The Department of Prints and Drawings, $V+A$, contains a self-portrait of the artist (F.88), which was reproduced for the author by Stephen Calloway.

5. Pilgrim, 1:277-78 and n. 3, [June 26, 1837].

6. See Pilgrim, 1:715; 2:510; 3:646; and fortheoming volumes for relevant index entries under Cattermole.

7. Pilgrim, 1:375-76 [?February, 1838].

8. Ibid., 376. See also $D N B, 3: 1231$, and Stonehouse, p. 11, who notes that CD's library included the twenty-six volumes of 
Britton's Beauties of England and Wales (London, 1801), which he purchased December 30,1839 , according to Pilgrim, 1:621, n. 4, and 646.

9. Unpub. ALS, [1839], in the Elkins Collection, which is partly quoted here by permission. See also Pilgrim, 4:261, n. 4.

10. See Ley, Circle, p. 64.

11. Pilgrim, 1:576, [August 21, 1839], and see Mrs. Cattermole's recollections, quoted in Kitton, $P+P, 2: 181$.

12. Ibid.

13. See Mrs. Cattermole, quoted in Kitton, $P+P, 2: 182$; Pilgrim, 1:583, Cattermole, September 21, 1839; and see entry for October 5, 1839 in William Charles Macready, The Diaries of William Charles Macready, 2:25-26.

14. See Pilgrim, 2:8, n. 2, and Harvey, pp. 118-19.

15. Pilgrim, 2:7-9, January 13, 1840, from which subsequent quotes in the paragraph below are also taken.

16. Ibid., 8 , n. 4 , contains the same observation.

17. Ibid., 12, Cattermole, [?January 21, 1840].

18. Ibid., 8, n. 6, and 12, Cattermole, [?January 21, 1840].

19. Ibid., 12, Cattermole, [?January 21, 1840].

20. Ibid., 42, March 9, 1840.

21. Ibid., 379, September 12, 1841.

22. Ibid., 110, Cattermole, [?August 7, 1840].

23. Ibid., 115, Cattermole, August 13, [1840].

24. Ibid., 183, January 14, [1841], and 344, July 28, 1841.

25. Ibid., 111, Cattermole, [?August 7, 1840].

26. Ibid., 219, February 26, 1841; cf. 362, August 19, 1841.

27. Ibid., 42, Cattermole, March 9, 1840.

28. Ibid., 115, n. 1, offers a detailed description of this frontispiece.

29. Hood, "Master Humphrey's Clock, Volume I," p. 887.

30. See n. 3 above.

31. See Leonardo Cattermole, quoted in Kitton, $P+P$, 2:180; Patten, "The Story-Weaver at His Loom," p. 52, who also notes the similarities between the two interiors; and Kitton, DI, who feels that the artist's apartment is "strongly reminiscent" of his most characteristic work in general (p. 135).

32. Pilgrim, 2:45, Landells, [?March 20, 1840].

33. Ibid., 46-47 and n. 7, Chapman, March 25, [1840], and 48-49, Williams, [March 31, 1840]; cf. Kitton, DI, who states that the drawing was copied by Williams on wood from one "undoubtedly supplied by Cattermole" (p. 123).

34. Pilgrim, 2:170 and n. 2, Cattermole, December 21, [1840], and see also Kitton, $D I$, p. 125, who notes that the lanthorn mentioned in the instructions appears neither in the text nor in the drawing.

35. See entry for January 21, 1841, in Macready, Diaries, 2:116, and widely quoted elsewhere, and Pilgrim, 2:171-72, Cattermole, [?December 22, 1840].

36. Two of these sketches are reproduced in Kitton, $D I$, plate 50 , facing p. 126 .

37. Pilgrim, 2:183 and $n$. 3, January 14, [1841]. The altered sketch is in the Elkins Collection.

38. Leavis, p. 345 , makes the same criticism in enumerating these symbols.

39. Pilgrim, 2;172, [?December 22, 1840], and Leavis also observes that the artist "devoted as much-if not more-care to the architecture of the church and its tombs" (p. 345, n. 2).

40. Stevens, pp. 117-18, 122, also notes this interplay between the various scenes, including the ones mentioned here, and Kitton,
$D I$, p. 133 , notes that the original of the old church where Nell is buried is at Tang in Shropshire.

41. Pilgrim, 2:183-84, January 14, [1841].

42. Dickinson's MS is in the Houghton Library (MS AM 111 8.5), as is the copy of OCS (Philadelphia: Lea and Blanchard, 184-) from which the illustrations have been cut out on pp. 281 and 359. The poem was probably written ca. 1859 but was not published until 1891 as "Escape" according to The Poems of Emily Dickinson, ed. Thomas H. Johnson (Cambridge, Mass.: Harvard University Press, Belknap, 1955), 1:62-63, where the poem is reproduced.

43. See Leavis, pp. $344-45$, whose discussion has benefited the one below; cf. Fraser, "The Illustrators of Dickens, III: George Cattermole," Dick. 2 (September, 1906): "There can be no question that Cattermole was a greater artist than 'Phiz'" (p. 238).

44. Pilgrim, 2:110 and n. 3, Cattermole, [?August 7, 1840].

45. See discussion in chapter 4 above.

46. Leavis, pp. 34445.

47. Pilgrim, 2:199, January 30, 1841. See also Perugini, "Charles Dickens as a Lover of Art and Artists," p. 167, and Harvey, quoted in $n .3$ above.

48. See Pilgrim, 2:172, [?December 22, 1840].

49. Kitton, $D I$, p. 134 , says CD commissioned 'Little Nell's Home,' now at Dickens House, and 'Little Nell's Grave,' now in the Forster Collection, a smaller version of which is in the Berg Collection. Five OCS watercolor scenes, including versions of these two subjects, are in the Parrish Collection, Princeton. A watercolor portrait of Nell, which greatly resembles the reproductions of Browne's portrait of Mary Hogarth, is in the Elkins Collection. It is not known why, when, or for whom Cattermole executed these other watercolors.

50. Pilgrim, 3:397-98 and n. 1, Cattermole, December 20, 1842.

51. See Forster, p. 133, for a description of the Shakespeare Society; Leonardo Cattermole, quoted in Kitton, $P+P, 2: 178$, for a description of the "Portwiners"; and n. 6 above.

52. Forster, pp. 497-98, n., and Ley, Circle, pp. 67-68. A sketch of "Sloppy" by Leonardo Cattermole is reproduced in Kitton, $P+P$ $1: 179$.

53. Letter to Mrs. Carmichael-Smyth, January 19, 1840, Letters, 1:413, and see also letter to Frank Stone, January 20, 1837, 1:329, and diary, April 20, 1836, 1:282.

54. The description below is indebted to the reminiscences of Leonardo Cattermole, quoted in Kitton, $P+P, 2: 177-81$.

55. See Pilgrim, 3:433-34 and n. 1, Lane, January 31, 1843. The Lane portrait is discussed in Kitton, $P+P, 2: 36$, as is Leonardo Cattermole's sketch of $\mathrm{CD}$ in one of Byron's chairs, which is reproduced facing p. 177, and mentioned in Slater, Suzannet Catalogue, p. 206, lot 150 (according to Sotheby's, the original was sold to M. H. Mushlin who, in a letter of April 28, 1977 to the author, wrote that $h$ sold it to Maggs who, in a letter of May 23, 1977 to the author, said they had no record of it). A sketch of Cattermole by Maclise, in the Department of Prints and Drawings, V+A (F.88), and reproduced for the author by Stephen Calloway, may also have been executed at this time.

56. Harvey makes a relevant observation: "The setting had an active role and was not mere background" (p. 125).

57. Pilgrim, 2:183, Cattermole, January 14, [1841], and see Harvey, pp. 125-26, for a discussion of the scene. The Elkins Collection contains a sketch of the Maypole Inn, which Forster, pp. 166 and 172, n. 1, and Kitton, $D I$, p. 127, suggests is the artist's fanciful representation of the King's Head in Chigwell, and the Clark Library contains another sketch, signed H.K.B., which suggests that Browne is still copying Cattermole's drawings on to the woodblock in January, 1841, a practice that soon ceased, to 
judge by Pilgrim, 2:206 and n. 4, Cattermole, February 9, [1841]. 58. Pilgrim, 2:219, Cattermole, February 26, 1841.

59. Ibid., 206 and n. 5, Cattermole, February 9, [1841]; 206, Chapman and Hall, February 9, 1841; 219-20 and n. 2, Cattermole, February 26, 1841. The Elkins Collection contains two sketches of this subject in an album.

60. Pilgrim, 2:197-98, January 28, 1841, and 199, January 30 , 1841.

61. Ruskin, "Ariadne Florentina," Works, 22:467-68.

62. Pilgrim, 2:318, Forster, [June 30, 1841].

63. Ibid., 362 and n. 2, Cattermole, August 19, 1841.

64. Ibid., 353, August 6, 1841.

65. Letter from Cattermole to CD, August 12, 1841, quoted in ibid., 352, n. 5 , and see Kitton, $D I$, p. 130, who also notes the lack of darkness.

66. Letter from Cattermole to CD, August 9, 1841, quoted in Pilgrim, 2:353, n. 1.

67. Ibid., 361-62, Cattermole, August 19, 1841.

68. Kitton, $D I$, p. 130 , also notes this lapse in lighting.

69. Pilgrim, 2:378-79, September 12, 1841.

70. Ibid., 218-19, n. 2.

71. Ibid., 378, n. 4; cf. Steig, "Ghosts in Master Humphrey's Clock: Two Notes on Scholarly Errors," DSN 4 (June, 1973): 40-41.

72. Pilgrim, 2:387 and n. 5, Cattermole, September 21, 1841.

73. Ibid., 378, September 12, 1841 .

74. Ruskin, "Modern Painters," Works, 3:220.

75. Unpub. ALS, Cattermole to CD, July 16, [1841], Huntington Library (HM 18540), quoted by permission.

76. Letter from Cattermole to CD, February 13, 1841, quoted in Pilgrim, 2:210-11, n. 2, and see also Forster, who notes that the artist "wanted only a little more ballast and steadiness to possess all that could have attraction to good fellowship" (p. 130).

77. Pilgrim, 4:316, Forster, [June 1 and 2, 1845].

78. Ibid., 365, August 27, 1845.

79. Ibid., 4:368, nn., Costello, [late August, 1845]; 382, Macready, September 18, 1845; 414-15, Cattermole, October 26, 1845; 416. Cattermole, [?October 27, 1845]. For accounts of the play's success see Johnson, 1:571, ef. Charles Greville, entry for November 16, 1846, in The Greville Memoirs, ed. Lytton Strachey and Roger Fulford (London: Macmillan, 1938), 5:23, who notes that he and his friends were so bored that they left early.

80. Pilgrim, 4:422, Frederick Dickens, [November 1, 1845].

81. See CD's praise in ibid., 428-29, Cattermole, November 6 , 1845, and Macready's in "The Late George Cattermole," Art Journal, n.s. 9 (March, 1870): 93, which is, however, based on information largely supplied by Mrs. Cattermole.

82. NL, 2:370, January 15, 1852.

83. Pilgrim, 2:220, Cattermole, February 26, 1841.

84. $D N B, 3: 1232-33$.

85. NL, 2:781, Beard, June 21, 1856.

86. NL, 3:648, Mrs. Cattermole, May 16, 1868.

87. Ibid., 667, Mrs. Cattermole, September 13, 1868.

88. Ibid., 753, Mrs. Cattermole, 1869.

89. Ibid., 678, Frith, November 16, 1868, and unpub. ALS, Frith to Mrs. Cattermole, September 12, 1868, Elkins Collection.

90. NL, 3:715, Bicknell, March 30, 1869, and see also Macready, "The Late George Cattermole," p. 92, for a public appeal for the relief of the Cattermoles.

91. Mrs. Cattermole, quoted in Kitton, $P+P, 2: 182$.

\section{Chapter 6: Samuel Williams}

1. See Pilgrim, 2:48, n. 3, which cites and quotes Kitton, DI, whose surmise that Williams merely copied on wood a drawing "undoubtedly supplied by Cattermole" (p. 123) had gone long unchallenged. Hatton and Cleaver, p. 165, cited by Harvey, p. 194, also note that Williams engraved five of the $M H C$ illustrations but do not specify which ones.

2. See Joseph Lionel Williams, "Mr. Samuel Williams," p. 1261; cf. [J.T.], "Samuel Williams," p. 312, and F[reeman] M[arius] $O^{\prime} D$ [onoghue], "Samuel Williams," $D N B, 2: 453$, who note without comment Williams's apprenticeship to Marsden, and Samuel Redgrave, A Dictionary of Artists of the English School, p. 451, who says that Williams was apprenticed to a house painter.

3. [J.T.], "Samuel Williams," p. 312, and Henry Ottley, $A$ Biographical and Critical Dictionary of Recent and Living Painters and Engravers, p. 178, both mention this habit from his earliest years.

4. O'D[onoghue], "Samuel Williams," p. 453, dates Williams's arrival in London as 1819; cf. Ottley, p. 178, who says 1822.

5. This is asserted by [X], "Modern Wood-Engraving," p. 275; cf. William Andrew Chatto, An Historical, Antiquarian, and Practical Treatise on Wood Engraving, Ancient and Modern, 4:633, who places the Williams brothers at the head of his honorable mention list after Chariton Nesbit and John Thompson (who Kitton, $D I$, pp. 137 and 167, notes engraved three designs for CD's Christmas books, though Maclise would have preferred that Williams or Dalziel engrave his two, as is mentioned below). O'D[onoghue], "Samuel Williams," p. 454, supplies further information about Thomas Williams.

6. See Williams, "Mr. Samuel Williams," p. 1261, and [J. T.], "Samuel Williams," p. 312, who notes that Williams exhibited two paintings at the Royal Academy, one of which-'Sketching a Countryman'-is confirmed in Algernon Graves, The Royal Academy of Arts, 8:292, under one of the three "S. Williams". listed.

7. Mary Howitt, letter to Mary Russell Mitford, October 23, 1837, quoted in Rev. A. G. L'Estrange, ed., The Friendships of Mary Russell Mitford, p. 250, the London edition of which is cited and partly quoted in Pilgrim, 2: 48-49, n. 3. Vera Watson, Mary Russell Mitford (London: Evans Brothers, 1949), refers to William Howitt as a "Quaker author" (p. 213).

8. See Pilgrim, 2:8, Cattermole, January 13, 1840, and Harvey, pp. 193-95, who discusses the other "hands."

9. Williams, "Mr. Samuel Williams," p. 1261. See also Geoffrey Wakeman, Victorian Book Illustration, pp. 17-22, who provides a useful discussion of wood engraving before 1850 .

10. Pilgrim, 2:12, n. 3, asserts that Williams engraved this design, whose printed signature in the Houghton Library copy of $M H C$, however, is almost indecipherable and might lead one to think it by Landells, whose signature also utilizes block capitals and contains the same number of letters as Williams's.

11. Pilgrim, 2:46, Chapman, March 25, [1840].

12. See ibid., 2:8 and n. 7, Cattermole, January 13, 1840, and 12 , Cattermole, [January ?21, 1840]; cf. 206 and n. 4, Cattermole, February 9, [1841], and Browne, pp. 164-65; cf. Jackson, "How I Engraved the Cover for 'Pickwick," p. 516.

13. See Johannsen, p. 173, who lists Browne's other work in addition to $M H C$; Pilgrim, 2:210, Cattermole, February 13, 1841, and 210 , n. 2, Cattermole to Dickens, February 13, 1841, on Cattermole's preoccupations; and Pilgrim, 2:8, Cattermole, January 13,$1840 ; 144$, Maclise, November 3, 1840; 144, Forster, [November 3,1840 ]; 145-46, Maclise, [November 6, 1840]; and 146, Maclise, [?November 6, 1840], on Maclise's involvement with $M H C$.

14. Pilgrim, 2:49, [March 31, 1840]. 
15. Ibid., 48-49 and n. 2, which says that the sketch is owned by (the late) Mrs. Elaine Waley but she disclaimed ownership and any knowledge of the present whereabouts of it in her letter of June 25, 1977 to the author.

16. W[illiam] J[ames] Linton, The Masters of Wood-Engraving, p. 188.

17. [Hood], "Master Humphrey's Clock, Volume I," p. 888.

18. Pilgrim, 2:220 and nn. 5-7, [?late February, 1841].

19. Forster, 152. Harvey, pp. 122-23 and 225, nn. 25 and 29, convincingly demonstrates that these words are so close to the anonymous review "Barmaby Rudge. The Old Curiosity Shop . . Master Humphrey's Clock," Examiner (December 4, 1841): 772 , as to warrant its attribution to Forster and that both Forster's discussions display an obvious debt to Hood's review as a whole.

20. See Harvey, pp. 123-24.

21. Harvey makes a similar point: "In endorsing Hood's review, Dickens . . bore out Forster's suggestion that the subsequent course of the novel was a fanciful extension of the picture" (pp. 124-25).

22. Muir, pp. 37 and 54, praises examples of work both designed and engraved by this "delightful artist-craftsman."

23. Kitton, $D I$, p. 137, lists the engravers and the number of their designs for CD's Christmas books, and, pp. 166-67, quotes Maclise's complaint to Forster, nd.

24. See Reynolds Stone, introduction to Wood Engravings of Thomas Bewick, pp. 7-47, who provides a useful survey of Bewick's achievement and influence; Williams, "Mr. Samuel Williams," p. 1261, in which the artist's son alludes to his father's difficulties; Chatto, 4:635, who, writing in 1839 , observes that "perhaps no art exercised in this country is less known to the public than that of wood-engraving"; Sutherland, p. 22, who notes that illustration costs, previously 30 percent of the total, were reduced in the 1860 's by one-third; and Wakeman, pp. 69-73, who discusses wood engraving after 1850 .

25. [J.T.], "Samuel Williams," p. 312.

26. Athenaeum (October 15, 1853), 1232.

Chapter 7: John Leech

1. Buss, English Graphic Satire, p. 182, suggests that the increasing refinement of Leech and Browne occurred after working with $\mathrm{CD}$, as does Steig, "English Caricature," p. 222, about Browne.

2. See Kitton, $D I$, p. 146, who notes Leech's lessons from Cruikshank; Frith, Leech, 2:20, who notes their subsequent coolness, perhaps because of the student's greater success and/or intimacy with CD; and James, "Du Maurier and London Society," in Partial Portraits, p. 338, and Harvey, p. 81, who note the artist's adherence to proper anatomical proportion on the whole.

3. Johnson, 1:140, suggests Cruikshank's role; cf. Grego, Pictorial Pickwickiana, 1:126-27, noted in Ley, Circle, p. 230, who implies that the publishers invited Leech to apply, which seems to be contradicted by Pilgrim, 1, [?August 24, 1836]: 168-69, Leech, and 169-70, Chapman and Hall.

4. Pilgrim, 1:168, Leech, [?August 24, 1836].

5. Ibid., 170, Chapman and Hall, [?August 24, 1836].

6. Ibid., 168-69, [?August 24, 1836].

7. See ibid., 169 , n. 1.

8. Ibid., 219, Harley, [?December, 1836]. Leech's sketch is in the Berg Collection, and his pencil and color wash drawing is in the Department of Prints and Drawings, British Musequm, Dexter Collection, Volume 1 .
9. See Pilgrim, 1:358 and n. 5. As is noted in n. 71 of chapter 4 above, this project may have supplied the original inspiration for $M H C$.

10. This picture is noted by Kitton, Leech, p. 130, but the present writer has been unable to trace it.

11. Pilgrim, 3:358-59, November 5, 1842.

12. See Price, p. 43.

13. Pilgrim, 3:361 and n. 3, November 7, [1842].

14. du Maurier, Social Pictorial Satire, p. 7. Bentley, "Dickens and His Illustrators," p. 218, also suggests Browne's many obligations at this time.

15. Ruskin, letter to Charles Eliot Norton, June 19, [1870], Works, 37:7.

16. This parallel is noted by Slater, ed., The Christmas Books by $C D, 1: 34$ (hereafter cited as Slater, ed., $C B$ ), who in turn credits Butt, Pope, Dickens and Others (Edinburgh: Edinburgh University Press, 1969), p. 134.

17. For subsequent aesthetic changes dictated by $C D$ concerning the title page and the endpapers, see the Yale University Library Gazette, 37:67, also cited in $\mathrm{n}$. 22 of the Introduction above and discussed in its accompanying text.

18. See Pilgrim, 4:312, Mitton; May 20, 1845, and Thomson, Life and Labours of Hablot Knight Browne, "Phiz," pp. 149-50, who note CD's partiality for the color green and its use on most of his wrappers.

19. Pilgrim, 3:608, December 14, 1843

20. "A Christmas Carol," Illustrated London News 3 (December 23, 1843): 411; and see also "A Christmas Carol," Dublin Review 15 (December, 1843): 523. Cf. Bentley, "Dickens and His Illustrators," p. 216, who finds Leech's illustrations disappointing.

21. [M.A.T.] (Thackeray), "A Box of Novels," p. 169.

22. See Forster, pp. 314-15, whose figures, together with those mentioned in Philo Calhoun and Howell J. Heaney, "Dickens's Christmas Carol after a Hundred Years," p. 277, and in Waugh, Nonesuch Dickensiana, p. 36, have been utilized in the discussion below.

23. See Slater, ed., $C B, 1: 138$, xiv, and xxii-xxiv, to which the discussion below is indebted.

24. Leavis, p. 369 (but, p. 368 , there is an erroneous implication that CD first tried the experiment of "A number of aritists [sic]" in $B L$ though, in fact, this experiment was initiated in CD's second holiday book, TC)

25. According to a fragment of Punch table conversation, May 12, 1862, quoted in Ray, Thackeray: The Uses of Adversity, 1811-46, p. 287 (hereafter cited as Ray, Thackeray, 1), Leech thought Forster a "snob" in the pre-Thackeray sense, one "never at ease among gentlemen."

26. Pilgrim, 4:233, December 1, 1844.

27. Ibid., 234, December 2, 1844.

28. Ibid., 233 and n. 3, December 3, 1844.

29. Leavis, p. 368 , notes this and other links between the $C B$ s and CD's other novels, as does Slater, ed., $C B$, 1:vii-xxiv.

30. See, for example, "The Chimes," The Eclectic Review 17 (January, 1845): 88 .

31. Pilgrim, 4:392, September 29, 1845.

32. Ibid., 395, October 2, 1845.

33. Slater, ed., $C B$, 1:vii.

34. Leavis, p. 369.

35. Slater, ed., $C B, 1: x v i$.

36. Slater, ibid., 1:xviii, also makes this point. 
37. According to Kitton, DI, p. 141.

38. Ruskin "John Leech and John Tenniel," The Art of England, Works, 33:359.

39. Kitton, $D I$, p. 142 , also notes the unusual pair that Browne, as Patten, "The Art of Pickwick's Interpolated Tales," p. 591, points out, also utilized in the first but not the subsequent states of 'Christmas Eve at Mr. Wardle's' ( $P P$, XXVIII, facing p. 390), both of which are reproduced in Johannsen, pp. 40-42.

40. See Pilgrim, 4, Leech: 437, November 18, 1845, and 439, [November 19, 1845].

41. Ibid., 442, Leech, [?November 29, 1845].

42. See Slater, ed., $C B, 1$ :viii.

43. Pilgrim, 4:628, Forster, [October 3, 1846].

44. Ibid., 648, Forster, [October 26-29, 1846]; cf. Thackeray, "A Grumble about the Christmas-Books," pp. 125-26, who criticized CD's and Maclise's execution of this idea, as is noted in the text and n. 71 of chapter 10 below.

45. Letter of November 16, 1846, quoted in Kitton, $D I$, p. 143. The Forster Collection contains an ALS (No. 229) from Leech to Forster, November 22, 1846, which laments the impossibility of his doing the blocks in the allotted time, a fact confirmed by Pilgrim, $4: 671$, n. 1 .

46. Letter of November 16, 1846, quoted in Kitton, DI, p. 143.

47. Ibid.

48. Ibid., letter of [November 18, 1846], quoted on pp. 143-44.

49. Muir, noting the same examples in the $B L$ and other examples from $T C$, calls them "hopelessly incongruous together" (p. 93).

50. Ibid., p. 107.

51. Pilgrim, 4:628, Forster, [October 3, 1846]. Browne, p. 82 , notes that if Leech had seen Maclise's preceding illustration $(B L, 336)$, showing Warden with his hand over his heart and Marion holding Clemency's hand, his misreading would have been reinforced.

52. Pilgrim, 4:679, [?December 12, 1846].

53. Ibid.

54. Forster, p. 439; Layard, Suppressed Plates, pp. 36-38, and Kitton, DI, p. 145 and Leech, pp. 54-56, further discuss this matter.

55. Pilgrim, 4:679, Forster, [?November 12, 1846]; cf. NL, 2:7, Mrs. Watson, January 25, 1847.

56. See Slater, ed., $C B, 1:$ viii, who further discusses this pervasive theme.

57. See ibid., 1:xix.

58. NL, 2:125, October 30, 1848.

59. Ibid., 130, November 22, 1848.

60. Ibid., 129, November 19, 1848.

61. Ibid., December $1,1848: 133-34$, Stanfield, and 134, Bradbury.

62. See Leavis, p. 369; cf. Kitton, $D I$, who feels Leech's are not among his "happiest efforts" (p. 146).

63. Slater, 1:xxi, also notes the parallel between the two Leech scenes, but not their link with the Tenniel one.

64. See Forster, p. 527.

65. See Kitton, Leech, p. 38, and [Dexter], "Dickensian Peeps into 'Punch,'" p. 264.

66. See Punch: Brougham as Oliver, 6 (March 30, 1844): 141, and as Miss Mowcher, 18 (April 6, 1850): 135; Louis Philippe as Fagin, 13 (October 2, 1847): 125; Peel as Tilly Slowboy, 10 (January 31, 1846): 57; Russell as Tetterby, 16 (February 10, 1849): 59; Peel and Russell as Dombey and Son, 13 (August 28, 1847): 90;
Russell and Disraeli as Toots and Mrs. Blimber, 15 (September 9 , 1848): 111; and for use of Mrs. Gamp and other characters, as well as those mentioned above, see [Dexter], "Dickensian Peeps into 'Punch," Dick. 31 (Autumn, 1935): 264-66 through 35 (Summer, 1939): $175-79$.

67. See NL, 2:42, Ireland, July 11, 1847; Ruskin, Works, 14:332-33, 16:361, and 33:359 and 362; William Rossetti, pp. 282-88; and James, Partial Portraits, p. 338.

68. Steig, "English Caricature," p. 220, and see n. 1 above.

69. See Kitton, Leech, p. 84; Frith, Leech, 2:9-10 and 35-36; Ley, Circle, pp. 232-33; and Gordon Tidy, A Little About Leech, p. 28.

70. See entry for September 20, 1845, Macready, Diaries, 2:304, and letter to Elizabeth Barrett Browning, [September 24, 1845], The Letters of Robert Browning to Elizabeth Barrett Browning, 1845-46, 1:210.

71. For example, see Pilgrim, 4, Leech: 352, n. 1, August 10, 1845 , and 395, October 1, 1845. Leech's sketch is reproduced in Kitton, $P+P, 2: 105$.

72. Frith, Leech, 2:63, and see Pilgrim, 4:462, n. 3.

73. NL, 2:87, Leech, May 7, 1848, and 88, Beard, May 10, 1848.

74. See Kitton, Leech, pp. 69-75 and 80-81; du Maurier, Social Pictorial Satire, pp. 16-17, who cites Thackeray and Millais in support of his own high estimation of Leech; and Price, p. 159, who notes that Lord Russell nominated Leech's son to Charterhouse and gave his family a Civil List pension after his death.

75. See Forster, p. 9, and Johnson, Charles Dickens, 1:501, on CD's father, and Ray, Thackeray, 1:359, Leonée Ormond, George Du Maurier, p. 157, and Pilgrim, 4:456, n. 5, on Leech's father.

76. See [Dexter], "Letters to John Leech," Dick. 34 (Winter, 1937-38): 3-13, (Spring, 1938): 101-8, (Autumn, 1938): 225-31, and 35 (Winter, 1938-39): $37-44$, which prints the correspondence included in the then recently published Nonesuch edition.

77. See NL, 2:145, Forster, [February, 1849], on the Brighton holiday; "An Awful Appearance of a Wopps at a Picnic," Punch 17 (August 25, 1849): 76, reproduced and discussed in Kitton, $P+P$, 1:56-58 and 3:38; and NL, 2:174, Forster, September 23-24, 1849; 174-75, Evans, September 25, 1849; 175, Forster, September 26, 1849 ; and 175-76, Lemon, September 26,1849 , on the Isle of Wight holiday.

78. See, for example, NL, 3:25, Leech, May 31, 1858. That Punch refused to print Dickens's "Address" about his marital arrangements must have caused strain as well between the two men.

79. See [Mamie Dickens], "Charles Dickens at Home by His Eldest Daughter," p. 35, and My Father as I Recall Him, pp. 27-28; and NL. 3:405, Dallas, November 12, 1864.

80. NL, 3:214-15, April 6, 1861.

81. See Kitton, Leech, p. 69.

82. See Everitt, p. 399; Browne, p. 22; Charles Mackay, Forty Years Recollections of Life, Literature, and Public Affairs (London: Chapman and Hall, 1877), 2:300-301; and Marcus Stone, unpub. "Reminiscences," p. 36, in the Suzannet Collection, a typescript of which Dr. Michael Slater provided the author.

83. See Kitton, Leech, pp. 111-16; NL, 3:265, Leech, December 4,$1861 ; 389$, Leech, May 16, 1864; 389-90, Bass, [May, 1864]; and [Charles Collins], "An Unreported Speech."

84. See Marcus Stone, "Reminiscences," p. 39.

85. NL, 3:404, [November], 1864, and see also Frith, Leech, 2:304.

86. Quoted in Frederick Locker-Lampson, My Confidences, p. 299 . 


\section{Chapter 8: Richard Doyle}

\section{Rossetti, pp. 282-83.}

2. See Browne, p. 25, and n. 20 in chapter 4 above.

3. See Ray, Thackeray, 1:361.

4. Kitton, $D I$, p. 155 , notes that both artists reproduced the belfry of St. Dunstan's in Fleet Street. Philip F. Skottowe, in a letter of July 1, 1967 to the author, says that the belfry was then relatively new as the old one had burned down along with the church. The curious clock-two giants striking a gong on the hour, for which it was known-survived and was used by a man for a new house in Regent's Park, which he then called St. Dunstan's. During World War I, the house was given by its owner, Otto Kahn, the banker, to an organization tending blind servicemen, which took the name St. Dunstan's. The house then passed to the Woolworth heiress and from her to the U.S. government, which made it the residence of the American ambassador. The clock was returned to the church. See also Pilgrim, 4:200, n. 2.

5. Kitton, $D I$, p. 151 , notes that Doyle introduced only three bells rather than the four needed to sound the quarter.

6. Pilgrim, 4:234 and n. 2, Mrs. CD, December 2, 1844.

7. Ibid., 392, Bradbury and Evans, September 29, 1845.

8. See Maclise, letter to Forster, nd, quoted in Kitton, DI, p. 165.

9. See-Doyle's cartoon in Punch 19 (November 16, 1850): 204, opposite Jerrold's "A Short Way with the Pope's Puppets," 205. See also "Richard Doyle, Painter and Humorist," pp. 310-11 and Price, p. 67.

10. See Mrs. Proctor, letter to Thackeray, March 8, 1853, quoted in Letters, 3:231, and Ruskin, letter to Williams, January 1, 1864, Works, 36:463. Thackeray had Doyle illustrate his Rebecca and. Rowena (1849) and The Newcomes (1853-55) and provided space for his "Bird's Eye View of English Society" in the Cornhill, $3-6$ (1861-62). Ruskin had him illustrate his The King of the Golden River (1851). See also Everitt, p. 390, who notes Doyle's reported refusal to illustrate Swift, and entry for January 24, 1867, The Diaries of Lewis Carroll, ed. Roger L. Green (London: Cassell, 1953), 1:249, which refers to Carroll's proposal that Doyle illustrate Alice Through the Looking Glass.

\section{Chapter 9: John Tenniel}

1. NL, 2:125, October 30, 1848.

2. Tenniel, quoted in Monkhouse, "Sir John Tenniel:" "Caricature is always ugly and often vulgar, and I do not like it" (p. 1).

3. See Monkhouse, "Sir John Tenniel," pp. 12, 22; "Sir John Tenniel," Punch 146 (March 4, 1914), Supplement: 2; and T. S. R. Boase, "The Decoration of the New Palace of Westminster, 1841-1863," p. 338.

4. Ruskin, Works, 22:361.

5. Tenniel, quoted in Kitton, $D I$, p. 173.

6. Ruskin, Works, 33:367, and see 22:358, n., for praise of his "humour, or precision of expressional touch."

7. Rossetti, p. 271, and see Muir, who feels that the artist lacked the "depth of scorn and fire of indignation" (p. 108) necessary for great caricature.

8. Quoted in Kitton, $D I$, p. 173.

9. NL, 2:415, [September, 1852], and see C. W., "Sir John Tenniel," Dick. 10 (April, 1914): 101, and Kitton, $P+P, 2$ : following p. 114.

10. See "Sir John Tenniel," p. 11, and NL, 2:663, Layard, May 20, 1855, for example.

11. Ruskin, Works, 33:359; and see also Tenniel, quoted in M. H.
Spielmann, The History of 'Punch', pp. 463-64, on his "politics"; and Ormond, George Du Maurier, p. 166.

12. See Kitton, "Dickens and Punch," p. 801, and [Dexter], "Dickensian Peeps into Punch,"” 38:28 and 34:25, who notes most of the following examples in Punch: Bumble in 52 (January 19, 1867): 25; 81 (November 12, 1881): 223; 86 (January 12, 1884): 19 and (April 19, 1884): 187; and 91 (December 25, 1886): 307; Sikes in 96 (April 27, 1889): 199 and 97 (December 21, 1889): 295; Mrs. Nickleby and Smike in 109 (Oetober 5, 1895): 163; Mrs. Gamp in 44 (April 5, 1873): 141 and 100 (May 9, 1891): 223; and Mark Tapley in 118 (February 21, 1900): 137 .

13. See Tenniel, quoted in Monkhouse, "Sir John Tenniel," p. 24, on his "opportunity of studying Mr. Gladstone's face carefully when he did me the honour of inviting me to dinner at Downing Street," and [Dexter], "Dickensian Peeps into 'Punch," 34:25 and 35:39, who also notes the following additional examples of Gladstone in Punch: as Nell's grandfather in 92 (January 15, 1887); as Micawber in 86 (May 10, 1884): 233; as Mrs. Gummidge in 88 (May 2, 1885): 211; as Betsey Prig in 104 (March 11, 1893); and as Mrs. Gamp in 94 (March 3,1888 ): 103 .

14. See Kitton, $D I$, p. 174.

15. Ruskin, Works, 33:368, and see also Spielmann, quoted in "Sir John Tenniel," p. 2.

\section{Chapter 10: Daniel Maclise}

1. Helpful to the details in the paragraph below are M[onkhouse], "Daniel Maclise," DNB, 12:664-66, and Richard Ormond and John Turpin, introduction to Daniel Maclise: 1806-1870, [Exhibition Catalogue] pp. 16-18 (hereafter cited as Ormond and Turpin, Maclise Catalogue).

2. See Pilgrim, 1:201 and n. 2, Mahony, [?November, 1836], and Thackeray's sketch of CD, Maclise, Mahony, and himself, 1836, reproduced in Letters, 1: facing p. 308, which may have recorded that meeting "at St. James's Square 1836." The portrait of CD as a Parliamentary reporter, ca. 1837, is attributed to Maclise in The Yale University Library Gazette, 37:50, No. 14, and will continue to be in the forthcoming catalogue of the Gimbel Dickens Collection, being prepared by John Podeschi, according to Marjorie Wynne of the Beinecke Library in her letter of July 27, 1977 to the author; Ormond, in a letter of July 14, 1977 to the author, doubts the attribution judging from a photograph of it, feeling it is not a good likeness of $\mathrm{CD}$ and that it lacks the "very fine and distinctive features" found in the artist's Nickleby portrait of 1839 .

3. Quoted in Charles Duffy, Conversations with Carlyle (New York: C. Scribner's Sons, 1892), p. 75.

4. Macready, entry for March 22, 1840, Diaries, 2:54, calls him "the poet-painter."

5. Forster, p. 130, and Pilgrim, 2:60, Maclise, [?April 18, 1840]. Two sketches by Maclise of Forster in the Forster Collection have been reproduced in Johnson, 1, between pp. 10 and 11, and in the $V+A$ Dickens Catalogue, [p. 142], plate 27 .

6. See the relevant entries under Maclise in Pilgrim, 1:733; 2:533; $3: 672$, and the indexes of forthcoming Pilgrim volumes for the details of these many occasions.

7. See Charles G. L. DuCann, The Love-Lives of Charles Dickens (London: Frederick Muller, [1961]), p. 85, and J. F. Dexter, Dickens Memento, p. 12, quoted in Pilgrim, 1:65, n. 3.

8. See, for example, Ormond and Turpin, Maclise Catalogue, p. 10, and ALS, Maclise to CD, July 16, [1841], in the Huntington Library (HM 18540) for further details concerning the artist's flirtations.

9. Pilgrim, 1:558, Harley, June 28, 1839.

10. See ibid., 557 , Maclise, June 28,1839 , which may be a reply to 
the unpub. ALS, Maclise to Forster, 1839, in the Forster Collection, postponing his planned visit to $\mathrm{CD}$ in Petersham due to bad health.

11. Ormond and Turpin, p. 56, no. 61 , cite the artist's portrait of Thomas Moore in Fraser's 2 (October, 1830): facing p. 266 as an example.

12. [Thackeray] (Michael Angelo Titmarsh), "A Pictorial Rhapsody Concluded," p. 112, and widely quoted elsewhere.

13. George Eliot, letter to Sara Hennell, December 15, 1871, Letters, 5:226, and widely quoted elsewhere. See also Forster, p. 129, for remarks of Georgina Hogarth; Kitton, $P+P, 2: 180$, for remarks of Mrs. Cattermole and her son Leonardo; Grego, "Dickens and His Artist Friends," p. 374, for quoted comments by C. C. Lester to Washington Irving; and Marcus Stone, "Reminiscences," p. 20.

14. See Pilgrim, 3:418, n. 1; ef. Ormond, Early Victorian Portraits, 1:140, who maintains that the publishers would only own the copyright so that the gift really came from Maclise. See also discussion and $\mathrm{nn} .27-28$ below.

15. Pilgrim, 2:230-32, Maclise, March 12, 1841, and letters from Maclise to Forster, quoted in 232, nn. 1 and 2.

16. See ibid., 232, n. 1.

17. Maclise, letter of [September 27] 1841, quoted in ibid., 393, $n$. 1. Maclise's sketch of Devonshire Terrace, dated only "October," is more likely to have been executed at this time than during any other Octobers between 1840 and 1850 when the family, so often abroad, lived there.

18. See Slater, ed., $C B, 1: 262$, n. 9, on Strutt's Costumes. $A$ Complete View of the Dress and Habits of the People of England, which was first published in 1796-99 and reissued in 1842 at the time of Maclise's sketch, and was also mentioned in The Chimes in 1844 (I, 102).

19. See Pilgrim, 3:155, n. 1, March 22, 1842, and 4:162, Maclise, July 22, 1844; see also 3, March 22, 1842: 152, Lady Holland, and 161, Mitton; and George W. Putnam, "Four Months with Charles Dickens," pp. 478-79.

20. See Pilgrim, 3:41, n. 1, Maclise to Forster, ?February 8, 1842; 153, Maclise, March 22, 1842; 178, Forster, April 2, 1842; and 248, Forster, May 26, [1842].

21. See, for examples, Pilgrim, 3: 172, Forster, March 28, 1842; 178, Forster, April 2, 1842; 123, Forster, March 13, 1842; and 244, Felton, May 22, 1842.

22. Ibid., 244, Felton, May 21, 1842, and see 302, n. 4 .

23. See Forster, p. 278.

24. For the Hamlet scene, see Pilgrim, 3:299, Sumner, July 31, 1842; cf. Ruskin, "Modern Painters," Works, 3:82, and Shaw, preface to Great Expectations, x-xi; for Longfellow's visit, see Longfellow, Letters, 2:282, Forster, December 15, 1842, and 495, Freiligrath, January 6,1843 ; and for CD during the preparation of $A N$, see Forster, pp. 278-79.

25. See Forster, p. 288, and Pilgrim, 3:414-16, Felton, December $31,1842$.

26. Ormond and Turpin, Maclise Catalogue, p. 73 , no. 78 , provide a useful discussion of this painting.

27. Pilgrim, 3:396-97, Beard, December 18, [1842], and see F. M. Redgrave, Richard Redgrave, C.B., R.A., pp. 314-15, and Forster, p. 289; cf. W. Justin O'Driscoll, A Memoir of Daniel Maclise, R.A., pp. 66-67, and Ormond and Turpin, Maclise Catalogue, p. 73, no. 78, and Ormond, Early Victorian Portraits, 2:140, who maintain the ruse involved the Nickleby portrait (as did Pilgrim, 1:577, n. 1; cf. $3: 418, n .1)$. See also discussion and $n .28$ below.

28. Quoted in Pilgrim, 3:418, n. 1, and see 397, n. 2, for CD's check to the artist via Beard; cf. Ormond, Early Victorian
Portraits, 2:140, whose argument that the letter involved the Nickleby portrait was partly based on the impossibility of CD's having sent a check directly to the artist.

29. Pilgrim, 3:418, Maclise, [?late December, 1842], and see 418, n. 1 , which corrects the 1839 misdating of this interchange in 1:577 and $n .1$.

30. On the full-size portrait of Mrs. CD, see Forster, pp. 129, $\mathrm{n}$. 131, and 290; Ormond, Early Victorian Portraits, 1:140; and Frith, My Autobiography and Reminiscences, 2:30-31, who notes that it was exhibited at the R.A. in 1848 under the mistaken title, 'Mr. Charles Dickens.' Nor further information seems to exist on the other portrait of Mrs. CD from which the better known engraving has been made.

31. Pilgrim, 3:440 and n. 1, Forster, [February 12, 1843].

32. See Forster, p. 293; Mamie Dickens, quoted in Kitton, $P+P$, 3:47; and Marcus Stone, "Reminiscences," p. 21.

33. Pilgrim, 4:42, Forster, [February 11, 1844].

34. Ibid., 158-59, July 22, 1844.

35. Ibid., 298 and n. 7 and 299, Forster, [?April, 1845].

36. Pilgrim, 2:8, Cattermole, January 13, 1840.

37. Ibid., 144 and n. 3, Maclise, November 3, 1840, and see $14 \dot{4}$, Forster, [November 3, 1840], and unpub. ALS, Maclise to CD, 1841 , at the Huntington Library (HM 18544), requesting the author to have his publishers send a copy of $S B B$ and $O T$, perhaps to assist him in his $M H C$ task; ef. Forster, p. 149, who forgot that the meeting had borne "fruit" after all.

38. Pilgrim, 2;145-46, Maclise, [November 6, 1840] and 146, Maclise, [?November 6, 1840]. See also Pilgrim, 1:198, Cruikshank, [?November 26, 1836], though modified by 202 , Bentley, [November 30,1836 ] and 206 (2) Cruikshank and Bentley, [December 5, 1836], discussed in the text related to $n .32$ in chapter 1 above.

39. Pilgrim, 2:146, nn. 2-4, also notes these discrepancies and others between CD's suggestions and/or text and Maclise's illustration, probably due to lack of time, as the illustration appeared on November 28.

40. Harvey, pp. 115-16, provides a full analysis of this scene, especially the artist's use of verticals and light, which has informed the discussion of the scene below.

41. Ibid., p. 117.

42. Maclise, letter to Forster, ca. 1846, quoted in Pilgrim, 4:599, n. 1, and in Ley, Circle, p. 61. For the artist's continuing interest in OCS, see Pilgrim, 2:182, n. 1, which quotes letter from Maclise to CD, nd, and 3:398, Cattermole, December 20, 1842.

43. "The Cricket on the Hearth," the Times (London) (December $27,1845), 6$.

44. "Christmas Revels: An Epic Rhapsody in Twelve Duans," a description of the canvas, appears under the artist's literary pseudonym, "Alfred Croquis, Esq." in Fraser's 17 (May, 1838): 635-44.

45. Maclise, letter to Forster, nd, quoted in Kitton, DI, p. 163.

46. See letter from Maclise to Forster, nd, quoted in Kitton, $D I$, p. 164 and $n$. The page size of the Widener Collection copy of $C C$, for example, measures $6^{*} / 8^{\prime \prime} \times 3^{15} / 16^{\prime \prime}$ and that for TC measures $61 / 2^{\prime \prime}$ $\times 4^{\prime \prime}$, and the Nonesuch $C B$, p. 83 , notes that the pages of the last four holiday books measured "about $61 / 2$ " $\times 41_{4}^{\prime \prime}$."

47. See Ormond and Turpin, Maclise Catalogue, p. 78, nos. 86-87, whose discussion of the frontispieces for $T C$ and $C H$ have influenced the discussions below of these and the other $C B$ frontispieces.

48. See Pilgrim, 4:234, Mrs. CD, December 2, 1844; cf. "The Chimes," Christian Remembrancer 9 (January, 1845): 303.

49. Ormond and Turpin, Maclise Catalogue, p. 78 , no. 86. 
50. Pilgrim, 4:209, Forster, [?November 1-2, 1844], and 210, Forster, November 3 and [4], 1844.

51. See K. J. Fielding, "Two Sketches by Maclise: The Dickens Children and The Chimes Reading," DS 2 (January, 1966): 16-17, and Forster, p. 363.

52. Maclise, letter, December 8, [1844], quoted in Fielding, "Two Sketches by Maclise," p. 13, and partly quoted in Pilgrim, $4: 234-35$, n. 6.

53. The Times (London), (December 27, 1845), 6.

54. See Pilgrim, 4:317, Forster, [June 1 and 2, 1845], 324, De La

Rue, 29 June 1845; and Forster, p. 377.

55. Pilgrim, 4:392, September 29, 1845.

56. Ibid., 397, Oetober 4, 1845, and see 417, Bradbury and Evans, October 28, 1845.

57. Maclise, letter, nd, quoted in Kitton, $D I$, p. 164, and see Pilgrim, 4:437, n. 3.

58. Pilgrim, 4:437, Bradbury and Evans, November 19, 1845. 59. Ormond and Turpin, Maclise Catalogue, p. 78 , no. 87.

60. See Thackeray, Morning Chronicle (December 24, 1845), partly quoted in Pilgrim, 4:397, n. 3; "The Cricket on the Hearth," Illustrated London News (December 27, 1845), 406, partly misquoted in Pilgrim, 4:397, n. 3; and "The Cricket on the Hearth" the Times (London) (December 27, 1845), 6.

61. See Forster, p. 387.

62. Maclise, letter, nd, quoted in Kitton, DI, p. 165.

63. Ibid.

64. Ibid.

65. Letter from Maclise to Forster, nd, quoted in Kitton, $D I, \mathrm{pp}$. $165-66$.

66. See Forster, p. 439, and Pilgrim, 4:657 and n. 4, Forster, [November 21, 1846].

67. Pilgrim, 4:673, Thompson, December 2, 1846.

68. See Leavis, who praises this scene as well as the "graceful pseudo-Blakean frontispiece" (p. 368).

69. Leech, letter of November 16, 1846, Forster, quoted in Kitton, $D I$, p. 143 , and see discussion in chapter 7 above.

70. Maclise, letter to Forster, nd, quoted in Kitton, DI, pp. 166-67. Maclise may have been making a pun on "moonbeams," a summer drink, a recipe for which in CD's hand, dated November 1846-the same time as the production of $B I-$ is at the Rosenbach Foundation and, as Anthony Burton pointed out to the author, was reprinted in Dick. 33 (Spring, 1987): 78.

71. [Thackeray] (M. A. Titmarsh), "A Grumble about the Christmas-Books," pp. 125-26, and see Pilgrim, 4:648, Forster, [October 26-29, 1846], for CD's request for late eighteenth-century costumes, mentioned in the text and n. 44 of chapter 7 above.

72. Letter to Forster, nd, quoted in Kitton, $D I$, p. 167.

73. Maclise, letter, nd, quoted in Kitton, DI, p. 167; cf. Ormond and Turpin, Maclise Catalogue, p. 78, no. 87, who relate this letter and the portion of the one quoted in $\mathrm{n} .72$ above to $\mathrm{CH}$, probably due to their sequence in the Forster Collection. The exact date is open to question but their "last straw" tone makes Kitton's order more plausible.

74. See NL, 2:7, Mrs. Watson, January 25, 1847, in which CD proclaims he was "shocked" by all the illustrations except Stanfield's; ef. Pilgrim, 4:679, Forster, [?November 12, 1846], in which he says "the illustrations altogether are by far the best that have been done for any of the Christmas books." It is hard to account for this change of mind: possibly $C D$ was affected by the poor critical reception of $B L$; or perhaps Mrs. Watson complained about the sensuousness of many of the scenes and CD thought it wiser to agree than argue the point.
75. Forster, p. 382, yet see also p. 457 for the artist's name for the traveling company-the "splendid strollers"-which was quickly adopted by $\mathrm{CD}$.

76. See Pilgrim, 4:371, Maclise, September 4, 1845, and 376-77, Maclise, September 11, 1845; letter to Elizabeth Browning, [September 25, 1845], Letters, 1:217; cf. T. Purland's notes, quoted in Richard Renton, John Forster and His Friendships, p. 117, which describes the costumes as "awfully bad," with Forster and CD being the only characters correctly dressed.

77. Ormond and Turpin, Maclise Catalogue, p. 76, no. 84, discuss Maclise's oil painting of Forster as Kitely, ca. 1848; Pilgrim, 4:383, n. 2, notes a playbill sketch of the same subject at the NYPL; and 391 and n. 1, Mme. De La Rue, September 27, 1845, refers to CD's sitting for a more formal portrait by Maclise but nothing further is known about this.

78. See NL, 2:48, Forster, August 4, 1847, and 295, Duke of Devonshire, April 4, 1851.

79. See unpub. ALS, CD to Maclise, June 24, 1857, in the Huntington Library (HM 17710); NL, 2:859, Maclise, July 8, 1857; and Queen Victoria, journal extracts in The Letters of Queen Victoria, 2:9 (March 9, 1870) and 20-21 (June 11, 1870), which clearly indicate CD's preference to meet his sovereign as an author, not an actor.

80. See Pilgrim, 2:23, Landor, [February 11, 1840]; 25, Thompson, [February 13, 1840]; and 34, n. 3, Maclise to CD and Forster, nd.

81. See Pilgrim, 2:25, n. 5, which quotes some of the queen's diary references to the artist, and Ormond and Turpin, Maclise Catalogue, p. 16, who note that he changed the spelling of his surname in 1835 .

82. For CD and Maclise's "grief," see Forster, p. 155; Pilgrim, 2:24, Forster, [February 12, 1840]; 25-27, Thompson, [February 13, 1840]; and 27-29, Maclise, [February 13, 1840]. For the artist's work for the royal couple, see Pilgrim, 3:519 and n., Maclise, July 6, 1843; 549-50, Felton, September 1, 1843; and 612, Maclise, December 25, 1843; Macready, entries for September 2, 1843 and April 7, 1846, in Diaries, 2:219 and 334-35; ef. Ruskin, entry for August 13, 1844, in The Diaries of John Ruskin, 1:511; and [Thackeray] (Michael Angelo Titmarsh), "Strictures on Pictures," p. 759 .

83. Pilgrim, 3:550, Felton, September 1, 1843.

84. See Boase, 17:319-58, for a full account of the artistic proceedings at Westminster. For CD's unabashedly partisan commentary, see Pilgrim, 4:168-69 and n. 1, D'Orsay, August 7. 1844; 285, D'Orsay, March 18, 1845; 304 and n. 2 and 305, Countess of Blessington, May 9, 1845; 306, Maclise, May 9, 1845; 332, D'Orsay, July 14, 1845, and, for the artist's appreciative response, 304, n. 2, Maclise to Forster, nd. See Ormond and Turpin, Maclise Catalogue, pp. 84-87, nos. 91-94, for a detailed discussion of Maclise's 'The Spirit of Chivalry'; and Ruskin, Works 3:51, n., and Maclise, "Autobiography," p. 42, on the artist's over-attentiveness to detail.

85. Ormond and Turpin, Maclise Catalogue, pp. 87-88, no. 95, and 108-16, nos. 117-22, provide a detailed discussion of these three frescoes; and see also William Rossetti, pp. 245-54 and n.; William Bell Scott, Autobiographical Notes of the Life of William Bell Scott, 1:112 and 2:83; and Winslow Ames, Prince Albert and Victorian Taste, pp. 56, 219.

86. See Pilgrim, 4:390, Mme. De La Rue; September 27, 1845; 498, De La Rue, February 16, 1846; and O'Driscoll, pp. 99-101.

87. See Macready, entry for May 9, 1847, Diaries, 2:365; Pilgrim, 4:161, Maclise, July 22, 1844, and 168, D'Orsay, August 7, 1844; and Macready, quoted in Kitton, $P+P, 3: 57$.

88. See fragment of letter to Forster, January 7, 1848, quoted in 
Forster, p. 465, n.; letters of June 23-24 and July 28, 1850 in $M r$. and Mrs. Charles Dickens: His Letters to Her, pp. 136-41; and letter from Maclise to Forster, July 29, 1855, quoted in O'Driscoll, p. 118 .

89. See Prince Albert, letter to Eastlake, [August, 1859] and Maclise's report on the new stereochromic process, quoted in O'Driscoll, pp. 147-48, 241-57; and Ormond and Turpin, Maclise Catalogue, p. 6, on the German influence on the artist's work.

90. See NL, 3:279, Leech, January 15, 1862, and 397, Leech, September 5, 1864.

91. Quoted in Scott, Autobiographical Notes, 2:85, but see Ruskin, "The Royal Academy Commission," Works, 14:488, and D. G. Rossetti, "Maclise's Character Portraits," Academy 2 (April 15, 1871): 217. Ormond and Turpin, Maclise Catalogue, p. 89, no. 97 , discuss Charles West Cope's sketch inscribed 'McClise/Fresco/ Painting/under/difficulties/H of Lords,' ca. 1846-49, ironically purchased by the House of Lords more than a century later, reproduced in R. J. B. Walker, Catalogue of Paintings, Drawings, Sculpture and Engraving in the Palace of Westminster, Supplement No. 4 (1968-69) (London: Ministry of Public Buildings and Works, 1970), p. 5 .

92. See Pilgrim, 2:28, n. 8; Kitton, $D I$, p. 162; O'Driscoll, p. 207; and Ormond and Turpin, Maclise Catalogue, p. 14.

93. CD's removal of an allusion in PP, for the 1867 edition, to Maclise's portrait of Sir John Soane, which so displeased the subject that he burned it, is mentioned in the text and $n .36$ in the Introduction above.

94. NL, 3:773, Forster, April 29, 1870.

95. See Kate Perugini, quoted in Ley, Circle, pp. 62-63; G. D. Leslie, quoted in Kitton, $P+P, 2: 165$; and Redgrave, entry for April 30, 1870, F. M. Redgrave, Richard Redgrave, p. 310.

\section{Chapter 11: Edwin Landseer}

1. Quoted in Frith, My Autobiography and Reminiscences, $1: 60-61$.

2. See NL, 2:727, Landseer, January 10, 1856, and Perugini, "Charles Dickens as a Lover of Art and Artists," pp. 165-66.

3. See Forster, p. 133; Macready, entry for Mareh 30, 1839, Diaries, 1:504; and Pilgrim, 4:356, n. 1.

4. Quoted in Kitton, $P+P, 2: 179$; and see also Campbell Lennie, Landseer: The Victorian Paragon, pp. 124-25.

5. Forster, p. 130. See also Pilgrim, 3:298, n. 4; Hood, letter to Mrs. Elliott, quoted in Ley, Circle, p. 129; and Jeremy Maas, Victorian Painters, p. 79.

6. See Pilgrim, 1:601 and nn. 1 and 2, Macready, November 14, 1839; 566, n. 2; 4:147, n. 1; and Marcus Stone, "Reminiscences," p. 19.

7. Pilgrim, 2:417-18 and n. 1, John Landseer, November 5, 1841, the tone of which seems most cordial; cf. the "coldly polite" reply noted by Lennie, p. 155.

8. See Pilgrim, 3:519, n. 5; Richard R. Holmes, Queen Victoria (New York: Longmans, Green and Co., 1901), p. 121; and Macready, entries for September 2, 1843, and April 7, 1846, Diaries, 2:219 and 334; cf. Ruskin, entry for August 17, 1844, Diaries, 1:311.

9. See Queen Victoria, entry for December 7, 1837, The Girlhood of Queen Victoria, 1:241-42, and extract from journal, October 1, 1873, Letters, 2:282.

10. Landseer, quoted by Henry Burnett, in Kitton, $P+P, 3: 9$, and discussed in Lennie, pp. 124-25.

11. See Pilgrim, 4, Landseer: 131 and n. 5, May 27, 1844, and 335 and $\mathrm{n} .4$, July 23,1845 .
12. Quoted in George Dunlop Leslie, The Inner Life of the Royal Academy, p. 14. For further comment on Landseer's dogs, see Ruskin, Works: "Modern Painters," 4:302-3, 337; "Lectures on Art," 20:31; and "Addresses," 34:641; William Rossetti, Fine Art Chiefly Contemporary, p. 160; and Jerrold, p. 193, who says Landseer took more than one hint from Cruikshank's dogs. For praise of CD's dogs here and in OT (Sikes's Bull's Eye), $D C$ (Dora's Jip) and $H T$ (Sissy's Merry Legs), see "Dickens's Dogs: or the Landseer of Fiction," pp. 48-61, and Arnold Quamoclit, "Charles Dickens as a Humaniser," pp. 281-91, both cited and quoted in Kitton, Dickensiana, pp. 122-23, 183.

13. See Forster, p. 356; Lennie, who says Landseer's absence at the reading (see Pilgrim, 4:210, Forster, November 3 and [4], 1844, and $234, n .6$ ) caused a "rupture temporary but never healed" (p. 125); and Pilgrim, 4:436, Bradbury and Evans, [November $17,1845]$.

14. Slater, ed. $C B, 2: 10$, also observes Landseer's use of CD's name but not, as Angus Easson also notes in his review of Slater, DSN 4 (September, 1973): 70, Doyle's use of his initials in his earlier illustration.

15. See Pilgrim, 4:437, Leech, November 18, 1845; 437, Bradbury and Evans, November 19, 1845; and 439, Leech, [November 19, 1845].

16. This opinion is also shared by Percy Fitzgerald, The Life of Charles Dickens as Revealed in His Writings (New York: Haskell House, 1973. Reprint of 1905 edition.), p. 144, noted in Waugh, Nonesuch Dickensiana, p. 37.

17. "The Cricket on the Hearth," the Times (London) (December $27,1845), 6$.

18. See Forster, p. 528; Pilgrim, 3:483, n. 1; 507, n. 1; 544, n. 2; and 4:544, n. 3; and Macready, entry for May 7, 1846, Diaries, 2:337.

19. See theater program for May 18, 1850, reproduced in Cohen, "'All-of-a-Twist," plate 9, facing p. 336, and NL, 2:667, Stanfield, May 29, 1855, and 818, Landseer, December 23, 1856.

20. Jerrold, quoted in James A. Manson, Sir Edwin Landseer, $R . A$., p. 150 .

21. See Forster, p. 526.

22. See Moses F. Sweetser, Landseer, p. 88, and Lennie, pp. 211-12. See also NL, 2:31, Landseer, June 13, 1847, and 43-44, Miss Power, July 14, 1847; and a delightful self-portrait, 'Recumbent Lion with Paws on Landseer,' ca. 1850, reproduced in Erna Auerbach and C. Kingsley Adams, comps., Paintings and Sculpture at Hatfield House (London: Constable \& Co., 1971), pp. 294, 219 (288e).

23. See NL, 2:728, Wills, January 14, 1856.

24. See Perugini, "Charles Dickens as a Lover of Art and Artists," p. 166.

25. See Forster, p. 606, and C[0smo] M[onkhouse], "Sir Edwin Landseer," $D N B, 11: 507$, who says that the artist won the "large gold medal, an honor not accorded to any other English artist"; cf. C[osmo] M[onkhouse], "George Cattermole," $D N B, 3: 1233$, who says "Cattermole received one of the two grandes médailles d'honneur, Landseer taking the other." Three medals may be involved here, but this seems unlikely. Meanwhile the surprise expressed by [Ford], "Oliver Twist," in 1839-that "such judges as . . . Landseer .. have not ere now insisted on breaking through all the puny laws" (p. 102) which, for example, prevented the election of a black-and-white artist such as Cruikshank to the R.A.-must have turned to great sadness by 1865 .

26. See letter from Forster to Landseer, June 20, 1858, quoted in the $V+A$ Dickens Catalogue, p. 99, no. M9; a letter from Landseer to Maclise, July 5, 1842, quoted in Pilgrim, 3:264, n. 3, in which the artist thoughtfully suggests a welcome home dinner also be given to Mrs. CD, may be relevant; and Lennie, pp. 124-25. 
27. Quoted in Walter Frith, "Small Talk with My Father," p. 809, and, slightly differently, in Lennie: "I shall see less of you than ever" (p. 125), which is then misleadingly juxtaposed next to an observation that the two men saw less of one another after 1844, though the anecdote relates to events in 1858-59; and see also Frith, Autobiography, 1:307-8 and 2:184-85; Ley, Circle, p. 92; and NL, 3:385, Frith, April 13, 1864.

28. Quoted in Forster, pp. 668-69.

29. See Perugini, "Charles Dickens as a Lover of Art and Artists," p. 166. Ley, Circle, p. 92, reports that the artist was a guest at the dinner given by CD to celebrate Percy Fitzgerald's wedding at Hyde Park Place, perhaps their last meeting.

\section{Chapter 12: Clarkson Stanfield}

1. See Ruskin, Works: "Modern Painters," 3:397, n., and "The Art of England," 33:373; Forster, p. 328, on dinner for CD to which Stanfield brought Turner; Pilgrim, 4:217, Forster, [November 12, 1844], in which CD implicitly compares the artist to Canaletto; and Maas, pp. 34, 62 .

2. See Kitton, DI, pp. 153-54, and C[0smo] M[onkhouse], "Clarkson Stanfield," DNB, 18:884-86, for biographical details that have been helpful in the paragraph below; and the portraits of the artist as a younger man by J. Simpson (?) [2637] and William Brockedon [2515 (40)] at the NPG, London.

3. See Ruskin, Works: "Dilecta," 35:572; "Modern Painters," 4:357; and "Praeterita," 35:91.

4. See Pilgrim, 1:561 and n. 1, and 611 and n. 1, Stanfield, [December 7, 1839], for associations with Macready and the Shakespeare Society; NL, 2:602, November 1, 1854, for Maclise's comment; and Pilgrim, 1:740; 2:543; 3:686; 4:767; and relevant index entries in future volumes for their constant socializing together.

5. For CD's nicknames, see Pilgrim, 4:18 and n. 2, Stanfield, January 9, 1844 (Philo Forecastle); 182, Stanfield, August 24, 1844 (Dick); 515, Stanfield, March 6, 1846 (Henry Bluff); NL, 2:623, Lemon, February 3, 1855 (Genial Oil). For the artist's nicknames, see NL, 2:443, Stanfield, January 2, 1853 (Stanfell); 658, Stanfield, May 7, 1855 (Old Tarpaulin); 623, Lemon, February 3, 1855 (Old Salt); and 663, Stanfield, May 20, 1855 (lad with the tarry legs).

6. See Pilgrim, 3:519, n. 5; Macready, entry for September 2, 1843, Diaries, 2:219, and letter from Stanfield to Forster, partly quoted in Winifred Myers, Ltd., Catalogue No. 6 (Spring, 1967), p. 82, item 440 .

7. See Pilgrim, 3:416, Felton, December 31, 1842, and 437-38, Stanfield, [February] 3, 1843, for the Twelfth Night party; and 4:10, Macready, January 3, 1844, for the Carol party.

8. See Pilgrim, 3:563, Coutts, September 16, 1843; 531, Stanfield, July 26, 1843; 4:116 and n. 2, Stanfield, April 30, 1844; NL, 2:44, Stanfield, July 25, 1847; Locker-Lampson, quoted in Kitton, $P+P$, 2:189; and for his work on the benefit theatricals, see the discussion in the pages below.

9. See chapter 8 above, n. 4, for the history of this church.

10. Pilgrim, 4:234, December 2, 1844; and see also 209, Forster, [?November 1-2, 1844]; 210, Forster, November 3-[4], 1844; and Forster, p. 363 .

11. Pilgrim, 4:396, October 6, 1845, which is quoted and discussed in Kitton, D1, pp. 155-56.

12. Pilgrim, 4:397, Stanfield, October 4, 1845. See also Macready's earlier similar difficulty in compensating the artist in Diaries: entries for December 21, 1837, 1:433; January 5, 1838, 1:438; January 20, 1838, 1:441; February 7, 1842, 2:157; and March $7,1842,2: 160$, which may have given CD the idea of giving silver gifts to the artist for his work on $T C$ and for the $H M$, discussed below.
13. Pilgrim, 4:417, and 432, n. 2, Bradbury and Evans, October $28,1845$.

14. Ibid., 439, Stanfield, November 21, 1845.

15. Ibid., 442 and n. 2, Stanfield, November 28, 1845.

16. See Forster, p. 439; and Pilgrim, 4:652, Forster, [November 4, 1846]; 666-67, Watson, November 27, 1846; and 396, n. 2.

17. Pilgrim, 4:680, [?December 12, 1846].

18. NL, 2:7, Mrs. Watson, January 25, 1847.

19. Ibid., 128, Leech, November 18, 1848.

20. Ibid., 134, Bradbury and Evans, December 1, 1848.

21. See Pilgrim, 4:396, n. 2, and 515, Stanfield, March 6, 1846, about some silver candlesticks that were not a gift.

22. "Pictures from Italy," Athenaeum (May 26, 1846), 519. See also David Paroissien, ed., Pictures from Italy by CD, pp. 9-32, for a useful account of its stages of composition (hereafter cited as Paroissien, ed., PFI).

23. Pilgrim, 4:503, Evans, February 24, 1846, and 516-17, Bradbury and Evans, March 11, 1846.

24. See Paroissien, ed., PFI, pp. 248, 258, and Pilgrim, 4:511, Wills, March 2, 1846.

25. See, for example, Pilgrim, 4: Forster: 611, [August $24 \& 25$, 1846], and 632-33, [October 11, 1846].

26. See Pilgrim, 4: 530 and n. 2, Forster, [?June 28, 1846], and Forster, p. 400, n.

27. See Paroissien, ed., $P F I$, pp. 247-48.

28. See Pilgrim, 4:518, n. 1, which notes the artist's conversion on October 3,1846 .

29. Ibid., 517-18 and n. 1, March 12, 1846. This entire discussion has benefited from the assistance of Philip F. Skottowe in his letters of July 1, 1967, May 16, 1975, and May 24, 1975 to the author.

30. See Pilgrim, 4:652, Forster, [November 4, 1846]; NL, 2:75, Marryat, March 6, 1848; and 2:763, Wilkie Collins, April 22, 1856.

31. Cf. Pilgrim, 2:422, n. 2, which erroneously states that the frontispiece was for the 1855 edition, which was really the reissue of the 1850 Cheap Edition.

32. See Forster, pp. 278, 288-89; Pilgrim, 3:38, Frederick Dickens, January 30, 1842, and 414-16, Felton, December 31, 1842; and 4:183, Stanfield, August 24, 1844; and another sketch of the Cornwall Quartet, attributed to Thackeray (and see also Forster, p. 289), reproduced in Kitton, $P+P, 3: 67$. Perhaps relevant to this period, though the date is not known, is Stanfield's watercolor of CD's mother, reproduced in Dick. 44 (March 1, 1948): 58, which is at the Dickens Birthplace Museum in Portsmouth.

33. Journal entry of November 25, 1842, The Journals and Miscellaneous Notebooks of Ralph Waldo Emersom. 1841-1843, ed. William H. Gilman and J. E. Parsons (Cambridge, Mass.: Harvard University Press, Belknap Press, 1970), 8:222.

34. See NL, 2:215, Chapman, May 11, 1850; Harvey, p. 193; and Muir, p. xiv.

35. NL, 2:223, Chapman, July 22, 1850. This letter seems to bear out Kitton, DI, p. 158; ef. Harvey, p. 193, whose misreading suggests that the publishers agreed to use lithography.

36. This error has been noted by Swinburne, p. 73, and by Admiral Sir Gerald Dickens, "S.S. Britannia," Dick. 55 (May, 1959): 67, who explains that the flag of the country of origin (England here) should have been flown at the mizzenmast, that of the country of destination (the United States) at the foremust. His son, Captain Peter Dickens, who showed the author the original watercolor now in his possession (reproduced in the $V+A$ Dickens Catriogue, plate no. 33), further notes that the Cunarder's smokestack should have been colored red, not white. 
37. See NL, 2:223, Chapman, July 22, 1850.

38. See, for example, Pilgrim, 1:553, Macready, [June 7, 1839], and 2:548-49, Felton, September 1, 1843; NL, 2:751, Georgina Hogarth, March 14, 1855; Macready, entries for July 20, 1839 and April 1, 1846, Diaries, 1:19 and 2:333; and "The Late Mr. Stanfield," June 1, 1867, in CP, 2: 46.

39. Pilgrim, 4:182, August 24, 1844, and see also 308, Stanfield, May 9, 1845.

40. See Pilgrim, 4: 332-33, Stanfield, July 15, 1845; 334, Stanfield, July 18, 1845; 342, Stanfield, July 28, 1845; 359, Coutts, August 21, 1845; and 363, Forster, [August 22, 1845].

41. See Pilgrim, 4: 355, Kelly, August 14, 1845; 362, Cruikshank, [?August 22, 1845]; 364, Keeley, Aigust 25, 1845; 365, Cattermole, August 27, 1845; 384, Kelly, September 22, 1845; and 391, Stanfield, September 27, 1845; and see praise in letter from Robert to Elizabeth Browning, [September 25, 1845], Letters, 1:217.

42. Exactly where young Stanfield injured himself is not clear: Pilgrim, 4:46, n. 5, says in the leg; Skottowe, in his letter of July 1 , 1967 to the author, says the hip; and Maas, p. 61, refers to the foot.

43. See, for example, Pilgrim, 4:415, Stanfield, October 26, 1845, and 455, Stanfield, December 25, 1845.

44. See Charles Knight, Passages of a Working Life (London: Bradbury and Evans, 1864), 2:115-16.

45. See NL, 2:650, Forster, April 3, 1855; 663, Stanfield, May 20, 1855; 665, Coutts, May 24, 1855, and Frank Stone, May 24, 1855; and 666, Coutts, May 29, 1855. The act drop, reproduced in Ley, Circle, p. 98, now hangs at Diekens House.

46. NL, 2:769, Georgina Hogarth, May 5, 1856; 774, Coutts, May 13, 1856; 803-4, Mrs. Watson, October 7, 1856; 808-9, Wilkie Collins, October 26, 1856; 810, Wilkie Collins, November 1, 1856; 813, Telbin, December 2, 1856; 814, Coutts, December 4, 1856; 815, Macready, December 13, 1856; and 816, Power, December 15, 1856.

47. Shaw, preface to Great Expectations, p. x, and Thackeray, quoted in Marvy, np.

48. NL, 3:95, Forster, February 21, 1859.

49. Ibid, , 175, Lillie, August 24, 1860, and 487, Wilkie Collins, October 4, 1866.

50. See Forster, p. 654; Dolby, p. 48; and unpub. ALS, CD to Dolby, August 29, 1867, at the Rosenbach Foundation [530/10], which reports Landseer's high aesthetic and monetary valuation of the sets.

51. Letter of May 20,1857, partly quoted in Slater, Suzannet Catalogue, p. 266, lot 282.

52. Ibid.

53. See NL, 3:279, Stanfield, January 16, 1862; 343, Macready, February 19, 1863; 398, Stanfield, September 21, 1864; and 524, Stanfield, April 18, 1867.

54. See Forster, pp. 678-84, n. 448, for an account.

55. See, for examples, NL, 3:343, Macready, February 19, 1863, and 529, Chorley, June 2, 1867.

56. See Arthur A. Adrian, Mark Lemon, pp. 136-37, and NL, 3:781, Harry Lemon, May 25, 1870.

57. See NL, 3:527-28, George Stanfield, May 19, 1867; 529, George Stanfield, May 21, 1867; and 535, Tennent, July 3, 1867.

\section{Chapter 13: Frank Stone}

1. Marcus Stone, quoted in Ley, Circle, p. 145.

2. See Marcus Stone, "Reminiscences," pp. 6-11, 13, 128-29; E[dward] I[rving] C[arlyle], "Frank Stone," DNB, 18:1297; Kitton, $D I$, p. 175; and Ley, Circle, p. 145, for these and further details of the artist's life. The City Art Gallery in Manchester, England, has a self-portrait in oil, undated, but perhaps executed about this time as the subject is quite young (and unexpectedly elegant; cf. fig. 171).

3. See Macready, entry for March 14, 1841, Diaries, 2:127; Marcus Stone, "Reminiscences," p. 38; and Thackeray, diary entry, April 20, 1835, Letters, 1:283. He must also have known Cruikshank well to judge from his widely reproduced portrait of the artist in George Cruikshank's Omnibus 1 (May, 1841): facing p. 1.

4. See Marcus Stone, "Reminiscences," pp. 11-13, and "The Shakespeare Club," Dick. 41 (December 1, 1944-45); 40-41; and Pilgrim, 1:392, n. 3. The Shakespeare Club is not the same as the later Shakespeare Society to which $\mathrm{CD}$ and probably Frank Stone also belonged-see Pilgrim, 2:462, n. 2.

5. See Pilgrim, 4:363, Cruikshank, [?August 22, 1845]; 367, Frank Stone, August 29, 1845; 378, Lady Holland, [?September 10-15, 1845]; 394, Frank Stone, October 1, 1845; 420, Frank Stone, [late October, 1845]; 448-49, n. 5; 451-52, Frank Stone, [December $17,1845]$.

6. Ibid., 377, Maclise, September 11, 1845.

7. Ibid., 413, Talfourd, October 22, 1845, and see 700-701.

8. NL, 2:30, Thompson, June 9, 1847.

9. Ibid., 48, Forster, August 4, 1847.

10. Ibid., 88, Beard, May 10, 1848.

11. Ibid., 30, Thompson, June 9, 1847.

12. See Kitton, DI, pp. 178-79.

13. Ibid., p. 178, and see Pilgrim, 4:546, n. 4, for the Thackeray quote.

14. NL, 2:129, Leech, November 19, 1848.

15. Ibid., 131, November 23, 1848, which is also quoted and discussed in Kitton, $D I$, p. 177, as if only one sketch was involved, but the sense of CD's letter, which refers to Milly being on the chair (cf. the extant sketch, which shows her standing on the floor, fig. 172), suggests an alternative that may not have survived.

16. NL, 2:131, November 23, 1848; however, Kitton, DI, p. 177, prefers the portrayal of the old man in the sketch (fig. 172) to that in the engraving (fig. 173).

17. NL, 2:129, November 21, 1848.

18. Ibid., 131, November 23, 1848.

19. Ibid., 131-32, November 27, 1848.

20. Ibid.

21. Ibid., 134, Leech, December 1, 1848.

22. "The Haunted Man," Athenaeum (December 23, 1848), 1293.

23. See Forster, p. 527.

24. NL, 2:240, Beard, October 18, 1850.

25. Ibid., 286, Bulwer, March 23, 1851, and 303, Bulwer, April 28, 1851; and see Marcus Stone, "Reminiscences," p. 23.

26. NL, 2:405, Wills, August 1, 1852, and 665, Frank Stone, May $24,1855$.

27. Ibid., Frank Stone: 790-91, July 9, 1856; 868, August 9, 1857; 870-71, August 17, 1857; and 872, August 18, 1857.

28. Ibid., 331, Frank Stone, July 20, 1851.

29. Ibid., 339-40, Frank Stone, Auguist 23, 1851.

30. Ibid., 341-42, Austin, September 7, 1851, and see Marcus Stone, "Reminiscences," pp. 25-26, 29-30.

31. See, for example, NL, 2, Frank Stone: 155, May 24, 1849; 214, June 4, 1850; and 435, December 20, 1852.

32. See, for example, NL, 2:52, Forster, September 2, 1847; 169, Forster, [September, 1849]; 466-67, Frank Stone, June 23, 1853; Marcus Stone, "Reminiscences," pp. 5-6, 15; and photograph of the artist, nd, but probably in his last decade, reproduced in Kitton, $D I$, plate 49 , facing p. 153 . 
33. See Kitton, $D I$, p. 178, and NL, 2:466, Frank Stone, June 23, 1853; 444-45, Bradbury and Evans, January 17, 1853; and 3:128-29, Frank Stone, October 19, 1859.

34. NL, 2, Frank Stone: 218, June 4, 1850; 466-67, June 23, 1850; and 851, June 1, 1857.

35. Timber appears in 'The duet "Andante con moto",' according to Marcus Stone, "Reminiscences," p. 14, and the $V+A$ Dickens Catalogue, p. 45, no. F45; the portrait of Alfred Dickens is reproduced in Kitton, $P+P$, l: facing p. 151; the whereabouts of the sketches of Mamie and Kate or any reproductions of them are not known; the portrait of Sydney Dickens, in the New York Public Library Picture Collection, is reproduced in Johnson, Charles Dickens, 2: no. 63 , between viii and 569 , but is mistakenly attributed to Mareus Stone, ef. letter to Forster, nd, partly quoted in Forster, p. 455, n., which contains CD's opinion of Frank Stone's portrayal of his fifth son.

36. See NL, 2:306, Duke of Devonshire, May 9, 1851; 429, Duke of Devonshire, November 11, 1852; 771, Georgina Hogarth, May 5 , 1856; 3:733, Mamie Dickens, August 3, 1869; and chapter 16 below.

37. For example, see NL, 3:137, Forster, November 19, 1859, and 137, Wills, November 19, 1859.

38. Marcus Stone, "Recollections," Dick. 6 (March, 1910): 61, and see chapter 16 below.

\section{Chapter 14: Samuel Palmer}

1. Pilgrim, 4:521 and n. 1, March 16, 1846. See also Palmer, letter to Rev. John Preston Wright, February, 1868, in The Letters of Samuel Palmer, 2:771, which says "The head quarters for information as to prints in General is Messrs Colnaghi's Pall Mall East." Colnaghi's, now on Old Bond Street, has no records on CD's request, which was probably dealt with orally, not in writing.

2. See Palmer, Letters, 2:1101, under Colnaghi, for frequent references to this dealer and his gallery.

3. See A. H. Palmer, ed., The Life and Letters of Samuel Palmer, p. 59, and Lord David Cecil, Visionary and Dreamer, Two Poetic Painters, pp. 8-13.

4. See Ruskin, Works: "Modern Painters," 2:604-5, n., and letter to George Richmond, August 30, [1846], 36-65; and "Samuel Palmer," The Collected Works of Dante Gabriel Rossetti, 2:504.

5. Yet see Edward G. Malins, Samuel Palmer's Italian Honeymoon, pp. 77-78, which notes Palmer's surprise on learning that Stanfield was in Italy at one point without a commission, as he had always thought of the R.A. member as "rolling in riches."

6. See letter to [Dr. Walter Williams], March 18, 1839, in Letters, 1:308.

7. A. H. Palmer, quoted in Kitton, DI, pp. $187-88$.

8. See, for example, letter to Lizzy Linnell, July 8, 1838, Letters, 1:155.

9. Raymond Lister, in his letter of November 9, 1977 to the author, notes the undeniable influence of CD's continental travels on $L D$.

10. See A. H. Palmer, p. 72, quoted in Lister, Samuel Palmer and His Etchings, p. 46, and Lister, Samuel Palmer, A Biography, p. 156.

11. Letter to "Dear Sir," [1846], in the Huntington Library (HM 26326), and quoted here by permission, is also quoted in Paroissien, ed., $P F I$, pp. 248 49 , with regularized punctuation. In Palmer, Letters, 1:439-40, the editor suggests that "Sir" is [John Linnell] and that the date [after March 16, 1846] is the day CD told his publishers he was looking for a new artist to replace Stanfield, whereas Pilgrim, 4:521, n. 1, suggests that the correspondent, if not Linnell, is Edward Calvert, an old friend, and that the date is
March 17 or 18.

12. See Pilgrim, 4:541, Palmer, April 27, 1846, and Paroissien, ed., $P F I$, pp. 9-34, for a useful account of the stages of the composition of $P F I$.

13. Pilgrim, 4:541, Palmer, April 27, 1846, and Paroissien, ed., $P F I$, p. 249 .

14. See Pilgrim, 4:521, Bradbury and Evans, March 16, 1846, and Palmer, letter to [Linnell], [after March 6, 1846], Letters, 1:441.

15. See Palmer, Letters: letter to [Linnell], [?March 29], 1846, 1:440 41 , and letter from Hannah Palmer to Linnell, nd, quoted in 1:442, n. 4; and Pilgrim, 4:521, n. 1.

16. See Pilgrim, 4:503, Evans, February 24, 1846; Kitton, $D I$, p. 183; and Paroissien, ed., PFI, p. 249.

17. See Kitton, $D I$, p. 183 (whose subsequent account of Palmer's work on PFI is reprinted in Lister, Samuel Palmer and His Etchings, pp. 121-24), and see pp. 31, 56 for the artist's other few wood engravings, one of which, 'Harvest under a Waning Moon' (1826), he may have engraved himself unless Welby Sherman did, according to Raymond Lister in his letter of November 9, 1977 to the author.

18. Pilgrim, 4:541, April 27, 1846.

19. See Kitton, $D I$, p. 185.

20. Quoted in Kitton, DI, pp. 185-87.

21. See Lister, Samuel Palmer and His Etchings, pp. $46-47$ and plate 21 .

22. Pilgrim, 4:546, May 13, 1846, also quoted in Kitton, DI, p. 184. There is no evidence that supports the idea that CD saw any of the artist's sketches for PFI.

23. Ibid.

24. See, for example, Robert Browning, letter to Elizabeth Barrett Browning, May 21, 1846, Letters, 2:167, and Swinburne, p. 73.

25. "Pictures from Italy," Dublin Review 21 (September, 1846): 187, which ignores the fact that Palmer also produced an untitled vignette for the title page.

26. See Palmer, Letters, 2:1101, for index entry under Dickens, for works cited or quoted in the artist's correspondence.

Chapter 15: Francis W. Topham

1. Frank W. W. Topham, quoted in Kitton, DI, p. 191.

2. See Eckel, p. 128.

3. See R[obert] E[dmund] G[raves], "Francis William Topham," $D N B, 19: 982-83$; Kitton, $D I$, pp. 189-90; Maas, p. 240; and the portrait of 'Sir Thomas Wentworth and John Pym at Greenwich, 1628,' painted by Topham in conjunction with Cattermole, in the Forster Collection.

4. See "Theatrical Examiner," Examiner (January 31, 1846): 69, and Frank W. W. Topham, quoted in Kitton, DI, pp. 190-91.

5. See NL, 2:98-99, Leech, June 13, 1848; 102, Evans, June 17, 1848; and 103-4, Topham, Jine 18, 1848.

6. See playbill, May 18, 1850, reproduced in Cohen, "Allof-a-Twist,'”. facing p. 336 , and NL, 2:285-86, Bulwer-Lytton, March 23, 1851.

7. See NL, 2:358, Mrs. CD, November 13, 1851, and 415, Forster [September, 1852]; and letter to Mrs. CD, February 12, 1852, $M r$. and Mrs. Charles Dickens: His Letters to Her, p. 163.

8. See NL, 2:128, Leech, November 19, [1848]; Kitton, DI, p. 190; G[raves], "Francis William Topham," p. 982; Ley, Circle, p. 250; and Perugini, "Charles Dickens as a Lover of Art and Artists," p. 165, in which the third watercolor is reproduced. It is possible that these watercolors were done on commission for CD 
but the tone of the evidence above suggests they were done as a gift.

9. Swinburne, pp. 73-74.

10. Shaw, preface to Great Expectations, p. xiii.

11. NL, 2:360-61, Evans, December 2, 1851.

12. Ibid. There seems to be variation in the tints used in different copies of $C H E$. For example, Kitton, $D I$, p. 189 , says that all the borders are light mauve; Eckel, p. 128, says that they seem light gray in vols. 1 and 3, almost mauve in vol. 2; yet in the $C H E$ copy in the Houghton Library, the borders might be termed pale mauve in vols. 1 and 3 but that for vol. 2 is clearly gray, as are the overall tones of the ones reproduced in the Nonesuch edition, which, according to Hatton, Nonesuch Dickensiana, p. 73, were not printed from the original engravings, which have been lost.

13. NL, 2:526, Marcus Stone, December 19, 1853.

14. The Nonesuch edition has reversed the proper order of the frontispieces to $C H E$, vols. 2 and 3 , in reproducing them.

15. See Ley, Circle, p. 250; NL, 2:456, Duke of Devonshire, April 3, 1853, and G[raves], "Francis William Topham," pp. 982-83.

16. "Academy Notes, 1857," Works, 14:130; cf. Bentley, "Dickens and His Illustrators," who finds them "laboured and undistinguished" (p. 221).

\section{Chapter 16: Marcus Stone}

1. See Leavis, p. 364. As Bentley, "Dickens and His Illustrators," p. 223, observes, CD was obviously not displeased by the PRB type of literalism in Marcus Stone's illustrations for $O M F$.

2. For example, see Harvey, pp. 164-65. Leavis asserts that in $O M F$ "the submerged part of that society that needed an artist's interpretation and comment . . . are right outside the ambience and beyond the talents of the Early and Mid-Victorian illustrators" (p. 363), such as Browne presumably.

3. See Marcus Stone, "Reminiscences," pp. 20-21, and "Recollections," Dick. 6 (March, 1910): 62.

4. Quoted in Kitton, $D I$, p. 192, and, in slightly different form, in Marcus Stone, "Reminiscences," p. 30 and in "Recollections," p. 62.

5. NL, 2:526, December 19, 1853, also quoted and discussed in Marcus Stone, "Reminiscences," p. 30 , and reproduced in A. L. Baldry, The Life and Work of Marcus Stone, p. 11.

6. See, for example, NL, 3:137 (2), Forster, November 19, 1859, and Wills, November $19,1859$.

7. See NL, 3:350-51, William Howard Russell, May 19, 1863, and letter to David Roberts, December 26, 1863, partly quoted in Slater, Suzannet Catalogue, p. 274, lot 296; cf. Henry Silver, diary entry for March 11, 1863, quoted in Price, p. 105. For discussion on whether Thackeray's anonymous "A Shabby Genteel Story" was based on the unhappy marriage of Frank Stone or of the author, see Silver, diary entry for January 19, 1859, quoted in Ray, Thackeray, 1:233-34 and 474, n.; cf. Silver, diary entry for May 27, 1863, quoted in Price, p. 105.

8. See Mareus Stone, quoted in Ley, Circle, p. 149, and Kitton, $D I$, p. 203.

9. See unpub. ALS from Marcus Stone to Charles Kent, October 25, 1867, in the Huntington Library (HM 18690), and L. V. Fildes, Luke Fildes, R.A., p. 194, about the artist's hearing problem.

10. For Marcus Stone's portraits of members of CD's family, see the portrait of Kate Dickens Collins that is reproduced and mentioned below in chapter 17 (fig. 188), and another full-length watercolor of her, nd, now at Dickens House; the portrait of Edward Bulwer-Lytton ("Plorn") Dickens, CD's youngest child, which is in the NYPL Picture Collection, and is reproduced in Johnson, Charles Dickens, 2: between pp. viii and 589, no. 64; and
Ley, Circle, p. 149, also mentions his watercolor of Gad's Hill. Marcus Stone is mentioned for his skills in croquet and billiards in the August 19, 1865 and the August 26, 1865 issues of the Gad's Hill Gazette and for other reasons in the issues of January 14, 186a, July 29,1865 , and January 27, 1866 (which mentions his portrait of Kate), copies of which are in the Berg and Gimbel collections, among others.

11. See Marcus Stone, quoted in Kitton, $D I$, p. 203, and in Ley, Circle, p. 148.

12. Quoted in Ley, Circle, p. 149.

13. See Marcus Stone, "Reminiscences," pp. 3-4, and NL, 3:138, Longman, November 28, 1859.

14. See NL, 3:138, Longman, November 28, 1859, for example.

15. According to Kitton, DI, p. 195.

16. Fraser, "The Illustrators of Dickens, IV: Marcus Stone," Dick. 2 (October, 1906): 264, notes that the man following the monk-guide in In the Catacombs (PFI in AN, 387) is supposed to be CD. For further discussion of Marcus Stone's illustrations for $G E$, see Ira E. Simmons, Jr., Hogarthian Elements in the Illustrations of Marcus Stone and S. L. Fildes, pp. 67-166, and Kaufman, pp. 117-44. Leavis is misleading when she states that CD's perception that illustrations were now less necessary made him "risk publishing Great Expectations without any pictures" (p. 361), as it first appeared in CD's unillustrated magazine, All the Year Round.

17. Browne, letter to Robert Young, nd, quoted in Kitton, $D I$, pp. 112-13.

18. See Ley, Circle, pp. 149-50; cf. Kitton, $D I$, p. 195, who speculates that in giving Stone small commissions, CD was testing his artistic capabilities, as well as helping his old friend's son, without any intention of permanently "ousting" Browne. See also the relevant discussion in chapter 4 above.

19. Quoted in Kitton, $D I$, p. 196.

20. NL, 3:380, Marcus Stone, February 23, 1864.

21. Swinburne, p. 60 .

22. NL, 3:380, February 23, 1864.

23. Ibid.

24. Ibid.

25. See Marcus Stone and CD quoted, with slight differences but to the same effect, in Kitton, $D I$, pp. 196-97, and in [eds.], "Mr. Marcus Stone, R. A. and Charles Dickens," Dick. 8 (August, 1912): 217.

26. NL, 3:380, February 23, 1864.

27. See NL, 3:380, Forster, February 25, 1864, and unpub. ALS, CD to Marcus Stone, February 29, 1864, in the Morgan Library; cf. Leavis, who notes instead "the poverty of his comprehensive cover-design, which Dickens's other artists made a valuable accessory to the novels" (p. 360).

28. As Kitton, $D I$, pp. 195-96, notes, at the beginning of $O M F$, CD was about four numbers ahead but finally was just keeping pace with each monthly number, no doubt due partly to his extended absences, noted in his letters of July 7,1864 , November 17,1864 , and September 2, 1865, quoted in Kaufman, pp. 423, 426, 430.

29. Marcus Stone, quoted in "Mr. Marcus Stone, R. A. and Charles Dickens," p. 217.

30. See Kitton, $D I$, p. 197 , and, for example, letters from $C D$ to Marcus Stone, July 7, 1864, November 17, 1864, January 10, 1865, February 15, 1865, April 13, 1865, August 29, 1865, September 2, 1865 , and September 13, 1865, quoted in Kaufman, pp. 427-30.

31. See, for example, letters from CD to Marcus Stone, July 7, 1864 , January 10, 1865, and April 13,1865, quoted in Kaufman, pp. $423-426,427$, and NL, 3:435-36, Marcus Stone, September 13, 1865 , all of which qualify Stone's subsequent assertion of complete 
independence in "Mr. Marcus Stone, R. A. and Charles Dickens," p. 217, as well as Harvey, who states CD "let the artist take whatever subject he liked" (p. 165).

32. Letter from CD to Marcus Stone, April 22, 1865, quoted in Kaufman, p. 427; cf. Kitton, $D I$, who asserts, doubtless on the basis of his interview with the artist, that "in no instance did the novelist question the propriety of his selection as with his earlier artists" (p. 197).

33. See, for example, letters from CD to Marcus Stone: July 7, 1864, October 4, 1864, November 17, 1864, February 24, 1865, and April 22, 1865, quoted in Kaufman, pp. 423-27; unpub. ALSs, CD to Marcus Stone, May 24, 1864, June 18, 1864, August 6, 1864, October 21, 1864, and September 22, 1865, in the Morgan Library; and see also Kitton, DI, p. 197.

34. Kitton, DI, p. 197 ; cf. Harvey, whose assertion that CD "even neglected to inspect the sketches before the illustrations were engraved" (p. 165) is misleading in its implications of the author's indifference.

35. See, for example, unpub. ALS, CD to Marcus Stone, June 14, 1864, in the Morgan Library, and letters from CD to Marcus Stone, July 7, 1864, quoted in Kaufman, p. 423.

36. See letters from CD to Marcus Stone, July 7, 1864 and November 17, 1864, quoted in Kaufman, pp. 423, 426.

37. See Marcus Stone in Kitton, DI, p. 197; cf. Harvey, who utilizes this statement to assert without further qualification that "When Dickens first engaged Marcus Stone, however, he expected him to produce illustrations in the manner of Browne, and when he found that artist incapable of doing so, he took little interest in his work, and little interest in illustration generally . and never took Stone seriously as a collaborator-as, at every stage, he had taken Browne" (pp. 164-65). The evidence already cited above appears to undermine this overstatement.

38. NL, 3:380, February 23, 1864, which seems an obvious misdating as the bulk of this letter concerns the wrapper that appeared in May, whereas the first portrayal of Jenny did not appear until October; cf. the September 29, 1864 date of the letter in the Morgan Library, quoted in Kaufman, p. 423. Leavis feels that Stone missed "all the weirdness Dickens wanted in the doll's dressmaker" (p. 363), whereas Henry James, "The Limitations of Dickens," Nation 1 (December 21, 1865): 787, unaccountably links Jenny with CD's other "pathetic" characters, like Smike, Nell, and Paul Dombey, who carry on the author's "sentimental" business.

39. NL, 3:380, February 23, 1864, which is another obvious misdating as the ALS in the Morgan Library is dated May 5, 1864, and, in any case, the subject did not appear until July. Bentley, "Dickens and His Illustrators," notes, in this "the worst Dickens illustration ever perpetrated" (p. 216), that the carriage has only three wheels, which, according to the artist in Kitton, $D I$, p. 201, was the fault of the engraver.

40. See NL, 3:380, Forster, February 25, 1864, and Kitton, DI, pp. 199-200.

41. See Kitton, $D I$, pp. 198-99.

42. See unpub. ALS, CD to Marcus Stone, July 19, 1865, in the Morgan Library, and CD, quoted by Marcus Stone, in Kitton, DI, p. 197 .

43. See letter from CD to Marcus Stone, September 2, 1865, quoted in Kaufman, p. 430, and NL, 3:435-36, Marcus Stone, September 13, 1865 .

44. See unpub. ALS, CD to Marcus Stone, February 29, 1864, in the Morgan Library; the copy of $O M F$ containing the artist's original drawings in the Berg Collection; and Kitton, DI, pp. 200-201, which notes Stone's own discontent on this score and his subsequent duplication of his drawings on wood by photography, a process, described by Muir, pp. 7-8, that he claims to have brought "into repute."

45. Waugh, Nonesuch Dickensiana, p. 102 , who also quotes Hatton and Cleaver, pp. $347-48$, to the same effect, and see relevant comment by Lynton Lamb, p. 41 , quoted also in Leavis, p. 360, in her discussion of Browne's decline.

46. See Marcus Stone, "Recollections," Dick. 6:64 and [eds.] "Mr. Marcus Stone, R. A. and Charles Dickens," Dick. 8:216.

47. Marcus Stone in Kitton, DI, p. 198.

48. See Baldry, pp. 14-15; cf. Leavis, who feels he "threw away his opportunities" (p. 364) on this work, and pp. 121, 256 n. 260.

49. See Waugh, Nonesuch Dickensiana, pp. 46-47; Sitwell, Narrative Pictures, p. 65; and Lytton Strachey, essay on June 26, 1916, in Lytton Strachey by Himself, ed. Michael Holroyd (New York: Holt, Rinehart \& Winston, [1971]), pp. 153-54.

50. Potter, entry for June 10, 1882, Journal, p. 17.

51. Marcus Stone in Kitton, DI, p. 198, and see Fildes, pp. 29, 71.

\section{Chapter 17: Charles Collins}

1. NL, 3:159, de Cerjat, May 3, 1860.

2. See Autobiographical Notes of the Life of William Bell Scott, 1:285; "James Smetham and C. Allston Collins," p. 283; and unpub. ALS, Collins to Hunt, July 16, 1859, in the UCLA copy of Forster, $3: 2$, yet see also W[illiam] Holman Hunt, Pre-Raphaelitism and the Pre-Raphaelite Brotherhood, 1:215 (hereafter cited as Hunt, Pre-Raphaelitism)

3. For further details of Collins's own complex relations with the PRB, see Hunt, Pre-Raphaelitism, 1:189-91; Robert Ashley, Wilkie Collins, p. 24; Nuel P. Davis, The Life of Wilkie Collins, pp. 53-54; and Mary Lutyens, ed. "Letters from Sir John Everett Millais, Bart., P.R.A. (1829-1896) and William Holman Hunt, O.M. (1827-1910) in the Henry E. Huntington Library, San Marino, California," in The Forty-Fourth Volume of the Walpole Society, 1972-1974 (University Press, Glasgow, for the Walpole Society, 1974), (hereafter cited as Lutyens, Walpole Society) called to my attention by Lady Dione Gibson, which reproduces a pen and ink caricature of Collins in 1853 facing p. 14, plate 1(b) and deseribes it on p. 11. The Ashmolean has two profile sketches of Collins by Millais, one inscribed "whilst playing a rubber, Oet. 3, 1850" (Scrapbook 145 [4m], nos. 13 and 55). CD's notorious Podsnappian invective against the PRB, consistent with his previous criticisms of religious art and of nostalgia for the "good old days," as Angus Wilson, The World of Charles Dickens, also observes, p. 191, may have been retribution as well for Rossetti's harsh eriticism of "Frank Stone: 'Sympathy' (1850)," Works, 2:490. If so, this makes likely the suggestion by Graham Reynolds, "Charles Dickens and the World of Art," p. 423, that Stone, the art editor of the Athenaeum, was the anonymous author of "Royal Academy," Athenaeum (June 1, 1850): 590-91, which criticizes the PRB in general and Millais' canvas in particular as did CD's "New Lamps for Old Ones," Household Words 1 (June 15, 1850): 265-67. CD's subsequent friendship with Millais and Hunt is noted in the discussion and n. 9 below.

4. See Ruskin, "Academy Notes, 1855," Works, 14:29; Forster, p. 686; Hunt, Pre-Raphaelitism, 2:249-50; and Lutyens, Walpole Society, p. 6.

5. See NL, 2:871, Wilkie Collins, August 17, 1857; the program for The Frozen Deep, August 22, 1857, reproduced in Kitton, $P+P$, 2:119; the drawing of Georgina Hogarth, reproduced in Dick. 50 (March 1954): 50; and Davis, p. 218.

6. See Forster, p. 686, and NL, 3:36, Wills, August 8, 1858; 105, Hawes, June 6, 1859; and 193, Hogarth, November 28, 1860; cf. 137-38, Charles Collins, November 19, 1859, and Davis, p. 219. Collins's pieces for All the Year Round were collected in The 
Eye-Witness and His Evidence about Many Wonderful Things (London: Sampson Low \& Son, 1860).

7. See Johnson, Charles Dickens, 2:712-13.

8. See Ashley, p. 24; Davis, pp. 28-29, 219; and Lutyens, Walpole Society, p. 11, who all rely on the description of Collins in Hunt, Pre-Raphaelitism, 1:192-93, 212; and Annie Fields (Mrs. James T.), Memories of a Hostess, p. 190, who noted that Kate's pure coloring made her resemble one of Stothard's pictures.

9. It is unclear whether they posed separately, as Reynolds, "CD and the World of Art," p. 425, and the $V+A$ Dickens Catalogue, p. 9, no. b 28, maintain, or together, as Davis, p. 219, asserts. For further details of CD's relations with Millais, see Ley, Circle, pp. 279-80, and with other PRB members, such as Hunt, who consulted him about the price of 'The Finding of the Saviour in the Temple' the same year he was Charles Collins's best man at his wedding to Kate, see $V+A$ Dickens Catalogue, p. 38, no. f 10; and Ford, Dickens and His Readers, pp. 76-77.

10. See Gladys Storey, Dickens and Daughter, pp. 104, 212.

11. See NL, 3:105, Hawes, June 6, 1859, and 159-60, de Cerjat, May $3,1860$.

12. See Kenneth Robinson, Wilkie Collins, A Biography (London: Bodley Head, 1951), pp. 125-26; unpub. ALS, Collins to Pigott, March 29, 1860, at UCLA; and Davis, p. 219, for details of Kate's depressed behavior before, as well as on, her wedding day.

13. This family legend was volunteered by Mrs. Stuart Dickens McHugh in a letter of April 21, 1977 to the author, and is here utilized by permission. Davis, pp. 28-29, reports that the handsome Collins was so attractive to painters that he studied ways to make himself less conspicuous.

14. Quoted in Storey, pp. 105-6, and widely elsewhere; and see Hunt, Pre-Raphaelitism, 2:168. (According to Mrs. McHugh, in a letter of May 5, 1977 to the author, Kate was apparently called "Kitty" by everyone except her father who preferred Katey, spelled with a " $y$ "; ef. the usual practice of CD's biographers.)

15. Letter from CD, quoted in Davis, p. 227.

16. See NL, 3:760, Fields, January 14, 1870, and for further details about the Collinses' friendship with the Thackerays, as well as its effect on the estranged CD, over the Yates-Garrick Club controversy, mentioned in the Appendix and $n .12$ below, see Ray, Thackeray, 2:398, 416, 427; Kate Perugini, "Thackeray and My Father," p. 215; unpub. ALS, Charles Collins to Wilkie Collins, February 17, 1864, in the Berg Collection; and Blanche Cornish, "An Impression of Thackeray in His Last Years," pp. 24-25.

17. See, for example, Forster, p. 686; and NL, 3:284, Wills, January 29, 1862; 295, Leech, May 28, 1862; and 362, Wills, September 14, 1863. That CD may have also edited the Cruise on Wheels, as he often did Collins's pieces for All the Year Round, according to Davis, p. 219, is suggested by "Cruise on Wheels," Saturday Review 14 (October 4, 1862), which remarks that the author's humor "forcibly recalls $\mathrm{Mr}$. Dickens . . . frequently exaggerated and overdone" (p. 414).

18. NL, 3:312, Forster, October 22, 1862.

19. See, for example, NL, 3:401, de Cerjat, October 25, 1864; 446, de Cerjat, November 30, 1865; 513, Elliot, March 4, 1867; and unpub. ALS, CD to de Cerjat, January 4, 1869, in the Berg Collection.

20. See, for example, NL, 3:658, Millais, July 19, 1868.

21. NL, 3:742, Chapman, September 24, 1869.

22. NL, 3:748, Chapman, October 29, 1869.

23. See Kitton, $D I$, p. 205.

24. On the subject of the wrapper alterations, see discussion and n. 37 below.
25. Collins, letter to Augustin Daly, May 4, 1871, quoted in Joseph F. Daly, The Life of Augustin Daly, pp. 107-8, and Charles Allston Collins, "The Mystery of Edwin Drood," Dick. 15 (October, 1919): 196, and widely elsewhere.

26. Quoted in Fildes, “The Mysteries of Edwin Drood," p. 373 (hereafter cited as Fildes, "Mysteries of $E D$ "). For other useful discussions of the wrapper, see C. F. Lehmann-Haupt, "New Facts Concerning 'Edwin Drood,'” Dick. 25 (Summer, 1929): 168-70; Richard M. Baker, The Drood Murder Case, pp. 159-64; Felix Aylmer, The Drood Case, pp. 77, 164; Margaret Cardwell, ed., The Mystery of Edwin Drood by CD, pp. 241-42 (hereafter cited as Cardwell, ed., $E D$ ); and see other discussions cited in $\mathrm{n} .37$ below.

27. Cardwell, ed., $E D$, p. 242 , n. 1, notes the similar device on the wrapper for $M C$ but its use here is a far more pointed visual pun.

28. Collins, letter to Augustin Daly, May 4, 1871, quoted in Daly, p. 108.

29. Ibid.

30. Ibid:, and Kate [Collins] Perugini, "Edwin Drood' and the Last Days of Charles Dickens," pp. 643-46.

31. See Collins, letter to Augustin Daly, quoted in Daly, p. 107; Fildes, "Mysteries of $E D$," p. 373; and unpub. ALS from Fildes to Lord Curzon, May 6, 1912, in the Forster Collection.

32. See Cohen, "Dickens's Artists and Artistry in The Mystery of Edwin Drood," pp. 126-45.

33. Collins, letter, quoted in Daly, p. 108.

34. Ibid.

35. Ibid., pp. 107-8.

36. Ibid.

37. None of the written or published evidence provided by CD-NL, 3:760, Fields, January 14, 1870, and unpub. ALS, Chapman, January 24, 1870, in the Elkins Collection; Fildes - "Mysteries of $E D, "$ p. 373; letter to Hughes, October 25, 1890, quoted in William R. Hughes, A Week's Tramp in Dickens-land, p. 129; letter to G. F. Gadd, May 2, 1904, quoted in Laurence Gadd, "Sir Luke Fildes and Edwin Drood," Dick. 23 (Summer, 1927): 159-60; Kate [Collins] Perugini- "ED and the Last Days of CD," pp. 643-46; CD's son-Hughes, p. 140n.; or Forster-p. 810, suggests that anyone but Collins had anything to do with the final published wrapper design. Moreover, unpub. ALSs of Sir Paul Fildes to Dr. Margaret Cardwell, August 27, 1970 and David Davin, September 30 and December 29, 1970, in the Forster Collection (which together with all the unpub. ALSs to and from Fildes cited below were called to the author's attention by Anthony Burton) repeatedly insist that Fildes did not touch up or alter Collins's "scribble." Yet since $E D$, debate periodically rages as to whether or not Fildes made the changes between Collins's wrapper sketch and the published design: see Lehmann-Haupt, "New Facts Concerning 'ED'," pp. 165-75; cf. S. M. Ellis, "Edurin Drood," Dick. 25 (Autumn, 1929): 323, and Percy T. Carden, "The Drood Case-A Correction and New Discovery," Dick. 31 (Winter, 1934-35): 151-52; cf. Spielmann, "The Drood Case," Dick. 31 (Summer, 1935): 233, and Lehmann-Haupt, "Studies on 'Edwin Drood," Dick. 31 (Autumn, 1935): 299-300; Cardwell, ed., ED, pp. xxi and n. 6 and 241 and $n$. 1, also assumes that Fildes revised Collins's design. It is possible that the $E D$ principals were being protective of Collins in his and his wife's lifetime, which may explain why Fildes's "claims," which contradict his published testimony, were made verbally but not mentioned by Spielmann, nor utilized by Lehmann-Haupt, together with Lady Henry Dickens's less convincing assertions, until 1935, more than a half-century after $E D$ 's publication. Moreover, Spielmann seems to have confused a proposed illustration for the fourth $E D$ number, which occasioned debate between Fildes and CD, with one of the wrapper vignettes (as is discussed 
further in chapter 18 and $n .16$ below), which is his main "evidence" that the later illustrator altered the work of the first. But all this concealment, of a situation that would have been wholly understandable, seems unnecessary and unlikely. The evidence, though it is not conclusive, suggests that Collins executed the wrapper design as published.

38. See NL, 3:748, Chapman, October 29, 1869; 754, Forster, December 22, 1869; and 760, Fields, January 14, 1870; and The Graphic, 1 (December 11, 1869): 26; cf. The Graphic (December 4, 1869): 2, which notes that Collins, who was to provide all the $E D$ illustrations, will provide only the wrapper.

39. See Cardwell, ed., $E D$, p. 240 and n. 2; cf. xxi, which notes that the first number was finished by the third week in October (which makes it certain that the second number was completed sometime in November, as proofs for both were ready by December 1), long before Collins withdrew from $E D$ at the end of November. Moreover, Collins's alterations in the so-called Cathedral group sketches, discussed below, appear to be based on the text in some finished form, unless CD corrected them verbally, which seems less likely.

40. See NL, 3:725, Eytinge, May 14, 1869, and 775, Bowring, May 5, 1870; James T. Fields, Yesterday with Authors, pp. 202-3; Dolby, pp. 419-20; Gustave Doré and Blanchard Jerrold, Landon: A Pilgrimage (London: Grant \& Co, 1872), pp. 141-50; and LehmannHaupt, "New Facts Concerning 'ED,'" p. 175, who suggests that Collins was trying to portray different scenes, not different versions of the same one.

41. This unfinished sketch or sheet of studies was previously noted by Lehmann-Haupt, "New Facts Concerning 'ED,'” p. 168, Aylmer, pp. 18-20 (who imperfectly recalled that Jasper was seated at a table), and Cardwell, ed., ED, p. 238 and n. 1, and "A Newly-Discovered Version of a Collins Sketch for Edwin Drood," Dick. 70 (January, 1974):31-34 (hereafter cited as Cardwell, "Collins's Sketches for Edwin Drood: A Postscript," pp. 45-46; the further discussed by Cardwell in "Collins's Sketches for Edwin Drood: A Postscript," Dick. 71 (January, 1975):45, before which time the owner had made it known to the author.

42. These "Cathedral" group sketches are reproduced and discussed in Cardwell, "Collins sketch for $E D$," pp. 31-34, and in "Collins's sketches for Edwin Drood: A Postscript," pp. 45-46; the longer known pair are further discussed in Lehmann-Haupt, "New Facts Concerning 'ED,'” pp. 173-75, and Aylmer, in reproducing them facing p. 87, suggests different identities in his titles.

43. See Cardwell, ed., ED, pp. 240-41, and see Simmons, pp. $168,179-81,186-90$, for discussions of 'Mr. Crisparkle is overpaid' (X, facing p. 107), 'Durdles cautions Mr. Sapsea against boasting' (XII, facing p. 129), and 'Under the Trees' (III, facing p. 28).

44. Collins's dinner party scenes are reproduced and discussed in Lehmann-Haupt, "New Facts. Concerning 'ED," pp. 172-73, and Simmons, pp. 198-96, discusses Fildes's 'At the Piano.'

45. See NL, 3:137, Collins, November 19, 1859; Forster, p. 686; W[ilkie] C[ollins], "Charles Allston Collins," DNB, 4:822; and example provided in Gaunt, p. 49; cf. Hunt, Pre-Raphaelitism, 2:250.

46. NL, 3:753, Chapman, November 28, 1869.

47. See discussion and $n$. 3 above and chapter 18 below.

48. Forster, p. 686.

49. See Annie [Mrs. James T.] Fields, MS diary entry for August 30, [1870], np, in the Massachusetts Historical Society, partly quoted in Arthur A. Adrian, "A Note on the Dickens-Collins Friendship," p. 212.

50. Fechter, quoted in Adrian "Note on the Dickens-Coliins Friendship," p. 212, and in Fielding, "Dickens and Wilkie Collins: A Reply," Dick. 49 (June, 1953): 134-35.
51. Davis, pp. 223, 257-59, 265, supplies further details about this strain, which peaked in 1868 , but unaccountably fails to mention in his text, notes, or bibliography the added evidence published three years previously in Adrian, "Note on the Dickens-Collins Friendship," pp. 212-13, repeated in Fielding, "Dickens and Wilkie Collins," pp. 134-35, which effectively demolished the assertion in Ashley, p. 79, that no estrangement existed, and further helped to explain, no doubt, why Forster mentioned Wilkie Collins as rarely as possible in his biography of $C D$, as is noted by Earle Davis, "Charles Dickens and Wilkie Collins," Municipal University of Wichita Bulletin 16 (June, 1945): 8-9.

52. "Charles Dickens's Study," The Graphic 2 (December 25, 1870): 14, quoted in Forster, pp. 654-55n.

53. See Fechter's report and Fields's account of it, partly quoted in Adrian, "Note on the Dickens-Collins Friendship," p. 212, and Georgina Hogarth and the Dickens Circle, p. 146.

54. See $D N B, 4: 822$, and Davis, p. 273, for an account of Collins's sad death; cf. Adrian, "Note on the Dickens-Collins Friendship," p. 212, who mistakenly dates it on April 9, 1874 rather than 1873; Hunt, Pre-Raphaelitism, 2:249-50, who mentions and reproduces his deathbed sketch of him; and letter from Georgina Hogarth to Annie Fields, June 9, 1894, quoted in Adrian, pp. 212-13.

\section{Chapter 18: Luke Fildes}

1. NL, 3:753, Chapman, November 28, 1869.

2. See T[ancred] Borenius, "Sir (Samuel) Luke Fildes," $D N B$ $1922-30,2045$, for a summary of the artist's life, and Bentley, "Dickens and His Illustrators," facing p. 196, no. 4, which reproduces another good likeness of the artist by Furniss. The roles of Millais and Frith are discussed below.

3. See Fildes, quoted in Kitton, $D I$, p. 207, and White, p. 93.

4. See Hugo, quoted in Fildes, Luke Fildes, R.A., pp. 10-11; The Graphic 119 (February 18, 1928): 257, which reproduces the 1869 engraving together with a photograph of a comparable Embankment group in 1928; and The Graphic 1 (December 4, 1869): 2; cf. The Graphic (December 11, 1869): 26, an irony also noted by Cardwell, ed., $E D$, p. xxii.

5. See letter from W. H. Chambers to Howard Duffield, November 28, 1927, quoted in Cardwell, ed., $E D$, p. xxi; Fildes, Luke Fildes, R.A., p. 7, who notes Millais's early influence on Fildes; Maas, pp. 237-38; and W. S. Gilbert, "Anglicized Utopia," The Bab Ballads (London: Macmillan, 1964), pp. 497-98, which mentions CD and both Millais and Fildes, by then equally well known.

6. Van Gogh, letter to Theo, [ca. Christmas 1882], Complete Letters, 1:509, and see letters to Theo, [January 7, 1882], nd, and November 1 [?], 1:302, 382, 477.

7. See Kitton, DI, pp. 207-8; Fildes, Luke Fildes, R.A., p. 13; and letter from Chambers to Duffield, November 28, 1927, quoted in Cardwell, ed., $E D$, p. xxii.

8. NL, 3:760-61, Fildes, January 16, 1870; NL remarks that the probable date is February, which is noted and tacitly accepted in Cardwell, ed., $E D$, p. xxiv, n. 1; cf.' Cardwell, "Dickens's Correspondence with the Illustrator of Edwin Drood," Dick. 69 (January, 1973): 42-43, which indicates that the ALS in the Gimbel Collection is dated December 16, 1869.

9. NL, 3:760, Fields, January 14, 1870, and see Kitton, DI, pp. 207-8, who says that the artist submitted more than one sketch but does not indicate their subjects.

10. Fildes, letter to Henry Woods, January 17, 1870, quoted in Fildes, Luke Fildes, R.A., p. 14, and see p. xiv for information about Woods, R.A.

11. See Fildes, quoted in Kitton, DI, p. 208 and $P+P, 2: 184-85$. 
12. See Fildes, in Kitton, DI, p. 209.

13. See Kitton, $D I$, pp. 200-201, 213, for mixed results, and Fildes, Luke Fildes, R.A., p. 13.

14. See Fildes, quoted in Kitton, $D I$, pp. $208-9$ and $P+P$, 2:184-85, and unpub. ALS, CD to Chapman, January 24, 1870, in the Elkins Collection.

15. See Cohen, "Dickens's Artists and Artistry in $E D$," pp. 126-45, on the artists in $E D$, and Thomson, The Life and Works of Luke Fildes, p. 28, (hereafter cited as Thomson, Fildes), and Fildes, Luke Fildes, R.A., p. 1, on Fildes's name.

16. See unpub. ALS, CD to Chapman, January 24, 1870, in the Elkins Collection and n. 37 in chapter 17 above. The only evidence that Fildes altered Collins's cover design in any way comes from Lady Henry Dickens's assertion to Lehmann-Haupt, quoted in "New Facts Concerning 'ED," p. 165, and "Studies on 'ED," pp. 299-300, and Spielmann, "The Drood Case," p. 233, who says Fildes often told him that he redrew Collins's sketch, particularly the lowest bottom vignette, which $C D$ thought should be dark until the artist pointed out that the figures would then not be seen, but as substantially the same interchange is related by Spielmann in a Graphic article, quoted in Kitton, $P+P, 2: 184$, in regard to a scene from the text (XIV, 162) discussed below and in $n .28$, it seems clear that Spielmann's memory, so long after the publication of $E D$, is understandably confused.

17. See unpub. ALSs, CD to Fildes, February 19, March 13, April 27, and June 7, 1870, in the Gimbel Collection, which are paraphrased and discussed in Cardwell, “Dickens's Correspondence with the Illustrator of $E D, "$ pp. $42-43$, and Fildes, quoted in Thomson, Fildes, pp. 27-28; Kitton, DI, pp. 211-12; letter from Chambers to Duffield, November 28, 1927, quoted in Cardwell, ed., $E D$, p. 239; and n. 21 below.

18. See Kitton, DI, p. 211.

19. See ibid., pp. 211-12; modified by Fildes, letter to Hughes, October 25, 1890, quoted in Hughes, p. 129; and Simmons, p. 168, who expresses surprise that architecture is not as prominent in the illustrations as it is in the text.

20. Fildes, Luke Fildes, R.A., p. 15, says CD retained this right; cf. Kitton, $D I$, who maintains that $C D$ "did not consider it essential that preliminary sketches should be submitted to him" (p. 212).

21. See evidence provided in Cardwell, ed., $E D$, pp. xxii-xxvii, that Fildes clearly had access to the proofs of the first two numbers, ready on December 1, 1869 , but probably not subsequently; ef. Kitton, DI, pp. 209-10, who asserts that the artist received the proof-sheets of each number.

22. CD, letter, April 16, 1870, quoted in Fildes, Luke Fildes, R.A., p. 15.

23. See Kitton, $D I$, p. 213.

24. Studies for Edwin, Jasper, and Mr. Grewgious, now in the Gimbel Collection, are reproduced in Kitton, $D I$, plates $63-65$, facing pp. 208, 210, 215; and Fildes's emphasis on hands is also noted by Aylmer, p. 21, and Fildes, Luke Fildes, R.A., who feels that these studies and sketches have "a bravura and a beauty of draughtsmanship which the illustrations in their final form sometimes lack" (p. 118).

25. See Alice Meynell, "How Edwin Drood Was Illustrated," p. 525, and Kitton, $D I$, p. 211. Yet Leavis feels that in the artist's dependence on "photographic naturalism" (p. 364), Fildes's characters are insufficiently distinguished from one another and are less memorable; cf. Lewis Carroll, letter to Fildes, July 2, 1877, quoted in Fildes, Luke Fildes, R.A.: "I fancy I see in these pictures almost unlimited power of drawing, and wonderful variety (quite avoiding the painful family likeness that spoils so many of Cruikshank's pictures)" (pp. 43-44).
26. See letter from Lockett Agnew to Fildes, March 16, 1897, quoted in Fildes, Luke Fildes, R.A., p. 144, and Fildes, quoted in Kitton, $D I$, p. 216, and interviewed in Hughes, p. 141.

27. See NL, 3:766, Chapman, March 14, 1870, and unpub. ALS, Sir Paul Fildes to David Davin, September 30, 1970, in the Forster Collection, who says that the illustrations for the first two chapters were engraved by the Dalziels utilizing the phototransfer process -mentioned by Marcus Stone in Kitton, DI, 200-201, and Fildes, Luke Fildes, R.A., p. 15-but they forgot to reverse the prism and thereby reversed the designs, and that the next pair of drawings were engraved by an "anonymous hack"; cf. Kitton, DI, pp. 212-13, who erroneously claims that all but the first two illustrations are signed by $C$. Roberts, but whose assertion that the published illustrations suffer from technical problems caused by the phototransfer process seems valid when they are compared to the original drawings, sketches, and studies, now in the Gimbel Collection.

28. The details in the remainder of the paragraph below are based on Meynell, pp. 526-27; Fildes, "Mysteries of ED," p. 373; letter to Gadd, May 2, 1904, quoted in Gadd, "Sir Luke Fildes and $E D$," pp. 159-60; unpub. ALS to Lord Curzon, May 6, 1912, in the Forster Collection; Kitton, DI, pp. 213-14; Fildes, Luke Fildes, R.A., p. 15; and see n. 16 above, which asserts that Spielmann, "The Drood Case," p. 233, really refers to this scene, not the bottom wrapper vignette.

29. Kitton, $D I$, p. 211 , says that CD subsequently let the artist select the subjects, and Fildes, Luke Fildes, R.A., p. 15, maintains that the artist always had the right to choose the subjects but the evidence is to the contrary in the unpub. ALS, CD to Fildes, April 27, 1870, discussed in Cardwell, "Dickens's Correspondence with the Illustrator of $E D, " \mathrm{pp} .42-43$.

30. The unutilized Rochester sketches, the first two of which are in the Gimbel Collection, are reproduced in Meynell, pp. 526-28; and see Kitton, $D I$, p. 216, who also notes that the signature on the vignette reads J. L. Fildes instead of S. L. Fildes, doubtless the engraver's error.

31. See interview with Fildes, in Hughes, p. 140; CD's concern seems oddly premature, but perhaps he had intimations of his approaching death.

32. See Collins, letter to Augustin Daly, May 4, 1871, quoted in Daly, p. 108, and Forster, p. 808.

33. Quoted in Hughes, p. 140 and, with variations, in Kitton, DI, p. 214.

34. Fildes, letter to Chambers, June 14, 1870, quoted in Gadd, "Sir Luke Fildes and $E$ dwin Drood," p. 159, and unpub. ALS, CD to Fildes, June 7, 1870, noted in Cardwell, "Dickens's Correspondence with the Illustrator of $E D, "$ p. 43; cf. Waugh, Nonesuch Dickensiana, p. 51, who says that Fildes arrived at Gad's Hill on the day of CD's death, and Kitton, $D I$, p. 214, who says that CD planned to travel back to Kent with Fildes.

35. Simmons, p. 186, also makes the same point about this illustration but Leavis, p. 364, summarized in $n$. 25 above, feels the problem is applicable to all of Fildes's work for $E D$.

36. Cf. Simmons, pp. 196-98, and Wilson, p. 283, who regard this scene more highly.

37. See n. 12 above.

38. See Simmons, p. 190, for more detailed discussion of this scene.

39. See Cardwell, "Dickens's Correspondence with the Illustrator of $E D, "$ pp. $42-43$.

40. Simmons, pp. 181-84, discusses more appreciatively Fildes's portrayal of Grewgious and Lobley, if not Rosa, but says nothing about Tartar. 
41. Simmons, pp. 173-79, 191-93, discusses Fildes's use of lighting in these and other scenes, and his use of hands is noted by Aylmer, p. 21, and Fildes, Luke Fildes, R.A., p. 118.

42. See Kitton, $D I$, p. 215.

43. The engraving appears in The Graphic 2 (December 25, 1870): facing p. 14; a sketch, given to Kate Collins Peruginj by the artist-see eds., "When Found," Dick. 13 (June, 1917): 143, and reproduced in Meynell, p. 528-is in the Gimbel Collection; and a pencil and wash drawing is in the Suzannet Collection. The engraving is further discussed by Fildes, quoted in Thomson, Fildes, p. 28; in Kitton, DI, p. 215, and by Angus Wilson, who says it "was not, as we have come to think, a sentimentalism, but a fitting tribute to the void left by this untimely parting" (The World of Charles Dickens, p. 297).

44. This influence is suggested by Ronald Pickvance in his introduction to English Influences on Van Gogh. Exhibition Catalogue (London, 1974-75), p. 7, which would seem to be supported by Van Gogh, letters to Theo, [1882], and to Reynard, [end February-beg. March, 1883] and [March, 1883], Complete Letters, 1:424, and 3:367, 374.

45. "Charles Dickens's Study," The Graphic 2 (December 25, 1870): 14, quoted in Forster, pp. 654-55n.

46. See Fildes, Luke Fildes, R. A., p. 17; and unpub. ALSs from Collins to Fildes-June 28, 1870, September 14, 1871, September 18, 1871, and March 19, 1872-in the Forster Collection, more interesting for their kindly tone than their contents. Fildes also illustrated Trollope's The Way We Live Now (London: Chapman and Hall, 1875).

47. See Fildes, Luke Fildes, R.A., pp. 19, 21-22.

48. See ibid., pp. 48,56 ; the 1880 portrait of Kate Collins Perugini reproduced in Storey, facing p. 14; the 1920 portrait of Henry Fielding Dickens, K.C., mentioned in Dick. 16 (July 1920), 118; and unpub. ALSs, between Fildes and "Kitty" (Kate Collins Perugini), November 18, 1906, November 29, 1910, and March 12, [?], in the Forster Collection.

49. See Fildes, Luke Fildes, R.A., p. 16. The 'Grave in the Abbey' appears in Forster, The Life of Dickens (London: Chapman and Hall, 1874), 3: facing p. 503, and was probably engraved from the watercolor now in the Forster Collection; an unfinished original sketch is in the Gimbel Collection.

50. See letters to Fildes, July 2 [July 4 in the ALS in the Forster Collection] and July 14, 1877, quoted in Fildes, Luke Fildes, R.A., pp. 44 45; and entry for June 6, [1891], The Diaries of Lewis Carroll, ed. Roger L. Green, 2:483-84.

51. See CD, letter to Forster, November 8, 1855, quoted in Forster, p. 576; Forster's revelation to Fildes, quoted and discussed in Kitton, DI, pp. 215-16; and Thomson, Fildes, p. 26.

52. See Kitton, $D I$, p. 216, and Fildes, Luke Fildes, R.A., pp. 24-25.

53. See Fildes, Luke Fildes, R.A., pp. 54, 56, and also pp. 23, 33, $43,71-74,99,106,129$ for further details of Fildes's relationship with Marcus Stone.

54. See ibid., pp. 53-54, and unpub. ALS from Browne to Fildes,

February 15, 1879, in the Forster Collection.

55. Fildes, quoted in Fildes, Luke Fildes, R.A., p. 227.

56. Ibid., p. 175: "My father was always being dogged by Edwin Drood."

57. See Fildes's published pronouncements on $E D$ listed in n. 37 in chapter 17 above.

\section{Conclusion}

1. See Muir, pp. 4-10, who provides a useful survey of these technological changes and their effects.

2. See Philip Hofer, The Illustration of Books, pp. 416-17.

3. See Lamb, p. 52; Hammelmann and Boase, p. 8; John Lewis, The Twentieth Century Book, p. 247, and Marquez, quoted in Rita Guibert, Seven Voices, trans. Frances Partridge (New York: Alfred A. Knopf, 1973), p. 322 .

4. Quoted and discussed in David Bland, A History of Book Illustration p. 19, in Philip James, English Book Illustration, $1800-1900$, p. 65 , and widely elsewhere.

5. Lamb, p. 67.

6. du Maurier, "The Illustrating of Books from the Serious Artist's Point of View," p. 353, and quoted in Leavis, p. 371, and widely elsewhere.

7. Yet Anthony Gross illustrated a 1950 edition of Galsworthy's Forsyte Saga, published by Heinemann. Perhaps as these earlier twentieth-century works become more dated and "picturesque," other editions of their works will be illustrated.

8. Harvey, p. 181, and see Lamb, p. 52.

9. See Autobiography, p. 69 , for example, quoted and cited in chapter $4, n .68$ above, for the effect of Cruikshank's etchings on James. See also Leon Edel and Dan H. Lawrence, A Bibliography of Henry James (London: Rupert Hart-Davis, 1951), pp. 294 (D45) and 295 (D53) for two 1868 short stories in Galaxy that were illustrated; pp. 190-192 for The Painter's Eye, ed. John Sweeney (London: Rupert Hart-Davis, 1956), a collection of James's reviews and notes on art; and pp. 64-67, 130-32, and 142-44 for A Little Tour in France (1900), English Hours (1905), and Italian Hours (1909), respectively, all illustrated with representational drawings by Joseph Pennell, and published in London by William Heinemann and in Boston and New York by Houghton Miffin and Co.

10. James, preface to The Golden Bowl in The Art of the Novel (New York, [1962]), p. 333. See also Betsy L. Jablow, Illustrated Texts from Dickens to James, which discusses the use of photographs as illustrations, according to the summary in Dissertation Abstracts International, sec. A., vol. 38, no. 12, pt. 1 (1978), p. 7355A; it was called to the author's attention by $D S N, 9: 95$, too late to be consulted for this study.

11. James, preface to The Golden Bowl in The Art of the Novel, p. 332, and quoted (though the phrase "interesting enough" is omitted) and discussed in Harvey, pp. 166-67.

12. See Purdy, pp. 280-87, who provides the following details: each of the sixteen volumes in The Wessex Novels (London: Osgood, Mellvane \& Co., 1895-96) contains an etched frontispiece by H. Macbeth-Raeburn, a scene from the novel drawn on the spot, and a map of 'The Wessex of the Novels' drawn by Hardy himself; each of the twenty-four volumes of The Wessex Novels and Poems (London: Macmillan and Co, 1912-31) contains only a photogravure frontispiece and Hardy's map; and of the thirty-seven-volume limited Mellstock edition (London: Macmillan and Co., 1919-20), based on the latter Wessex, only vol. 1, with William Stang's portrait of Hardy, and vol. 2, with Hardy's map, contain any illustrated matter.

13. According to information researched for the author by Scott Ward, Bashilov's illustrations - two drawings for which are reproduced in Edward Crankshaw, Tolstoy: The Making of a Novelist (New York: Viking Press: Studio Book, [1974]), pp. 224-25, called to the author's attention by Liz Zagaroff-were not utilized because many were consumed in a fire. Cf. Henri Troyat, Tolstoy, trans. Nancy Amphoux (New York: Dell Publishing Co., [1967]), who notes Tolstoy's involvement with the artist (pp. 354, 358-59) but implies that their omission was a decision mutually agreed on by the publisher, printer, and author (p. 363). According to Ward, Tolstoy also included a pencil drawing of faces in the MS of Anna 
Karenina, reproduced in the recent Russian edition (Moscow: Nauka, 1970), p. 825, and liked to illustrate the stories of Jules Verne for his children.

14. See St. John Ervine, Bernard Shaw: His Life, Work and Friends (New York: William Morrow and Co., 1956), pp. 180-81, 200-201, 248, and John Farleigh, Graven Image, An Autobiographical Textbook (London: Macmillan, 1940), pp. 214-17, 312-39, which includes reproductions of Shaw's sketches.

15. See Harvey, p. 6.

16. See Alice's Adventures Under Ground (New York: Dover Publications, 1965), a reprint of the 1886 facsimile edition of the 1864 MS.

17. See Purdy, pp. 96, 105, who notes his illustrated Wessex Poems and Other Verses (London: Harper \& Bros., 1898) and Hardy's denigration of them publicly in his preface and privately in his letter to Edward Clodd, nd; facing p. 25 is a reproduction of Hardy's letter to Arthur Hopkins, February 20, 1878, with sketches to assist his illustrations for The Return of the Native in the May issue of Belgravia; see also pp. 24, 280-81, and 285, which reproduce the author's maps for The Return of the Native and the Wessex Editions.

18. For Butler and his artistic ambitions, training, and productions, see Lee E. Holt, Samuel Butler (New York: Twayne Publishers, 1964), pp. 25, 32-which notes that he did illustrate his travel book on Italy, Alps and Sanctuaries (London: David Bogue, 1882); pp. 58, 92-93-which notes that his 'Family Prayers,' reproduced in The Family Letters of Samuel Butler, 1841-1886, ed. Arnold Silver (London: Jonathan Cape, [1962]), facing p. 32, was used as a frontispiece to the first edition of the posthumously published The Way of All Flesh (London: Grant Richards, 1903); and 119-122. See also Henry Festing Jones, Samuel Butler: A Memoir (New York: Octagon Books, 1968 [reprint of 1919 edition]), 1:116, which notes he wanted to reproduce, in The Way of All Flesh, a careful outline of a church similar to the one Theobald/Canon Butler restored, but deemed it impracticable to have only one illustration; and Stanley B. Harkness, The Career of Samuel Butler (1835-1902): A Bibliography (London: The Bodley Head, 1955), pp. 29, 32, 36, 39-40, for a list of his drawings and paintings, many of which were exhibited at the Royal Academy up to 1877. For Lawrence, see Warren Roberts, A Bibliography of D. H. Lawrence (London: Rupert Hart-Davis, 1963), p. 245 (C1), which reproduces one of his illustrations for "A Prelude," a short story published in the Nottinghamshire Guardian (December 7, 1907); and The Paintings of D. H. Lawrence, ed. Mervyn Levy (New York: Viking Press, [1964]).

19. For James, see Leon Edel, Henry James, The Untried Years: 1843-1870 (Philadelphia and New York: Lippincott, 1953), pp. 160-61. For Stevenson, see David Daiches, Robert Louis Stevenson and His World (London: Thames and Hudson, 1973), p. 36, and Stevenson's A Mountain Tour of France, a Fragment (New York and London: John Lane; The Bodley Head, 1896), in which appeared five of these sketches by permission of "representatives" of his estate two years after his death. For Kipling, see James McG. Stewart, Rudyard Kipling: A Bibliographical Catologue, ed. A.W. Yeats (Toronto: Dalhousie University Press and University of Toronto Press, 1959), pp. 218-20. For Wells, see Norman and Jeanne Mackenzie, The Time Traveller: The Life of $H$. G. Wells (London: Weidenfeld and Nicolson, 1973), p. 63 and following p. 82, nos. 12, 14-15, which reproduces some of these "picshuas" which also adorn some presentation copies of his works in the Houghton Library; and see H. G. Wells Society, comp., H. G. Wells, A Comprehensive Bibliography (London: H. G. Wells Society, 1966), pp. $6,8,11-12,14$, which note his shorter fictions that were illustrated by others. For Waugh, see Christopher Sykes, Evelyn Waugh: A Biography (Boston and Toronto: Little, Brown and Co.,
1975), pp. 67, 84; and for Lewis, see Geoffrey Wagner, Wymdham Lewis (New Haven: Yale University Press, 1957), especially pp. 6-17, 315-36.

20. For Hugo, see Samuel Edwards, Victor Hugo: A Tumultuous Life (New York: David McKay, 1971), following p. 148, no. 34, and André Maurois, Victor Hugo and His World (New York: Viking Press, 1966), pp. 30 (133), 65 (136), 93 (139), 97 (139), and 111 (140), which reproduces some of his many drawings with comments (page numbers noted parenthetically). For Mann, see Andrew White, Thomas Mann (Edinburgh and London: Oliver and Boyd, 1965), p. 4, and Viktor Mann, Wir Waren Fünf: Bildnis Der Familie Mann (Konstanz: Gmb H. Südverlag, [1949]), following p. 56, which reproduces some of Mann's drawings for the children's book.

21. For Cummings-who regarded himself as "an author of pictures, a draughtsman of words," according to the dust jacket of Fairy Tales by E. E. Cummings (New York: Harcourt, Brace, and World, [1950]), which was pointed out to the author by Evelyn Simha-see By E. E. Cummings (New York: Covici Friede, 1980) for some illustrated short fictions; CIOPW (New York: Covici Friede, 1913) for examples of his art; George J. Firmage, $E$. $E$. Cummings: A Bibliography (Middletown, Conn.: Wesleyan University Press, 1960), pp. 97-100, for lists of other art works by him; and the edition of The Enormous Room, ed. Firmage (New York: Liveright, 1978), which contains largely-unpublished drawings done at the time of the work's composition but, except for one, used on the first edition jacket, not included in earlier editions, probably because of the extra cost, according to information supplied by Victor Schmalzer, general manager at Liveright, in a letter of February 3, 1978 and a telephone call of February 14, 1978 to the author.

22. For Faulkner, see Joseph Blotner, Faulkner: A Biography (New York: Random House, 1974), 1:190, 207-8, 217, 271-74, 306, $312,337,345$, who discusses these early illustrations and reproduces some of them as well as other unrelated ones in 1:191, 217-18, 272-73, 286-87, and see also 1:529, which describes a drawing on p. 8 verso of the Father Abraham MS (1926), 2:1308, which describes his sudden but unrealized desire to paint watercolors in 1950 , and 2:1514 which relates his refusal to permit the reproduction of his early art, partly on the ground that they were mere copies -unlikely, though their style is perbaps derivative or "Beardsleylike," as described by the New York Times (December 2, 1977), c 18, which follows Blotner's description concerning an MS copy of "Of the Marionettes: A Play in One Act" being auctioned at Sotheby Parke Bernet.

23. For Vonnegut, see Breakfast of Champions (New York: Delacorte, 1973), p. 5 .

24. Victorian Painting (New York, 1966), p. 141.

25. See Leonée Ormond, George Du Maurier, p. 184.

26. See ibid., pp. 125-26, and letter to Henry James, September 27, 1888, quoted and discussed, p. 308.

27. The Novels and Tales of Henry James, 18 (New York: Charles Scribner's Sons, 1922), p. 310.

28. Draft of speech for Graphic dinner, ca. 1890, quoted in Fildes, Luke Fildes, R.A., p. 120.

29. See Sidney Hutchison, The History of the Royal Academy, $1768-1968$, p. 182, which was called to the author's attention, along with the election date, by Professor David A. Robertson, Jr., in a letter of June 21, 1974.

30. Letter to Mother, [April, 1861], in The Young George du Maurier: A Selection of His Letters, 1860-67, p. 36.

31. See Muir, pp. 183-84, who also notes Beardsley's illustrations for Wilde's play, Salome (1894), and the author's and Holbrook Jackson's more widely shared objections to them; pp. 191-93, 
Rickett's noted designs for Wilde's poem, The Sphinx (1894); and p. 202, whose assertion that "a host of contemporary authors had their new books illustrated" appears to need some qualification. For example, even the works of Stevenson, one of the leading authors of the time mentioned by Muir, were not usually illustrated on their debut, though an "Illustrated Edition" often followed a success (see Colonel W. F. Prideaux, A Bibliography of the Works of Robert Louis Stevenson [London: Frank Hollings, 1917]); even Treasure Island (1883) was not illustrated, except by a map, initially, though it has been numerous times since (see Lewis, pp. 204-15). Moreover, even the highly regarded artists who often illustrated what has proved to be the most enduring of the fiction of the 1880 's and 1890's-such as Phiz's son, Gordon Browne-are not now regarded as the outstanding illustrators of the period.

32. See Muir, pp. 179-212, who provides a useful survey of the fin-de-siècle, which has helped this discussion of it.

33. Leo Stein, letter to Mabel Weeks, February 7, 1913, Journey into the Self, ed. Edmund Fuller (New York: Crown Publishers, 1950), p. 52.

34. See Lamb, p. 49, and Philip James, British Book Illustration, 1985-1945, who notes: "The inspiration of English art lies in literature; in France the visual arts have always been supreme" (pp. 7-9).

35. This story, told to the author by David Godine, was corroborated by Philip Hofer in a letter to the author, June 17, 1974, in regard to Richard Meryman, Andrew Wyeth (Boston: Houghton Mifflin, 1968).

36. See Muir, pp. 3, 7-10; James, English Book Illustration, p. 9; and Robert F. Gossop, Book Illustration: A Review of the Art as It is Today, p. 17, provide further details on points raised in the discussion below.

37. See John Reynolds Taylor, The Art Nouveau Book in Britain, and Colin Franklin, The Private Presses, on the private press movement that flourished from the 1890 's to the Second World War.

38. See Quentin Bell, Virginia Woolf, A Biography (New Yoru: Harcourt Brace, Jovanovich, [1972]), 2:65, but Vanessa Bell subsequently illustrated Woolfs Monday or Tuesday (1921) and Flush (1933), as is noted in B. J. Kirkpatrick, A Bibliography of Virginia Woolf (London: Rupert Hart-Davis, 1957), pp. 13, 47, as well as designed the publisher's device and many of the dust jackets.

39. Leavis, p. 366.

40. "Book Illustrations," wall the Year Round, 18 (August 10, 1867): $151-55$, also mentioned in Harvey, p. 165 and $n$. 15, who erroneously gives the date as 1869 , but notes other pieces expressing similar attitudes in Household Words as well as in All the Year Round. See also Thomson, Browne, p. 59, who registers a comparable complaint in 1884.

41. du Maurier, quoted in Purdy, p. 21, and Trollope, quoted in An Autobiography (London: Oxford University Press, 1961), p. 128.

42. Layard, Suppressed Plates, p. 38.

43. Shaw, letter to John Farleigh, May 8, 1932, quoted in Farleigh, p. 215, and in Lewis, p. 169.

44. Quoted in Sykes, p. 304, in regard to "The Wish," Good Housekeeping 124 (March, 1947); 22-23, 319-26, 328.

45. Arthur Brown, quoted in "Milestones," Time 88 (November 4, 1966): 100.

46. See Lawrence Stone, "Literacy and Education in England, $1640-1900$," pp. 120-21, for literacy statistics after 1870, and Leavis, p. 366.

47. Gombrich, Meditations on a Habby Horse, p. 134, makes the same point about the "nourishment" afforded sixteenth-century purchasers of crudely engraved broadsheets.

48. James, "George du Maurier," Harper's Weekly 38 (April 14, 1894): 342 . Note also the similar diction in Hardy's letter to Edward Clodd, partly quoted in Purdy, p. 105, about the "sort of illegitimate interest" preparing the illustrations for his Wessex Poems (1898) had for him, and see du Maurier, "The Illustrating of Books from the Serious Artist's Point of View," pp. 349-50, who understands but does not share James's views.

49. Gertrude Stein, Wars I Have Seen (New York: Random House, 1945), p. 5. See also earlier relevant opposition to the illustrated book expressed by Stéphane Mallarmé, "Sur le livre illustré," Oeuvres complètes, ed. Henri Mondor and G. Jean-Aubry ([Paris]: Gallimard, 1945).

50. Harvey, pp. 196-98, provides a useful summary of post-1870 editions of CD's collected works using the original or newly commissioned illustrations; Kitton, DI, pp. 219-26, lists other artists who illustrated single volumes of his novels; and the British Museum General Catalogue of Printed Books (London: Trustees of the British Museum, 1959), 52:236-359, provides the most comprehensive list of all editions of his works.

51. du Maurier, "The Illustrating of Books from the Serious Artist's Point of View," p. 350.

52. Timothy D'Arch Smith, "Dickens and Aubrey Beardsley," Dick. 63 (January, 1967): 25, notes that Beardsley used Dickensian subjects to decorate menu cards for family dinner parties. For Whistler, see n. 8 in chapter 3 above.

53. See Joseph Pennell, Modern Illustration, p. 53, and White, English Illustration, 'The Sixties,' p. 18, for example.

54. Gissing, Charles Dickens, p. 33.

55. See n. 48 above.

56. C. S. Lewis, quoted in Surprised by Joy, p. 145, and in Dick. 71 (September, 1975): 177. Lewis's comment recalls the more discriminating one made by Henry James, Autobiography, p. 69, which is quoted, discussed, and cited (in n. 68) in chapter 1 above.

57. See Lewis, p. 145, and Green, introduction to Oliver Twist by Charles Dickens (London: Hamish Hamilton, 1950), p. vii, and widely quoted elsewhere.

58. See George Cukor, quoted in Gavin Lambert, On Cukor (New York: G. P. Putnam's Sons, 1972), p. 83, who explicitly acknowledges that he was "guided by Phiz" in realizing the "outward semblance" of scenes and characters in his adaptation of $D C$ (1935); "Speaking of Pictures: 'Nicholas Nickleby' Brings Phiz to Film," Life 232 (December 23, 1947): 2-3, which notes Alberto Cavalcanti's obvious debts to Browne throughout; cf. John McCarten, "The Current Cinema," New Yorker 23 (December 6, 1947): 92, who unaccountably denies any such indebtedness; and Selznick and Conway's TTC (1935), Stuart Walker's ED (1935), and David Lean's $O T$ (1947), to name a few more examples, seem similarly indebted to Browne, Fildes, and Cruikshank, respectively. Lucy Tupper, "Dickens on the Screen," Films in Review 10 (March, 1959): 152, noting that none of the film adaptations of CD's novels up to that time were in color, suggests that the memorable black-and-white illustrations of the original novels have become too firmly implanted in the English-speaking mind. Ana Laura Zambrano, The Novels of Charles Dickens and the Modern Film, pp. 229-343, 396-427, provides the most complete account of films adapted from CD's novels but, aside from noting Noel Langley's debt to Browne in his 1954 "Pickwick Papers" (p. 299) and Robert'Solo's to Leech in his 1970 "Scrooge" (pp. 315, 317), does not stress their debt to the original illustrations.

59. For the most complete account of CD's "cinematic" techniques and their influence, see Zambrano, pp. 76-230, 344-61, which incorporates the seminal comments of Sergei Eisenstein, "Dickens, 
Griffith, and the Film Today," Film Form: Essays in Film Theory (New York: Harcourt, Brace and World, 1949), pp. 195-255; and see also Taylor Stoehr, Dickens: The Dreamer's Stance, pp. 285-86; George Ford and Steven Marcus, "Dickens's Camera Eye," New York Times (May 8, 1977), Arts \& Leisure Section: 29, 41; and Ford, Dickens and His Readers, pp. 227-28, who notes that the film has been a more effective medium for $\mathrm{CD}^{\prime}$ s adaptations than the stage, which raises provocative questions.

60. See Wilson, "Dickens: The Two Scrooges," The Wound and the Bow (Boston: Houghton Mifflin, 1941); pp. 1-104, and Orwell, "Charles Dickens," Inside the Whale and Other Essays (London: Victor Gollancz, 1940), pp. 9-85, reprinted in Dickens, Dali, and Others (New York: Reynal and Hitchcock, 1946), pp. 1-75, neither of which mentions the original illustrations, however.

61. Harvey, p. 197, comments on the quality of the reproductions; Stevens, pp. 129-33, criticizes their placement, especially in editions of $O C S$ and $B R$; and John N. B. Millican, 'Phiz' Without Sparkle," Dick. 41 (September 1, 1945): 198-96, and D'A. P. Yarre, "Dickens Without Phiz?" Dick. 42 (December 1, 1945): 32-34, debate whether or not the original illustrations should be included in modern editions of CD.

62. Among the most notable of twentieth-century illustrations for CD's novels are Arthur Rackham's for PP (London: William Heinemann and Philadelphia: J. B. Lippincott, [1915]), Edward Ardizzone's for GE (New York: Heritage Press, 1939), and Barnett Freedman's for OT (New York: Heritage Press, 1939), but this is a matter of subjective opinion.

63. Fitzgerald, The History of Pickwick, pp. 73-74.

64. James Agate, "Trade Winds," Saturday Review/World (September 25, 1973): 41, which was called to the author's attention by Laurence Senelick.

65. Kitton, $D I$, p. ix, and Harvey, p. 180 , also comment on this point, which is implicit in most extensive discussions of the subject.

\section{Appendix: Thackeray}

1. According to Buss, pp. 130-31 and n., and Kitton, $D I, 58-59$, other artists, aside from Buss, Browne, and Leech, who had the same idea were Alfred Forrester, Lee, and unspecified "others."

2. See Thackeray, speech at Royal Academy Dinner, May, 1858, reprinted in Lewis Melville [Lewis S. Benjamin], William Makepeace Thackeray, 2:115, the relevant CD remarks being widely quoted elsewhere; Buss, "My Connexion with $P P$," pp. 130-31; Kitton, DI, pp. 59-60 and n. 1; Ray, Thackeray, 1:169; and discussion and $\mathrm{nn} .53$ and 55 in chapter 5 above and $n .11$ below, for further mention of Thackeray's early artistic and social career. For more detail on his present and future relationship with Cruikshank, see Cruikshank, quoted in Moncure Daniel Conway, Autobiography of Moncure Daniel Conway, 1:6; Thackeray's appreciation of the artist in "George Cruikshank," pp. 4-60; and Cruikshank's etching of Thackeray's sketch and inscription on a presentation copy of Vanity Fair, reproduced in A Handbook for Posterity, No. 35, and in Drawings of George Cruikshank, Plate 48.

3. Thackeray, speech at R. A. dinner, quoted in Melville, 2:115, but exactly what the subjects of these designs are is not known. See discussion and $\mathrm{n} .5$ below.
4. See John Dexter, Dickens Memento, p. 11, and repeated without qualification in Johnson, Charles Dickens, 1:140, but omitted in his revised and abridged edition (New York, 1977), p. 100 .

5. See Waugh, One Hundred Years of Publishing, pp. 24-25; Johnson, Charles Dickens, 1:140; and Leavis, p. 339, for similar general comments on this sketch and the artist's suitability; Edward Fitzgerald's relevant plea to Thackeray: “Don't exaggerate the faces, pray, but get them near to nature," quoted in Cahoon, p. 71; and discussion and $\mathrm{n} .81$ in the Cruikshank chapter above on the border of 'The Last Song.'

6. See Kitton, Phiz, p. 12; Allchin, Century, 23:388; and letter from Thackeray to Landells, nd, partly quoted in Charles Sawyer Catalogue 284 (February, 1971), p. 40, item 323: “ . . . I should not like to take away work from Phiz, or indeed for my own sake be obliged to follow him. ...."

7. See letter of April 21-25, 1836 in Letters, pp. 311-12 and n.

8. See Browne, pp. 17-18; Macready, diary entry, April 26, 1836, Diaries, 1:299; and Cruikshank, quoted in Conway, p. 6.

9. The story appeared under the pseudonym Goliah Gahagan in Bentley's Miscellany 2 (September, 1837): 277-88, in the same issue as the fourteenth chapter of $O T$ (94-103); cf. Charles Riddell Williams, "The Personal Relations of Dickens and Thackeray," Dick. 35 (Spring, 1939): 76, who says it appeared in July. It is noted also by Johnson, Charles Dickens, 1:220, and Ray, Thackeray, 1:327n.

10. See Harvey, p. 12, who also notes the effect of $P P$ on Thackeray; Ray, Thackeray, 1:153-54, on Thackeray's admiration of D'Orsay; and Sadleir, ed., Peter Simple, "Biographical Note," who quotes the following MS note in which R. W. Buss reportedly said: "The outline to Peter Simple [1837] originated thus. Count D'Orsay employed artists to work up his slight drawings and pictures. From this a fashion arose of authors illustrating their own works [italics added]. Thackeray did this; Marryat attempted it, persuading his friend, Stanfield the R.A., to retouch his designs. These were handed to me for completion and etching. After a while Stanfield tired of the job and the illustrations were handed over to me" (p. xiii).

11. See Harvey, pp. 76-103, for a detailed discussion of Thackeray's self-illustrated works and p. 82 for a discussion of Charlotte Brontë's lavish praise of Thackeray's realistic draftsmanship in letter to W. S. Williams, March 11, 1848, in Shorter, The Brontës, 1:402; cf. the more usual negative appraisals by contemporaries, such as Fitzgerald, quoted in n. 5 above; by his most notable biographer, Ray, The Illustrator and the Book: "Thackeray's draftsmanship ... leaves much to be desired" (p. 74); and by Thackeray himself, according to the anecdote in Kitton, $D I$, p. 60 , n. 1 .

12. See Johnson, Charles Dickens, 2:930-36 and 1013-14; Ray, Thackeray, 2:276-90 and 405-6; and the discussion and n. 16 in chapter 17 above for further details on these events in their complex relationship.

13. Speech at R. A. dinner, quoted in Melville, 2:115.

14. The proofs of this piece, in the Free Library of Philadelphia, show revisions that exclude unflattering references to Thackeray. 


\section{SELECTED BIBLIOGRAPHY}

No comprehensive bibliography currently exists in the field of Dickensian illustration. The following list, though not exhaustive, attempts to remedy this deficiency by including most, but not all, of the works cited in the text as well as others not cited but which are relevant and valuable. Single published and unpublished letters, drawings, etc., too numerous to be listed here, can be located in the notes to the text and still others can be found in the private and institutional collections listed in the acknowledgments.

à Beckett, Arthur William. The à Becketts of "Punch": Memories of Father and Son. London: A Constable, 1903.

Adrian, Arthur. Georgina Hogarth and the Dickens Circle. London: Oxford University Press, 1957.

Mark Lemon: First Editor of Punch. London: Oxford University Press, 1966.

- "A Note on the Dickens-Collins Friendship." Huntington Library Quarterly 16 (February, 1953): 211-13.

Allchin, Arthur. "An Illustrator of Dickens: Hablot Knight Browne ('Phiz')." Century Magazine 23 (January, 1893): 386-94.

Altick, Richard D. The English Common Reader. Chicago: University of Chicago Press, 1957.

Ames, Winslow. Prince Albert and Victorian Taste. New York: Viking Press, 1968.

Antal, Frederick. Hogarth and His Place in European Art. London: Routledge, 1962.

Arnold, Matthew. "To George Cruikshank." In Early Poems, Narrative Poems, and Sonnets, p. 8. New York: Macmillan, 1923.

Ashley, Robert. Wilkie Collins. Ann Arbor, Mich:: University Microfilms, 1973.

"Author of 'A Cruise Upon Wheels,' The: Mr. Charles A. Collins." Athenaeum (April 19, 1873): 506 [reprinted in the Times (London) (April 21, 1873): 12].

Aylmer, Felix. The Drood Case. London: Hart-Davis, 1964.

Baker, Richard M. The Drood Murder Case: Five Studies in Dickens's Edwin Drood. Berkeley: University of California Press, 1951.

Baldry, A[lfred] L[ys]. The Life and Work of Marcus Stone. London: [Art Annual], 1896.

Bates, William. George Cruikshank: The Artist, the Humourist, and the Man. London: Houlston \& Sons, 1878.

Baudelaire, Charles. Oeuvres complètes. Edited by Y.-G. Le Dantec. [Paris: Gallimard, 1958].

Bede, Cuthbert. "A Reminiscence of George Cruikshank and His 'Magazine.'" Notes and Queries, 5th ser. 9 (April 13, 1878): 281-83.

Bell, H. T. Mackenzie. "Memoirs of Grimaldi." Notes and Queries, 7th ser. 2 (December 4, 1886): 456-57.

. "Pickwick' and Its Illustrators." Athenaeum (June 11, 1887): 767 .
Bell, Quentin. Victorian Artists. Cambridge: Harvard University Press, 1967.

Benesch, Otto. Artistic and Intellectual Trends from Rubens to Daumier as Shown in Book Illustration. Cambridge: Harvard College Library, 1943.

[Benjamin, Lewis S.] See Melville, Lewis.

Bentley, Nicolas. "Dickens and His Illustrators." In Charles Dickens, 1812-1870: A Centenary Volume, edited by E. W. F. Tomlin pp. 196-227. London: Weidenfeld and Nicolson, [1969]. [A shorter version appeared in the Dickensian 65 (September, 1969): 148-62.]

Bentley's Miscellany, 1-5 (January, 1837-April, 1839).

Binyon, [Robert] Lawrence. Catalogue of Drawings by British Artists and Artists of Foreign Origin Working in Great Britain. 4 vols. London: Trustees of the British Museum, 1898-1919.

- The Followers of William Blake. London: Hatton \& Truscott Smith, 1925.

Bland, David. A History of Book Illustration. 2d rev. ed. Berkeley: University of California Press, 1969.

Boase, T. S. R. "The Decoration of the New Palace of Westminster, 1841-1863." Journal of the Warburg and Courtauld Institutes 17 (1954): 319-58.

Bogusch, George E. "Clarkson Stanfield, R.A.: Scene Painter, Artist, Gentleman and Friend." Quarterly Journal of Speech 56 (October, 1970): 245-55.

Bohn, Henry G. "A Biographical Notice of Robert Seymour." In Seymour's Humorous Sketches, pp. i-viii. London: T. Miles, 1888.

. "Seymour's Drawings." Athenaeum (April 7, 1866: 464.

"Book Illustrations." All the Year Round 18 (August 10, 1867): 151-55.

Borowitz, David. "George Cruikshank: Mirror of an Age." In Charles Dickens and George Cruikshank, pp. 73-95. Los Angeles: William Andrews Clark Memorial Library, 1971.

[Brown, John]. "John Leech." North American Review 42 (March, 1865): 108-19.

Brown, John. "John Leech and Other Papers." In Horae Subsecivae. New ed., 3d ser., pp. 1-79. Edinburgh: D. Douglas, 1882.

Browne, Edgar. Phiz and Dickens. London: James Nesbit, 1913.

"Browne Study, A." Diogenes 2 (September 10, 1853): 112.

Browning, Elizabeth Barrett, and Robert Browning. The Letters of Robert Browning and Elizabeth Barrett Browning, 1845-1846, edited by Elvan Kintner. 2 vols. Cambridge: Harvard University Press, 1969.

Buchanan-Brown, John. Phiz!, Illustrator of Dickens's World. New York: Charles Scribner's Sons, 1978. 
[Buller, Charles]. "Sketches by Boz; The Pickwick Papers, Nos. 1-15; Bentley's Miscellany." London and Westminster Review 5 and 27 (July, 1837): 194-215.

Bury, Adrian. "In the Galleries." Connoisseur 166 (December, 1967): 244.

Buss, Alfred G. "R. W. Buss." Notes and Queries, 5th ser, 3 (April 24, 1875): 330-31 and (June 5, 1875): 451.

Buss, Robert William. English Graphic Satire. London: Virtue \& Co. for the author.

- "My Connexion with The Pickwick Papers." In The Origin of Pickwick, by Walter Dexter and J. W. T. Ley, pp. 109-39. London: Chapman and Hall, 1936.

Butt, John, “Dickens's Instructions for Martin Chuzzlewit, Plate 18." Review of English Literature 2 (July, 1961): 49-50.

Butt, John, and Kathleen Tillotson, Dickens at Work. London: Methuen, 1957.

Cahoon, Herbert. "The Author as Illustrator." In Book Illustration, ed. Frances J. Brewer, pp. 66-73. Berlin: Mann, 1963.

Calhoun, Philo, and Howell J. Heaney. "Dickens's Christmas Carol after a Hundred Years." The Papers of the Bibliographical Society of America 39 (1945): 271-317.

Cardwell, Margaret, ed. The Mystery of Edwin Drood, by Charles Dickens. Oxford: Clarendon Press, 1972.

Carr, Sister Lucille, ed. Catalogue of the VanderPoel Dickens Collection at the University of Texas. $2 \mathrm{~d}$ ed. Austin: University of Texas Humanities Research Center, [1968].

Carter, John, ed. New Paths in Book Collecting. London: Constable \& Co., [1934].

Carter, John, and Brook Crutchley. The Printed Book. 3d ed. Cambridge: Cambridge University Press, 1951.

Cecil, Lord David. Visionary and Dreamer, Two Poetic Painters: Samuel Palmer and Edward Burne-Jones. London: Constable, [1969].

Chapell, Marian C. "The Man Who Drew for Dickens." Country Life 137 (June 10, 1965): 1447-48.

Charles Dickens: An Exhibition of the Life and Works of Charles Dickens. Philadelphia: Free Library, JuneJuly, 1946.

Charles Dickens: An Exhibition to Commemorate the Centenary of His Death, June-September 1970. London: Victoria and Albert Museum, 1970.

Charles Dickens: The J. F. Dexter Collection. London: British Museum Publications for the British Library Board, 1974.

"Charles Dickens and His Works." Fraser's Magazine 21 (April, 1840): 381-400.

Charles Dickens, 1812-1870: An Anthology Chosen and Correlated by Lola L. Szladits from Materials in the Berg Collection of English and American Literature in Commemoration of the Centennial of Dickens's Death. New York: The New York Public Library and Arno Press, [1970].

Chatto, William Andrew. An Historical, Antiquarian, and
Practical Treatise on Wood Engraving, Ancient and Modern. 4 vols. London: Samuel Bentley, 1839.

Chesson, W[ilfred] H[ush]. George Cruikshank. London: Duckworth, and New York: E. P. Dutton.

Chesterton, Gilbert Keith. Charles Dickens, A Critical Study. New York: Dodd, Mead \& Co., 1935.

Child, Francis W., ed. "Lord Bateman." In The English and Scottish Popular Ballads, vol. 2, pp. 454-83. Boston: Houghton Mifflin, 1884.

"Chimes, The." Christian Remembrancer, n.s. 9 (January, 1845): $301-4$.

"Chimes, The." Illustrated London News 5 (December 21, 1844): 395 .

"Christmas Books and Gift Books." Saturday Review 20 (December 2, 1865): 711-12.

Clark, Charles, and Mary Cowden. Recollections of Writers. London: Sampson Low, Marston, Searle, \& Rivington, 1878.

Clark, Cumberland. The Story of a Great Friendship: Charles Dickens and Clarkson Stanfield. London: Chiswick Press, 1918.

[Cleghorn, Thomas]. "Writings of Charles Dickens." North British Review 3 (May, 1845): 65-87.

Cohen, Jane R. "'All-of-a-Twist': The Relationship of George Cruikshank and Charles Dickens," Harvard Library Bulletin 17 (April, 1969): 169-94 and (July, 1969): $320-42$.

. "Charles Dickens and His Original Illustrators." Ph.D. dissertation, Harvard University, 1968.

- "Dickens's Artists and Artistry in The Mystery of Edwin Drood." Dickens Studies 3 (October, 1967): 126-45.

"Marcus Stone." In Great Expectations, by Charles Dickens, edited by Edgar Rosenberg. Boston: Houghton Mifflin, Riverside Press, forthcoming.

- " "A Melancholy Clown'-The Relationship of Robert Seymour and Charles Dickens." Harvard Library Bulletin 19 (July, 1971): 250-79.

-. "Strained Relations: George Cattermole and Charles Dickens." Dickens Studies Annual, 1, edited by Robert B. Partlow, Jr., pp. 81-92. Carbondale, Ill.: Southern Illinois University Press, 1970.

Cohn, Albert M. A Few Notes Upon Some Rare Cruikshankiana. London: Karslake, 1915.

- George Cruikshank: A Catalogue Raisonné. London: Office of the Bookman's Journal, 1924.

- "Loving Ballad of Lord Bateman, 1839." Times Literary Supplement (May 16, 1935): 313.

C[ollins], C[harles]. "Charles Dickens's Study." Graphic 2 (December 25, 18705: 14.

[- ]. "An Unreported Speech." All the Year Round 6 (November 16, 1861): 179-81.

Collins, Philip. "Charles Dickens." In Victorian Fiction: A Second Guide to Research, edited by George H. Ford, pp. 34-113. New York: Modern Language Association, 1978. 
- A Critical Commentary on Dickens's 'Bleak House.' London: Macmillan, 1971.

- ed. Dickens: The Critical Heritage. New York: Barnes and Noble, 1971.

Combe, William. The Tour of Dr. Syntax in Search of the Picturesque. London: Rudolph Ackermann, 1812.

Conway, Moncure Daniel. Autobiography of Moncure Daniel Conway. 2 vols. Boston: Houghton Mifflin, 1904.

Cooper, Thomas Parsons. With Dickens in Yorkshire. London: B. Johnson, 1923.

Cornish, Blanche Warre. "An Impression of Thackeray in His Last Years." Dublin Review 150 (January, 1912): 12-28.

"Coroner's Inquest." The Times (London) (April 22, 1836): 7.

Cowan, Robert E., and William Andrews Clark, Jr. The Library of William Andrews Clark, Jr.: Cruikshank and Dickens. 2 vols. San Francisco: John Henry Nash, 1921 and 1923.

"Cricket on the Hearth, The." The Times (London) (December 27, 1845): 6 .

Cruikshank, George. The Artist and the Author: A Statement of Facts. [London]: Bell and Daldy, 1872.

"A Bit of Literary History." New York Tribune 30 (February 8, 1871): 6.

- Cruikshank's Water Colours, edited by Joseph Grego. London: A. \& C. Black, 1903.

- Drawings by George Cruikshank Prepared by Him to Illustrate an Intended Autobiography. London: Chatto \& Windus for Sir Benjamin Ward Richardson, 1895.

. George Cruikshank's Fairy Library. London: G. Routledge and Sons, [1865].

- A Handbook for Posterity; or, Recollections of 'Twiddle Twaddle.' London: W. T. Spencer, 1896.

-A Letter from Hop-o-My-Thumb to Charles Dickens, Esq. Upon 'Frauds on the Fairies,' 'Whole Hogs,' etc." George Cruikshank's Magazine 1 (February, 1854): 74-80.

- "My Portrait." George Cruikshank's Omnibus 1 (May, 1841): 1-8.

. "The Origin of 'Oliver Twist." The Times (London) (December 30, 1871): 8.

- "Total Abstainers," Illustrated London News, 24 (May 20, 1854): 465.

Cutler, Fred. "Robert Seymour: A Psycho-Historical Autopsy." Omega 2 (August, 1971): 195-214.

Daly, Joseph F. The Life of Augustin Daly. New York: Macmillan, 1917.

[Dalziel, Edward, and George Dalziel]. The Brothers Dalziel. London: Methuen, 1901.

Dana, Henry Wadsworth Longfellow. "Longfellow and Dickens: The Story of a Trans-Atlantic Friendship." Cambridge Historical Society 28 (Cambridge, Mass., 1942): 55-104.

Davis, Nuel P. The Life of Wilkie Collins. Urbana, Ill.:
University of Illinois Press, 1956.

"Death of Charles Dickens." The Times (London) (June 10, 1870): 12 .

"Devonshire-House Theatricals, The." Bentley's Miscellany 29 (June, 1851): 660-67.

Dexter, John F. Dickens Memento. London: Field and Tuer, 1870.

Dexter, Walter, and J. W. T. Ley. The Origin of Pickwick. London: Chapman and Hall, 1936.

Dickens, Charles. Letters from Charles Dickens to Angela Burdett-Coutts, 1841-1865. Edited by Edgar Johnson. London: Jonathan Cape, 1953.

- The Letters of Charles Dickens; Volume 1, 1820 1839. Edited by Madeline House and Graham Storey. The Pilgrim Edition. Oxford: Clarendon Press, 1965.

- The Letters of Charles Dickens; Volume 2, 18401841. Edited by Madeline House and Graham Storey. The Pilgrim Edition. Oxford: Clarendon Press, 1969.

- The Letters of Charles Dickens; Volume 3, 18421843. Edited by Madeline House, Graham Storey, and Kathleen Tillotson. The Pilgrim Edition. Oxford: Clarendon Press, 1974.

- The Letters of Charles Dickens; Volume 4, 18441846. Edited by Kathleen Tillotson. The Pilgrim Edition. Oxford: Clarendon Press, 1977.

. The Life of Our Lord. London: Associated Newspapers, 1934.

[- ]. The Loving Ballad of Lord Bateman. London: Charles Tilt, 1839.

[—]. The Loving Ballad of Lord Bateman. London: Bell and Daldy, 1870.

[- ]. The Loving Ballad of Lord Bateman. London: Bell and Daldy, 1871.

- ed. Memoirs of Grimaldi, edited by Richard Findlater. Rev. ed. London: MacGibbon \& Kee, 1968.

. Mr. and Mrs. Charles Dickens: His Letters to Her. Edited by Walter Dexter. London: Constable, 1935.

The Nonesuch Dickens. Edited by Arthur Waugh,

Hugh Walpole, Walter Dexter, and Thomas Hatton. 24 vols. Bloomsbury: The Nonesuch Press, 1938. [This edition of the complete works of $\mathrm{CD}$ also includes Retrospectus and Prospectus: The Nonesuch Dickens (1937), also known as Nonesuch Dickensiana, and The Letters of Charles Dickens, edited by Walter Dexter, 3 vols.]

[Dickens, Mamie]. "Charles Dickens at Home by His Eldest Daughter." Cornhill Magazine 51 (January, 1885): 32-51.

Dickens, Mamie. My Father as I Recall Him. London: Roxburghe Press, 1897.

Dickensian, The. (London: The Dickens Fellowship, January, 1905-September, 1978), vols. 1-74.

"Dickens's Dogs; or, The Landseer of Fiction." London Society 4 (July, 1863): 48-61.

Dickens Studies. ([Boston]: Emerson College, January, 1965-May, 1969), vols. 1-5. 
Dickens Studies Annual, edited by Robert B. Partlow, Jr. (Carbondale, Ill.: Southern Illinois University Press, 1970, 1972, 1974-76), vols. 1-5.

Dickens Studies Newsletter. (Carbondale, Ill.: The Dickens Society, December, 1970-September, 1978), vols. 1-9.

Dictionary of National Biography, The. Edited by Leslie Stephen and Sidney Lee et al. London: Oxford University Press, 1921-22 (21 vols.) and 1949-71 (7 supps.).

Dobson, Austin. "Illustrated Books." In The Library, edited by Andrew Lang, 2d ed., pp. 123-78. London: Macmillan, 1892.

Dolby, George. Charles Dickens as I Knew Him. London: T. F. Unwin, 1885.

Downey, Edmund. Charles Lever: His Life in His Letters. 2 vols. London and Edinburgh, 1906.

Doyle, Richard. Dick Doyle's Journal, 1840. London: Smith, Elder \& Co., 1885.

du Maurier, George. "The Illustrating of Books from the Serious Artist's Point of View." Magazine of Art (August, 1890): 349-53 and (September, 1890): 371-75.

- Social Pictorial Satire. London and New York: Harper \& Bros., 1898.

- The Young George du Maurier: A Selection of His Letters, 1860-1867. Edited by Daphne du Maurier. London: Peter Davies, 1951.

Dunn, Frank T., comp. A Cumulative Analytical Index to the Dickensian 1905-1974. With foreword by Michael Slater. London: Harvester Press, 1976.

Dwiggins, William Addison. Form Letters: Illustrator to Author. New York: William Edwin Rudge for the author, 1930.

Eckel, John. The First Editions of the Writings of Charles Dickens. Rev. ed. New York: Maurice Inman, and London: Maggs Bros., 1932.

Eliot, George. The George Eliot Letters. Edited by Gordon S. Haight. 7 vols. New Haven: Yale University Press, 1954-55.

Ellis, S[tewart] M[arsh]. William Harrison Ainsworth and His Friends. 2 vols. London: John Lane, 1911.

Engel, Monroe. "Dickens on Art." Modern Philology 53 (August, 1955): 25-38.

- The Maturity of Dickens. Cambridge: Harvard University Press, 1959.

English Influences on Vincent Van Gogh. An Exhibition Organised by the Fine Arts Department, University of Nottingham and the Arts Council of Great Britain. London: 1974-75.

Evans, Hilary, and Mary Evans. The Man Who Drew the Drunkard's Daughter: The Life and Art of George Cruikshank, 1792-1878. London: Frederick Muller, 1978.

Everitt, Graham. English Caricaturists and Graphic Humorists of the Nineteenth Century. $2 \mathrm{~d}$ ed. London: Swan Sonnenschein \& Co., 1893.

"Everybody's Books, Popular Taste, and Clever Enterprises, 1837-1937." Times Literary Supplement (May 1, 1937): 328-29.
Fielding, K. J. "Charles Whitehead and Charles Dickens." Review of English Studies, n.s. 3 (April, 1952): 141-54.

Fields, Annie [Adams] (Mrs. James T. Fields). Memories of a Hostess. Edited by Mark A. De Wolfe Howe. Boston: Atlantic Monthly Press, 1922.

Fields, James T. Yesterday with Authors. Boston: Houghton Mifflin, 1900. (The Dickens chapter was reprinted from In and Out of Doors with Charles Dickens. Boston: James R. Osgood and Co., 1876.)

Figaro in London, edited by Gilbert à Beckett. 3-4 (January, 1834-January, 1835).

Fildes, Luke. "The Mysteries of Edwin Drood." Times Literary Supplement (November 3, 1905): 373.

Fildes, L. V. Luke Fildes, R.A.: A Victorian Painter. London: Michael Joseph, 1968.

Findlater, Richard. Grimaldi: King of Clowns. London: MacGibbon \& Kee, 1955.

Fitzgerald, Edward. Letters of Edward Fitzgerald, [ed. W[illiam] Aldis Wright]. 2 vols. London: Macmillan, 1894.

Fitzgerald, Percy. The History of Pickwick. London: Chapman and Hall, 1891.

Ford, George H. Dickens and His Readers. New York: W. W. Norton, 1965.

Ford, George H., and Lauriat Lane, Jr., eds. The Dickens Critics. Ithaca: Cornell University Press, 1961.

[Ford, Richard]. "Oliver Twist." Quarterly Review 64 (June, 1839): 83-102.

Forster, John. "George Cruikshank's Fairy Library: Hop o" My Thumb and The Seven-League Boots." Examiner (July 23, 1853): 469.

. The Life of Charles Dickens. Edited by A. J. Hoppé. 2 vols. London: J. M. Dent \& Sons, 1966.

- The Life of Charles Dickens. Edited by J. W. T. Ley. London: Cecil Palmer, 1928.

[-? ]. "The Pickwick Papers, No. VII." Examiner (October 9, 1836): 647-48.

[—_]. "The Pickwick Papers, No. XV." Examiner (July 2, 1837): 421-22.

Forster Collection: A Catalogue of the Printed Books Bequeathed by John Forster, Esq. LL.D. London: Her Majesty's Stationery Office, 1888.

Franklin, Colin. The Private Presses. London: Studio Vista, 1970.

Frith, Walter. "Small Talk with My Father." Comhill Magazine 23 (December, 1907): 802-10.

Frith, W[illiam] P[owell]. John Leech, His Life and Work. 2 vols. London: Bentley \& Son, 1891.

My Autobiography and Reminiscences. 2 vols. 7th ed. London: Bentley \& Son, 1899.

Garvey, Eleanor, comp. The Artist and the Book, 18601960. With an introduction by Philip Hofer. Boston: Museum of Fine Arts, 1961.

Gaultier, Bon [Sir Theodore Martin], ed. "The American Apostrophe to 'Boz.'" In The Book of Ballads, p. 52. London: William S. Orr, 1845. 
"George Cruikshank." The Times (London) (February 2, 1878), 9.

George Cruikshank: A Revaluation, edited by Robert L. Patten. Princeton University Library Chronicle. 35 (Autumn and Winter, 1973-74). Princeton: Princeton University Press, 1974.

George Cruikshank. Exhibition Catalogue, Victoria and Albert Museum, Febmary 28-April 28, 1974. London: Arts Council of Great Britain, 1974.

"George Cruikshank, Esq." Fraser's Magazine 8 (August, 1833): 190.

George, Mary Dorothy. Catalogue of Political and Personal Satires. Volume X, 1820-1827. London: British $\mathrm{Mu}$ seum, 1952.

- Catalogue of Political and Personal Satires. Volume XI, 1828-1832. London: British Museum, 1952.

Gettman, Royal. A Victorian Publisher: A Study of the Bentley Papers. Cambridge: Cambridge University Press, 1960.

Gimbel, Richard. "An Exhibition of 150 Manuscripts, Illustrations, and First Editions of Charles Dickens to Commemorate the 150th Anniversary of His Birth: Selected from His Collection and Described by Colonel Richard Gimbel, 1920." Yale University Library Gazette 37 (October, 1962): 46-93.

Gissing, George. Charles Dickens. London: Blackie, 1903.

Gogh, Vincent van. The Complete Letters of Vincent van Gogh. 3 vols. Greenwich: New York Graphic Society, 1958.

Goldberg, Michael. Carlyle and Dickens. Athens: University of Georgia Press, 1972.

Gombrich, E. H. "The Cartoonist's Armoury." In Meditations on a Hobby Horse, pp. 127-42. London: Phaidon Press, 1963.

. "The Experiment in Caricature." In Art and Illusion, pp. 330-58. New York: Pantheon, 1960.

Gossop, Robert P. Book Illustration: A Review of the Art as It Is Today. London: J. M. Dent, 1937.

Grant, James. Portraits of Public Characters. 2 vols. London: Saunders and Otley, 1841.

Graves, Algernon, comp. A Dictionary of Artists Who Have Exhibited Works in the Principal London Exhibitions from 1760 to $1898.3 \mathrm{~d}$ ed. London: H. Graves \& Co., 1901.

- The Royal Academy of Arts: A Complete Directory of Contributors and Their Works from Its Foundation in 1769 to 1904.8 vols. London: Henry Graves and Co. and George Bell \& Sons, 1903-6.

Gray, Basil. The English Print. London: Adam and Charles Black, 1937.

Grego, Joseph P. "Dickens and His Artist Friends." Graphic 45 (March 19, 1897): 374-75.

—_, ed. Pictorial Pickwickiana. 2 vols. London: Chapman and Hall, 1899.

Hagstrum, Jean H. The Sister Arts. Chicago: University of Chicago Press, 1956.

Haight, Anne Lyon. "Charles Dickens Tries to Remain
Anonymous: Notes on The Loving Ballad of Lord Bateman." Colophon, New Graphic Series, no. 1 (Spring, 1939), np.

Hall, Samuel Carter. Retrospect of a Long Life: From 1815 to 1883. New York: Appleton, 1883.

Hambourg, Daria. Richard Doyle: His Life and Work. London: Art and Technics, 1948.

Hamilton, Walter. George Cruikshank: Artist and Humourist. London: Elliot Stock, 1878.

Hammelmann, Hanns. Book Illustrators in EighteenthCentury England. Edited and compiled, by T. S. R. Boase. New Haven and London: Yale University Press for the Paul Mellon Centre for Studies in British Art (London), 1975.

Hardy, Barbara. The Moral Art of Dickens: Essays. New York: Oxford University Press, 1970.

Harvey, John R. Victorian Novelists and Their Illustrators. New York: New York University Press, 1971.

Hatton, Thomas, comp. "A Bibliographical List of the Original Illustrations to the Works of Charles Dickens, Being Those Made Under His Supervision." Retrospectus and Prospectus: The Nonesuch Dickens (also known as Nonesuch Dickensiana), pp. 55-78. Bloomsbury: The Nonesuch Press, 1937.

Hatton, Thomas, and Arthur H. Cleaver. A Bibliography of the Periodical Works of Charles Dickens. London: Chapman and Hall, 1934.

[Hayward, Abraham?]. "The Posthumous Papers of the Pickwick Club . . . Oliver Twist," Quarterly Review 59 (October, 1837): 484-518.

Hazlitt, William. The Complete Works of William Hazlitt. Edited by P. P. Howe. 33 vols. London: J. M. Dent, 1930-34.

Hearn, Michael Patrick, ed. The Annotated Christmas Carol by Charles Dickens. New York: Avon Books, 1977.

Hemstedt, Geoffrey C. Some Victorian Novels and Their Illustrations. Ann Arbor, Mich.: University Microfilms, 1971 (Ph.D. thesis).

Hill, Draper. Fashionable Contrasts. London: Phaidon Press, 1966.

-Mr. Gillray the Caricaturist: A Biography. London: Phaidon Press, 1965.

Hill, Nancy K. Visual Art in the Imagery of Charles Dickens. Ann Arbor, Mich: University Microfilms, 1972 (Ph.D. thesis).

Hodgson, S[idney]. "The Ballad of Lord Bateman." Times Literary Supplement (June 13, 1935): 380.

Hofer, Philip. The Illustration of Books. New York: The Dolphin, 1938.

Hogarth, William. Hogarth Moralized. Edited by Rev. John Trusler. London: John Major, 1831.

Holmes, Richard R. Queen Victoria. New ed. London: Longmans, Green \& Co., 1901.

[Hood, Thomas]. "Master Humphrey's Clock, Volume I." Athenaeum (November 7, 1840): 887-88.

- The Works of Thomas Hood. Edited by his 
Daughter [Mrs. F. F. Broderip] and Son [Thomas Hood]. 7 vols. London: E. Moxon, 1862-63.

Horsman, Alan, ed. Dombey and Son by Charles Dickens. Oxford: Clarendon Press, 1974.

Hotten, John Camden. Charles Dickens. New York: Harper \& Bros., 1870.

Houghton, Walter, ed. The Wellesley Index to Victorian Periodicals, 1824-1900. 2 vols. London and Toronto: University of Toronto Press, 1966 and 1972-

Hughes, William R. A Week's Tramp in Dickens-land. London: Chapman and Hall, 1893.

Hunt, John Dixon, ed. Encounters: Essays on Literature and the Visual Arts. New York: Norton, 1971.

Hunt, W[illiam] Holman. Pre-Raphaelitism and the PreRaphaelite Brotherhood. 2 vols. $2 \mathrm{~d}$ ed. New York: E. P. Dutton and Co., 1914.

Hutchison, Sidney. The History of the Royal Academy 1768-1968. London: Chapman and Hall, 1968.

Inimitable George Cruikshank, The. Catalogue of Exhibition of Items from the David Borowitz Collection with an essay by Richard Vogler. J. B. Speed Art Museum, October 12-November 15, 1968. Louisville, Ky.: University of Louisville Libraries, 1968.

[Irreconcilable]. "The Penny Magazine." Saint Paul's Magazine 12 (May, 1873): 542-49.

Ivins, William M., Jr. How Prints Look. Boston: Beacon Press, 1958.

[J. T.]. "Samuel Williams." Notes and Queries, 1st ser. 8 (October 1, 1853): 312.

Jablow, Betsy L. Illustrated Texts from Dickens to James. Ann Arbor, Mich.: University Microfilms, 1978 (Ph.D. thesis).

Jackson, Mason. "How I Engraved the Cover for 'Pickwick." Sketch 25 (April 12, 1899), 516-17.

[-]. "'Pickwick' and Its Illustrators." Athenaeum (June 11, 1887): 767.

James, Henry. The Art of the Novel. New York: Charles Scribner's Sons, [1962].

- Autobiography. Edited by Frederick W. Dupee. New York: Criterion, [1956].

- "Du Maurier and London Society." The Century Magazine 26 (May, 1883): 49-65. (Reprinted in Partial Portraits, with an introduction by Leon Edel, pp. 327-72. Ann Arbor: University of Michigan Press, 1970).

_. "George du Maurier." Harper's Weekly 38 (April 14, 1894): $341-42$.

. "Our Mutual Friend." Nation 1 (December 21, 1865): 786-87.

- The Painter's Eye: Notes and Essays on the Pictorial Arts. Edited, with introduction, by John L. Sweeney. Cambridge: Harvard University Press, 1956.

James, Philip. British Book Illustration, 1985-1945: Catalogue of Exhibit. London: British Book Council, November, 1946.

- English Book Illustration, 1800-1900. Harmondsworth, England: Penguin, 1947.
"James Smetham and C. Allston Collins." Art Joumal 66 (September, 1904): 281-84.

Jerrold, [William] Blanchard. The Life of George Cruikshank. London: Chatto \& Windus, 1883.

Johannsen, Albert. Phiz: Illustrations from the Novels of Charles Dickens. Chicago: University of Chicago Press, 1956.

"John Leech." Punch 47 (November 12, 1864): 195.

[Johnson, Charles Plumptre]. "'Pickwick' and Its Illustrators." Athenaeum (June 14 1887): 737-38.

Johnson, Charles Plumptre, ed. The Posthumous Papers of the Pickwick Club by Charles Dickens. 2 vols. London: Chapman and Hall, 1887.

Johnson, Edgar. Charles Dickens: His Tragedy and Triumph. 2 vols. New York: Simon \& Schuster, 1952. (Published in 1 vol. rev. and abr. New York: Viking Press, Richard Seaver, 1977.)

Kamm, Josephine. How Different from Us: A Biography of Miss Buss and Miss Beale. London: The Bodley Head, [1958].

Kaufman, Robert F. The Relationship Between Illustration and Text in the Novels of Dickens, Thackeray, Trollope, and Hardy. Ann Arbor, Mich.: Xerox University Microfilms, 1974 (Ph.D. thesis).

[Keneally, Edward]. "Daniel Maclise, R.A." Dublin University Magazine 29 (May, 1847): 594-607.

Keynes, Geoffrey L., ed. Samuel Palmer Sketch Book, 1824. London: Trianon Press for William Blake Trust, 1962.

Kirby, Andrew. "Watts Phillips: A Man of Letters." Apollo, n.s. 95 (May, 1972): 400-401.

[Kitto, John]. "A Poor Student's Literary Expenditure." Penny Magazine 4 (June 14, 1835): 227-28.

Kitton, Frederic G. Charles Dickens by Pen and Pencil. 3 vols. London: Frank T. Sabin, 1890-92.

. Dickens and His Illustrators. London: George Redway, 1899.

. "Dicken and Punch." English Illustrated Magazine 8 (August, 1891): 799-807.

- Dickensiana: A Bibliography of the Literature Relating to Charles Dickens and His Writing. London: G. Redway, 1886.

- John Leech: Artist and Humourist. New rev. ed. London: Georre Redway, 1884.

- Phiz (Hablot K. Browne): A Memoir. London: George Redway, 1882.

- "Pseudo-Dickens Rarities." Athenaeum (September 11, 1897): 355-56.

Klingender, F[rancis] D[onald]. Hogarth and English Caricature. London and New York: Transatlantic Arts, 1944

Lamb, Charles. The Complete Works and Letters of Charles Lamb. New York: Random House, Modern Library, 1935.

Lamb, Lynton. Drawing for Illustration. London: Oxford University Press, 1962.

Lambert, Samuel W. When Mr. Pickwick Went Fishing. 
New York: Brick Row Bookshop, 1924.

Lang, Andrew. "The Mysteries of Edwin Drood." Times Literary Supplement (November 10, 1905): 381.

Layard, George Somes. "George Cruikshank: A Defence." Temple Bar 99 (December, 1897): 560-67.

. George Cruikshank's Portraits of Himself. London: W. T. Spencer, 1897.

-. "Our Graphic Humourists: Robert William Buss." Magazine of Art 26 (June, 1902): 361-64.

- Suppressed Plates. London: Adam \& Charles Black, 1907.

Q. D. Leavis. "The Dickens Illustrations: Their Function." In Dickens the Novelist, by F. R. Leavis and Q. D. Leavis, pp. 332-71. London: Chatto \& Windus, 1970.

Lennie, Campbell. Landseer: The Victorian Paragon. London: Hamilton, 1976.

Leslie, George Dunlop. The Inner Life of the Royal Academy. London: John Murray, 1914.

L'Estrange, Rev. Alfred Guy, ed. The Friendships of Mary Russell Mitford. 2 vols. New York: Harper \& Bros., 1882.

Lewis, John. The Twentieth-Century Book: Its Illustration and Design. New York: Reinhold Publishing Corp., 1967.

Ley, J. W. T. The Dickens Circle. London: Chapman and Hall, 1918.

"Library of Fiction, The, The Posthumous Papers of the Pickwick Club." Literary Gazette (April 9, 1836): 233.

"Life and Adventures of Nicholas Nickleby, The." Athenaeum (March 31, 1838): 227-29.

Linton, W[illiam] J[ames]. The Masters of Wood-Engraving. London and New Haven, Conn.: B. F. Stevens, 1889.

Lister, Raymond. Samuel Palmer: A Biography. London: Faber and Faber, 1974.

-. Samuel Palmer and His Etchings. London: Faber and Faber, 1969.

Victorian Narrative Paintings. New York: C. N. Potter, 1966.

[Lister, T. H.]. "Dickens's Tales." Edinburgh Review 68 (October, 1838): 75-97.

Locker-Lampson, Frederick. My Confidences. London: Smith, Elder \& Co., 1896.

[Lqekhart, John G.]. "Lectures on the Fine Arts: No. 1 on George Cruikshank." Blackwood's Edinburgh Magazine 14 (July, 1823): 18-26.

Longfellow, Henry Wadsworth. The Letters of Henry Wadsworth Longfellow. Edited by Andrew Hilen. 4 vols. Cambridge: Harvard University Press, 1967-72.

"Loving Ballad of Lord Bateman, The." Spectator (June 8, 1839): 568.

[Lucas, Samuel]. "Modern English Caricature." In Mornings of the Recess, 1861-1864: A Series of Biographical and Literary Papers. 2 vols; vol. 2, pp. 191-211. London, 1864.

Lusk, Lewis. "The Best of Richard Doyle." Art Journal (1902): 248-52.

Lutyens, Mary. "Selling the Missionary." Apollo 86
(November, 1967): 380-87.

Maas, Jeremy. Victorian Painters. London: Barrie \& Rockeliff, Cresset Press, 1969.

McKenzie, Gordon. "Dickens and Daumier." In Studies in the Comic, vol. 8, pp. 273-98. Berkeley: University of California Press, 1941.

MacKenzie, R. Shelton. "George Cruikshank." London Journal 6 (November 20, 1847): 177-82.

. "George Cruikshank vs. Charles Dickens." Philadelphia Press (December 19, 1871), p. 2, col. 2-3.

. The Life of Charles Dickens. Philadelphia: T. B. Peterson, 1870. $155-56$.

McLean, Ruari. George Cruikshank: His Life and Work as a Book Illustrator. New York: Pellegrini \& Cudahy, [1948]. English Book Illustraton: 966-1846. London: British Book Centre, 1965.

. Victorian Book Design and Colour Printing. $2 \mathrm{~d}$ ed. rev. London: Faber and Faber, 1972.

Maclise, Daniel. "Autobiography." Manuscript. Library of the Royal Academy, London. October, 1846.

Macready, William Charles. The Diaries of William Charles Macready, 1833-1851. Edited by William Toynbee. 2 vols. London: Chapman and Hall, 1912.

Madden, Richard Robert. The Literary Life and Correspondence of the Countess of Blessington. 3 vols. $2 \mathrm{~d}$ ed. London: T. S. Newby, 1855.

Malins, Edward G. Samuel Palmer's Italian Honeymoon. London: Oxford University Press, 1968.

Manson, James Alexander. Sir Edwin Landseer, R.A. London: W. Scott, 1902.

Marten, Harry. "Exaggerated Characters: A Study of the Work of Dickens and Hogarth." Centennial Review 20 (Summer, 1976): 290-308.

. "The Visual Imagination of Dickens and Hogarth: Structure and Scene." Studies in the Novel 6 (Summer, 1974): 145-64.

Martin, Sir Theodore. See Gaultier, Bon.

[Martineau, Harriet]. "Tubal-Cain." Household Words (May 15, 1852): 192-97.

Marvy, Lewis, ed. Sketches after English Landscape Painters: with Short Notes by W. M. Thackeray. London: David Bogue, [1850].

"Master of the Comic Catastrophe." Times Literary Supplement (December 8, 1972): 1473-75.

Matz, B[ertram] W., ed. Dickens in Cartoon and Caricature. Boston: Bibliophile Society, 1924.

"'Phiz': The Centenary of Hablôt Knight Browne." Bookman 48 (June, 1915): 69-74.

Maurice, Arthur Bartlett. Criikshankiana. New York: Robert H. Dodd, 1916.

Mayor, A. Hyatt. Prints and People: A Social History of Printed Pictures. New York: Metropolitan Museum of Art, 1971. 
Melville, Lewis [Lewis S. Benjamin]. William Makepeace Thackeray. 2 vols. London: John Lane, The Bodley Head, 1910.

Memorials of Thomas Hood. Edited by his Daugher [Mrs. F. F. Broderip]. 2 vols. Boston: Ticknor \& Fields, 1860.

Meynell, Alice. "How Edwin Drood Was Illustrated." Century Magazine 27 (February, 1884): 522-28.

Miller, J. Hillis. "The Fiction of Realism: Sketches by Boz, Oliver Twist, and Cruikshank's Illustrations." In Charles Dickens and George Cruikshank, pp. 1-69. Los Angeles: William Andrews Clark Memorial Library, 1971, and reprinted in Ada Nisbet and Blake Nevius, eds., Dickens Centennial Essays, pp. 85-153. Berkeley, Los Angeles, London: University of California Press, 1971.

Miller, William. The Dickens Student and Collector. Cambridge: Harvard University Press, 1946.

Miller, William, and E. H. Strange. A Centenary Bibliography of the Pickwick Papers. London: Argonaut, 1936.

"Mr. Forster's 'Life of Dickens', vol. II." Nation 16 (January 9, 1873): 28-29.

"Mr. Samuel Williams." Athenaeum (October 15, 1883): 1231-32.

Monkhouse, [William] Cosmo. "Sir John Tenniel." Art Journal (Easter number, 1901): 1-32.

Moore, Robert E[theridge]. Hogarth's Literary Relationships. Minneapolis: University of Minnesota Press, 1948.

Muir, Percy. Victorian Illustrated Books. New York: Praeger, 1971.

[Murray, P. A.]. "Dickens's Pictures from Italy." Dublin Review, 21 (September, 1846): 184-201.

"Mystery of Edwin Drood, The." New Monthly Magazine 147 (October, 1870): 461.

"Mystery of Edwin Drood, The." Spectator, 43 (October 1, 1870): $1176-77$.

Nicoll, [Sir] W[illiam] Robertson. The Problem of Edwin Drood: A Study in the Methods of Dickens. London: Hodder \& Stoughton, 1912.

Nisbet, Ada. "Charles Dickens." In Victorian Fiction: A Guide to Research, edited by Lionel Stevenson, pp. 44-153. Cambridge: Harvard University Press, 1964.

O'Driscoll, W. Justin. A Memoir of Daniel Maclise, R.A. London: Longmans, Green, 1871.

Oliver Twist Exhibition, An: A Memento for the Dickens Centennial, with an Essay by.Richard A. Vogler. May 7 -Jine 15, 1970. Los Angeles: University Research Library (UCLA), 1970.

Ormond, Leonée. George Du Maurier. London: Routledge \& Kegan Paul, 1969.

Ormond, Richard. "Daniel Maclise." Burlington Magazine 110 (1968): 685-93.

_. Early Victorian Portraits. 2 vols. London: Her Majesty's Stationery Office, 1973.

Ormond, Richard, and John Turpin. Daniel Maclise, 18061870. [Exhibition Catalogue]. National Portrait Gallery, March 3-April 16, 1972; National Gallery of Ireland, Dublin, May 5-June 18, 1972. London: Arts Council of
Great Britain, 1972.

Ottley, Henry. A Biographical and Critical Dictionary of Recent and Living Painters and Engravers. London: Henry G. Bohn, 1866.

"Our Critic among the Pictures." Punch 22 (June, 1852): 232-33.

[Paget, John]. "George Cruikshank." Blackwood's Edinburgh Magazine 94 (August, 1863): 217-24.

Palmer, A[lfred] H[erbert], ed. The Life and Letters of Samuel Palmer. London: Seeley \& Co., 1892.

- Samuel Palmer: A Memoir. London: Fine Arts Society, 1882.

Palmer, Samuel. The Letters of Samuel Palmer. Edited by Raymond Lister. 2 vols. Oxford: Clarendon Press, 1974.

Parker, Robert A. "The Great George." Arts 6 (October, 1924): 211-24.

Paroissien, David, ed. Pictures from Italy by Charles Dickens. London: André Deutsch, 1973. [An earlier version of the discussion of the illustrations, "Pictures from Italy and Its Original Illustrator," appeared in The Dickensian 67 (May, 1971): 87-90.]

Partlow, Robert B., Jr., ed. Dickens the Craftsman: Strategies of Presentation. Carbondale: Southern Illinois University Press, 1970.

Patten, Robert L. "The Art of Pickwick's Interpolated Tales." English Literary History 34 (September, 1967): 349-66.

"Boz, Phiz, and Pickwick in the Pound." Joumal of English Literary History 36 (September, 1969): 575-91.

- ed. The Pickwick Papers by Charles Dickens. Harmondsworth, England: Penguin, 1972.

"Pickwick Papers and the Development of Serial Fiction." Rice University Studies 61 (Winter, 1975): 51-74.

Paulson, Ronald. Hogarth: His Life, Art, and Times. 2 vols. New Haven: Yale University Press, 1971.

Hogarth's Graphic Works. Rev. ed. 3 vols. New Haven: Yale University Press, 1970.

- Rowlandson: A New Interpretation. New York: Oxford University Press, 1972.

Peacock, Thomas Love. "The New Year." In The Works of Thomas Love Peacock, edited by H. F. B. Brett-Smith and C. E. Jones, vol. 7, p. 251. London: Constable, 1931.

Pennell, Joseph. The Illustration of Books. New York: Century, 1896.

- Modern Illustration. London and New York: G. Bell \& Sons, 1895.

Perugini, Kate. "Charles Dickens as a Lover of Art and Artists." Magazine of Art, n.s. 1 (1903): 125-30 and 164-69.

- " "Edwin Droad' and the Last Days of Charles Dickens." Pall Mall Magazine 37 (June, 1906): 643-54.

. "Thackeray and My Father." Pall Mall Magazine 42 (August, 1911): 213-19.

Phillips, E[mma] Watts. Watts Phillips: Artist and Playwright. London: Cassell \& Co., 1891. 
“'Pickwick Club, The,' 'Sketches by Boz,' 'Bentley's Miscellany.'" Monthly Review 1 (February, 1837): 156.

"Pictures from Italy." Athenaeum (May 23, 1846): 519-20 and (May 30, 1846): 546-47.

"Pictures from Italy." Dublin Review 21 (September, 1846): 184-201.

"Pictures in the Houses of Parliament." Athenaeum (August 20, 1864): 249.

"Posthumous Papers of the Pickwick Club, The. ed. by Boz: Nos. 1 to 10." Athenaeum (December, 1836): 841-43.

"Posthumous Papers of the Pickwick Club, The: Nos. 1 to 12." Eclectic Review 1 (April, 1837): 343.

"Posthumous Papers of the Pickwick Club, The." Metropolitan Magazine 16 (May, 1836): 15; (June, 1836): 46-47; (July, 1836): 76; and (August, 1836): 110.

Potter, Beatrix. The Journal of Beatrix Potter from 1881 to 1897. Transcribed by Leslie Linder. London and New York: Frederick Warne \& Co., 1966.

Price, Richard G. G. A History of Punch. London: Collins, 1957.

Pritchett, V. S. "Books in General." New Statesman and Nation 23 (February 28, 1942): 145.

Punch; or The London Charivari. London, 1841-1895. Vols. 1-108.

Purdy, Richard L. Thomas Hardy: A Bibliographical Study. London: Oxford University Press, 1954.

[Putnam, George W.]. "Four Months with Charles Dickens." Atlantic Monthly 26 (October, 1870): 476-82 and (November, 1870): 591-99.

Quamoclit, Arnold. "Charles Dickens as a Humaniser." St.James Magazine 35 (April, 1879): 281-91.

Ray, Gordon N. The Illustrator and the Book in England from 1790 to 1914. New York: The Pierpont Morgan Library and Oxford University Press, 1976.

. Thackeray: The Age of Wisdom, 1847-1863. New York: MeGraw-Hill, 1958.

Thackeray: The Uses of Adversity, 1811-1846. New York: McGraw-Hill, 1955.

Redgrave, F. M. Richard Redgrave, C.B., R.A.: A Memoir, Compiled from His Diary. London: Cassell \& Co., 1891.

Redgrave, Samuel. A Dictionary of Artists of the English School: Painters, Sculptors, Architects, Engravers and Ornamentists. London: Longmans, Green \& Co., 1874.

Reed, John R. "Emblems in Victorian Literature." Hartford Studies in Literature 2 (1970): 19-39.

Reid, George William. A Descriptive Catalogue of the Works of George Cruikshank. 3 vols. London: Bell \& Daldy, 1871.

Renton, Richard. John Forster and His Friendships. London: Chapman and Hall, 1912.

Reynolds, Graham. "Charles Dickens and the World of Art." Apollo 91 (June, 1970): 422-29.

- Victorian Painting. New York: Macmillan, 1966.

[Reynoids, John Hamilton?]. "Memoirs of Joseph Grimaldi." Athenaeum (February 17, 1838): 114-17.
[-_]. "Memoirs of Joseph Grimaldi (Second Notice)." Athenaeum (March 3, 1838): 164-65.

"Richard Doyle, Painter and Humourist." Month 50 (March, 1884): 305-19.

Ridley, Annie E. Frances Mary Buss and Her Work for Education. London and New York: Longmans, Green \& Co., 1895.

Ritchie, Lady Anne Thackeray. Chapters from Some Unwritten Memoirs. New York: Harper \& Bros., 1895.

- "Comment on Lord Bateman: A Ballad." Harper's Magazine 86 (December, 1892): 124-29.

Robb, B. "George Cruikshank's Etchings for Oliver Twist," The Listener 74 (July 22, 1965): 130-31.

Robinson, Henry Crabb. Henry Crabb Robinson on Books and Their Writers. Edited by Edith J. Morley. 3 vols. London: J. M. Dent \& Sons, 1938.

Roe, F. Gordon. "Portrait Painter to 'Pickwick': or Robert Seymour's Career." Connoisseur 77 (March, 1927): $152-57$.

- "Seymour, the 'Inventor' of 'Pickwick." Connoisseur 77 (February, 1927): 67-71.

$$
\text { 177-78. }
$$

Rosenbach, A. S. W. A Catalogue of the Works Illustrated by George Cruikshank and Isaac and Robert Cruikshank in the Library of Harry Elkins Widener. Philadelphia: Privately printed, 1918.

- A Catalogue of the Writings of Charles Dickens in the Library of Harry Elkins Widener. Philadelphia: Privately printed, 1918.

Rosenberg, Edgar. From Shylock to Svengali: Jewish Stereotypes in English Fiction. Stanford: Stanford University Press, 1960.

Rossetti, Dante Gabriel. The Collected Works of Dante Gabriel Rossetti. Edited by William M. Rossetti. 2 vols. London: Ellis \& Elvey, 1897.

Rossetti, William Michael. Fine Art Chiefly Contemporary. London: Macmillan, 1867.

Ruskin, John. The Diaries of John Ruskin. Edited by Joan Evans and John Howard Whitehouse. 3 vols. Oxford: Clarendon Press, 1956-59.

The Works of John Ruskin. Edited by E. T. Cook and Alexander Wedderburn. 39 vols. London: George Allen, 1903-12.

Sadleir, Michael, ed. Peter Simple by Captain [Frederick] Marryat. 2 vols. London: Constable \& Co., 1929.

Sala, G[eorge] A[ugustus]. "George Cruikshank: A Life Memory." Gentleman's Magazine 242 o.s. (May, 1878): $544-68$.

—. "William Hogarth: Painter, Engraver, and Philosopher, Nos. 1-9." Cormhill Magazine 1 (February, 1860): 177-93, through 2 (October, 1860): 438-61.

Salamon, M. C. Modern Book Illustrators and Their Work. London: The Studio, 1914.

Sarzano, Francis. Sir John Tenniel. London: Art \& Technics, 1948. 
Sauerberg, Annette, "On The Literariness of Illustrations: A Study of Rowlandson and Cruikshank." Semiotica 14 (1975): 364-86.

[Sawyer, William]. "The Pickwick Papers." Belgravia, 2 0.s. or 12 n.s. (July, 1870): 33-36.

Scott, Sir Walter. The Letters of Sir Walter Scott. Edited by H. J. C. Grierson. 12 vols. London: Constable, 1932-37.

Scott, William Bell. Autobiographical Notes of the Life of William Bell Scott. Edited by William Minto. 2 vols. London: Osgood \& McIlvaine, 1892.

Sellars, James. Samuel Palmer. London: Academy Editions, 1974.

Seymour, Mrs. Jane Holmes. An Account of the Origin of the Pickwick Papers. London: Privately printed, [1854].

Seymour, Robert. The Heiress. London: T. McLean, 1830. . New Readings of Old Authors. 26 Nos. London: E. Wilson, [1833-34].

Seymour's Comic Album. London: W. Kidd, 1834. . Seymour's Humorous Sketches. London: Henry G. Bohn, 1866.

[?Seymour, Robert (son)]. "Life of Robert Seymour." Seymour's Sketches: The Book of Cockney Sports, Whims and Oddities. London: J. C. Hotten, [1867].

"Seymour's Sketches." Athenaeum (March 24, 1866): 398.

Shaw, George Bernard. Preface to Great Expectations by Charles Dickens, pp. v-xxii. Edinburgh: R. \& R. Clark for Limited Editions Club, 1937.

Shore, W. Teignmouth. Charles Dickens and His Friends. London: Cassell \& Co., 1909.

Shorter, Clement K. The Brontës: Life and Letters. 2 vols. London: Hodder \& Stoughton, 1908.

Simmons, Ira E., Jr. Hogarthian Elements in the Illustrations of Marcus Stone and S. L. Fildes for Dickens' Last Three Novels. Ann Arbor, Michigan: University Microfilms (Master's thesis).

Simon, Howard. Five Hundred Years of Art and Illustration. New York: World, 1942.

"Sir John Tenniel," (eds.) Punch 146 (March 4, 1914): supplement, 1-16.

"Sir Luke Fildes." The Times (London) (February 28, 1927): 17.

Sitwell, Edith, Osbert Sitwell, and Sacheverell Sitwell. "George Cruikshank." In Trio: Dissertations on Some Aspects of National Genius, pp. 221-48. London: Macmillan, 1938.

Sitwell, Sacheverell. Narrative Pictures: A Survey of English Genre and Its Painters. London: B. T. Batsford, 1937.

Slater, Michael, ed. Catalogue of the Suzannet Charles Dickens Collection. London: Sotheby Parke Bernet, 1975.

, comp. Catalogue of Treasures from the Dickens Collection Formed by the Late Comte Alain de Suzannet. Exhibition, Dickens House, June 1-September 12, 1970.
, ed. The Christmas Books by Charles Dickens. 2 vols. Harmondsworth, England: Penguin, 1971.

- The Composition and Monthly Publication of Nicholas Nickleby. London: Scolar Press, 1973.

Smith, Wilbur J. "Note 277: Boz's Memoirs of Joseph Grimaldi, 1838." Book Collector 16 (Spring, 1967): p. 80.

"Some Unpublished Sketches by George Cruikshank." Strand Magazine 14 (August, 1897): 183-91.

Spencer, Walter T. "The Loving Ballad of Lord Bateman, 1839." Times Literary Supplement (May 2, 1935): 288.

-. "Loving Ballad of Lord Bateman." Times Literary Supplement (June 6, 1935): 364.

Spielmann, M[arion] H[arry]. The History of 'Punch.' London: Cassell, 1895.

Steig, Michael. "A Chapter of Noses: George Cruikshank's Psychonography of the Nose." Criticism 17 (Fall, 1975): 308-25.

"The Critic and the Illustrated Novel: Mr. Turveydrop from Gillray to Bleak House." Huntington Library Quarterly 36 (November, 1972): 55-67.

"Cruikshank's Peacock Feathers in Oliver Twist." Ariel E4 (April, 1973): 49-53.

. Dickens and Phiz. Bloomington and London: Indiana University Press, [1978].

"Dickens, Hablôt Browne, and the Tradition of English Caricature." Criticism 11 (Summer, 1969): 219-33.

-_. "Dombey and Son: Chapter XXI, Plate 20." English Language Notes 7 (December, 1969): 124-27.

- "The Iconography of David Copperfield." Hartford Studies in Literature 2 (1970): 1-18.

- "Martin Chuzzlewit: Pinch and Pecksniff." Studies in the Novel 1 (Summer, 1969): 181-87.

- "Structure and the Grotesque in Dickens: Dombey and Son, Bleak House." Centennial Review 14 (Summer, 1970): 313-30.

Stephens, Frederic George. A Memoir of George Cruikshank. London: Sampson Low, Marston, Searle \& Rivington, 1891.

Stevens, Joan. "Woodcuts Dropped Into the Text: The Illustrations in The Old Curiosity Shop and Bamaby Rudge." Studies in Bibliography 20 (1967): 113-34.

Stoehr, Taylor. Dickens: The Dreamer's Stance. Ithaca: Cornell University Press, 1965.

[Stone, Frank?]. "The Royal Academy." Athenaeum (June 1, 1850): 390-91.

Stone, Harry. "Dark Corners of the Mind: Dickens's Childhood Reading." Hom Book Magazine 39 (June, 1963): 306-21.

Stone, Laurence. "Literacy and Education in England, 1640-1900." Past and Present 42 (February, 1969): 69-139.

Stone, Marcus. "Reminiscences." Typescript. London: Dickens House, nd.

Stone, Reynolds. Introduction to Wood Engravings of 
Thomas Bewick, pp. 7-47. London: Rupert HartDavis, 1953.

Stonehouse, J[ohn] H[arrison], ed. Catalogue of the Libraries of Charles Dickens and William Thackeray. London: Piccadilly Fountain Press, 1935.

Storey, Gladys. Dickens and Daughter. London: Frederick Muller, 1939.

Stott, R. Toole, "Note 277. Boz's Memoirs of Joseph Grimaldi, 1838." Book Collector 15 (Autumn, 1966): $354-56$.

Sucksmith, Harvey Peter, ed. Little Dorrit by Charles Dickens, Oxford: Clarendon Press, 1978.

Sullivan, Edmund J. The Art of Illustration. London: Chapman and Hall, 1921.

[Surtees, Robert Smith], and Edward D. Cuming. Robert Smith Surtees. Edinburgh and London: W. Blackwood \& Sons, 1924.

Sutherland, J. A. Victorian Novelists and Publishers. Chicago: University of Chicago Press, 1976.

Sweetser, Moses F. Landseer. Boston: Houghton, Osgood, 1879.

Swinburne, Algernon Charles. Charles Dickens. London: Chatto \& Windus, 1913.

"Tale of Two Cities, A." Saturday Review 8 (December 17, 1859): $741-43$.

Taylor, John Russell. The Art Nouveau Book in Britain. London: Methuen and Co., 1966.

[Taylor, Tom]. "The Late George Cattermole." Art Journal, n.s. 9 (March, 1870): 92-93.

[Thackeray, William Makepeace] (M.A.T.). "A Box of Novels." Fraser's Magazine 29 (February, 1844): 153-69.

[—_]. "George Cruikshank." Westminster Review 34 (June, 1840): 1-60.

[-] (Michael Angelo Titmarsh). "A Grumble about the Christmas-Books." Fraser's Magazine 35 (January, 1847): 125-26.

—. "Hogarth, Smollett and Fielding." In The English Humourists and the Four Georges. London: J. M. Dent \& Sons, 1949.

- - The Letters and Private Papers of William Makepeace Thackeray. Edited by Gordon N. Ray. 4 vols. Cambridge: Harvard University Press, 1945-46.

[—] [M. A. Titmarsh]. "May Gambols; or, Titmarsh in the Picture Galleries." Fraser's Magazine 29 (June, 1844): $700-16$.

[—] [T.]. "Parisian Caricatures." London and Westminster Review 32 (April, 1839): 282-305.

[—_] (Michael Angelo Titmarsh). "A Pictorial Rhapsody." Fraser's Magazine 21 (June, 1840): 720-22.

[—] (Michael Angelo Titmarsh). "A Pictorial Rhapsody Concluded." Fraser's Magazine 22 (July, 1840): 112-26.

[—_] (Michael Angelo Titmarsh). "Pictures of Life and Character by John Leech." Quarterly Review 96 (December, 1854): $75-86$.

[—]. "A Shabby Genteel Story," Fraser's Magazine 21
(June 1840): 677-89 through 22 (October, 1840): 399-414.

[-_ ]. "Speech at Royal Academy Dinner May, 1855." Harper's Weekly 2 (May 29, 1858): 343.

[-_] (Michael Angelo Titmarsh). "Strictures on Pictures." Fraser's Magazine 17 (June, 1838): 758-64.

Thomson, David Croal. Life and Labours of Hablot Knight Browne, "Phiz". London: Chapman and Hall, 1884.

- The Life and Works of Luke Fildes. London: Art Annual (Art Journal Christmas Number), 1895.

Thornber, Harry. "John Leech." Manchester Quarterly 9 (1890): 328-53.

. "The Later Work of George Cruikshank." Manchester Quarterly 26 (April, 1888): 97-126.

Thorpe, James H. English Illustration: The Nineties. London: Faber \& Faber, 1935.

Tidy, Gordon. A Little about Leech. London: Constable, 1931.

Tillotson, Kathleen. Novels of the Eighteen Forties. Oxford: Clarendon Press, 1954.

- ed. Oliver Twist by Charles Dickens. Oxford: Clarendon Press, 1966.

"'Pickwick' and Edward Jesse." TLS (April 1, 1960): 214.

[Titmarsh, M. A.]. See William Makepeace Thackeray.

Trollope, Anthony. An Autobiography. London: Oxford University Press, 1961.

Victoria, H. M. Queen. The Girlhood of Queen Victoria: A Selection from Her Majesty's Diaries Between the Years 1832 and 1840. Edited by Viscount Esher. 2 vols. London: John Murray, 1912.

The Letters of Queen Victoria: A Selection of Her Majesty's Correspondence and Journal Between 1862 and 1878. Edited by George Earle Buckle. 2d ser. 3 vols. London: John Murray, 1926.

Vizetelly, Henry. Glances Back through Seventy Years. 2 vols. London: K. Paul, Trench and Trübner \& Co., 1893.

Vogler, Richard A. Cruikshank and Dickens: A Review of the Role of Artist and Author. Ann Arbor, Mich.: University Microfilms, 1970 (Ph.D. thesis).

Wakeman, Geoffrey. Victorian Book Illustration: The Technical Revolution. Newton Abbot, England: David and Charles, 1973.

Wall, Stephen, ed. Charles Dickens: A Critical Anthology. Baltimore: Penguin, 1970.

Ward, Henrietta M. A. [Mrs. E. M. Ward]. Memories of Ninety Years. Edited by Isabel G. McAllister. London: Hutchinson \& Co., 1924.

Wardroper, John. The Caricatures of George Cruikshank. London: Gordon Fraser, 1978.

Watt, Ian. The Rise of the Novel. Berkeley: University of California Press, 1957.

Waugh, Arthur. "Dickens and His Illustrators." Retrospectus and Prospectus: The Nonesuch Dickens (also known as Nonesuch Dickensiana), pp. 9-52. London: The Nonesuch Press, 1937. 
A Hundred Years of Publishing. London: Chapman and Hall, 1930.

Wedmore, Frederick. "Cruikshank." Temple Bar 52 (April, 1878): 499-516.

. "Hablôt Browne and Book Illustration." Fortnightly Review 41 (January 1, 1884): 67-73.

Weitenkampf, Frank. The Illustrated Book. Cambridge: Harvard University Press, 1938.

"On Some Illustrators of Dickens." Book Buyer, n.s. 18 (March, 1899): 103-7.

White, [Joseph William] Gleeson. English Illustration, 'The Sixties': 1855-1870. Westminster: Constable, 1897.

Williams, Joseph Lionel. "Mr. Samuel Williams." Athenaeum (October 22, 1853): 1261-62.

Wilson, Angus. The World of Charles Dickens. London:
Viking Press, 1970.

Wilson, John [Christopher North]. "Noctes Ambrosianae." Blackwood's Edinburgh Magazine 20 (November, 1826): 770-92.

Wright, Thomas. A History of Caricature and Grotesque in Literature and Art. London: Chatto \& Windus, 1875. 1935.

[X]. "Modern Wood-Engraving." London and Westminster Review. 29 or 31 (1838): 265-80.

Zambrano, Ana Laura. The Novels of Charles Dickens and the Modern Film: A Study in the Aesthetics of Visual Imagination. Ann Arbor, Mich.: University Microfilms, 1972 (Ph.D. thesis). [Published with slight revision as Dickens and Film. New York: Gordon Press, 1976.] 


\section{INDEX}

a Beckett, Gilbert, 41, 46, 149

Ainsworth, William Harrison, 5, 15, 19, 27, 29, 69; and Browne, 82, 120; on Cruikshank's claims about role in Dickens's novels, 37; Jack Sheppard, 32; and The Pic Nic Papers, 19

Ainsworth's Magazine, 36

Albert, Prince, 134, 149, 157, 171; death of, 173; and Landseer, 174; Royal Commission of, 155

Alchemist, The, 30

Alger, Horatio, 77

Animal Magnetism, 30, 150, 186

Architectural Antiguities of Great Britain, 127

Arnold, Matthew, "To George Cruikshank," 32

Artists' General Benevolent Institution, 197

Asia, 229

Athenaeum, 26, 39, 49, 182; on Nicholas Nickleby, 73; on Frank Stone, 187-88; on Samuel Williams, 137, 138

Austen, Jane, 9

Austin, Henry, 189

Barham, R. H., Ingoldsby Legends, 56, 142

Bashilov, M. S., 230

Baudelaire, Pierre Charles, 24, 40, 45

Beard, Thomas, 163

Beardsley, Aubrey, 232, 233

Bede, Cuthbert. See Bradley, Edward

Belgian Society of Water-Colour Painters, 134

Bell, Vanessa, 232, 275, n. 38

Bennett, Arnold, 230

Bentley, Richard, 20, 21, 22; and Barnaby Rudge, 27, 77; and Memoirs of Joseph Grimaldi, 26

Bentley's Miscellany, 17, 24, 27, 36, 56; appearance of Oliver Twist in, 20, 21, 31, 69; illustration by Browne in, 67;

Thackeray's "The Professor" in, 236

Bewick, Thomas, 5, 135, 138

Bicknell, Elhanan, 62, 81

Blackwood's, 10, 31

Blake, William, 5, 193; Songs, 51

Blessington, Cowntess of, 125, 159

Blue Beard, 30

Bohn, Henry, 49

Bowring, Sir John, 26

Bradbury and Evans, 35, 89, 114, 121, 185; and All the Year Round, 120; and The Chimes, 152, 180; and The Cricket on the Hearth, 145-46, 153, 168; and Oliver Twist, 31: and Pictures from Italy, 182, 198, 194; and Tenniel, 155

Bradley, Edward [pseud. Cuthbert Bede], 23

British Museum, 62

Britton, John, 125, 127

Brontë Sisters, the, 9; Charlotte, 238 n. 41

Brougham, Henry, 149

Brown, Arthur, 233

Browne, Hablot K. [pseud. Phiz], 5, 7, 10, 17, 31, 35, 61-122; artistic interests pursued by, apart from Dickens, 82; Buss on, 57; death of, 122; and death of Leech, 151; end of association with Dickens, 120-21; etching help sought by, 8; illustrations by, for Barmaby Rudge, 77-82, 118, 133; illustrations by, for Bleak House, 90, 107-14, 121, 129; illustrations by, for David Copperfield, 90, 100-107, 109; illustrations by, for Dombey and Son, 32, 90-100, 109; illustrations by, for Little Dorrit, 114-17, 118; illustrations by, for Martin Chuzzlewit, 84-89, 133, 142; illustrations by, for Master Humphrey's Clock, 29, 74-75, 76, 121, 127, 136; illustrations by, for Nicholas Nickleby, 69-73, 75; illustrations by, for The Old Curiosity Shop, 75-77, 119, 129-30; illustrations by, for The Pickwick Papers, 19, 20, 48, $62-67,68,141-42$; illustrations by, for $A$ Tale of Two Cities, 118-20; later years of, 121-22, 228; other collaborations of, with Dickens, 67-69; personal relationship of, with Dickens, 82-84, 101; portrait of Dickens mistakenly attributed to, 67-68, $250 \mathrm{n}$. 46; portrait of Mary Hogarth by, 68-69; portrait of Mrs.

Pickwick attributed to, 68; professional relationship of, with Dickens, 61-62, 63; replaces Buss as Pickwick illustrator, 55, 62-63; and Marcus Stone's illustrations for Our Mutual Friend, 203-8 passim; talent and temperament of, 6; travels of, with Dickens, 21

Browne, Susannah (Reynolds), 82

Browning, Robert, 150, 171

Buck, Pearl, The Good Earth, 229-30

Bulwer-Lytton, Edward, 121, 125, 127, 131; Not So Bad as We Seem, 157, 171, 184, 188, 197

Bunyan, John, Pilgrim's Progress, 4, 74

Burne-Jones, Sir Edward, 38

Burnett, Fanny (Dickens), 26

Burnett, Henry, 26, 36

Buss, Frances, 57

Buss, Robert, 6, 8, 39, 42, 51-58, 83, 121; admiration of, for Dickens, 51, 56, 57; death of, 58; 'Dickens's Dream,' 58; English Graphic Satire, 57-58; illustrations by, for The Pickwick Papers, 51, 52-55; "My Connexion with The Pickwick Papers," 57; replaced as illustrator by Browne, 55-57, 62-63; and Samuel Williams, 135, 136, 137

Butler, Samuel, 231, 274 n. 18

Butt, John, 84, 90, 107, 114

Byron, George Gordon, Lord, 4, 125, 131

Cardwell, Margaret, 217

Carlyle, Jane, 26

Carlyle, Thomas, 118, 159

Carroll, Lewis, 6, 7; Alice books of, 155, 228, 231

Caswell, Edward [pseud. Quiz], Sketches of Young Ladies, 69 Cattermole, Clarissa (Elderton), 125-27, 131, 134

Cattermole, George, 6, 69, 73, 121, 125-34, 174; death of, 134; Dickens's nickname for, 84,128 ; grande médaille d'honneur received by, 134, 178; illustrations by, for Bamaby Rudge, $27-29,77-81,128,129,131-33$; illustrations by, for Master Humphrey's Clock, 74-75, 76, 83, 84, 125, 127-33, 135-36; illustrations by, for The Old Curiosity Shop, 75-76, 128-31, 133; personal relationship of, with Dickens, 125-27, 131; professional relationship of, with Dickens, 127-28, 132; role of, in Every Man in His Humour, 134; and Frank Stone, 186; and Topham, 197; waning of relationship with Dickens, 133-34 
Chagall, Marc, 232

Chapman, Edward, 29, 41-42, 82; and The Pickwick Papers, 43, $44,45,48-49$

Chapman and Hall, 19, 20, 35, 41, 121, 184; and Barmaby Rudge, 27; and Browne, 62, 67, 72, 122; Dickens's departure from, 89, 143, 168; and Dickens's relationship with Cattermole, 127; dismissal of Buss by, 56, 57; and Leech's illustrations for $A$ Christmas Carol, 142, 143; Library of Fiction of, 41-42, 51, 52, 62, 141-42; and Maclise's portrait of Dickens, 160; and The Mystery of Edwin Drood, 221, 224; and Nicholas Nickleby, 73, 187; and Oliver Twist, 34; and The Pickwick Papers, 43, 45-46, 50, 53, 64; and Stanfield's frontispiece for American Notes, 183; and Marcus Stone, 204; and Samuel Williams, 135, 136

Chesterfield, Lord, Letters, 78

Chesterton, G. K., 23, 49, 120, 189

Clarke, William, Three Courses and a Dessert, 41

Colburn, Alvin, 230

Colburn, Henry, 56

Collier's, 230

Collins, Charles, 6, 151, 210-20, 223, 228, 236; Cruise upon Wheels, 211; death of, 220; Dickens's hostility toward, 212, 217-20, 275 n. 51; handsome appearance of, 210,290 n. 13; ill health of, 212, 217; illustrations by, for The Mystery of Edwin Drood, 208, 210, 212-17, 220; marriage of, to Dickens's daughter Kate, 210-12; "The Uncommercial Traveller Upside Down," 212

Collins, Kate (Dickens) (daughter of CD), 162, 189, 236; husband's illness, 212, 217; marriage of, to Charles Collins, 210-12; remarriage of, to Carlo Perugini, 220, 228

Collins, Wilkie, 121, 212, 228; estrangement of, from Dickens, 217-20; The Frozen Deep, 171, 184, 210; The Lighthouse, 184, 210

Colnaghi's (art gallery), 193, 267 n. 1

Combe, William, 42

Comfortable Lodgings, 186

Conrad, Joseph, 230

Cornhill Magazine, 236

Corot, Jean Baptiste Camille, 7

Cosens, Frederic W., 35, 122

Costello, Dudley, 184

Courbet, Gustave, 7

Court Magazine, 67, 68

Cowper, William, 62

Crane, Walter, 232

Cruikshank, Eliza (Widdison), 33

Cruikshank, George, 4, 5, 6, 17-38, 109; The Artist and the Author, 37; and Bentley's Miscellany, 20; 'The Bottle,' 31, 32, 33 ; and Browne, 86-87; Cinderella, 35; claims of, about role in Dickens's books, 9, 36-38, 48, 50; Comic Almanac, 27; death of, 38; declining reputation of, 31-32; Dickens's criticism of, 22; Dickens's evaluation of, as caricaturist, 149-50; "The

Drunkard's Children,' 7, 31, 33; end of professional relationship of, with Dickens, 27-29; etching process mastered by, 8; and Every Man in His Homour, 134; Foiry Library, 31, 34-35; 'The First of May,' 51-52; Hop $O^{\prime} M y$ Thumb, 34; illustrations by, for Oliver Twist, 20-24, 29, 31, 32-33, 34, 69; illustrations by, for Sketches by Boz, 16-19, 29, 38, 42; Jack and the Beanstalk, 34; and Leech, 141, 151; and The Loving Ballad of Lord Bateman, 26-27, 36; Maclise's portrait os, 65-16, 36; Magazine, 31, 34; and Memoirs of Joseph Grimaldi, 26; Omnibus, 27-29, 30,31, 32; personal friendship of, with
Dickens, 29-30; plates of, in Three Courses and a Dessert, 41; professional relationship of, with Dickens, 15, 16, 17, 20, 23; $P$ uss in Boots, 35; roles played in Dickens's amateur theatricals, 30-31; Royal Academy pension of, 122; and Seymour, 39, 40, 48; sketch portrait of Dickens by, 24-26, 36; strains on friendship of, with Dickens, 33-36; Table Book, 31; and temperance movement, 31, 32, 33-34, 38; Thackeray's studies with, 235, 236; 'The Worship of Bacchus,' 35

Cruikshank, Mary (Walker), 29

Cruikshank, Robert, 32, 41

Cummings, E. E., 231

Daumier, Honoré, 87

da Vinci, Leonardo. See Vinci, Leonardo da

Deane, Reverend John, 37

Degas, Hilaire Germain Edgar, 7

Dickens, Alfred (brother of CD), 189

Dickens, Catherine (Hogarth) (wife of CD), 121, 160, 167, 235; Dickens's letters to, 43, 197; and Leech, 142, 150; Maclise's portrait of children of, 161-62; Maclise's portraits of, 163; separation of, from Dickens, 150,185

Dickens , Charles

- All the Year Round (CD, ed.), 84, 133, 151, 189; Charles Collins's contributions to, 210, 211; on contemporary vs. Victorian illustrators, 232; Dickens's Christmas stories published in, 149; "The Late Mr. Stanfield," 7, 185; A Tale of Two Cities published in, 118, 120

-American Notes, 84, 89, 163, 198; Stanfield's marine frontispiece for, 183-84; Marcus Stone's illustrations for, 204

-Barnaby Rudge, 19, 21, 27, 73, 84, 174; Browne's illustrations for, 77-82, 118; Cattermole's illustrations for, 27-29, 77-81, $128,129,131-33$; Dickens's hysterical note to his publisher near end of, 82

-The Battle of Life, 137; Doyle's illustrations for, 146, 153-54, 170; Leech's illustrations for, 146-48, 170; Maclise's illustrations for, 137, 146, 147, 153-54, 169-71; Stanfield's illustrations for, 146, 147, 170, 181

-Bleak House, 61, 62, 198, 203, 205; Browne's illustrations for, $90,107-14,121,129$

-A Child's History of England, 3, 34, 112, 203; Marcus Stone's Illustrations for, 204; Topham's illustrations for, 197, 198, 199 , 268 n. 12

-The Chimes, 41, 89, 143-44, 146, 148; Dickens's private reading of, 167, 176; Doyle's illustrations for, 144, 152-53; Leech's illustrations for, 144-45, 152; Maclise's illustrations for, 144, 152, 153, 166-67, 168; Stanfield's illustrations for, 144, 152, 180

-Christmas Books. See under Dickens, Charles: The Battle of Life; The Chimes; A Christmas Carol; The Cricket on the Hearth; The Haunted Man

-A Christmas Carol, 89, 144, 148, 166, 180; Leech's illustrations for, 142-43; low profits from, 163, 176; presentation copies of, 5

-The Cricket on the Hearth, 89, 145-46, 148, 149, 182; Doyle's illustrations for, 146, 153,176,181; Landseer's illustrations for 146, 174, 176; Leech's illustrations for, 146, 153, 176; Maclise's illustrations for, 146, 167-69, 170; Stanfield's illustrations for, $146,153,176,180-81$

-David Copperfield, 5, 94, 146, 154, 198; Browne's illustrations for, 90, 100-107, 109; Dickens's analysis of self in, 114; Fildes's sketch of scene from, 222; Leech's influence on, 149

-Dombey and Son, 62, 88, 100, 101, 146; Browne's illustrations 
for, 32, 90-99, 109; Leech's influence on, 149; Ruskin on, 114

-Gabriel Varden, 19, 77. See also Barnaby Rudge

-Great Expectations, 3, 5, 10, 29, 94, 149; Marcus Stone's illustrations for, 204

-Hard Times, 3, 10, 34, 114, 145

-The Haunted Man, 154: Leech's illustrations for, 148-49, 181; Stanfield's illustrations for, 148, 180, 181; Frank Stone's illustrations for, 181, 187-88; Tenniel's illustrations for, 155-57, 181

-Household Words (CD, ed.), 84, 112, 120, 133, 210; A Child's History of England published in, 197; Dickens's account of his marital troubles in, 185; Dickens's Christmas stories published in, 149; "The Friends of the Lions" published in, 7, 176; "Whole Hogs" published in, 34

-Life of Our Lord, 118, 182, 194

- Little Dorrit, 7, 62, 134, 194; Browne's illustrations for, 114-17, 118; dedication of, to Stanfield, 184-85; Marcus Stone's illustrations for, 204

-The Loving Ballad of Lord Bateman, 26-27, 36

-Martin Chuzzlewit, 30, 62, 90, 101, 131, 141; Browne's illustrations for, 84-89,133, 142; disappointing sales of, 143 , 163, 176; Leech's influence on, 149; Frank Stone's frontispiece for, 187

-Master Humphrey's Clock, 5, 27, 73-74, 82; Browne's illustrations for, 29, 74-75, 76, 121, 127; Cattermole's illustrations for, 74-75, 76, 83, 84, 125, 127-33; Maclise's illustrations for, 127, 136, 163-65; Topham's watercolor scenes of, 198; Williams's illustrations for, 74, 135-37

-Memoirs of Joseph Grimaldi (CD, ed.), 26, 236

-The Mystery of Edwin Drood, 3, 35, 137, 149; Charles Collins's illustrations for, 208, 210, 212-17, 220; Dickens's death halfway through, 212, 225; Fildes's illustrations for, 208, 221-28

-Nicholas Nickleby, 19, 75, 95, 110, 125, 127; Browne's illustrations for, 69-73; Maclise's portrait of Dickens in, 160; Frank Stone's illustrations for, 187

-The Old Curiosity Shop, 73, 95, 137; Browne's illustrations for, 75-77, 118; Cattermole's illustrations for, 75-76, 128-31, 133; Maclise's illustration for, 159

-Oliver Twist, 9, 19, 35, 212; Cruikshank's claims about role in, 36, 37, 38, 48; Cruikshank's illustrations for, 20-24, 29, 31, $32-33,34,69$; publication of new edition of, 31

-Our Mutual Friend, 10, 131, 137, 151; Marcus Stone's illustrations for, $120,203,204-8,223,238$ n. 44

-The Pickwick Papers, 9, 19, 20; Browne's illustrations for, 19 , $20,48,55,62-67,68,141-42$; Buss's illustrations for, 51, 52-55; controversy about origins of, 228; Cruikshank's claims about role in, 36; discretion exercised by Dickens in, 6-7; Seymour's and his widow's claims about role in, $33,35,48-50$; Seymour's illustrations for, 8, 17, 19-20, 40, 41-46; success of, 4, 48, 63; Thackeray's application as illustrator for, 141, 235-36

-The Pic Nic Papers, 19, 27, 48, 77

-Pictures from Italy, 3, 7, 10, 90, 198; Palmer's illustrations for, 182, 193-96; poor critical reception of, 196; and Stanfield, 182; Marcus Stone's illustrations for, 204

-Sketches by Boz, 3, 24, 32, 35, 41; Cruikshank's claims about role in, 36, 37; Cruikshank's illustrations for, $16-19,29,38,42$; 'The First of May,' 51-52

-Sketches of Young Couples, 69

- Sketches of Young Gentleman (companion to Sketches of Young Ladies, by Caswell), 69

-The Strange Gentleman, 17, 67, 142
-Sunday Under Three Heads, 62

$-A$ Tale of Two Cities, 62, 77, 82, 117-18, 121, 203; Browne's illustrations for, 118-20; Marcus Stone's illustrations for, 204; wrapper for, 212

—"Travelling Letters," 182, 193, 194. See also Dickens, Charles, Pictures from Italy

-The Uncommercial Traveller, 33

-The Village Coquettes (Dickens's libretto for Hullah operetta), 17,67

Dickens, Charley (son of CD), 49, 162

Dickens, Dora (daughter of CD), death of, 188

Dickens, Frederick (brother of CD), 46, 49, 134, 183

Dickens, Henry Fielding (son of CD), 204

Dickens, John (father of CD), 26

Dickens, Kate (daughter of CD). See Collins, Kate (Dickens)

Dickens, Mary ("Mamie") (daughter of CD), 24-26, 162, 163, 189, 211

Dickens, Captain Peter (grandson of CD), 265 n. 36

Dickens, Sydney (son of CD), 189

Dickens, Walter (son of CD), 162

Dickinson, Emily, 129

Disraeli, Benjamin, 158, 171

Dobson, Austin, 29, 37

D'Orsay, Count, 125, 159, 236

Doyle, John, 76, 249 n. 20

Doyle, Richard, 27, 40, 152-54, 155; departure of, as Christmas book illustrator, 148,181; illustrations by, for The Battle of Life, 146, 153-54, 170; illustrations by, for The Chimes, 144, 152-53; illustrations by, for The Cricket on the Hearth, 146, $153,176,181$; resignation of, from $P$ unch, 154, 155; sketch by, of Lord Bateman, 27

Drury Lane Theatre, 30, 179

Dublin Review, 196

du Maurier, George, 5, 9, 5, 142, 233; and decline of illustrated novel, 230, 231-32

Dutch Royal Academy, 134

Egan, Pierce, 42; Life in London, 4

Eliot, George, 5, 23, 160; Romola, 8

Eliot, T. S., 107

Eller, Thomas, 26

Elton, Edward, 30, 180

Emerson, Ralph Waldo, 183

Every Man in His Humour (Jonson), 30, 134, 150, 171, 184

Farleigh, John, 230

Faulkner, William, 231, 274 n. 22

Fielding, Henry, Tom Jones, 4

Figaro in London, 41

Fildes, Luke, 6, 7, 8, 35, 122, 208, 221-28; and Charles Collins, 212, 213, 216, 217; 'The Empty Chair,' 58, 226, 228; illustrations by, for The Mystery of Edwin Drood, 208, 217, 221-28; personal relationship of, with Dickens, 224; picture of Dickens's Gad's Hill library by, 220, 226; professional relationship of, with Dickens, 223-24; sketch of David Copperfield by, 222; on value of illustrations, 231

Films: influence of $\mathrm{CD}$ adaptations, 234; reliance of, on illustrators in adapting CD's fiction, 234, 275 n. 58 
Finden's (engravers), 62, 65, 160

Fitzgerald, F. Scott, 233

Fitzgerald, Percy, 121, 234

Flaubert, Gustave, 238 n. 24

Forster, E. M., 230

Forster, John, 3, 5, 30, 32, 114, 143; and The Battle of Life, 146-48, 153-54, 181; and Browne, 67, 69, 83, 90, 91; and Buss, 51, 57; on Charles Collins, 217; conversion of, to Catholicism, 182; and Cruikshank's claims about role in Dickens's books, 36 37; and David Copperfield, 100; and Dickens's battles with his publishers, 21, 27; Dickens's correspondence with, 7; and Dickens's friendship with Cattermole, 125, 131; on Dickens's relationships with his illustrators, 10; and Every $M$ an in $H$ is Humour, 134; and Fildes, 228; and illustrations for Oliver Twist, 22; and Landseer, 174; and Leech, 144, 151; The Life of Charles Dickens (vol. 1), 36, 57, 94; The Life of Charles Dickens (vol. 2), 37; and Maclise, 159-73 passim; and The Mystery of Edwin Drood, 225; on Nicholas Nickleby, 75; and Tenniel, 157; and Topham, 197; travels of, with Dickens, 21; and Samuel Williams's engraving for Master Humphrey's Clock, 137

Fortunio, 176

Fraser, W. A., 29

Fraser's Magazine, 16, 32, 159, 160, 166

Frith, William P., 134, 178, 221, 223

Frozen Deep, The, 171, 184, 210

Fuseli, Henry, 4, 176

Gad's Hill Gazette, 204

Galsworthy, John, 230

Garrick Club, 204, 236

Gaskell, Mrs. Elizabeth, 228

Gillray, James, 4, 32, 149, 158; grotesque caricatures of, 3, 7, 70

Gissing, George, 230, 233

Gladstone, William, 158

Goethe, Johann Wolfgang von, 9

Gogh, Vincent van, 5, 221, 228

Goldsmith, Oliver, 147, 169; The Vicar of Wakefield, 4, 6

Good Housekeeping, 230

Gosse, Edmund, 9

Grant, James, Portraits of Public Characters, 29-30

Graphic, The, 221, 226-28

Green, Henry, 117

Greene, Graham, 236

Grimaldi, Joseph, Memoirs, 26, 236

Grimm's Tales; 34

Guild of Literature and Art, 171, 184

Hall, Samuel Carter, 159

Hall, Mrs. Samuel Carter, 49

Hall, William, 29, 42, 49, 89; death of, 96; and The Pickwick Paper8, 43, 46, 48, 52-53. See also Chapman and Hall

Hardy, Barbara, 65

Hardy, Thomas, 4, 5, 230, 231, 232, 273 n. 12, 274 n. 17

Harley, John, 142

Harvey, John, 66, 74, 87, 137, 230: on Browne's illustrations for Bleak House, 109, 110; and David Copperfield, 106; on
Maclise's illustrations for Master Humphrey's Clock, 166

Hawthorne, Nathaniel, 228

Hazlitt, William, 22, 26

Hemingway, Ernest, The Old Man and the Sea, 230

Hervey, Thomas, The Book of Christmas, 41

Hogarth, Catherine (Kate). See Dickens, Catherine (Hogarth)

Hogarth, Georgina, 163, 198, 210, 211

Hogarth, Mary, 130, 160; Browne's portrait of, 68-69; death of, $68,82,128,163$

Hogarth, William, 4, 18, 24, 110, $237 \mathrm{n} .11$; and causes of drunkenness, 33; 'The Election Series,' 22; influence of, on Browne, 85, 87; realistic satires of, 3

Hone, William, 30

Hood, Thomas, 75, 84, 128, 137, 179

Hood's Comic Annual, 142

Hotten, J. C., 36; Seymour's Sketches, 49

Howitt, Mary, 135

Howitt, William, 136; Rural Lives of England, 135

Hughes, Arthur, 203

Hugo, Victor, 231; L'Hormme qui rit, 221

Hullah, John, The Village Coquettes, 17, 67

Hunt, Holman, 203, 210

Hunt, John Dixon, 18, 32

Hunt, Leigh, 6, 26, 30, 108, 134

Hunt, Poole, and Knowles, 30

Illustrated London News, 143, 169

Illustrated novel: decline of, in England, 229-34; rise of, in England, 3-11

Illustrations: importance of, to Dickens, 3-11 passim, 82, 230

Jackson, John, 52, 53, 62, 159

James, Henry, 5, 6, 149, 230, 233; on Dombey and Son, 99; on Little Dorrit, 117; on Oliver Twist, 24, 32; "The Real Thing," 231

James, Thomas, Aesop's Fables, 155

Jerrold, Douglas, 157, 176, 179

John Day Company, 230

Johnson, Edgar, 45

Johnson, Samuel, 26

Jonson, Ben. 186; Every Man in His Humour, 30, 134, 150, 171, 184

Joyce, James, Ulysses, 230

Kean, Edmund, 30

Kipling, Rudyard: illustrates Just So Stories, 231

Kitton, Frederick G., 117, 208, 212

Ladies' Home Joumal, 230

Lamb, Charles, 4, 82

Lamb, Lynton, 229

Landells, Ebenezer, 8

Landseer, Charles, 131, 174

Landseer, Edwin, 6, 7, 131, 153, 174-78; death of, 178; declines presidency of Royal Academy, 178; friendship of, with Dickens, 174, 176-78; friendship of, with Queen Vietoria, 174-76; grande 
médaille d'honneur received by, 134, 178; illustration by, for The Cricket on the Hearth, 146, 174, 176; incompatibility between Dickens and, 178; and Maclise, 171

Landseer, Tom, 131, 174

Lane, Richard, 131

Lawrence, D. H., 231

Layard, G. S., 233

Leavis, Queenie D. 9, 120, 129, 130, 144; on "Art for Art's Sake" movement, 232; on illustrations for The Cricket on the Hearth, 146; on illustrations for The Haunted Man, 149; and pictorial fiction, 233

Leech, John, 6, 7, 8, 20, 27, 141-51; applications of, to Dickens for work as illustrator, $63,141-42$; Browne's opposition to, 84, 142; contributions of, to Chapman and Hall's Library of Fiction, 141-42; contributions of, to Punch, 120, 141, 142, 149, 150,151 ; death of, 151, 158; Dickens's evaluation of, as caricaturist, 149-50; illustrations by, for The Battle of Life, 146-48, 170; illustrations by, for The Chimes, 144-45, 152; illustrations by, for A Christmas Carol, 142-43; illustrations by, for The Cricket on the Hearth, 146, 153, 176; illustrations by, for The Haunted Man, 148-49, 181; personal relationship of, with Dickens, 141, 149-50; popularity of, 31; professional relationship of, with Dickens, 148; The Rising Generation, 149; and Seymour's Sketches, 40; and Tenniel, 155; theatrical roles of, 150, 197; waning of relationship of, with Dickens, 150-51

Leech, Mrs. John, 151

Leighton, Frederic, 8

Lemon, Mark, 149, 157, 185

Lever, Charles, 5, 89, 228; and Browne, 82, 83, 120; Harry Lorrequer, 82, 83

Lewes, G. H., 30, 197

Lewis, C. S., 234

Lewis, Wyndham, 231

Library of Fiction (Chapman and Hall), 41-42, 51, 52, 62, 141-42 Life magazine, 230

Linnell, John, 194

Linton, William, 136-37

Literary Fund, 30

London Chronicle, 89

London Courier, 89

London Daily News, 89-90, 146, 169; "Travelling Letters" published in, 182, 194

London Examiner, 33, 137, 149, 197

London Herald, 89

London Magazine, The, 142

London Morning Chronicle, 51

London Morning Herald, 30

London Morning Post, 26

London Observer, 56, 89

London Standard, 89

London Temperance League, 33

London Times, 5, 10, 36, 37, 89; on illustrations for Dickens's Christmas books, 166, 167, 169, 176

Longfellow, Henry Wadsworth, 29, 30, 163

Louis Philippe, 149

Love, Law, and Physic, 30, 197

Macaulay, Thomas Babington, 26, 108
MeClellan, W. J.., 36

MacKenzie, R. Shelton, 31, 32-33, 36, 37

Maclise, Daniel, 6, 8, 73, 74, 121, 131, 159-73, 238 n. 36, 264 n. 93; death of, 173; 'The Death of Nelson,' 171; declines presidency of Royal Academy, 173, 178; departure of, as Christmas book illustrator, 148, 171, 181; Dickens's nickname for, 84; Dickens's purchase of painting by, 163; dissolution of friendship with Dickens, 171; illustrations by, for The Battle of Life, 137, 146, 147, 153-54, 169-71; illustrations by, for The Chimes, 144, 152, 153, 166-67, 168; illustrations by, for The Cricket on the Hearth, 146, 167-69, 170; illustrations by, for Master Humphrey's Clock, 127, 136, 163-66; illustration by, for The Old Curiosity Shop, 159; involvement of, with Dickens's amateur theatricals, 171; "The Meeting of Blucher and Wellington,' 171; personal relationship of, with Dickens, $159-60,161,162-63$; portrait of Cruikshank by, 15-16, 36; portrait of Dickens's children by, 161-62; portraits of Dickens by, $160,163,171$; portraits of Mrs. Dickens by, 163 ; professional relationship of, with Dickens, 159, 163-65; scene by, from Hamlet, 163; 'The Spirit of Chivalry,' 7, 171; 'The Spirit of Justice,' 171; and Stanfield, 179; and Frank Stone, 186; work of, at Westminster, 171-73

Maclise, Isabella, 160

Macready, William, 56, 69, 128, 150, 176; and Stanfield's friendship with Dickens, 179, 184; on Frank Stone, 186; on Thackeray, 236

Macrone, John, 15, 16, 17, 19, 77

Macrone, Mrs. John, 19, 27, 48, 77

Maginn, William, 21

Manet, Édouard, 7

Mann, Thomas: Buddenbrooks, 231; illustrates Picture Book for Good Children, 231

Márquez, Gabriel García, 229

Marryat, Captain Frederick, 56, 84

Marsden (printer), 135

Martin, John, 74

Martineau, Harriet, 84

Matisse, Henri, 230

Maugham, Somerset, 105

Mayhew, Henry, 23, 37, 41

Meredith, George, 5, 210

Merry Wives of Windsor, The, 30, 150, 186, 197

Metropolitan Magazine, 46

Millais, John Everett, 203, 210, 217, 221, 228; periodicals illustrated by, 231

Miller, J. Hillis, 18, 23

Miller, Thomas, Godfrey Malvern, 90

Mitford, Mary Russel, 83

Mitton, Thomas, 91

Monthly Magazine, 41-42

More Hints on Etiquette, 27

Morris, William, 229, 232

Mozart's "Requiem," 105

Mr. Nightingale's Diary, 188

Murray (publisher), 211

Musgrave, Lord, 183

National Gallery, 9 
National Temperance Society, 32,33

Not So Bad as We Seem (Bulwer-Lytton), 157, 171, 184, 188, 197

o. Henry, 233

Old St. Paul's, 27

Once a Week, 120, 121, 151

Ormond, Richard, 160, 167

Orwell, George, 234

Pailthorpe, F. W., 27, 35

Palmer, Samuel, 6, 8, 198-96, 210; illustrations by, for Pictures from Italy, 182, 193-96

Paris Art Exhibition (1855), 7, 178

Park, Mungo, 30

Parker, Al, 233

Paroissien, David, 182

Pasternak, Boris, 230

Pasternak, Leonid, 230

Patmore, Coventry, 210

Patten, Robert L., 41, 65

Peacock, Thomas Love, 24

Peel, Sir Robert, 149, 158

Perugini, Carlo, 220, 228

Perugini, Kate. See Collins, Kate (Dickens)

Philadelphia Press, 36

Phillips, Watts, The Dead Heart, 120

Phiz. See Browne, Hablot K.

Picasso, Pablo, 232

Pilgrim's Progress (John Bunyan), 4, 74

Pissarro, Lucien, 232

Plutarch, 26

Poole, John, 134; Turning the Tables, 188

Poor Gentleman, The, 30, 157, 197

Pope, Alexander, Dunciad, 4

Portwiners, 131, 160, 235

Potter, Beatrix, 96, 110, 208, 238 n. 43, 249 n. 20

Pritchett, V. S., 10

Proust, Marcel, 151

Punch, 6, 31, 32, 41, 95, 185; and Bradbury and Evans, 120; on death of Browne, 122; Doyle's resignation from, 154, 155; Leech's contributions to, 120,141,142; 149, 150, 151; Tenniel's work for, 151, 154, 155, 157, 158

Putnam, George, 162

Quarterly Review, 31, 32, 64, 65

Reade, Charles, 5, 228

Reid, George, 36

Rembrandt, 34

Rent Day, The, 157, 197

Richardson, Samuel, Pamela: Hogarth's projected frontispiece for, $237 \mathrm{n} .11$

Ricketts, Charles, 232

Ritchie, Leitch, Scott and Scotland, 127

Roberts, Charles, 224

Rogers, Samuel, Italy, 194
Rossetti, Dante Gabriel, 8-9, 26, 38, 193, 203

Rossetti, William, 38, 149, 152, 157

Round Table, The, 36

Rowlandson, Thomas, 4, 42, 149, 158; grotesque caricatures of, 3 , 7,70

Royal Academy, 6, 7, 35, 39, 52, 210; award of pension to Browne by, 122; and black-and-white art, 231-32; Browne's painting exhibited at, 82; exclustion of Leech and Cruikshank from membership in, 149; Fildes's exhibits at and election to, 228; Landseer's work exhibited at, 174; Maclise's membership in, 159; pension sought by Cattermole's wife from, 134; presidency of, declined by Landseer, 178; presidency of, declined by Maclise, 173, 178; Stanfield's membership in, 179, 184; Marcus Stone's election to, 209; Marcus Stone's exhibits at, 204;

Tenniel's painting exhibited at, 155; Topham's exhibits at, 197, 199

Ruskin, John, 4, 9, 18-19, 34, 62, 154, 166; on Barnaby Rudge, 81, 82, 132; and Cattermole's engravings for Master Humphrey's Clock, 133; on Charles Collins, 210; on Cruikshank's works, 24, 34, 35, 38; on Dickens's Christmas books, 142-43, 146; on Dombey and Son, 114; and Leech, 149; on Palmer, 193; and Stanfield, 179; on steel engraving and woodcuts, 73; on Tenniel, 155, 157, 158; on Topham, 199

Russell, Lord John, 149, 158

Satirist, 48

Scott, Sir Walter, 4, 127, 137, 159, 160, 238 n. 27

Scribner's, 230

Seymour, Jane (Holmes), 39, 41, 42, 51; Account, 49; claims by, of husband's role in The Pickwick Papers, 48-50; resentment of Dickens, 48; suicide of husband of, 46

Seymour, Robert, 5, 6, 7, 9, 39-50, 67; Buss on, 57; claims about role in origim of The Pickwick Papers, 33, 35, 39, 48-50; Comic Album, 41; early career of, 39-40; Figaro humiliation of, 41; illustrations by, for The Pickwick Papers, 8, 17, 19-20, 40, 41-46; replaced as Pickwick illustrator by Buss, 51, 52, 53; Sketches, 40, 49; suicide of, $4,19,39,46,221,235$

Seymour, Robert, Jr., 49

Shakespeare Club, 186

Shakespeare Society, 131, 160, 174, 179

Shannon, Charles, 232

Shaw, George Bernard, 6, 17, 184, 198, 233; The Adventure of the Black Girl in Her Search for God, 230; Short Stories, Scraps and Shavings, 230

Shawe, Isabella, 235, 236

Sickert, Walter R., 38

Sickle, Noel, 230

Sitwell, Sacheverell, 29

Slater, Michael, 143, 146, 148

Smollett, Tobias George, Peregrine Pickle, 4

Society of Arts, 62

Society of Painters in Water Colours, 125, 134

Spectator, 20, 26

Stanfield, Clarkson, 6, 7, 35, 56, 73, 121, 179-85; conversion of, to Catholicism, 182, 193; death of, 185; dedication of Little Dorrit to, 184-85; Dickens's nicknames for, 84, 179; and Every Man in His Humour, 30, 134; friendship of, with Dickens, 154, 179-80, 182-83, 185; illustrations by, for The Battle of Life, 146, 147, 170, 181; illustrations by, for The Chimes, 144, 152, 180; illustrations by, for The Cricket on the Hearth, 146, 153, 176, 
180-81; illustrations by, for The Haunted Man, 148, 180, 181; marine frontispiece by, for American Notes, 183-84; and Pictures from Italy, 182, 193; reputation of, as painter, 179; role of, in Dickens's amateur theatricals, 184

Steig, Michael, 10, 149; on Browne's illustrations for Bleak House, 109, 110; on Browne's illustrations for Martin Chuzzlewit, 84-85, 86

Stein, Gertrude, 233

Stein, Leo, 232

Sterne, Laurence, Tristram Shandy, 4, 238 n. 24

Stevens, Joan, 74, 77

Stevenson, Robert Louis, 101, 231

Stone, Arthur, 189

Stone, Ellen, 189

Stone, Frank, 6, 134, 148, 174, 186-89, 208, $268 \mathrm{n}$. 7; death of, $120,189,203,204$; Dickens's nicknames for, 189; friendship of, with Dickens, 186, 187, 188-89; frontispiece by, for Martin Chuzzlewit, 187; illustrations by, for The Haunted Man, 181, 187-88; illustrations by, for Nicholas Nickleby, 187; role of, in Dickens's amateur theatricals, 186-87, 188

Stone, Mrs. Frank, 189

Stone, Marcus, 6, 6, 8, 121, 186, 189, 203-9; A Child's History of England given to, 198; close relationship of, with Dickens and his family, 203-4, 207-9; and death of Leech, 151; election of, to Royal Academy, 209, 228; illustrations by, for Our Mutual Friend, 120, 203, 204-8, 223; as model for Mr. Venus in Our Mutual Friend, 10; professional relationship of, with Dickens, 204-5, 206, 207; professional relationship of, with Trollope, 121, $208,256 \mathrm{n}$. 260; supplementary illustrations for variety of Dickens's novels by, 204

Stothard, Thomas, 4, 194

Strutt, Joseph, Costumes, 162

Sullivan, E. J., 232

Surtees, R. S., 42; Jorrock's Jaunts and Jollities, 41

Swift, Jonathan, 4

Swinburne, Algernon, 21, 29, 38, 198, 205

Sykes, Lady, 171

Tasso, Torquato, 39

Taylor, Weld, 46

Tenniel, Sir John, 6, 7, 31, 120, 148, 155-58, 231; and Doyle, 154; illustrations by, for The Haunted Man, 155-57, 181; knighthood awarded to, 158; personal relationship of, with Dickens, 158; theatrical roles of, 157; work by, for Punch, 151, $154,155,157,158$

Ternan, Ellen, 121

Thackeray, Anne, 27, 228

Thackeray, William Makepeace, 4, 6, 20, 35, 149, 154, 238 n. 35, 268 n. 7; on Ainsworth's Jack Sheppard, 32; application by, as Pickwick illustrator, 141, 235-36; and Browne, 70, 87; and Cattermole, 125, 131; and Charles Collins, 210, 211; and Cruikshank's children's stories, 34; on Dombey and Son, 95; and illustrations for Oliver Twist, 22, 24; on Leech, 143, 151 and "The Loving Ballad of Lord Bateman," 26, 27, 36; on Maclise's illustrations for Christmas books, 169, 170; on Maclise's portrait of Dickens, 160; on physical attributes of Dickens's characters, 18; on Stanfield, 184; and Frank Stone, 186, 187; unfinished last work of, 228

Thompson, John, 135, 137, 170

Thomson, Hugh, 232

Thrale, Mrs. (Hester Lynch Piozzi), 4
Tillotson, Kathleen, 84, 90, 107, 114

Tilt, Charles, 27

Tolstoy, Leo: commissions illustrations for Resurrection and War and Peace, 230

Topham, Francis W., 6, 197-199 friendship of, with Dickens, 198-99; illustrations by, for A Child's History of England, 197, 198, 199; illustrations by, for Master Humphrey's Clock, 198; roles of, in Dickens's amateur theatricals, 197

Trollope, Anthony, 5, 7, 9, 92, 151, 232; Browne's illustrations for work of, 120-21; Can You Forgive Her, 121, 256 n. 260; Fildes's illustrations for The Way We Live Now, 273 n. 46

Trollope, Mrs. Frances, 56, 84

Turner, Joseph, 5, 179, 194

Turning the Tables, 30

Used Up, 30, 157

van Gogh, Vincent. See Gogh, Vincent van

Vanity Fair, 236

Vaughan, Thomas, 39

Vicar of Wakefield, The (Oliver Goldsmith), 4, 6

Victoria, Queen, 35, 157, 171, 174-76

Vinci, Leonardo da, 9

Vogler, Richard, 26, 27, 37

Vonnegut, Kurt, Breakfast of Champions, 231

Ward, Henrietta, 33

Warren's Blacking warehouse, 3,15

Watkins, John, 58

Waugh, Arthur, 121, 207

Waugh, Evelyn, 233; Decline and Fall, 231

Wells, H. G., 231

Whistler, James Abbott MacNeill, 38, 55, 233

Whitehead, Charles, 42

Whittington, Dick, 76-77

Wilde, Oscar: The House of Pomegranates, 232; The Picture of Dorian Gray, 232

Wilks, Thomas, 26

Williams, Mary Ann, 135

Williams, Samuel, 8, 74, 128, 129, 135-38, 170; contributions of, to wood engraving, 135, 137-38; death of, 137, 138; illustrations by, for Master Humphrey's Clock, 74, 135-37

Williams, Thomas, 8, 135, 137, 170

Wilson, Angus, 122,120 n. 53, 255 n. 238

Wilson, Edmund, 234

Winkle, Henry, 62

Winkle's Cathedrals of England and Wales, 62, 76, 129

Wiseman, Cardinal, 182, 196

Woolf, Virginia, 230, 232

Wordsworth, William, 9

Wyeth, Andrew, 232

Wyeth, N. C., 232

Yates, Edmund, 121, 236

Young, Robert, 8, 62, 63, 72, 83, 114; and Browne's dissociation from Dickens, 121; and Browne's illustrations for Dombey and Son, 90 



But though Dickens's abiding preoccupation with illustrations was to some extent motivated by economic considerations, they apparently served the far more important function of providing a necessary outlet for the rich overflow of his remarkably visual imagination. He once explained the process by which his fiction was created: "I don't invent it really do not-but see it and write it down." And his instructions to his artists do indeed confirm that he visualized very thoroughly and in a multiplicity and wealth of detail the scenes that he wished to see depicted.

It was, in fact, as much the force of Dickens's personality and pictorial imagination that assured the success of his illustrations as it was the talent of the artists he employed. He managed quickly to reverse the traditional roles that subordinated author to artist; and though the less complacent and more famous among them must have resisted this, the illustrators of Dickens fared better than most of their colleagues at a time when they were to painters as novelists were to poets - the less prestigious, though usually more popular, practitioners of their craft. If George Cruikshank and Robert Seymour assisted Dickens in his rise to fame, they, in turn, have been assured of immortality by virtue of their work for him. Hablot Browne's stature as an artist rested almost exclusively on his illustrations for Dickens. John Leech's name on the title pages of the Christmas books consolidated his reputation as a talented satirist, and John Tenniel's byline led to his work for Punch and his collaboration with Lewis Carroll. Some of the artists were already respected painters when they went to work for Dickens; others became so as a result of the association. Many, like Edwin Landseer and Samuel Palmer, have earned a place in art history not dependent on their Dickens illustrations; but with few exceptions, until the recent revival of interest in Victoriana, most were better remembered for their illustrations of Dickens than for their ambitious canvases. At a time when scholars have begun to recognize that the major achievement in the graphic arts of the Victorian era may have been in the field of book illustration, those who labored to illustrate Dickens are deserving of renewed attention. Certainly, his modern readers owe it to Dickens to accord to his artists some measure of the serious consideration he lavished on their efforts to embellish in pictures the pages that he wrote.

Jane R. Cohen teaches in the Radcliffe Seminars Program at Radcliffe College. 
$x^{2}=4 x+x^{2}+x^{2}$ achun 5 in

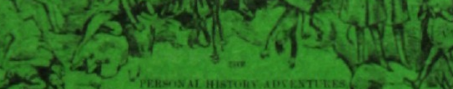
osth $\rightarrow$

A.

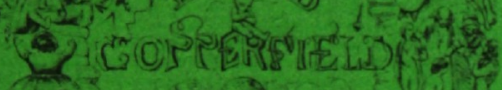

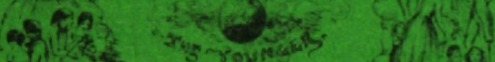

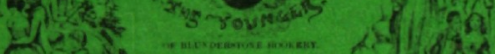
up2

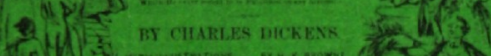

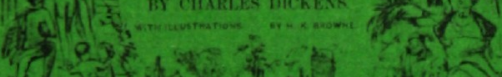

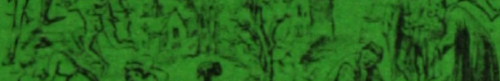

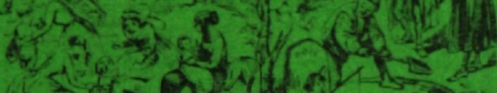

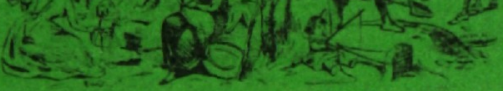

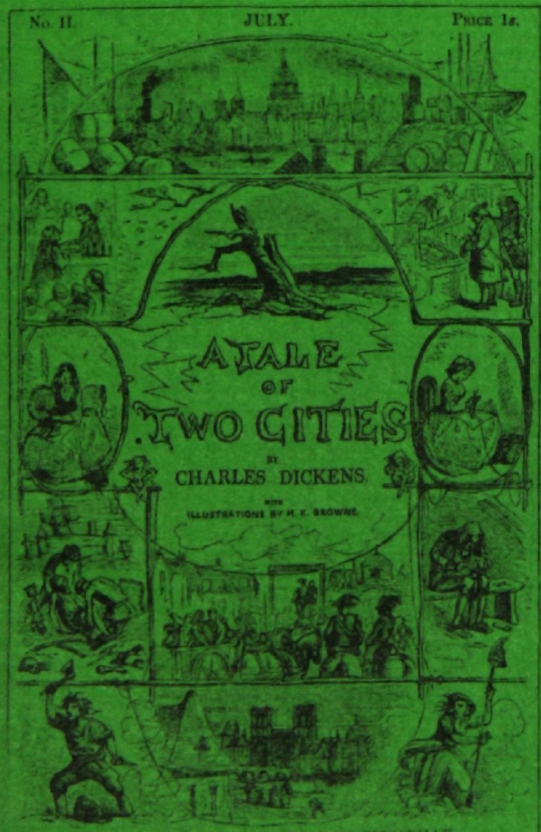

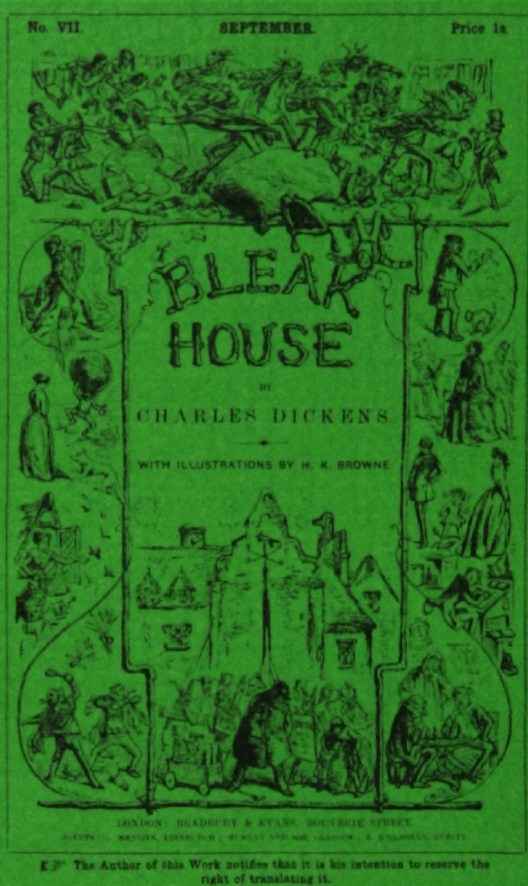

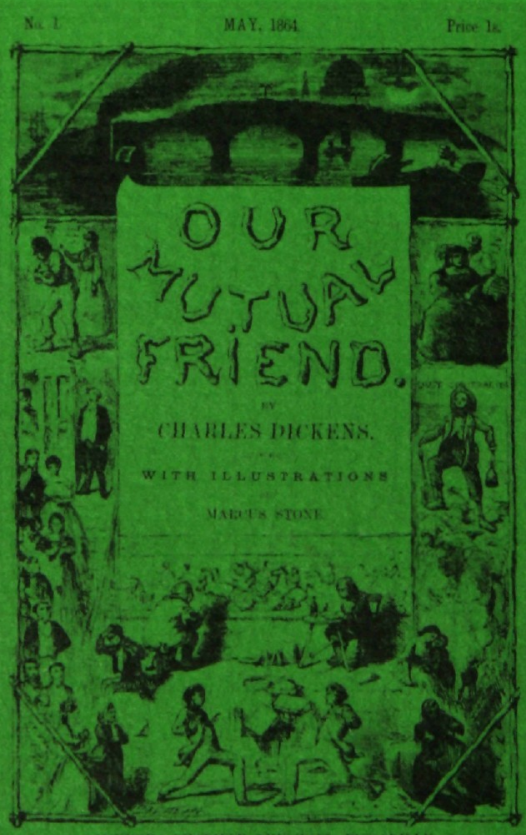

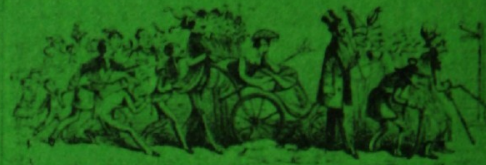

कs जit: $x^{5} 7 x^{2}-k^{2}$

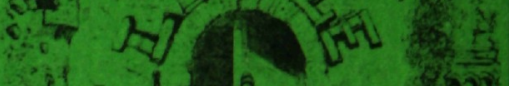
sis

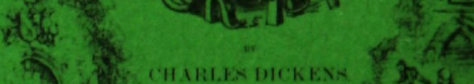

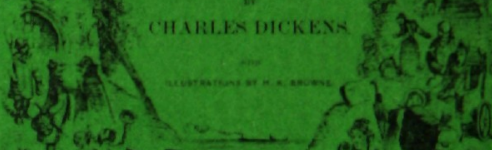
5.

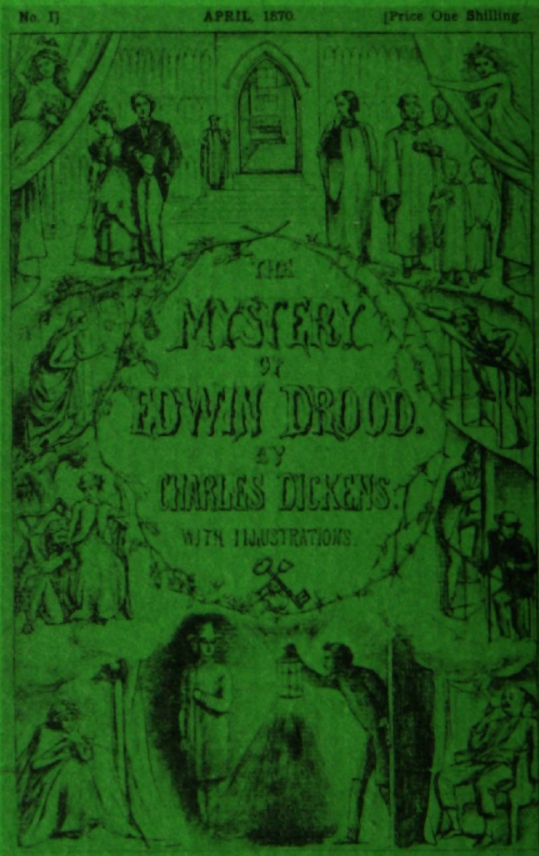

